Claremont Colleges

Scholarship@ Claremont

CGU Theses \& Dissertations

CGU Student Scholarship

2012

\title{
An Assessment of United States Ethanol Policy
}

Mark Chapin Johnson

Claremont Graduate University

\section{Recommended Citation}

Johnson, Mark Chapin, "An Assessment of United States Ethanol Policy" (2012). CGU Theses \& Dissertations. Paper 24.

http://scholarship.claremont.edu/cgu_etd/24

DOI: $10.5642 /$ cguetd $/ 24$

This Open Access Dissertation is brought to you for free and open access by the CGU Student Scholarship at Scholarship @ Claremont. It has been accepted for inclusion in CGU Theses \& Dissertations by an authorized administrator of Scholarship @ Claremont. For more information, please contact scholarship@cuc.claremont.edu. 


\title{
An Assessment of United States Ethanol Policy
}

\author{
By
}

Mark Chapin Johnson

\begin{abstract}
A dissertation submitted to the Faculty of Claremont Graduate University in partial fulfillment of the requirements for the degree of Doctor of Philosophy in the Graduate Faculty of Politics and Economics.
\end{abstract}

Claremont Graduate University

2012

Approved by the Dissertation Chair

Michael Uhlmann, Ph.D.

(C) Copyright Mark Chapin Johnson, 2012

All rights reserved. 


\section{Approval of the Dissertation Committee}

We, the undersigned, certify that we have read the dissertation of Mark Chapin Johnson and approve it as adequate in scope and quality for the degree of Doctor of Philosophy.

Dissertation Committee:

Michael Uhlmann, Chair

Jean Reith Schroedel, Member

Sallama Shaker, Member 


\section{Abstract \\ An Assessment of United States Ethanol Energy Policy \\ By \\ Mark Chapin Johnson \\ Claremont Graduate University, 2012}

From 1978 on there have been a series of legislative acts that have placed substantial protectionist burdens on the American taxpayer. Those acts have provided incentives, credits and mandates for the production and use of ethanol under the rationale of reducing U.S. dependence on foreign sources of oil while purporting to economically benefit the American economy and strengthening American security. While there has been much discussion about the economic benefits of ethanol policy, there is growing literature suggesting that in addition to being neither economically nor environmentally beneficial, ethanol policy may not be achieving its intended goals. Connection between political contributions, policy formation, and the actual outcomes of the enacted policies does not appear to have been addressed. Throughout the course of ethanol policy development the narrow interests of some stakeholders may have been met at the expense of others. Given the very large economic and social costs of ongoing ethanol subsidies and mandates an exploration of such a nexus would be illuminating and valuable. 
Hence the question of this research will be:

Has the ethanol energy policy of the United States, as outlined in legislative actions, requiring subsidies and mandates from taxpayers, been reflective of a deliberative democratic process that after taking into account the input and influence of various competing viewpoints has resulted in a beneficial national policy? Consequently have the policy outcomes of the legislative stakeholders matched the stated intentions of those involved in the deliberative debate that enacted it or, where have those objectives not been met?

Research that can increase understanding of how such an important policy may have failed can inform future policy deliberation in such diverse areas as agriculture, national security and energy policy while illuminating how and why such public policy was made. Examination of a policy created and continuing which may have failed the most basic cost benefit analysis and does very little to enhance national energy security could demonstrate how a distortion of the legislative process resulted in outcomes that differ markedly from the stated intentions of those who enacted the policy. 


\section{Dedication}

Sometimes in life we are blessed with that one special person that brings out more in us than we ever imagined possible. I am so fortunate to have found an encourager and partner to walk through life with that has been the wind beneath my wings through the years this journey has taken. This dissertation would not have been written were it not for her.

It is to my wife and love, Barbara that this work belongs. 


\section{Acknowledgments}

I never could understand the significance of "acknowledgements" at the front of an author's work nor the difficulty of presenting them. Now I do! The shoulders I stand on are many and go back in my life several decades. I owe thanks to countless friends, family and colleagues that encouraged me to accomplish what frequently seemed impossible. There are my sons Wayne, Mark, Jason and Cameron that endured my absence and preoccupation with study over several years; their encouragement has meant the world to me. My late Aunt, Elizabeth Luttrell, a scholar and English teacher instilled a language foundation and discipline that would serve me well. She would be much pleased. Over a decade ago, a friend and mentor, Jim Doti, President of Chapman University, encouraged me, a middle aged entrepreneur and CEO, to return to university and begin an academic adventure that would enrich my life beyond my imagination. David Brady of the Hoover Institution encouraged me to attend Claremont, believing it would serve me well at the graduate level - it certainly has - (although he later pointed out that his encouragement was in part because he knew that CGU would not cut an old guy any slack at all). General H R McMaster set an example demonstrating that career professionals can pursue knowledge while performing the most demanding of challenges while even having the time to encourage me. Victor Davis Hanson presented the highest level of critical thinking and writing skills I have encountered in academia and always inspired my efforts. Lee Solow propped me up when I thought it difficult to continue. Then there those that literally tutored me through those dark and difficult courses and without whom I 
would never have reached this point. Thanks to Mirya Holman I survived Quantitative Analysis. Dave Dickey, Scott Waller and Alex Hindman spent untold hours insuring I would successfully pass Qualifying exams, to them I owe much. Moana Vercoe coached me through the Nature of Inquiry and then in subsequent years she read, critiqued and encouraged me through endless iterations of this dissertation and its proposal. I deeply appreciate her counsel through this journey. From the first day, many years ago at CGU I was always amazed at the smile and support from Gwen Williams. She may be the secret weapon of CGU that keeps the institution together.

My deepest appreciation goes to three remarkable professors that brought knowledge, critical thinking skills and perspective to my life in abundance. Michael Uhlmann brought to life the Founding and the importance of Constitutional Law and their place in the world today in ways I would never dreamed possible. Jean Schroedel drove me to understand dimensions of traditions and changes over time and how we became the nation we are (for better or worse I now really understand coverture). Sallama Shaker brought to me an insight and appreciation of how culture matters so dramatically and how, when nations fail to understand different cultures, the world suffers deeply. It is with much gratitude that I thank these three professors, friends and colleagues for their continual encouragement, counsel and wisdom. Because of their unique skills and knowledge I now see and understand much which I previously did not. They have made my journey a joy in ways untold. 


\section{Table of Contents}

Acknowledgments

$\begin{array}{ll}\text { Table of Figures } & \text { ix }\end{array}$

$\begin{array}{ll}\text { Introduction } & 1\end{array}$

Chapter One: Whence Ethanol? Background and Context 5

Presidential Energy Positions Leading to Increasing Use of Ethanol

Ethanol and environmental quality

Ethanol and national security

Chapter Two: Literature Review and Study Approach 25

Deliberative Democracy methodology and study design

Research question

Chapter Three: The Winding Road of Ethanol Legislative History 49

Presentation and History of significant ethanol policy enactments

Goals of examined legislation

Chapter Four: Deliberative Democracy Legislative Examination

National Political and Social Circumstances Driving Ethanol Policy

The Post Arab Oil Embargo Ethanol Policy Era

Analysis of selected ethanol policy acts legislated prior to 911

Chapter Five: Current Ethanol Policy Legislative Directions 198

The expansion and mandating of ethanol policy post 911

Chapter Six: Analysis and Conclusions

What has been learned?

What is the prognosis for Deliberative Democracy?

Appendices

Bibliography 
Table of Figures

Figure 1 Nominal Real Oil Prices 1968-2006

Figure 2 Expanded Renewable Fuels Mandate

Figure 3 Direct Ethanol Taxpayer Costs

Figure 4 Direct \& Indirect Ethanol Taxpayer \& Consumer Costs

Figure 5 Examples of Political \& Deliberative Perspectives

Figure 6 US Oil Production and Imports 1920 to 2005

Figure 7 Fuel Ethanol Productions in the United States

Figure 8 Crude Oil Prices, History \& Analysis

Figure 9 Foreign Oil Dependencies by U.S. President

Figure 10 Inflation Adjusted Corn Prices 1973 - 2008

69

Figure 11 Renewable Fuels Standard vs. Ethanol Production

Figure 12 Projected Loses to Federal Tax Revenues

Figure 13 Imports and Dependency Chart

Figure 14 The Price of Oil per Barrel 1978-1988

Figure 15 Imports of Crude Oil and Petroleum Products 


\section{Introduction}

In the summer of 1787 John Quincy Adams presented the Harvard College commencement address wherein he offered the term "a critical period" as he was reflecting on the tumultuous years after the revolutionary war. During these years of both confusion and the forming of the American democracy many states were beset with farmers rebellions, unpaid militia and the nation was near bankruptcy unable to pay its remaining war debts. It was during this decade of the 1780's, the "critical period," that in May of 1787 the "Constitutional Convention" was convened in Philadelphia to address the myriad of problems besetting the United States as it was being governed by the Articles of Confederation. Some delegates wished to retain and revise the "Articles" while others desired to create a new government more responsive to the citizens of the whole nation. From this convention emerged a proposed new constitution which was adopted on September $17^{\text {th }}, 1787$. On June $21^{\text {st }}$ of the following year the required nine states ratified the instrument and the constitution was confirmed.

Between October of 1787 and the fall of 1788 a series of essays were published under the title "The Federalist." It was the desire of the authors of The Federalist to influence the vote in favor of ratification and to shape future interpretations of the Constitution. Amongst the eighty five essays published was one particularly significant article that laid a foundation for much of this dissertations thesis and research.

${ }^{1}$ (East, 1962) 
In Federalist 10 James Madison presents his perspective on the value of a constitutional construct that establishes the republican principle of electing representatives in appropriate proportion to the population as a whole which will result in a beneficial process of "refine(ing) and enlarge(ing) the public views, by passing them through the medium of a chosen body of citizens, whose wisdom may best discern the true interest of their country, and whose patriotism and love of justice will be least likely to sacrifice it to temporary or partial considerations. Under such a regulation, it may well happen that the public voice, pronounced by the representatives of the people, will be more consonant to the public good than if pronounced by the people themselves, convened for the purpose.",2

In 1980 Joseph Bessette presented his article, "Deliberative Democracy: The Republican Majority Principle in Republican Government."3 Later, in 1994, Bessette published an additional text, "The Mild Voice of Reason,", that expanded upon his earlier work. These works together added to a foundation established by Madison over two hundred years earlier. In his deliberative democracy framework, Bessette articulates the attributes which legislators should possess to engage in dialogues that lead to decisions which are beneficial to "the permanent and aggregate interests of the community...those interests described in the Federalist Papers as 'the public good,' 'the good of the whole,' 'the public

\footnotetext{
2 (Madison, 1787)

3 (Bessette, 1980)

${ }^{4}$ (Bessette J. M., 1994)
} 
weal,' 'the great and aggregate interests,' 'the great interests of the nation' and the comprehensive interests of the country." 56

The objective of this dissertation and research is to analyze the legislative process that transpired over several decades, from inception to decline, that established the nation's ethanol energy policy. The lens through which this assessment is made is that of the deliberative democracy concept originally published in Federalist 10 and refined through the work of Bessette and others more recently.

Bessette presents succinctly, "despite the possibility of a kind of deliberative coalition building within Congress, it is abundantly clear from the founding records that the framers very much sought to create legislative institutions that would not be mere collections of advocates of narrow interests and in light of their experience it was the framers hope and expectation that (1) electoral mechanisms would bring into government men of broad experience and outlook who were not unduly tied to local or partial interests and (2) their institutional design would foster a growing knowledge of and attachment to national concerns. ",7

The research herein examines the legislative record of bills, hearings, testimony and Congressional committee membership as well as enacted legislation to discern the degree to which a deliberative democracy paradigm was followed by legislators crafting national ethanol energy policy.

\footnotetext{
5 (IBID)

${ }^{6}$ (Madison, 1787)

${ }^{7}$ (Bessette J. M., 1994)
} 
The underlying precept of deliberative democracy is that when such elements of deliberative and legislative behavior, as presented by both Madison and Bessette are followed, the Nation as a whole will benefit and narrow parochial interests minimized. This assessment of the life cycle of the political and policy paradigm of ethanol policy formation shows a clear and documentable outcome that is directly tied to how the deliberative democracy framework has operated over the decades of energy challenges facing the United States.

The conclusions reached are problematic and of significant concern for the future economic health and strategic interests of the Nation. An in-depth analysis of ethanol policy history shows that while this energy paradigm has not been particularly controversial until recently, the long term ramifications of the policies enacted are seriously detrimental to America as a whole. 


\section{Chapter One}

\section{Whence Ethanol? Background and Context}

Ethanol policy lies at the intersection of science, industry and politics. This nexus has created strange policy outcomes. Observing how the nation's energy policies have been shaped, crafted and enacted through the legislative process can reveal much about how the Founders intent in relation to Constitutional structure actually functions in the current era. The history of evolving ethanol energy policy in the United States represents a unique opportunity to study a national economic and security policy presented as beneficial to the nation that may have been detrimental at almost every decision point. This contrasts with ethanol expansion within agricultural policy that has succeeded in meeting its stated goals. Throughout the course of ethanol policy development the narrow interests of some stakeholders appear to have been met at the expense of others. This dissertation explores and evaluates the question of whether or not a deliberative democracy process was adhered to over the life cycle of ethanol policy since coming to the national consciousness in the early 1970's.

To understand what ethanol is and how it evolved as an additive and fuel that became part of the energy resource chain in American energy policy requires some basic historical foundation. Ethanol is a basic chemical compound which has been part of mankind's environment for many millennia. It is the primary ingredient in alcoholic beverages and is frequently used as a solvent and 
preservative in pharmaceutical manufacturing. ${ }^{8}$ In the United States the manufacture of ethanol is a distilling and fermenting process of simple sugars, primarily from corn. ${ }^{9}$

A brief timeline of ethanol history from the early 1800's through the end of World War II shows: ${ }^{10}$

1826 Stanley Morey develops an engine that runs on ethanol and turpentine.

1860's Ethanol is taxed to help fund the Civil War.

1876 Otto cycle engine is the first combustion ethanol and gasoline engine.

1896 Henry Ford builds the quadricycle car to run on pure ethanol.

1908 Ford Model T runs on corn ethanol.

1920’s Standard Oil adds ethanol to gasoline to reduce engine knocking.

1940’s Army builds ethanol facility in Omaha to produce military fuel.

1940's to late 1970's Low price of gasoline precludes public sales of fuel ethanol.

\section{Presidential Energy Positions Leading to Increasing Use of Ethanol}

For better or worse ethanol as a source of energy is part of the Nation's energy portfolio. Over the past several decades Presidents have been vocal and outspoken about the use and preservation of America's natural energy resources as important to national security. Until recently ethanol played an important part in these discussions as a significant renewable energy resource. Prior to the painful

\footnotetext{
${ }^{8}$ (National Institutes of Health, 1988)

${ }^{9}$ (Yacobucci, Fuel Ethanol - Background and Public Policy Issues RL33290, 2008)

${ }^{10}$ (MLR Solutions - Fuel Testers , 2009)
} 
experiences of the Arab Oil Embargo of 1973 Presidents from Teddy Roosevelt forward made pronouncements on the importance, management and utilization of our Nation's natural energy resources.

The irony of historical Presidential positions on American ethanol energy policy is that while they were similar over recent decades, regardless of Presidential political affiliation, proposed or enacted legislation only exacerbated an already ineffective energy policy. As time has progressed, U.S. ethanol energy policies have become profoundly inadequate for contributing to the economic health and strategic interests of America.

In the 1930's, President Roosevelt concluded that his administration could not effectively solve the Nation's crushing economic problems without playing a pivotal role in energy policy. It was not his intention to nationalize this sector, but to coordinate its activities within the national economy. American involvement in World War II required a substantial participation of government to insure an adequate supply of energy to military forces. Interestingly, even though there was a great demand for oil and energy resources during that era, in 1950 the U.S. provided 52\% of the world's oil supply. By 2004 the U.S. was providing only 8.5\%. ${ }^{11}$ This data alone shows the abject failure the stated intention by policy makers of the United States to become energy self-sufficient and in part explains the legislative desire to have the Nation produce more ethanol.

${ }^{11}$ (Bahgat, 2006) 
In the 1950's, President Eisenhower concluded that as America imported an increasing proportion of its energy requirements from foreign sources as oil imports, this dependence was detrimental to national security and the Nation's preeminent position in world affairs. His policy goal was clear: reduce dependence on distant, possibly less reliable oil suppliers and rely more on imports from Canada and Mexico. The unintended consequence of his policy was to also increase domestic production while concurrently reducing reserves that resulted in little or no spare capacity or inventory reserves. While at first glance this policy would seem economically desirable, it brought about another unexpected result, which would plant the seeds of tremendous dislocation and economic pain for the U.S. in the 1970's. Out of the energy policies of the Eisenhower administration came an industry phenomenon in the 1960's and 1970's. In a free market economy, industry will always take the path of least resistance and greatest profitability. The energy sector recognized a simple, but profound economic reality that changed American energy policy at the time: "In the late 1960s and early 1970s, oil companies found that it was more profitable to pay additional import fees than to use domestic oil, since domestic production costs were higher than the total cost of imported oil plus the import fees.",12

While Presidents Kennedy and Johnson would follow Eisenhower in offering similar pronouncements about the importance of American energy selfsufficiency, their eras did not experience the violent supply and economic disruptions which were to follow. The fragile and unsustainable import construct

${ }^{12}$ (IBID) 
which developed in the 1960's and 1970's would come to haunt the administrations of Presidents Nixon, Ford and Carter.

In October of 1973 the Arab-Israeli Yom Kippur war raged for several weeks and would have long term catastrophic effects for the American economy. Arab nations collectively decided to curtail the supply of oil to Western markets, resulting in dramatic disruptions to the world economy. ${ }^{13}$ By the early 1970 's domestic oil production had declined sharply and with the Arab embargo of 1973 the energy supply in the U.S. was in complete disarray. In short order, and with the concurrence of Congress, several administrations implemented a series of "plans" which would turn out, over time, to be totally ineffective and counterproductive to the economic and strategic well-being of the Nation. It will be shown that during this era ethanol would emerge front and center in Congressional dialogue as a partial answer to the energy dilemma. President Nixon presented his "Project Independence," which was designed to develop domestic energy resources within a decade to meet the country's energy requirements without depending on foreign suppliers. This goal was never remotely achieved. American dependence on foreign oil supplies continued to grow. President Ford presented a detailed plan to raise taxes on imported oil and eliminate the market distorting price controls implemented by President Nixon with the goal of reducing reliance on foreign sources of oil. Additionally, President Ford signed the Energy Policy and Conservation Act, which authorized the establishment of the Strategic Petroleum Reserve. These actions were

${ }^{13}$ (Elass \& Jaffe, 2010) 
expected to make the U.S. less dependent on imports. However, subsequent to the Ford administration the U.S. continued to import yet more foreign oil energy resources.

In 1977 President Carter declared the national energy crisis to be the "moral equivalent of war." ${ }^{14}$ His policies were designed to reduce energy consumption while transitioning the country to a greater use of coal and renewable resources such as ethanol. The Department of Energy was created at President Carter's request as a cabinet level agency. Again at the end of the Carter Presidency the Nation was importing yet a higher proportion of foreign sources of energy. ${ }^{15}$ During the Reagan administration's early years in the 1980's a severe recession led to a significant oversupply of world oil resources and a consequent price collapse. During this period and into the 1990's, the basic energy policy of the U.S. was to encourage deregulated markets, which would rely on capital being efficiently allocated and result in competitive consumer prices brought about by competition. ${ }^{16}$ Despite the temporary increase in the supply of oil and the concurrent price reduction of the era, the continuing policies of the U.S. ensured that the proportion of imported energy continued to rise.

In the 2000's the Bush administration made energy policy a key focus of its strategic priorities. Both the President and Vice-President brought energy knowledge to their offices and both recognized the critical importance of

\footnotetext{
${ }^{14}$ (McClay, 2010)

15 (Bahgat, 2006)

16 (IBID)
} 
American energy policy for the U.S. economy and strategic interest. The Bush energy policy was dynamic and active. Immediately upon taking office the President established the National Energy Policy Development Group to craft (yet another) national energy policy. It took four years of wrestling with Congress to create an acceptable bill, 1,700 pages long, that the President signed in August of 2005. This bill had a variety of attributes: It would NOT open the Arctic Wildlife Preserve to oil and gas leasing (taking yet another domestic energy rich resource off the table), and it required increasing amounts of renewable fuel to be blended into the Nation's gasoline supply (from 4.0 billion gallons in 2006 to 7.5 billion gallons in 2012). The requirement for renewable fuel took no account of how much food producing acreage this provision would remove from domestic food supply resulting in grain shortages and price spikes around the world along with consequent food riots in third world countries. The bill was seriously flawed. It did not address issues of possible greenhouse gas concerns, expanded daylight savings time, contained a variety of tax incentives designed to encourage new capital investments in plant and equipment for domestic energy production, provided for an extension of a wind energy tax credit and created a 30\% solar energy tax credit, expanded the federal governments oversight and regulatory authority over liquefied natural gas terminals, provides new incentives for the building of advanced nuclear power plants for the production of electricity, created a variety of tax credits for the construction of new advanced clean coal facilities. 
What then have been the results of these numerous administration's intensive efforts to address the energy challenge? In 2004 as the Bush administration approached the implementation of its new energy policy, the gap between domestic oil production and domestic consumption was as large as ever: 7.4 million barrels per day produced, 20.5 million barrels per day consumed. ${ }^{17}$ By any objective measure, the outcome of five decades of American energy policy has been an extraordinary increase in foreign source dependence and vulnerability both economically and strategically for the nation. Data presented in chapters 3 and 6 suggests that the limits of the Nation's economic and agricultural ability to meet the legislated mandates for ethanol production have been exceeded. The documented inability to meet statute requirements indicates that the life cycle of ethanol policy is coming to an end.

\section{Ethanol and environmental quality}

As America experienced rapid population and economic growth after World War II, potentially negative health effects of expanding transportation and industry became more visible to the public and legislative bodies. Over time this focus would come to include the perceived benefits of ethanol as part of our national public health, environmental and energy policy.

Preceded by the Air Pollution Control Act of 1955, which established air pollution as a danger to public health and welfare, in 1963, the first in a series of

${ }^{17}$ (IBID) 
Clean Air Acts was enacted into law. ${ }^{18}$ These were the first laws specifically bearing the name "clean air", which recognized the growing issue of air pollution and that automobile exhaust emissions were harmful to the environment. Other clean air acts that followed include:

1963 Air Quality Act standards enacted to set standards for pollution reduction.

1970 Clean Air Act identifies and sets standards for six pollutants requiring control.

1977 Clean Air Act Amendments remove grandfathered polluters from exemption.

1990 Clean Air Act Amendments control acid rain and prohibit lead in fuel.

Between 1963 and 1990 these Acts would complicate gasoline refining and remove lead from fuel. ${ }^{19}$ In addition to outlawing lead from gasoline, as it had been found harmful to health, the Clean Air Acts also required oxygenation of gasoline in order to make it burn more cleanly, thereby reducing air pollution. Both ethanol and MTBE (Methyl tert-butyl ether) are acceptable anti-knock additives (a requirement for modern engines) and oxygenates. MTBE can be transported by pipeline where ethanol cannot because it is corrosive and consequently is moved primarily by rail tank cars. Those unique transportation costs along with significant government subsidies reduced the economic attractiveness of ethanol production. ${ }^{20}$ Consequently MTBE was preferred over ethanol as an anti-knock and oxygenate compound added to gasoline. With this

${ }^{18}$ (Environmental Defense Fund, 2006)

19 (IBID)

${ }^{20}$ (Creagh, 1998) 
choice industry and government collectively made a public health policy mistake. As a result of the Clean Air Acts, MTBE would remain the additive of choice for anti-knock and oxygenation after 1979 into the 1980's as a lead ban took effect nationally. Yet just as quickly as it had become the additive of choice, MTBE became an environmental and public health nightmare.

The 1990 Clean Air Act amendments required increased oxygenates in gasoline for air quality improvements. By 1992 MTBE was in widespread use to meet EPA requirements. At this time data became available indicating that MTBE was contaminating ground water supplies in various parts of the United States. ${ }^{21}$ By 2005 refiners were discontinuing the use of MTBE as they faced hundreds of lawsuits from the public alleging harmful health issues as a result of MTBE additives. Under the Energy Policy Act of 2005 Federal mandate no longer required refiners to oxygenate their gasoline. This legislation also removed the existing liability shield exposing refiners to potential lawsuits which further encouraged them to discontinue MTBE production. ${ }^{22}$

Public debate and policy responses to public health and concerns about environmental damage caused by air pollution have continued through the years from 1963 to the present. While the policy dialogue came to include ethanol as a potentially valuable resource not only for protecting public health, but also as a national security resource, it should be noted that more recently even the clean air

\footnotetext{
${ }^{21}$ (MTBE and Ethanol)

22 (IBID)
} 
and health benefits of ethanol have come into sharp debate. Literature shows that producing ethanol from corn grain can release large amounts of very unhealthful nitrous oxide, a greenhouse gas that is 300 times more potent than carbon dioxide, into the environment. ${ }^{23}$

A very visible and growing concern regarding global warming as a potential environmental disaster, verifiable or not, was permeating much of the Nation's consciousness and legislators were under increasing pressure to respond. In the spring of 2006 a seminal global warming documentary warning that the world was facing a catastrophic future because of manmade greenhouse gas emissions was released by $\mathrm{Al}$ Gore under the title An Inconvenient Truth. ${ }^{24}$ The Academy Award winning documentary received widespread public attention which was not lost on legislators. The magnitude of public attention to the concern over global warming became so substantial during 2006 that Al Gore would be awarded the Nobel Peace Prize in October of 2007 to recognize his efforts to combat the concept. $^{25}$

\footnotetext{
${ }^{23}$ (Doll, 2011)

${ }^{24}$ (An Inconvenient Truth, 2008)

25 (The Nobel Peace Prize , 2007)
} 


\section{Ethanol and national security}

The national security attribute of ethanol arose out of the Arab oil embargo of late 1973 and early 1974. The embargo was a catalyst for a national focus on finding ways to both reduce oil consumption and dependency on oil imports. The earliest mention of ethanol as a significant fuel additive and energy resource in Congressional thinking appears in the spring of 1974 at a Senate Subcommittee on Priorities and Economy hearings chaired by Senator William Proxmire. ${ }^{26}$ Just as the initial oil embargo was coming to a close, Mobil Oil ran a series of national newspaper advertisements which were captioned "Garbage is Not a Smelly Word" wherein the corporation illuminated ethanol as an alternative in the public consciousness. Mobil suggested that an ethanol producing process being developed at the Army's Natick Laboratories in conjunction with Mobil could help reduce U.S. dependence on foreign oil supplies by adding a $10 \%$ to $15 \%$ blend of ethanol to refined gasoline. The thrust of the Mobil Oil testimony before Senator Proxmire was that government funding was necessary to continue their joint ethanol research with the Army. Senator Proxmire stated in the Congressional record that the National Science Foundation was supportive of ethanol research being conducted by the Army and Mobil and that feasibility studies should continue. ${ }^{27}$ It is significant that in the spring of 1974 the price of oil had increased dramatically and caused great economic pain and uncertainty in the U.S. economy. Figure 1 shows the price of oil since 1968.

\footnotetext{
${ }^{26}$ (Proxmire, 1974)

27 (IBID)
} 


\section{Figure 1 Nominal Real Oil Prices 1968-2006 ${ }^{28}$}

\section{Imported Costs}

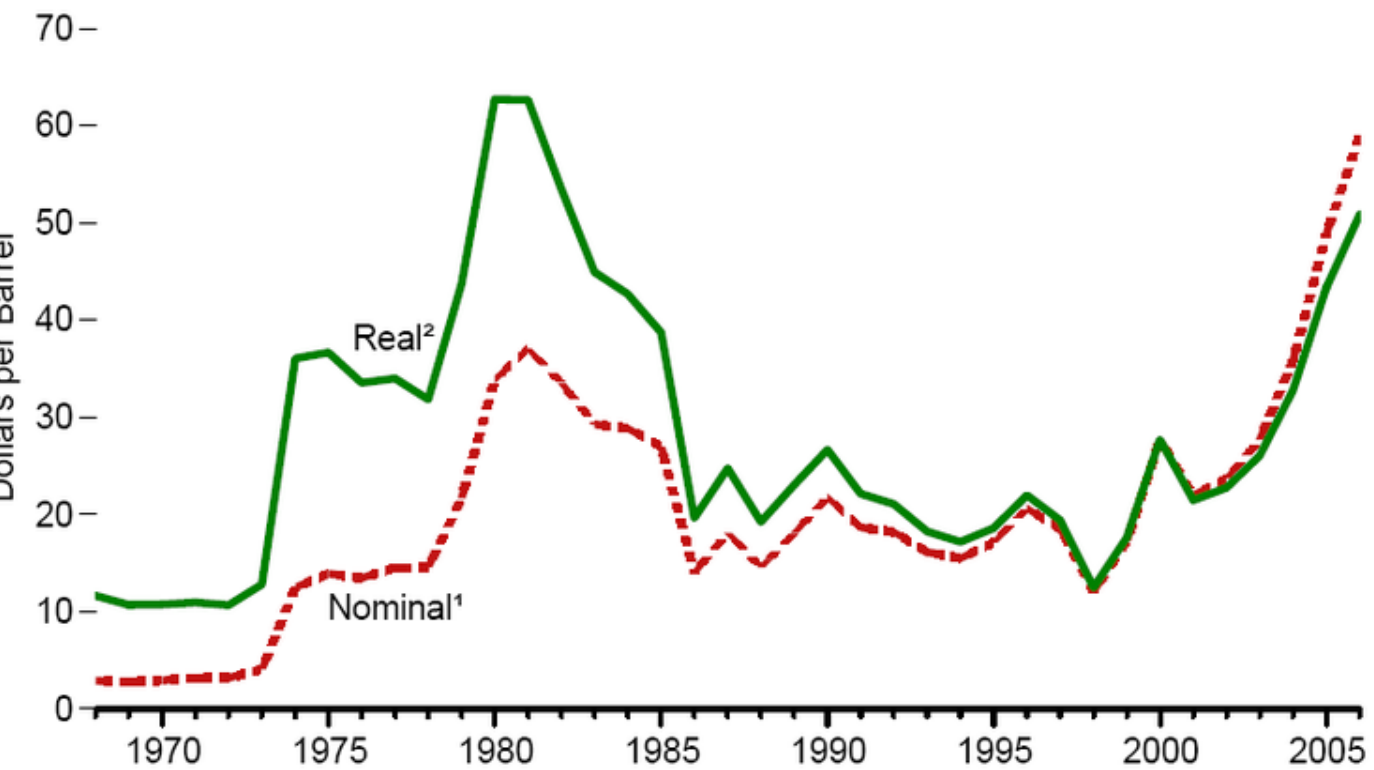

It is against this background of oil shortages and price increases that corporations such as Mobil and others solicited the Federal government for research dollars and generated a national focus on ending or reducing foreign oil imports with ethanol as an alternative fuel source.

From the Arab Oil embargo of 1973 through the present, there has been a progression of policy legislation which has presented ethanol as a major factor in reducing U.S. dependence on foreign imports of oil, improving American national security in an economically beneficial manner for the taxpayer and contributing to environmental goals. Ethanol was presented as a major part of the solution to increasing dependence on imported oil supplies, which were subject to political disruption with severe economic consequences for the United States. If ethanol

${ }^{28}$ (Oilism, 2007) 
was economically viable and could be produced domestically it would be in the national interest to promote an "ethanol policy." The initial expectations were that a $10 \%$ or $15 \%$ measure of ethanol could be blended into refined gasoline "stretching" oil supplies accordingly and reducing our dependence on foreign suppliers. Congressional enthusiasm for ethanol policy was heightened because ethanol was presented as having advantages in meeting the requirements of the evolving Clean Air Acts. Eventually Congress enacted legislation which required even more stringent air quality standards. Additionally the Energy Policy Act of 2005 (P.L. 109-58) established a renewable fuels standard (RFS), which required mandated amounts of renewable (read ethanol) fuels to be produced and blended into the national fuel supply. The mandate began at 4 billion gallons in 2006 rising to 7.5 billion gallons in 2012. The Congressional-Executive enthusiasm for these renewable fuels was so intense that in 2007 the Energy Independence and Security Act of 2007 (P.L. 110-140) expanded the RFS, increasing the 2008 requirement to 9.0 billion gallons of renewable fuel and further dramatically easing the requirement to 36 billion gallons in 2022(figure 2 below). As will be shown further into this work, these additional mandates that ethanol be blended into fuel are another significant distortion of the open market pricing of gasoline in that they add a third layer of cost to the American taxpayer by forcing the production and use of ethanol. The first two layers are the 45 cents per gallon tax incentive to producers for ethanol blended with gasoline along with a 54 cents per gallon import tariff precluding the economical importation of lower priced foreign produced ethanol. 
Figure 2 Expanded Renewable Fuels Mandate ${ }^{29}$

\begin{tabular}{|c|c|c|c|c|c|}
\hline Year & $\begin{array}{l}\text { Previous } \\
\text { RFS } \\
\text { (billion } \\
\text { gallons) }\end{array}$ & $\begin{array}{l}\text { Expanded } \\
\text { RFS } \\
\text { (Billion } \\
\text { gallons) }\end{array}$ & $\begin{array}{l}\text { Advanced } \\
\text { Biofuel } \\
\text { Mandate } \\
\text { (billion } \\
\text { gallons) }\end{array}$ & $\begin{array}{l}\text { Cellulosic } \\
\text { Biofuel } \\
\text { Mandate } \\
\text { (billion } \\
\text { gallons) }\end{array}$ & $\begin{array}{l}\text { Biomass- } \\
\text { based } \\
\text { Diesel Fuel } \\
\text { (billion } \\
\text { gallons) }\end{array}$ \\
\hline 2006 & 4.0 & & & & \\
\hline 2007 & 4.7 & & & & \\
\hline 2008 & 5.4 & 9.00 & & & \\
\hline 2009 & 6.1 & 11.10 & 0.60 & & 0.50 \\
\hline 2010 & 6.8 & 12.95 & 0.95 & 0.10 & 0.65 \\
\hline 2011 & 7.4 & 13.95 & 1.35 & 0.25 & 0.80 \\
\hline 2012 & 7.5 & 15.20 & 2.00 & 0.50 & 1.00 \\
\hline 2013 & 7.6 (est.) & 16.55 & 2.75 & 1.00 & 1.00 \\
\hline 2014 & 7.7 (est.) & 18.15 & 3.75 & 1.75 & 1.00 \\
\hline 2015 & 7.8 (est.) & 20.50 & 5.50 & 3.00 & 1.00 \\
\hline 2016 & 7.9 (est.) & 22.25 & 7.25 & 4.25 & 1.00 \\
\hline 2017 & 8.1 (est.) & 24.00 & 9.00 & 5.50 & 1.00 \\
\hline 2018 & 8.2 (est.) & 26.00 & 11.00 & 7.00 & 1.00 \\
\hline 2019 & 8.3 (est.) & 28.00 & 13.00 & 8.50 & 1.00 \\
\hline 2020 & 8.4 (est.) & 30.00 & 15.00 & 10.50 & 1.00 \\
\hline 2021 & 8.4 (est.) & 33.00 & 18.00 & 13.50 & 1.00 \\
\hline 2022 & 8.6 (est.) & 36.00 & 21.00 & 16.00 & 1.00 \\
\hline
\end{tabular}

Ethanol has been widely recognized as an engine fuel with advantages and disadvantages. While it serves as an effective oxygenate and anti-knock additive, it is difficult to transport as it is corrosive and cannot be moved by pipeline. It is produced from organic biomass, primarily corn in the US.

Given that oil and natural gas represent upwards of $7 \%$ of the American economy $^{30}$ for uses as diverse as transportation, plastics manufacturing and electricity generation, the growing mandated presence of ethanol in energy policy represents a significant national economic issue. There has been much debate about the actual economics of ethanol production, such as the issues of water

${ }^{29}$ (Yacobucci, Fuel Ethanol - Background and Public Policy Issues RL33290, 2008)

${ }^{30}$ (PricewaterhouseCoopers, 2009) 
demand to grow additional corn, devoting additional acreage to growing corn, ethanol production driving up corn prices to provide feed to ethanol facilities, possible shortages of grain and resultant food supplies internationally, the efficiency of converting corn to fuel (is more energy produced than input or does the process result in a net energy loss), the quantification of American dependence on foreign sources of oil over the past few decades of growing ethanol production and other ethanol attributes.

Recent decades have seen a robust dialogue about the importance of the U.S. becoming energy independent of foreign oil suppliers. The gas lines in the 1970 's, ${ }^{31}$ even-odd day rationing of fuel purchases, electricity brownouts and rolling blackouts across California, along with a growing population lead to increasing numbers of vehicles and greater demand for fuel and electricity. This has resulted in increasing dependence on foreign sources of energy ${ }^{32}$ even as ethanol production was mandated and subsidized. As this dichotomy persisted, the country experienced profound fluctuations in gasoline price and availability despite policy enactments. As this national energy challenge was being debated, the concept of using ethanol not only as an additive, but as a significant source of fuel came into the discussion.

Proceeding from the ongoing policy deliberation is a national legislative paradigm that has mandated subsidies be paid to ethanol producers (beginning with the

\footnotetext{
31 (Adelman, Winter, 1972-1973)
}

32 (Adkins, April 1973) 
National Energy Act of 1978), ${ }^{33}$ tariffs imposed on ethanol imports (beginning with The Ethanol Import Tariff of 1980) ${ }^{34}$ and increasing quantities of ethanol produced (Energy Policy Act (EPAct) of 2005). ${ }^{35}$ These current policies (45 cents per gallon tax incentive for ethanol blended with gasoline along with a 54 cents per gallon import tariff and annual required gallons of blended ethanol) give significant economic incentives to ethanol producers and corn farmers while penalizing lower cost foreign suppliers, but at what cost and for what reason?

These incentives are an expense to the American taxpayer under the rationale that such policy reduces dependence on foreign oil imports and consequently increases American national security. ${ }^{36}$ These policies may cost the taxpayer as much as 53.6 billion dollars between 2005 and 2015, having already cost over 17 billion dollars between 2005 and 2009. ${ }^{37}$ Despite these enormous costs, outcomes documented in chapter 6 show that the American economy and agricultural sector is no longer capable of meeting the legislated mandates for ethanol production and use, which indicates the life cycle of ethanol policy is coming to an end.

\footnotetext{
${ }^{33}$ (Duffield, 2006)

${ }^{34}$ (MacDonald, 2004)

${ }^{35}$ (Schnepf, 2010)

${ }^{36}$ (Bryce, 2010)

37 (Cox, 2010)
} 


\section{Figure 3}

\section{Direct Ethanol Taxpayer Costs ${ }^{38}$}

\begin{tabular}{c|c|c|c}
\hline Year & $\begin{array}{c}\text { ETHANOL } \\
\text { PRODUCTION } \\
\text { (MHLION GALLONS) }\end{array}$ & $\begin{array}{c}\text { SUBSIDY } \\
\text { (CENTS PER } \\
\text { GALLON) }\end{array}$ & $\begin{array}{c}\text { COST TO TAX- } \\
\text { PAYER } \\
\text { (BILLIONS) }\end{array}$ \\
\hline 2005 & 3.904 & 51 & $\$ 1.991$ \\
\hline 2006 & 4.855 & 51 & $\$ 2.476$ \\
\hline 2007 & 6.500 & 51 & $\$ 3.315$ \\
\hline 2008 & 9.000 & 45 & $\$ 4.590$ \\
\hline 2009 & 10.600 & 45 & $\$ 4.770$ \\
\hline 2010 & $12.000^{*}$ & 45 & $\$ 5.670^{*}$ \\
\hline 2011 & $12.600^{*}$ & 45 & $\$ 5.940^{*}$ \\
\hline 2012 & $13.200^{*}$ & 45 & $\$ 6.210^{*}$ \\
\hline 2013 & $13.800^{*}$ & 45 & $\$ 6.480^{*}$ \\
\hline 2014 & $14.400^{*}$ & 45 & $\$ 6.750^{*}$ \\
\hline 2015 & $15.000^{*}$ & & $\$ 592$ \\
\hline Total & 115.859 & Data from 2010 to 2015 are based on the levels of ethanol production & \\
\hline
\end{tabular}

*Note: Data from 2010 to 2015 are based on the levels of ethanol production required by the 2007 Energy Independence and Security Act.

As significant as the above expense to the American taxpayer appears, the data presented by Cox and Hug is only for what they calculate as direct costs. When other real, but indirect costs to the taxpayer and the national economy are included, the total cost of ethanol subsidization becomes enormous. In his work, Glozer presents a variety of additional costs enumerated in figure 4 below. $^{39}$ These additional transfers of wealth from taxpayers and consumers to corn growers and ethanol producers increase the total costs to the nation's economy over a ten year period (2008-2017) by upwards of over 500 billion dollars.

\footnotetext{
38 (Cox, 2010)

39 (Glozer, 2011)
} 


\section{Figure 4}

\section{Direct and Indirect Ethanol Taxpayer and Consumer Costs ${ }^{40}$}

[All \$ in current \$ (not adjusted for inflation) to nearest tenth billion]

$$
2008-2017
$$

\section{Federal Budget-Cost Increases}

Department of Agriculture and Energy plus the

Environmental Protection Agency

-- Various production-related subsidies paid to corn and

36.4 soybean producers

-- Subsidized crop insurance

-- Disaster payments to corn and soybean producers

-- Estimated costs of a strategic ethanol reserve of 3 billion

gallons to mitigate corn production shortfalls due to floods and drought

Department of Treasury

-- Tax revenues forgone because of the tax credit for ethanol blending in gasoline

Total estimated federal taxpayer costs:

\begin{tabular}{lr} 
Consumer Cost Increases & \\
Mileage penalty - lower BTU ethanol blend & 115.0 \\
Increase in food costs & 198.1 \\
Increase in domestic ethanol pricing resulting from fee on & 35.2 \\
imported ethanol & \\
Increase in vehicle costs for flexible-fuel vehicle upgrade & 15.4 \\
Total estimated consumer costs: & $\$ 363.70$ \\
& \\
Grand Total of Taxpayer and Consumer Costs: & $\$ 506.70$ \\
\hline
\end{tabular}

As this dissertation's literature review shows, there is intense debate concerning the economic effectiveness of ethanol policy and whether or not it has achieved its intended objective of reducing American dependence on foreign oil imports.

\footnotetext{
${ }^{40}$ (Glozer, Corn Ethanol Who - Pays? Who Benefits ?, 2011)
} 
These arguments become germane in an assessment of Congressional deliberative democracy behavior during the past 35 years of ethanol policy development. 


\section{Chapter Two}

\section{Literature Review and Study Approach}

The background and context in chapter one illuminates how from 1978 on a series of legislative acts placed substantial subsidy burdens on the American taxpayer to provide incentives, credits and mandates for the production and use of ethanol. The stated rationale for this legislation lies in reducing U.S. dependence on foreign sources of oil, economically benefitting the American economy, enhancing the environment and strengthening American security. While much discussion has continued about the benefits of ethanol policy over recent decades, the available data and literature show that ethanol policy is a failure according to several metrics. In addition to being neither economically nor environmentally beneficial, it will be shown that over its lifespan ethanol policy never achieved its intended goals in relation to energy independence nor has it increased national security. In examining the failure of ethanol policy, the connection between political contributions, policy formation, and the actual outcomes of the enacted policies does not appear to have been addressed in the literature. Given that ethanol policy was influenced by a variety of constituents including "Big Oil", environmental organizations, trade groups as well as Presidential involvement, their contributions to the debate has been significant, although not always valuable. In addition to the literature that debates the costs and benefits of ethanol production, there is literature that indicates the significant influence of a very small number of individuals, companies and organizations upon the development of national ethanol policy. A related branch of literature documents the size and 
scope of political contributions to those legislators that have championed and voted for ethanol policy. As there are very large economic and social costs of ongoing ethanol subsidies and mandates, the exploration of such a nexus is illuminating, valuable and adds to the literature in a previously unaddressed manner.

The corpus of literature surrounding ethanol legislation and policy development from its inception to decline is largely bifurcated between those for and against subsidizing ethanol and what its value is in the Nation's energy portfolio. That literature presents several conflicting points of view regarding ethanol policy.

The early literature of the field was born out of the Arab Oil embargo of 1973-74 and came most visibly from a concerned Congress that saw America dangerously dependent on foreign sources of oil that were easily disrupted with harmful consequences to the national economy. By the spring of 1974 the Senate was considering actions to respond to the oil embargo. Senator William Proxmire publically encouraged the use of biomass and renewable fuels (ethanol) in his Senate Subcommittee on Priorities and Economy hearings. ${ }^{41}$ By the late 1970's a number of energy laws had been enacted. The Energy Tax Act of 1978 began a series of mandated policies to encourage and incentivize the production of ethanol. The initial $\$ 0.40$ per gallon ethanol tax exemption from the $\$ 0.04$ cents per gallon Federal fuel excise tax increased over the years to the current 2011 tax exemption of $\$ 0.45$ per gallon of ethanol in the form of a Volumetric Ethanol

${ }^{41}$ (Proxmire, 1974) 
Excise Tax Credit (VEETC). The tax exemption combines with a continuing $\$ 0.54$ cents per gallon tariff on ethanol imports to subsidize and protect the domestic ethanol industry. ${ }^{42}$

Out of this continuum of legislation and policy action emerged ongoing intense academic debate concerning the efficacy of ethanol policy. It appears that in many cases, not surprisingly, those authors' perspectives seem to correlate with the sources of their funding.

Pivotal in most literature addressing the economics of ethanol is the concept of net energy value (NEV). Argument concerning the relative benefit of extracting ethanol from corn serves to either support ethanol production or refute the value of doing so. The formula for net energy value for producing ethanol from corn is quite direct: does $\mathrm{X}$ amount of energy (corn) input into the conversion process produce $\mathrm{X}$ plus or $\mathrm{X}$ minus energy? Authors cited, while using statistical methods of analysis, present widely differing conclusions on the NEV of ethanol production. The effect of these differences is critical to conclusions in this research.

An early exploration of ethanol NEV which supported ethanol policy was conducted by Shapouri and Duffield ${ }^{43}$ concluded that NEV was quite high, in the order of 1.65. Although widely cited in academic literature, Shapouri and Duffield

\footnotetext{
${ }^{42}$ (Babcock B. A., 2010)
}

${ }^{43}$ (Shapouri \& Duffield, 2002) 
are researchers at the Department of Agriculture, amongst several Federal agencies charged with, and funded to, extoll the virtues of ethanol production. Subsequent to this work Pimentel \& Patzek $^{44}$ (from Cornell and UC Berkeley respectively) present quite different findings in concluding that NEV is very negative and makes ethanol production uneconomical. Pimentel and Patzek mathematically dispute Shapouri's conclusion that ethanol NEV's are positive, let alone as high as 1.65 .

Indicative of continuing interest and controversy regarding NEV, Dennis Keeney of Iowa State University, a Professor in the Department of Agronomy and Agriculture and Biosystems Engineering discusses the debate over NEV. While he believes and calculates that the NEV equation is slightly positive, he points out that there are those such as Pimentel $\& \operatorname{Patzek}^{45}$ who are equally sure that NEV is just the opposite. Adding additional understanding to his analysis in "Ethanol USA " ${ }^{, 46}$ Keeney weaves fine lines recognizing the connection between American taxpayers, Dwayne Andreas and the Archer-Daniels-Midland Company in establishing ethanol policy as a unique profit center for his company flowing from the Federal trough.

The mid-2000's saw collaboration between universities and federal agencies to prove the viability of ethanol as an alternative fuel source. The first of several

\footnotetext{
44 (Pimentel, Ethanol Fuels: Energy Balance, Economics, , 2003)

${ }^{45}$ (Pimentel \& Patzek, Ethanol Production Using Corn, Switchgrass and Wood; Biodiesel Using Soybean and Sunflower, 2005)

${ }^{46}$ (Keeney, 2008)
} 
studies commonly referred to as "billion ton" articles purporting to show the efficacy of ethanol, was originally conducted in collaboration between several federal agencies under the direction of the Department of Energy. The Environmental Sciences Division of the Oak Ridge National Laboratory (DOE), the Forest Service (USDA) and the Agricultural Research Service (USDA) were the primary collaborators. Their initial report, "Biomass as Feedstock for a Bioenergy and Bioproducts industry: The Technical Feasibility of a Billion-Ton Annual Supply "47 was published in April of 2005 and informed the debate about the potential of renewable biofuels. The literature presented that the United States had readily available resources of biomass on the order of a billion tons per year. The authors hypothesized that such resources could meet the goal of producing approximately 60 billion gallons of ethanol from biomass replacing $30 \%$ of the petroleum used for transportation by $2030 .{ }^{48}$

In 2006 the Department of Energy coined the $\mathbf{3 0 x 3 0}$ acronym from the reports data. ${ }^{49}$ In November of 2006 the University of Tennessee published a study which proposed that the United States could domestically produce $25 \%$ of its total energy requirements by 2025 from biomass renewable resources without disrupting food prices. ${ }^{50}$ Over 100 major corporations and trade groups endorsed the Tennessee $25 \times 25$ study and insured that it was widely circulated through

\footnotetext{
47 (Perlack, Wright, \& Turhollow, 2005)

${ }^{48}$ (Dayton, 2007)

49 (Sims, 2007)

${ }^{50}$ (English \& De La Torre Ugarte, 2006)
} 
Congress. ${ }^{51}$ The report assumed that cellulosic ethanol would be economically competitive and widely available by 2012 even though corn-based ethanol was only marginally competitive with oil based gasoline and required large federal subsidies and high oil prices. ${ }^{52}$ These published studies, focusing on the seemingly vast availability of agricultural resources, were optimistic projections that legislators and the President could cite during 2007 as reliable foundations for the dramatic new Renewable Fuels Standard in H.R. 6. Unfortunately the studies were later shown to have concentrated primarily on cropland sustainability and did not adequately address salient economic and environmental considerations that would later prove much of the study's conclusions faulty.

Wallace E. Tyner at Purdue University (Department of Agricultural Economics) modeled the future economics of ethanol policy ${ }^{53}$ showing the relationship between increasing ethanol production as a result of increasing mandates and escalating corn prices that might result in political/consumer resistance to higher food prices. He contrasts this resistance with policy responses to an increasingly profitable ethanol industry supported by high oil prices and increasingly valuable tax and production subsidies. He concludes that the benefits of ethanol production in corn states will be limited by rising corn prices. The missing piece in these articles is that they present from the perspective of a corn state university highlighting their perspective that ethanol is both economically beneficial to farm

\footnotetext{
${ }^{51}$ (Glozer, 2011) pp. 63

52 (IBID)

${ }^{53}$ (Tyner, 2007)
} 
states agricultural interests and helpful in achieving less dependence on imports of foreign oil.

In their work "Economics of Current and Future Biofuels",54 Tao and Aden present detailed financial models of the potential costs of ethanol production as well as other biofuels. Although they point out that ethanol production may well be limited to no more than 15 billion gallons per year because of upward corn market price pressures, they do not factor into their presentation the Federal mandate under Renewable Fuels Standards that requires the production and use of 36 billion gallons of ethanol by 2022. Additionally, none of the economic impacts of tax subsidization or tariff protection are factored into the models they present. While their widely cited findings taken in isolation appear compelling, the objectivity of their research could be called into question considering that it was done under the auspices of the Department of Energy through the National Renewable Energy Laboratory and subsequently leaves out any data regarding subsidy, tax or political implications which could be the largest component of the economics of ethanol production and use. It is of note that while both Tao and Tyner use common statistical analyses of corn into ethanol for their outcomes; they arrive at different conclusions regarding economic efficiencies.

Babcock and Barr of Iowa State University in 2010 analyzed various scenarios of ethanol efficiencies starting in 2011 by allowing corn and oil prices to vary

\footnotetext{
${ }^{54}$ (Tao \& Aden, 2009)
} 
somewhat. ${ }^{55}$ Their work unintentionally highlights the law of the unexpected; their bench mark price for corn in 2010 was in the $\$ 3.24$ to $\$ 3.75$ per bushel price range depending upon differing modeling scenarios. By January of 2011 corn cost over $\$ 7.00$ per bushel and oil exceeded $\$ 100.00$ per barrel in February, which rendered their conclusions meaningless. Their work suggested that abolishing subsidies and tariffs for ethanol production would save the American taxpayer over 6 billion dollars per year. It is interesting to note that they present their conclusions in terms of taxpayer savings, which marks a departure from an earlier literature's focus on the efficiency of ethanol production. Their conclusions and framing seem informative until the funding source for their work is highlighted: a research grant to Iowa State University from UNICA - the Brazilian Sugarcane Industry Association which is lobbying hard for an end to subsidies and tariffs on ethanol which would dramatically benefit the Brazilian ethanol industry.

These and other articles from the academic community all have various attributes they present while leaving out others, i.e. some will clearly show costs and economics of production with or without subsidies, others will refer to the importance of national security yet leave out any discussion of using existing resources for security, some will discuss the problems of rising corn prices upon the world and American consumer because of vastly increased acreage dedicated to corn crops for ethanol production, and virtually none of the authors address the political office holder cost benefit dynamics nor do they delve significantly into the social costs to the taxpayer of ethanol policy, etc. One common defect of the

55 (Babcock B. A., 2010) 
literature regarding economic outcomes is that they look at ethanol in isolation without examining alternatives that might well completely obviate the need for ethanol production and mitigate any concerns about national energy security. What is not discussed is the economic cost of not using domestic oil reserves presently available. Attributes of using those readily available sources of domestic oil and the resulting beneficial Federal economics as well as lifting the burden from the national taxpayer subsidizing ethanol production are completely left out of the literature. While addressing some of these omissions might well be important in enhancing the literature, such efforts are outside the scope of this dissertation.

In addition to the academic literature there is the very visible non-academic think tank literature which approaches ethanol policy in a different manner. Examining think tank literature reveals dozens of articles written over the past several years that with only one apparent major exception appear to read like advocacy essays. This think tank literature presents in a similar manner to the academic articles in that different articles highlight particular perspectives while strategically omitting others i.e. farmers benefits vs. taxpayer costs, national security vs. reducing oil imports, environmental safeguards vs. consumer costs etc. 
One apparent exception was published by the Cato Institute in 1995 and written by James Bovard. ${ }^{56}$ This article presents in depth the history of ethanol policy development and illuminates the synergistic connection between Dwayne Andreas, the Archer Daniels Midlands Company, tactical political contributions and the enactment of Federal ethanol energy policy. Bovard is unique in that he presents the chronology of tactical political contributions by Dwayne Andreas to specific elected officials and ties them to public statements by Andreas (Chairman of Archer Daniels Midland) that illuminate how and why, he believes, ADM almost single-handedly proposed, established and paid (through political contributions) for a national ethanol policy uniquely constructed to create massive ongoing profits for $\mathrm{ADM}$ at taxpayers' expense. It is noteworthy that the most extensive literature analysis documenting Andreas and ADM was published by a "Think Tank," rather than in traditional academic sources. ${ }^{57}$ This essay presents in detail Bovard's belief that self-serving political behavior (not deliberative democracy) regarding ethanol policy dominates the legislative process. His explanations of how the politics of ethanol operate are largely neglected or simply assumed away in the balance of literature.

Bovard $^{58}$ documents the contributions to corn state legislators to suggest a connection between those contributions and the development of ethanol policy. He was one of the first to present inferences between donations and policy outcomes that sporadically appear in the literature. While Bovard presented his

\footnotetext{
56 (Bovard, 1995)

57 (IBID)

58 IBID
} 
observations concerning the political dynamics of ethanol politics and contributions in 1995, it wasn't until 2008 that Keeney combined the element of ethanol economic efficiencies with the concept of economic political behavior within academic literature. Although Bovard's observations of campaign finance influence initially appear plausible, chapters four and five discuss a more subtle, yet significant, explanation of legislative behavior that occurred.

Recently (2011) Ken Glozer contributed unique insight and perspective to the history of ethanol policy formation in his publication, "Corn Ethanol: Who Pays? Who Benefits?"59 The author presents his view that the ethanol policy as enacted over recent decades has "had little to do with energy and a lot to do with wealth transfer." His work offers a substantive analysis of data which shows that all but one of many claims made by ethanol advocates at each juncture of legislative action were factually unsupportable after various ethanol policies were enacted. The only verifiable claim that Glozer could substantiate through his research was that "the policy (ethanol) does create jobs in rural areas, mainly the top ten (ethanol) producing states. All other claims investigated were found to be questionable or not correct." Glozer takes the work of Cox and Hug further. ${ }^{60}$ Their original article documents the direct costs of ethanol subsidies clearly, (see chart page 17) but Glozer skillfully adds a variety of identifiable indirect costs which significantly increase the total costs of ethanol production for the taxpayer and consumer (see chart page 18). This addition to the literature is distinctively

\footnotetext{
${ }^{59}$ (Glozer, Corn Ethanol Who - Pays? Who Benefits ?, 2011)

60 (Cox \& Hug, Driving Under The Influence, EWG, June 2010)
} 
and particularly valuable in that it was written by an Executive branch official that as a Senior Executive served six Presidents in the White House Office of Management and Budget focused almost exclusively on national energy policy for over 30 years. Glozer was a key participant in the formation of every Presidential National Energy Plan starting with the Presidency of Richard Nixon. His work is scholarly, well researched and academically informed as well as being rigorously documented. The "value added" attribute of his contribution to the literature is that he was a participant pivotally involved in the development of energy policy. Interviews with the author were invaluable to the research of this dissertation and are presented in the discussions in Chapter Six. ${ }^{61}$

While there has been much written in several distinct areas focused on ethanol economics and some literature on the politics of ethanol policy, there hasn't been an exploration of the framework and process showing how ethanol policy throughout its life cycle as a national priority was conducted through a deliberative democracy construct and debate. Examining ethanol policy and the debates surrounding its life cycle through the lens of a deliberative democracy framework reveal insights into a process that traverses energy, agriculture, politics and national security over several decades. This work shows how the political system has addressed this complex issue over time and evaluates its outcomes.

\footnotetext{
${ }^{61}$ (Glozer, Retired Associate Deputy Director, White House Office of Management and Budget, 2011) See chapter six
} 
Using this line of inquiry this dissertation asks, examines and answers the following question:

Has the ethanol energy policy of the United States, as outlined in legislative actions, requiring subsidies, mandates and increased consumer costs from taxpayers, been reflective of a nationally deliberatively democratic process that after taking into account the input and influence of various competing viewpoints, turned out to be a beneficial national policy? Consequently have the policy outcomes of the legislative stakeholders matched the stated intentions of those involved in the deliberative debate that enacted it or where have those objectives not been met?

These questions concerning the deliberatively democratic creation of United States ethanol policy are important inasmuch as energy production and use in America is a significant part of the national economy, an important element of national security and environmental policy. Research that can contribute to understanding the creation of a policy that in large part failed can inform future policy deliberation in such diverse areas as agriculture, national security and energy policy while illuminating how and why such public policy was made. 


\section{Methodology and Design}

This dissertation is constructed as a case study based on an analysis of relevant literature from the 1970's through the present to address the central research question regarding the development and efficacy of ethanol policy. How Public Laws were enacted leading the United States from a zero base of ethanol production in the late 1970 's to a 36 billion gallon mandate by 2022 is part of this analysis. The areas investigated, studied and documented include: Congressional hearings relative to ethanol with analysis of witness testimony, analysis of lobbying organizations positions and comments made before such hearings, as well as publically, corporations in the production of ethanol, energy providers and agricultural associations making comments to Congress, or publically, advocating particular positions either pro or against ethanol. Data on energy resources, economic behavior and deliberative behavior is researched, developed and organized to articulate a change over time explanation of how ethanol policy, although changing over recent years, has persisted in spite of demonstrated flaws. Significant think tank/national press articles published over the history of ethanol politics have been researched for relevant data or insights to illuminate this study.

The case study approach was selected for this research as most appropriate to thoroughly and clearly examine a political behavioral circumstance that does not lend itself directly to a quantitative or statistical inquiry; in this case the genesis, evolution and outcome of a national ethanol public policy. This work explores a "how" or "why" assessment of a specific political behavior. As Yin presents in his 
text on case study research, "the more a question seeks to explain some present circumstance (e.g., "how or why some social (political) phenomenon works), the more that the case study method will be relevant."62 The research conducted in this work was not an accumulation of empirical and numerical data that could be statistically quantified to arrive at a predictable conclusion. Rather the research was into the "holistic and meaningful characteristics of real life events," 63 in this case the life cycle of a political and policy paradigm. The inquiry conducted for this research was directed at understanding complex political and social phenomena that did not have the necessary attributes for quantitative measurement, hence the desirability of the case study method approach.

While the primary construct of this work is as a case study and that choice explained, the examination would be incomplete without significant quantitative substantiation and support as well. As is presented in the following chapters, there are a variety of underlying metrics which are informative to the conclusions reached in this case study such as: measurements of numbers of bills introduced, committees considering bills, numbers of hearings regarding policies being considered, numbers of laws enacted, majority and minority party figures, dollars and cents costs of policy proposals as well as statistical outcomes of enacted policies along with a variety of measures of several deliberative democracy attributes. While these substantial quantitative data cannot support or predict

\footnotetext{
62 (Yin, 2009) pp. 4

63 (IBID)
} 
deliberative democracy outcomes alone nor explain the subjective characteristics of a complex political and policy paradigm, such data is supportively informative to the analytical process.

The work of Kuhn in his "The Structure of Scientific Revolutions",64 contributes supportive insight into how an ethanol political and policy life cycle could fail as dramatically as this work concludes in chapter six. Supporting Madison, Bessette and other's presentation of a logically based deliberative democracy framework it would be expected that over time legislators would in their substantive considerations on the merits of public policy examine outcomes and respond with beneficial responses as necessary. Kuhn presents a cycle of normal science that reflects on history, looks at anomalies, recognizes observational and conceptual changes that require explanation and new thinking, recognizes crisis and when faced with a paradigm that is no longer satisfactory for the circumstances at hand, responds with a new successful paradigm. What this dissertation presents is that throughout the life cycle of the ethanol policy deliberative democracy policy formation paradigm, legislators did not follow any construct of "normal science" and responded repeatedly at virtually every inflection point in a non-beneficial manner leading to disastrous outcomes.

Case study data and exploration is informed by applying a deliberative democracy framework overlay to examine how and why ethanol policy evolved as it has and

${ }^{64}$ (Kuhn, 1962) 
how it has met or fallen short of stakeholder's expectations. Sources elucidating the deliberative democracy framework and lens are referenced in the examination of how ethanol policy evolved through the legislative process.

The concept of deliberative democracy was conceived in 1980 by Joseph Bessette in an AEI article ${ }^{65}$ and further refined in his 1994 work "The Mild Voice of Reason." ${ }^{66}$ The core attribute of "deliberation" in the deliberative democracy framework is that legislators are "simply reasoning on the merits of public policy" and "seriously considering substantive information which so defined states the proximate aim of a deliberative process is the conferral of some public good or benefit. "67 Built upon the foundation of Madison's Federalist $10^{68}$ is this concept of refining and enlarging the public's views so that the best possible outcomes will be realized for the national, not sectarian good. This concept suggests that at the Federal level the process of numerous legislators being elected from the states, but aggregated at the national level, would lead to a consensus' benefitting the country as a whole. As Bessette points out from Federalist 10; if the number and variety of groups is sufficiently great, then a "coalition of a majority of the whole society could seldom take place on any other principles than those of justice and the general good."69 Upon this foundational definition Bessette and others ${ }^{70,71,72,73,74,75}$ have presented methods by which effective

\footnotetext{
65 (Bessette J. M., 1980)

${ }^{66}$ (Bessette J. M., 1994)

67 (IBID) pp. 46

${ }^{68}$ (Madison)

${ }^{69}$ (IBID)

${ }^{70}$ (Goldwin, 1980)

71 (Gutman, 2004)
} 
measurement of deliberation in policy creation may be conducted. Several measurements are presented to assess the process creating ethanol policy to examine if it has been genuinely deliberative and/or beneficial. The difference between "deliberative" and "political" policy formation needs to be articulated first and can be presented thus: deliberative consideration includes three basic elements; information, arguments and persuasion, while political consideration may include three different aspects; logrolling, compromise and side-payments. As data was gathered from the legislative and other records it was examined to discern if in hearings, conferences and debate as the policies were being formulated, the deliberation appeared deliberative or political. To the degree identifiable, the general sense of the deliberative/political balance, as articulated by Bessette, is presented. A matrix of several clearly identifiable and measurable attributes of deliberation is presented for measuring the collected research data -figure 5 .

Research into the evolution of ethanol policy formation is analyzed for the presence of deliberative democracy and reveals that a significant series of hearings, testimony, bills and debate culminated in the enactment of several noteworthy laws formulating national ethanol strategy. It is these activities that were researched to determine the degree to which deliberative democracy attributes could be ascribed.

\footnotetext{
72 (Schroedel, 1994)

73 (Maass, 1983)

74 (Fishkin J. S., 2003)

75 (Mucciaroni, 2006)
} 
Given the national economic and security consequences outcomes of this several decades long process, this research shows a most problematic conclusion to the question of whether or not deliberative democracy concepts were in operation as these policies were crafted.

A central methodology of this research is a chronological study of legislative history and resulting laws enacted that resulted from ethanol policy examination by Congress over time. As presented in chapter one background, ethanol did not significantly enter Congressional lexicon until the 1970's. After the Arab oil embargo of 1973 the questions of energy self-sufficiency, conservation and energy security became widely discussed by legislators. Subsequently, ethanol incentives, mandates, tax preferences and other regulations appeared frequently in Congressional records.

A foundation of assessing the deliberative democracy attributes of policy formation was identifying and documenting the legislative activities surrounding the enactment of a variety of laws which encouraged the production and sale of ethanol. While there have been hundreds of bills introduced since 1978 in both chambers of Congress regarding ethanol policy, there have been many fewer that have found their way through committees, hearings and floor debate, presidential scrutiny and signed into law. Many of the provisions that have been relevant to ethanol have been imbedded in legislation that at first glance seems entirely unrelated to energy, let alone ethanol policy. While this is not unusual, it made researching ethanol debate and legislation challenging. The following list is not 
presented as all encompassing, but does include those Acts which have had the greatest effect on producers, growers, taxpayers and consumers. The sample selected is more than adequate to sustain the conclusions of this research.

1978 Energy Tax Act of 1978

1980 Crude Oil Windfall Profit Tax Act

1980 Energy Security Act

1980 Gasohol Competition Act

1980 Omnibus Budget Reconciliation Act

1982 Surface Transportation Assistance Act

1984 Tax Reform Act

1988 Alternative Motor Fuels Act

1990 Customs and Trade Act

1990 Omnibus Budget Reconciliation Act

1990 Clean Air Act Amendments

1992 Energy Policy Tax Act

1993 Omnibus Budget Reconciliation Act

1997 Taxpayer Relief Act

1998 Transportation Equity Act $21^{\text {st }}$ Century

1998Agricultural Research, Extension, and Education Reform Act

1998 Internal Revenue Service Restructuring and Reform Act

2000 Agriculture Risk Protection Act
Public Law 95-618

Public Law 96-223

Public Law 96-294

Public Law 96-493

Public Law 96-499

Public Law 97-424

Public Law 98-369

Public Law 100-494

Public Law 101-382

Public Law 101-508

Public Law 101-549

Public Law 102-486

Public Law 103-66

Public Law 105-34

Public Law 105-178

Public Law 105-185

Public Law 105-206

Public Law 106-224 
2002 Agriculture, Rural Development, Food Public Law 107-76

\& Drug Administration, \& Related Agencies Appropriations Act

2004 American Jobs Creation Act

Public Law 108-357

2005 Energy Policy Act

Public Law 109-58

2005 Safe, Accountable, Flexible, Efficient

Public Law 109-59

Transportation Equity Act

2006 National Defense Authorization Act

Public Law 109-63

2006 Tax Relief and Heath Care Act

Public Law 109-432

2007 Independence and Security Act

Public Law 110-140

2008 Food, Conservation and Energy Act

Public Law 110-234

2007 Paul Wellstone Mental Health and

Public Law 110-343

Addiction Equity Act

2008 Food, Conservation and Energy Act

Public Law 110-246

2010Tax Relief, Unemployment Insurance

Public Law 111-312

Reauthorization and Job Creation Act

The laws presented above examined can be categorized as follows:

10 budget and/or tax

9 energy

4 transportation

3 agriculture

3 food

3 environment/conservation

2 defense/security

2 employment 
1 customs and trade

To assess the degree to which deliberative democracy behavior is present in the analysis of ethanol policy development, several attributes of the Congressional process were identified and used as filters to measure Congressional deliberation. It is important to show that these Congressional attributes, when defined, had different definitions depending upon whether they were presented as political explanations or deliberative explanations. It is these different perceptions of deliberation that require a more detailed and nuanced examination of the record to determine if actual deliberative democracy occurred, or something else, during policy development. The comparisons used for measurements shown below are based upon the work of Bessette presented in $1994 .^{76}$

${ }^{76}$ (Bessette, 1994) 


\section{Figure 5}

\section{Examples of differences between political and deliberative Congressional perspectives $^{77}$}

\begin{tabular}{|c|c|c|}
\hline Issue or Characteristic & Political Explanation & Deliberative Explanation \\
\hline
\end{tabular}

\begin{tabular}{|c|c|c|}
\hline $\begin{array}{c}\text { Function of committee } \\
\text { hearings }\end{array}$ & $\begin{array}{l}\text { To publicize issues in order } \\
\text { to mobilize support outside } \\
\text { Congress }\end{array}$ & $\begin{array}{c}\text { To elicit the information } \\
\text { and arguments } \\
\text { necessary to make } \\
\text { informed judgments }\end{array}$ \\
\hline $\begin{array}{l}\text { Committee dominance in } \\
\text { the legislative process (i.e. } \\
\text { high success on the floor) }\end{array}$ & $\begin{array}{c}\text { An implicit logroll across } \\
\text { committees }\end{array}$ & $\begin{array}{l}\text { Members defer to the } \\
\text { judgment of those who } \\
\text { have deliberated fully on } \\
\text { the pending issue }\end{array}$ \\
\hline Function of floor debate & $\begin{array}{l}\text { Merely "pro forma”; or only } \\
\text { tactically significant; or } \\
\text { useful for enhancing } \\
\text { standing with constituents }\end{array}$ & $\begin{array}{l}\text { Final opportunity to hear } \\
\text { the strongest arguments } \\
\text { pro and con; useful also } \\
\text { as an information source } \\
\text { regarding the contents of } \\
\text { complex bills. }\end{array}$ \\
\hline $\begin{array}{l}\text { Influence of committee and } \\
\text { party leaders }\end{array}$ & $\begin{array}{l}\text { Control over resources } \\
\text { and/or parliamentary } \\
\text { procedures enhances } \\
\text { bargaining opportunities }\end{array}$ & $\begin{array}{l}\text { Members of Congress } \\
\text { defer to individuals of } \\
\text { sound judgment; leaders } \\
\text { persuade others through } \\
\text { rational argument }\end{array}$ \\
\hline $\begin{array}{l}\text { Role of subgroups, such as } \\
\text { state delegations or } \\
\text { ideological groups }\end{array}$ & $\begin{array}{l}\text { Tactically advantageous for } \\
\text { coordinating the actions of } \\
\text { like-minded legislators (e.g. } \\
\text { maximizing attendance on } \\
\text { key votes) }\end{array}$ & $\begin{array}{l}\text { Facilitates collective } \\
\text { reasoning about } \\
\text { common concerns }\end{array}$ \\
\hline Influence of lobbyists & $\begin{array}{l}\text { Ability to influence votes; } \\
\text { source of campaign funds; } \\
\text { employment for retired } \\
\text { legislators; bribery }\end{array}$ & $\begin{array}{l}\text { Source of highly } \\
\text { relevant information and } \\
\text { arguments }\end{array}$ \\
\hline $\begin{array}{l}\text { Influence of the executive } \\
\text { branch }\end{array}$ & $\begin{array}{l}\text { Possesses vast resources with } \\
\text { which to bargain for support } \\
\text { within Congress }\end{array}$ & $\begin{array}{c}\text { Uses its extensive } \\
\text { information resources to } \\
\text { persuade legislators of } \\
\text { the merits of its } \\
\text { proposals }\end{array}$ \\
\hline
\end{tabular}

77 (Bessette, 1994) 
As also documented in the following chapters, analysis of the above enumerated deliberative measurements is only a partial answer to the research question posed. The outcome of ethanol policy formation must be measured against the analytical conclusions evaluating the deliberative democracy legislative process. As the research shows, even if in partial or large part, a deliberative democracy process appears to have been followed, but the policy outcomes can be shown to have been detrimental and not beneficial to the nation as a whole, deliberative democracy cannot be shown to have been adequately transacted during the democratic process of policy formation.

Better explanations for understanding ethanol policy can be developed by an approach that integrates an analysis of the political process in conjunction with the possible economic failings of ethanol policy. This work closes a gap in understanding how the deliberative democracy theoretical framework as applied to ethanol policy in recent years has performed. The results of this research contribute additional insight to the literature of deliberative democracy. 


\section{Chapter Three}

\section{The Winding Road of Ethanol Legislative History}

The Arab Oil Embargo of late 1973 was a pivotal moment in American legislative history. In a brief moment of time the United States went from being a historically self-sufficient nation for much of its energy requirements to a country that for decades to follow would experience dramatic shortages of oil, fluctuations in price and increasing dependence upon foreign sources of oil. In the "fog of war" mentality that gripped the Congress and Presidents as they wrestled with the serious security and energy challenges facing our economy post 1973, numerous bills, hearings, reports, debates and legislation were brought before Congress, Senate and the President. This chapter examines the evolution of a major component (ethanol) of the legislative answer to the energy crisis that has consumed much policy debate and consideration since the early 1970's.

The chart below outlines both the abrupt reversal between domestic oil production and imports and the increase in oil consumption that began early in the 1970's and persists today. While the Oil Embargo did not in and of itself create the inversion of declining production and rising imports, it occurred almost at the precise time the nation experienced a serious interruption of imported oil. This abrupt change brought about severe economic disruptions and raised concerns over national security. When faced with this challenge to energy resources, how did the American legislative and executive branches respond? While the ethanol component of energy might well have been a small element in the larger spectrum 
of American energy policy, it is revealing to document how the subsidies, tax preferences and mandates enacted over the years has shifted enormous sums of money from the tax payer and consumer to corn growers and ethanol producers while contributing little to solving the nation's energy problems.

Figure 6 US Oil Production and Imports 1920 to $2005^{78}$

\section{US Oil Production and Imports}

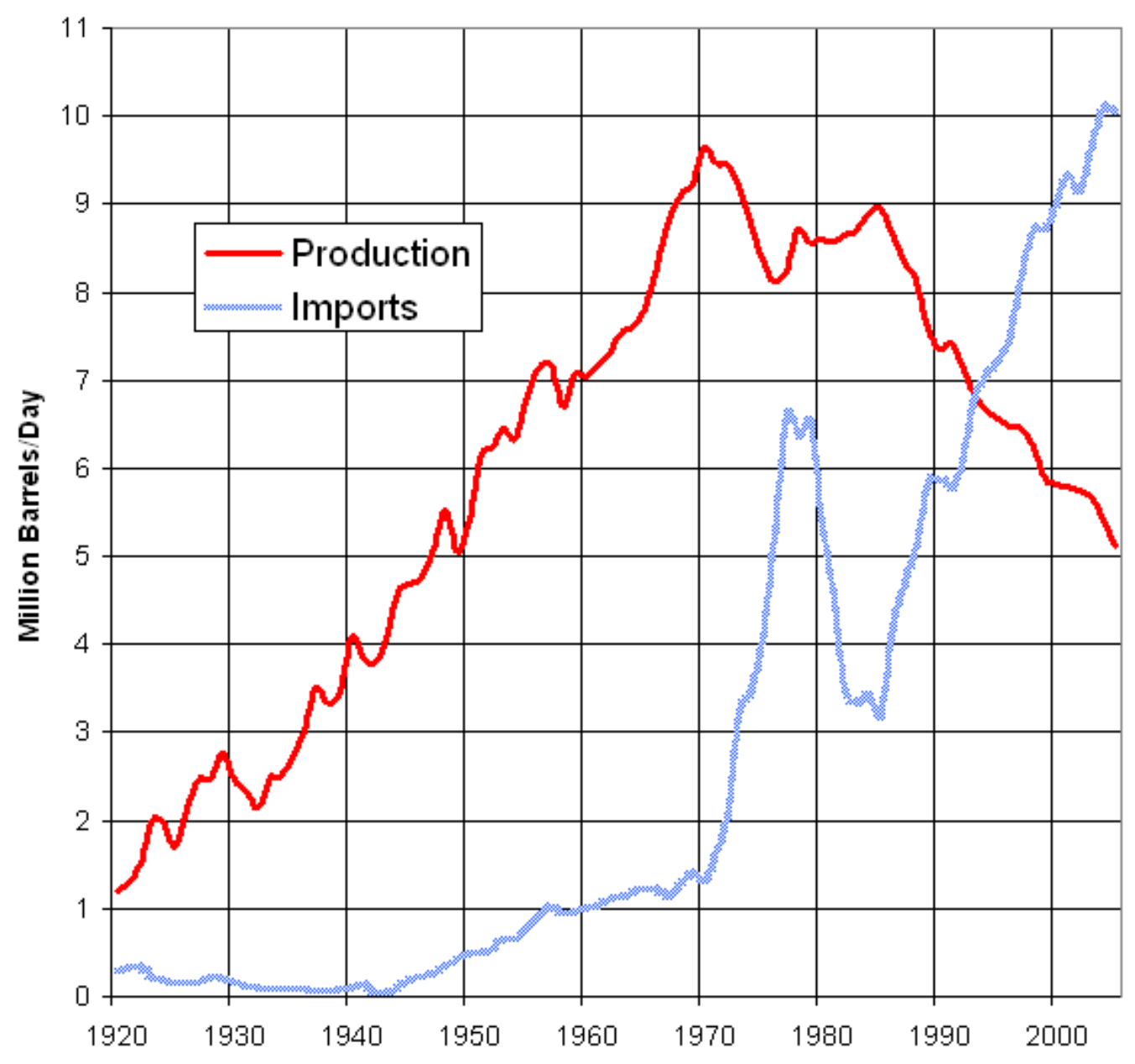

${ }^{78}$ (U.S. Energy Information Administration, August 19th, 2010) 
By some estimates over 500 billion dollars in ethanol subsidies will be transferred from the taxpayer and consumer to ethanol producers, distributors and corn growers in the decade from 2008-2017 as shown in Chapter 1, figure $4 .^{79}$

The deliberative democracy paradigm, if adhered to over the years post 1973, would show a clear record of substantive debate on the merits of proposed laws defining ethanol policy in Congress, Senate and the Executive branch as part of a considered and rational response to the energy challenges facing the United States. Reasoned discussion would, at least in theory, lead to positive outcomes from enacted legislation. As chapter 6 will show, this has not occurred. The basis of deliberation of ethanol policy development within the wider contexts of energy and agricultural policy over time has been concerns about dependence on foreign sources of oil from potentially hostile nations and the consequences of such dependence on the economy and strategic security of America.

In November of 1973 President Nixon addressed the Nation and presented his desire for energy independence. The strategic importance of energy independence has been echoed by every President since (notwithstanding the fact that the goal has never been achieved):

Let us set as our national goal, in the spirit of Apollo, with the determination of the Manhattan Project, that by the end of this decade we will have developed the potential to meet our own energy needs without depending on any foreign energy sources. President Richard Nixon (November 7, 1973)

\footnotetext{
${ }^{79}$ (Glozer, Corn Ethanol Who - Pays? Who Benefits ?, 2011)
} 
I am recommending a plan to make us invulnerable to cutoffs of foreign oil. ... [a] new stand-by emergency programs to achieve the independence we want...

- President Gerald Ford (January 15, 1975)

This intolerable dependence on foreign oil threatens our economic independence and the very security of our nation.

- President Jimmy Carter (July 15, 1979)

We will continue supportive research leading to development of new technologies and more independence from foreign oil.

- President Ronald Reagan (February 18, 1981)

There is no security for the United States in further dependence on foreign oil.

- President George H. Bush (August 18, 1988)

We need a long-term energy strategy to maximize conservation and maximize the development of alternative sources of energy.

- President Bill Clinton (June 28, 2000)

This country can dramatically improve our environment, move beyond a petroleum-based economy, and make our dependence on Middle Eastern oil a thing of the past.

- President George W. Bush (January 31, 2006)

For decades, we have known the days of cheap and accessible oil were numbered.... Now is the moment for this generation to embark on a national mission to unleash America's innovation and seize control of our own destiny.

- President Barack Obama (June 15, 2010) ${ }^{80}$

Since 1973 hundreds of bills have been presented to both houses of Congress addressing energy issues and within them ethanol. How these bills originated, were considered, where they were considered, possibly enacted and by whom is a separate study of legislative complexity. For purposes of this chapter it is useful to observe only that Members and Senators are assigned to various committees and

${ }^{80}$ (Gerholdt, 2010) All Presidential quotations 
subcommittees based on party leadership preferences, the legislators preferences and the minority majority division of power in each chamber.

When a legislator introduces a bill it is assigned (referred) to a committee or subcommittee with the authority to determine whether or not to consider the bill. Chairmen of such committees and subcommittees have significant power to decide the bills that their committees will consider. Appendices informing deliberative democracy measurement attributes for each of the laws documented are included at the end of the work. The process whereby hundreds of bills are synthesized over time into a single bill passed and enacted into law is informative to the deliberative democracy research question and is explored in chapter 4 .

During the decades studied, the political party in the majority in either chamber as well as holding the Presidency changed several times. Such changes in majority power consequently changed committee/subcommittee chairmen and policy priorities. In order to understand how ethanol policy as constructed currently came to be enacted over time, it is necessary to track the evolution of bills that were introduced, by whom, to which committees they were referred and what final attributes were included.

This chapter presents a series of over twenty public laws enacted since 1978 that have directed or affected the development of ethanol policy. Each of these laws was an attempt to achieve, at a moment in time; a national benefit alluded to by the above Presidential statements observing the need for strategic, economic or 
national security. Examination of enacted laws relating to ethanol policy over time show a process whereby shortcomings or policy failures, after being discerned by Congress, are addressed in new legislation devised to correct prior deficiencies. It will be shown in chapter 6 that these attempts are frequently counterproductive and not effective. A more detailed deliberative democracy assessment focusing on 6 of these laws is presented in chapters 4 and 5 .

As this examination focuses on the impact on ethanol production and use through the enactment of laws contributing to ethanol policy development, the following chart is foundational to the study. This study shows that increasing ethanol productive capacity was a pivotal objective of continuing ethanol policy legislation. The United States produced essentially no fuel ethanol prior to 1980. While the 1980s saw legislation laying the foundation for ethanol incentives and mandates, the decade from 1997 to 2007 saw an exponential rise in fuel ethanol production with the Energy Independence and Security Act of 2007 (see later discussion of P.L. 110-140, H.R. 6), mandating further dramatic increases so that United States transportation fuel supply would contain 36 billion gallons of ethanol blended fuel yearly by the year 2022. An ancillary question of this research is then: How did the United States proceed from a zero base of ethanol production in the late 1970 's to a 36 billion gallon mandate by $2022 ?$ 
Figure 7 Fuel Ethanol Production in the United States ${ }^{81}$

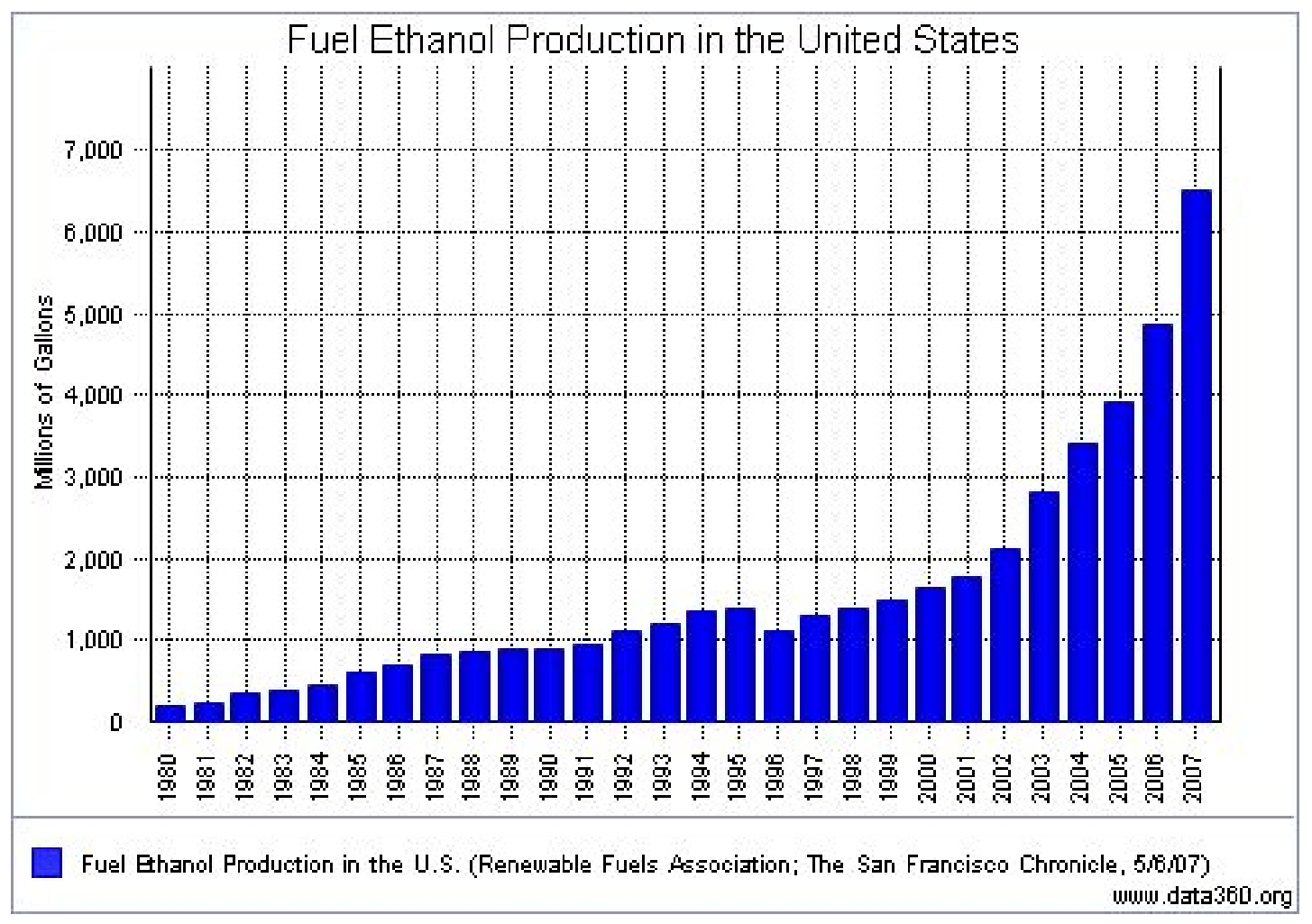

The Energy Tax Act of 1978, Public Law 95-618

The Energy Tax Act of 1978 was the first major legislative initiative addressing the national angst resulting from the Arab Oil Embargo of 1973 to gain passage. This Act was part of an overarching group of five enacted bills entitled the National Energy Act of 1978. The other four; The Public Utilities Regulatory Policies Act, The National Energy Conservation Policy Act, The Power Plant and Industrial Fuel Use Act and The Natural Gas Policy Act dealt with energy issues not including ethanol. The Energy Policy Act was introduced into the House by Dan Rostenkowski (D-IL) March 21, 1977 without cosponsors; however, its

\footnotetext{
${ }^{81}$ (Renewable Fuels Association, 2011)
} 
genesis can be traced back to 1973. Since that time numerous committees considered hundreds of bills, consolidated those bills, held hearings, issued reports and finally passed 95 H.R. 5263 which was enacted into Public Law 95618 with the official title "An Act to provide tax incentives for the production and conservation of energy, and for other purposes" upon President Carter's signature November $9^{\text {th }}$, 1978. These are the several committees which debated the provisions of the bill enacted: ${ }^{82}$

Subcommittee on Advanced Energy Technologies and Energy Conservation Research, Development, and Demonstration, Committee on Science and Technology. House.

Committee on Energy and Natural Resources. Senate.

Committee on Energy, Ad Hoc. House.

Subcommittee on Energy, Committee on Economic. Joint.

Committee on Ways and Means. House.

Committee on Interstate and Foreign Commerce. House.

Committee on Banking, Finance, and Urban Affairs. House.

Committee on Energy and Natural Resources. Senate.

Subcommittee on Administration of the Internal Revenue Code, Committee on Finance. Senate.

Committee on Budget. House.

Subcommittee on Energy and Foundations, Committee on Finance. Senate.

Subcommittee on Antitrust and Monopoly, Committee on Judiciary. Senate.

Subcommittee on Science, Technology, and Space, Committee on Commerce, Science, and Transportation. Senate.

Subcommittee on Energy Conservation and Regulation, Committee on Energy and Natural Resources. Senate.

Committee on Finance. Senate.

Committee on Energy and Natural Resources. Senate.

Subcommittee on Agricultural Research and General Legislation, Committee on Agriculture, Nutrition, and Forestry. Senate.

Committee on Economic. Joint.

82 (Library of Congress, 1978) 
President Carter made the following statement upon signing the enactment of this

law:

Enacting these five bills as everyone here knows has been a difficult and sometimes a painful process. . . . Events of the past 18 months have underscored the importance of this legislation. A severe natural gas shortage during one of our more severe winters, a crippling and unpredictable coal strike, the severe imbalance of payments in our Nations trade, a deterioration in the value of the American dollar, and more recently in Iran a threat to a major source of world supplies-each of these problems has either aggravated or portends the aggravation of our domestic inflationary pressures. And each of them has been made worse or would be making them worse in the future without this legislation on the desk before me. The energy bills that I am about to sign encompass the three major principles that I outlined to the public and the Congress in April of 1977: first of all that we must learn to use energy efficiently. . . Second, that we must provide adequate incentives and predictability in the Federal Government, its laws and regulations, to encourage additional production of available expendable energy supplies in our own country. And third, that we must shift toward more abundant supplies of energy than those that we are presently using at such a great rate, to coal with which our Nation is blessed, and also, of course, with the renewable supplies of energy, particularly solar energy itself. ${ }^{83}$

This complex legislation enacted in these five laws and President Carter's signing statement reflect the Nation's pain and frustration with disruptions of energy supplies and dramatic increases in energy costs. As shown in the chart below, in the 5 years prior to the enactment of this law, oil prices had more than quadrupled. The illustration also shows clearly the effects of international events upon the price of oil in the marketplace and America's inability to have any control over those prices over time. Even with domestic price controls in place for a decade, the United States had very minimal control over prices (compare the

${ }^{83}$ (Library of Congress, 1978) 
black line to red). It was the recognition of these painful gyrations that caused successive Presidents and Congress to focus on the long term national security interests of the nation through a variety of legislative actions enumerated on the following pages.

Figure 8

\section{OILISM Crude Oil Prices, History \& Analysis ${ }^{84}$}

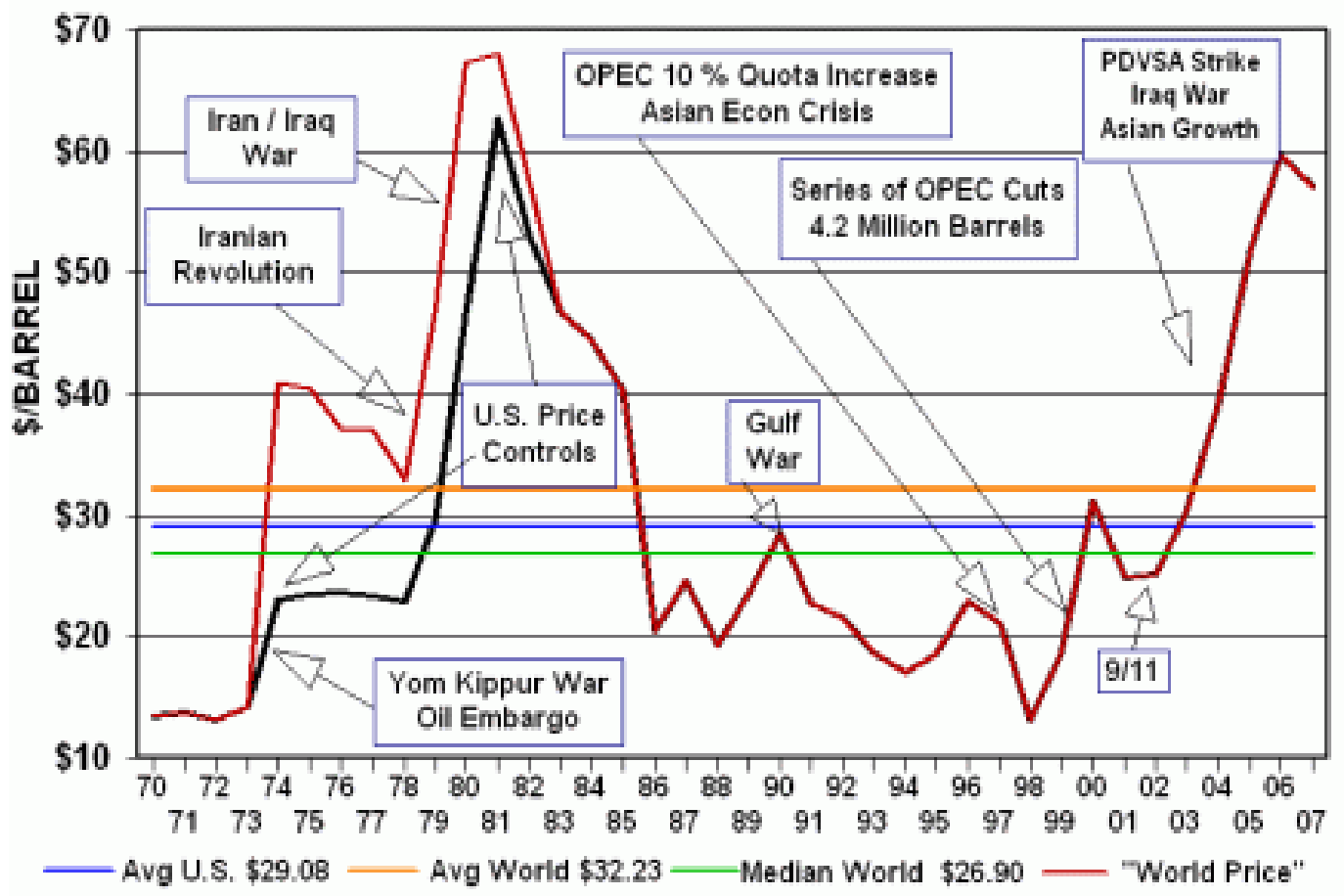

The key provision of the 1978 law which began the development of ethanol production was a tax exemption of 4 cents per gallon from the federal tax on motor fuels. The exemption required a minimum $10 \%$ ethanol content per gallon by volume. At such concentrations, the exemption was equivalent to 40 cents per

${ }^{84}$ (Oilism, 2007) 
gallon of fuel ethanol produced. Additionally, homeowners and businesses would get tax credits for installing energy-saving devices in their buildings. Homeowners were eligible for a credit of $15 \%$ on the first $\$ 2,000$ spent on insulation or other devices, for a maximum of $\$ 300$. Investment in solar, wind or geothermal energy equipment made the homeowner eligible for a tax credit of up to $30 \%$ on the first $\$ 2,000$ and $20 \%$ of the next $\$ 8,000$, for a total maximum credit of $\$ 2,200$. A $10 \%$ investment credit was made available to businesses that installed specified types of energy conservation equipment. The bill also provided tax incentives for companies that produced synthetic fuels from coal or other resources. Cars that used fuel inefficiently, known as gas-guzzlers, were to be taxed to discourage manufacture and purchase. Starting with 1980 models, new cars getting less than 15 miles per gallon (mpg) would be taxed \$200. The law contained progressive tax and mileage requirements increasing every year so that by 1986 , cars getting less than $12.5 \mathrm{mpg}$ would be taxed $\$ 3,850$. The Energy Tax Act brought ethanol into the nation's energy portfolio. In 1979 alone a series of 41 actions focusing on gasohol and domestic alcohol fuels were brought before the House and Senate. These are included as Appendix I, (41 actions proposed in 1979). Of these 26 were House actions (18 brought by Democrats and 8 by Republicans) and 14 were introduced in Senate (11 by Democrats and 3 by Republicans). The most active representatives in promoting legislation related to ethanol were both from farm states. Berkley Beddell (D-IA) introduced 5 of the House actions and Birch Bayh (D-IN) introduced 5 of the actions to the Senate. Although some of the proposed legislation never made it past the committee 
stage, a number of the actions survived and were incorporated into larger pieces of legislation.

In the winter of 1976, after the election of Jimmy Carter to the Presidency, an event transpired which would impact the evolution of ethanol production and policy. Dwayne Andreas, the CEO of ADM received a phone call from PresidentElect Carter with a question related to energy. Carter, an engineer by training, was acutely aware of the ongoing energy crisis facing the nation and had was aware of the concept of using corn sugar to produce ethanol. He asked the Andreas' if they and ADM were producing ethanol to which Dwayne Andreas answered no. Carter suggested that he could have several of his agency departments, such as Agriculture, Defense and Energy Agencies make their services available to ADM if Andreas would like to explore the concept of producing corn based ethanol by building a couple of pilot plants with government support. Very understandably, Andreas and ADM enthusiastically agreed to assist the Carter Administration with such projects. ADM would become a massive producer over the years of corn ethanol primarily produced in the number one corn growing state in America: Iowa.

\section{The Crude Oil Windfall Profit Tax Act of 1980, Public Law 96-223}

The Crude Oil Windfall Profit Tax Act of 1980 was introduced by William Cotter

(D-CT) April 4, 1979 with 22 cosponsors. Although the law includes "windfall" 
in its title, the resulting tax was simply an excise tax on domestically produced crude oil and included three tiers of oil production to capture all levels of domestic oil production. The law was enacted in response to the phasing out of price controls on crude oil from June 1979 to September 1980. These had largely been ineffective in terms of mitigating the consumer gasoline price at the pump. The intention of this legislation was to tax the expected fair share of additional revenues accruing to oil producers and royalty owners resulting from price decontrol without effecting production incentives. It is interesting to note, from the figures of imported and domestically produced oil in Figure 6 that domestic oil production dropped off markedly in the mid-1980s which could be in part attributable to this legislation and the trend against domestic oil production and the perceived interest of 'Big Oil' that began with this legislation. This was a purely domestic Act that explicitly made no provisions regarding imported oil.

While the law was directed primarily at the domestic oil industry, it had several provisions offering business and household incentives for alternative energy including solar, wind, ocean thermal, geothermal, hydroelectric, coke ovens and ethanol. It included assistance for low income families for home climate control systems. With regards to ethanol the Act extended the energy tax credit for gasohol and certain biomass fuel facilities through to 1985. It also extended the $10 \%$ investment tax credit on energy properties that included alcohol production and storage facilities, establishing tax exemptions for municipal bonds used to finance such facilities and streamlining the licensing process for plants producing 
fuel alcohol and made provision for an income tax credit of 40 cents per gallon of fuel ethanol use. ${ }^{85}$

The excise tax on domestic oil production was repealed with Public law 100-148, the Omnibus Trade and Competitiveness Act of 1988. The original forecast of revenues turned out to have been significantly overestimated, reflecting overestimates of crude oil prices. From 1980 to 1990 the tax generated gross revenue of about $\$ 80$ billion, or $80 \%$ less than the projected amount of $\$ 393$ billion. ${ }^{86}$ By 1988 Congress was concerned that $96-223$ had contributed to the nation's increased dependence on foreign oil.

\section{The Energy Security Act of 1980, Public Law 96-294}

On April 9, 1979 Senator William Proxmire (D-WI) introduced "A bill to extend the Defense Production Act of 1950, as amended" in the Senate with no cosponsors. June 30, 1980 President Carter signed the Energy Security Act of 1980 into law. This extensive legislation designated energy as "a strategic and critical material." Portions of this legislation were included under a number of other titles:

Acid Precipitation Act of 1980

Biomass Energy and Alcohol Fuels Act of 1980

Defense Production Act Amendments of 1980

\footnotetext{
${ }^{85}$ (Glozer, Corn Ethanol Who - Pays? Who Benefits ?, 2011)
}

${ }^{86}$ (Lazzari, 2008) 
Geothermal Energy Act of 1980

Renewable Energy Resources Act of 1980

Solar Energy and Energy Conservation Act of 1980

Solar Energy and Energy Conservation Bank Act

United States Synthetic Fuels Corporation Act of 1980

Title 2 of the Act, the Biomass Energy and Alcohol Fuels Act of 1980 directed the Secretary of Energy and the Secretary of Agriculture to prepare a plan that would lead to the production of 60,000 barrels of ethanol per day by December 1982 with ethanol production being equivalent to ten percent of domestic gas consumption by December 1990. It established the responsibilities of the Secretaries of Agriculture and Energy in relation to the production of energy from biomass (i.e. ethanol) and set up research grants, and financial assistance and loan guarantees for agricultural projects focusing on biomass for energy. This portion of the Act amended: the Agricultural Research Extension and Teaching Policy Act of 1977 to include educational projects focusing on the feasibility of biomass energy; the Food and Agriculture Act of 1977 to include crops for energy production within its provisions; and the National Gas Policy Act of 1978 to include fuels from biomass.

The other part of the Act with the greatest impact on evolving ethanol policy was Part B, the United States Synthetic Fuels Corporation Act of 1980, which established a new Federally owned business - the Energy Security Corporation (later named the Synthetic Fuels Corporation). This part of the Act articulated a 
national goal of 500,000 barrel per day production of synthetic fuel by 1987 with that quota ramping up to two million barrels per day by 1992. Synthetic fuels were included, but were not limited to ethanol, methanol and coal. In helping fulfill these goals, the Corporation was given proposed spending authority of eighty eight billion dollars to extend loans, loan guarantees and other assistance to private corporations for the construction of synthetic fuel facilities. Initially 19 billion dollars was allocated for loans, price guarantees and support of private corporations for the construction and operation of synthetic fuel facilities. It was expected that these production plants would produce 1.75 million barrels per day of oil equivalent. Congress anticipated that windfall profits tax revenues would fund the provisions of this law, but with the collapse of oil prices in 1981 those tax revenues evaporated. By 1986 President Reagan eliminated the agency entirely canceling its few remaining projects. ${ }^{87}$

\section{The Gasohol Competition Act of 1980, Public Law 96-493}

By 1980 both Congress and Senate were concerned that major retail gasoline suppliers were refusing to allow their pumps and storage tanks to be used for the sale and storage of non-petroleum based fuels or ethanol blends. On February 4, 1980 Howard Metzenbaum (D-OH) with 28 cosponsors introduced "A bill to amend the Clayton Act to prohibit restrictions on the use of credit instruments in the purchase of gasohol" in the Senate. Almost concurrently, William Hughes (DNJ) introduced a bill to the House on March 4, 1980 with the same title and 38

\footnotetext{
${ }^{87}$ (Glozer, Corn Ethanol Who - Pays? Who Benefits ?, 2011)
} 
cosponsors. With this legislation drafted in response to oil company resistance in the marketplace, Congress amended the Clayton Anti-Trust Act to prevent such economic interference by enacting The Gasohol Competition Act of 1980 which made it unlawful for any person: "to impose any condition [or] restriction ...that ...unreasonably discriminates against or unreasonably limits the sale, resale, or transfer of gasohol or other synthetic motor fuel of equivalent usability. ",88

This Act attempted to level the playing field in allowing consumers the choice in purchasing renewable fuels:

The Senate Report language on the legislation that became the Gasohol Competition Act noted that the statute was intended "to remove any potential obstacles that may be raised by the major oil companies to dealers who desire to market gasohol and other synthetic fuels. ${ }^{89}$

The effects of this law were, however, not as persuasive as Congress intended. As recently as 2007 Congressional hearings were being held to examine concerns that major oil suppliers were restricting and curtailing the sale of E-85 ethanol fuel through restrictions on their independent retailers. ${ }^{90}$

\section{The Omnibus Budget Reconciliation Act of 1980, Public Law 96-499}

Although the short title of this law is cited as the "Medicare and Medicaid Amendments of 1980," among its numerous provisions it included additional ethanol producing inducements. Signed into law December 5, 1980, this was the

${ }^{88}$ (Renewable Fuels Association, Joint Economic Hearing, US Congress, 23 May 2007, Samantha Slater)

89 (BID)

90 (IBID) 
first budget reconciliation bill to pass in both the Senate and the House. While the major spending changes affected such areas as child nutrition subsidies, interest rates for student loans, "look back" COLA benefit provisions for retiring federal employees, highway obligational authority, railroad rehabilitation, airport development, planning, and noise control grants, veterans' burial allowances, disaster loans, Medicare and Medicaid, unemployment compensation, and Social Security, it also included additional subsidies for the ethanol industry. On the revenue side, this law enacted a 40 cent per gallon tariff on imported ethanol to protect domestic producers from lower cost foreign providers.

\section{The Surface Transportation Assistance Act of 1982, Public Law 97-424}

This comprehensive transportation funding act was introduced in the House by Glenn Anderson (D-CA) April 29, 1982 with three cosponsors under the title "A bill to authorize appropriations for construction of certain highways in accordance with title 23, United States Code, for highway safety, for mass transportation in urban and rural areas, and for other purposes." Provisions of this act were titled:

Highway Improvement Act of 1982

Highway Safety Act of 1982

Federal Public Transportation Act of 1982

Highway Revenue Act of 1982

This law was subject to prolonged debate with 23 amendments proposed in the House and 13 in the Senate before being signed into law January 6, 1983. Provisions relating to ethanol were relatively minor and uncontentious. Untitled 
Section IV of the Act authorized a tax exemption of 9 cents per gallon of E85 ethanol that could be used by flex-fuel vehicles (E85 being fuel that contains at least $85 \%$ ethanol by volume).

These laws were enacted from 1978 to 1982 during a time of political and economic struggle for the United States. The Nixon Presidency and resignation was a time of turmoil. The Ford Administration was a time of transition from the upheaval of the Watergate scandal to the hopeful new beginning of the Carter Administration. The Carter Presidency was a time of significant economic travail and recession with serious foreign policy challenges (including the Iran hostage crisis). The Reagan election ushered in a time of high expectations and economic improvement for the nation as a whole.

Two much more subtle dynamics were at play in the development of ethanol policy during this era of the 1970's and 1980's. Despite all the Presidential and Congressional proclamations, the United States was failing abysmally (and would continue to do so) at reducing its dependence on the foreign oil. In addition to heightened national security concerns, the farming sector in American was facing dramatic economic problems. Figure 9 illuminates clearly the inability of legislative action to either reduce oil imports or improve the economics of farming. (See graph on US Oil Production and Imports 1920 to 2005 page 50). 


\section{Figure 9}

\section{Foreign Oil Dependency by U.S. President ${ }^{91}$}

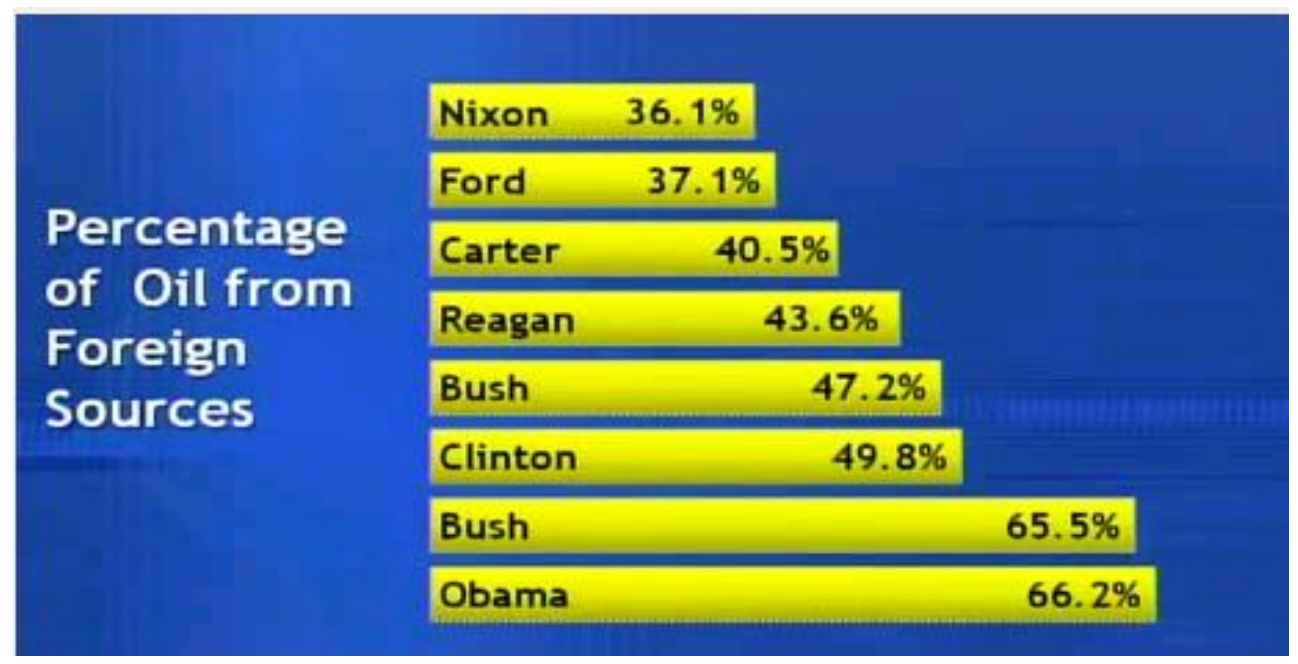

Figure 9 further demonstrates the dependence upon imported oil and the shift from domestic to foreign sources of oil in spite of decades of Congressional and Presidential effort.

Figure 10 presents a much more nuanced and not widely known picture of farm income in inflation-adjusted dollars that mirrors the development of ethanol policy. Until the middle of this decade (around 2005) the American farmer had experienced decades of collapsing and stagnating commodity prices for corn, the largest crop in the country by acres planted and dollars of sales. The high inflation of the 1970s meant that farmers' costs of production were increasing as their profits from sales declined. The economic facts caused farmers and farm associations to put extreme pressure on their legislators to remedy this and prop up farm incomes. The emergence of ethanol as a potential energy sources was an

91 (Perry, 2010) 
answer to the economic challenges faced by farmers, although it would take many years for the beneficial effects to be felt.

\section{Figure 10}

Inflation Adjusted Corn Prices: 1973-2008 ${ }^{92}$

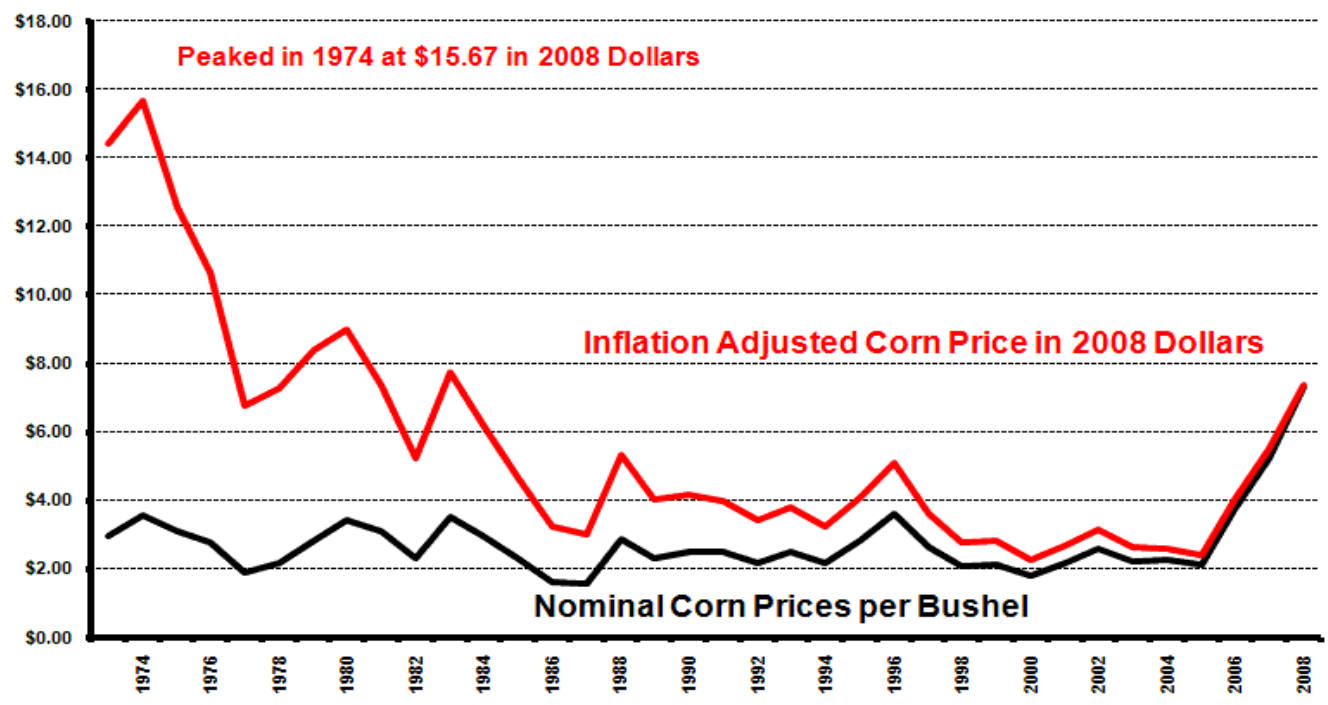

Bills continued to be submitted to various committees and synthesized through the federal legislative process into laws that were designed to address farmer's needs as well as national security issues relating to the nation's increasing dependence on foreign oil.

92 (Inflation Data, 2008) 


\section{The Tax Reform Act of 1984, Public Law 98-369}

This law attempted to deal with a struggling economy that had worsened since 1982. By 1984 unemployment had reached $10 \%$ and government revenues were declining. ${ }^{93}$ H.R. 4170, enacted as Public Law 98-369, was introduced in October of 1983 and signed by President Reagan in July of 1984. The Congressional Quarterly Almanac for the 98th Congress, Second Session., provided the following general discussion of H.R. 4170:

Efforts to cut federal budget deficits, estimated to remain near $\$ 200$ billion annually through 1989, occupied legislators for most of 1984. After months of negotiations among administration officials, Democratic leaders in the House and Republican leaders in the Senate, lawmakers in October finally agreed to cut deficits by $\$ 149.2$ billion through fiscal year 1987..$^{94}$

Buried deep within the deficit reduction provisions of this law were two provisions aimed at corn growers and ethanol blenders. The first raised the federal excise tax exemption for $10 \%$ ethanol fuel to 6 cents per gallon and the second increased the ethanol income tax credit to 60 cents per gallon. ${ }^{95}$ The irony of these provisions being inserted into this bill for enactment is that this law was intended to reduce tax deductions in general and primarily raise revenue during a difficult economic period.

\footnotetext{
93 (U.S. Bureau of Labor Statistics | Division of Labor Force Statistics, www.bls.gov/CPS)

94 (Sanders, Legislative History Report and Analysis Public Law 98-369, 2011)

95 (IBID)
} 


\section{The Alternative Motor Fuels Act of 1988, Public Law 100-494}

On July 21, 1987 John Rockefeller (D-WV) introduced "A bill to amend the Motor Vehicle Information and Cost Savings Act to provide for the appropriate treatment of methanol and ethanol, and for other purposes" in the Senate. In his opening statement in the floor debates Rockefeller reiterated the failures of past policy initiatives aimed at reducing the national dependence on foreign oil:

Mr. President, for years we have talked about the need for alternative fuels, and the need to displace some of the 100 billion gallons of gasoline used in the transportation sector each year. Our sense of urgency became stronger at the time of the OPEC oil embargo 15 years ago and with the overnight doubling in the price of oil some 9 years ago. However, we never seized the opportunity to switch away from gasoline. In my view, that was a mistake that hurt us then and continues to hurt us today, economically and environmentally. Today, we once again see oil imports on the rise. Tensions in the war-torn Persian Gulf region are increasing and at home, tough choices face us concerning the further development of domestic oil resources. This country is no more energy secure today than we were 9 or 15 years ago, and our petroleum consumption is just as large. This country must accelerate the development of alternatives to gasoline or suffer the economic and military consequences of its dependence on an unstable fuel supply. ${ }^{96}$

The sense of urgency in Rockefeller's statement is reflected in the 64 cosponsors listed for this act.

The Alternative Motor Fuels Act amended the Energy Policy and Conservation Act of 1975 by requiring that a maximum number of Federal passenger automobiles and light trucks be at least partially powered by alternative fuel by 1990. Public Law 100-494 created demand for alcohol fuel for the Federal fleet.

${ }^{96}$ (Congressional Quarterly, 1988) Senate, at page 7045, April 15, 1988 
An additional provision aimed at circumventing oil industry resistance to distributing ethanol blends and alcohol fuels required public access to locations providing alcohol fuels to federal vehicles. This measure attempted to encourage consumer demand by opening up Federal supply channels.

In providing further incentives for consumer vehicles using alcohol fuel blends, the law provided fleet mileage credits to the auto industry for manufacturing flex fuel vehicles that would operate on E85 - a fuel blend containing at least $85 \%$ ethanol fuel. The government had been pressuring the industry to increase the average mileage efficiency of manufactured vehicles since 1975. The incentives provided by this law won the automobile industry's enthusiastic support for ethanol as an alternative fuel. Such flex fuel vehicles could be manufactured at minimal marginal cost while deriving the benefit in increasing their overall fleet mileage averages.

\section{The Customs and Trade Act of 1990, Public Law 101-382}

On March 23, 1989 Sam Gibbons (R-FL) with two cosponsors introduced an act

"To extend nondiscriminatory treatment to the products of the Peoples' Republic of Hungary for 5 years" in Congress. Although the primary concern of the original legislation was trade with Hungary, other titles that were included in the act that which was eventually passed indicate the expansion of this law beyond its initial narrow goals. The following titles were included for portions of the Act:

Caribbean Basin Economic Recovery Expansion Act of 1990 
Forest Resources Conservation and Shortage Relief Act of 1990

The general provisions of the Act sought to extend preferential trading status for certain Eastern European nations. Title II, the Caribbean Basin Economic Recovery Act of 1990 attempted to stimulate the economies of America's Caribbean Basin neighbors by granting tax preferences or duty exemptions on products produced or enhanced in such nations. A Congressional Research Service Report summarizes a rare instance wherein an exception is made for the import of ethanol:

As Congress noted in the Customs and Trade Act of 1990, the Caribbean Basin Initiative (CBI) was established in 1983 to promote "a stable political and economic climate in the Caribbean region." As part of the initiative, duty-free status is granted to a large array of products from beneficiary countries, including fuel ethanol under certain conditions. If produced from at least $50 \%$ local feedstocks (e.g., ethanol produced from sugarcane grown in the CBI beneficiary countries), ethanol may be imported duty-free. If the local feedstock content is lower, limitations apply on the quantity of duty-free ethanol. Nevertheless, up to $7 \%$ of the U.S. market may be supplied duty-free by CBI ethanol containing no local feedstock. In this case, hydrous ("wet") ethanol produced in other countries, historically Brazil or European countries can be shipped to a dehydration plant in a CBI country for reprocessing. After the ethanol is dehydrated, it is imported duty-free into the United States. ${ }^{97}$

This law is one of the very few instances where the domestic corn growers and ethanol producers were not able to prevent foreign competition. Although the law allowed for some modest competition, domestic ethanol producers and farmers were largely unaffected by the enactment.

${ }^{97}$ (Yacobucci, Ethanol Imports and the Caribbean Basin Initiative RS21930, 2008) 


\section{The Omnibus Budget Reconciliation Act of 1990, Public Law 101-508}

The second major budget reconciliation act was introduced in Congress October 15, 1990 by Leon Paneta (D-CA) as a bill "To provide for reconciliation pursuant to section 4 of the concurrent resolution on the budget for fiscal year 1991." The scope of this budget initiative is evident in the titles of major portions of the Act:

Abandoned Mine Reclamation Act of 1990

Agricultural Reconciliation Act of 1990

Airport Noise and Capacity Act of 1990

Aviation Safety and Capacity Expansion Act of 1990

Budget Enforcement Act of 1990

Child Care and Development Block Grant Act of 1990

Coastal Zone Act Reauthorization Amendments of 1990

Computer Matching and Privacy Protection Amendments of 1990

FDIC Assessment Rate Act of 1990

Federal Aviation Administration Research, Engineering, and Development Authorization Act of 1990

Federal Credit Reform Act of 1990\

Pollution Prevention Act of 1990

Portability of Benefits for Non-appropriated Fund Employees Act of 1990

Revenue Reconciliation Act of 1990

Student Loan Default Prevention Initiative Act of 1990

Many of the more controversial aspects of the law were included in Title XI, the Revenue Reconciliation Act of 1990, which dealt with government revenue and 
thus increased taxes and reduced deductions across a variety of economic circumstances.

Of relevance to this study is the insertion of ethanol into the provisions of Title I of the Law - Agriculture and Related Programs. Although the overall aim of this extensive law was to balance the budget, it included additional incentives for ethanol production. These incentives included the Small Ethanol Producer Credit valued at 10 cents per gallon of ethanol produced. The credit could be claimed on the first 15 million gallons of ethanol produced by a small producer in a given year. Qualified applicants were defined as: "Any ethanol producer with production capacity below sixty million gallons per year." 98 In addition to further incentivizing ethanol production this law increased the gasoline excise tax to 14.1 cents per gallon while extending ethanol fuel tax incentives through to $2000 .^{99}$

\section{The Clean Air Act Amendments of 1990, Public Law 101-549}

On September 14, 1989 Max Baucus (D-MT) with 22 cosponsors introduced "A bill to amend the Clean Air Act to provide for attainment and maintenance of health protective national ambient air quality standards, and for other purposes." This act was the third significant amendment to the original Clean Air Act, P.L. 90-148.

\footnotetext{
98 (Yacobucci, Biofuels Incentives: A Summary of Federal Programs RL33572, 2006)

99 (Jackson, 2006)
} 
Provisions of the act included: emissions trading; measures to address acid rain, ozone depletion and toxic air pollution; the creation of a national permits program. Included among the ozone protection provisions was the requirement that gasoline refiners oxygenate fuels to lessen air pollution and improve air quality. Over time these requirements would create tremendous demand for ethanol. The following Congressional Research Report synopsis presents a clear picture of this significant change:

Title II of the Clean Air Act has required emission standards for automobiles since 1968. The 1990 amendments significantly tightened these standards: for cars, the hydrocarbon standard was reduced by $40 \%$ and the nitrogen oxides (NOx) standard by 50\%. The new standards referred to as "Tier 1" standards - were phased in over the 1994-1996 model years.

The 1990 amendments also required that oxygenated gasoline, designed to reduce emissions of carbon monoxide, be sold in the worst $C O$ nonattainment areas and that "reformulated" gasoline (RFG), designed to reduce emissions of volatile organic compounds and toxic air pollutants, be sold in the nine worst ozone nonattainment areas...

Use of alternative fuels and development of cleaner engines was to be stimulated by the Clean-Fuel Fleet Program. In all of the most seriously polluted ozone and CO nonattainment areas, centrally fueled fleets of 10 or more passenger cars and light-duty trucks must purchase at least $30 \%$ clean-fuel vehicles when they add new vehicles to existing fleets, starting in 1999... The percentage rose to 50\% in 2000 and 70\% in 2001. Heavyduty fleets are required to purchase at least $50 \%$ clean-fuel vehicles annually. A clean fuel vehicle is one which meets Low Emission Vehicle (LEV) standards and operates on reformulated gasoline, reformulated diesel, methanol, ethanol, natural gas, liquefied petroleum gas, hydrogen, or electricity. ${ }^{100}$

100 (McCarthy, 2005) 


\section{The Energy Policy Act of 1992, Public Law 102-486}

President George H. W. Bush signed Public Law 102-486 in 1992 - the year after he unveiled his National Energy Strategy. This law was the legislative culmination of that strategy. President Bush had supported the Clean Air Act Amendments and this "Strategy" was his strongest enunciation of support for a robust ethanol production policy. This law was the centerpiece of his Administration's presentation of a "balanced program of greater energy efficiency, use of alternative fuels, and the environmentally responsible development of all U.S. energy resources.” The plan was to reduce oil imports by 1.3 million barrels per day by 2000 and 3.4 million barrels by $2010 .^{101}$

This law was introduced as a bill "to provide for improved energy efficiency" by Philip Sharp (D-IN) with 54 cosponsors in Congress February 4, 1991. The extensive nature of this law is evident in the number of laws it amended:

Energy Conservation and Production Act

Cranston-Gonzalez National Affordable Housing Act

National Energy Conservation Policy Act

Public Utility Regulation Policy Act of 1978

Hoover Power Plant Act of 1984

Energy Policy and Conservation Act

Federal Property and Administrative Services Act of 1949

Natural Gas Act

${ }^{101}$ (Glozer, Corn Ethanol Who - Pays? Who Benefits ?, 2011) pp. 39 
Public Utility Holding Company Act

Nuclear Waste Policy Act of 1982

Atomic Energy Act of 1954

Uranium Mill Trailing Radiation Control Act

Renewable Energy and Efficiency Competition Act of 1989

Federal Nonnuclear Energy Research and Development Act of 1974

Surface Mining Control and Reduction Act of 1977

Mineral Leasing Act

Energy Reorganization Act of 1974

Alaska Natural Gas Transportation Act of 1976

Radiation Exposure Compensation Act of 1976

Internal Revenue Code

The law established requirements for private and government fleets to acquire alternative fuel vehicles, extended the motor fuel tax exemption for ethanol blends, and provided $\$ 227$ million in government funds for research and development of alternative energy sources. This act included two new provisions that directly benefited ethanol producers and distributors. Buyers and retrofitters of alternative fuel vehicles were given favorable tax write offs for a portion of their purchase costs, and retail outlets that invested in equipment to store and dispense alternative fuels such as ethanol could write off up to $\$ 100,000$. 


\section{The Omnibus Budget Reconciliation Act of 1993, Public Law 103-66}

Introduced to Congress by Martin Olav Sabo (D-MN) with no cosponsors as a bill "To provide for reconciliation pursuant to section 7 of the concurrent resolution on the budget for fiscal year 1994," this is the third budget reconciliation bill intended to reign in the deficit that included a number of provisions increasing taxes in different areas. The following titles of portions of the Act demonstrate its scope:

Agricultural Reconciliation Act of 1993

Mickey Leland Childhood Hunger Relief Act

Revenue Reconciliation Act of 1993

Student Loan Reform Act of 1993

Veterans Reconciliation Act of 1993

Once again, ethanol policy would benefit from attempts to balance the Federal budget. The Revenue Increases of Title XIII (Revenue, Health Care, Human Resources, Income Security, Customs and Trade, Food Stamp Program, and Timber Sale Provisions) included an increase in the gasoline excise tax from 14.1 cents per gallon to 14.4 cents per gallon. In as much as ethanol was heavily subsidized, any increase in the price of gasoline increased the attractiveness of tax-exempt ethanol. ${ }^{102}$ Although ethanol policy may not have been among the stated goals of this act, this is a good example of indirect ethanol policy.

102 (Jackson, 2006) 


\section{The Transportation Equity Act $21^{\text {st }}$ Century in 1998, Public Law 105-178}

On September 4, 1997 Bud Shuster (R-PA) with 118 cosponsors introduced a bill "To authorize funds for Federal-aid highways, highway safety programs, and transit programs, and for other purposes" in Congress. This was a transportation bill, rather than an energy act, and those attributes are reflected in the following titles:

Federal Transit Act of 1998

Intelligent Transportation Systems Act of 1998

National Highway Traffic Safety Administration Reauthorization Act of 1998

Sport fishing and Boating Safety Act of 1998

Surface Transportation Revenue Act of 1998

Transportation Infrastructure Finance and Innovation Act of 1998

Veterans Benefits Act of 1998

Although ethanol was not a major consideration of this legislation, the passage of 105-178 brought both good news and bad to ethanol producers. The law reduced the tax credit for ethanol blenders: from 60 cents per gallon to 53 cents per gallon in 2001, 52 cents in 2003 and then 51 cents in and after 2005. This reduction in tax credit advantages was offset by the extension of tax exemptions for blenders from 2000 until 2007 that were due to expire. ${ }^{103}$ Because Congress could not agree on funding levels, the Act was allowed to lapse after initial extension.

${ }^{103}$ (Public Law 105-178-June 9, 1998, section 9003) pp. 395 


\section{The Agricultural Research, Extension, and Education Reform Act of 1998, Public Law 105-185}

Introduced to the Senate by Richard Lugar (R-IN) without cosponsors as "An original bill to ensure that federally funded agricultural research, extension, and education address high-priority concerns with national or multistate significance, to reform, extend, and eliminate certain agricultural research programs, and for other purposes," this legislation focused on funding and accountability of agricultural research and built on provisions of the Federal Agriculture Improvement and Reform Act of 1996.

Funding through the United States Department of Agriculture for ethanol and renewable fuels research was included in this research mandate. Ethanol was included among high priority research initiatives (REF Subtitle D, SEC 242). The wording, while innocuous, is typical of provisions inserted in the ongoing stream of ethanol production supporting legislation:

ETHANOL RESEARCH AND EXTENSION. - Research and extension grants may be made under this section for the purpose of carrying out or enhancing research on ethanol derived from agricultural crops as an alternative fuel source. ${ }^{104}$

This Act made matching grants available from the Department of Agriculture for ethanol research.

${ }^{104}$ (United States Department of Agriculture, 1998) pp. 28 


\section{The Agriculture Risk Protection Act of 2000, Public Law 106-224}

On July 20, 1999 Larry Combest (R-TX) with 12 cosponsors introduced a bill "To amend the Federal Crop Insurance Act to strengthen the safety net for agricultural producers by providing greater access to more affordable risk management tools and improved protection from production and income loss, to improve the efficiency and integrity of the Federal crop insurance program, and for other purposes" in to Congress to revise federal crop assistance and provide emergency assistance to farmers. While the primary focus of the Act was providing relief and assistance to farmers the subtitles of portions of the Act provide insight into the opportunistic nature of the development of ethanol policy. While Title VI of the Act, 'Plant Protection Act,' restricts the movement of unauthorized plant pests, Title III, 'Biomass Research Development Act of 2000' presented the perception of Congress regarding the potential benefits of bio-fuels and renewable resources such as ethanol.

Congress finds that-

(1) conversion of biomass into biobased industrial products offers outstanding potential for benefit to the national interest through-

(A) improved strategic security and balance of payments;

(B) healthier rural economies;

(C) improved environmental quality;

(D) near-zero net greenhouse gas emissions;

(E) technology export, and

$(F)$ sustainable resource supply;

(3) biobased fuels, such as ethanol, have the clear potential to be sustainable, low cost, and high performance fuels that are compatible with both current and future transportation systems and provide near-zero net greenhouse gas emissions;

(5) biobased power can-

(A) provide environmental benefits;

(B) promote rural economic development; and

(C) diversify energy resource options; 
(6) many biomass feedstocks suitable for industrial processing show the clear potential for sustainable production, in some cases resulting in improved soil fertility and carbon sequestration;

(7) (A) grain processing mills are biorefineries that produce a diversity of useful food, chemical, feed, and fuel products; and

(B) technologies that result in further diversification of the range of valueadded biobased industrial products can meet a key need for the grain processing industry;

(8) (A) cellulosic feedstocks are attractive because of their low cost and widespread availability; and

(B) research resulting in cost-effective technology to overcome the recalcitrance of cellulosic biomass would allow biorefineries to produce fuels and bulk chemicals on a very large scale, with a commensurately large realization of the benefit described in paragraph;

(11) the creation of value-added biobased industrial products would create new jobs in construction, manufacturing, and distribution, as well as new higher-valued exports of products and technology;

(12) (A) because of the relatively short-term time horizon characteristic of private sector investments, and because many benefits of biomass processing are in the national interest, it is appropriate for the Federal Government to provide precommericial investment in fundamental research and research-driven innovation in the biomass processing area; and

(B) such an investment would provide a valuable complement to ongoing and past governmental support in the biomass processing area. ${ }^{105}$

Congressional perception of an ethanol benefit and the commitment to fund it is relevant to the discussion presented in chapter 6.

With the above provisions Congress reaffirmed the role of ethanol as central to the strategic security and economic concerns of the nation, rural development, environmental sustainability and job creation. They further stated their support for research and development investment in biofuels and biomass processing as part of the national interest. In addition to the statement of support for ethanol policy and biofuel development, this act allocated additional funding for the construction of yet another ethanol 'research facility;'

${ }^{105}$ (United States Government Printing Office, 2000) PP. 73 
Of the amount made available under section 261(a)(2), the Secretary shall use \$14,000,000 to provide a grant to the State of Illinois to complete the construction of a corn-based ethanol research pilot plant (Agreement No. 59-3601-7-078) at Southern Illinois University, Edwardsville, Illinois. ${ }^{106}$

\section{The Agriculture, Rural Development, Food \& Drug Administration, \&}

\section{Related Agencies Appropriations Act of 2002, Public Law 107-76}

On June 27, 2001 Henry Bonilla (R-TX) introduced in Congress without cosponsors a bill "Making appropriations for Agriculture, Rural Development, Food and Drug Administration, and Related Agencies programs for the fiscal year ending September 30, 2002, and for other purposes." Two years after the Agricultural Risk Protection Act of 2000, PL 107-76 provided grant funding of \$6 million dollars for the construction of a "farmer-owned cooperative" ethanol production plant:

TITLE VII-GENERAL PROVISIONS. --- Notwithstanding any other provision of law, \$3,000,000 shall be made available from funds under the rural business and cooperative development programs of the Rural Community Advancement Program for a grant for an integrated ethanol plant, feedlot, and animal waste digestion unit, to the extent matching funds from the Department of Energy are provided if a commitment for such matching funds is made prior to July 1, 2002: Provided, That such funds shall be released to the project after the farmer-owned cooperative equity is in place, and a formally executed commitment from a qualified lender based upon receipt of necessary permits, contract, and other appropriate documentation has been secured by the project. ${ }^{107}$

\footnotetext{
${ }^{106}$ (Public Law 106-224--June 20, 2000, Section 3226) pp. 51

107 (Public Law 107-76 - November 28, 2001, Section 747) pp. 738
} 


\section{The American Jobs Creation Act of 2004, Public Law 108-357}

Introduced in Congress as a bill "To amend the Internal Revenue Code of 1986 to remove impediments in such Code and make our manufacturing, service, and high-technology business workers more competitive and productive both at home and abroad" by William Thompson (R-CA) with 40 cosponsors, the American Jobs Creation Act of 2004 is primarily a tax act. The original intent of the law was to repeal the Extraterritorial Income Exclusion, which the World Trade Organization insisted was in violation of the WTO trade agreement. This was achieved in the measures of Title I.

The remainder of this 650 page act dealt with changes to tax statutes to encourage and promote business activity and job creation. Title III, Tax Relief for Agriculture and Small Manufacturers included more incentives for ethanol production. Section 301 outlined a new construct established to encourage and simplify the tax treatment of ethanol and renewable fuels. The new tax policy was presented as:

The Volumetric Ethanol Excise Tax Credit (VEETC). Before this Act, gasoline blenders could choose between an income tax credit of 51 cents per gallon of ethanol blended or a reduced rate of Federal excise tax on each gallon of gasoline blended with ethanol. Thus, gasoline containing 10 percent ethanol would be taxed at 13.2 cents per gallon instead of the usual 18.3 cents per gallon in calendar year 2005. Gasoline blended with 5.7 percent or 7.7 percent ethanol would receive a proportionally smaller reduction in the excise tax. The VEETC is instead assessed at a rate of 51 cents per gallon of ethanol, and the entire excise tax is assessed on the finished gasoline. This gives several advantages over the existing structure. VEETC applies to any blend of ethanol and gasoline. It also applies to ethyl tertiary butyl ether (ETBE), a gasoline blending component made from ethanol. The excise tax exemption does not apply to 
blends containing less than 5.7 percent or more than 10 percent ethanol, such as E85. The income tax credit can be taken for ethanol used in such blends or to make ETBE, but not all gasoline blenders have sufficient Federal income tax liability to take the credit. The VEETC is effective through 2010; the excise tax reduction will expire in 2007. This section also extends the alcohol income tax credit through 2010. AEO2005 includes these tax credits and, in addition, assumes that they will remain in force indefinitely, given that historically they have been extended when they expired. ${ }^{108}$

Although enacted as a "jobs bill," the provisions affecting corn farmers and ethanol producers were written as tax simplification provisions. The actual effect of the law was to further extend for 3 years the tax credits and exemptions benefiting corn farmers and ethanol producers.

\section{The Energy Policy Act of 2005, Public Law 109-58}

\section{The Energy Independence and Security Act of 2007, Public Law 110-140}

The debate at this time amongst various factions of the Congress, Administration and interest groups as to the best and most effective manner in which to meet the goals of energy independence, environmental stewardship, renewable energy economic viability and national security was informed significantly and very publically with the publication of several versions of a "billion ton study." The study was originally conducted in collaboration between several federal agencies under the direction of the Department of Energy. The Environmental Sciences Division of the Oak Ridge National Laboratory (DOE), the Forest Service

108 (U.S. Energy Information Administration, 2008) 
(USDA) and the Agricultural Research Service (USDA) were the primary collaborators. The initial report, "Biomass as Feedstock for a Bioenergy and Bioproducts industry: The Technical Feasibility of a Billion-Ton Annual supply" 109 was published in April of 2005 and informed the debate about the potential of renewable biofuels. The report presented that the United States had readily available resources of biomass on the order of a billion tons per year. The authors hypothesized that such resources could meet the goal of producing approximately 60 billion gallons of ethanol from biomass replacing $30 \%$ of the petroleum used for transportation by $2030 .^{110}$

In 2006 the Department of Energy coined the $\mathbf{3 0 x 3 0}$ acronym from the reports data. ${ }^{111}$ In November of 2006 the University of Tennessee published a study which proposed that the United States could domestically produce $25 \%$ of its total energy requirements by 2025 from biomass renewable resources without disrupting food prices. ${ }^{112}$ As H.R. 6 was being considered in 2007, over 100 major corporations and trade groups endorsed the Tennessee $25 \times 25$ study and insured that it was widely circulated through Congress. ${ }^{113,114}$ Subsequent to the consideration and enactment of this bill, the range and depth of support for the $25 \times 25$ concept expanded significantly as can be shown in the support groups listed in the appendices noted below. ${ }^{115}$ Advocacy groups ranged from state legislators to House and Senate members to Fortune 500 corporations to

109 (Perlack, Wright, \& Turhollow, 2005)

110 (Dayton, 2007)

111 (Sims, 2007)

112 (English \& De La Torre Ugarte, 2006)

113 (Glozer, 2011) pp. 63

${ }^{114}$ (See Appendix XIV for the complete list of endorsers)

${ }^{115}$ (See appendix XIII for lists of support groups) 
environmental defense organizations to agricultural associations to universities and local governments. The report assumed that cellulosic ethanol would be economically competitive and widely available by 2012 even though corn-based ethanol was only marginally competitive with oil based gasoline and required large federal subsidies and high oil prices. ${ }^{116}$ These published studies, when combined with the global warming greenhouse gas climate change concerns being presented by Al Gore and other climate change advocates, were optimistic projections that legislators and the President could cite during 2007 as reliable foundations for the dramatic new Renewable Fuels Standard in H.R. 6.

A very visible and growing awareness of global warming as a concept, real or not, was permeating much of the Nation's consciousness and legislators were under increasing pressure to respond. In the spring of 2006 a seminal global warming documentary warning that the world was facing a catastrophic future because of manmade greenhouse gas emissions was released by Al Gore under the title $A n$ Inconvenient Truth. ${ }^{117}$ The Academy Award winning documentary received widespread public attention which was not lost on legislators. ${ }^{118}$ The movie was

\footnotetext{
116 (IBID)

${ }^{117}$ (An Inconvenient Truth, 2008)

${ }^{118}$ (The awareness and sensitivity by Congress to this issue became so great that in January of 2007 Speaker of the House Nancy Pelosi would create the Select Committee On Energy Independence and Global Warming to "find solutions that address the energy, economic and national security challenges associated with our dependence on foreign oil and increasing carbon pollution" http://globalwarming.house.gov/ The Committee was abolished in January of 2011 when Republicans took control of the House.)
} 
critiqued very favorably in the New York Times ${ }^{119}$ and was a cover article in Time Magazine. ${ }^{120}$ Time stated that:

the climate is crashing and global warming is to blame, noting that a new Time/ABC News/Stanford University poll showed that 87 percent of respondents believe the government should encourage or require a lowering of power-plant emissions. ${ }^{121}$

The magnitude of public attention to the concern over global warming became so substantial during 2006 that Al Gore would be awarded the Nobel Peace Prize in October of 2007 to recognize his efforts to combat the concept. ${ }^{122}$ National discontent concerning the war, the economy and global warming was so widespread during 2006 that in November voters returned both chambers of the Congress to Democratic control.

Public Law 109-58 was the first of two legislative actions which would usher in the most significant stimulus for the extensive growth of the ethanol industry in America. The second of these laws was the Energy Independence and Security Act of 2007, Public Law 110-140. These two laws, for the first time, mandated the production and blending of ethanol into the nation's fuel supply. Although the other laws presented in this chapter are in chronological order, these two acts are so intertwined and pivotal to the expansion of ethanol policy, that they are addressed together. No longer would there just be a variety of subsidies, incentives, tariffs and tax benefits to encourage ethanol production, but beginning with these laws, increasing specific amounts yearly of ethanol would be required

\footnotetext{
119 (Kakutani, 2006)

${ }^{120}$ (Time Magazine, 2006)

121 (IBID)

122 (The Nobel Peace Prize , 2007)
} 
to be blended into fuel gasoline. The amounts required, as a portion of total national fuel usage are substantial and consume a significant portion of the American corn crop with resulting benefits for both corn farmers, land owners and ethanol blenders. The costs to consumers and taxpayers are extensive. The amounts shown below and their ramifications to national energy policy are discussed in detail in chapter 6.

Figure 11

Renewable Fuels Standard (RFS2) vs. US Ethanol Production Since $1995^{123}$

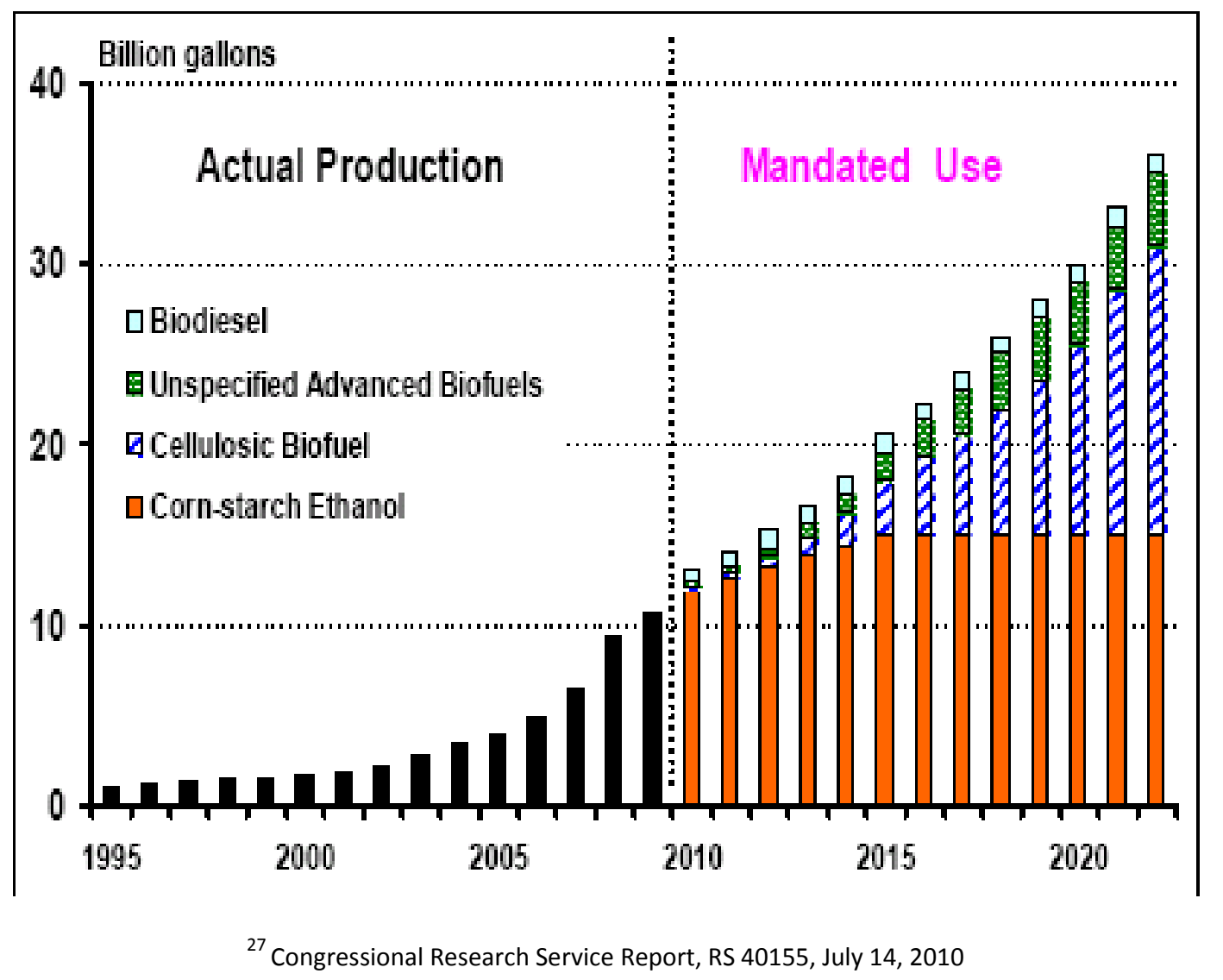

${ }^{123}$ (Schnepf, 2010) 
Projected loses to Federal tax revenues from these two laws was expected to be very significant through the year 2025. As will be seen in later analysis, even these figures below appear to be understated.

Figure 12

Projected loses to Federal tax revenues ${ }^{124}$

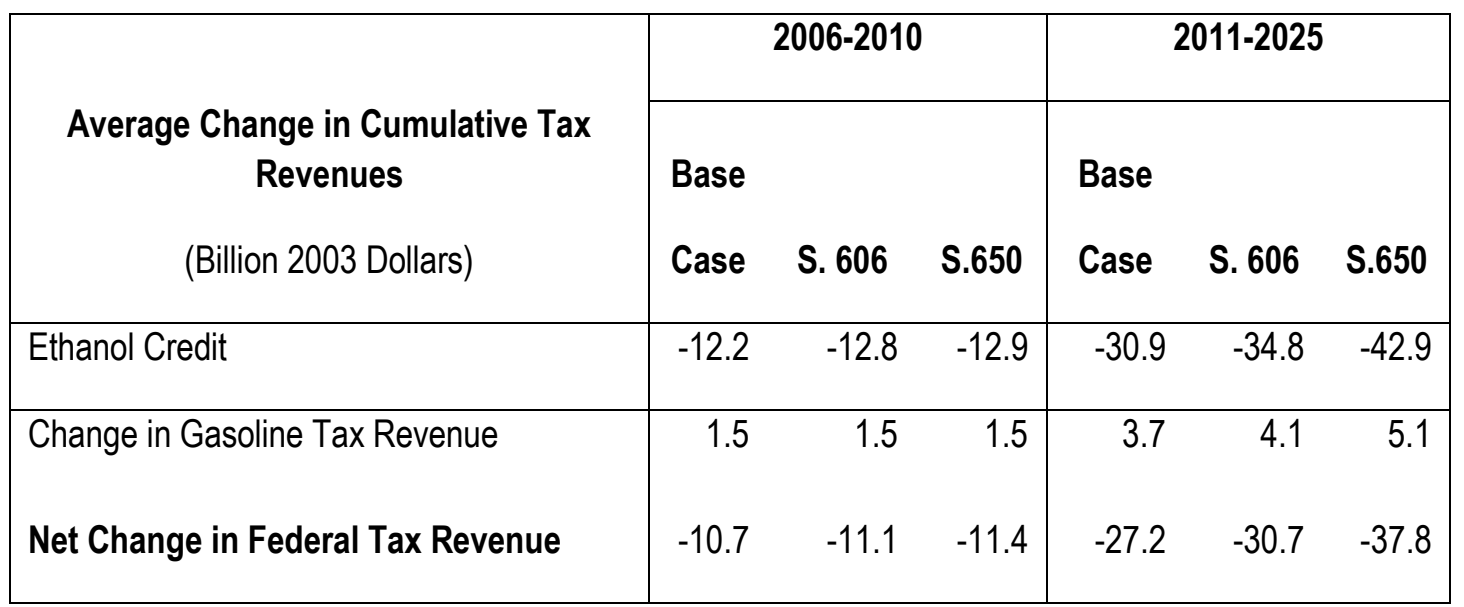

Renewable Fuels Legislation Impact Analysis, Annual Energy Outlook 2005 (AEO2005)

The following excerpt from a Congressional Research Report captures the subtle, but important observation that with the discontinuation of MTBE as a fuel additive and its replacement by ethanol, the supply and price of gasoline supplies were brought into question with the significantly increased mandates required by P.L. 109-58 and P.L. 110-140. ${ }^{125}$

A key component of P.L. 109-58 is a requirement that gasoline sold in the United States must contain 7.5 billion gallons annually of ethanol and other renewable fuels by 2012. The measure also eliminates Clean Air Act requirements for the use of oxygenates in reformulated gasoline. The oxygenate standard led to the increased use of MTBE in gasoline. (MTBE

\footnotetext{
${ }^{124}$ (Energy Information Administration, 2005)

${ }^{125}$ (Figure 12 above references S. 606 and S.650 which were underlying Senate bills which were incorporated into P.L. 109-58 and 110-140)
} 
is a fuel additive used to increase combustion efficiency that was found to contaminate drinking water supplies, primarily due to leaking underground fuel storage tanks). The voluntary transition away from MTBE by gasoline suppliers in spring 2006 (along with high petroleum prices) led to historically high gasoline prices and concerns over the supply of ethanol for blending into gasoline. ${ }^{126}$

\section{The Safe, Accountable, Flexible, Efficient Transportation Equity Act of 2005, Public Law 109-59}

On February 9, 2005, Don Young (R-AK) with 79 cosponsors introduced a bill to

"To authorize funds for Federal-aid highways, highway safety programs, and transit programs, and for other purposes" in Congress. Subtitles of the Act illuminate the scope of this legislation:

Federal Public Transportation Act of 2005

Hazardous Materials Transportation Safety and Security Reauthorization Act of 2005

Household Goods Mover Oversight Enforcement and Reform Act of 2005

Motor Carrier Safety Reauthorization Act of 2005

Sanitary Food Transportation Act of 2005

Sport fishing and Recreational Boating Safety Act of 2005

Unified Carrier Registration Act of 2005

This innocuously titled law had a specific impact making it much easier for ethanol interests to obtain very large mandated renewable fuel standards from PL109-58 and later PL 110-140. An unintended consequence of the Energy Tax Act of 1978 was an ongoing struggle between Members representing agricultural

${ }^{126}$ (Fletcher, 2006) 
interests and those that representing transportation interests such as roads and mass transit. The tax credits and exemptions for ethanol production granted by the 1978 act were legislated as deductions from taxes levied on motor fuel sales. Motor fuel taxes were collected and segregated into the Highway Trust Fund for road projects. The effect of this provision in the Energy Tax Act, PL 95-618 was that by 2004, with ethanol consumption rising significantly, the ethanol exemptions were reducing the Highway Trust Fund by over $\$ 2$ billion a year money that transportation interests wanted retained. Public Law 109-59 directed that in the future general revenues would be used to compensate the cost of ethanol deductions, not highway trust funds. This resolution removed the opposition of Members representing significant transportation interests to the expanded mandates for subsidized ethanol production ${ }^{127}$ and essentially switched the subsidy of ethanol from a levy on oil consumption to an expense from the general federal revenues.

\section{The National Defense Authorization Act of 2006, Public Law 109-163}

Introduced to Congress by Duncan Hunter (R-CA) with one cosponsor on April 26, 2005 as a bill "To authorize appropriations for fiscal year 2006 for military activities of the Department of Defense, to prescribe military personnel strengths for fiscal year 2006, and for other purposes" this act authorized appropriations for military activities of the Department of Defense and defense activities of the Department of Energy. Included in the section for Operation and Maintenance

${ }^{127}$ (Glozer, Corn Ethanol Who - Pays? Who Benefits ?, 2011) pp. 55 
was a provision directing an examination of increased biodiesel and ethanol use by the military:

Section 357, Study on use of BIODIESEL AND ETHANOL FUEL:

(a) IN GENERAL.-The Secretary of Defense shall conduct a study on the use of biodiesel and ethanol fuel by the Armed Forces and the Defense Agencies and any measures that can be taken to increase such use. ${ }^{12}$

This legislation's provision to study ethanol use and increased production is an example of the prevailing attitude held by many Members that ethanol was both a viable and desirable adjunct to gasoline.

\section{The Tax Relief and Health Care Act of 2006, Public Law 109-432}

On September 19, 2006, Ellen Tauscher (D-CA) without cosponsors introduced a bill "To amend the Internal Revenue Code of 1986 to provide that the Tax Court may review claims for equitable innocent spouse relief and to suspend the running on the period of limitations while such claims are pending." PL 109-432 was essentially a tax law enacted to extend provisions from other tax legislation. Among those expiring provisions were ethanol tax credits that were extended for an additional year. More significantly a special depreciation allowance was included among the other purposes that provided ethanol producers with an attractive tax benefit to build or acquire production facilities. Such "special" tax preferences were at the expense of general tax revenues.

${ }^{128}$ (United States Congress, 2006) pp. 73 


\section{Paul Wellstone Mental Health and Addiction Equity Act of 2007, Public Law 110-343}

This extensive legislation was introduced in Congress by Patrick Kennedy (D-RI) with 274 cosponsors as a bill "To amend section 712 of the Employee Retirement Income Security Act of 1974, section 2705 of the Public Health Service Act, and section 9812 of the Internal Revenue Code of 1986 to require equity in the provision of mental health and substance-related disorder benefits under group health plans" on March 9, 2007. In addition to the official titles of this legislation as proposed and enacted, the subtitles of this law reveal the range of issues covered by this law:

Emergency Economic Stabilization Act of 2008

Energy Improvement and Extension Act of 2008

Heartland Disaster Tax Relief Act of 2008

Paul Wellstone and Pete Domenici Mental Health Parity and Addiction

Equity Act of 2008

Tax Extenders and Alternative Minimum Tax Relief Act of 2008

The mental health provisions of this law mandated that if health insurance companies provide coverage for mental health and substance abuse, the coverage must be equal for conditions such as psychological disorders, alcoholism, and drug addiction and were included under Title V, Subtitle B, the Paul Wellstone and Pete Domenici Mental Health Parity and Addiction Equity Act of 2008 . 
Division A of this Act is made up of the Emergency Economic Stabilization Act of 2008, with Title I enacting the Troubled Asset Relief Program, generally referred to as TARP. This program authorized the Secretary of the Treasury to purchase troubled assets from financial institutions in response to the subprime mortgage crisis. Other expenditures aimed at mitigating unforeseen losses were included as disaster relief for areas hit by Hurricanes Ike and Katrina in Title V.

The Energy Improvement and Extension Act of 2008, included as Division B, far removed from mental health issues, did, however, even within the economic crisis of 2008, show that ethanol interests were able to include provisions benefiting producers such as:

Title II - Transportation and Domestic Fuel Security Provisions Section 201 - Includes cellulosic biofuel within the definition of biomass ethanol plant property for purposes of bonus depreciation. ${ }^{129}$

\section{The Food, Conservation and Energy Act of 2008, Public Law 110-234/110-264}

In analyzing the legislative record related to ethanol from 2005 to 2008 PL 110234, also known as the Farm Bill, presents an interesting anomaly. Prior to 2008 the previous omnibus farm bill, Public Law 107-171 enacted in 2002 governed farm and food policy. Included in the law were programs ranging from commodity price supports, income support for farmers, farm credit, foreign and

${ }^{129}$ (United States Congress, 2008) 
domestic food programs (food stamps). In early as 2005 Congress began considering the impending need to reauthorize a new "Farm Bill." The process was so contentious that in the spring of 2008 - six years after enacting the existing Farm Law and three years into negotiations over the new act -- several one-week extensions of PL 107-171 were granted prior to enactment of the new law since many of the provisions of PL 107-171 had expired. The Farm Bill that was eventually sent to President Bush in 2007 was promptly vetoed as he had made it clear to Congress that he wished to see some attributes of farm programs reduced. (See appendix II for the text of President Bush's veto message wherein he explains in detail his concerns with the bill) The Congressional and Senate response to the Presidential veto was unusual:

On May 21-22, [2008] both the House and the Senate voted to override a presidential veto of the conference agreement on the 2008 farm bill (H.R. 2419, the Food, Conservation, and Energy Act of 2008), and the conference bill became law on May 22, 2008 (P.L. 110-234). However, an enrolling error resulted in one title of the bill (Title III, Trade) being omitted from the version that was sent to the White House and the newly enacted law contains 14 of 15 farm bill titles. To resolve this issue, both the House and Senate passed a version of the 2008 farm bill with all 15 original bill titles (H.R. 6124). The President vetoed H.R. 6124 on June 18 , but both the House and Senate voted to override the veto that same day and the bill became law (P.L. 110-246), replacing P.L. 110-234. ${ }^{130}$

The resulting law, PL 110-246 while continuing traditional farm and food programs, has many provisions funding ongoing and expanded ethanol production, blending and facility construction. The following summary by the Congressional Research Service illuminates those provisions:

The Food, Conservation, and Energy Act of 2008 (P.L. 110-246, the 2008 farm bill) extends and expands many of the renewable energy programs

${ }^{130}$ (Schnepf, 2010) 
originally authorized in the Farm Security and Rural Investment Act of 2002 (P.L. 107-171, 2002 farm bill). The bill also continues the emphasis on the research and development of advanced and cellulosic bioenergy authorized in the 2007 Energy Independence and Security Act (P.L. 110140). Farm bill debate over U.S. biomass-based renewable energy production policy focused mainly on the continuation of subsidies for ethanol blenders, continuation of the import tariff for ethanol, and the impact of corn-based ethanol on agriculture. The enacted bill requires reports on the economic impacts of ethanol production, reflecting concerns that the increasing share of corn production being used for ethanol had contributed to high commodity prices and food price inflation.

Title VII, the research title of the 2008 farm bill, contains numerous renewable energy related provisions that promote research, development, and demonstration of biomass-based renewable energy and biofuels. The Sun Grant Initiative coordinates and funds research at land grant institutions on biobased energy technologies. The Agricultural Bioenergy Feedstock and Energy Efficiency Research and Extension Initiative provides support for on-farm biomass energy crop production research and demonstration.

Title IX, the energy title of the farm bill, authorizes mandatory funds (not subject to appropriations) of $\$ 1.1$ billion, and discretionary funds (subject to appropriations) totaling $\$ 1.0$ billion, for the FY2008-FY2012 period. Energy grants and loans provided through initiatives such as the Bioenergy Program for Advanced Biofuels promote the development of cellulosic biorefinery capacity. The Repowering Assistance Program supports increasing efficiencies in existing refineries. Programs such as the Rural Energy for America Program (REAP) assist rural communities and businesses in becoming more energy-efficient and self-sufficient, with an emphasis on small operations. The Biomass Crop Assistance Program, the Biorefinery Assistance Program, and the Forest Biomass for Energy Program provide support to develop alternative feedstock resources and the infrastructure to support the production, harvest, storage, and processing of cellulosic biomass feedstocks. Cellulosic feedstocks-for example, switchgrass and woody biomass - are given high priority both in research and funding.

Title XV of the 2008 farm bill contains tax and trade provisions. It continued current biofuels tax incentives, reducing those for corn-based 
ethanol but expanding tax credits for cellulosic ethanol. The tariff on ethanol imports was also extended. ${ }^{131}$

\section{The Tax Relief, Unemployment Insurance Reauthorization and Job Creation Act of 2010, Public Law 111-312}

Introduced in Congress by James Oberstar (MN-D) with five cosponsors on March 16, 2010 as a bill "to amend the Internal Revenue Code of 1986 to extend the funding and expenditure authority of the Airport and Airway Trust Fund, to amend title 49, United States Code, to extend authorizations for the airport improvement program, and for other purposes," Public Law 111-312 was enacted

upon President Obama's signature December $17^{\text {th }}, 2010$. This Act extended expiring concessions primarily relating to income and estate taxes. Title VII, Temporary Extension for Certain Expiring Provisions extended the Volumetric Ethanol Excise Tax Credit (VEETC), and the "blenders credit" of 45 cents per gallon for one year until the end of 2011. The law also extends the 54cents per gallon tariff on ethanol until the end of 2011, which discourages ethanol imports into the U.S. ${ }^{132}$

\footnotetext{
${ }^{131}$ (Stubbs, 2011)

132 (Public Law 111-312-December 17, 2010, Section 708, Extension of Provisions Related To Alcohol Used as Fuel) pp. 18
} 


\section{Summary}

This chapter presented a series of laws enacted over the decades subsequent to the Arab Oil Embargo of 1973 which address many of the deep concerns the nation has had regarding energy security, national security and the possibilities of ethanol to alleviate some of those concerns. It is the evolution of these laws which resulted in a Nation producing virtually no fuel ethanol in 1978 to America requiring a mandated 36 billion gallons of yearly usage by 2022 . Throughout the evolution of ethanol policy, one common theme was evident: a growing and intense concern on both sides of the aisle about the environment. By 2006 and 2007 when the last law examined was being debated and crafted, there was intense focus on the Inconvenient Truth, ${ }^{133}$ a movie produced and narrated by $\mathrm{Al}$ Gore contributing to global warming fears permeating both the public and legislative spheres. The common perception in Congress was that the production and use of ethanol reduced global warming. In 2007 The Union of Concerned Scientists presented that conclusion. ${ }^{134}$ In no small part, the very substantial RFS (Renewable Fuels Standard) mandate increase enacted in 2007 was based on that belief, yet that widely accepted foundational assumption was contradicted by an equally eminent Nobel Prize winning scientist, Paul Crutzen in his 2007 publication $^{135}$ concluding that:

When the extra $\mathrm{N} 2 \mathrm{O}$ emission from biofuel production is calculated in "CO2-equivalent" global warming terms, and compared with the quasicooling effect of "saving" emissions of fossil fuel derived CO2, the

\footnotetext{
${ }^{133}$ (An Inconvenient Truth, 2008)

${ }^{134}$ (The Union of Concerned Scientists, 2007)

135 (Crutzen, 2008)
} 
outcome is that the production of commonly used biofuels, such as biodiesel from rapeseed and bioethanol from corn (maize), depending on $N$ fertilizer uptake efficiency by the plants, can contribute as much or more to global warming by $\mathrm{N} 2 \mathrm{O}$ emissions than cooling by fossil fuel savings. ${ }^{136}$

What Crutzen and others had come to understand was that on balance the production and use of ethanol increased global warming rather than reduced it. Science, while divided on the issue, illuminated the very real (and subsequently verified) possibility that the required large increases in nitrogen fertilizers to grow additional corn was increasing global warming more than the "clean burning" ethanol was reducing it. This information was available and read by legislators in their deliberative democracy structured deliberations, ${ }^{137}$ yet even with informative Congressional Research data available to them, no modifications were made to mandates, subsidies, tax credits or incentives to produce and use more ethanol. Included in the global warming 'unintended consequences' data Congress was considering about this issue was information that plainly presented another worrisome concern: an area the size of New Jersey, just off the Mississippi River delta in the Gulf of Mexico was becoming a 'dead zone' to aquatic life as a result of increasing quantities of nitrogen fertilizer being washed from crop lands across the mid-west down the river. ${ }^{138}$

As legislators considered increasing the RFS mandates significantly in 2007 they relied on the several iterations of the 'billion ton study,' which had indicated the availability of a billion tons yearly of cellulosic material with which ethanol could

\footnotetext{
${ }^{136}$ (IBID) pp.389

137 (Bracmort, 2010)

138 (Donner, 2008)
} 
be produced. ${ }^{139}$ Through their deliberative democracy deliberations legislators accepted the studies assertion that the United States had in excess of a billion tons of cellulosic material available which could replace $30 \%$ of the nation's petroleum consumption by the middle of the $21^{\text {st }}$ century. As they considered the reports they, for some inexplicable reason, did not include the additionally required energy, gathering/harvesting, infrastructure and transportation costs of using the cellulosic material. As the Department of Energy report presented:

The report only provides estimates of biomass to roadside or the farmgate. The potential biomass inventory at a given spatial scale is biomass in the form and quality of the production system, which is identified in the report for a specific feedstock. It is important to understand that the estimates in the report do not represent the total cost or the actual available tonnage to the biorefinery. There are additional costs to preprocess, handle, and transport the biomass. There may be storage costs for specific feedstocks. Although the estimates do include losses to roadside, the estimates do not include losses due to continued handling, additional processing, storage, material degradation, and quality separation. In effect, for example, more than one billion tons from estimates in the report would be required to have one billion tons ready to process at a biorefinery. The amount would be dependent on many variables in the continued supply chain and final conversion technology. In addition, the biomass is in varied forms and may not be directly comparable at a biorefinery in either cost or conversion efficiency. Determining such values is outside the scope of the report. $^{140}$

Some of the government's own research presented to Congress show clearly unattainable harvest growth expectations in the future, yet these were not factored into the mandates either:

Agricultural lands can provide nearly 1 billion dry tons of sustainably collectable biomass and continue to meet food, feed and export demands.... Providing this level of biomass will require increasing yields of corn, wheat, and other small grains by 50 percent; doubling residue-tograin ratios for soybeans; developing much more efficient residue harvesting equipment; managing active cropland with no-till cultivation;

${ }^{139}$ (United States Department of Energy , 2011)

140 (IBID) pp.xvii 
growing perennial crops whose output is primarily dedicated for bioenergy purposes on 55 million acres of cropland, idle cropland, and cropland pasture; using animal manure in excess of what can be applied on-farm for soil improvement for bioenergy; and using a larger fraction of other secondary and tertiary residues for bioenergy. ${ }^{141}$

While some of these laws illuminated may seem more significant than others and some may be more focused than others on the development of ethanol policy, it is in the totality of these laws that an assessment may be made as to the presence, or not, of deliberative democracy in the legislative process that established America's ethanol energy policy. As will be seen in the examination and assessments made in chapters 4 and 5, along with the conclusions in chapter 6 , the process of evaluating the efficacy of deliberative democracy in creating ethanol legislation is more than just evaluating current outcomes of ethanol policy and comparing those outcomes to the intentions of the legislators who enacted such policies. An assessment of a deliberative democracy presence in the creation of the nation's ethanol policy requires examining a minimum of several laws enacted over several decades and tracking the outcomes and stated intentions of those individual statutes to discern if those goals were met. To meet the change over time parameter chapter 4 examines four of those acts during the pre-911 era for their outcomes and presents the dynamics of the legislative process behind their enactment. Chapter 5 examines two further acts in the post-911 era in a similar manner. To the degree that the national interest has, or has not, benefited from the accumulation of a series of enacted policies, conclusions have been reached determining the effectiveness of deliberative democracy in the legislative process and are presented in chapter 6.

${ }^{141}$ (Perlack, Wright, \& Turhollow, 2005) pp. 38 
Appendix III presents the detailed legislative histories for each of the examined laws showing the observable attributes of deliberative democracy in the formation of ethanol policy. 


\section{Chapter Four \\ Deliberative Democracy Legislative Analysis}

\section{National Political and Social Circumstances Driving Ethanol Policy}

In the early 1970's the United States experienced unprecedented economic challenges as a result of disruptions in global oil markets, as illustrated in chapter 1. Post World War II global economic expansion combined with a growing world population resulted in increased international use of oil to power state economies. The balance between production and consumption of oil globally has always been sensitive and changes in market circumstances have dramatic effects on both price and availability. The Arab Oil Embargo of 1973 illuminated America's dangerous sensitivity to any curtailment of imported oil supplies. Congressional-Executive leadership of the nation came under significant political pressure at the time to construct a sound response to the sudden financial shocks affecting the American economy. Legislative leaders recognized that the nation was not just vulnerable at that moment in time to disruptions of energy supplies, but that unless and until a new policy construct was created, America's economic and national security would be uncertain far into the future. In light of these circumstances legislators and Presidents embarked upon a series of policy actions which they believed would reduce America's dependence on imports of foreign oil, increase the nation's economic and strategic security, and enhance the nation's financial health by creating new jobs domestically in a growing national economy. As has been shown, the policies enacted over the past three decades have transferred enormous 
sums of wealth from consumers and taxpayers to ethanol producers and corn farmers as a consequence of legislated attempts to insure America's energy independence and self-sufficiency. The research question studied in this work examines the outcomes of deliberative democracy actions over time in the creation of an expensive and pervasive policy that affects virtually all American citizens. This work shows that while the central attributes of deliberative democracy were present (see figure 5, page 47), in varying degrees during the creation of the examined laws, the expected outcomes of beneficial national ethanol policies, were not achieved with the enactment of any of the laws examined. Additionally it is also shown that even with the presence of deliberative democracy attributes, the policy outcomes were, in fact, highly detrimental.

In 1973 the United States produced essentially zero ethanol for use as a transportation fuel. The Arab oil embargo of that year shocked the American economy and sense of invulnerability to the nation's core. Recognizing America's dependence on imports of foreign oil and the attendant national security implications, the first enacted legislative response was the Energy Tax Act of 1978. In 2007 with the enactment of the Energy and Security Act the nation has been mandated by legislative policy to produce and use 36 billion gallons per year of fuel ethanol by 2022. This creation and expansion of an entire new industry and national policy has evolved in only little over three decades. During this short time span almost 30 significant federal laws have been enacted to encourage, stimulate, support and mandate a variety of consumer, business and governmental 
behaviors that were intended to benefit national security. Each of the successive laws enumerated in chapter 3 were enacted to build upon prior legislation and respond to the then current circumstances of ethanol use, production and national security concerns.

During these years of legislative responses to energy and economic disruptions, successive Congresses have debated intensely as to the best and wisest courses of action to insure energy security and independence. These debates occurred during times of significant events which affected the legislative perception of energy security: A wrenching oil embargo, the Iranian Revolution of 1978, the Iran-Iraq war of 1980-1988, the fall of the Soviet Union, the Persian Gulf War in 1991, widely fluctuating oil prices (see figure 8 in chapter 3 ), the dramatic expansion of fundamentalist terrorism with the 911 attacks upon America and the more recent Iraq War. As the research question addressed in this work examined legislative history and process to determine the presence or absence of deliberative democracy it was necessary to select and analyze a representative range of enacted laws over time. The selected six legislative acts begin with the first law enacted in 1978 and conclude with law enacted in 2007. In the intervening years there were, amongst many, significant acts which occurred in 1988, 1992, 2000 and 2005 that were intended to enhance and enlarge ethanol policy. The six laws analyzed were selected to assess, in the aggregate, over time, the attributes of deliberative democracy present and the outcomes both individually and collectively, of the enactment of these laws, for the nation. The outcomes of each examined law were analyzed to conclude the effectiveness of the presence of 
deliberative democracy in the legislative process of policy formation. The stated objectives of each law at its inception and enactment were compared to the results over time subsequent to the laws implementation. It is shown that despite changes of political parties in majority control of the Congress or Presidency over the decades,${ }^{142}$ the presence of legislative agreement or discord in the debate records, the intended outcomes designed to insure a national benefit have not been met.

Each of these laws, as presented below, has a robust legislative history which is traced and examined for attributes of deliberative democracy. As is seen in this chapter's summary, this series of laws intended outcomes have varied significantly from the stated intentions of legislators and Presidents enacting such policies. This calls into question the ability of our nation's current legislative and administrative framework to enact nationally beneficial policy outcomes even when debating legislation within the deliberative democracy framework envisioned in the Founders original concept.

\section{The Post Arab Oil Embargo Ethanol Policy Era}

1974 saw the nation wrestling with the aftermath of the Arab Oil Embargo. Inflation was high and the country struggled with a shrinking economy. A new term had entered the popular lexicon: stagflation; having both inflation and recession at the same time. The political atmosphere of the nation was hostile and angry. President Nixon was struggling with the Watergate scandal and would

\footnotetext{
${ }^{142}$ (See Appendix XV for Executive-Legislative dominance during the period)
} 
resign the Presidency in August of the year. The Congress was consumed with debate over issues ranging from impeachment to the Cold War to the energy crisis to the recession affecting the national economy. In January of 1975 Bruce K. MacLaury, President of the Minneapolis Federal Reserve Bank published a synopsis of the current economic circumstances entitled "The Limping Giant: The American Economy 1974-75."143 His thesis was direct and clear: There were four main issues the nation had to address to right itself. Those were inflation, recession, "the energy crisis," and questions of financial stability. ${ }^{144}$ It is to "the energy crisis" issue that this section looks to examine the response of political leadership. If the presence of deliberative democracy as envisioned by the Madison and Bessette was evident during these trying times, then resulting legislative policies should have successfully resolved American vulnerability to disruptions in oil supplies and the nation's strategic security strengthened. Such outcomes would also enhance the nation's economic performance and balance of trade.

It is with this mid-1970's perspective that the three decade examination of the selected relevant laws begins. The presence or absence of deliberative democracy attributes are analyzed to assess their effects on legislative outcomes.

\footnotetext{
143 (MacLaury, 1975; MacLaury, 1975)

144 (IBID)
} 


\section{Public Law 95-618 - Energy Tax Act of 1978}

\section{H.R. 5263}

\section{Initial Legislative Ethanol Policy Response to the "Energy Crisis"}

In November of 1976 Jimmy Carter was elected President during the difficult national economic circumstances presented above. Carter's first address to a joint session of Congress occurred on April 20 ${ }^{\text {th }}$, 1977 exactly 90 days after his inauguration. The address presented an outline of his National Energy Program legislative proposals. ${ }^{145}$ The timing of his address was significant in that he had expressed his desire to formulate a comprehensive energy policy within the first three months of his Presidency. Only two days prior, on April $18^{\text {th }}$, the President addressed the nation in a televised message from the Oval Office presenting to the American people his understanding of the severe energy crisis facing the country. ${ }^{146}$ The rhetoric of this address was alarming and included comments such as:

If it were possible for world demand to continue rising during the next few years at the rate of 5 percent a year, we could use up all the proven reserves in the entire world by the end of the next decade. ${ }^{147}$

While not scientifically accurate, these comments were intended to focus the attention of Congress and the public that an energy crisis did exist. Two days

\footnotetext{
145 (Woolley, John \& Peters, Gerhard, 1977; Woolley, John \& Peters, Gerhard, 1977)

146 (IBID)

147 (IBID)
} 
earlier, President Caters had outlined the ten fundamental principles of his energy program: ${ }^{148}$

The first principle is that we can have an effective and comprehensive energy policy only if the government takes responsibility for it and if the people understand the seriousness of the challenge and are willing to make sacrifices.

The second principle is that healthy economic growth must continue. Only by saving energy can we maintain our standard of living and keep our people at work. An effective conservation program will create hundreds of thousands of new jobs.

The third principle is that we must protect the environment. Our energy problems have the same cause as our environmental problems -- wasteful use of resources. Conservation helps us solve both at once.

The fourth principle is that we must reduce our vulnerability to potentially devastating embargoes. We can protect ourselves from uncertain supplies by reducing our demand for oil, making the most of our abundant resources such as coal, and developing a strategic petroleum reserve.

The fifth principle is that we must be fair. Our solutions must ask equal sacrifices from every region, every class of people, every interest group. Industry will have to do its part to conserve, just as the consumers will. The energy producers deserve fair treatment, but we will not let the oil companies' profiteer.

The sixth principle, and the cornerstone of our policy, is to reduce the demand through conservation. Our emphasis on conservation is a clear difference between this plan and others which merely encouraged crash production efforts. Conservation is the quickest, cheapest, most practical source of energy. Conservation is the only way we can buy a barrel of oil for a few dollars. It costs about $\$ 13$ to waste it.

The seventh principle is that prices should generally reflect the true replacement costs of energy. We are only cheating ourselves if we make energy artificially cheap and use more than we can really afford.

The eighth principle is that government policies must be predictable and certain. Both consumers and producers need policies they can count on so they can plan ahead. This is one reason I am working with the Congress to create a new Department of Energy, to replace more than 50 different agencies that now have some control over energy.

\footnotetext{
148 Jimmy Carter, "The President's Proposed Energy Policy." 18 April 1977. Vital Speeches of the Day, Vol. XXXXIII, No. 14, May 1, 1977, pp. 418-420.
} 
The ninth principle is that we must conserve the fuels that are scarcest and make the most of those that are more plentiful. We can't continue to use oil and gas for 75 percent of our consumption when they make up seven percent of our domestic reserves. We need to shift to plentiful coal while taking care to protect the environment, and to apply stricter safety standards to nuclear energy.

The tenth principle is that we must start now to develop the new, unconventional sources of energy we will rely on in the next century.

The $95^{\text {th }}$ Congress would consider the President's proposals for many months and eventually pass five laws referred to as the National Energy Act of 1978 relating to the conservation, production, taxation and regulation of energy as well as restructuring government agencies.

The Energy Tax Act of 1978, Public Law 95-618, one of the five laws, was the first energy legislation that included ethanol policy provisions. The objective of this law was to move from the dependency on foreign oil and gas sources towards energy conservation. The law sought to promote fuel efficiency and renewable energy through the fiscal mechanisms of taxes and tax credits. While there had been much Congressional discussion regarding ethanol policy issues prior to 1977, this legislation was the first successfully enacted to include provisions for ethanol production and blending. In spite of the stated preference of the President and many in Congress for coal as the alternative fuel source of choice, the relatively minor tax concession granted to gasoline containing a ten percent alcohol blend initiated ethanol policy. 


\section{Deliberative Democracy Measurements and Timeline}

Legislative history data, showing the deliberative democracy attributes in the legislative steps from introduction of 95 H.R. 5263 through the phases leading to the bills enactment into law by the President are presented in appendix IV. The operation of deliberative democracy, whether resulting in positive policy outcomes or not, is examined through the various steps of legislation introduction, committee assignments, hearings, floor debate, consideration of amendments and conference reports leading to the passage of this law required examining available data through the matrix of measurement tools presented on page 47, figure 5 . (Also refer to appendix XVI for presentation of an additional deliberative democracy measurement table). Examination of this law through the lens of a deliberative democracy measurement matrix reveals informative data significant to the discussion and analysis following in the next section of this chapter. Committee hearings are presented as an integral component of the deliberative process. This legislation was referred to, and considered by, no less than 18 committees during its gestation. ${ }^{149}$ These committees held no less than 30 hearings receiving testimony relating to aspects of the proposed legislation. ${ }^{150}$ Committee hearings and activities were numerous, well attended and publicized. (Appendix XXIII shows witness presentations and data lobbying before the Senate Committee on Agriculture, Nutrition and Forestry considering this bill. The testimony, typical of many hearings on the subject of ethanol, presents a variety of supportive and critical, conflicting positions on the economic and

\footnotetext{
149 (Library of Congress, 1978) and Appendix IV

150 IBID
} 
energy independence attributes of the proposed bill). Such a process is an assessable attribute of deliberative democracy. There was vigorous floor debate on several occasions (18 July 1977, 25 - 31 October 1977 and 12 - 31 October 1978). At this formative stage in the development of ethanol policy, only one heating directly addressed the option of ethanol as an alternative fuel.

It is significant to note that the $95^{\text {th }}$ Congress was the last Congress until 2009 to enjoy a filibuster proof majority of one party in power. This supremacy combined with the Presidency residing in the same party resulted in an ability of the majority to dictate whatever outcome they desired. The record of numerous committees considering this legislation, many hearings being held, various witnesses' statements being heard and the extensive Congressional Record reflecting debate on the proposed legislation all indicate the presence of deliberative democracy attributes despite the strong majority of one party.

\section{Exploration of Legislative Activity}

While the circumstances driving ethanol policy creation and its formation in this law - the intense energy and economic challenges facing the new President, Jimmy Carter - are discussed in this chapter, it is also necessary to examine the process of committee assignments, hearings held and the perspectives evident in representative testimony. Such an examination can ascertain the operation and extent of deliberative democracy present in the crafting of ethanol policy at this historical juncture. At its inception H.R. 5263 was referred to eighteen different 
committees including: Senate Committee on Energy and Natural Resources, House Committee on Energy, House Committee on Ways and Means, House Committee on Budget, Senate Committee on Finance as well as the Senate Committee on Energy and Natural Resources, and others (see appendix IV for more details) whose chairmen exercised their oversight authority to also hold hearings on the bill.

Bob Dole (R-KS) articulated the mood of Congress in approaching energy legislation in context of President Carter's National Energy Program in an August 1977 hearing of the Senate Committee on Finance, where he stated:

By failing to take corrective action in the past, this Nation has permitted its energy problem to reach crisis proportions. We are to the point of paying $\$ 42$ billion this year for imported oil. Our oil imports are so large that we will probably suffer a record trade deficit in 1977 of over $\$ 30$ billion. These deficits are a serious drain on our economy. They point up the importance of taking steps to curb our oil imports.

Given the expansion of H.R. 5263 from a bicycle parts bill to an omnibus energy act, the hearings record details the wide range of issues considered in formulating what would become Public Law 95-618. These included:

- Mandatory Energy Conservation Amendments to President Carter's Energy Program

- Mandatory installation of radial tires and demand actuated engine fans on certain trucks

- Economic Feasibility of Gasohol

- Large scale production of ethanol from fermentation of grains and farm waste materials 
- Stricter minimum fuel economy standards

- Increased Government regulation of end-use energy efficiency

- Objections to minimum fuel economy standards as disrupting manufacturers

- Adverse impact on auto dealers of "gas guzzlers" tax

- Graduated efficiency incentive tax on new automobiles not meeting Federal fuel efficiency standards, with revenues to go into a new trust fund to retire the public debt

- Consumption taxes on industrial and utility use of petroleum products and natural gas to encourage conversion to coal use, with rebates for investment in alternative energy facilities

- Tax incentives for the development of geothermal energy

- Control oil and natural gas prices and production

- Suggested tax incentives to encourage natural gas exploration and development

- Proposed tax increase on noncommercial aviation fuel

- Merits of applying "gas guzzler" tax to recreational vehicles and light trucks

- Suggested alternatives to stimulate domestic energy exploration and development

- Review of oil companies capital expenditure and indebtedness trends; potential adverse impact of bill on petroleum industry access to credit 
- Proposed amendments to provide incentives to develop alcohol-based fuels

- Assessment of oil shale development costs and problems

- Detrimental impact of equalization tax on small refiners

- Assessment of proposed bill's ability to stimulate domestic production

- Administration's proposed use of energy price increases to encourage energy conservation

- Appraisal of petroleum supply and demand elasticity

- Assess the economic feasibility of substituting gasohol, a blend of $90 \%$ gasoline and 10\% alcohol-based liquids, for gasoline as the primary fuel for automobiles

- Assessment of economics of grain-based alcohol production including impact on agricultural surpluses and nature of subsidies required

- Effects of alcohol-based fuels on vehicle emissions

- Review of DOE gasohol research program findings

- Negative aspects of alcohol fuel production and use

- Status of alcohol-based liquids research; belief in economic viability of gasohol; support for additional research funding to reduce alcohol fuel production costs

- Review of proposal's major tax elements, including crude oil and gas equalization tax and credits, residential and business conservation tax credits 
The topics selected, combined with identifiable preferences of policy makers in guiding the tone of the hearings, while demonstrating the presence of deliberative democracy, largely resulted in predetermined outcomes. Thus the selection of witnesses and the range of the positions they represent are significant to the examination of deliberative democracy. In addition to testimony from agents of the Executive branch, including the Department of Energy and the EPA, testimony delivered in hearings directly addressing ethanol can be broken down into the following categories:

- Associations lobbying committees on ethanol production and usage issues National Electric Manufacturers Association

National Governors' Conference

Battelle Memorial Institute

New England Fuel Institute

Center for Auto Safety

National Automobile Dealers Association

Worldwatch Institute

American Automobile Association

International Taxicab Association

Edison Electric Institute

American Gas Association

Energy Consumers and Producers Association

National Association of Recycling Industries

Petrochemical Energy Group

Aircraft Owners and Pilots Association 
American Association of Homes for the Aging

Public Citizen's Tax Reform Research Group

Consumer Federation of America

Western Oil and Gas Association

National Liquid Petroleum Gas Association

National Oil Jobbers Council

National Association of Motor Bus Owners

National Taxpayers Union

Solar Energy Industries Association

Mechanical Contractors Association of America

National Solid Wastes Management Association

Gas Appliance Manufacturers Association

AFL-CIO

Chamber of Commerce of the U.S.A

American Petroleum Refiners Association

Independent Refiners Association of California

Independent Refiners Association of America

Oil Chemical and Atomic Workers International Union

United Automobile Workers

National Electric Reliability Council

American Textile Manufacturers Institute

National Canners Association

Center for Advanced Research

U.S. Auto Club 
Indiana Farm Bureau Cooperative Association

Indiana Farmers Union

Academic institutions presenting data on energy and ethanol issues

Wharton Econometric Forecasting Association

Purdue University

University of Southern California

Brookings Institution

Massachusetts Institute of Technology

- Corporate entities:

Thermo Electron Corporation

American Natural Resources Company

General Motors Corporation

Ford Motor Company

Chrysler Corporation

Middle South Utilities

Texas Utilities Company

Montana Power Company

Ebasco Services, Incorporated

Foster Wheeler Corporation

B F Goodrich Company

Outboard Marine Corporation

General Electric Company

Marathon Oil Company

Louisiana Land and Exploration Company 
El Paso Products Company

Salomon Brothers

Billings Energy Corporation

Peter Pan Bus Lines

Continental Trailways

Atlantic Richfield Company

Tosco Corporation

Republic Geothermal, Incorporated

Geothermal Resources International

Union Oil Company of California

Mount Airy Refining Company

Rock Island Refining Corporation

Seaboard Coast Line Industries

Illinois Central Gulf R.R

Crown Central Petroleum Corporation

Cities Service Company

Pester Refining Company

United Refining Company

Amoco Oil Company

Midwest Solvents Company

Kaiser Industries

- Environmental groups:

Environmental Policy Center

Citizens for Clean Air 
Resources for the Future

Environmental Defense Fund

Although, at this point in alternative energy deliberations much of the discussions in hearings focused on coal, nuclear power and shale, some general comments about the orientation towards energy policy in general and alternative fuels in particular is informative in tracing some of the assumptions rooted in ethanol policy. In a August 1977 hearing of the Senate Committee on Finance entitled "Energy Tax Act: Administration Witnesses" representatives from both the legislature and administration articulated the need for Federal support in order make alternative fuel sources a reality. Senator Russell Long (D-LA) stated:

It appears to me you have to put enough resources into alternatives to make them work. For example, if we put enough subsidy into solar energy, we could induce everybody in the country to use solar energy, or everybody below the Mason-Dixon line to go to solar to heat their water. Take areas like the Virgin Islands, Puerto Rico California and Hawaii, we could put enough into developing wind, solar geothermal energy to make tremendous breakthroughs.

The general premise behind this thinking was that behavior would change given sufficient incentives, regardless of the alternative chosen. These sentiments were echoed later in that hearing in testament offered by Michael Blumenthal, the Secretary of the Treasury Department:

The substitution of coal and of other fuels for oil and gas is to be achieved by providing an incentive in the tax system for businesses to convert to these alternative fuels. Solar, wind, geothermal energy sources will also be favorably treated to encourage greater residential and industrial use. 
In looking more specifically at alternatives to fossil fuels, John Schlesinger, Secretary of the Department of Energy in that same hearing commented:

One effect of the oil and gas user taxes will be to increase the attractiveness of a large number of alternative technologies. Now going beyond you have that, in terms of general subsidy for a variety of technologies--coal gasification is one which is normally suggested-it is a question of how much should be distributed.

While this hearing did not directly address ethanol as an alternative fuel option, it reveals the general policy orientation to alternative fuel development at this early stage of policy development. The commitment of Federal funds to increase the use of alternative technologies was taken as given by the administration and the legislature.

At the hearing stage of deliberation regarding H.R. 5263, one committee hearing specifically addressed ethanol. On December 12, 1977 the Senate Subcommittee on Agriculture Research and General Legislation (part of the Committee on Agriculture, Nutrition and Forestry) held a hearing entitled "Economic Feasibility of Gasohol" in Indianapolis, Indiana. The purpose of this hearing was to assess the economic feasibility of substituting gasohol, a blend of ninety percent gasoline and ten percent alcohol, for gasoline as the primary fuel for automobiles. This hearing heard testimony from nine panels of witnesses representing interests ranging from farm groups to the Department of Energy, university researchers and car companies. The hearing was an overall endorsement of the need for gasohol. What are interesting are the comments made by Richard Lugar (R-IN), one of two Senators in attendance. In this early ethanol hearing, Lugar reflected the parochial nature of his interest in ethanol in his opening comments: 
We have now come to a part of history in this country in which we are deeply concerned about various energy sources, and their availability. We are deeply concerned in the farm community about the market for grain, sugar and other crops that might be grown, that might produce fuel for transportation or industrial purposes. Here we have people who are less interested in energy, but more interested in surpluses, raise the gasohol question.

Lugar's comments continued to show that for him, and many at the hearing, ethanol was primarily a market for farm products and then an alternatives fuel and finally national security asset.

I would say that I make no apology, nor do members of the Agricultural committee, for raising the question of how we are to provide more substantial markets for farm products. As a matter of fact, this is a timely question, trying to think through how our biomass sources, such as corn that we have available in Indiana, might be utilized. At the same time, I think we are mindful that our sources of supply of petroleum may not be unlimited, and the question of gasohol is raised therefore from this standpoint; likewise of national security interests.

In keeping with the overall legislative orientation to alternative fuels, Lugar ended his comments with a call for Federal funding:

If gasohol is feasible and made competitive with Federal tax advantages or various other subsidies, the amount of petroleum or other fossil fuels needed to produce gasohol leads to en energy deficit situation. In other words, the Btu's required for the production of gasohol exceeds that Btu's that might come forward from this process.

Lugar's final statement acknowledged what should have been a very serious barrier to ethanol as an alternative fuel alternative, its cost - in terms of Federal price support needed and energy input. Like much of the debate that would follow in committee hearing and on the floors both Houses of Congress, these concerns were put aside in the enthusiasm for expanding ethanol production. 
Ethanol would be included in the Energy Tax Act as gasoline alternative, but at its policy inception its roots trace back to being presented as both an alternative to gasoline and a solution to excess farm production and low commodity prices. It is interesting to note in the presentation of laws that follow that some of the more perplexing aspects of the economics of ethanol policy may reflect its genesis in "An Act to provide tax incentives for the production and conservation of energy, and for other purposes."

Public Law 95-618, The Energy Tax Act of 1978, had a complex gestation. Originally the bill was introduced in the House by Representative Rostenkowski as H.R. 5263 entitled "A bill to extend until the close of June $30^{\text {th }}, 1979$, the duty on certain bicycle parts" clearly having nothing to do with energy or ethanol policy. The proposed legislation was a very small 3 page bill of little complexity only extending dates of tax exclusions on bicycle parts. The bill was referred to the Committee on Ways and Means and reported out to the full house quickly on June $16^{\text {th }}$ wherein on July $18^{\text {th }}$ it was passed and sent to the Senate for consideration and referred to the Senate Committee on Finance on July 20, 1977. On October $21^{\text {st }}$ the bill was reported out of Committee to the full Senate. On October $25^{\text {th }}$ the bill was reconsidered by the Senate and recommitted to the Appropriations Committee for consideration and amendment. The bill was quickly reported out and the Senate considered and passed the bill on October $31^{\text {st }}$ wherein it was immediately scheduled for conference committees in both the House and Senate beginning on November $3^{\text {rd }}$ and $4^{\text {th }}$. The bill reported out of the

\footnotetext{
${ }^{151}$ This was the official title of Public Law 95-618, commonly known as the Energy Tax Act.
} 
Senate Finance Committee on October $21^{\text {st }}$ and subsequently approved as amended by the Senate on October $31^{\text {st }}$ bore no remote resemblance to the bicycle parts bill H.R. 5263 originally introduced and passed by the House. Senator Russell Long (D-LA) used his prerogative to literally strip out all of the language in the 3 page proposed H.R. 5263 and replace the language with several hundred pages of proposed energy legislation entitled "The Energy Production and Conservation Tax Incentive Act." It was this bill which included a myriad of energy issue provisions. It was at this juncture that the speedy and uncomplicated process of considering these bills ended. It was a full year later that the Conference Committee Reports were filed in the Senate and House on October $11^{\text {th }}$ and $12^{\text {th }}$ of 1978 . After debate and voting, both chambers agreed to the amended conference reports and passed H.R. 5263, now titled "The Energy Tax Act of 1978."

The legislative process over the intervening year between the House submission of bicycle parts legislation to the Senate in July of 1977 and the resulting Energy Tax Act in October of 1978 is a study in extensive debate, numerous committees' consideration and complex maneuvering within Congress. (See appendix IV presenting the legislative timeline of Congressional actions on this bill). For purposes of examining this law for outcomes of deliberative democracy there are two areas of consideration: How capacious and voluminous was the debate surrounding the enactment of this law and did the observed outcomes over time reflect the intended benefits of the law? The examination focuses on the specific 
provisions and attributes of the law that relate to this study of ethanol policy formation and proposed benefits.

Although there were many significant energy provisions emanating from the enacted legislation, the singular foundational attribute that began the national ethanol policy was clear and definable:

The Act exempted sales of gasoline containing at least 10 percent alcohol (by volume) from the 4 cent a gallon share of the federal tax on motor fuel that otherwise went into the federal Highway Trust Fund to pay for highway construction. At 10 percent concentrations, the exemption was worth 40 cents for every gallon of ethanol produced.

The goal of the tax exemption was to encourage the production and blending of ethanol into gasoline thereby reducing use of oil and consequent imports of foreign oil, by $10 \%$. Such a reduction in oil imports would, in theory, increase America's strategic security by reducing our vulnerability to disruptions of such imports. Additionally by reducing our reliance on imported oil we would expect to have less price escalation. This bill's ethanol provision had 26 sponsors by enactment $^{152}$ and was strongly supported by both Republicans and Democrats passing the House 231 to 168 and the Senate 60 to 17.

Although this law affected consumers and taxpayers in many ways, the central goal of the ethanol provision in the legislation was to reduce imports. The below

${ }^{152}$ (Glozer, 2011) pp. 17 
chart shows clearly that whatever other costs and effects the act may have had, it did not reduce imports of oil.

\section{Figure 13}

\section{Imports and Dependency Chart $^{153}$}

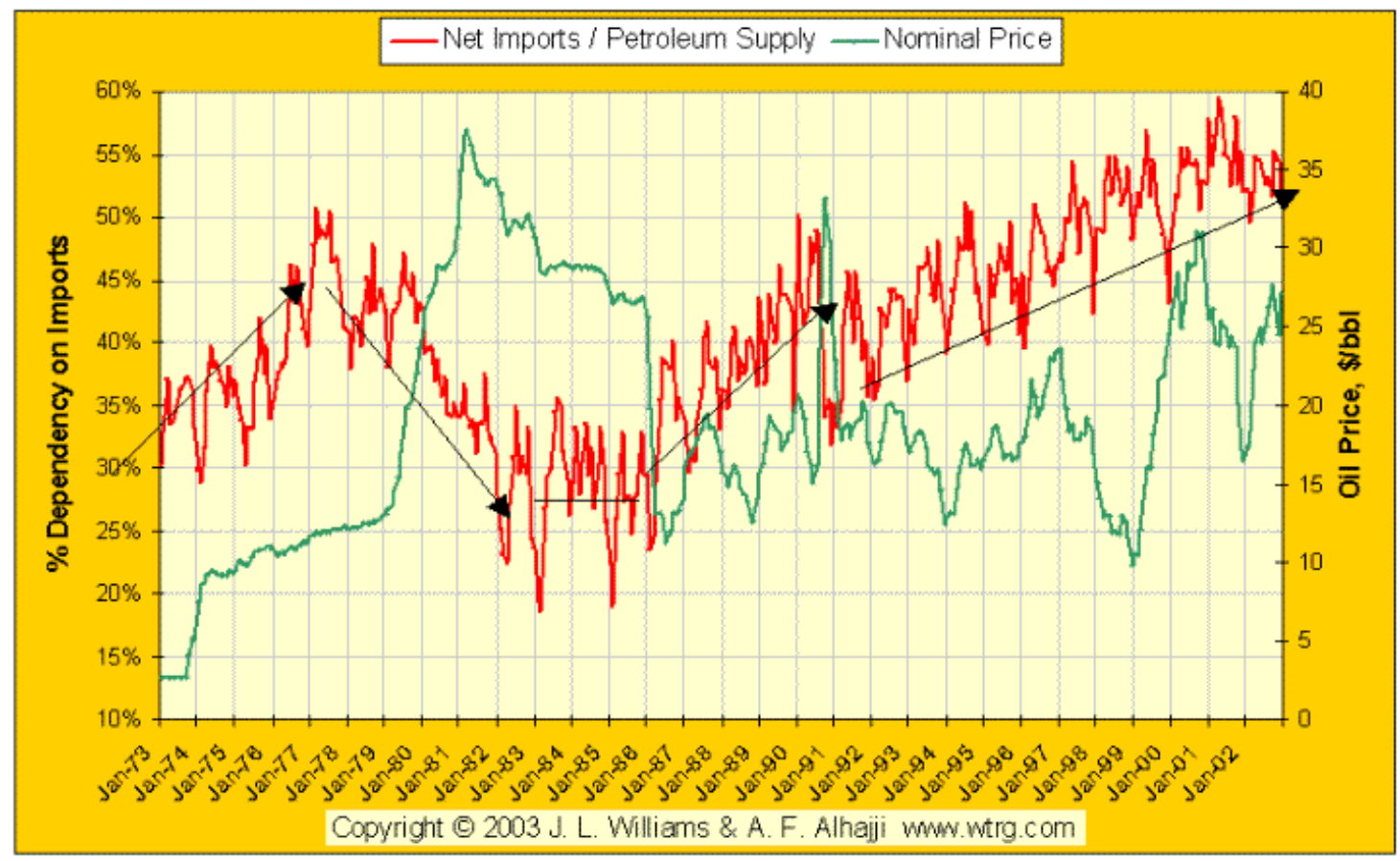

During 1974, just after the Arab Oil embargo, the nation imported between 35 and $40 \%$ of the oil it consumed. During 1978 and the extensive debate over the provisions surrounding the enactment of this law, the nation was importing between 40 and $47 \%$ of the oil it consumed. At the time of the Arab Oil embargo oil was trading at approximately $\$ 4.75$ per barrel. In 1974 it was trading in the

153 (WTR Economics, 2003) 
$\$ 9.35$ per barrel range and by 1978 while this legislation was being considered, oil was trading in the $\$ 14.95$ per barrel range. ${ }^{154}$

An analysis of this law, and the era during which it was legislated, shows a period of increasing oil prices and oil imports which were seen as painful to the nation. Out of these circumstances Congress determined that the most effective response to these challenges was, amongst several, to strongly encourage the production and use of ethanol fuel in order to reduce imports, stabilize prices and increase national security.

Assessing whether or not deliberative democracy attributes were present in the formulation of this law yields mixed results. This law had a complicated genesis in expanding from bicycle parts to a comprehensive energy package, including the first enacted provisions supportive of ethanol. The scope of committee hearings and extensive floor debate indicate the general presence of deliberative democracy attributes in the process of initiating ethanol policy. However, one particular area deviated from the general deliberative trend and served as a potential indicator that political behavior rather than deliberative behavior might be occurring as ethanol policy consideration proceeded. The Senate Subcommittee on Agricultural Research and General Legislation hearing held in Indiana conforms more to a political than deliberative activity. Although the purpose of the hearing was to assess the economic feasibility of substituting gasohol for gasoline as a primary automobile fuel, very little assessment occurred in the hearing. Instead the Senators in attendance endorsed ethanol policy while

154 (Inflation Data, 2011) 
mobilizing early support for ethanol as a policy option from a constituency with a vested interest in tying this aspect of energy policy to the farm economy.

This law, the Energy Tax Act of 1978 is the baseline and foundation of this dissertations research. Following this section are examinations of five subsequent acts which addressed changing national circumstances over time that Congress believed required legislative responses. 


\section{Public Law 100-494 - Alternative Motor Fuels Act of 1988}

\section{S. 1518}

\section{Deliberative Democracy Measurements and Timeline}

Legislative history data, showing the deliberative democracy attributes in the legislative steps from introduction of the initial bill through the phases leading to the bills enactment into law by the President are presented in appendix V.

The $100^{\text {th }}$ Congress was in session from January 1987 until January of 1989. Between the enactment of Public Law 95-618 in November of 1978 and the $100^{\text {th }}$ Congress there had been several laws enacted encouraging the development of alternative fuels as a national priority. While the price of oil had varied significantly both up and down over the preceding decade (see graph, page 63) the Nation's dependence on foreign oil imports had gone in precisely the opposite direction of the objectives envisioned for the policies enacted; i.e. a significant increase from $40.5 \%$ imports under the Carter Presidency to $47.2 \%$ under the George H.W. Bush Presidency by 1989 (see chart, page 55). Between the enactment of Public Law 95-618, The Energy Tax Act of 1978 and the introduction of S. 1518 in 1988 the price of oil per barrel annually is shown in the following figure 14 . 


\section{Figure 14}

The Price of Oil per Barrel 1978-1988 ${ }^{155}$

\begin{tabular}{|c|c|c|c|c|c|c|c|c|c|c|c|}
\hline Year & 1978 & 1979 & 1980 & 1981 & 1982 & 1983 & 1984 & 1985 & 1986 & 1987 & 1988 \\
\hline $\begin{array}{l}\text { Price } \\
\text { of oil }\end{array}$ & $\$ 14.95$ & $\$ 25.10$ & $\$ 37.42$ & $\$ 35.75$ & $\$ 31.83$ & $\$ 29.08$ & $\$ 28.75$ & $\$ 26.92$ & $\$ 14.44$ & $\$ 17.75$ & $\$ 14.87$ \\
\hline
\end{tabular}

During this same period the importation of foreign oil had not declined at all as anticipated by the 1978 Act. When the cost of oil was low the numbers below clearly show the continuing reliance upon and vulnerability to foreign sources for the Nation's fuel supply. Congress clearly had not been able to prevent the free market from prevailing.

\section{Figure 15}

\section{U.S. Imports of Crude Oil and Petroleum Products (Thousand Barrels) ${ }^{156}$}

\begin{tabular}{|c|c|c|c|c|c|c|c|c|}
\hline Year & 1981 & 1982 & 1983 & 1984 & 1985 & 1986 & 1987 & 1988 \\
\hline $\begin{array}{c}\text { Crude Oil } \\
\text { Imports }\end{array}$ & 2,188 & 1,866 & 1,843 & 1,990 & 1,850 & 2,272 & 2,437 & 2,709 \\
\hline
\end{tabular}

The late 1980's was a period of relative geopolitical and economic security. The economy was doing well and oil prices were at near record lows. Given the relatively cheap cost of oil available from foreign sources, domestic oil production had fallen. The impetus for energy policy as a National priority had waned and the Department of Energy saw its research budget slashed dramatically. These conditions contributed to a lull in legislative activity in the push for increased production and use of alternative fuels. Daniel Adams, (R-

\footnotetext{
155 (Inflation Data, 2011)

156 (U.S. Energy Information Administration, 2011)
} 
WA) addressed the need for continued focus on energy policy within that context in a statement made before Senate Committee on Commerce, Science and Transportation in June 1985:

It is true that today there are few signs of an impending energy apocalypse. In fact, the current picture appears quite rosy. It has been some time since we have seen the words 'energy crisis' in a headline. It is some time since we have heard of gasoline shortages. And it has been some time since we have had to speak of an OPEC sword of Damocles hanging over us. And yet it could change tomorrow. We cannot afford to forget that world oil prices shot up over 150 percent during the Iranian crisis of 1979, or that lines of two hours or even longer formed at gasoline stations throughout the country following the 1973-74 oil OPEC embargo.

Adams went on to project the outcome of consumer response to low oil prices and articulated the challenge of continuing alternative fuel discussions in that environment.

With domestic production declining, it is not farfetched to project that oil imports could surpass their previous peak, achieved in 1977 of 9.3 million barrels a day. In short, all estimates indicate that the United States will become increasingly dependent on foreign sources of oil, particularly if present consumption trends continue. The challenge is clearly before us. Today, with the economic recovery we are now experiencing, consumption of oil is increasing.

Slade Gorton (R-WA) echoed these sentiments in comments made before the same Senate hearing:

While gasoline prices may be at an unanticipated low, and supplies at an unexpected high, we will be naïve to presume that these conditions will prevail indefinitely. Our foreign oil sources continue to be vulnerable and unpredictable because they are for the most part located in politically volatile regions. And it has recently come to light that our domestic sources are not as plentiful as we had believed. We must therefore direct our energies toward developing alternative fuels 
Demonstrating the bipartisan nature of concerns of not losing energy policy momentum in that environment, Jay Rockefeller (D-VW) made these remarks before the same Senate hearing:

This country is once again in the business of pretending that the world has limitless supplies of oil and gas and that we are going to go into the $21^{\text {st }}$ century and right on through it on these two substances, and we simply know that is not true; that there has been a relatively low price of oil these days, but that has been shaken up before and it will be shaken up again, and that in fact the strength of our national security, the United States for its own clean air and for its own position for its coal miners and its economic situation, we must now renew our commitment to synthetic fuels in all varieties

This continuing failure of alternative fuel policy to reduce imports of foreign oil and improve national security motivated the introduction of several bills in the $100^{\text {th }}$ Congress encouraging further development, production and therefore use of alternative fuels, with ethanol emerging as the alternative fuel of choice as is evidenced in the names of the proposed laws. Among the proposed energy bills that failed to gain passage in the years following 95-618 were:

- S. 1097 Methanol Vehicles Incentives Act of 1985

- H.R.168 Replacement Motor Fuels Act of 1987

- H.R. 1505 to amend the Motor vehicle Information and Cost Saving Act

- H.R. 2031 to amend the Clean Air Act

- H.R. 2052 Ethanol Motor Fuel Act of 1987

Although these bills did not become law, many of their provisions were debated and/or included in the two energy bills that were introduced to the House and Senate in 1987 and woven into S. 1518. 
By 1987 the House and Senate were considering energy legislation focused on alternative fuels. The major policy tools for decreasing oil consumption were the CAFE (corporate average fuel economy) standards encoded in the P.L. 94-163, the Energy Policy Conservation Act of 1975 that mandated fuel economy standards for new vehicles and promotion of alternative fuels through alternative or flex-fuel vehicle production and increasing the supply of alternative fuels.

Senate bill S. 1518 was introduced by Senator John D. Rockefeller IV (D-WV) on July $21^{\text {st }}, 1987$ as the "Methanol and Alternative Fuels Promotion Act of 1987." This was the principal and surviving Senate legislation focusing on alternative fuels. In introducing this bill to a hearing of the Senate Subcommittee on Consumer Affairs entitled "Methanol and Alternative Fuels Promotion Act of 1987 " in November 1987, Rockefeller stated:

This country is on an unhealthy trip in terms of its fuels policy. We are bow feeding off of gasoline which comes from oil. I thought, and I think we all thought about price and about stability and supply. We at the time, I thought, vowed not to repeat our mistakes. We did not want to see disruption, and we wanted to develop alternatives. We made grand national pledges, and we did not do much. And we talked about making fuels from grains, from natural gas, from coal, and there was a lot of talk and not a great deal of action as a result of that talk... There has been some progress on conservation, but there has been precious little progress toward developing transportation fuel replacements

S. 1518 was based on S. 1097, Methanol Vehicles Incentives Bill introduced by Senator John Danforth (R-MO) in 1985 that had aimed to stimulate and accelerate the manufacture of methanol, ethanol and natural gas fitted vehicles that would in turn facilitate the fuelling and distribution cycle. The flaw in this logic - that the 
delivery infrastructure would naturally follow if the supply was provided - would be perpetuated in the provisions of S. 1518 as passed. This would become the chicken-and-egg aspect that would characterize the disconnect between ethanol production and distribution that would come to permeate ethanol policy as it evolved out of alternative fuel policy.

Almost concurrently with S. 1518, House bill H.R. 3399 was introduced by Philip R. Sharp (D-IN) on October 1, 1987 as the Alternative Motor Fuels Act of 1987. ${ }^{157}$ Introducing provisions of this bill in a hearing entitled "Alternative Automotive Fuel Hearings: before the House Subcommittee on Energy and Power, of which he was chair, in June 1987 Philip Sharp stated:

The questions before us are whether Government policy should encourage development of alternatives, which are the most promising; and what incentives or mandates are necessary.

This questioning of which alternatives to develop marks a turning point in alternative fuels policy as ethanol took over from methanol as the alternative fuel of choice.

While several factors lead to the demise of methanol as the alternative fuel of choice, including the non-renewable nature of the coal and natural gas use in methanol production and the environmental impact of methanol as a vehicle fuel, it is instructive to take a short detour into methanol advocacy in the mid 1980's to examine how the debate changed and along with it assumptions about the economics of alternative fuel production in the move to from methanol to ethanol.

${ }^{157}$ (http://thomas.loc.gov/cgi-bin/bdquery/z?d100:HR03399:\#) 
In a July 1985 hearing of the Senate Committee on Commerce, Science and Transportation entitled "Rollback of CAFÉ Standards and Methanol Vehicles Incentives Act of 1985," the following Senators offered the following endorsements for methanol as the primary alternative fuel:

Methanol exists now. It can be produced domestically in nearly inexhaustible quantities, it burns more cleanly than gasoline and it can be priced competitively. Most experts agree that methanol is the most promising fuel for the future.

$\sim$ John Danforth (R-MO)

Methanol is one of the most promising of these alternative fuels. Indeed I consider promoting of methanol fuel - which is not yet well understood by our public - I believe that the promotion of methanol through legislation is critical to our Nation's future, not just our national security, not just our lack of dependence on foreign oil supplies, but also, quite frankly, for our job situation in West Virginia and Kentucky and Appalachia, because of the future of coal involved with this, and also because of clean air.

$\sim$ Jay Rockefeller (D-WV)

Methanol production employs a proven technology; in fact there is an oversupply of methanol in the world today. It can be produced from a variety of sources, with the most attractive being coal. Clearly methanol is an appropriate fuel.

Donald Riegle (D-MI)

I am a proponent of what I call the fuel of the future - methanol. Since coming to Congress I have spent a great deal of time and energy investigating its use as a vehicle fuel. The reason is quite clear, and it is true throughout the Appalachian region. We have great commodities of coal and natural gas, both of which could be used should the methanol market develop.

$\sim$ Robert Wise (D-WV)

This support for methanol was also expressed in House hearings focusing on alternative fuels as can be seen in this statement by Philip Sharp (D-IN) in 
November 1985 as chairman of the House Subcommittee on Fossil, Synthetic Fuels:

Methanol is in America's future as a transportation fuel. Methanol burns cleaner than gasoline, is very efficient, and as a liquid is safe for use as a consumer transportation fuel. It can be made from coal, natural gas, and wood, resources the United States has in abundance.. .Methanol is the fuel of the future. The technology is here today. Methanol is an efficient fuel.

Support for methanol at the Executive level was expressed in the same hearing. Richard Wilson, Director of the Office of Mobile Source of the EPA, endorsed methanol stating:

We consider methanol to be the most promising alternative motor vehicle fuel for this country... Methanol is an excellent engine fuel that can be produced from natural gas, coal, or biomass, and is currently priced at a level fairly close to gasoline on an energy basis.

Within two years the strong advocacy for methanol would come to be equaled by voices calling for increased ethanol production. The most vocal supports for methanol at the Congressional level came from representatives from states abundant in coal and natural gas resources reflecting the parochial nature of alternative fuel policy as it developed.

Part of the attractiveness of methanol was that it was the most cost-competitive of the alternative fuels to produce. In supporting methanol as the chosen alternative fuel, Scott Campbell, Director of Policy, Planning and Analysis at the Department of Energy stated:

When the price is right, methanol from U.S. coal becomes economic, providing long-term security from indigenous sources - certainly the ultimate goal of this country. 
The assumption was that methanol would become attractive to consumers when it became cost competitive with oil and gasoline. The cost differential between methanol and gasoline was close enough for policy makers to believe that methanol costs could be reduced through minor technological advances and thus methanol would not require subsidies in order to be a viable competitor in the market.

By October 1987 the desirability of methanol as an alternative fuel was declining due to environmental concerns and the fact that it was based on nonrenewable resources. Even in the heyday of methanol as policy option, ethanol was a factor in National Energy policy. Under Public Law 96-493, the Gasohol Competition Act of 1980, ethanol was being blended into the gas supply. By October 1987 approximately 260 pieces of legislation had been introduced at the State level in 27 States including provisions related to ethanol as alternative fuel. The economics of alternative energy policy changed with the demise of methanol as the favored alternative fuel. Instead of reliance on the market and an alternative fuel (methanol) that might compete with foreign oil on price, the economics changed as ethanol brought an additional element to the alternative fuel debate agriculture.

Testimony offered in the 8 hearings (2 Senate and 6 House) related to S. 1518 and H.R. 3399 is illustrative in documenting the shift in alternative energy policy to ethanol policy and the attendant change in the economic basis of alternative fuel policy that became encoded in the Alternative Motor Fuels Act of 1988. Appendix XVII details the range of issues presented in the hearings related to S. 
1518 (later Public Law 100-494) and the range of policy issues addressed at this level of deliberation. The selection of witnesses and their testimony is significant to the examination when viewed through the lens of deliberative democracy. In addition to testimony from agents of the Executive branch, including the Department of Energy and the EPA, testimony delivered in hearings directly addressing ethanol can be broken down into the following categories:

- Associations lobbying committees on ethanol policy

American Gas Association

Renewable Fuels Association

Southwest Gas Corporation

Center for Auto Safety

Center for Food and Agricultural Policy

Automobile Importers of America

National Coal Association

Council on Alternative Fuels

American Petroleum Institute

National Petroleum Refiners Association

Service Station Dealers of America

Ohio Farm Bureau Federation

Renewable Fuels Foundation

Automotive Warehouse Distributors Association

Oxygenated Fuels Association

National Corn Growers Association

- Academic institutions lobbying for research funding 
Harvard University

- Corporate entities:

Ford Motor Company

General Motors Corporation

Chrysler Motors Corporation

Bank of America

Celanese Corporation

Chevron Corporation

Marathon Petroleum Company

ARCO Petroleum Products Company

Union Oil of California

AMOCO Corporation

Eastman Kodak Company

- Environmental groups:

Environmental Policy Center

American Lung Association of California

California Energy Commission

Although it was introduced as the Methanol and Alternative Fuels Act of 1987, by the time S. 1518 was signed into law by President Reagan in October 1988 methanol had been dropped from the title of the Act and the majority of alternative fuel provisions focused on ethanol. However, the forging together of ethanol policy and agricultural policy was evident in committee hearings before the House Subcommittee on Energy and Power. In a June 1987 hearing entitled 
“Alternative Automotive Fuel Hearings" Bill Alexander (D-AR) tied ethanol to the farm economy stating:

Implementation of a comprehensive national alternative fuels policy can help us address the business of improving energy security, reducing dependence on imported fuels, helping the farm economy, and cleaning the air... Now very quickly, farm income in real dollars is at a near depression level as exports plunge and surpluses increase. Federal spending on agricultural programs is at an all-time high of about $\$ 30$ billion annually.

This statement tied ethanol policy to farm commodity prices.

In addressing a possible objection to using corn as the basis of expanded ethanol production, in the same hearing Edward Madigan (R-IL) countered:

The other argument that we most often hear is that we could be using food for fuel. In the area that you represent, Mr. Chairman, and in the area that I represent, and the areas represented by Mr. Durbin and Glickman, and others, we have agriculture commodities in storage that are going to go out of condition, they are going to spoil, and they are not going to be suitable for any use... My point is that it isn't food if nobody is eating it and nobody wants to eat it - it is something that can be used, and this legislation is trying to find a use for it.

Richard Durbin (D-IL), one of the Bill's cosponsors spoke of the broad based support from agricultural interests galvanized by ethanol as an agricultural option:

Like the Chairman, I am from a farm community. You and I both know that facing our farmers we usually hear a cacophony of different voices and opinions. This bill, however, has done something extraordinary. It has mobilized every farm group in America in support. I can't recall another proposal that has done that. It has brought together disparate groups on the political spectrum who all agree that increasing demand is essential to bringing up price and doing something with the surplus and carryover which we have from year to year. 
Reinforcing both the support for ethanol from the farming sector and advocating the integration of agricultural and energy policy in ethanol, Richard Stallings (DID) stated:

An energy policy which includes the promotion of ethanol is supported by many groups. This is one of the few issues that has united all of the agricultural groups together and brought in as well many environmental interests. Indeed ethanol production can be an integral part of agriculture policy. It is a fact that the ethanol industry has saved hundreds of millions of dollars in Federal outlays for farm programs because of the usage of grain stocks in ethanol production.

With H.R. 3399, which would be substituted into S. 1918, ethanol became the answer to a myriad of policy issues, as expressed by Byron Dorgan (D-ND) in the June hearing:

I think this is the first real focus on what can be great potential to solve some environmental problems, to solve some agricultural problems, and to extend the country's energy supply.

Summing up the potential impact of expanded ethanol production on the agricultural sector before the hearing, Barry Carr, an Agricultural Policy Specialist with the natural Resources Policy Division of the Congressional Research Service offered:

This would increase the total net income of the agricultural sector, allow idle crop production capacity to return to production, reduce the sector's reliance on Government payments, and to some degree, reduce its reliance on rather unstable export markets.

He went on to state that although enhanced ethanol production could increase the price of corn per bushel, the effect on farm incomes would be less than expected because farm incomes were already subsidized by the Federal Government. 
With such statements it is clear that the market competitiveness that had been touted as the benchmark for methanol would be surpassed by other concerns in developing ethanol policy. Louis Frank, President of Marathon Petroleum Co was one of few voices in the July 1987 hearing not to offer ringing endorsement of ethanol as the alternative fuel of choice. He acknowledged the complex milieu of ethanol policy, stating:

Ethanol proponents focus on three primary themes as they promote their interests and lobby for continued government support. Depending on the audience, ethanol is presented as an energy program, an agricultural program, or an environmental program. The political seductiveness of these claims is obvious, though the realities fall short of their perceptions

In outlining areas where ethanol would fall short, Frank highlighted the economic inefficiency of producing ethanol for fuel:

Indeed, the gasohol excise tax exemption alone equates to a Federal subsidy of $\$ 25.20$ per barrel of ethanol, with a total ethanol cost of per $\$ 50$ per barrel.

He then highlighted the change in the economics of alternative fuels with the renewed emphasis on ethanol:

While gasoline and methanol are roughly equivalent at current prices, even when the Federal excise tax subsidy is netted out, without massive subsidies, ethanol is not a competitive fuel. In view of the generous subsidies and prudential waivers now afforded gasohol, ethanol is likely to remain as a gasoline blendstock.

Thus the ability of alternative fuels to attract consumers in the market by competing with petroleum on price was countered as ethanol was already partially in the market as a subsidized alternative. 
Between October of 1987 when H.R. 3399 was reported to the full House and April of 1988, both the House and Senate bills worked their way through the committee hearings and were both amended and approved by their respective chambers. Examination of Congressional records show that there was substantial discussion regarding this Senate bill. Discussion, rather than debate, characterized the nature of the legislative process surrounding this act. There were 64 cosponsors to Rockefeller's bill by the time the legislation was enacted upon the signature of President Reagan on 14 October $1988 .{ }^{158} 64$ cosponsors, 36 of whom signed on as cosponsors in the 3 days between November 18 and 20 of 1987, 44 Democrats and 20 Republicans, represented something more akin to a legislative stampede than deliberative democracy. ${ }^{159}$

On April $15^{\text {th }}$ S. 1518 was passed and sent to the House. On June $28^{\text {th }}, 1988$ the House passed S. 1518 after stripping out all Senate wording and inserting the language of H.R. 3399. As would be expected the Senate did not agree to the changes and a conference committee was established to resolve the differences between bills that had passed. On September $20^{\text {th }}$ and $23^{\text {rd }}$ the Senate and House respectively approved the conference reports and on September $28^{\text {th }}$ the bills were enrolled in both chambers and sent to the President to become Public Law 100494. The outcomes expected from the policy enactment were stated succinctly: the act would:

provide for the application of fuel economy standards to methanol, ethanol and natural gas powered passenger automobiles and dual fuel passenger automobiles; and increase the use of methanol, ethanol, and

\footnotetext{
158 (The American Presidency Project)

159 (See Appendix XXII for list of co-sponsors)
} 
natural gas by consumers and the production of methanol, ethanol, and natural gas powered automobiles.

In looking back over the preceding several years and recognizing the challenges debated in the creation of this law, Congress crafted this statute which would theoretically address the nation's continuing dependence on foreign oil by increasing the production and use of ethanol. The policy attributes implemented were designed to affect the behavior of consumers, auto manufacturers and energy producers. The primary provision of this law was: an incentive for automakers to build cars that would run on E85 (fuel that is $85 \%$ ethanol and $15 \%$ gasoline) through a modification to the CAFÉ (Corporate Average Fuel Economy) manufacturers fleet mileage requirements mandated by Public Law 94-163, The Energy Policy and Conservation Act of $1975 .^{160}$

With relative stability in the Middle East and lack of domestic pressure in reaction to high oil prices, agriculture became central to the expansion of ethanol policy. The deliberation on this proposed bill centered on what was seen as a win-win proposition wherein surplus corn could be channeled into the production of ethanol as an alternative fuel reducing the nation's oil imports.

Over the prior decade previous attempts by Congress to in any way reduce the imports of foreign oil or increase the use of ethanol clearly failed. The Alternative Motor Fuels Act with its provisions to increase the use of ethanol and E85 was the legislative answer to a glut in agricultural commodities and a step towards an effective alternative fuel policy. The incentives engineered into this law had significant impact on both ethanol production and FFV vehicle production. (Flex

${ }^{160}$ (Glozer, 2011) pp. 25 
fuel vehicles can operate on any combination of gasoline through E85). The auto manufacturers had struggled for years to meet the CAFE requirements of the 1975 law. Any provision which would help them meet the CAFE requirements without introducing significant costs to their operations were most welcome. This law specified that any FFV vehicle sold would be given a mileage credit towards the required CAFE standard of 6.7 times their actual mileage rating. This credit would then be incorporated into the manufacturer's total fleet sales including those non-FFV vehicles. This provision, while having absolutely no rational basis which would reduce oil imports or increase ethanol use, did exactly as intended.

By 2006 there were approximately six million FFV's on American roads. The FFV's cost very little in incremental expense to manufacture over traditional vehicles, yet would provide a significant benefit to the manufacturers when sold. Hence those manufacturers became vocal proponents of ethanol immediately. ${ }^{161}$ Despite hearings and debate in Congress, legislators overlooked a very obvious shortcoming in the design of their measure. It did not seem relevant to them that at the time there were only a few dozen filing stations in the nation that could provide E85 fuels at retail. This critical shortcoming has continued to exist to the present. As recently as 2010 out of nearly 180,000 gas stations nationwide, there are still only about 1,500 which dispense E85. ${ }^{162}$ Additionally Congress did not take into account that neither car owners nor auto manufacturers had any reason to care about their vehicles FFV capabilities for ethanol use. FFV's run more efficiently on gasoline. As a result of ethanol and E85 having much less energy

\footnotetext{
161 (Glozer, 2011)pp. 25

162 (IBID) pp. 32
} 
per gallon when compared to gasoline (on the order of only 65\%), drivers would get significantly better mileage operating their FFV's on gasoline. As a recent Congressional Research Report succinctly stated:

A key barrier to wider use of fuel ethanol is its cost relative to gasoline. Even with tax incentives for ethanol use, the fuel is often more expensive than gasoline per gallon, Further, since fuel ethanol has a somewhat lower energy content per gallon, more fuel is required to travel the same distance. This energy loss leads to a 2\%-3\% decrease in miles-per-gallon vehicle fuel economy with $10 \%$ gasohol. This is due to the fact that there is simply less energy in one gallon of ethanol than in one gallon of gasoline, as opposed to any detrimental effect on the efficiency of the engine. ${ }^{163}$

A provision of a prior law also had a detrimental effect on the outcome of this statutes intent. The Energy Tax Act of 1978 had amongst its sections, a tax on new vehicles that did not obtain certain specified mileage per gallon of fuel. A significant attribute of the provision would become very valuable to both vehicle buyers and auto manufacturers: pickup trucks, SUVs and cars more than 6000 pounds in weight were specifically exempted from this "gas guzzler" tax. ${ }^{164}$

The practical effect of these provisions was almost the opposite of the legislative intent. Manufacturers, in response to this law began to aggressively and successfully market SUVs and light trucks which were exempt from the "gas guzzler" provisions of 95-618 that were suppressing the sales of lighter cars. Concurrently, at little additional cost, they began the increased production of FFV's to gain CAFÉ mileage credit. The consumer was not sensitive to their vehicle having the ability to use E85 and as there were practically no dispensing stations available it was of no consequence. The irony was that manufacturers

\footnotetext{
163 (Yacobucci, 2006)

164 (Library of Congress, 1978)
} 
were building and selling increasing numbers of vehicles getting much less mileage than Congress desired, operating primarily on gasoline with little increase in ethanol sales and use, while the nation continued to import an increasing percentage of its oil needs from foreign sources deemed to be unreliable.

Assessing the operation of deliberative democracy in the formation of this legislation, as with P.L. 95-618, yields mixed results. Most relevant to this law is the move from methanol as an alternative fuel. This initiated ethanol as the alternative fuel of choice. Evident in the committee hearings is a shift in primary proponents supporting increased production of alternative fuels from coal states to farm states (as was shown previously in this chapter.) Although Senator Richard Lugar (D-IN) had envisioned alternative fuels as a market for farm products in 1977, the cost advantages of methanol had eclipsed the attractiveness of ethanol. With the environmental impact of methanol and its perception as being a nonrenewable fuel source, attention moved back to ethanol and alternative fuels (read ethanol) again became linked to agricultural commodity prices. This brought about a change in the economics of alternative fuels. While methanol had the potential to compete on price with gasoline, ethanol was far from cost competitive. Linking ethanol to agricultural commodity prices and thus farm incomes introduced an alternative criteria for economic evaluation - one where the benefits would be concentrated in the farming and ethanol production sectors, but the costs would be diffuse and borne by the taxpayer. Thus two policy streams came together in pushing for increased ethanol - agricultural policy with its domestic focus on farm incomes and energy policy that focused on increasing 
security by replacing foreign sources of energy. Ethanol policy would advance through both energy and agricultural enactments. However, the different policy streams had different goals for ethanol as alternative fuel. While the overarching goal of alternative fuels within energy policy was to enhance energy security through decreased reliance on imports from geopolitically sensitive regions, the goal for alternative fuels within agricultural policy was to provide an additional market for farm products securing increased farm incomes.

The emergence of ethanol as the primary alternative fuel choice changed the economic criteria for assessing alternative fuels as P.L. 100-494 initiated an increase in unbalanced testimony in hearings that undermined the ability of policy makers to make informed judgments. The flawed logic whereby both legislators and witnesses in the hearings would raise the possibility of limitations of ethanol as an alternative fuel - economically or through the logistics of production - only to ignore them in endorsing ethanol carried over into floor debates. 


\section{Public Law 102-486 - Energy Policy Act of 1992}

\section{H.R. 776}

\section{Deliberative Democracy Measurements and Timeline}

Legislative history data, showing the deliberative democracy attributes in the legislative steps from introduction of the initial bill through the phases leading to the bills enactment into law by the President are presented in appendix VI.

The 102nd Congress was in session from January 1991 until January of 1993. Congress opened its session amongst great national angst concerning the Persian Gulf War which had begun with the invasion of Kuwait the prior August and would culminate with the expulsion of Iraq in February of 1991. As the Congressional Almanac presents;

the Persian Gulf War appeared to have created an inexorable push for new energy legislation. Many Democrats insisted that American soldiers were being sent to defend a national policy of gluttony and demanded strong new conservation and efficiency programs...legislators were alarmed that U.S. oil imports had climbed to account for roughly half of the nation's oil consumption and threatened to larger still. ${ }^{165}$

With the Persian Gulf War and economic downturn, the national security vulnerability of potential oil import disruption was also becoming a balance of payments issue. The Persian Gulf Crisis was a vivid reminder that oil shocks could still reverberate throughout the entire U.S. economy. Prior legislation to reduce oil imports and increase the use of alternative fuels - by this time increasingly ethanol - had failed dramatically. In 1991 the nation would continue

${ }^{165}$ (Congressional Quarterly, 102nd Congress First Session , 1991) pp. 195 
to import almost half its consumption. ${ }^{166}$ In 1991 the U.S. Import of Crude Oil and Petroleum Products (Thousand Barrels) ${ }^{167}$ was 2,146,066. By1991 the legislative effort to increase the use of ethanol was beginning to have a small effect, but it was minimal when compared to total gasoline consumption.

\section{Figure 16}

\section{Millions of Gallons per year of domestic ethanol production. ${ }^{168}$}

\begin{tabular}{|c|c|c|c|c|c|c|}
\hline Year & 1980 & 1981 & 1982 & 1983 & 1984 & 1985 \\
\hline Gallons (mil) & 175 & 215 & 305 & 375 & 430 & 610 \\
\hline
\end{tabular}

\begin{tabular}{|c|c|c|c|c|c|c|}
\hline Year & 1986 & 1987 & 1988 & 1989 & 1990 & 1991 \\
\hline Gallons (mil) & 710 & 830 & 845 & 870 & 900 & 950 \\
\hline
\end{tabular}

In response to these challenges President Bush released his National Energy Strategy to the American people on February 20, 1999 stating:

The driving force behind [our National Energy Strategy] is straightforward. It relies on the power of the marketplace, the common sense of the American people and the responsible leadership of industry and government.

The National Energy Strategy was a comprehensive strategy designed to increase America's energy security, enhance environmental quality, and fuel future economic growth that formed the President's blueprint for energy security. The stated goals of this strategy were to:

- Diversify U.S. sources of energy supplies

\footnotetext{
166 (Perry, 2010)

167 (U.S. Energy Information Administration, 2011)

168 (Renewable Fuels Association, 2011)
} 
- Increase efficiency and flexibility in energy consumption

- Reduce the dependence of the U.S. economy on oil while increasing domestic oil production;

- Increase the use of natural gas, a domestically abundant source of clean energy

- Increase the production and use of renewable energy resources

- Increase the use of alternative transportation fuels

- Encourage efficiency and competition in electricity generation and efficient use of electric power

- Reduce U.S. emissions of greenhouse gases from projected levels;

- Improve air, land, and water quality by developing and using environmentally superior technology

- Create jobs and promote economic growth

- Maintain U.S. preeminence in fundamental science and engineering research and accelerate commercialization of technologies developed through federally funded research.

The keystone of this strategy was reliance on market forces rather than intervention to drive the Nation's energy portfolio. The Strategy's major recommendations relating to expanding ethanol as the alternative fuel of choice were: requiring centrally fueled fleets to purchase vehicles capable of operating on alternative fuels and efforts to make ethanol more cost competitive through the research efforts of the Department of Energy. 
The dilemma facing Congress regarding alternative fuels policy was clear: although they had been able to legislate moderate increases in ethanol production, at great expense to consumers and taxpayers, overall use of gasoline continued to climb annually at a much faster rate than ethanol mandates had neither anticipated nor could keep pace with. Although ethanol production between 1981 and 1991 had increased by almost $450 \%$, the actual proportion of ethanol used as transportation fuel remained extremely low at less than $1 \%$ of domestic gasoline consumption. ${ }^{169}$ Another potential barrier to the formulation of en effective energy policy response was general distrust of the provisions of the President's National Energy Strategy by many in Congress.

\section{Exploration of Legislative Activity}

House bill H.R. 776, was introduced by Representative Philip R. Sharp (D-IN) on February 4, 1991 as the National Energy Efficiency Act of 1991 and became Public Law 102-486, the Energy Policy Act of 1992 on October 24, 1992. As the representative of a corn state, Sharp had been deeply involved in energy issues from early in the legislative debate concerning ethanol and other alternative fuels. He had introduced H.R. 3399 on October 1, 1987 as the Alternative Motor Fuels Act of 1987 which as S. 1518 was signed into law by President Reagan in October 1988.

${ }^{169}$ (Research and Innovative Technology Administration, 2010) 
House bill H.R. 776 was introduced 2 weeks after the aerial bombardment of Baghdad commenced and 2 weeks before the ground invasion of Iraq by American forces. Upon introduction H.R. 776 was referred to 20 committees (see appendix XVIII for details). This legislation was considered by the widest range of committees of any recent energy policy proposal (41 House and 39 Senate hearings held) requiring 104 days of testimony resulting in over 26,200 pages of hearing records considering the positions of several hundred witnesses, Members and Senators. Committees from Ways and Means to the Senate Subcommittee on Nuclear Regulation, Committee on Environment and Public Works, the House Subcommittee on Energy and Environment, Committee on Interior and Insular Affairs to the Senate Committee on Energy and Natural Resources and were among those that considered testimony and offered policy recommendations related to H.R. 776 .

In focusing on ethanol policy within this legislation, a wide series of hearings reflected both current concerns about oil price and availability as well as measures from previous legislation that were proposed for either extension or amendment. Witnesses chosen to present testimony spanned a spectrum of positions that, while reflecting frustrations with the failures of previous energy policies and the lack of progress towards energy security, continued to lobby for the solutions they advocated, and further funding for their projects. Appendix XVIII details the range of issues presented in the 105 hearings related to H.R.776 (later Public Law 102-486) and the range of policy issues addressed at this level of deliberation. 
There were 17 hearings which focused on policy discussions relative to renewable fuels. Those topics included:

- Energy Impact of the Persian Gulf Crisis

- Recommendations for market-based Federal policies to ensure adequate oil supply

- Adverse effects of increased fuel costs on airlines

- Outlook for international oil supplies and trade

- Analysis of oil and gasoline price increases and industry profits

- Recommendations for measures to regulate oil prices and allocations

- Prospects for $\mathrm{CO} 2$ emissions reduction through fuel economy standards for highway vehicles

- Examination of global warming/climate change (greenhouse effect) consequences of energy policies

- Merits of pollution-based fuel taxes for reducing $\mathrm{CO} 2$ emissions

- Consideration to amend the Motor Vehicle Information and Cost Savings Act to require owners of commercial and public motor vehicle fleets in urban areas to use alternative fuel vehicles

- Role of NYMEX in emergency monitoring of oil prices and supplies, including development of preparedness plan to ensure orderly trading of oil futures and options

- Need for U.S. leadership in reducing worldwide CO2 emissions

- Review of U.S. global climate change strategy, including role of National Energy Strategy implementation 
- Analysis of options for reducing CO2 emissions

- Examination of data, models, and methodology used by DOE in developing the National Energy Strategy (NES), the Administration longrange plan for enhancing and maintaining U.S. energy efficiency and security

- Consideration of establishing goals for reduced oil consumption and importation, improved energy efficiency, and increased use of renewable energy resources to improve U.S. energy security, and to require DOE to establish plans for achieving and measuring progress toward such objectives

These topics demonstrate once more that geopolitical concerns and the status of the fuel supplies from the Middle East were driving the demand for energy policy in general and more specifically energy independence through alternative fuels. In addition, environmental concerns related to carbon monoxide emissions were increasingly becoming part of energy discussions leading up to the passage of H.R. 776. As presented in figure 5, page 47 if deliberative democracy attributes are present in committee hearings, then they provide: [a venue] to elicit the information and arguments necessary to make informed judgments.

The selection of witnesses and the positions they represented are significant to the examination of deliberative democracy. In addition to testimony from agents of the Executive branch, including the Department of Energy and the EPA, testimony delivered in hearings directly addressing ethanol policy can be broken down into the following categories: 
- Associations presenting their views on proposed legislation American Petroleum Institute

National Association of State Energy Officials

Petroleum Marketers Association

Air Transport Association

Alliance To Save Energy

American Council for an Energy Efficient Economy

National Association of Fleet Administrators

Renewable Fuels Association

Motor Vehicle Manufacturers Association

Energy Conservation Coalition

American Coalition for Traffic Safety

Electricity Consumers Resource Council

Association of American Railroads

Minority Business Enterprise Legal Defense and Education Fund

Electric Transportation Coalition

American Methanol Institute

Natural Gas Vehicle Coalition

American Gas Association

Independent Petroleum Association

Independent Refiner/Marketers Association

Mid-Continent Oil and Gas Association

American Nuclear Energy Council

Edison Electric Institute 
Coalition to Oppose Energy Taxes

National Association of Manufacturers

Chemical Manufacturers Association

National Taxpayers Union

U.S. Public Interest Research Group

- Environmental groups presenting their views on proposed legislation

Worldwatch Institute

World Resources Institute

Natural Resources Defense Council

Global Climate Coalition

Friends of the Earth-Environmental Policy Institute

- Public activist group presenting their views on proposed legislation

Citizen Action

- Corporate entities presenting their views on proposed legislation

Mesa Limited Partnership

Central Fiber Corporation

Energy Masters Corporation

Ford Motor Company

American Honda Motor Company

Orbital Engine Company

Norton/TRW Ceramics

James River Corporation

Nashua Corporation 


\section{Concord Steam Corporation}

Wheelabrator Environmental Systems

Gannon Company

Southern California Edison Company

Johnson Controls

Honeywell, Incorporated

Venus Oil Company

Commonwealth Edison Company

- Academic institutions presenting their views on proposed legislation University of California, Berkeley

Harvard University

As can be seen from this list, legislators heard testimony from witnesses representing a wide range of organizations. Although the influence of the Executive branch was present through the testimony of representatives from several federal agencies and in the amount of time in hearings dedicated to matters related to the President's National Energy Strategy, the selection of witnesses demonstrates growing distrust between Congress and the Executive branch - particularly the Department of Energy - over energy policy. The influence of lobbyists is documented throughout the record, the comments of legislative leaders at many of the committee hearings show their influence in the process and the very substantial number and length of hearings show the deliberation on the merits of public policy attributes in the process. 
The mood of the Nation and Congress in approaching energy policy at this juncture was articulated by Dick Swett (D-NH) in an October 1991 hearing of the House Subcommittee on the Environment entitled "U.S. Industrial Competitiveness and Alternative Energy Development" when he stated:

The Persian Gulf War, rapidly increasing oil prices and concerns for our environment have forced the entire Nation to focus on the need for Energy options.

Jan Meyers (R-KS) in a July 1991 hearing of the House Subcommittee on Regulation, Business operations, and Energy reiterated the impact of the Persian Gulf War in re-establishing the need for energy policy as a national priority:

When oil prices began to rise last summer after Iraq's invasion of Kuwait, Americans became painfully aware, once again, of our Nation's dependency on foreign oil, and how unreliable those sources can be. While the swift victory of Operation Desert Storm eased the pinch at the gas pump, I believe Americans have realized how detrimental this dependence can be to our economy.

At that same hearing, David Camp (R-MI) expressed deeper concerns over the need for energy policy:

Our Nation has, over the years, experienced months of great difficulty, even crisis, that have underscored the need for thoughtful planning to assure greater energy efficiency and, consequently, less dependence on others for our energy needs. Unfortunately, it has been hard for us to remain focused on energy policies, particularly in the area of conservation.

Although there was consensus on the need for energy policy, suspicion of the President's National Energy Strategy formed a potential barrier to formulating an effective legislative response. The title of the July 1991 hearing mentioned above, "Has the National Energy Strategy Been Short-Circuited?" reflected the level of 
Congressional suspicion. This possible policy impasse was commented on by Judy England-Joseph, Associate Director, Energy Issues, Resources, Community and Economic Division, GAO who stated:

During the last 8 or 10 months we were nearing or at war in Iraq, the public, I think, was most mindful and most concerned about the need for a national energy policy and National Energy Strategy. I think that if there was ever an opportunity to gain national consensus on energy, this was it. Gaining such consensus is a tremendously difficult task. We have not been that effective over the last 15 to 20 years, through the previous two oil and energy crises, to handle that effectively.

Resistance to the bundled solutions offered in the National Energy Strategy lead to questions in both the Senate and the House committee hearings about the nature of energy policy. Thomas Carper (D-DE) subcommittee chairman in his opening comments to a November 1991 hearing entitled "National Energy Policy: Implications for Economic Growth" before the hearing before Subcommittee on Economic Stabilization House stated:

Despite energy bills that have been introduced in both Houses of Congress, there has been little discussion of what our energy policy is supposed to do... In my view until we do answer that question and until the country has reached a consensus as to what we are about with respect to energy, it will be very difficult to agree on what steps need to be taken to get the job done.

These sentiments were echoed in the opening statements of Jeff Bingaman (DNM), committee chairman, in a July 1991 hearing of the Senate Committee on Energy and Natural Resources:

There remains a real question in my mind - and in the minds of many of my colleagues - whether we will really see a new energy policy in the near future, and if so, what it will mean... Many of you have been, to one degree or another, involved in years' worth of discussions, debates and 
negotiations on the issue of energy policy. Much of that activity has focused on the intricate details of one energy proposal or another. I think the time is ripe to step back, reflecting on legislative developments of the past year or so, to ask ourselves the basic question: Why do we need an energy policy?

While these two comments express frustration and possible fatigue among legislators over the lack of meaningful progress in energy in creating energy policies that contributed to the stated goal of securing energy independence, on a more superficial level, they reflect suspicion of the assumptions of commercialization as the criteria of success embedded in the President's National Energy Strategy. Elaborating on his earlier comment, Bingaman went on to say:

Unfortunately when it comes to energy policy, efforts to establish concrete goals for policy have met with tremendous opposition and suspicion, particularly by the administration. When we look at the administration's National Energy Strategy, much of which I find commendable, we find very vague objectives. Lack of specific goals makes evaluation of our energy policy options difficult and makes the formulation of an overall strategy impossible. I am not sure what Congress will do, but one of the reasons why I think we will have difficulty finding our way is that we have not reached a consensus on what energy legislation is intended to accomplish.

Defending the Administration's position of letting the market set the criteria for determining the elements of the Nation's energy portfolio, Peter Saba, Principle Associate Deputy Under Secretary of Policy, Planning and Analysis, Department of Energy in the same hearing responded:

Energy targets lack flexibility and have limited relevance in an international energy market. In a market economy, countless individual decisions by producers and customers determine the level of energy goods and services that are provided. The flexibility of this system and the ability of consumers and producers to adjust to price signals is at the core of our dynamic economy. 
In offering an additional critique of the lack of goals in allocating Federal research and development funding at April 1992 hearing of the House Subcommittee on Investigation and Oversight examining the Department of Energy Budget within the framework of the National Energy Strategy, Howard Wolpe (D-MI), Chairman of the Subcommittee referenced a failure in previous energy policy:

The beginning of my service in the House and on the Science Committee coincided with the fall of the Shah of Iran and the second oil shock in 1979. The long gasoline lines and the soaring energy prices that followed caused Congress to debate national energy policy in a crisis atmosphere. As a naïve freshman Member of this institution, I suggested that we adopt objective criteria to determine where we should focus increased energy $R \& D$ spending. I suggested those $R \& D$ investments that would most quickly, cheaply and cleanly reduce our dependence upon petroleum. My suggestions were met at that point by glazed eyes and deafening silence. Instead, we passed the Energy Security Act of 1980 and created the Synthetic Fuels Corporation or SFC. We gave the SFC a \$20 billion lump sum appropriation to move technologies directly from the laboratory to the market place. In other words we decided to create a commercial industry out of thin air... It was a fiasco. The SFC produced almost nothing

This personal anecdote provides an example of deliberative democracy failing to deliver productive policy outcomes. Although Wolpe's point was to demonstrate the need for objective criteria in allocating Department of Energy research and development funding, the example of SFC as a failure to create an artificial market would be mirrored in later analyses of the unintended consequences of some of the provisions of the Energy Policy Act in attempting to drive consumer demand. It is ironic that Wolpe's additional comments were made in advocating for increased funding for research in renewable fuels: 
To determine how investments should be made on the merits, the policy office ranked competing energy technologies on energy contribution, economic growth, environmental impact, technical and market risk. After applying these objective criteria, energy conservation and renewable energy technologies - which have been perennially underfunded - came out on top. Nuclear fission, fusion and fossil technologies - which have enjoyed multibillion taxpayer subsidies - came out on the bottom.

The tensions between the reliance on market forces in furthering the President's preferences in the National Energy Strategy and the suspicion of the market in relation to defining an effective energy policy expressed by legislators resulted in certain assumptions becoming even more entrenched in policies focused on promoting ethanol as alternative fuel. Because of the dynamic in action at this time in which political instability in the Middle East drove domestic economic instability through reliance on foreign sources of oil, the agricultural benefits of ethanol expenditures were not a factor in deliberations of H.R. 776. Instead, the motivation to put in place a domestically sourced fuel supply at this point in time outweighed concerns for the costs that might be involved.

Thomas Carper (D-DE), Chair of the House Subcommittee on Economic Stabilization questioned the wisdom of market dynamics in relation to alternative fuels in a November 1991 hearing:

I note, with interest, the strong thread running through the testimony of several witnesses today which emphasizes an energy strategy that is sensitive to market forces and signals. All I know is that in the political arena, the sensitivity can cut both ways. When the going gets tough - as in 1973, 1979 and late last year, Congress and the white House respond to the clarion call. Unfortunately, at the moment that clarion call sounds more like a caribou yawn on the North Slope. The market signals I am hearing are saying "buy Saudi." 
With this statement Carper tied the operation of market forces to the preference for petroleum. A stronger statement of skepticism of the market was offered by Richard Morse, Executive Vice President of the Economic Strategy Institute in testimony before a July 1991 hearing of the Senate Committee on Energy and Natural Resources:

I think the American people do not believe that the marketplace is a fair and equitable way to manage the American economy

The underlying assumption of both of these statements was that allowing the market to influence alternative fuel decisions was not desirable as the market would not produce the proposed policy outcome. This assumption and the policies that resulted set in place the course of ethanol expansion based on a different type of economics as legislators tried to develop a different type of market.

Donald Aitken, Senior Energy Analyst of the Union of Concerned Scientists, elaborated on the role of government transfers in developing alternative fuels before an April 1992 hearing of the House Committee on Ways and Means stated:

Tax incentives for the renewables and for efficiency are not tax subsidies. They are instead ways of reducing the tax inequities which impede the investment in the renewable. We can also look at the revenue-producing benefits of the tax incentives. They stimulate early serious investment... That generates a more reliable market. That enhances investor confidence, and that in turn aids in further driving down the cost of renewables, so that the market itself becomes self-perpetuating... We must give the market a chance.

In acknowledging the failings of ethanol if based evaluated solely on economic cost or energy efficiency criteria, Linda Stuntz, Deputy Under Secretary and 
Director of the Office of Policy, Planning and Analysis, Department of Energy in an October 1991 hearing of the House Subcommittee on Economic Stabilization offered a different benchmark for ethanol:

There are alternative fuels which can, if looked at on the fuel cycle basis, actually consume more energy to produce than the energy they provide in terms of a motor fuel. But again, it may not be totally fatal, because if what they consume is something that we have in abundance and what they are replacing is fuel that is imported, and the results in benefits in terms of local jobs.

It is interesting to note that these limitations of ethanol hark back to comments made by Senator Lugar (R-IN) in the first ethanol hearing in 1977 leading to Public Law 95-618. In the fourteen intervening years of ethanol policy, technology had not developed to resolve these issues. An additional consideration that would come to permeate the alternative fuels debate and ethanol policy was concern for the environment. Concerns over carbon monoxide emissions had effectively removed methanol as an alternative fuel option. Debate between legislators in these hearings revealed deep divisions over the issue of global warming and those differences would be central to proposed provisions in H.R. 776. In a Senate Committee on Energy and Natural Resources hearing in May 1992 entitled "Global Climate change" Malcolm Wallop (R-WY) presented stated:

Perhaps the most distressing aspect of the negotiations on global climate change is that the process is being driven by politics rather than science. 
Although applied to the scientific assumptions that were being relied upon in considering the environment in energy policy, Wallop's comment could be paralleled in an analysis of negotiations of ethanol policy at that time: the process was being driven by politics rather than economics, in a process that was itself appearing increasingly political and less deliberative. With the demise of methanol as an alternative fuel option, ethanol had become the alternative/renewable fuel of choice, but it came with a huge cost disadvantage. Discussions and testimony in hearings contributing to H.R. 776 document the development of the alternative economics of ethanol at this point in the ongoing expansion of ethanol production.

H.R. 776 was introduced in the House of Representatives on May 19, 1992. An example of legislative bravado in support of this bill was expressed by Harris Fawell (R-IL):

the Comprehensive National Energy Policy Act, is a visionary piece of legislation, enactment of which will immediately move our Nation closer toward our stated goal of achieving energy independent. As one of the conferees on this national energy strategy, I rise in strong support of the conference report to H.R. 776, which will be remembered as one of the highlights of the 102d Congress. While every Member of Congress can take pride in this accomplishment, the actions of several individuals merit special attention. President Bush took the first step in this arduous process by sending the first draft of this legislation to Congress. ${ }^{170}$

The Bill was read twice in the Senate on June 4, 1992. This process of discussion and amendment provided many indicators of deliberation, but resulted in the chambers being unable to agree on the provisions of H.R. 776 and consequently a conference committee was constituted to resolve those differences. The

${ }^{170}$ (Harris Fawell (R-IL) House Record E3214) 5 October 1992 
conference committee was extraordinarily large by any previous standard and was comprised of 31 Senators and 100 House Members. The conference committee was so large that with attendant staff it required the largest available venue on Capitol Hill: The Cannon caucus room. The conference committee began its deliberations on 10 September 1992 and worked virtually non-stop for 3 weeks until agreement was reached allowing the House to approve the bill on October 5th and the Senate on October 8th. The conference report that documented the chambers agreement and cleared upon voting was a complex 443 pages. As the Congressional Almanac states; "The bill passed on voice votes - capping a difficult journey that took virtually every day of the $102^{\text {nd }}$ Congress."

When enacted, the new law's provisions encompassed a myriad of issues: Energy goals, greenhouse gases, interior department proposals to limit development of hydroelectric power on public rivers, energy strategy, emissions reductions, technology transfer, alternative-fuel fleets, eligible alternative-fuels, credit, penalties, mass transit, electric vehicles, loans, natural gas, building standards, hydroelectric power, industrial efficiency, electric motors, lighting, appliance and plumbing standards, nuclear licensing, research, uranium enrichment, natural gas, strategic petroleum reserve, energy taxes, ethanol blending, chemical taxes, Yucca Mountain dump, electric utilities, foreign investment, clean coal promotion, tax provisions to encourage conservation and others to tax coal production to pay for miner's health benefits, ${ }^{171}$ tax relief for oil and gas drillers, oil pipelines, federal on and offshore leases, fuel prices, Indian energy resources,

${ }^{171}$ (Congressional Quarterly, 102nd Congress Second Session, 1992) pp. 236 
programs to promote the commercial development of renewable energy and energy efficiency technologies, one step licensing of nuclear power plants, expansion of the strategic petroleum reserve and even tax benefits for car pooling and mass transit subsidies, ${ }^{172}$ and many more in the laws 30 separate voluminous Titles.

Throughout this passionate debate and resulting legislation, the resulting Act did not address some most intensely debated energy issues of the prior twenty years: offshore oil drilling, drilling in Alaska's Artic Wildlife Refuge, requiring even more fuel efficient vehicles or increasing energy taxes to further curb consumption. $^{173}$

There were several specific provisions directed towards the use and production of ethanol. The Energy Policy Act did articulate a national goal of alternative fuels comprising $10 \%$ of motor-fuel consumption by 2000 and $30 \%$ by 2010 . In order to meet those targets the Act extended the existing retail tax exemption for gasohol blends and created two new significant tax incentives for consumers and producers. ${ }^{174}$ Buyers and retrofitters of alternative-fuel vehicles were allowed to write off part of their costs $(\$ 2,000$ for cars and increased amounts for light and heavy trucks) and retail facilities that invested in alternative fuel equipment could write off up to $\$ 100,000 . .^{175}$

\footnotetext{
${ }^{172}$ (Congressional Quarterly, 102nd Congress Second Session, 1992) pp. 255

${ }^{173}$ IBID)

${ }^{174}$ (Glozer, 2011) pp. 41

${ }^{175}$ (IBID) pp. 42
} 
What an analysis of this extremely complex, time consuming legislative process crafting the Energy Policy Act of 1992 shows, when examined in the light of its outcome in future years, is that virtually regardless of time spent, lobbying, testimony attempting to persuade legislators, agency input, presidential desires, and public polling, minimal ethanol production and use expectations were met. When the costs of the modest increase in ethanol production and use resulting from this and prior legislation are examined in the context of costs to the consumer and taxpayer, the detriment to the national benefit is seen to be enormous as is shown in the conclusions chapter.

After extensive committee hearings and debate, when enacted, this law was projected by the Energy Department to reduce oil imports by 4.7 million barrels per day by 2010. That reduction against a daily consumption of about 17 million barrels would have been almost a $28 \%$ reduction in imports. Despite these projections, and although the law would impact virtually all aspects of the energy industry, the bill was seen as a "political and policy compromise that was expected to cap rather than significantly reduce U.S. dependence on foreign oil. "176

The consequence of this substantial legislative effort can be seen to have resulted in a bifurcated result, as with other laws examined in this work. The record shows that during the legislative process, the necessary attributes of deliberative democracy were present at various points in the process, but that in hearings, floor debates and the influence of the executive branch, the process was appearing

${ }^{176}$ (Congressional Quarterly, 102nd Congress Second Session, 1992) pp. 250 
more skewed to political rather than deliberative decision making. Although the hearings for this Act were substantial, the interests represented and the information presented with respect to ethanol were for tailored towards increasing ethanol and were therefore insufficient to support substantive reasoning on the merits of public policy by Members of Congress. In addition, the strained relationship between Congress and the Executive precluded full access to an additional information source that could have provided a fuller perspective. While the extensive Conference Committee indicates possible deliberative activity in arguing the provisions of this complex legislation, the resulting ethanol policy was simply a continuation of the repeated failures of enacted legislation and did not result in a beneficial national outcome. 


\section{Public Law 106-224 - Agricultural Risk Protection Act of 2000}

\section{H.R. 2559}

\section{Deliberative Democracy Measurements and Timeline}

Legislative history data, showing the deliberative democracy attributes in the legislative steps from introduction of the initial bill through the phases leading to the bills enactment into law by the President are presented in appendix VII. To assess the presence of deliberative democracy, whether resulting in positive policy outcomes or not, through the various steps of legislation introduction, committee assignments, hearings, floor debate, consideration of amendments and conference reports leading to the passage of this law, required examining available data through the matrix of measurement tools presented on page 47 , page 53. (Also refer to appendix XVI for presentation of an additional deliberative democracy measurement table). Examination of this law through the lens of a deliberative democracy measurement matrix reveals informative data significant to the discussion and analysis following in the next section of this chapter. Committee hearings are presented as an integral component of the deliberative process. This bill was referred to three different committees that conducted 14 hearings. Of those hearings, only three addressed renewable fuels and thus ethanol; 8 focused on crop insurance and farm income support with some peripheral mention of alternative fuels, two noxious weeds and one agriculture and climate change. Although the ostensible focus of the proposed bill was agriculture and crop risk insurance; the "and for other purposes" section of the bill lead to floor debate focused on ethanol policy. 
The three laws examined prior to 106-224 reveal that from 1973 through 1992 the expectations of Congress to reduce America's dependence on the imports of foreign oil and desire to enhance the nation's strategic security had not been met. In 1991 the nation operated 192,314,000 vehicles and consumed 128,563 million gallons of gasoline doing so. In 2000 there were 225,821,000 vehicles on America's roads that consumed 162,260 million gallons of gasoline. ${ }^{177}$

In 1991 the nation produced about 1 billion gallons of ethanol and in 2000 about 1.6 billion gallons, a $60 \%$ increase over a decade. ${ }^{178}$ In the same period gasoline consumption increased almost 30\%. Ironically, the increase in ethanol consumption wasn't driven by legislative action designed to reduce the Nation's dependency on imports of oil, but rather resulted from legislative direction in the Clean Air Act Amendments of 1990 to use ethanol as an oxygenate in gasoline to improve air quality. ${ }^{179}$

Remembering that the goal of ethanol legislation for the prior two decades was to reduce the imports of foreign oil to enhance national security, the above increased ethanol usage in the context of increasing numbers of vehicles in America and gasoline consumption must be compared to the quantity of imported oil over the same time. In 1973 the nation imported 34.8\% of its oil consumption and by 1978 when Congress responded with legislation encouraging the production and use of ethanol, the percentage had risen to $42.5 \%{ }^{180}$ By 2000 when the law in this

\footnotetext{
177 (Research and Innovative Technology Administration, 2010)

178 (Renewable Fuels Association, 2011)

179 (Glozer, 2011) pp.44

${ }^{180}$ (U.S. Department of Energy, 2005)
} 
section was under consideration $52.9 \%$ of the Nation's consumption was being imported. $^{181}$

The decade of the 1990's saw a dichotomy that allowed legislative focus to wane on energy policy and ethanol policy within it. World oil prices stayed within a relatively stable and attractive range of under $\$ 30$ per barrel and there were no threats to oil supply, but even after spending billions on ethanol policy the nation continued to import increasing quantities of oil demonstrating both the failure of ethanol policy and a fundamental misunderstanding by the Legislature and Executive of the dynamics and complexity of the energy market and of market forces themselves. The legislation examined in this section comes at the end of a decade which saw much discussion, little action and even less results for meeting the frequently expressed Congressional goals of energy independence through increased ethanol production and use, along with a concurrent enhancement of national security.

In the absence of a geopolitical crisis to focus attention on the economic and security implications of the growing dependence on foreign fuel sources, ethanol policy had changed venue and provisions for expanding ethanol production had made their way into a number of agricultural bills. The underlying bill for the Agricultural Risk Protection Act of 2000 - Public Law 106-224 was H.R. 2559 introduced by Representative Larry Combest (R-TX.) on 20 July 1999. The bill dealt primarily with agricultural price support and crop insurance issues - in other words increasing farm incomes - but included other issues relevant to the

181 (IBID) 
agricultural sector that had failed to gain passage in previous bills. H.R. 2559 was intermediate farm legislation that sought to remedy some of the perceived failings of the Federal Agricultural Improvement Act of 1996, also known as the Freedom to Farm Act that among other provisions had removed the link between income support payments to farmers and commodity prices. More comprehensive Farm Act would follow with the Farm Security and Rural Investment Act of 2002.

While Title VI of the Agricultural Risk Protection Act, the 'Plant Protection Act" sought to protect crops by restricting the movement of unauthorized noxious plants, Title II, the "Biomass Research Development Act of 2000," presented biomass-based fuels derived from cellulosic feedstocks (ethanol by implication) as offering a range of benefits. Contributing to healthier rural economies ranked second, only behind improving strategic security and the balance of payments in the benefits of biobased power offered in the bill's wording. The full excerpt from the Act as passed is given later in this chapter.

Appendix XVIX details the range of issues presented in the hearings related to H.R. 2559 (later Public Law 106-224) and the range of policy issues addressed at this level of deliberation. These include:

- Research to promote the conversion of biomass into biobased industrial products, including fuels

- Invasive species

- Benefits of biomass energy production and use

- Risk management and crop insurance legislation

- Noxious weed coordination 
- Anticipated positive effect of biomass $R \& D$ in reducing the cost of biomass conversion

- Importance of establishing legislation to promote the bioenergy industry

- Differing views on H.R. 2827 (National Sustainable Fuels and Chemicals Act ) provision to establish a corn-based ethanol research pilot program

- effects of large gasoline price changes in the market

- Disproportionate influence of Middle Eastern governments on American Foreign policy

- Importance of supporting farm income through crop insurance to maintain farm production

\section{Exploration of Legislative Activity}

While the circumstances driving ethanol policy creation and its continuation in this law are discussed in this section, it is also necessary to examine the process of committee assignments, hearings held and perspective of representative testimony given in attempting to ascertain the operation and character of deliberative democracy present in the perpetuation of ethanol policy. This exploration hinges on a number of pivotal questions:

What committees considered the proposed bill?

Why was the bill referred to those particular committees?

Amongst the witnesses, which testimony appeared to prevail in the eventual outcome of the enacted legislation? 
What groups appeared to be represented by testimony and what was their perspective?

At its inception H.R. 2559 was referred to three committees (appendix VII): House Agriculture, Subcommittee on Risk Management, Research and Specialty Crops and Senate Agriculture, Nutrition and Forestry. 14 hearings were conducted by these committees between May 1998 and January of 2000. Although H.R. 2559 focused primarily on crop insurance and farm support, significant policy discussion and proposed alternative fuel provisions were contained in the legislation.

Comments made by legislators in the hearings focusing on agricultural price and crop supports reveals a subtle insight into an unspoken core belief, or assumption, that the agricultural sector should to be sustained regardless of market forces. This foundational perspective is germane to the issue of ethanol production and use in that subsidized ethanol production could prop up incomes to corn growers. The consequent national impacts on the economic viability and costs of ethanol become substantial. It is of note that the agricultural sector is unique in the American economy in that an entire industry has been completely protected from market failure because it is perceived by policy makers to be uniquely special. Examples of this mind-set can be discerned in legislator's comments such as in hearings on the Federal Crop Insurance Program by the House Subcommittee on Risk management and Specialty Crops, in February 1999 reviewing the Federal Crop Insurance program by Thomas Ewing (R-IL) who stated that:

More than any other program, crop insurance has become a vital link to the soundness and prosperity of the American agricultural producer. It is 
the safety net that assists the producer in managing risks on the farm. It allows the producer, not the Government, to decide how to manage this risk, but it financial, market, or legal risk. By no means is it the program perfect.

Speaking before the House Subcommittee on Risk Management, Research, and Specialty Crops in March 1999, Gary Condit outlined the centrality of the crop insurance program to the stability of the agricultural economy:

The future of the Federal Crop Insurance Program is a keystone to any plan aimed at stabilizing America's farm economy. Members of the Agricultural Committee are committed to comprehensively review the insurance program... Historically the Federal Government has used two approaches to assist farmers in the event of a natural disaster - ad hoc disaster assistance and crop insurance. Although both intended to help farmers in the event of a natural disaster, there are significant differences... Crop insurance is a permanent program made available to farmers at subsidized premiums contracted before the occurrence of a disaster.

Condit further linked the farm incomes to the health of the national economy:

Agricultural producers face a severe economic threat to their continued economic viability. Conditions are severe enough to trigger a chain reaction that could have a dramatic and detrimental impact on the rural and national economy.

This coupling of farm profitability with the national economy underlies the assumed need of the Federal Government to prop up farm incomes that is evident in legislators' statements the hearings and in their policy response as encoded in Public Law 106-224.

Like much of the legislation propelling ethanol policy forward, the Agricultural Risk Protection Act sought to remedy deficiencies in previous law. In a March 1999 hearing before the House Subcommittee on Risk Management, Research, and Specialty Crops, Sanford Bishop (D-GA) elaborated both the failings of the 
1996 Freedom to Farm Act, but also the assumption that farmers required relief from market forces:

Farmers do need relief from high production costs and low commodity prices.

I think it is time for the entire Congress to face up to the fact that in a number of respects the 1996 Freedom to Farm Act has become the freedom to fail act.... It has some major shortcomings. Most of all, it did not address the safety net issues that most affect farm income.

And in another hearing titled 'Review of the Federal Crop Insurance' conducted in Sioux Falls John Thune (R-SD), a major proponent of Crop Insurance articulated his backing of farm income support and brought into question the intention of the original provisions of crop insurance given the prevailing market realities:

Anybody who deals with agriculture today understands that with the current environment we are in, we have to have a crop insurance program that works for our producers which really achieves the objective I think that was set out for us to achieve.

Bill Barrett (R-NE) presented his perspective on the importance of shielding farmers from natural as well as market disasters with his comments:

The risk management tool was established to protect producers from unavoidable risks such as natural disasters, insect infestation, and disease. However, it is clear that the current Federal Crop Insurance Program does not provide a large enough umbrella in times of natural disaster, and it certainly doesn't do enough to protect producers from low market prices, such as we experienced last year.

Equating suppressed agricultural prices with natural disasters further demonstrates the assumptions embedded in the Congressional approach to agricultural economics. In addition to extending the concept of an agricultural disaster, and hence the applicability of the crop insurance program, Barrett went on to question the cost of this income safety net: 
The Crop Insurance Program has become a very costly toll to producers. Many producers in my area of Nebraska have mentioned the fact that they cannot afford the amount of coverage that is required to survive a true disaster.

Also expressing support for revised crop insurance measures from the other side of the aisle in Sioux Falls, Collin Peterson (D-MN) observed:

We have for the first time up there a lot of land that nobody wants to rent. It may go idle. It is a big mess. What I'm concerned about at this point is if we are going to make this whole thing work, we have got to get the crop insurance system so people can buy insurance to cover their risk

This statement demonstrates the further extension of the original provisions of crop insurance to cover not only the crops grown, but also provide compensation when it is more profitable to leave the land idle.

Peterson's sentiments are reflected in a slightly different form in comments made Terry Everett (R-AL) in a March 1999:

We must seize the opportunity to help producers effectively manage risk.

With low commodity process for this crop year, simply having a good yield does not insure a profitable harvest for our farmers. We need to look at ways for successful farmers to be assured they won't lose money by taking a successful crop yield to completion. One area where I see promise is coverage that not only insures yield, but also insures crop prices

While the premise of a government role in farm income risk management carries over from previous agricultural legislation, the notion that farmers should produce in a vacuum insulated from the market realities of demand and supply are particular to this legislation. Everett and his colleagues on both sides of the aisle started from the assumption that farmers were entitled to be protected from losing money, experiencing failure or feeling the effects of the marketplace. The supposition that farm income was to be guaranteed by the taxpayer, unlike any 
other sector of the marketplace, was one that would come to find expression in the economic assumptions of ethanol policy as it progressed.

Within this context of agricultural policy as market remedy, Richard Lugar (RIN), Chair of the Senate Committee on Agriculture, Nutrition and Forestry proposed the ethanol industry as a possible solution to suppressed farm incomes in a May 1999 hearing:

With a world population of 5 billion to 6 billion, expected to grow to nearly 9 billion, there will be less land available to produce more food. The only way to meet increasing demands will be through continued dramatic improvements in agricultural efficiency, as we have witnessed over the last half century. Producing fuels and chemicals from plants and crops should be viewed as intrinsic to this goal of greater efficiency

Although upon examination this statement suggests a fundamental misunderstanding of both the ethanol solution being offered and population dynamics in general, ethanol as a policy solution to farm incomes was immediately attractive. However, Lugar went on to explain that as with agricultural incomes, ethanol would at least initially require Federal funding:

One of the great problems with ethanol -- and we have been in this battle for the last 20 years - is that the price of corn goes up and down - we have these ethanol debates because clearly it is not at this point something that goes into the market and competes on its own. It is still sustained by this committee, by USDA, by the Federal Government, and for good reason.

Lugar advocated funding for research that would improve the economics of ethanol production and "overcome the technical barriers to low-cost biomass conversion":

Recently I joined with 53 other Senators to express bipartisan support for increasing funding for renewable energy research, including biomass. Our agricultural, energy and environmental future depends upon 
development of new supplies of renewable energy. Over a week ago, an unexpectedly large rise in the gasoline prices rattled the markets. That event reminded us of the extreme price volatility of an old and familiar source of uncertainty for American strategy player, namely oil.

Comments from legislators of both parties show an overriding belief that agriculture was entitled to special consideration not afforded other sectors of the national economy. Given this pervasive mindset amongst many legislators, the progression of thinking that ethanol use and production, particularly for improving national security, was also exempt from market and economic forces was a natural outcome. This added another layer of cost to the already distorted economics of ethanol. The assumption was the technical barriers making ethanol production unprofitable at this juncture in time could be overcome by funded research and that ethanol production and expansion should proceed in order to take advantage of these coming technological advances. Unfortunately, the underlying premise was faulty, unsustainable and would lead to painful economic consequences for the country.

In addition to testimony from agents of the Executive branch, including the Department of Energy and the EPA, testimony delivered in hearings directly addressing ethanol can be broken down into the following categories:

- Associations lobbying for increased ethanol production and incentives American Farm Bureau Federation National Corn Growers Association American Soybean Association National Research Council 
South Dakota Farm Bureau

South Dakota Farmers Union

South Dakota Corn Growers Association

Indiana Corn Growers Association

- Academic institutions lobbying for research funding

Michigan State University

Dartmouth College

University of Illinois

National Association of State Universities and Land-Grant Colleges

- Corporate entities:

Prairie Lands Bio-products

Genencor International

du Pont de Nemours, E. I., and Company

- Environmental groups:

Natural Resources Defense Council

Union of Concerned Scientists

Natural Resources Defense Council

Several interest groups testified before the relevant hearings on H.R. 2559 to lobby their positions and preferences regarding ethanol expansion. Witness testimony in the hearings on H.R. 2559 reveal efforts on the part of several organizations to lobby legislators for additional government funding of federal crop insurance, which is a mechanism whereby farmers are insured at taxpayers' 
expense to grow various crops including corn, which is then additionally subsidized to produce ethanol.

The farm lobby was particularly vocal in seeking to insure income support from the Federal Government as can be seen in several examples of direct requests for support such as that of Tom Olson of the South Dakota Farm Bureau giving testimony before the House Subcommittee on Risk Management and Specialty Crops in November of 1998;

We feel that we should expand levels of coverage including considering an increased premium subsidy on the part of the Treasury

Wally Koester, President of the South Dakota Corn Growers Association reiterated these concerns before the same hearing:

Basically we want to help ourselves, but we want the Federal Government to get involved in that respect.

In addition to the general continuation of transfers requested above, at that same hearing Phil Cyre on behalf of the South Dakota Farmers Association requested a much wider spectrum of crops be included in subsidized federal crop insurance:

Expanding covered crops is essential especially as we seek to adapt our marketing...

Like legislators, farm interests embraced the possibility of increasing farm incomes through biomass fuel production (i.e. ethanol expansion). Dean Kleckner, President of the American Farm Bureau called for direct government support of the ethanol industry in a May 1999 hearing of the Senate Committee of Agriculture, Nutrition and Forestry:

We need to continue the existing renewable alcohol tax credits. It is our hope that ethanol can, through technological advances, become competitive or even less expensive than fossil fuels. Until that time, we 
should provide this needed incentive to the industry. Congress needs to send a strong message to the industry that the Federal Government intends to support a vital domestic renewable energy source.

Although unrelated to ethanol, the attractiveness of biofuels as a remedy to farm incomes is evident in the testimony of Mike Shuter, Chairman of the Indiana Soybean Growers Association, who lobbied the same committee for stronger investment in biodiesel.

Soybean prices are at a 25-year low, and the biodiesel industry needs and deserves a strong investment from Congress, USDA and DOE.

The need for government investment in biomass energy production in the absence of demonstrated commercial viability was advocated by both environmental and commercial interests. John Seller, President of Prairie Lands Bio-products tied environmental concerns to market incentive in stressing the need for government funding in the absence of an established and proven market:

Absent an established market, there is no incentive to create acreage sufficient to support the interests of energy producers. Feasibility studies are also underway to define the potential of ethanol and industrial fiber based on this emerging infrastructure for grassland use. While technically viable, energy crops need market incentives to close the price gap... Our research indicates that all the benefits of the USDA's Conservation Reserve Program, including those for wildlife, can be maintained of increased while harvesting biomass. Therefore CRP or a similar reserve specifically for energy crops should be considered to support the development of new grassland uses.

Environmental issues also figured testimony offered Jeffrey Fielder, Climate Policy Specialist with the Natural Resources Defense Council offered this testimony before a May 1999 hearing of the Senate Committee on Agriculture, Nutrition and Forestry who tied deployment of biomass-to-energy technology that was not commercially viable to a sustainable energy economy: 
Realizing the potential of biomass will require investment and long-term basic research and the precommercial deployment of promising technologies. Private sector investment is highly unlikely to meet this need, given the long time line from technology development to commercial development. We believe therefore that Federal Government investment in the area as envisioned in this bill is entirely appropriate and is one of several important policy measures that are needed to move the United States to a sustainable energy economy

The irony of this statement from both an environmental and economic standpoint is self-evident.

Advocacy for funding to overcome cost issues with biomass production was also evident in testimony from researchers. Professor Lee Lynd from the Engineering faculty of Dartmouth College stated:

In a nutshell, we need to bring the prices of biomass-based production down to the prices of their counterparts produced from low-priced petroleum rather than waiting for the price of petroleum to increase. A substantial increase in Federal funding for biomass processing $R \& D$ and an increased emphasis on research driven innovation and applied fundamentals is consistent with the findings of several comprehensive studies.

This restated the assumption that biomass-based fuels would become economically feasible given sufficient R\&D funding.

Although technical barriers to the commercial viability of ethanol were acknowledged, some witnesses offset these against a wider range of benefits. Karl Sanford, Vice President Technology Development for Genencor International positioned production based on renewable sources in terms of the benefits of elevated farm incomes and enhanced economic security:

The more energy, chemicals and consumer products we can manufacture using renewable carbon, the less we have to import from offshore. This has obvious balance of trade and national security benefits. Helping 
farmers find new markets and agricultural products also has a major positive impact on rural economic life.

Robert Dorsch, Director of Biotechnology Development at DuPont Co. suggested that ethanol production could sway the market forces that at that time were suppressing farm incomes:

the bill should consider other approaches to the conversion of biomass into finished chemicals will exist, whether that is a chemical conversion or perhaps even the use of plants to make chemicals as desired in the stalks and cobs from corn, for example where these materials would have the benefit of raising the value of the farmer's effort per acre so that there is actually more value coming off the land and so that the supply/demand balance does not so much control the price of materials

His testimony went on to suggest that Federal Government had monopoly power over its choices with regard to investment in alternative fuel technologies:

Since the Federal Government is really customer number 1, the largest single purchasing entity in the Nation, it can encourage these technologies and manufacturing approaches by specifying a purchase preference for these types of materials. Again, that is not far from the model for ethanol, but it could provide an incentive to get the work started.

The monopoly power of the Federal Government in driving alternative fuel development choices has important consequences within a deliberative democracy framework. As will be shown here and elsewhere in this analysis it was not so much the national interest that informed these decisions, but rather misinformation, emotion and an imbalance of advocacy over dissenting voices that resulted in poor policy choices and dire outcomes for the Nation.

The underlying bill for the Agricultural Risk Protection Act of 2000 - Public Law 106-224 was H.R. 2559 introduced by Representative Larry Combest (R-TX.) on 
20 July 1999. The bill, which dealt primarily with agricultural price support and crop insurance issues, contained one section that was significant in that it presented the sense of the Congress at the time in their support of ethanol. ${ }^{182}$

The law as enacted contained section 301 "Title III - Biomass Research and Development Act of 2000". The section first presented (in part) that Congress found:

conversion of biomass into biobased industrial products offers outstanding potential for benefit to the national interest through-

(A) improved strategic security and balance of payments;

(B) healthier rural economies;

(C) improved environmental quality;

(D) near-zero net greenhouse gas emissions;

(E) technology export; and

$(F)$ sustainable resource supply;

(3) biobased fuels, such as ethanol, have the clear potential to be sustainable, low cost, and high performance fuels that are compatible with both current and future transportation systems and provide nearzero net greenhouse gas emissions;

(5) biobased power can-

(A) provide environmental benefits;

(B) promote rural economic development; and

(C) diversify energy resource options;

(6) many biomass feedstocks suitable for industrial processing show the clear potential for sustainable production, in some cases resulting in improved soil fertility and carbon sequestration;

(8)(A) cellulosic feedstocks are attractive because of their low cost and widespread availability; and

(B) research resulting in cost-effective technology to overcome the recalcitrance of cellulosic biomass would allow biorefineries to produce fuels and bulk chemicals on a very large scale, with a commensurately large realization of the benefit described in paragraph (1);

(11) the creation of value-added biobased industrial products would create new jobs in construction, manufacturing, and distribution, as well as new higher-valued exports of products and technology;

${ }^{182}$ (Library of Congress, 2000) 
(12)(A) because of the relatively short-term time horizon characteristic of private sector investments, and because many benefits of biomass processing are in the national interest, it is appropriate for the Federal Government to provide precommericial investment in fundamental research and research-driven innovation in the biomass processing area. ${ }^{183}$

This act also included two rather obscure, but expensive provisions for investment in ethanol related areas:

Section 306: (a) ESTABLISHMENT - There is established the Biomass Research and Development Technical Advisory Committee, which shall supersede the Advisory Committee on Biobased Products and Bioenergy established by Executive Order No. 13134."

(f) AUTHORIZATION OF APPROPRIATIONS - In addition to funds appropriated for biomass research and development under the general authority of the Secretary of Energy to conduct research and development programs (which may also be used to carry out this title), there are authorized to be appropriated to the Department of Agriculture to carry out this title \$49,000,000 for each of fiscal years 2000 through 2005.

Section 226: ETHANOL RESEARCH PILOT PLAN - Of the amount made available under section 261(a)(2), the Secretary shall use \$14,000,000 to provide a grant to the State of Illinois to complete the construction of a corn-based ethanol research pilot plant (Agreement No. 59-3601-7-078) at Southern Illinois University, Edwardsville, Illinois. ${ }^{184}$

Section 301 offers a statement of strong Congressional support for biomass-based alternatives fuel of which ethanol derived from corn was the major option. Thus this law endorsed ethanol as alternative fuel and ethanol policy. An illustrative comment on the Congressional approach to ethanol economics by Members considering this bill was offered by Betty McCollum (D-MN) in floor debates:

We are making progress in using energy more efficiently and reducing our reliance on oil and natural gas through energy efficiency technology and

${ }^{183}$ (IBID)

${ }^{184}$ (IBID) 
conservation. We must make bigger investments in current programs. Investments don't have to cost money either. ${ }^{185}$

Senators engaged in spirited floor debate while considering the energy provisions this bill. Examples of reflective comments include: John Shimkus (R-IL) who supported the National Ethanol Research Plant, which was to be a shared-cost enterprise with the state of Illinois. In outlining the benefits of this project, he stated that it would provide: "cutting-edge research that will lead to increased efficiencies coupled with cheaper production of ethanol." He estimated the plant could reduce the cost of ethanol by over 10 cents/gallon in the near term. Senator Barbara Boxer (D-California) introduced an amendment (which had bipartisan support) to replace MTBE with ethanol as the oxygenate additive to gasoline. Senator Richard Durbin (D-IL) strongly supported replacing MTBE with ethanol. He stated that "Ethanol has lower carbon monoxide emissions and reduced reactivity, along with a lower incidence of environmental contamination when compared to MTBE." He acknowledged that Illinois produced $40 \%$ of the 1.5 billion gallons of ethanol produced nationally annually. Senator Kit Bond (R-MO) stated:

replacing $M T B E$ with ethanol in RFG markets would increase net farm income \$1 billion annually, create 13,000 new jobs, enhance our balance of trade and reduce farm program costs over the next ten years. Moreover, USDA reports ethanol can replace MTBE without price spikes or shortages in supplies within three' years.

Although not on environmental or public welfare grounds, Senator James Inhofe (R-OK) opposed the MTBE replacement with ethanol. He was concerned that the increase in ethanol use would lead to a depletion of the Highway Trust Fund

${ }^{185}$ (Betty McCollum (D-MN) House Congressional Record H 12635) 29 June 2001 
(which is where the subsidy was allocated from at this point in the timeline; in one of the later laws they switched the funding to the general Treasury fund because the depletion of the HTF was too visible.)

Senator Tom Harkin (D-IA) strongly supported ethanol and the Boxer amendment. Like much of the character of ethanol deliberation, he raised a possible issue with the viability of ethanol only to dismiss it. Harkin mentioned a genuine problem that would later challenge the assumed environmental benefits of ethanol: that ethanol evaporation could contribute to ozone production at ground level. Senator Chuck Grassley (R-IA) strongly supported replacing MTBE with ethanol. He also reminded the Senate of the usual claims for ethanol benefits: "has a positive economic impact, solidifies our national defense, benefits our environment, and reduces our trade deficit." He also argues that the ethanol exemption is not a subsidy, but rather eliminating the ethanol exemption would be a tax (a most intriguing argument that exemplifies another strange understanding of ethanol economics). Senator Rodney Grams (R-MN) supported ethanol, and wanted the small ethanol producer credit to apply to ethanol cooperatives. He said:

ethanol production boosted nationwide employment by over 195,000 jobs. Ethanol improved our trade balance by $\$ 2$ billion and added $\$ 450$ million to state tax receipts. It reduces emissions from gasoline use and therefore helps us clean up the environment.

Senator John McCain (R-AZ) was one of the lone voices that strongly opposed the ethanol subsidy (a change subsequent to his strong support of ethanol policy while considering Alternative Motor Fuels Act of 1988 S. 1518 several years earlier). He proposed "a three-year nationwide school choice demonstration 
program targeted at children from economically disadvantaged families" and he wanted to fund this program with the "pork" that goes to the ethanol, gas, oil, and sugar industries. He estimated the ethanol subsidy to be $\$ 1.5$ billion. He stated:

Ethanol is an inefficient, expensive fuel that has not lived up to claims that it would reduce reliance on foreign oil or reduce impacts on the environment. It takes more energy to produce a gallon of ethanol than the amount of energy that gallon of ethanol contains. Ethanol tax credits are simply a subsidy for corn producers.

This was a rare assertion challenging the stated benefits of ethanol as encoded in the Act. In addition to articulating the lack of efficiency of ethanol production, McCain also tied ethanol economics to the farm subsidies. As will be seen in later hearings and debate, arguments focusing on the efficiency of ethanol production were largely swept aside by claims of improving technology or questions of the metrics for evaluating ethanol viability.

President Clinton signed H.R. 2559 into law on June $20^{\text {th }}, 2000 .^{186}$

These statements drawn from hearings and floor debates show knowledge and deliberation concerning ethanol provisions in the proposed bill, but as is shown in the narrative and analysis, the process appeared more political than deliberative and did not lead to nationally beneficial outcomes as would have been desired. ${ }^{187}$ As with testimony in Indiana supporting ethanol in relation to 95-618, the results of committee hearings related to the ethanol provisions of this Act functioned to mobilize parochial public support for the desired policy outcome instead of eliciting information upon which informed judgments could be made. An obvious

\footnotetext{
${ }^{186}$ (Woolley, 2000)

187 (Appendix VII Public Law 106-224 Agricultural Risk Protection Act of 2000 - HR 2559 Timeline)
} 
irony in the testimony of legislative witnesses is their acknowledgement that there are serious drawbacks to ethanol, yet as with the previous law, Public Law 102468 , they continue to endorse its production and subsidization. This testimony shows the possible presence of a political rather than a deliberative democracy process, it also suggests that the resulting discussions and debates - both in hearings and on the floor -- may have been shallow and intellectually lacking.

Although this law continued ethanol policy within the agricultural realm, the flaws in the process of creating this law follows the pattern documented in the three energy laws discussed thus far. Political processes, at least at the hearing level, resulted in unbalanced information that may have impeded the ability to make informed judgments.

An examination in chapter 6 will show that virtually all of the "findings" presented in section 301 were demonstrably false when published. The literature shows that although there was much debate about the attributes, both economically and environmentally, objective and substantive impartial analysis would have revealed to legislators the impossibility of their legislated provisions leading to any national benefit. The examination shows the significant divide between the attributes of deliberative democracy being present, which they were, and outcomes of such deliberations, which were very negative.

This Act while addressing some of the ethanol policy issues did so in a far more limited manner than the laws examined across the preceding 20 years; however, the Act encoded Congressional commitment to continuing ethanol policy expansion. While ethanol policy continued to fail to meet its goals within the 
context of energy policy, this Act made important contributions to its success as a mechanism for supporting farm incomes. A sense of complacency had set in within Congress and although significant funds continued to be spent on ethanol production subsidies, corn growing subsidies, research and development activities, it very much appears that legislators were either unable or unwilling to engage at the time in productive debate which would lead to the realization of their long term desires of making ethanol viable as an alternative energy option. 


\section{Summary}

The acts examined in this chapter span an era of roughly 25 years of legislative activity ending in 2000. The legislation was directed towards insuring that America reduced its dependence on imported oil and improving its strategic national security. The data presented for each law examined in this chapter show that as each law was proposed, the intended outcomes of the prior legislation had not been met. The three energy acts examined had the same basic intentions:

Provisions to reduce the imports of foreign oil

Provisions to increase the production and use of methanol or ethanol

Provisions to reduce the use of oil consumption

Provisions designed to promote energy independence

This contrasts to the aims of ethanol expansion within agricultural policy, where ethanol as an alternative fuel was promoted as a solution to low agricultural commodity prices and suppressed farm incomes. Within the agricultural policy stream, the economics of ethanol focused on the benefits of increasing the production of corn and other agricultural products rather than the cost of conversion to ethanol. For example, although Public Law 106-224 sought to support farm incomes, in section 301 it encoded congressional support for ethanol as an environmentally beneficial fuel that, in addition to contributing to "healthier rural economies," would improve strategic security and diversify the energy resource base. While ethanol policy appears to have been meeting its agricultural goals, it was falling far short of its energy goals. 
Deliberative democracy in practice is expected to lead to outcomes which contribute to a national benefit. ${ }^{188}$ The process as envisioned in Federalist 10 suggests that substantive debate amongst reasonable and receptive legislators should lead to positive outcomes benefiting the nation as whole and not sectional interests. The data informing each of this chapter's law examined reveals that extensive debate, dialogue and compromise occurred in the creation of each bill which was enacted into law; however, these activities increasingly took on the appearance of political characteristics described in Figure 5. Figure 5 on page 47 shows two alternative sets of characteristics that can be used to categorize the activities of Republican democracy that influence the nature of Congressional decision making in the formation of laws. These different perspectives; one deliberative and one political suggest potentially different outcomes and those results are addressed in the conclusions found in chapter 6. From 1973 through to 2000 the Nation experienced a profound disruption to its sense of security, economy and energy independence. The challenges of energy security and independence became even more pressing than they had been previously. Yet, although the nation entered a wholly new and unprecedented policy and national security era after 911, the outcomes of the laws examined in chapter 5 will show similar problematic results as in the prior era.

${ }^{188}$ (Bessette J. M., 1994) 


\section{Chapter Five}

\section{Current Ethanol Policy Legislative Directions}

\section{The Post 911 New World Ethanol Legislative Order}

On September $11^{\text {th }}, 2001$ America experienced its worst terrorist attack in the history of the Republic. The ramifications of the attack influenced many areas of public policy and amongst them, energy policy very significantly. The prior chapter of this work examined four selected ethanol policy laws and their outcomes which began after the 1973 Arab Oil Embargo. As the data show, the nation and Congress had wrestled unsuccessfully to reduce the imports of foreign oil and increase national security for the prior almost three decades. The last ethanol related law examined prior to 911 and addressed in chapter four was Public Law 106-224 - the Agricultural Risk Protection Act of 2000. In brief, it was another unsuccessful attempt to articulate and enact an ethanol policy which would reflect the often stated legislative desire for lowering oil imports and increasing ethanol use.

After the 911 attack in the fall of 2001 the Nation became intensely focused on national security and a desire for energy independence from Middle East oil imports which were seen as coming from an unstable, and hostile to America, part of the world. President Bush had been in office for only a few months, yet had already embarked upon a new proposed energy strategy which he announced in the spring of 2001 even as the nation struggled with increasing gasoline prices 
and California faced electricity shortages. ${ }^{189} 2001$ began with the Nation struggling with energy challenges and the 911 attacks exacerbated those concerns. The President's new energy plan presented 105 specific attributes to deal with energy shortages and challenges. ${ }^{190}$ The energy situation facing the nation in the fall of 2001, for all the debate, legislation and money spent over the prior three decades, was very problematic, and could be distilled as follows;

In 1973 America imported $34.8 \%$ of its oil consumption

In 2001 America imported $55.5 \%$ of its oil consumption ${ }^{191}$

In 1973 America consumed 17 million barrels per day of oil

In 2001 America consumed 20 million barrels per day of oil ${ }^{192}$

In 1973 Oil was $\$ 4.75$ per barrel

In 2001 Oil was $\$ 23.00$ per barrel $^{193}$

In 1973 America produced near zero gallons of ethanol fuel.

In 2001 America produced 1,770 million gallons of ethanol fuel ${ }^{194}$

In 1973 annual federal costs for ethanol were near zero

In 2001 annual federal costs for ethanol policy were several billion

dollars $^{195,196,197}$

189 (The Economist, 2001)

190 (IBID)

191 (Research and Innovative Technology Administration, 2010) \#362

192 (Research and Innovative Technology Administration, 2005) \#376

193 (Inflation Data, 2011)

194 (Renewable Fuels Association, 2011)

195 (Pimentel, 2003)

196 (Glozer, 2011) PP.126

${ }^{197}$ (This less than precise cost data is a function of the intentionally obscure and confusing manner in which federal agencies budgets, subsidies for farmers through crop insurance, and ethanol subsidies as well as tax preferences are legislated. In addition to the direct costs through subsidies and tax preferences, there are billions of dollars of indirect costs to consumers and taxpayers brought about by ethanol legislation and are discussed in chapter six. In subsequent years the costs are shown to be more identifiable.) 
The accumulated outcomes of extensive ethanol legislative activity and policy enactments up until 2001 had clearly failed.

The circumstances of 2001 were the foundation for intense legislative activity and debate which would take several years to culminate in the enactment of Public Law 109-58 - Energy Policy Act of 2005. Appendix IX shows that over 50 bills were introduced back as far as 2001 incorporating various aspects of H.R 6 which was enacted on August $8^{\text {th }}, 2005$ by President Bush. The following examination of the debate, enacted legislation and policy outcomes of this Act will further show deficiencies in the outcomes of a process that may have presented only the façade of deliberative democracy. 


\section{Public Law 109-58 - Energy Policy Act of 2005}

\section{H.R. 6}

\section{Deliberative Democracy Measurements and Timeline}

Legislative history data, showing the presence of deliberative democracy attributes, or their absence, in the legislative steps from introduction of the initial bill through the phases leading to the bills enactment into law by the President are presented in appendix IX To assess the presence of deliberative democracy, whether resulting in positive policy outcomes or not, through the various steps of legislation introduction, committee assignments, hearings, floor debate, consideration of amendments and conference reports leading to the passage of this law required examining available data through the matrix of measurement tools presented on page 47, figure 5. (Also refer to appendix XVI for presentation of an additional deliberative democracy measurement table). Examination of this law through the lens of a deliberative democracy measurement matrix reveals informative data significant to the discussion and analysis following in the next section of this chapter. Committee hearings are presented as an integral component of the deliberative process. While this bill, H.R. 6 in the $109^{\text {th }}$ Congress was referred to 9 different committees, those bodies considered testimony from 90 hearings on a wide range of issues related to energy policy. ${ }^{198}$ Testimony offered in the hearings supported the ongoing concern of legislators and witnesses regarding the continuing frustration with the price of gas at the pump within the wider international context of the Iraq War and post-911 fears.

198 (See Appendix XX for Public Law 109-58 Hearing Testimony) 
Witnesses chosen to present testimony spanned a spectrum of positions that, while reflecting frustrations with the failures of previous energy policies and the lack of progress towards energy security, continued to lobby for the solutions they advocated and funding for their projects. Appendix IX details the range of issues presented in the 90 hearings related to H.R.6 (later Public Law 109-58) and the range of policy issues addressed at this level of deliberation. These include:

- Tax incentives to increase the use of non-petroleum alternative motor fuels

- The importance of alternative motor fuels and advanced vehicle technologies in reducing U.S. dependence on foreign oil

- Differing views on tax incentives to encourage domestic oil and gas production

- Anticipated benefits of tax incentives to encourage domestic gas and oil production

- Tax incentives to encourage the use of renewable energies and alternative fuels other than oil and gas

- Federal tax rules impacting energy production, supply, and conservation, with specifics on incentives to increase oil and gas production, perspectives on hydrogen fuel and hydrogen $R \& D$

- Reauthorization of the Hydrogen Future Act, which authorizes the DOE $\mathrm{R} \& \mathrm{D}$ and demonstration program on the storage, transportation, and use of hydrogen as a fuel

- Hydrogen technology issues, developments, and challenges

- Proposed mandates for ethanol production and use through a renewable fuels standard 
- Issues and opportunities available to the Department of Energy's Office of Science

- Energy Conservation Potential of Extended and Double Daylight Saving Time

- Importance of establishing a national comprehensive energy policy for the electric utilities industry,

- Consideration of solar photovoltaic (PV) energy systems procurement and installation program for new and existing Federal buildings

- Role of Tax Incentives in Addressing Rural Energy Needs and Conservation

- Oil Supply and Prices

- the Financial Condition of the Electricity Market

- Energy Efficiency Improvements in Federal Buildings and Vehicles

- Tribal Energy Self-Sufficiency and the Native American Energy Development and Self-Determination Act

- Future of the Hydrogen Fuel Cell

- Future of University Nuclear Science and Engineering Programs

- Competition for Department of Energy Laboratory Contracts

- Oversight of the Nuclear Regulatory Commission

- Nuclear R\&D and the Idaho National Laboratory

While the preceding examples are not exhaustive, and reveal only the tip of the iceberg, these topics demonstrate the range and extent of the policy debate concerning energy independence leading up to the passage of 2005's Energy 
Policy Act. As presented in figure 5, page 47 if deliberative democracy attributes are present in committee hearings, then they provide: [a venue] to elicit the information and arguments necessary to make informed judgments.

\section{Congressional Pressure to Mandate Ethanol Production}

Reflecting the popular concerns about energy and a commitment to addressing them, in January 2001 and only his second week in office, President Bush created the National Energy Policy Development Group. In June of that year President Bush announced the creation an additional initiative to address climate change, the Climate Change Research Initiative that became known as the National Climate Change Technology Program, or CCTP, to support applied research and technology demonstration project focused on the environment and climate change.

The National Energy Policy Development Group was tasked with developing answers to continuing energy shortages, disruptions in energy supplies and price increases that had plagued the nation leading into the spring of $2001 .{ }^{199}$ The specific mandate was to: "develop a national energy policy designed to help the private sector, and, as necessary and appropriate, State and local governments, promote dependable, affordable, and environmentally sound production and distribution of energy for the future." ${ }^{200}$ The Task Force was composed of Vice President Dick Cheney, the Secretaries of State, Treasury, Interior, Agriculture,

\footnotetext{
${ }^{199}$ (National Energy Policy Development Group, 2001)

${ }^{200}$ Reliable, Affordable, and Environmentally Sound Energy for America's Future: Report of the National Energy Policy Development Group. US Government Printing Office. May 16, 2001
} 
Commerce, Transportation and Energy, as well as other cabinet and senior administration officials. According to the GAO, this committee held ten meetings over the course of three and a half months and heard submissions from lobbyists representing petroleum, coal, nuclear, natural gas, and electricity industry interests. None of the meetings were open to the public. The final report, entitled Reliable, Affordable and Environmentally Sound Energy for America's Future, was presented by the Group's Chair, Vice President Cheney, in May 2001. The report cited the wise use of energy as the Nation's paramount challenge and outlined 106 energy policy recommendations to modernize America's energy production and distribution systems, promote energy efficiency and conservation, strengthen the economy and create new jobs, and reduce dependence on foreign sources of energy. In addressing the recommendations requiring legislative action, Congress would wrestle with for many months before agreeing on legislation that could be sent to the President.

The provisions of the report relating to ethanol proposed the continuation and potential expansion of ethanol production by extending subsidies and tax exemptions for ethanol production, and providing additional tax credits to encourage the purchase of hybrid vehicles. ${ }^{201}$ The report specifically referenced the failure of prior legislative attempts to increase ethanol consumption by requiring fleet operators to purchase alternative fuel vehicles. The report noted that although the legislation had resulted in the intended increase in sales of flex fuel FFV vehicles, these vehicles could operate on gasoline just as efficiently

${ }^{201}$ (IBID) pp.99 
(actually more so) as ethanol. The ability of FFV vehicles to operate on gasoline and the greater availability of gas were among the factors that prevented the number of vehicles on the road that could operate on ethanol from translating into greater ethanol consumption. ${ }^{202}$ However, the failure of fleet mandates to stimulate ethanol demand in the market did not detract from the attractiveness of mandates as a policy option. The concept of mandating ethanol use - not through equipment purchase, but by requiring that increasing amounts of ethanol be blended with gasoline -- began to infuse the legislative process.

By 2005 the Administration had implemented most of the provisions of President Bush's National Energy Policy. The remaining recommendations required Congressional action. Between 2001 and 2005 no major energy legislation had been promulgated and the price of oil had more than doubled to over $\$ 50.00$ a barrel. ${ }^{203}$ In his 2005 State of the Union Address, President Bush once again highlighted the need for reliable, affordable, and clean supplies of energy to keep the economy growing and create new jobs. As the President said: "Four years of debate is enough: I urge Congress to pass legislation that makes America more secure and less dependent on foreign energy."

This frustration with the lack of progress on energy policy was not confined to the Executive. It was a common concern in Congress as well as among corporate interests. In July 2001, Tim Johnson (D-SD) stated:

Frankly, I don't believe that either party's administrations or members of Congress has done an adequate job of focusing on the long term of what

\footnotetext{
202 (IBID) pp. 28

203 (Inflation Data, 2011)
} 
needs to be done on energy. These problems have gone back, at least in recent memory, all the way to the Carter administration with the oil shortages that we had, and the long gas lines at that time. And sometimes Congress's attention has waned as prices have gone down and then has increased as prices have gone up, and it should be apparent to al that we need now to address these issues with some urgency and we need to do it in a bipartisan fashion.

These sentiments are echoed by James Inhoff (R-OK), who in 2003 stated:

I firmly believe that what we are dealing with is a national security issue. This goes all the way back to the early 1980's for me, when I was critical of the Reagan Administration for not having an energy policy that has some type of cornerstone that would have a minimum of our reliance on foreign countries for our ability to fight a war.

These comments reflect bipartisan discontent with energy policy in the years leading up to H.R. 6. What is also interesting is that each of these legislators traces problems with energy policy back to administrations where the incumbent was from their own party. It is unfortunate to note that for all of the abundance of comments and posturing by legislators and witnesses, the preponderance of discussion revolves around blaming every conceivable circumstance for failure rather than objectively assessing the challenges and crafting rational solutions.

In spite of years of frustration with the failures of existing energy policy, it would not be until 2005 that the Legislature formulated a bill that could gain passage through the House and Senate. In 2005, while H.R. 6 was being marked up, Lynn Westmoreland (R-GA), Vice Chairman of the House Committee on Energy and Resources included the following comments in his opening remarks to a hearing entitled "America's Energy Needs as Our National Security Policy:"

I think the bottom line to the problems that we are having with our energy is that we do not have an energy policy, and we desperately need an 
energy policy. I know that there have been two or three attempts made in the past several Congresses to come up with an energy policy.

One of the quandaries legislators faced in deliberating on ethanol policy was clearly presented in observation made by Richard Wagman, First Vice Chairman of the American Road and Transportation Builders Association before Senate Committee on Clean Air, Climate Change, and Nuclear Safety in a hearing entitled "Clean Air Act: Alternative Fuels and Fuel Additives:"

these tax policies are often debated and decided separately, and thus in a vacuum during a transportation bill, an energy bill or an environmental bill. As a result, positive impacts for one policy area sometimes contradict or even undermine goals and objectives in another area. This is certainly what happened in the case of ethanol tax law, as it impacts the Highway Trust Fund. The proposed renewable fuel standard would exacerbate the magnitude of the loss if the current ethanol tax stands.

Another possible barrier to the development of a consistent and timely energy policy was offered by Jeff Bingaman (D-NM) as Chairman of the Senate Committee on Energy and Natural Resources back in 2001. In his opening comments on a hearing entitled "National Energy Issues, Part 2" he outlined the pattern of cyclical demand for energy policy and some of its consequences:

I have noticed sort of a cyclical phenomenon going on where interest in energy issues and policy concerns obviously increase dramatically as the price of gas goes up and the price of electricity goes up and the price of natural gas goes up. And when the price comes back down the interest goes away... I have noticed unfortunately though, that there is something similar that happens in the budgeting for energy related research and development, that the interest of maintaining our efforts in those areas at the Federal level comes into vogue and is obvious and then goes away again as soon as the problem recedes in the public consciousness. 
With no viable energy policy forthcoming in the intervening years from 2001 to 2005, Robert Hormats, Vice President of Goldman Sachs testifying before the House Subcommittee on Energy and Resources in 2005 spoke of the cyclic and crisis-driven nature of energy policy:

The difficulty that we have is when we have a crisis; Americans tend to focus on the crisis. They reduce consumption, and then once the crisis is over, we revert back to gas guzzlers. We pay very little attention to production, conservation, efficiency and all those things, and this is why it's so hard to get a policy in concrete, because when the crisis passes, people pay very little attention to it. And the tragedy is the longer the impasse lasts, the greater the U.S. dependence becomes.

With the nation wrestling with the economic challenge of high gasoline prices and the resulting political fallout as well as the security challenges of the War on Terror, at this juncture a substantive and critical debate examining the assumptions propelling ethanol policy forward and differences in the research findings presented rather than the focus on ethanol advocacy could have produced different policy outcomes. Instead of alleviating the price pressures related to fuel and transportation, the resulting policy included provisions seeking to substitute ethanol for gasoline, which much like the FFV vehicle mandates could never meet their policy goals.

H.R.6 was introduced on April 18, 2005 by Representative Joe Barton (R-TX) who was serving as Chairman of House Committee on Energy and Commerce. Comments by Greg Walden (R-OR) are typical of the emotive nature of the national security concerns and economic angst that permeated the crafting and discussion of this bill: 
I don't want to be held hostage for my energy and our country's energy to countries that aren't always exactly friendly toward us, and yet can pull our chain and our economy and cause severe problems. We need a comprehensive energy program.

While much of the deliberation in hearings and floor debates framed the need for increased ethanol supply in terms of national security and economic dependency with an occasional reference to environmental issues, an additional theme continued to permeate ethanol advocacy - concern for the agricultural sector and the need to prop up farm incomes. While the energy security, economic and environmental concerns driving energy policy were generally crisis-driven and reactive to the shocks of geopolitical events and price surges, the association of energy policy, and ethanol in particular, with farm interests, although in the background, was constant. The emotional sense of the Congress could be discerned in the comments of Dennis Kucinich (D-OH):

We can grow our way out of our energy crisis; and farmers growing biomass feedstocks that can be processed locally to supply, in our case, nearby cities such as Cleveland and Toledo can help we do that. They will benefit with new and more stable markets; our fuel supply is home grown, thus reducing our dependence on foreign oil; fuel prices are reduced; and the air we breathe is cleaner. ${ }^{204}$

\section{Exploration of Legislative Activity}

While the circumstances driving ethanol policy creation and its continuation in this law - given the particular conditions from the President's initiatives in early 2001 to the passage of H.R. 6 as Public Law 109-58 - are discussed in this

${ }^{204}$ (Dennis Kucinich (D-OH) Congressional Record H2403) April 21st, 2005 Floor debate 
chapter, it is also necessary to examine the process of committee assignments, hearings held and the perspectives evident in representative testimony given in attempting to ascertain the operation and character of deliberative democracy present in the perpetuation of ethanol policy at this historical juncture. Although at its inception H.R. 6 was referred to nine different committees (see appendix IX for more details) including: House Energy and Commerce Committee, Subcommittee on Energy and Air Quality, House Financial Services, House Agriculture, House Natural Resources, House Science, House Ways and Means, House Transportation and Infrastructure, the complexity of the legislative process influenced the eventual provisions of the bill. From its genesis to enactment, aspects of the bill were discussed in 90 committee and subcommittee hearings. From July 2000 to July 2005 with 52 hearings before House committees and 38 before Senate committees heard evidence relating to H.R. 6. Under the umbrella of considering H.R. 6 and attendant bills, many of the 90 hearings focused on national security, nuclear power plants, electricity supply disruptions and other issues not relevant to the ethanol policy formation studied here. Out of the 90 hearings conducted, only 14 examined ethanol and issues related to alternative motor fuels. The titles of these hearings reveal the framing of the ethanol debate at this formative stage of the legislative process:

Energy Tax Issues

Renewable Fuels for Energy Security

Role of Tax Incentives in Energy Policy

National Energy Issues, Part 2 (Part 1 had focused on nuclear power)

Renewable Fuels 
Role of Tax Incentives in Addressing Rural Energy Needs and Conservation

U.S Energy Security: Options to Decrease Petroleum Use in Transportation Sector

Energy Use in the Transportation Sector

Clean Air Act: Alternative Fuels and Fuel Additives

Rural Economy, Renewable Energy, and the Role of Our Cooperatives

What are the Administration Priorities for Climate Change Technology?

Renewable Energy and the Rural Economy

Energy Policy Act of 2005

America’s Energy Needs as Our National Security Policy

Agriculture's Role in a Renewable Fuels Standard

Although national security and environmental issues were taken into account, four of the fourteen ethanol related hearings incorporated agricultural concerns into their titles. In addition to hearing titles that explicitly frame ethanol policy in relation to agriculture, a hearing entitled "Renewable Fuels for Energy Security" was held in Sioux Falls, South Dakota and heard testimony from a range of regional agricultural concerns. While the crisis created by high fuel prices and national security concerns supported calls for increased ethanol production, the consistent interests of the farm sector are reflected in the hearings and the intermingling of alternative fuels and farm incomes through ethanol.

The primary committees which were given jurisdiction over the debate relating to ethanol were the Senate Energy and Natural Resources Committee and the Senate 
Finance Committee. These two committees held 6 of the 14 ethanol related inquiries. The variation in the number of witnesses per hearing and the identities/affiliations of those witnesses is revealing. It reflects the assumptions regarding ethanol held by the committee members who assembled witnesses for their committees. These assumptions combined with identifiable preferences of policy makers in guiding the tone and outcomes of those hearings. Thus the selection of witnesses and the range and concentration of the positions they represent are significant to the examination of deliberative democracy. In addition to testimony from agents of the Executive branch, including the Department of Energy and the EPA, testimony delivered in hearings directly addressing ethanol can be broken down into the following categories:

- Associations lobbying committees on ethanol production and usage issues American Gas Association

Western Organization of Resource Councils

New Mexico Oil and Gas Association

National Association of Regulatory Utility Commissioners

American Council for an Energy-Efficient Economy

Domestic Petroleum Council

Coal Utilization Research Council

Alliance of Automobile Manufacturers

Edison Electric Institute

Electric Power Supply Association

American Public Power Association

Alliance To Save Energy 
Renewable Fuels Association

Sound Energy Solutions

National Association of Manufacturers

Resources for the Future

Domestic Petroleum Council

Independent Petroleum Association

RCF Economic and Financial Consulting

Greenspirit Strategies Ltd

Emissions Control Technology Association

National Farmers Union

National Corn Growers Association

Virginia Poultry Growers Cooperative

American Forest \& Paper Association

- Academic institutions lobbying for research funding

School of Government, Harvard University

Center for Strategic and International Studies

Sloan Automotive Laboratory, Massachusetts Institute of Technology

- Corporate entities:

Dow Chemical Company

New York Mercantile Exchange

Xcel Energy, Inc.

Southern Company

Goldman Sachs

Shell Exploration and Production Company 
Constellation Energy Group

NuStart Energy Development, LLC

Virginia Biodiesel Refinery

- Environmental groups:

Wilderness Society

Natural Resources Defense Council

Sierra Club

Union of Concerned Scientists

Clean Air Task Force

As with all of the six laws examined within the deliberative framework, the hearings of H.R. 6 that influenced ethanol policy within the larger framework of energy legislation focused on increasing the production of ethanol. For H.R. 6, the primary vehicle in the continued ethanol expansion would become the establishment of renewable fuels standard (RFS) mandates. The driving force behind the desire to implement this policy appears to be the dramatic increase in the price of oil and gasoline along with the attendant concerns regarding the national security implications of such dependence on foreign sources of petroleum. Running parallel to these external influences is the continuing trend of low prices for farm commodities. Thus ethanol was proposed as the solution to the Nation's foreign policy and economic dilemma on one level while simultaneously addressing suppressed farm incomes in specific states. The tenor of the collective hearings, while showing debate between the political parties as to how the renewable fuels standards could be implemented, clearly illustrate agreement on the need to increase production and use of ethanol. Comments by 
legislators in these hearings reveal their perspectives and indicate the presence of deliberative democracy attributes, in reasoning on the merits of public policy.

In a hearing of the Senate Subcommittee on Taxation and IRS oversight, the subcommittee chair, Senator Orin Hatch (R-UT) expressed the prevailing sense of crises regarding national security and sticker shock at oil prices that resonated through committee hearings and framed much of the formation and debate regarding H.R. 6:

What is striking, though, is since the 1970's; our dependence on foreign oil has increased sharply, from 35 percent to a whopping 56 percent. Every day, Americas spend $\$ 300$ million on imported oil. This makes up a third of our entire trade deficit.

The discussions did reveal that legislators were aware of the interrelated complexity of the energy challenges they were facing.

With almost three quarters of petroleum demand going to the transportation sector, previous legislation had targeted the government fleets as part of a mechanism for increasing ethanol fuel consumption. As discussed earlier, mandates for FFV vehicles failed to increase ethanol consumption. Articulating his concerns about this policy failure, Charles Gibbens, representing the National Association of Fleet Administrators stated:

As a viable public policy, EPAct has failed. The marketplace has not risen to the challenge to address the economic barriers. Some are blaming fleet managers for the failure. To blame the fleet manager for failing to convince a mayor, a governor, a CEO that sound economics would be to acquire vehicles that cost more, are more expensive to operate, travel fewer miles, have limited cargo space, and cannot be easily refueled[would defy all common sense and logic].. 
Gibbens goes on to explain that the presence of alternative fuel vehicles on the road had not resulted in the infrastructure required for refueling, and where it did exist, ethanol was often more expensive than gasoline. The emphasis on ethanol production and increasing supply rather than the market dynamics of distribution and aspects of demand ignored consumer preferences in policy formation. Developing and manufacturing alternative fuel vehicles that could run on ethanol not only failed to produce demand for ethanol at the government fleet level, but also it did not pay off for auto manufacturers. In the same hearing before the Senate Committee on Energy and Natural Resources, Dana Gregory, Vice President of the Alliance of Automobile Manufacturers, testified:

Existing energy policies are not delivering anticipated results. Second, to be successful [auto manufacturers] must maintain consumer focus, because consumers determine fuel economy every day through their purchasing decisions on dealers' lots.

In spite of the policy failure of encouraging alternative fuel vehicles that could run on higher ethanol blends, the Executive and Legislature continued advancing policies for increased ethanol supply. Craig Thomas (R-KY), Chair of the Senate Committee on Energy and Natural Resources, placed ethanol firmly in the portfolio of energy alternatives for examination with respect to policies, incentives and other funding:

In particular this committee is interested in the following questions: One, what benefits can hybrid and diesel engine technologies offer conventional combustion engines? What fuel efficiency benefits are likely? Two, how can we diversify our fuel supply for use in transportation? Can alternative fuels, like ethanol, biodiesel and natural gases play a role? Three, what is envisioned for the President's Freedom CAR and Hydrogen Fuel Initiatives? What policies, incentives, and funding levels and incentives will be required? 
Although supporting infrastructure for ethanol distribution and supply still remained undeveloped, the push for more ethanol continued.

In a hearing of the Senate Subcommittee on Energy and Natural Resources held in Sioux Falls, Tim Johnson (D-SD), chair of the subcommittee, expressed insight into the disconnect between the legislative desire for greater ethanol production and consumer reality:

Recently there was some criticism in the national media about our incentives for the auto industry to develop dual use vehicles, that is, using ordinary gasoline or E-85, which is 85 percent blend, which does require some additional modification, not enormous, but it does involve modifications. Turns out that the problem is not really E-85, the problem was here was not a single station in the entire west coast selling E-85, so you continue to have a bit of a chicken and egg problem where we've got a product that is proven, but no one wants a vehicle if they can't buy fuel and you don't want to create the fuel if there is no product.

However, instead of following this recognition with recommendations to bridge the chicken and egg problem separating ethanol producers from potential consumers, Senator Johnson ignored this barrier to increased ethanol usage to defend alternative fuel tax breaks and subsidies in pushing for a critical mass of ethanol consumption:

Yes, we do provide some tax breaks for alternative fuels. On the other hand, the oil industry gets significant tax relief as you note in depletion allowances and production tax grants, not to mention the cost of keeping our fleet halfway around the world patrolling the oil flow form the Middle East among other places, and so I think the question is not that they are a free market and we are not. We're trying to get a critical mass of usage where hopefully we can minimize subsidies, but at the same time stay on a fair and level playing field with oil and there's a lot of good public policy and reasons we ought to be doing that, from the environment to the balance of trade, as you know. 
While Senator Johnson's comments recognizing the importance of minimizing subsidies, he frames this within the need for alternative fuels (read ethanol) to have a level playing field with oil, while considering environmental concerns. While the comments on subsidies might be seen as possibly alienating to some of his South Dakota constituents, they reflect the assumption that ethanol should continue to be subsidized up to the point of achieving price competitiveness with fossil fuels.

Testimony offered before the same hearing, "National Energy Issues, Part 2," by Gary Marshall, Vice Chair of the National Ethanol Vehicle Coalition, while endorsing ethanol as the energy policy solution, demonstrates how far ethanol technology would have to move to approach competitiveness with fossil fuels:

We believe there is no other form of transportation fuel that provides the broad range of environmental and economic benefits to the Nation as does E-85. But as I have been saying, obviously there are impediments to achieving those results. Lack of infrastructure - today we only have about 200 E-85 fueling stations in the United States. Ethanol contains less energy on a Btu basis than does gasoline and even with the existing blenders tax credit a gallon of gasoline equivalent E-85 often exceeds the cost of unleaded gasoline. I would like to offer a very general set of conclusions and recommendations that the committee might want to consider. No. 1, that all forms of alternative fuels be products produced in North America and promote national energy efficiency. No 2, E-85 and biodiesel are the only alternative fuels that can significantly reduce emissions and greenhouse gases. No. 3, E-85 and biodiesel are the only forms of renewable transportation fuels available in liquid form that could use the Nation's existing fuel delivery system. No. 4, renewable fuel production can be a cornerstone for important economic development and job creation across the country.

Although unresolved in his testimony, Marshall acknowledges the energy discrepancy between ethanol and gasoline. He further states that "even with the existing blenders tax credit," and producer incentives that would be irrelevant to 
him as an ethanol blender and distributor, E-85 is often not cost competitive with unleaded gasoline. The underlying assumption in both Marshall and Johnson's comments is that the priority should be increased ethanol production and supply regardless of cost concerns. Like Johnson, Marshall acknowledges impediments in the distribution and supply infrastructure for ethanol delivery and then ignores them in advocating a "very general set" of recommendations advocating the high percentage E-85 ethanol blend and biodiesel as the "only alternative fuels."

Data offered at these H.R. 6 hearings reflected the presenting organizations perspectives and lobbying desires and as seen above often glossed over known deficiencies in ethanol production and supply. Legislators faced the additional challenge of discerning what was relevant, plausible and achievable for ethanol as the energy solution. While significant legislative resources were available to them to assist in making informed decisions, contributions such as the following presented by Megan Smith, Co-Director of the American Bioenergy Association before the House Subcommittee on Rural Enterprises, Agriculture and Technology that contained significant errors and omissions made weighing the material and therefore thoughtful deliberation difficult:

Low-value/high quality cellulosic biomass is widely available throughout the U.S., mostly in the form of agriculture and forest residues and the cellulosic component of municipal waste

If we could begin to phase-down our hydrocarbon use and phase-in our biomass, or carbohydrate use, the impact would be tremendous. We would start down a critical path to true energy security, while helping to stabilize our economy overall, increasing jobs around the U.S. for many put out of work in rural areas where the majority of biomass is grown.

Biomass is currently being used for conversion to electric power through conventional combustion technology. 
The benefits of biomass conversion are numerous and great.

Cellulosic feedstocks such as agricultural/forestry residue and municipal solid waste, many of which are troublesome to the environment and communities nationwide, can be used for ethanol production.

There are several types of tax incentives which would help support both existing and new biomass facilities.

The above testimony is misleading on a number of counts. The availability of biomass is significantly exaggerated, no account of the substantial cost in both energy and cost to physically bring it to production facilities is included, even if biomass were used despite the economic disadvantages, the impact would not be "tremendous", use of biomass would not lead to "true energy independence" and "stabilize our economy," and lastly the requirement for additional tax incentives to "help support" new biomass facilities would represent a unproductive transfer of wealth from taxpayers and consumers to a narrow interest without increasing national security.

Some policy makers expressed concerns regarding the importance of sound information to good decision making. In 2001 Frank Murkowski (R-AK) stated before the Senate Committee on Energy and Natural Resources:

We want to make our decisions on sound science... So often, you know we are expected to have the knowledge and background to make the decision. We have to make decisions. We vote yes or no. We can't vote maybe, so we have to depend on people who are willing to put their reputations as experts behind their recommendations.

However, his follow up comments reveal evidence of a possible legislative blindspot in the search for energy alternatives:

Perhaps it is worth asking if we have been keeping score on the wrong scorecard. The focus on miles per gallon of gasoline puts alternative fuels certainly at a disadvantage and certainly overlooks and ignores their potential. Perhaps it is time for a new metric that directly addresses the 
goal of reducing dependence, as an example, on foreign oil, one that would promote finding another alternative to gasoline.

In addition to misleading or incomplete information offered in witness testimony, and discounting deficiencies in the infrastructure required to facilitate a consumer market, the assumption that ethanol should be made cost-competitive to the consumer even at the cost to the taxpayer was supplemented by such calls for an alternative cost metric.

Tim Pawlenty, Governor of Minnesota presented state legislation as an exemplar for Federal legislation in hearings in March 2004 and July 2005. The following statement emphasized the benefit to Minnesota farmers from the increase from $10 \%$ ethanol blending to $20 \%$ ethanol while ignoring the costs to the consumer and taxpayers:

The decision you make can propel us toward an energy future that not only strengthens our economy but our security as well. In addition to our distinction as the first state to require ethanol-blended gasoline, Minnesota is remarkable in that our ethanol industry is dominated by a collection of local farmer-owned cooperatives. This ensures that the economic benefits are spread throughout the rural communities where the plants are located. Minnesota has 14 ethanol plants, with two more under construction. All told, these plants produce more than 450 million gallons of ethanol every year. Minnesota corn growers send approximately 15 percent of their crop to ethanol plants, and that increases the prices they get for their crops. Specifically, Minnesota Department of Agriculture experts tell me the local cash price for corn in areas near ethanol plants tends to be 7 to 10 cents higher per bushel than it otherwise would be Tim Pawlenty (Governor, MN)

Given these examples of poor or incomplete information, it is not surprising, then, that Max Baucus (D-MT) in his opening statement as Chair of the Senate Committee on Finance before a May 2001 hearing addressing the role of tax 
incentives in energy policy articulates one of the flawed assumptions that went on to ground ethanol policy through the hearings and debates related to H.R. 6:

We will hear about the relative success of ethanol in achieving market penetration. It really is the lone success story in the world of alternative fuels. The signs indicate that ethanol will continue to grow as an important fuel source into the future.

While problems with the assumptions supporting increased ethanol advocacy and the evaluative criteria used to justify ethanol as the alternative fuel solution are evident in both legislators hearing testimony and those presenting before them, another theme that emerges from the hearings addressing ethanol within the policy framework of H.R. 6 is the centrality of agricultural concerns to the discussion. A hearing of the Senate Committee on Energy and Natural Resources entitled "Renewable Fuels for Energy Security" was held in Sioux Falls, South Dakota and included testimony from: the South Dakota Corn Growers, the Lake Area Corn Processors, the American Coalition for Ethanol, South Dakota Soybean Association, and the South Dakota Farmers Union and Farm Bureau. A representative of the National Farmers Union tied funding for farmers to energy policy in supporting the proposed renewable fuel standard.

South Dakota Farmers Union and the National Farmers Union wholeheartedly support your bill and other bipartisan legislation that you have cosponsored that will establish a renewable fuel standard for America. Aggressive demand policies are needed to improve farm income by stimulating investment by farmers in value-added processing facilities for ethanol and biodiesel.

Trevor Guthmiller, Executive Director of the American Coalition for Ethanol, a self-proclaimed grassroots voice of the U.S. ethanol industry and the nation's 
largest association dedicated to the production and use of ethanol reinforced the connection of ethanol to the farm economy:

The only real energy policy is one that tangibly and measurably charts our course towards increased utilization of renewable energy products like ethanol and biodiesel. That is why we believe the renewable fuel requirement is the best possible way to help the United States address concerns regarding our energy, economic agricultural and economic policies.

In his opening comments as Chair of the Senate Subcommittee on Clean Air, March 2003 George Voinovich (R-OH), Subcommittee Chair reiterated the assumption of a National benefit from ethanol in conjunction with the tangible impact of increasing ethanol in boosting the farming sector:

Ethanol is also good for our Nation's economy. Ohio is the sixth in the Nation in terms of corn production and is among the highest in the Nation in putting ethanol into gas tanks. Over 41 percent of the gasoline used in Ohio contains ethanol. An increase in the use of ethanol across the Nation means an economic boost to thousands of farm families across my state.

These sentiments simultaneously tying ethanol to a national and the rural economy are echoed in testimony by Tim Pawlenty, Governor of Minnesota, before the House Committee on Agriculture, July 2005:

Doubling our ethanol use doubles our benefits, including a stronger rural economy, cleaner air, and reduced dependence on foreign oil. It also puts our state at the leading edge of a very promising industry, and it gets us closer to the goal I set of making Minnesota the Saudi Arabia of renewable fuels.

By the final drafting of H.R. 6 the introduction of a renewable fuel standard (RFS) had emerged as the major mechanism for increasing ethanol production and 
funding. Details of this new mandate are offered later in this chapter, but in hearings, the RFS was met with resounding support from agricultural interests.

Back in the Sioux Fall hearing in 2001, Trevor Guthmiller, Executive Director, American Coalition for Ethanol advocated:

The best way that can lead to the further growth of the ethanol industry is to establish a renewable fuels requirement that would establish a framework for increasing ethanol use throughout the country

Another group that saw potential for a RFS was the National Corn Growers Association had been among the early advocates of a RFS. In a 2003 hearing before the Senate Subcommittee on Clean Air, the President of the Association, Fred Yoder had lobbied for a RFS:

RFS can help us fix some of those long-term obstacles facing agriculture, while at the same time playing a critical role in our Nation's comprehensive energy policy. We believe ethanol provides energy security for the United States, and we believe the necessary resources are here to make a significant contribution to our domestic fuel supply

In 2005 hearings addressing RFS as laid out in the draft bill H.R. 6, the President of the National Farmers Union, no small factor in farm state politics, presented the following comments:

Your legislation, and the Senate RFS language, would establish a strong renewable fuels standard mandate for the use of eight billion gallons of ethanol in our nation's transportation fuels by 2012, and it contains tough waiver language and anti-backsliding provisions to protect gains we have made in the Clean Air Act. Our farmers and ranchers will settle for no less than 8 billion gallons by 2012, and the other important and vital language included in your legislation and the Senate energy package. This robust RFS would more than double the production and use of domestic renewable fuels produced from biomass, and will create vital opportunities for family farmers and ranchers and their rural 
communities. A strong RFS would increase domestic demand for surplus farm commodities, lower federal outlays of federal farm subsidies, improve the environment, and decrease our reliance of foreign oil. Farmers urgently want to participate in the production of renewable fuels in America, and have entered innovative markets - - including renewable fuels production by forming cooperatives.

At the same hearing, Robert Dinneen, President and CEO of the Renewable Fuels

Association was emotional in his endorsement of the RFS:

With good crude oil prices topping $\$ 50$ a barrel and gasoline prices across the country once again on the rise, consumers are seeking the increased production use of domestic renewable fuels as a means of adding to supply and lowering prices. Consequently, we would hope that as the legislative process regarding the energy bill progresses, Congress would recognize the potential of U.S. ethanol companies to increase production and seek to expand the volume-excuse me-of ethanolexcuse me-in the RFS program. This all gets me choked up.

Another not unexpected supporter of RFS was Leon Corzine, President of the

National Corn Growers Association who at the same hearing stated:

The passage of comprehensive energy legislation that includes an RFS has long been a top legislative priority for NCGA. For more than 20 years, NCGA has worked side by side with farmers, industry and government to build the ethanol industry from the ground up. The ethanol market is the single most successful and fastest growing value-added market for farmers.

Representatives of the Executive branch also endorsed the RFS. Keith Collins, Chief Economist of the Department of Agriculture addressed his support of the ethanol and the RFS to the House Committee on Agriculture in 2005:

The major renewable fuel today, and the fuel most affected by the RFS, is ethanol. Ethanol production has grown from a few million gallons per year in 1979 to a forecast of nearly 4 billion gallons this year, accounting for about 3 percent of the Nation's gasoline use. During the 2004/05 crop 
year... Despite one recent report that ethanol requires more energy to produce a gallon than the energy contained in a gallon of ethanol, a recent USDA study, using more recent estimates of energy use in corn and ethanol production, found just the opposite: ethanol has a positive net energy balance.

Although he raises a possible source that questions the viability of the ethanol expansion needed to meet the mandates, as in other examples of testimony and statements, these concerns are summarily dismissed.

Evidence of possible limitations had been presented in previous hearings, but the weight of evidence was generally skewed towards representations of a rosy future in the ethanol economy. Back in 2003, David Garmin, Assistant Secretary of Energy Efficiency and Renewable Energy at the DOE testified before the Senate Subcommittee on Clean Air, Climate Change and Nuclear Safety suggesting a finite limit to the amount of additional corn that could be grown to facilitate the production of ethanol:

there are limits to the amount of ethanol that can be produced from grain before encountering secondary effects such as impacts on food and feed markets and the sustainability of production on marginal agricultural lands (DOE)

With RFS specified in the draft bill mandating increased ethanol production, James Mason, General Manager of the Virginia Poultry Growers Association offered additional insights into the implications on diverting limited corn yields to ethanol production as one of the few dissenting voices at the House Agricultural Hearing on the mark up of H.R. 6:

Proponents of the RFS claim that the standard will help further America's energy independence while having a minimal effect on the market for livestock and poultry feed. I'm going to focus strictly on the second claim. Those who support the RFS say livestock and poultry producers do not 
need to worry about the feed markets because the trend line on corn yields is increasing, thus ensuring corn harvests will routinely look like last year's 11.8 billion-bushel crop. They say that gasoline refiners will increasingly use products other than corn-based ethanol to meet the Renewable Fuels Standard... Congress also should recognize that an RFS at any level could put livestock and poultry producers at a competitive disadvantage in a tight corn market... We would ask Congress to recognize that the RFS in certain situations could have a market-distorting effect.

Another witness arguing against the energy solutions put forward in H.R. 6 was David Hamilton of the Sierra Club. Testifying before the House Subcommittee on Energy and Air Quality, Committee on Energy and Commerce in February 2005:

H.R. 6, we believe, is weighted far too heavily toward an answer to every energy problem that is more "supply solves the problem," and we believe that that ignores and neglects several of our key energy problems that we have yet to really make progress on, and those include oil dependency... H.R. 6 exacerbates, rather than solves, is the fact that energy prices in this country are hugely distorted by a system of subsidies, by the fact that things like environmental costs, like global warming, are not included in energy prices, vastly distort the relative values of energy supply options. And until we go back and take another look at what tax breaks, what subsidies, what externalities really cost the American public, whether it is rising childhood asthma rates, whether it is lower tree growth in the Northeast because of acid rain, until we start including those kind of costs in our energy prices, we will always have a distorted market.

Invited witnesses at these and other hearings could and did present very strong preferences in their lobbying positions which, given the political significance of the organizations, required legislators to weigh the political consequences of their policies against the national benefit. 
Hearings on H.R. 6 were framed within the context of the Nation's growing and painful dependence on foreign oil imports from what were viewed as unfriendly and vulnerable sources. The memory of 911 and the ongoing war in Iraq lent an emotional tone to much of the comments in hearings about achieving energy independence. In analyzing the hearings an unexpected attribute of the debate becomes evident: While there are a multitude of well-organized associations, government agencies and informed environmental and academic institutions called to present testimony, virtually all share a common trait: they each have articulate spokesman with a well prepared agenda to lobby for tax breaks, tax incentives, preferential treatment viz-a-viz some other segment of the economy or direct funding of their solutions to the energy dilemma.

The witness testimony from the myriad of entities lobbying for support is forcefully and articulately presented by their representatives; however in looking at the influence of lobbyists, the information offered was often biased and lacking in scientific basis. While Legislators frequently asked relevant questions in the hearings, they were responding to unbalanced information and thus their discussions were limited. The assumptions embedded in expanding ethanol policy were also biased towards the production of more ethanol, and these assumptions were consistently reflected in flawed comments that are not indicative of thoughtful deliberation or indicated a woeful lack of knowledge concerning the subject under review. The totality of this collective behavior, that appeared particularly political rather than deliberative in nature, lead to a debate that had no coordinating mechanism to counter-balance the vocal lobbies which 
were present to articulate their preferences and took tactical advantage of asymmetries in information.

The hearings on H.R 6 indicate a collective rush to legislate mandates to produce and use greatly expanded quantities of ethanol. Very little is said in any of the hearings about potential problems with mandated ethanol. The overwhelming sense throughout the hearings is simply more - more - more ethanol; that somehow it would solve the long festering oil import dilemma of the Nation. The lack of countervailing testimony is quite remarkable when it is noted that the Congressional Research Service produced dozens of detailed analyses of ethanol policies and yet virtually none of them were referred to in any of the hearings. Of greater irony is that representatives of the CRS were not invited to appear before the hearings, nor were any others strongly opposed to the concept of expanded ethanol use. Thus the information resources from the Executive branch and within the Legislative itself that were available and may have mitigated the unbalanced information that legislators were basing their decisions on regarding ethanol policy were not considered. This anomaly appears to be an example of a political process over-riding the prospect of a deliberative method in ethanol policy formation. Although they may well have articulated data in opposition to the preponderance of hearing witnesses, it would have been far more balanced to include any such testimony. Such witnesses might well have facilitated a more informed deliberative democracy process that might have resulted in informed judgments and lead to a beneficial national outcome. 
It is interesting to note the reemergence of partisan bickering in the final hearings leading up to floor debate of H.R. 6. Edward Markey (D-MA) offered the following remarks before the House Subcommittee on Energy and Air Quality in February, 2005:

Under the Republican Uncertainty Principle you know exactly at all times what their positions are on this bill. You know that they want to drill in the Arctic refuge, they want to weaken environmental laws in the name of energy production, they want to provide generous tax breaks and other favors to large oil, natural gas, coal, nuclear and electric companies. They want energy consumers to pay higher rates and big energy companies to grow even bigger. All of this is certain. But you can never quite determine what the forward momentum of their bill really is, what their process is, or if there is any process at all.

While at this stage many legislators and policy makers were optimistic about the provisions of the bill, this unnecessary retort seems out of place in any type of deliberative activity.

In what would erroneously seem as very fast action by the committees, the bill was reported out to the full house and passed on April $21^{\text {st }}$, just 3 days after introduction. In as much as prior bills had already been debated, although not passed, it was possible to move this bill through the Congress quickly. On June $28^{\text {th }}$ the bill was passed by the Senate and conference reports were accepted and agreed to on July $28^{\text {th }}$ and $29^{\text {th }}$. The bill was then sent to President Bush for his signature on August $8^{\text {th }}, 2005 .^{205}$ Several observations should be made surrounding the enactment of this bill that politically informed final agreement:

205 (IBID) 
All three branches of government; House, Senate and the Presidency were in the same parties control making enactment substantially easier.

The price of oil had increased from about $\$ 50$ per barrel to almost $\$ 60^{206}$ in 2005 with resulting fuel prices escalating from $\$ 1.74$ per gallon to $\$ 2.40$ by early 2006 .

Democratic legislators found Republicans in the majority more willing to compromise than in past Congresses leading to agreements. ${ }^{207}$

Prior Congresses had not been able to resolve the intense desire of some legislators, particularly those from Alaska, ${ }^{208}$ to allow drilling for oil in ANWR (Alaska National Wildlife Reserve) which caused earlier energy bills to fail. This bill did not include a provision allowing drilling in ANWR, ${ }^{209}$ which had been a contributing factor to the failure of earlier energy bills.

MTBE which was phased out by prior legislation had been found to be harmful to groundwater and contamination requiring expensive cleanup was facing oil companies. Several legislators had insisted in previous Congresses that the oil industry be exempted from legal liability for those cleanup costs associated with MTBE. While such a provision was included in the original bill, non-oil producing state legislators, recognizing that the federal government would have to step in to absorb the cleanup costs, burdening their states, if the industry received legal protection refused to consider such an exemption proving fatal to several

\footnotetext{
${ }^{206}$ (Inflation Data, 2011)

${ }^{207}$ (Congressional Quarterly, Inc., 2005)

208 IBID

209 IBID
} 
prior bills. Public Law $109-58$ when passed contained no such provision. ${ }^{210}$ Other provisions of the original bill that were not present in the law as included drilling for oil in the Arctic National Wildlife Refuge, increasing reliance on energy sources that did not emit greenhouse gases (similar to Kyoto Protocol standards) and increasing vehicle efficiency standards (CAFÉ). CAFÉ requirements would be increased two years later in the Energy Independence and Security Act of 2007.

In moving beyond corn-based ethanol, and seeking to extend the ethanol benefits to other parts of the agricultural sector, the act contained at least ten major programs to promote ethanol derived from cellulosic feedstocks - including R\&D. These programs included explicit authorizations for more than $\$ 4.2$ billion over the next decade to support critical R\&D as well as "first-mover" commercial facilities through a combination of grants, loan guarantees and production incentives. These programs demonstrated Congress's clear intention to promote biofuels and continue their support of the farm sector.

There were many provisions debated and incorporated into this act; directives to federal agencies to reduce energy consumption by $20 \%$ in 2015 below 2003 levels, a directive to the Architect of The Capitol to create a plan for saving energy in all Congressional facilities, changed the hours of daylight savings time with reporting requirements on energy usage reduction by the Energy Department, extended $\$ 1.8$ billion to assist low income homeowners with weatherization, allocated $\$ 15.3$ to help low income homeowners pay their energy

\footnotetext{
${ }^{210}$ (Congressional Quarterly, Inc., 2005)
} 
bills, authorized $\$ 425$ million for state energy conservation programs, allocated $\$ 250$ million to states for energy efficient appliance rebates, and dozens of others which deal with environmental, clean air, global warming and a myriad of energy issues. The Congressional Budget Office prepared a cost estimate in June of 2005 which projected a cost over five years $(2006$ - 2010) of $\$ 41$ billion dollars to fund the provisions of the act. ${ }^{211}$ Unforeseen in this act was a section with a provision that would have expensive costs that the CBO never anticipated. While $\$ 41$ billion dollars was expensive particularly in the deficit year of 2006, the enactment of an obscure part of the law would begin a march towards truly huge national ethanol costs in the years to follow. In Title XV - Ethanol and Motor Fuels, section 1501 - Renewable content of gasoline, at page 475 of the 551 page law was a provision amending section 211 of The Clean Air Act (1970). The amended law now stated that ethanol would be mandated to be blended into the national fuel supply as follows:

(i) CALENDAR YEARS 2006 THROUGH 2012.-For the purpose of subparagraph (A), the applicable volume for any of calendar years 2006 through 2012 shall be determined in accordance with the following table: Applicable volume of renewable fuel:

Calendar year: (in billions of gallons):

2006

${ }^{211}$ (Congressional Budget Office, 2005) pp. 2 
Examination of Public Law 110-140 which follows this act will show even significantly greater ethanol policy consequences than found in this statute; however the basic attribute, although there were many, of this legislation was: The establishment of a Renewable Fuels Standard.

The Congress passed, and the President signed, legislation that for the first time mandated that refineries, gasoline importers and fuel blenders must mix specified amounts of ethanol yearly into gasoline as shown in the chart above. After thirty years of repeated legislative failures to encourage, coerce, subsidize or incent the production and use of ethanol to the extent desired by Congress, this act would absolutely force the nation to use ethanol as an alternative fuel.

This mandate to blend into the nation's fuel supply 7.5 billion gallons of renewable fuel by 2102 was worded in such a manner as to allow other sources of biofuel to be counted towards the mandate. Those sources included soy oil, various cooking oils, landfill natural gas and others. The magnitude of the mandate, given the suppliers of alternative biofuels from which ethanol could be produced, insured that corn ethanol would be the overwhelming source of production. ${ }^{212}$ For several years prior to this statute there had been requirements for an oxygenate to be added to gasoline in order to reduce engine "knocking," reduce combustion emissions and improve air quality. Lead had been the primary oxygenate until it was phased out because of health concerns in 1996 with an

${ }^{212}$ (Glozer, 2011) pp. 56 
amendment to the Clean Air Act. Following the lead ban MTBE became the preferred oxygenate $^{213}$ until it too was found to cause health problems and was also banned. ${ }^{214}$ This law removed the "oxygenate" requirement previously included in Clean Air Act provisions which had insured vehicle emissions would not be harmful. The rationale was that is as much as ethanol was now mandated to be in significant portions in all gasoline, other oxygenate requirements would be redundant. This removal of the oxygenate requirement was an additional indirect provision directing that ethanol was used to insure that blended gasoline met all the new more stringent Clean Air Act requirements.

The manner in which the ethanol is blended into the nation's fuel supply is complex, convoluted and difficult to enforce. While the Congress legislated the provisions mandating the blending of ethanol, it directed the Environmental Protection Agency to determine the amounts of ethanol individual refiners, importers and blenders would be required to blend into fuel each year. ${ }^{215}$ One obvious problem the legislation does not address: if the required amount of ethanol to be blended by an individual supplier is not profitable, that supplier may well elect to not produce any fuel.

The Energy Policy Act of 2005 is a foundation and precursor for the Energy and Security Act of 2007. Legislative and Presidential thinking progressed on a continuum after the August $8^{\text {th }}, 2005$ enactment of this law.

\footnotetext{
${ }^{213}$ (U.S. Department of Energy, 2003)

${ }^{214}$ (Chapter 1, pp. 10)

215 (Glozer, 2011) pp. 58
} 
In examining the absence or presence of deliberative democracy attributes in the formation of this law and its place within the ongoing evolution of ethanol policy, it is interesting to note the frustrations expressed by legislators regarding the failures of previous energy enactments. In a 2001 hearing, Senator Jeff Bingaman, Chairman of the Senate Committee on Energy and Natural Resources, commented on the cyclical phenomena in energy policy whereby long lags with minimal activity were punctuated by calls for action in response to crises. The cyclical nature of energy policy appears at odds with the consistent agricultural policy push in relation to ethanol expansion. The differing dynamics of the two major streams feeding into ethanol policy may in part explain the balance between political and deliberative behavior as well as flaws in the assumptions perpetuated in legislating ethanol policy. The legislative histories of this act, and the one examined in the next section, are presented in appendices at the end of this work. The analysis in chapter 6 further addresses how the activities of deliberative democracy resulted in policy outcomes where costs consistently outweighed benefits at the national level. 


\section{Public Law 110-140 - Energy Independence and Security Act of 2007}

\section{H.R. 6}

\section{Deliberative Democracy Measurements and Timeline}

Legislative history data, showing the presence of deliberative democracy attributes, or their absence, in the legislative steps from introduction of the initial bill through the phases leading to the bills enactment into law by the President are presented in appendix X. Assessing the presence of deliberative democracy, or the operation of political activities in policy formation, whether resulting in positive policy outcomes or not, through the various steps of legislation introduction, committee assignments, hearings, floor debate, consideration of amendments and conference reports leading to the passage of this law involved examining available data through the matrix of measurement tools presented on page 47, figure 5. (Also refer to appendix XVI for a summary of the evidence of the attributes of deliberative democracy in this law). Committee hearings are presented as an integral component of the deliberative process. This bill was referred to 12 different committees and subcommittees that conducted 72 hearings. $^{216}$ Testimony offered in the hearings reflected the deep concern of legislators and witnesses regarding ongoing issues with the price of gas at the pump within the wider international context of the Iraq War. Witnesses chosen to present testimony spanned a wide spectrum of positions that while reflecting frustrations with failed energy policies and the lack of progress towards energy security often seemed optimistic in the solutions they advocated and the needs for

216 (See Appendix XXI for Public Law 110-140 Hearing Testimony) 
funding they advanced. Appendix X details the range of issues presented in the 72 hearings related to H.R.6 (later Public Law 110-140) and the range of policy issues addressed at this level of deliberation. These include:

- Overview of current and projected energy consumption trends in China and India

- Role of China and India in global energy markets, with review of U.S. energy policy response, perspectives on U.S. reliance on foreign oil for energy, focusing on economic, political, and security implications

- Concerns regarding future oil supplies in light of current prices, resources, and political climate in the Middle East

- Recommendations for policies to reduce dependence on imported oil, including development of alternative transportation fuels, concerns about economic impact of U.S. oil consumption and dependence on foreign oil, with recommendations

- Adverse economic effects of potential future oil supply disruptions

- Support for oil prices to reflect long-term environmental impact of oil consumption, with policy suggestions

- Testimony to review implementation of Energy Policy Act of 2005 (EPAct) provisions relating to electricity reliability

- Construction of new nuclear power plants, and the next generation nuclear plant

- Renewable fuel standard initiatives

- Advantages of ethanol and other biofuels in meeting future U.S. energy needs 
- Aspects of additional research, technological advancements, and financing needed to realize biofuels potential

- Views on EPAct renewable fuel standard implementation, presentations to examine strategies to reduce U.S. dependence on foreign oil, focusing on Federal policy options to expedite transition to alternative, sustainable energy sources including ethanol and biofuels, in light of concerns about energy security, overview of BLM and Fish and Wildlife Service efforts to improve oil and gas permitting process

- Assessment of progress in oil and natural gas production enhancement implementation, focusing on production on public lands in Wyoming and other western States

- Elaboration on issues related to oil and natural gas development on public lands, the importance of renewable energy resources development and use

- Perspectives on geothermal and other renewable energy development issues affecting western States

- Views on and recommendations regarding Federal role in assessment and promotion of renewable energy development and production; aspects of renewable energy research and technology development

While the preceding examples are not exhaustive, and reveal only the tip of the iceberg, these topics demonstrate the range and extent of the policy debate concerning energy independence and security at this juncture in history. As presented in figure 5, page 47 within the deliberative democracy framework committee hearings should provide: [a venue] to elicit the information and arguments necessary to make informed judgments. 


\section{The Legislative Effort to Double Down on Failing Ethanol Policy}

From the advent of ethanol as an option within energy policy and ensuing ethanol legislative activity in 1975, Congress sought to increase national security through policy enactments attempting to reduce the dependence on foreign oil, increase energy security and protect the economy. The desired outcome of this policy stream was the creation of an ethanol fuel industry that would be economically competitive with fossil oil gasoline - although propped up by government transfers - that would reduce oil consumption to benefit the Nation's economy. By 2007 concerns for the environment were increasingly relevant to this policy formulation. If the Madisonian method of deliberative democracy in the legislative process was followed over the decades following 1975, it would have been expected that this law would have added to a body of successful policy implementations that had, at least in major substance, met the intentions of the crafters of such policies. In actuality, this law was yet another response to an accumulation of failed energy legislation.

Although this law began as a bill introduced by Representative Nick Rahall II, (DWV), its roots went back several years. The predecessor statute to this, the Energy Policy Act of 2005, was signed into law by President Bush on August 8th, 2005 and was met with almost immediate pressure for modification. By January 2006 the Nation was facing severe challenges in terms of both consumer energy costs and national security. The data show a significant failure of previous energy 
policy when examined retrospectively from the beginning of 2006 after the enactment of Public Law 109-58.

In 1973 America imported $34.8 \%$ of its oil consumption

In 2005 America imported $60.3 \%$ of its oil consumption ${ }^{217}$

In 1973 America consumed 17 million barrels per day of oil

In 2005 America consumed 20 million barrels per day of oil ${ }^{218}$

In 1973 Oil was $\$ 4.75$ per barrel

In 2005 Oil was $\$ 50.00$ per barrel $^{219}$

In 1973 America produced near zero gallons of ethanol fuel.

In 2005 America produced 3,904 million gallons of ethanol fuel ${ }^{220}$

In 1973 annual federal costs for ethanol were near zero

From 1995 through 2005 federal costs for ethanol averaged

8 billion dollars annually ${ }^{221}$

The U.S. Department of Energy summed up the nation's energy challenge succinctly:

Before 1989 the U.S. produced enough petroleum to meet the needs of the transportation sector, but was still short of meeting the petroleum needs of all the sectors, including industrial, residential and commercial, and electric utilities. In 1973 the gap between what the U.S. produced and what was consumed was 5.6 million barrels per day. By 2035, the gap is expected to be at least 10.8 million barrels per day if all sources of petroleum are included or 13.9 million barrels per day if only conventional petroleum sources are use. ${ }^{222}$

${ }^{217}$ (U.S. Department of Energy, 2011)

218 (U.S. Department of Energy, 2011)

219 (Inflation Data, 2011)

220 (Renewable Fuels Association, 2011)

221 (Glozer, 2011) pp. 126

222 (Research and Innovative Technology Administration, 2010) 
It is instructive to look at the Nation's political and social environment during 2006 to understand the changing circumstances that lead, in part, to the enactment of this bill. Since 2003 the Nation had been enmeshed in the increasingly unpopular war in Iraq. A very visible organization was launched by the United States Institute of Peace on March $15^{\text {th }} 2006$, entitled the Iraq Study Group. ${ }^{223}$ The Institute is a Congressionally mandated and funded entity that promotes the study of peace throughout the world. The Iraq Study Group was bipartisan and had several very prominent members that would craft a report and submit it to President Bush on December $6^{\text {th }}, 2006$. This was a difficult year for the American economy; the economy slowed, the labor market weakened, the housing boom ended, consumers carried greater debt than at any time in history; the Nation's trade deficit set new records and $80 \%$ of America's large and growing debt was owed to foreign nations while the federal budget was expected to incur a $\$ 280$ billion shortfall. $^{224}$ Oil reached an all-time record price of $\$ 76.80$ per barrel in July causing additional and very visible pain at the gas pump for consumers. ${ }^{225}$

While H.R. 6 had incubated for some time, the circumstances in 2006 would combine in an unparalleled manner to result in the enactment of the Energy Independence and Security Act of 2007. The legislative history of H.R. 6 introduced by Representative Rahall (D-WV) shows an unprecedented number of co-sponsors. ${ }^{226}$ Frequently Members introduce a bill with no, or only a few, cosponsors, yet in this case, Rahall had accumulated 198 co-sponsors when this bill

\footnotetext{
223 (Iraq Study Group, 2006)

${ }^{224}$ (Weller, 2006)

225 (Crude Oil Price History, 2006)

${ }^{226}$ (Library of Congress, 2007)
} 
was introduced on January $12^{\text {th }} \cdot{ }^{227}$ This unusual occurrence was reflective of the national mood of fear and concern regarding energy availability and economic vulnerability, energy prices in a hostile world and the sense the nation needed to reduce its dependence on foreign oil. There were intense debates and veto threats during 2007 as this legislation wound its way towards the President's signature, but the foundation for the process had been very publically stated in President Bush's State of the Union Address on January $31^{\text {st }}, 2006$ a year earlier:

Keeping America competitive requires affordable energy. And here we have a serious problem: America is addicted to oil, which is often imported from unstable parts of the world. The best way to break this addiction is through technology. Since 2001, we have spent nearly $\$ 10$ billion to develop cleaner, cheaper, and more reliable alternative energy sources -- and we are on the threshold of incredible advances -breakthroughs on this and other new technologies will help us reach another great goal: to replace more than 75 percent of our oil imports from the Middle East by 2025. By applying the talent and technology of America, this country can dramatically improve our environment, move beyond a petroleum-based economy, and make our dependence on Middle Eastern oil a thing of the past. ${ }^{228}$

President Bush's visible proclamation addressing the nation's concerns about energy combined with an already receptive and sensitized Congress to culminate in the enactment of a law within two years that would result in expenses and disruptions for the American taxpayer and consumer not remotely anticipated in the bill originally presented.

\footnotetext{
${ }^{227}$ (See Appendix XXII for a list of co-sponsors)

${ }^{228}$ (White House Archives, 2006)
} 


\section{Exploration of Legislative Activity}

While the circumstances driving ethanol policy creation and its continuation in this law are discussed in this section, it is also necessary to examine the process of committee assignments, hearings held and perspective of representative testimony given in attempting to ascertain the operation and character of deliberative democracy present or absent in the perpetuation of ethanol policy. This exploration hinges on a number of pivotal questions:

What committees considered the proposed bill?

Why was the bill referred to those particular committees?

Amongst the witnesses, which testimony appeared to prevail in the eventual outcome of the enacted legislation?

What groups appeared to be represented by testimony and what was their perspective?

While at its inception H.R. 6 was referred to committees (appendix X) such as Ways and Means in the House and the Senate Energy and Natural Resources Committee, the complexity of the legislative process influenced the eventual provisions of the bill. From its genesis to enactment the bill it was referred to 5 committees and 7 sub-committees that held a combined total of 72 hearings. The hearings were conducted between July of 2005 and October 2007 with 34 hearings before House committees and 38 before Senate committees. Although under the umbrella of considering H.R. 6 and attendant bills, many of the 72 hearings focused on national security and other issues not relevant to the ethanol 
policy formation studied here. Out of the 72 hearings, 11 examined ethanol and issues related to alternative motor fuels.

Numerous significant interest groups testified before the 11 hearings on H.R. 6 to lobby their positions/preferences regarding ethanol expansion. The primary committees which were given jurisdiction over the debate were the Senate Energy and natural Resources Committee, the House Subcommittee on Energy and Air Quality, House Committee on Energy and Commerce, House Committee on Ways and Means and the Senate Foreign Relations Committee. The variation in the number of witnesses per hearing and the identities/affiliations of those witnesses is revealing. It suggests that the committee members who assembled witnesses for their committees had identifiable preferences over the tone and outcomes of those hearings. Thus the selection of witnesses and the positions they represent are significant to the examination of the presence or absence of deliberative democracy. In addition to testimony from agents of the Executive branch, including the Department of Energy and the EPA, testimony delivered in hearings directly addressing ethanol can be broken down into the following categories:

- Associations lobbying for increased ethanol production and incentives National Biodiesel Board

Khosla Ventures

National Commission on Energy Policy

Brazilian Association of Sugar Cane and Ethanol Producers

National Association of Convenience Stores

Renewable Fuels Association 
Energy Future Coalition

American Corn Growers Association

Governors' Ethanol Coalition

National Corn Growers Association

New Mexico Sorghum Producers

American Trucking Associations

American Forest \& Paper Association

Coalition of E85 Retailers

National Petrochemical and Refiners Association

American Petroleum Institute

National Petrochemical and Refiners Association

- Academic institutions lobbying for research funding

South Carolina Institute for Energy Studies, Clemson University

Auburn University

Massachusetts Institute of Technology

- Corporate entities:

Monsanto Company

Abengoa Bioenergy Corporation

Amyris Biotechnologies

du Pont de Nemours, E. I., and Company

Iogen Corporation

Chevron Oil Corporation

VeraSun Energy Corporation

General Motors Corporation 


\section{Clean Energy Fuels Corporation}

- Environmental groups:

\section{Natural Resources Defense Council}

World Resources Institute

These hearings focused primarily on expanding renewable fuels standards (RFS) and requiring increased fuel standards for all new cars and light trucks (CAFÉ). The driving force behind the desire to implement these provisions appears to be the belief accepted (on both sides of the political aisle) that global warming and dependence on foreign oil imports threatened American security. The tenor of the collective hearings, while showing debate between the political parties as to how the increased ethanol renewable fuels standards could be met, clearly showed agreement on the need to require increased production and use of ethanol. Comments by legislators in these hearings reveal their perspectives and indicate the presence of deliberative democracy attributes, in reasoning on the merits of public policy.

In focusing on ethanol policy development, it is instructive to examine representative statements of committee chairs and witness testimony in hearings to discern possible predispositions that such comments may indicate. H.R. 6 was introduced during a major shift in the political control of Congress. A new Congress was in session under the leadership of Democrats who had been in the minority in previous sessions. Their desire to redirect energy policy was evident in the comments of several committee chairs and congressional leaders of their party outlined below. Although not directly dealing with ethanol policy 
provisions in H.R. 6, the comments of Charles Rangel, Chairman of the Ways and Means Committee, just a few days after the introduction of H.R. 6 reveal much about the new majority's prevailing attitude concerning energy policy. On February 28, 2007 Chairman Rangel presided over a hearing entitled "Energy and Tax Policy" where he made the following statement:

This debate has come a long way since our former Member of this Committee, Tom Downing, and his buddy Al Gore, many, many years ago, attempted to bring this issue before the Committee and the Congress. The curiosity and the debate is over. Global warming is a fact, and human energy consumption is driving some of the detrimental effects of climate change. The Federal Government can and must play a role in changing this behavior. Carbon-based fuel consumption is one of the contributing factors to global warming problems, and the Federal Government can and must use the Tax Code to encourage the development of alternative sources of energy, reducing Americans' reliance on oil and other traditional carbon fuels as a priority on her agenda.

Interestingly, the comments of the ranking minority Member, James McCrery demonstrate a similar stance on climate control:

As we begin to explore the issue of climate change, I do note the lack of disagreement - another way of saying the agreement-among the panelists on the fact that the Earth is experiencing a period of warming. Any inquiry into the issue of global climate change must examine the impact of changes in the Earth's temperature and when those changes are going to be felt. Second, can the United States, acting on its own, reverse or even slow global warming?

It is in the testimony of the witnesses following these opening comments that the sense of the direction of the arguments being made by the speakers can be discerned. The witnesses chosen to testify are representative of a common frame of thought evidenced by their comments. Addressing this hearing, Ronald G. Prinn, Sc.D., Professor, Department of Earth, Atmospheric, and Planetary Sciences, MIT, Cambridge, Massachusetts stated 
The concentrations of carbon dioxide and many other long-lived greenhouse gases have increased substantially over the past two centuries, due in large part to human activity. Recently, the Intergovernmental Panel on Climate Change, in its fourth assessment, concluded that warming of the climate system is unequivocal. As one example, the last 12 years include the two warmest and 11 of the 12 warmest years since the year 1850. There is no doubt in my mind that climate is already changing in very significant ways. Regarding the needed emission reductions, it's important to know that it matters very little where the long-lived greenhouse gases are emitted, and that substantial reductions of the type in the policy wheel that I show there, require ultimate participation by all nations, not just the currently rich nations.

Stephen Schneider, Ph.D., Professor, Department of Biological Sciences, Stanford

University, and Stanford, California went further in advocating the need for a change in policy:

In short, a continuation of "business as usual" raises a serious concern from the risk-management point of view, given that the likelihood of warming beyond a few degrees before the end of this century (and its associated impacts) is a better than even bet. Few security agencies, businesses or health establishments would accept such high odds of potentially dangerous outcomes without implementing hedging strategies to protect themselves, societies and nature from the risks-of climate change in our case. This is just a planetary scale extension of the riskaverse principles that lead to investments in insurance, deterrence, precautionary health services and business strategies to minimize downside risks of uncertainty.

Building on this, the Honorable Eileen Claussen, President, Pew Center on

Global Climate Change, Arlington, Virginia reinforced concerns about climate change and reiterated the need for changes in transportation and energy policy as a consequence:

As you have heard from Drs. Schneider and Prinn, it is now well established that climate change is occurring and that humans are primarily responsible. The recently released summary of the IPCC's 4th assessment report calls the evidence of climate warming "unequivocal", and expresses over $90 \%$ confidence that most observed warming is due to human influence. Left unabated, climate change will have tremendous consequences on our country and the world. The greenhouse gas (GHG) 
emissions that contribute to climate change come from a wide variety of sources and sectors throughout the economy. These include transportation, electric power generation, use of energy in our homes and offices, manufacturing, and many others. Just as there is no single sector or emissions source that is responsible for greenhouse gas emissions, there is also no single technology or policy that will solve global warming. We need a portfolio of policies and technologies to meet this challenge.

W. David Montgomery, Ph.D., Vice President, Environmental Practice, CRA

International further elaborated:

There is clear evidence that the Earth is warming. The extent to which human activity has had a role in that warming is open to debate, but there is no question that we can play a role in slowing or stopping the trend. But we must do so with a clear understanding of the benefits as well as the costs of various approaches, and what difference specific actions can make in the consequences of climate change.

My testimony contains five key points.

- Mandatory U.S. greenhouse gas controls and any version of the Kyoto Protocol will impose a significant cost on the U.S. economy and will lead to a shift of investment away from the U.S. and toward countries like China and India that are not willing to undertake similar efforts.

- By creating these competitive advantages, unilateral policies adopted by industrial countries will actually strengthen the incentives for countries like China and India to resist controls.

- Since China, India and other developing countries will be responsible for the majority of global emissions over the next century; any prospect for halting global warming depends crucially on inducing these countries to cut their emissions.

- Even if all industrial countries met the emission targets set in the Kyoto Protocol, the emission reductions bought at these costs would not be sufficient to prevent most of the temperature increases now projected for the next century.

- Effective $R \& D$ is a necessity, in order to develop new technologies that will make it possible to reduce greenhouse gas emissions sufficiently to stop climate change at costs that do not exceed public willingness to pay, here and abroad.

- Minimizing the costs of achieving climate goals requires making sure that the timing of emission reductions matches with the availability of these new technologies. 
While this hearing was primarily concerned with tax matters related to energy policy, these examples of testimony show how these considerations were framed in conjunction with climate and environmental concerns. The witnesses chosen to testify and submit comments not only show a studied and focused belief in manmade global warming, but also the need for US government policy solutions to address this perceived challenge to the Nation's very way of life and economic security through transfers and mandates. The witnesses chosen and Chairman Rangel's comments become significant when examined in conjunction with ethanol policy through the deliberative democracy lens. The groups chosen to present their views for this foundational energy hearing were predominantly those that had environmental concerns and to a lesser degree those that wished some governmental support for their industry. This hearing is instructive because in addition to highlighting the importance now placed on environmental concerns, it outlines the pattern of other hearings more directly concerned with ethanol where the majority of witnesses advocate for greater funding for their organizations while framing their testimony in terms of environmental, security and/or economic issues. Once again the selection of witnesses was skewed which resulted in undermining informed judgment, since the testimony offered an incomplete perspective of the options available and their consequences. Control over the selection of witnesses meant that in Congress, Members deferred to individuals with access to the process, rather than informed judgment and the persuasion that occurred was based on flawed information. 
As a result, legislators presented ethanol as an environmental, economic and foreign policy solution. Nick Lampson (D-TX) combines environmental and foreign policy concerns in expressing his support for ethanol:

Energy is on everyone's mind these days. The price of fuels has been rising and awareness of the extent to which we are dependent upon foreign sources of oil has grown. At the same time, in an effort to reduce emissions of air pollution we are also transitioning to cleaner burning fuels. The good news is that we have developed and are continuing to develop alternative fuels and cleaner burning versions of our current petroleum-based fuels. But it is not enough simply to develop these new alternatives. We also must ensure the availability of infrastructure and equipment for transporting, distributing, and utilizing these new fuels at a reasonable cost.

Norm Coleman (R-NM) presents expanded ethanol production as an available

substitute in displacing the majority of oil consumption in automobiles:

[N]ot just corn ethanol but cellulosic ethanol and the possibility even of going to 60 billion barrels of ethanol sometime in the not too distant future... With those developments, oil in the years ahead will remain an important element of our energy future, but it no longer will be the dominant player

In committee deliberation following testimony by Alan Greenspan before the Senate Committee on Foreign Relations in a hearing entitled "Oil Dependence and Economic Risk" Joe Biden (D-DE) voiced strong support for expanding consumption of both corn-based and cellulosic ethanol:

The United States has just one third of the world's oil reserves, and less than five percent of its population, but we consume fully one third of the global oil output (factually incorrect). Ethanol from corn could be a first step away from our oil addiction, by providing a liquid fuel that is compatible with existing internal combustion engines that power our cars, trucks and buses. We will hear today about the costs and benefits of taking such a step, and the steps that must follow toward sugar or cellulosic ethanol. Ethanol will be just part of a broader energy policy that will reduce our dependence on oil, and will reduce the leverage that the oil producing nations have over our foreign policy and our national security. If it was not clear before, it is now. Domestic energy policy is at the center 
of our foreign policy. - I agree with you that we have to move faster on clean-coal technology and nuclear energy, but it seems to me we have to make sure first of all that we're driving good cars by increasing fuel efficiency by requiring that every car sold in the United States is a flexfuel vehicle that can run on alternative fuels like E85 -- 85 percent ethanol. Second, it seems to me we need to make sure that we're using good cars -- good fuels, I should say -- by requiring all major oil companies to add alternative fuel pumps to at least half the gas stations they own. And finally, it seems to me we need to put in place the market and the infrastructure for alternative fuels so that as new, more advanced fuel technologies like cellulosics that you referred to ethanol -- become more widely available with the -- with the cars -- available to cars and the pumps that we hopefully will already have begun to have put in place.

In that same hearing, Dick Lugar (R-IN), Chair of the Senate Committee on

Foreign Relations, voiced support for increased funding in support of the ethanol industry:

Efforts to reduce oil consumption must focus on developing sustainable fuels and increasing efficiency. I am pleased that the first commercial scale cellulosic ethanol plant in the United States is ready for construction and that Americans are beginning to demand more fuel efficient vehicles. We must continue investing in advanced energy research, but threats to our national security require us to efficiently deploy the oil-saving technology that is available now.

These sentiments are echoed from the other side of the aisle by Ken Salazar (D-

$\mathrm{CO})$ who presents ethanol as the panacea to America's deepening energy crisis:

I worry about the horrible, realistic facts that we face with our depending crisis today. America consumes one-quarter of the world's oil supplies but has just $3 \%$ of world oil reserves. Roughly $22 \%$ of the world's oil is in the hands of countries under U.S. or U.N. sanctions. By some accounts, only $9 \%$ of the world's oil is in the hands of "free" countries. - You know, when I look at the Department of Energy, the 1 Billion Ton Study that was done in 2005 -- there the Department of Energy concluded that there's enough biomass out there that we might be able to make it to 3.5 million barrels of oil. You know, when I talked to some of the experts at the National Renewable Energy Lab, they tell me that we are at a point where, within three years we ought to be able to move forward with the commercialization of cellulosic ethanol. 
Although legislators expressed broad support for ethanol production, some raised logistical issues involved in moving from greater ethanol production to greater ethanol consumption. Robert Menendez (D-NJ) places his state's interest in examining the benefits of increased ethanol production resulting from the provisions of H.R. 6:

So several sections of the bill, such as the additional bioresearch centers and local transportation grants, could, I believe, be very beneficial for those parts of the country that don't have enormous fields of corn or switchgrass. - does the Department of Energy have any existing initiatives that look at the specific problems faced by these areas that are outside the corn and grass belt? One of the things that's obviously a big problem in our part of the country is getting the ethanol from plants to consumers. We have a section of the bill that would look at dedicated ethanol pipelines, and that's certainly one potential way to address that issue. But I've been told by the pipeline industry that one of the biggest problems with ethanol is stress corrosion cracking, both in pipelines and in tanks, and that they're currently researching the issue. I'm wondering whether the DOE is undertaking any research into stress corrosion cracking due to ethanol?

Jane Harmon (D-CA) reiterates the distinction between ethanol production and consumption in relation to states outside of the Midwest:

The auto makers can give us the engines, but the fuel producers must meet them halfway. Bringing alternative fuels to market depends on fuel production and fuel infrastructure. Without more, for example, ethanol pumping stations -- presently, there are only about 1,100, mostly located in a handful of Midwestern states -- we cannot expect, as has been said, to see more flex fuel vehicles on the road. Manufacturers won't make them and the public won't buy them.

These comments show that among the clamor for increased ethanol production, there were continuing concerns over the logistics of commercializing and distributing the resulting increase. The distinct interests of different states in relation to ethanol production and consumption reveal that although the vast majority of legislators participating in the hearings supported mandates and incentives promoting increases in ethanol, this was not universally the case. John 
Sununu (R-NH) articulates not only a perspective in which ethanol is less relevant

- due to different projections regarding oil versus ethanol - but also relative

ambivalence to ethanol as a policy option or lifestyle choice for his constituents.

So I think that's important to emphasize here. While I understand that the value of the ethanol program to farmers and to those that participate in it, if you use every bushel of corn, you're still only talking about 10 percent of what we consume in petroleum. It seems to me to the extent that we are concerned about this problem -- you know, I don't see a great national security threat by a family of four deciding to buy a minivan that gets 22 miles to the gallon instead 28 miles to the gallon. I think as you point out, that's the choice they make, and Americans enjoy driving cars. Most of the oil -- a vast majority -- is used for transportation, and most of that is a consumer decision -- a lifestyle decision.

Coming from an agricultural state, Darlene Hooley (D-OR) communicates a more pragmatic concern regarding the viability of corn-based ethanol and its possible down-side. In addition to unintended consequences that ethanol may have for food prices, Hooley also questions the environmental attractiveness of ethanol.

Right now, corn is a hot commodity. We have a lot of people making a lot of money off of coal. They are turning it into ethanol. But at what point are we driving up the food prices, and how much land do you have to put in to really provide enough corn to produce enough fuel so it's a viable source. I just think it's important whether we're looking at coal to liquids, we're looking at ethanol, we're looking at biomass, we're looking at any of the alternative fuels that we also understand not only the upside of it, but the downside of it, and that we understand what the consequences are. And I think it's really important as we go through all of these issues, because not only are we looking at energy independence for security purposes, but we're also looking at global warming and how to deal with that. I would hope today that as you testify, that you talk about not only the great things that can happen with this, but also what are some of the downsides that can happen with this.

These comments reveal the general trend in the evidence presented in the hearings. While some call into question the viability and desirability of increasing ethanol production and consumption, these voices were in the minority. 
Similarly, dissenting voices giving testimony were often downplayed by committee members in their questions and discussions. An example of such dissenting testimony was offered by Jason Grumet, the Executive Director of the National Commission on Energy Policy in a hearing entitled "Energy Security and Oil Dependence" before the Senate Committee on Foreign Relations:

The fundamental liability of corn-based ethanol is that there is simply not enough corn to begin to keep pace with expected growth in transportation energy demand, let alone to reduce current U.S. gasoline consumption in absolute terms. Put simply, it takes roughly 4 percent of our nation's corn supply to displace 1 percent of our gasoline supply. Even organizations devoted to ethanol advocacy agree that it will be difficult to produce more than 10-12 billion gallons of ethanol a year without imposing unacceptable demands on corn supply and significant upward pressure on livestock feed prices. The added advantages of cellulosic ethanol lie in its significantly lower energy inputs and greenhouse gas emissions, its much larger base of potential feedstocks, and its greater potential to become cost-competitive with gasoline at very large production volumes. For cellulosic ethanol to succeed on a commercial scale, however, important concerns about land requirements must be overcome and production costs must be reduced. The central challenge is producing enough feedstocks without disrupting current production of food and forest products.

When taken in totality, the hearings supported ethanol policy expansion and advocated additional funding towards that end. Excerpts from more typical testimony are included below:

The report, now commonly referred to as "The Billion Ton Study," for the first time confirmed that the U.S. could yield more than a billion tons of biomass annually for energy needs. And, importantly, we could do this without negatively affecting the nation's ongoing needs for food or fiber. (EPA)

Our goal is to reduce the cost of producing cellulosic ethanol from $\$ 2.25$ a gallon in 2005, to $\$ 1.07$ in 2012. (DOE)

There is little doubt that ethanol will be, and should be, the first biofuel that we can use to reduce our dependence on petroleum. (DOE) 
Today's ethanol industry consists of 101 biorefineries located in 19 different states with the capacity to process more than 1.7 billion bushels of grain into nearly 4.7 billion gallons of high octane, clean burning motor fuel and 9 million metric tons of livestock and poultry feed. It is a dynamic and growing industry that is revitalizing rural America, reducing emissions in our nation's cities, and lowering our dependence on imported petroleum. (Abengoa Bioenergy)

If it was not for the rapid growth of our domestic ethanol industry, Americans would be seeing prices approaching $\$ 4$ a gallon or more. (Khosla Ventures)

We must pursue greater vehicle fuel economy and aggressive efforts to displace petroleum with biofuels. (National Commission on Energy Policy)

Until and unless private markets reflect the full economic, security, and environmental costs of oil dependence and until and unless consumers possess adequate information to make efficient choices, policies that rely solely on private market decisions will continue to fail. (National Commission on Energy Policy)

I can tell you that ethanol and biofuels in general don't have to be an alternative fuel. In fact, they can be our mainstream fuel. More importantly, with few policy changes, we can achieve this transition not by 2040 or 2050, but be irreversibly down the new path of energy independence in less than seven years, in my view (Khosla Ventures)

In inferring the preferences of policy makers through the selection of witnesses, one individual stands out. His testimony before six of the eleven hearings addressing ethanol strongly suggests that the staff and/or chairmen of several committees in both the House and Senate were in close contact with one forceful ambassador of the ethanol lobby. Robert Dinneen, President and CEO of the Renewable Fuels Association presented testimony at the following hearings:

Hearing on the Advanced Fuels Infrastructure Research and Development Act. House Subcommittee on Energy and Environment, Committee on Science and Technology

Hearing on Accelerated Biofuels Diversity. Senate Committee on Energy and Natural Resources 
Hearing on Biofuels for Energy Security and Transportation Act of 2007. Senate Committee on Energy and Natural Resources

Hearing on Alternative Fuels: Current Status, Proposals for New Standards, and Related Infrastructure Issues. House Subcommittee on Energy and Air Quality, Committee on Energy and Commerce

Hearing on Discussion Draft Concerning Alternative Fuels, Infrastructure, and Vehicles. House Subcommittee on Energy and Air Quality, Committee on Energy and Commerce

Hearing on a Path Toward the Broader Use of Biofuels: Enhancing the Federal Commitment to Research and Development to Meet the Growing Need. House Subcommittee on Energy and Environment, Committee on Science and Technology

The Renewable Fuels Association is the national trade association for the United States ethanol industry whose membership includes public and private farmerowned cooperatives growing crops for biomass conversion and a number of regional corn grower associations. The unparalleled access of this association to hearings before both Senate and House committees ranging from Energy and Natural Resources to Science and Technology demonstrates the power of the ethanol lobby.

The hearings and debates within the committees considering ethanol aspects of H.R. 6 shared several significant characteristics. Two themes emerged with the majority of the witnesses supporting the expansion of ethanol as a motor fuel and/or expressing environmental concerns. Often these were not mutually exclusive. Significantly, little testimony suggested that there might be any alternatives to increased ethanol mandates, that there might be other energy resources available to meet the concerns being debated, nor was there any testimony addressing the cost to the Nation of the mandates. This may be a function of how the hearings were broken down into discrete topic areas. Other 
hearings were devoted to hydrogen fuel cells and alternative automobile technology, but within these eleven hearings the focus was on ethanol and other biofuels. The conclusions of these hearings supported the allocation of additional resources to further encourage research into and production of ethanol - be it corn-based or cellulosic. Legislators from both chambers and both sides of the aisle were in substantial agreement supporting the mandated expansion of ethanol production and use.

Although there was debate over several months between Senate and the House regarding the provisions that would survive to be implemented, at the end of the process, as presented in a CSR report, the deliberative process produced the following key provisions enacted into law:

Corporate Average Fuel Economy (CAFE). The law sets a target of 35 miles per gallon for the combined fleet of cars and light trucks by model year 2020. Renewable Fuels Standard (RFS). The law sets a modified standard that starts at 9.0 billion gallons in 2008 and rises to 36 billion gallons by 2022.

Energy Efficiency Equipment Standards. The adopted bill includes a variety of new standards for lighting and for residential and commercial appliance equipment. The equipment includes residential refrigerators, freezers, refrigerator-freezers, metal halide lamps, and commercial walk-in coolers and freezers.

Repeal of Oil and Gas Tax Incentives. The enacted law includes repeal of two tax subsidies in order to offset the estimated cost to implement the CAFE provision.

The two most controversial provisions of H.R. 6 that were not included in the enacted law were the proposed Renewable Energy Portfolio Standard (RPS) and most of the proposed tax provisions, which included repeal of tax subsidies for oil and gas and new incentives for energy efficiency and renewable energy.

The arguments made in the crafting of this legislation revolved primarily around the degree to which the ethanol mandates would be expanded and how they would 
be paid for with little consideration for how the mandates would be met. While the hearings showed some political agreement on the basic goals of the proposed legislation, at the floor level debate, some serious wrestling occurred over the economic aspects of the bill.

The manner in which H.R. 6 was introduced on January $12^{\text {th }}, 2007$ illuminates revealing aspects of deliberative democracy and how its presence or absence contributed to ethanol policy defects. The incoming $110^{\text {th }}$ Congress under the Speakership of Nancy Pelosi began on January $9^{\text {th }}$, 2007 implementing a Democratic campaign promise of passing a 6 bill agenda within the first 100 hours of opening the first session of their Congress. ${ }^{229}$ The bill studied herein, H.R. 6 was passed within those first 100 hours, but only because the majority used a parliamentary rule precluding the introduction of amendments and/or meaningful committee debate regarding the provisions of the bill. The House Rules Committee issued House Resolution 66 on January 16 which was passed by the full house on January $18 .^{230}$ The resolution as passed was a legislative provision known as a "closed rule". ${ }^{231}$ On the same day, January $18^{\text {th }}$, the House took up the bill and conducted floor debate for 3 hours. No committee debates were allowed, no amendments were permitted and the bill was brought directly to the floor for a limited 3 hours of debate. This truncated process appears to be the antithesis of deliberative democracy in practice. Floor debate in the House was not even tactically significant as it consisted mainly of railings against the use of

\footnotetext{
${ }^{229}$ (Hunt, 2007)

230 (GovTrack.US, 2007)

${ }^{231}$ (For information on the closed rule see Appendix XII)
} 
the Close Rule, which had incensed the opposition party. As the Republican minority had no input into the proposed bill and was unable to offer amendments under the closed rule, the preponderance of comment on the floor was angry, vitriolic, juvenile, partisan and clearly not substantive, considered nor objective. Excerpts of the 'debate' are found in appendix XI (such as):

...the other side has now become so intoxicated with the power and authority that they have being in the majority, that they do not continue to misuse that power and authority and continue to ignore open debate and honest ideas and an exchange of honest ideas that the committee process typically allows and that brings better legislation to this floor and helps us address these things. Mike Conway (R-TX)

Despite the rancor present because of the manner in which H.R. 6 had been passed, only a few days later on January $29^{\text {th }}$ President Bush presented his State of the Union Address and strongly encouraged legislation similar to H.R. 6 to enact his vision of energy independence;

Let us build on the work we've done and reduce gasoline usage in the United States by 20 percent in the next 10 years. When we do that we will have cut our total imports by the equivalent of three-quarters of all the oil we now import from the Middle East.... To reach this goal, we must increase the supply of alternative fuels, by setting a mandatory fuels standard to require 35 billion gallons of renewable and alternative fuels in 2017 -- and that is nearly five times the current target. At the same time, we need to reform and modernize fuel economy standards for cars the way we did for light trucks -- and conserve up to 8.5 billion more gallons of gasoline by $2017 .^{232}$

The President suggested that by 2017 the nation could and should produce 35 billion gallons of renewable fuels representing 15 percent of our annual use, at costs competitive to petroleum based gasoline, while also reducing overall

${ }^{232}$ (White House Archives, 2007) 
consumption by 20 percent in 10 years. ${ }^{233}$ This Presidential rhetoric was instrumental in the Congress increasing the Renewable Fuels Mandate dramatically, but as the analysis and conclusions chapter shows, the intended outcomes of this act have not been met and are very expensive failures. As Glozer has shown, the subsidies supporting ethanol mandates by 2010 have already added direct and indirect costs of approximately 3.00 dollars per gallon to what would otherwise be the competitive market price of gasoline. ${ }^{234}$

Congressional Quarterly reports over a year of partisan bickering and White House veto threats before the President signed the bill. Between June and December of 2007 over 320 amendments to H.R. 6 were proposed in the Senate attempting to micromanage the process to the point of paralysis. Legislators on both sides of the aisle hoped to leverage the impasse to their advantage in seeking to raise taxes, reduce incentives, penalize oil companies, reduce subsidies, and mandate electric utilities to use renewable fuels, among a whole host of arcane provisions. The basic partisan divide between Democrats and Republicans, for all the extended acrimony, was over who would pay, and how much, for the mandated provisions of the bill. Republicans reluctantly conceded provisions extending Federal Unemployment surtaxes and extended oil and gas exploration amortization deductions to offset the increased costs of the bill's provisions. Democrats relinquished their desire to provide further tax credits and extended subsidies to alternative energy producers At the end of over 10 full days of Senate debate on these amendments, all but 45 were defeated and, although substantially

\footnotetext{
233 (IBID)

${ }^{234}$ (Glozer, Corn Ethanol Who - Pays? Who Benefits ?, 2011)
} 
altered, the final bill was agreed to with the House and sent to the President for signature with the provisions show above.

The partisan passage in the House of H.R. 6 in January began several months of political bickering as the House and Senate exchanged differing versions of the energy bill, yet by the bills final passage in December it would clear the Senate by an $86-8$ vote and the House by a $314-100$ vote, both very substantial majorities. ${ }^{235}$ The major provisions of the enacted bill were:

Increased fuel economy standards for all new cars and light weight trucks including SUV's to 35mpg by 2020 which was expected to result in reducing federal gas tax revenue by $\$ 2.1$ billion dollars over 10 years.

New energy efficiency standards for light bulbs, home appliances and buildings including residential, commercial, industrial and federal.

Raised revenue by $\$ 2.1$ billion through reducing write off expenses for corporations and extending a "temporary" Federal Unemployment Tax surcharge.

Authorized loan guarantees to encourage the manufacture of advanced vehicle batteries, grants to help states encourage the use of plug in electric vehicles.

And most significantly for this study:

Renewable Fuels Mandate that requires 36 billion gallons of biofuels to be blended into the nation's fuel supply by 2022 . The previous law passed

${ }^{235}$ (Library of Congress, 2007) 
just months before this had required 6.8 billion gallons to be blended by 2022. This law also requires the use of biofuel source materials other than corn such as sorghum, rice straw and switchgrass. ${ }^{236}$

The specific yearly requirements for the Renewable Fuels Mandate are found in section 202 of the act and are:

(I) RENEWABLE FUEL.-For the purpose of subparagraph (A), the applicable volume of renewable fuel for the calendar years 2006 through 2022 shall be determined in accordance with the following table:

Applicable volume of renewable fuel "Calendar year: (in billions of gallons):

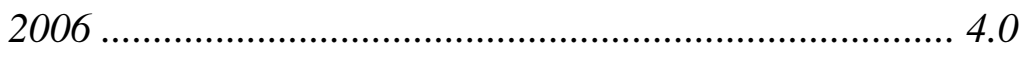

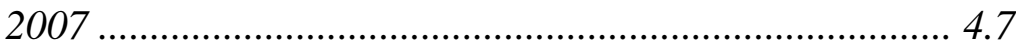

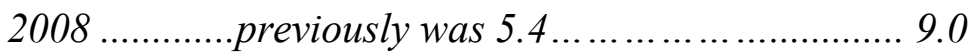

2009 ...........previously was $6.1 \ldots \ldots \ldots \ldots \ldots \ldots \ldots \ldots . . . . . . . . .11 .1$

2010 ...........previously was $6.8 \ldots \ldots \ldots \ldots \ldots \ldots \ldots . . . . . . . .12 .95$

2011 ..........previously was 7.4 ..................... 13.95

2012 ..........previously was 7.5 ....................... 15.2

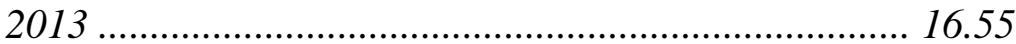

2014

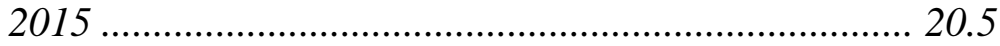

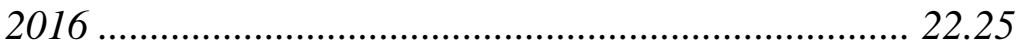

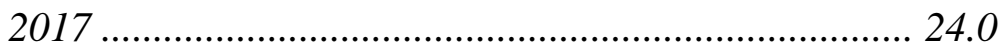

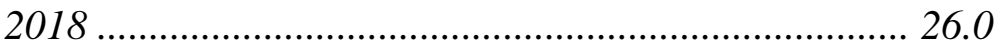

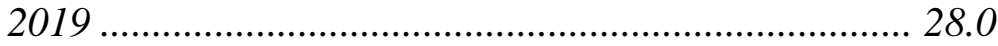

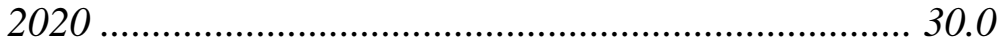

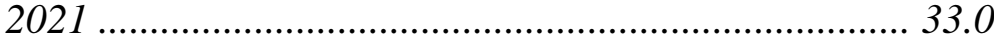

${ }^{236}$ (Congressional Quarterly, Inc., 2007)pp. 10-3 
(II) ADVANCED BIOFUEL.-For the purpose of subparagraph (A), of the volume of renewable fuel required under subclause (I), the applicable volume of advanced biofuel for the calendar years 2009 through 2022 shall be determined in accordance with the following table:

Applicable volume of advanced biofuel "Calendar year: (in billions of gallons):

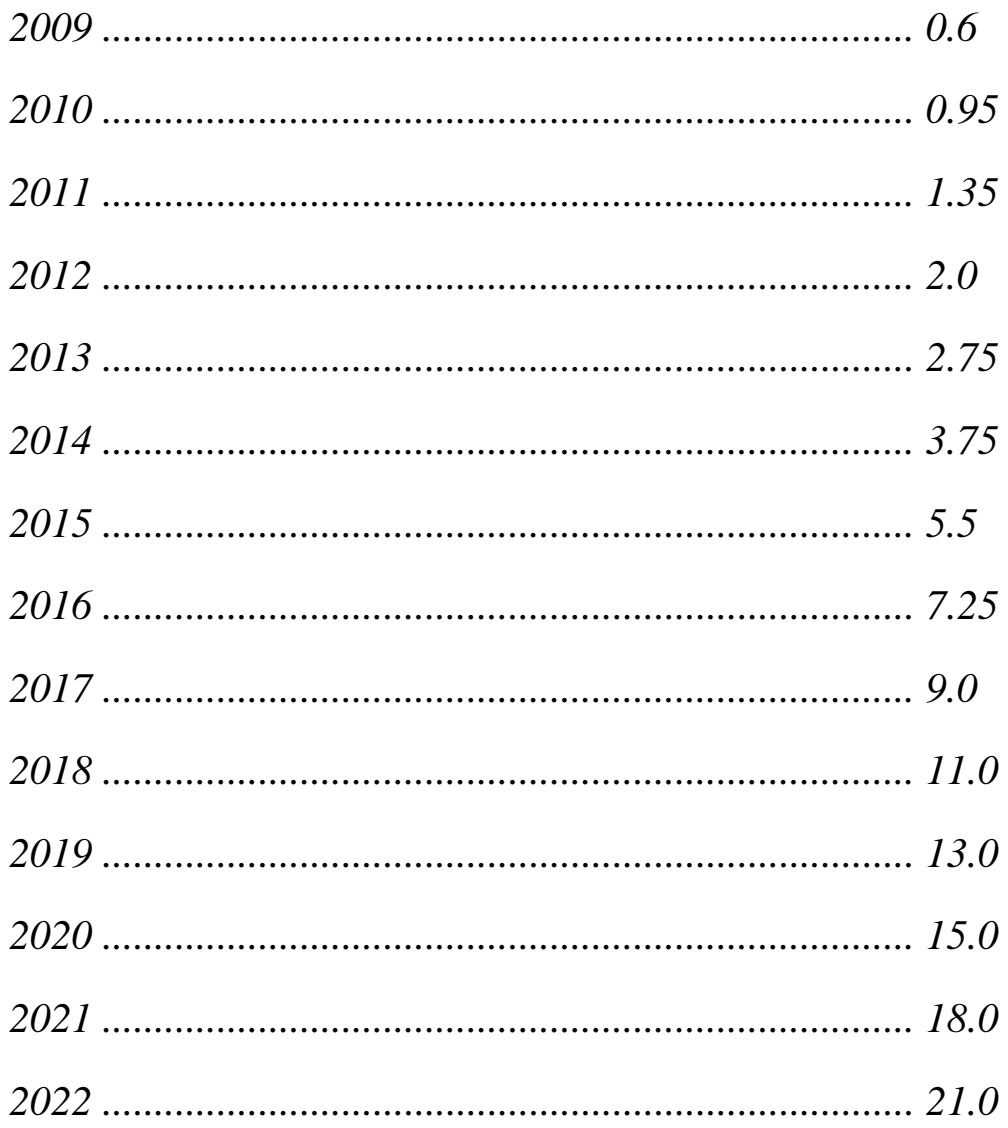

Additionally, the section also specified specific amounts of non-corn based biofuels to be blended yearly into the nations fuel supply:

(III) CELLULOSIC BIOFUEL.-For the purpose of subparagraph (A), of the volume of advanced biofuel required under subclause (II), the applicable volume of cellulosic biofuel for the calendar years 2010 through 2022 shall be determined in accordance with the following table:

Applicable volume of cellulosic biofuel "Calendar year: (in billions of gallons): 


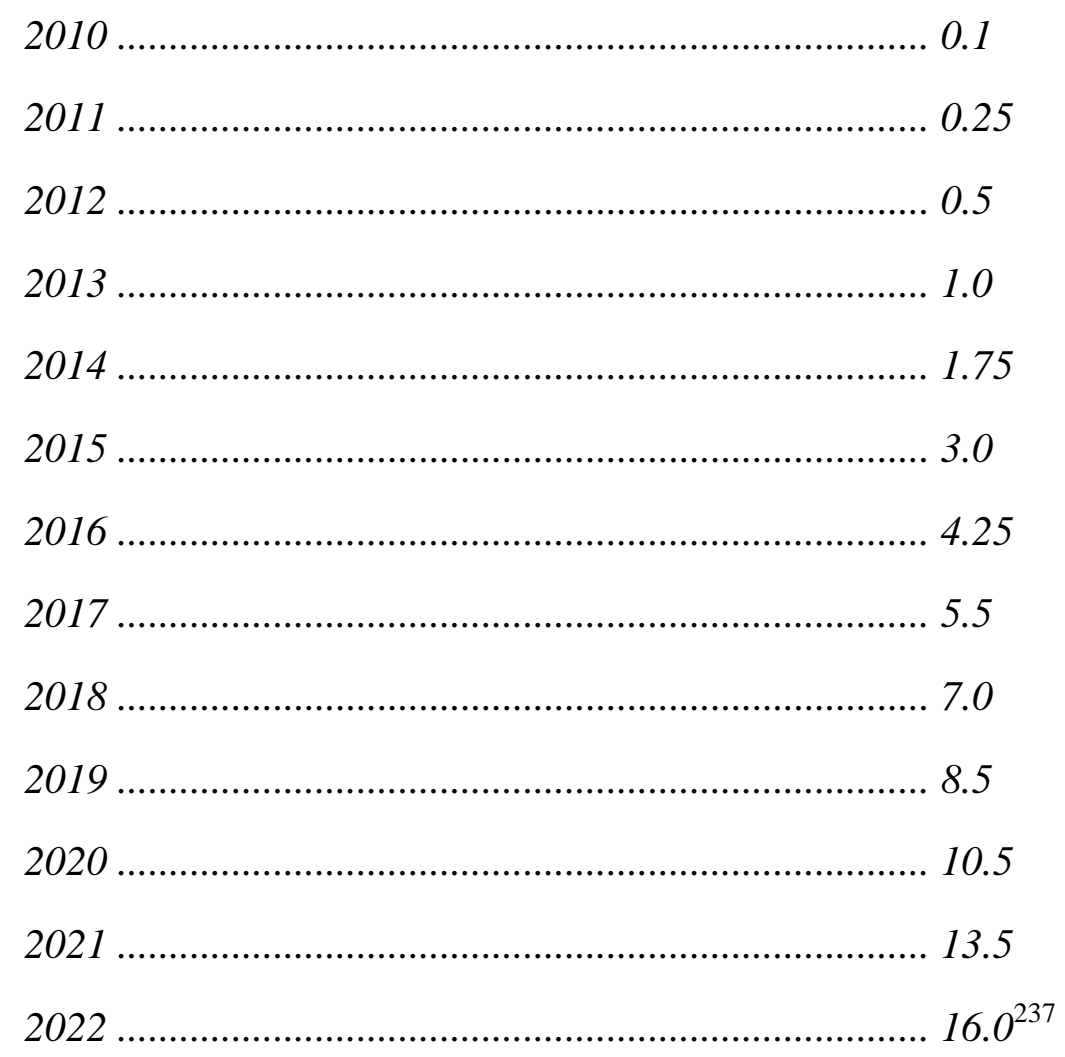

The "cellulosic biofuel" section above added an entirely new mandate on top of the previously enacted ethanol mandate of 2005 (P.L. 109-58). This law not only dramatically increased the mandated amounts of ethanol to be blended, but the statute also required an entirely new form, cellulosic, of renewable fuel to be produced and blended into gasoline in substantial quantities. It is instructive to examine the amounts of transportation fuel used in the nation in 2007 to see the impact these mandates were designed to accomplish. In 2007 the country consumed 176,203 million gallons of fuel. That is 176 billion gallons. ${ }^{238}$ In 2007 the nation with extensive subsidies, incentives, tax credits and tariffs produced just less than 7 billion gallons of ethanol for blending into the nation's fuel

\footnotetext{
${ }^{237}$ (United States Government Printing Office, 2007) pp. 33

238 (Research and Innovative Technology Administration, 2010)
} 
supply, or about $4 \%$ of fuel usage. ${ }^{239}$ As the Congress moved H.R. 6 through the legislative process, it did so with Presidents Bush's goal in mind that he had expressed the year before in his 2006 State of the Union Address:

New technologies will help us reach another great goal: to replace more than 75 percent of our oil imports from the Middle East by 2025. By applying the talent and technology of America, this country can dramatically improve our environment, move beyond a petroleum-based economy, and make our dependence on Middle Eastern oil a thing of the past. $^{240}$

Although the Presidential comment above was overly optimistic, it was no more

so than the perspective of the Senate Majority Leader, Harry Reid (D-NV):

It is time to stop talking and putting America on a path to a cleaner, safer and more affordable energy future. The Energy bill originally passed both the House and Senate with strong bipartisan majorities. Democrats and some Republicans agree we must pass this Energy bill for four main reasons: No. 1, we must take action that will help reduce the constantly rising price Americans pay for gasoline.... No. 2, we must begin to break our country's addiction to oil. We are addicted to oil. Even President Bush said that. We will use 21 million barrels of oil today. Almost 70 percent of it we import from foreign countries and most are led by tyrannical rulers, despots. No. 3, we must begin to reverse global warming. It is a crisis caused by our use of fossil fuel. And No. 4, we must invest in renewable energy. Why? It is good for the environment, and it creates lots of jobs. In Nevada alone, the tax portions of this bill will create thousands of jobs and countless--tens of thousands, hundreds of thousands--jobs throughout America. ${ }^{241}$

In 2007 there were several policies debated; The President's 20-by-10 proposal, the Tennessee 25x25 plan, the Department of Energy's 30x30 plan amongst others. Virtually all were to some degree founded on published studies which presented that there was tremendous unused and available biomass (cellulosic primarily) which could be used to dramatically increase the availability of

239 (Renewable Fuels Association, 2011)

240 (White House Archives, 2006)

241 (Harry Reid (D-NV) Congressional Record Senate S15388) 13 December 2007 Floor debate 
economically attractive renewable fuels. In fact the data show that the projections made only 4 years ago have not been remotely met and many of the assumptions made by legislators in considering H.R. 6 were erroneous.

The cellulosic biofuel allotment in the mandate, as established by Congress in EISA, was 100 million gallons due in 2010, 250 million gallons in 2011, and 500million gallons in 2012, increasing to 16 billion gallons by 2022.

EPA lowered the RFS cellulosic biofuel mandate to 6.5 million gallons in 2010 and 6.6 million gallons in 2011.

For the 2012 cellulosic biofuels mandate, EPA proposed a range of volumes from 3.55 to 15.7 million ethanol equivalent gallons from which to consider a value. ${ }^{242}$

These data show that within 2 years the mandated amounts of cellulosic ethanol production in the act were not being met at all. In 2010 less than $6 \%$ of the mandate was produced, in 2011 less than $3 \%$ of the mandate will be produced and in 2012 it is projected that potentially less than $1 \%$ of the original mandate may be met. Although not part of this examination, it is worth noting that the Congress also passed the 2007 Farm Bill which included billions of dollars for loan guarantees for cellulosic production facilities, a $\$ 45.00$ per ton cellulosic feedstock subsidy as well as a $\$ 1.01$ per gallon tax credit for ethanol production. ${ }^{243}$ The best synopsis of the outcomes of this legislative attempt to mandate substantial production and use of ethanol which the consumer and producer would not support is from Glozer:

The corn industry's rapid capacity and production expansion from 2005 through early 2008 was halted by a sharp decline in petroleum and

\footnotetext{
242 (Bracmort, 2011)

243 (Glozer, 2011) pp. 69
} 
ethanol prices in the latter part of 2008....ethanol production became uneconomic even with federal subsidy(s)... and a number of ethanol producers stopped production and filed for bankruptcy. ${ }^{244}$

This examination of the Energy Independence and Security Act of 2007 shows a change in the underlying forces of energy policy as, in the aftermath of $A n$ Inconvenient Truth, environmental concerns became enmeshed in energy policy goals. Although environmental concerns regarding ethanol would eventually contribute to the decline of ethanol policy, the rush to find environmentally compatible energy solutions initially fuelled the calls for expansion of ethanol production, based or incomplete and premature scientific speculation. Examining congressional hearings in terms of the witnesses selected and the testimony offered, shows that the information gathered continued the trend of being unbalanced, scientifically incomplete, and at times misrepresentative. By the formulation of H.R. 6 (Public Law 110-140) more consistent dissenting voices from within Congress and non-corn agricultural concerns were questioning the agricultural, logistic and economic viability of ethanol as an alternative fuel resource. These dissenting voices continued to be outweighed by the sheer bulk of others in the push for ethanol expansion. The bias in the information available to policymakers precluded full deliberation on aspects of ethanol as a fuel alternative. Although attributes of deliberative democracy may have been present in the creation of this policy legislation, the process of crafting the law seemed to tilt towards the political. As with all of the legislation examined, the outcomes of

${ }^{244}$ (IBID) pp.70 
ethanol policy within energy legislation differed dramatically from the stated intention of the legislators crafting the statute. 


\section{Summary}

The acts examined in this chapter are the final pieces of legislation studied for an era of roughly 30 years of legislative activity ending in 2007. This period was focused, in part, on insuring that America reduced its dependence on imported oil and improved its strategic national security. The data presented for the laws examined in this chapter show that as each law was proposed, the intended outcomes of ethanol provisions within prior energy legislation had not been met. Each law examined had the same basic intention:

Provisions to reduce the imports of foreign oil

Provisions to increase the production and use of ethanol

Provisions to reduce the use of oil consumption

Provisions designed to promote energy independence

While ethanol policy repeatedly failed to meet these energy goals, ethanol policy as a tool for supporting farm incomes in the agricultural policy stream was meeting its stated aim.

Deliberative democracy in practice is expected to lead to outcomes which contribute to a national benefit. ${ }^{245}$ The process as envisioned in Federalist 10 suggests that the presence of substantive debate amongst reasonable and receptive legislators should lead to positive outcomes benefiting the nation as whole and not sectional interests. The data examined in conjunction with the two laws addressed in this chapter reveal that extensive debate, dialogue and compromise occurred in the creation of each bill which was enacted into law; however, flaws in the

${ }^{245}$ (Bessette J. M., 1994) 
process of gathering and evaluating information through committee hearings and other sources undermined the effectiveness and nature of these activities. The imperatives of energy security and the threats of economic disruptions caused by the continuing dependence on foreign sources of oil in fueling demands for effective energy policy were exacerbated after the 911 attacks. As is seen in this chapter, these two final Acts were part of the response to the profound disruption to the Nation's sense of security, economy and energy independence in the aftermath of 11 September 2001 and subsequent wars in Iraq and Afghanistan. Emotions within the Nation and Congress ran high during the search for policy solutions.

September $11^{\text {th }}$ reiterated the crisis-response nature of much of the Nation's energy policy post 1978. The severity of this crisis exacerbated legislators' dissatisfaction with the failure of previous energy policies to address the underlying feelings of national vulnerability. While the energy components of ethanol policy depended on the perception of an external threat to propel it forward, the agricultural component of the policy continued regardless of national threat. Another emotional factor in energy policy development at this time was Al Gore's documentary, An Inconvenient Truth.

As with prior legislation, the selection of testimony heard in committee hearings, although voluminous, was biased and therefore insufficient to allow for informed judgment. The unbalanced nature of the information available through committee hearings undermined the quality of debates in the House as inadequate information fuelled further poor decision making and resulted in flawed policies. 
Deficiencies in the provisions of Public Law 109-58 were evident almost as soon as the President signed it into law in August 2005.

Public Law 110-140 was the response to the deficiencies in 109-58; however, the formation of this law suffered from a similar flaw at the committee level as had its predecessors. In addition, the Closed Rule removed any possibility of deliberative democracy from the House debates - adding another layer of political posturing to the process.

As is analyzed in chapter 6, the process of deliberative democracy where present did not result in positive outcomes for the era examined in this chapter; 2000 through 2008. The challenges of energy security and independence became even more pressing than they had been previously. Yet, although the nation entered a wholly new and unprecedented policy and national security era after 911 , the outcomes of the laws examined in this chapter show similar problematic results as in prior eras:

Since the law's enactment oil imports have remained high.

The price of oil has remained high

Adjusted for economic conditions, oil consumption has remained high

The nation is no closer to energy independence than 30 years ago

The mandates for cellulosic ethanol production are not being met

The legislative record shows a growing concern and debate within energy policy hearings regarding both the environmental and economic viability of 
agriculturally based alternative fuels such as ethanol, either corn or cellulosic. The Inconvenient Truth angst rampant amongst both the public and legislators heightened concern that ethanol might well not, in fact, be the panacea for improving air quality as it once was thought to be. While hearing testimony for each of the laws examined clearly showed that prior legislative attempts to address the energy challenges had failed, legislators continued to vote for ethanol subsidies, mandates, tariffs and a massive transfer of wealth from taxpayers and consumers to the agricultural community - despite well-articulated misgivings, doubts and concerns about the sustainability of the policies they were enacting.

It is informative to note that while the processes leading to expanding ethanol policy within the context of both the agricultural and energy policy streams at the level of committee hearings, executive influence the role of subgroups, appeared more political than deliberative in nature, the resulting legislation repeatedly failed to meet its energy policy goals while meeting its goal within agriculture as a mechanism for farm income support. While no national benefit resulted from ethanol as an energy policy option, ethanol as a tool of agricultural policy did contribute to legislative goals stated at the national level.

Figure 5 on page 47 shows two alternative sets of attributes that could explain Congressional behavior present during the legislative activity occurring during the consideration of the proposed bills addressed in this chapter. These different perspectives; one deliberative and one political suggest potentially different outcomes and those results are addressed in the conclusions found in chapter 6 . 


\section{Chapter Six}

\section{Analysis and Conclusions}

This research examined the legislative history of ethanol policy since its inception in the 1970's in the light of the Founder's concept of deliberative democracy. As the introduction presented, the underlying precept of deliberative democracy is that when such elements of political and legislative behavior as presented by both Madison and Bessette are followed, the Nation as a whole will benefit and narrow parochial interests will be minimized. Accordingly, in this study, it was expected that if deliberative democracy attributes were present during the ongoing ethanol policy legislative debates, outcomes would be beneficial for the national interest as suggested by both Madison and Bessette. If, on the other hand, such attributes were not present during the legislative process, the outcomes would be problematic and not in the national interest. The following analysis shows that an alternative deliberative democracy outcome occurred. In examining each of the six laws presented for attributes of deliberative democracy and then aggregating the totality of such attributes from all the laws examined, informative and disquieting findings resulted.

Analysis of the outcomes of the ethanol policy legislation examined clearly shows that somewhere between Madison's Federalist 10, Bessette's more recent work and current ethanol policies, a change in how deliberative democracy functions in America's legislative construct has occurred. An unanticipated question which arose during this study was: In the crafting of ethanol energy policy was there a 
disconnect between the activity of deliberative democracy and the outcomes of deliberative democracy? The answer to this question is presented for ethanol policy legislation, but the results of the analysis suggest that further study beyond the scope of this work examining wider legislative behavior and institutional construct is warranted.

The six laws examined to inform an assessment of ethanol policy outcomes were selected to reveal and illuminate any changes over time from the onset of ethanol policy discussions in the 1970's through 2007. Legislative histories documenting the process whereby ethanol policies were enacted were examined in detail for each law. Data showing the actual outcomes of each act as compared to intended outcomes was also available, examined and presented.

The stated intentions of legislators and Presidents on both side of the political aisle have not changed during the ethanol policy debates over the past 40 years. Examination showed that majority political power in both chambers of the Congress and the White House reversed several times over the decades studied. The resulting implication is unmistakable; for purposes of ethanol policy efficacy over time, political party control of the branches of government had no positive national beneficial effect on the outcome of enacted legislation. While costs and methods to accomplish ethanol policy goals have been intensely debated, the basic goals of ethanol policy within energy legislation enacted remained essentially agreed upon:

Reduce America's total imports of foreign oil substantially Reduce America's consumption of gasoline significantly 
Stabilize and minimize oil price changes over time

Increase America's national security through developing cost effective domestic sources of ethanol and other renewable fuels

Enhance America's economy through increased energy self sufficiency

Safeguard America's environment through reduced greenhouse gases.

The outcomes of implemented ethanol policies across all laws examined have fallen dramatically short of the stated intentions above.

Factual data relative to the above goals, in order, show the following:

In 1973 the United States imported an average of 6.2 million barrels per day of oil

In 2011 the United States is importing practically 11.5 million barrels per day of oil ${ }^{246}$

In 1973 American's consumed approximately 95 billion gallons of gasoline

In 2011 American's are projected to consume 160 billion gallons of gasoline $^{247}$

In 1973 Oil prices averaged $\$ 4.20$ per barrel

In 2011 Oil prices averaged $\$ 87.48$ per barrel $^{248}$

Analysis of how the goal of increased use of ethanol and cellulosic fuels to increase national security reveals counter-intuitive results illuminating an outcome of perhaps an additional facet of deliberative democracy. Within energy

\footnotetext{
246 (U.S. Energy Information Administration, 2011)

247 (Research and Innovative Technology Administration, 2010)

248 (Illinois Oil \& Gas Association, 2011)
} 
policy legislative goals, ethanol policy was an abject failure that at no stage of its evolution came close to achieving its stated national goals. However, ethanol policy was also enacted as a part of agricultural policy. The aim of expanding ethanol as an alternative fuel within farm policy was to provide an additional market for agricultural commodities and thereby elevate farm incomes. Within the larger context of agricultural policy, ethanol policy succeeded in delivering the desired result of increasing farm incomes.

Analysis of the economic impacts of increased ethanol production and use reveals a massive transfer of wealth from one portion of the citizenry to another. While the agricultural sector benefitted from this transfer, no other national benefit resulted from the decades of ethanol policy development as explained below.

Analysis of outcomes relative to the goal of safeguarding the environment through the use and production of ethanol concludes that such goals have not been met.

By any measurement, even adjusted for population growth, inflation or any other characteristic, not only have the aggregate outcomes of the energy laws intended effects not been met, but also the failure of ethanol policy has been dramatic.

The research question presented in chapter two was:

Has the ethanol energy policy of the United States, as outlined in legislative actions, requiring subsidies, mandates and increased consumer costs from taxpayers, been reflective of a nationally deliberatively democratic process that after taking into account the input and influence of various competing viewpoints, turned out to be a beneficial national policy? Consequently have the policy outcomes of the legislative stakeholders matched the stated intentions of those involved in the 
deliberative debate that enacted it or where have those objectives not been met?

The examination of each law enacted revealed a consistent and common thread: The basic attributes of deliberative democracy as presented by Madison and Bessette were not always adhered to throughout the legislative process as it related to individual legislation Clearly there was some dynamic present in the process which rendered the collective outcomes of legislators' efforts in energy policy related to ethanol an ongoing failure while simultaneously creating success for ethanol agricultural policy.

An appendix (IV-X) for each law examined presents the legislative history for each bill enacted and that history documents the legislative movement of introduced bills which after time, debate, amendment(s), and occasional veto threats, became law.

Figure 5 from chapter 2, presents measurement tools to gauge the presence of deliberative democracy attributes. Each attribute, if present, is believed to be evidence of the behavior each legislator should possess to engage in debate and dialogue that leads to decisions which are beneficial to "the permanent and aggregate interests of the community...those interests described in the Federalist Papers as 'the public good, 'the good of the whole', 'the public weal', ' the great and aggregate interests', 'the great interests of the nation' and the comprehensive interests of the country. ${ }^{, 249,250}$ Those attributes are:

\footnotetext{
249 (Bessette, 1994)

250 (Madison, 1787)
} 
- Through Committee hearings legislators will elicit the information and arguments necessary to make informed judgments.

- Committee dominance in the legislative process shows that Members defer to the judgment of those who have deliberated fully on a pending issue.

- Floor debate is the final opportunity to hear the strongest arguments pro and con; useful also as an information source regarding the contents of complex bills.

- Influence of committee and party leaders enables Members of Congress defer to individuals of sound judgment; leaders persuade others through rational argument.

- Subgroups, such as state delegations or ideological groups facilitate collective reasoning about common concerns.

- The influence of lobbyists provides a source of highly relevant information and arguments.

- Influence of the executive branch provides extensive information resources to persuade legislators of the merits of its proposals.

While the presence of measurable deliberative democracy attributes should lead to beneficial national outcomes as presented in Federalist 10, Congressional deliberation behavior based on political perspectives of issues, rather than truly deliberative consideration, is also addressed in the conclusions following this section. 
The following summary of deliberative democracy attributes for the laws examined reveals salient observations for each attribute as applied to each law. 
Summary of deliberative democracy attributes

\begin{tabular}{|c|c|c|c|c|c|c|}
\hline & $95-618$ & $100-494$ & $102-486$ & $106-224$ & $109-58$ & $110-140$ \\
\hline Sponsored by & $\begin{array}{l}\text { Rostenkowski } \\
\text { (D-IL) }\end{array}$ & $\begin{array}{l}\text { Rockefeller } \\
\text { (D-WV) }\end{array}$ & $\begin{array}{l}\text { Sharp } \\
\text { (D-IN) }\end{array}$ & $\begin{array}{l}\text { Combest } \\
\text { (R-TX) }\end{array}$ & $\begin{array}{l}\text { Barton } \\
\text { (R-TX) } \\
\end{array}$ & $\begin{array}{l}\text { Rahall } \\
\text { (D-WV) }\end{array}$ \\
\hline Cosponsors & 0 & 64 & 54 & 12 & 2 & 198 \\
\hline - ratio D:R & N/A & $44: 20$ & $49: 5$ & $0: 12$ & $0: 2$ & 195:3 \\
\hline Introduced in & House & Senate & House & House & House & House \\
\hline $\begin{array}{l}\text { Committees } \\
\text { referred to }\end{array}$ & 19 & 1 & 20 & 3 & 9 & 12 \\
\hline $\begin{array}{l}\text { Hearings } \\
\text { conducted }\end{array}$ & N/A & 8 & 105 & 14 & 90 & 72 \\
\hline $\begin{array}{l}\text { House } \\
\text { amendments } \\
\text { proposed }\end{array}$ & 0 & 3 & 22 & 3 & 34 & 0 \\
\hline $\begin{array}{l}\text { amendments } \\
\text { passed }\end{array}$ & 0 & 3 & 13 & 2 & 19 & 0 \\
\hline $\begin{array}{l}\text { Senate } \\
\text { amendments } \\
\text { proposed }\end{array}$ & 9 & 3 & 13 & 0 & 119 & 331 \\
\hline $\begin{array}{l}\text { amendments } \\
\text { passed }\end{array}$ & 8 & 2 & 10 & 0 & 34 & 45 \\
\hline $\begin{array}{l}\text { House debate } \\
\text { duration }\end{array}$ & & & 8 hours & 3 hours & 11 hours & 5 hours \\
\hline $\begin{array}{l}\text { Senate debate } \\
\text { duration }\end{array}$ & 6 days & 1 day & 3 days & 3 days & 5 days & 10 days \\
\hline $\begin{array}{l}\text { Conference } \\
\text { duration }\end{array}$ & 1 day & 3 days & 3 weeks & & 5 days & \\
\hline $\begin{array}{l}\text { House vote } \\
\text { - yay (D: R:I) }\end{array}$ & 231 & voice vote & $\begin{array}{r}363 \\
(239: 123: 1)\end{array}$ & $\begin{array}{c}\text { voice } \\
\text { vote }\end{array}$ & $\begin{array}{r}275 \\
(75: 200) \\
\end{array}$ & $\begin{array}{r}314 \\
(219: 95)\end{array}$ \\
\hline - nay (D:R:I) & 168 & & $60(20: 40)$ & & $\begin{array}{r}156 \\
(124: 31: 1) \\
\end{array}$ & $\begin{array}{r}100 \\
(4: 96) \\
\end{array}$ \\
\hline $\begin{array}{l}\text { Senate vote } \\
\text { - yay (D:R:I ) }\end{array}$ & 60 & voice vote & voice vote & $\begin{array}{r}91 \\
(43: 48) \\
\end{array}$ & $\begin{array}{r}74 \\
(25: 49)\end{array}$ & $\begin{array}{r}86 \\
(47: 38: 1)\end{array}$ \\
\hline - nay (D:R) & 17 & & & $\begin{array}{r}4 \\
(0: 4) \\
\end{array}$ & $\begin{array}{r}26 \\
(20: 6) \\
\end{array}$ & $\begin{array}{r}8 \\
(1: 7) \\
\end{array}$ \\
\hline
\end{tabular}

Upon examination, each of the laws studied in this work were found to have, to varying degrees, at least some of the required attributes to show evidence of deliberative democracy behavior as presented by Madison and Bessette. 
- Extensive hearings, from a minimum of 8 to as many as 105 , were held on each bill to elicit and obtain arguments that, if balanced, would facilitate informed judgments.

- Without exception all bills were considered by one or more committees.

- Hours to days of floor debate were conducted on every bill examined, although these varied from measured arguments and persuasion to bipartisan bickering lacking in substance under the Closed Rule

- Every bill examined showed evidence of informed members presenting information ranging from substantive to inadequate or superficial for consideration.

- Legislative history examination of the bills researched show that through the hearings process each bill considered was informed by several groups enumerated in figure 5 as attributes of deliberative democracy. Presented testimony showed evidence of relevant information and arguments to consider as well as facilitate collective reasoning about common concerns; one group was state, local, environmental and academic organizations and the other was comprised of market driven, economically market based organizations.

- Each bill researched showed contributions of information and persuasion by the Executive branch through the presentation of reports and testimony from the Office of Management and Budget. Frequently the relationship between Congress and the Executive was strained - particularly regarding 
ethanol policy - and was evident in the threat and use of the veto to encourage consideration of the President's views.

The ethanol policy legislative histories examined and presented show a voluminous record of hundreds of hearings conducted over decades by hundreds of legislators in venues across the country informed by thousands of witnesses presenting testimony. Because of the choices made in witness selection, these hearings were largely insufficient to deliver balanced information that would have allowed legislators present to make informed judgments and thus lead to debates on the Floor presenting the pros and cons of ethanol policy.

The record shows that for each bill introduced that became law, the proposed legislation was referred to one or several committees in each chamber as was thought appropriate by leadership. The involvement of committees in considering each bill should have resulted in those legislators being most informed on policies being considered weighing substantive testimony. These legislators then had the responsibility to make considered and (in theory) the most beneficial (collectively) decisions for the national interest. Floor debate on ethanol legislation examined ranged from considered and substantive to juvenile and childish, as when closed rules were used to keep the minority party out of considering particular legislation. ${ }^{251,252}$ Such behavior was evident in both political parties over the period examined. Hearings examined during the consideration of proposed bills revealed a large number of lobbyists presenting

\footnotetext{
${ }^{251}$ (Appendix XI)

${ }^{252}$ (Appendix XII)
} 
their retainers' perspectives on the benefits or damages of increasing ethanol production.

The Executive branch through agencies it controlled presented witnesses and voluminous data to inform Congress of its policy desires, although because of political friction, at some points in this process, witnesses from the Department of Energy refused to attend committee hearings. Organizations ranging from the Office of Management and Budget to the Department of Energy to the Agriculture Department to the Interior Department to the Defense Department to the Environmental Protection Agency as well as dozens of other lesser known federal agencies provided data to legislators upon which they could make decisions, but again the selection of witnesses was not always sufficient to facilitate informed decision making. From within the legislative branch the Congressional Budget Office and the Congressional Research Service produced hundreds of articles, essays, reports and data to inform legislators as they considered various ethanol bills. $^{253}$ At each decision point in the ethanol policy legislative process the Members and Senators considering bills had extensive data and information available to them with which to make informed decisions yet over time there were several major potential weaknesses of ethanol policy outcomes which were not recognized by either party or chamber. The data inconsistencies presented across hearings with skewed information offered encouraging the use and production of ethanol contributed to ongoing ethanol policy failures. Throughout the entire continuum of legislative activity, there was no appreciation of the reality that a

\footnotetext{
253 (See bibliography for examples)
} 
growing population of a developed nation continuously inventing new innovative technologies would require dramatically increased amounts of energy to power their activities. In a widely read book by Peter W. Huber and Mark P. Mills, "The Bottomless Well" (2005), ${ }^{254}$ the authors present a variety of data which show that throughout human history the availability, and use of energy has grown exponentially as man's technological prowess has evolved. Rather than there being progressively less energy available as technology has matured, their data shows persuasively that more energy becomes available with the development of more sophisticated science and technology. There is a common misunderstanding about the search for more energy resources. There is an important distinction that needs to be made: mankind and nations are searching for more power as technology advances. There is a rampant misconception that efficiency reduces energy usage. Huber et al sum it up clearly:

The more efficient our technology, the more energy we consume. More efficient technology lets more people do more, and do it faster-and more/more/faster invariably swamps all the efficiency gains, New uses for more efficient technologies multiply faster than the old ones get improved. To curb energy consumption, you have to lower efficiency, not raise it. ${ }^{255}$

Had legislators considered this paradigm, they might well have arrived at different ethanol policies.

As they were debating possible ethanol policy implementation, legislators were consumed with reducing energy usage through increasing efficiency in several ways, such as mandating higher mileage requirements from auto manufacturers.

\footnotetext{
254 (Huber \& Mills, 2005)

255 (Huber \& Mills, 2005) pp. xxvii
} 
Their inability to recognize that further increases in efficiency would lead to increased energy usage demonstrates a further misunderstanding of market behavior that contributed to the failure of ethanol as an energy policy.

Congress had significant data and research reports to inform legislators about the energy resources of the United States. This dissertations research examination revealed that there is a massive amount of energy resource data available from dozens of federal agencies. Much of it is internally inconsistent and many reports, although funded by Congress to document energy resources, were essentially ignored because to use such energy resources would entail political consequences no legislator wished to experience. The underlying premise that the United States was fossil oil resource deficient was accepted in the early days of ethanol energy policy debate; accordingly any suggestions of sourcing untapped domestic sources of oil as an energy supply had been dismissed with an emphasis on developing renewable fuels. It is not immaterial that this occurred as ethanol surpassed methanol as the alternative fuel of choice. This shift to ethanol, a farm product, resulted in combining agricultural and energy policy together to drive ethanol production growth. The dominance of ethanol as the alternative fuel choice coincided with a legislative backlash against Big Oil and resulted in legislators disregarding arguably the largest economically profitable sources of readily available oil in the world ${ }^{256}$ as alternatives to foreign oil imports. Data sustaining the above statement is found within the government's own publications. Going back to the late 1970's and early 1980's there was an

${ }^{256}$ (Whitney \& Behrens, 2009) pp.18 
abundance of data which showed the potential availability of oil within the United States. The National Strategic Unconventional Resources Report presented the following:

America's oil shale resource exceeds 2 trillion barrels. The richest, most concentrated deposits, amounting to approximately 1.8 trillion barrels of oil equivalent, are found in the Green River Formation in western Colorado, southeastern Utah, and southern Wyoming. The entire western oil shale resource (including federal, state lands, tribal lands, and privately owned "fee lands") is located within the Green River Basin and contains nearly 1.8 trillion barrels of oil in place. Nearly 80 percent of this western oil shale resource is owned and managed by federal agencies. $^{257}$

Although there are tremendous economically attractive quantities of shale oil readily available on small footprints of land in virtually uninhabited rural federal lands, development of such lands has been prohibited by Executive Order going back to the Presidency of Herbert Hoover. ${ }^{258}$ One of the most significant ironies reflecting a failure of deliberative democracy outcomes in the ethanol policy legislation process is that, of the increased use of imported oil for the past several years, Canada has been America's largest supplier, on the order of 2.5 million barrels per day and the oil we import is from Canadian oil sands mined through open pit procedures that American legislators are loathe to allow in the United States. $^{259}$

There has been frequent debate about using domestic resources, be they the Alaska National Wildlife Reserve, offshore drilling or onshore shale deposits.

257 (Office of Naval Petroleum and Oil Shale Reserves, 2006)

258 (Office of Technology Assessment Materials Program, 1980) pp. 239

259 (U.S. Energy Information Administration, 2011) US Imports of Crude Oil and Petroleum Products 
These were politically sensitive policy options that significantly impacted legislators' ability to pass energy legislation. The inclusion of such provisions in proposed bills generally resulted in their failure to gain passage. Congress's continued unwillingness to use these resources has resulted in significantly increasing imports of foreign oil, the antithesis of the ethanol policy outcomes anticipated. In as much as deliberative democracy attributes were evident during these resource debates, the question remains as to why this aspect of ethanol policy failed.

While much focus and debate was placed on wind, solar, and other forms of renewable energy in legislative discussions, research presented showed that even under the most optimistic circumstances those sources, including ethanol, could only contribute a small percentage of the nation's growing energy needs (under $7 \%){ }^{260,261,262}$ It remains perplexing that while deliberative democracy attributes were evident in debating renewable sources of energy and significant data was presented to legislators to make informed decisions, at each decision point, an apparent political policy enactment was made which lead to failed outcomes.

A central goal of ethanol energy policy in every iteration of laws examined was to increase our national security by reducing our imports of foreign oil and relying on increased amounts of domestic mandated ethanol production and consumption. In a glaring example of the deliberative democracy process not leading to a nationally beneficial outcome, legislators on neither side of the aisle at any time

\footnotetext{
${ }^{260}$ (U.S. Energy Information Administration, 2010) Renewable \& Alternative Fuels - Figure 1.1

261 (U.S. Energy Information Administration, 2010) US Energy Consumption by Energy Source

262 (Schnepf, 2010) pp.18
} 
took into account the variations of nature. Of all the sources of renewable energy that the Congress could mandate, corn ethanol may well have been one of the least dependable. The fear in Congress and amongst the American public has been that the nation is painfully vulnerable to any disruption of foreign oil sources in the event of war or embargo (as in the Arab Oil Embargo of 1973). Such a disruption would again entail severe economic consequences for the nation. The Congressionally unrecognized reality is that over even a few years, agricultural crop harvests are far more variable and undependable than foreign oil supplies in a globalized world. There have been 5 major crop harvest failures in the United States since 1975 where corn production has declined $16 \%$ or more from the previous year: $1980,1983,1988,1993$ and $1995 .^{263}$ These normal cyclical weather related events can result in very disruptive and unanticipated ethanol policy outcomes. The safety net construct of U.S. Agricultural policy insures farmers against a variety of natural casualty losses; crop failure insurance, price protection, flood protection, subsidies to plant or not plant under differing circumstances (such as crop insurance provisions debated in 106-224 debate). ${ }^{264}$

By requiring ethanol to be woven into the agricultural price support structure, Congress created a successful agricultural policy benefitting farmers; however, ethanol as an energy policy was based on faulty reasoning and was incapable of meeting its stated national goals from inception. Although crop failure is part of the normal agricultural cycle, the implications of crop failure for ethanol energy policy are catastrophic. The first effect is that adverse weather and reduced corn

\footnotetext{
${ }^{263}$ (Glozer, 2011) pp. 84

264 (US Department of Agriculture, 2009)
} 
harvests lead to increased agricultural prices. Good for farmers, but very bad for the rest of the world in as much as America produces about $70 \%$ of corn sold in the world. In 2008 Midwest flooding drove corn prices to almost $\$ 8$ per bushel, almost double what they had been not long before. ${ }^{265}$ The result was that with corn prices so high, even with large subsidies, some ethanol producers became unprofitable or reduced production. ${ }^{266}$ The result of this natural function of cyclical weather is clear: to whatever degree the nation relies on ethanol to replace fossil oil gasoline, the nation's energy supply will be that much less reliable. The most severe worldwide oil disruption in energy history occurred in 1979 during the Iran Revolution and reduced the world's oil supplies for about $5 \%$ for six months. As the mandate increases for ethanol use and consumption domestically, the vulnerability to far larger fuel and economic disruptions for longer lengths of time when there are crop failures becomes more probable. ${ }^{267}$ It seems clear from analyzing this ethanol policy national security attribute alone that the Congress, while substantively debating various elements and preferred policy outcomes consistent with the operation of deliberative democracy, enacted policies that have been very expensive to the consumer and taxpayer.

The following statements dissenting from the legislated requirements in both 2005 and 2007 ethanol mandates demonstrate a growing awareness of the probability of policy failure.

The cellulosic biofuel allotment in the mandate, as established by Congress in EISA, was 100 million gallons due in 2010, 250 million

\footnotetext{
265 (The World Bank, 2008)

266 (Glozer, 2011)

267 (IBID) pp. 87
} 
gallons in 2011, and 500 million gallons in 2012, increasing to 16 billion gallons by 2022. EPA lowered the RFS cellulosic biofuel mandate to 6.5 million gallons in 2010 and 6.6 million gallons in 2011. For the 2012 cellulosic biofuels mandate, EPA proposed a range of volumes from 3.55 to 15.7 million ethanol equivalent gallons from which to consider a value. EPA is accepting comments on what the final value should be. The cellulosic biofuel community may fare better at achieving the lower mandates set and proposed by EPA if certain obstacles are overcome. Roadblocks include unknown levels of feedstock supply, expensive conversion technology that has not yet been applied commercially, and insufficient financial support from private investors and the federal government. $^{268}$

These additional comments illustrate the growing evidence contributing to the demise of ethanol as an energy policy option:

- Critics of an RFS, particularly of the EISA expansion of the original RFS, have taken issue with many specific aspects of biofuels production and use, including the following:

- By picking the "winner," policymakers may exclude or retard the development of other, potentially preferable alternative energy sources. Critics contend that biofuels are given an advantage via billions of dollars of annual subsidies that distort investment markets by redirecting venture capital and other investment dollars away from competing alternative energy sources. Instead, these critics have argued for a more "technology-neutral" policy such as a carbon tax, a cap-and-trade system of carbon credits, or a floor price on imported petroleum.

- Continued large federal incentives for ethanol production are no longer necessary since the sector is no longer in its "economic infancy" and would have been profitable during much of 2006 and 2007 without federal subsidies.

- The expanded mandate could have substantial unintended consequences in other areas of policy importance, including energy/petroleum security, pollutant and greenhouse gas emissions, agricultural commodity and food markets, land use patterns, soil and water quality, conservation, the ability of the gasoline marketing infrastructure and auto fleet to accommodate

${ }^{268}$ (Bracmort, Meeting the Renewable Fuel Standard (RFS) Mandate for Cellulosic Biofuels, 2011) 
higher ethanol concentrations in gasoline, the likelihood of modifications in engine design, and other considerations.

- Taxpayers are being asked to finance ever-increasing biofuels subsidies that have the potential to affect future federal budgetary choices. ${ }^{269}$

The economic costs to consumers and taxpayers of ethanol energy policy have significantly increased beyond any legislative expectations. At the enactment of every ethanol policy bill into law, and during the legislative process, pronouncements were continually made that the signed ethanol laws would be economically advantageous. Although this has been the case with the agricultural component of ethanol policy, the magnitude of the cost of ethanol being borne by the Nation for an energy policy that has demonstrably failed continually is huge by any measure. Costs for the 10 years $2008-2017$ to the consumer and taxpayer are conservatively on the order of $\$ 500$ billion dollars or approximately $\$ 50$ billion dollars per year. The costs can be presented by these budget items:

\section{Departments of Agriculture and Environmental Protection}

Corn and Soybean subsidies $\$ 36.4$ billion

Subsidized crop insurance $\$ 30.6$ billion

Disaster payments to Corn and Soybean producers $\$ 7.2$ billion

\section{Department of Treasury}

Forgone tax revenues credited to ethanol producers $\$ 58.8$ billion

\section{Consumer Cost Increases}

Mileage penalty - lower energy per gallon of ethanol $\$ 115.0$ billion Increased food costs $\$ 198.1$ billion

${ }^{269}$ (Schnepf, 2010) 
Increase in ethanol price from tariff effect $\$ 35.2$ billion

Increased vehicle cost to upgrade fleet to Flex Fuel $\$ 15.4$ billion

These estimates total in excess of a half a trillion dollars and were calculated by a senior executive with over 20 years tenure in The Office of Management and Budget in the White House and are extensively researched and documented. ${ }^{270}$ What makes these figures all the more remarkable is the calculation of the approximate cost per gallon of ethanol produced and used and for displacing what percentage of domestic fuel use when assuming the mandates required by ethanol legislation are met. Although chapter 5 shows that it is virtually impossible that the current mandates will be met, for purposes of examining the cost of deliberative democracy the following cost per gallon assumes that the mandates could be met and that they will displace increasing amounts of fossil fuel gasoline rising to 10 percent of projected 2017 gasoline use. Based on those calculations, the taxpayer and consumer will be paying just over $\$ 3.00$ per gallon in taxes and indirect costs in addition to whatever the actual pump price per gallon may be. Currently that total is in the $\$ 7.00$ per gallon range. This is unsustainable economically and politically undesirable.

A central tenant of deliberative democracy at work is that it is "reasoning on the merits of public policy.... where the participants seriously consider substantive information." 271 Certainly there have always been a myriad of information and research sources for Congress, but these cogent Congressional Research Service examples show that even when presented with clear, specific and what should be

\footnotetext{
${ }^{270}$ (Glozer, 2011) pp. 143

${ }^{271}$ (Bessette, 1994) pp.46
} 
thought provoking data, even after substantive ethanol policy deliberation, the Congress as a whole has repeatedly failed at realizing beneficial national deliberative democracy outcomes.

It is counter to the expectations of deliberative democracy, that while well aware of ethanol environmental concerns and issues from the early 1970's, at virtually every legislative opportunity, Congress made policy decisions that did not lead to a beneficial national ethanol policy. This failure was despite voluminous data presented by the scientific and government community (some of which is presented in chapter 2 as well as this chapter).

The literature review in chapter two presents research and data from universities, subject matter experts, lobbying associations, journalists as well as think tanks. Widely varying theses present that ethanol is either the savior of all American energy dilemmas or a catastrophic environmental policy mistake. Articles are presented which suggest that ethanol has far greater energy per gallon than is required to produce it. Other literature persuasively shows that ethanol is far less beneficial than petroleum gasoline, has much less energy content than gasoline and is contributing significantly to global warming. Bovard appears to document a connection between political campaign contributions to farm state politicians that result in subsidies for their constituents. His extensive essay presents that the entire ethanol industry is the creation of the Archer Daniels Midlands Company so that they might receive billions of dollars of subsidies and that their creation of the industry was through their huge campaign contributions to corn state legislators. Other essays show the tension between farm state legislators 
supporting ethanol production and non-farm state legislators opposing ethanol production. Big oil is castigated as evil in some and environmental groups present in others that the environment and our national health is in terminal decline unless we replace all fossil fuels with renewables.

Interviews conducted to further research the evolution of ethanol policy, although anecdotal, provided surprising information on the origins of the ethanol industry and early legislation. Bovard, in his in-depth 1995 Cato article ${ }^{272}$ presented what has been a generally accepted belief about the birth of ethanol national policy: Dwayne Andreas and the Archer Daniels Midland Company (ADM) crafted an elaborate business plan around stimulating the federal government to create tremendous subsidies for corn farmers and ethanol blenders. It was believed that ADM originated the concept of using corn to produce ethanol as a significant profit center for their company and then "sold" the concept to the government for ADM's gain. Through very substantial advertising aimed at Capitol Hill it appeared that ADM was in effect insuring that legislators knew how important ADM was to the ethanol industry and consequently to their political fund raising. Bovard presented that campaign contributions were a major force behind ADM's efforts and documented the vast sums of money given to legislators supporting those bills benefiting ADM.

While there can be no doubt that ADM profited handsomely from ethanol legislation, there is another possible explanation for ADM's entry into the industry which has never appeared in the literature. In an interview with Marty

${ }^{272}$ (Bovard, 1995) 
Andreas in the summer of $2010,{ }^{273}$ a key executive with ADM from the beginning of ADM's involvement in the ethanol business emerged a different explanation for ADM's entry into the ethanol industry.

In the winter of 1976, after the election of Jimmy Carter to the Presidency, Andreas relates an occasion when he and his uncle, Dwayne Andreas, CEO of ADM received a phone call from President-Elect Carter. The Andreas' had known Carter from before the election and not in a political sense, but rather as fellow agricultural businessmen. Carter, as Andreas recalls, had two subjects on his mind when he called: first, his transition team had suggested to him that to avoid any appearance of conflict he might be advised to sell his peanut farm or place it in a blind trust. No one would have been better counsel to discuss the situation with than the Andreas'. The second item was related to energy. Carter, an engineer by training, was acutely aware of the ongoing energy crisis facing the nation and had heard about a concept of using corn sugar to produce ethanol. He asked the Andreas' if they and ADM were producing ethanol to which Dwayne Andreas answered no. In fact according to Marty Andreas' recollection, Dwayne indicated that they and ADM knew nothing about oil, fuel or oil marketing. At that point Carter suggested that he could have several of his agency departments, such as Agriculture, Defense and Energy Agencies make their services available to ADM if Andreas would like to explore the concept of producing corn based ethanol by building a couple of pilot plants with government support. Very understandably, Andreas and ADM enthusiastically agreed to assist the Carter Administration with

${ }^{273}$ (Andreas, 2011) 
such projects. ADM would become a massive producer over the years of corn ethanol primarily produced in the number one corn growing state in America: Iowa.

ADM's approach to working with Iowa federal legislators, as explained by Andreas was quite different from the "buy them with contributions" portrait presented by Bovard and others. In 1975 Tom Harkin, a Democrat and Chuck Grassley, a Republican were both elected to Congress from Iowa. The evolution of political support for ethanol policy from Andreas' and ADM's perspective appears quite different than that which Bovard et al have presented over the years. First, for better or worse, rational or not for the national benefit, agricultural states, farmers and farm state legislators had a long and strong record since the Roosevelt years of the 1930's of expecting and receiving ongoing significant federal support in the form of insurance and subsidies. From the viewpoint of $\mathrm{ADM}$ it was quite reasonable to expect that Iowa and other corn growing state legislators would enthusiastically support their efforts. After all, it was the federal government that had asked them to begin ethanol production. It is also critical to remember that in the early years of ethanol policy, biofuels were considered by many to be the holy grail of fuels to reduce the nation's dependence on foreign sources of oil.

From the perspective of corn farmers and ADM, it was not a Republican or Democrat political issue, it was their efforts which were helping the nation and so it behooved ADM (and others) to educate their legislators as to the value farmers and ethanol blenders were providing the nation. Hence the non-partisan ongoing 
substantial support to both Harkin and Grassley over several decades. ADM, as Andreas' relates was able to provide information, research and education to both Iowa Senators (Democrat and Republican) from the very birth of the industry, supporting their view of the national benefit ethanol brought to America. Although at a national deliberative democracy level, the nationally beneficial energy policy outcome was not being met by the development of the ethanol industry, it certainly was successful from the vantage point of ethanol as an agricultural policy, particularly for corn state legislators. Once ethanol as an alternative fuel option coupled agricultural and energy policy, support of ethanol expansion was not simply political; it was existential, well beyond responding to campaign contributions as suggested in Bovard's essay.

A second interview, also in August of 2010, ${ }^{274}$ illuminated a perspective on the evolution of ethanol policy from a dramatically different vantage point. For almost 30 years Ken Glozer served in the White House Office of Management and Budget. He started in the Nixon Administration and was involved directly in every Presidential National Energy Plan through the Clinton years. Glozer at different times during his tenure with the OMB headed up the energy, agricultural and policy studies examining divisions of the office. Serving Administrations of Presidents of different parties over such an extended period of time allowed for a unique insight into the process of ethanol policy formation and the presence, or not, of deliberative democracy.

\footnotetext{
274 (Glozer, Retired Associate Deputy Director, White House Office of Management and Budget, 2011)
} 
More recently Glozer wrote a text, Corn Ethanol: Who Pays? Who Benefits ${ }^{275}$ outlining his experiences with ethanol policy development.

Glozer during discussions recounted the foundational perspective of farmers, farm state legislators and farm lobby groups: farmers and agriculture are the very bedrock of America. The farmers view of society is that "without food we dissolve into anarchy," a unique, but not unreasonable view. From that rational foundation then proceeded the legislative response which since the 1920 s created over 140 federal programs to support farmers. Very subtly, but significantly, the nation has transitioned from an overwhelmingly agrarian country to one where over $90 \%$ of the nation's population lived on farms in 1800 to 2000 where less than $2 \%$ of the nation's population lived on farms and less than $1 \%$ of Americans were farmers. It is clear to Glozer that this understandable and rational evolution explains why and how agriculture came to have such a disproportionate legislative impact, but the prevailing ethanol policy construct which has emerged since 1978 seems to him to be based on something far different than beneficial agricultural history.

Glozer, in both his book and interview presents a clear recitation of deliberative democracy outcomes run amuck. The size and complexity of government with thousands of federal agency staffers creating endless reports and data to present to endless Congressional committees informing several hundred legislators dealing with innumerable challenges daily has simply overwhelmed the legislative competence of government. From his perspective there was a transition over the

275 (Glozer, Corn Ethanol Who - Pays? Who Benefits ?, 2011) 
past 3 decades from a 'deliberative' democracy to a 'special interest' democracy. What seems to have transpired is a change from government run by legislative leadership to government run by itself. Glozer recalls that although there were broad brush thinkers in the Senate in the early 1970s who could think 'outside the box,' the policy crafting process overtime dissolved into fights over free markets or government controls. On many occasions the whole process seemed to center on beating up Big Oil for their extreme profits at the expense of the consumer. During these years the number of lobbying groups representing every conceivable attribute of ethanol from corn growers to producers to facility builders to auto manufacturers to big oil to unions to environmentalists to federal agencies promoting their turf expanded exponentially. Several of his observations, while not centered directly on ethanol policy, clearly illuminate how the regulatory process, from his perspective, has become crushing and counterproductive to the economic health of the nation: in the 1960s there were about 200 federal staffers charged with writing and refining environmental regulations - by the 2000s there were on the order of 27,000 - President Reagan was the last President that was 'deliberative' and believed in the free market, yet even he had to increase ethanol subsidies in 1984 to get his Tax Reform Act passed.

Over time Glozer observed that legislators have become extremely creative at obligating the government to supporting and funding or guaranteeing loans to many entities and keeping such arrangements essentially hidden or off the governments balance sheet to the long term detriment of the nation. A sobering conclusion Glozer has come to is that the federal government now consumes over 
half of the nation's GDP through taxes, deficits and extreme compliance costs. Were such a conclusion from someone of less long term non-partisan executive White House experience, they could be marginalized. Coming from Glozer they are most thought provoking.

In analyzing the literature on ethanol policy over time and looking at it through the prism of deliberative democracy and mixed policy outcomes - with success for ethanol as agricultural policy, and failure as an energy policy - it became clear that there may have been a dynamic in operation that goes far beyond just ethanol policy. How legislators review, assess, deliberate, debate such extensive literature and yet create failed policies poses a dilemma to which this dissertation can only offer a preliminary response. 


\section{Conclusions}

The analysis presented shows that at virtually every decision point analyzed post the Arab Oil Embargo of 1973 the Congress and President enacted laws mandating ethanol provisions within energy policy that have been to the ongoing detriment of the Nation. Each of the energy sections of laws examined and analyzed anticipated nationally beneficial ethanol policy outcomes and in every case those expectations have not been met. By comparison, the agricultural component of ethanol policy legislation has been successful in meeting its aim of providing an alternative source for consumption of farm commodities and thereby supplementing farm incomes through subsidies. While the collective costs of these ethanol policies have been shown to be enormous in both economic terms (in excess currently of $\$ 50$ billion dollars annually), the national security costs are even more negative (with the Nation left more dependent than ever on imports of foreign oil as consumption has continued to increase). Despite a robust legislative process over 3 decades which incorporated, at least in appearance, all the attributes of deliberative democracy as presented by Madison and Bessette, the outcomes were mixed and may indicate an additional facet of deliberative democracy in operation.

Legislators met extensively, deliberated intensely, were swayed to change positions, listened, held hundreds of hearings although the balance of information resulting was skewed, argued on the merits substantively, read endless reports and met some of measurements required to show the presence of deliberative 
democracy. Sectional interests merged and diverged over time. Majority political power in both the Congress and Executive branches changed hands several times. Part of the challenge in examining deliberative democracy legislation and behavior in relation to ethanol policy evolution is that ethanol policy was developed in two venues - agricultural and energy - wherein it had differing, but not necessarily mutually exclusive goals. While the goals of ethanol as agricultural policy instrument were met in increasing farm incomes through a number of mechanisms including subsidies and other incentives, ethanol within energy policy never met its stated goals of decreasing reliance on foreign oil sources and increasing national energy, economic or strategic security.

The deliberative democracy framework presents that if certain characteristics are present; the very process outlined above and adhered to in the formation of ethanol policy should result in a beneficial national good. That good would transcend the narrow parochial interests of any one section or interest. While Federalist 51 is better known for "Ambition must be made to counteract ambition, ${ }^{1276}$ Madison, in Federalist 10 unmistakably presents that deliberative democracy in practice will result in the national good when he states, "coalition of a majority of the whole society could seldom take place on any other principles than those of justice and the general good. ${ }^{277}$

This work shows that Congress in legislating various provisions of ethanol policy through several deliberative democracy attributes as envisioned by the Founders,

\footnotetext{
${ }^{276}$ (Madison, 1788)

277 (IBID)
} 
and presented by Bessette, produced two outcomes: a narrow sectarian benefit as an agricultural policy advantage for farmers and a nationally detrimental energy policy. This examination of deliberative democracy focused on individual laws and their aggregation in developing ethanol policy. While this narrow focus offers insights into congressional behavior in relation to discrete laws, it cannot address interactions that occur between laws that may seem unrelated. The success of ethanol policy in one venue and simultaneous failure in another indicates the operation of a process - possibly deliberative, possibly political - at an institutional level beyond that of individual legislation. The trade-offs that allowed for these differing outcomes of ethanol policy may indicate a behavioral dynamic between individual legislators that allows them to promote their specific policy preferences. The consistently poor outcomes of energy policy in general, and the particularly costly failure of ethanol as a nationally beneficial policy, point to a potential collective action problem at this level of deliberation. While logrolling may occur regarding more discrete policies - such as agricultural - that balance parochial and special interests, broader policy goals bestowing a national benefit may be lost in a collective action problem. It is possible that, with ethanol as an agricultural policy, other tradeoffs were made - at a level not covered by the deliberative democracy attributes documented in Figure 5 (page 47) - that contributed to other, more directed policies achieving their goals. The magnitude of the persistent failings of ethanol energy policy at the national level was so great that any offsets benefiting agricultural interests were inconsequential strategically. 
A remaining question for further study beyond this research would be examining the possible subtle and elusive political explanations that may be present during what appears to be deliberative democracy in process. Such examination might well measure behavior of deliberative and political attributes at the policy level as opposed to a level of analysis that functions within individual legislation. It is difficult to reconcile how legislators en masse could be so collectively incompetent as to repeatedly construct ongoing policy failures of such great proportions as shown in this work without reference to how this failure may function at a higher level of analysis. To the degree that the political explanations presented by Bessette in Figure 5 may be operating in the formation of the examined laws, it would, in part, explain the lack of beneficial outcomes. A resulting inquiry for further study could focus on the following questions:

- Was the formation of ethanol policy based on façade or deliberation?

- If genuine deliberation did function in the formation of ethanol policy, at what level of legislative construct did it occur?

The present practice of deliberative democracy in relation to individual pieces of legislation as explored in this research reveals several defects in the legislative process leading to the following conclusions:

- Legislators and staff choose the witnesses they wish to hear from. Such witnesses reflect the preferences of those who requested their testimony. The process leads to unpopular or dissenting views on proposals being marginalized and inadequately represented. Associated with this 
shortcoming is the absence of any coordinating mechanism to counter balance those vocal lobbies in such hearings.

- As the witness selection process is frequently skewed foundationally, dissent is minimalized or not allowed, which leads to legislators deliberating on unbalanced information. This process creates a snowballing effect which builds legislative provisions on information flawed from inception of the process.

- The process of bias in selection of data sources leads to faulty reasoning on substantive issues being amplified.

- At virtually every decision point through the decades of ethanol legislative consideration, there was little to no questioning of basic assumptions presented in testimony. This anomaly over time lead to data being considered becoming increasingly skewed.

- Surprisingly, across the party divide, over the years, the deliberative democracy attributes present in the formation of ethanol policy forged a common mindset which could not be broken out of. The process lead to a self-reinforcing collective behavior which disregarded alternative views and resulted in detrimental outcomes.

- An inescapable conclusion of this research is that absent an additional, as yet unexplained deliberative behavior, there was a profound lack of competence present in the consideration of ethanol policy questions both institutionally and by individual legislators. 
- The only remaining, and virtually unused, ethanol subsidy is for cellulosic ethanol and that subsidy will in all likelihood not be used. The mandated amounts of required cellulosic fuels are not, and will not be met in a free market economy with current technology. This last remaining direct subsidy should be discontinued to prevent any possible resurrection of further wasteful policy costs to the taxpayer or consumer.

While beyond the scope of this research to apply results obtained here to any other policy area, inescapable questions arise: What has changed in the nature, function or construct of legislative government over the past two centuries that would obviate the previous benefits of deliberative democracy at the level of individual laws? Has the very nature and motivation of legislators changed over time leading to dramatically different deliberative democracy behavior operating that that could result, however unlikely, in poor individual policy outcomes aggregating to a national benefit? Has the Nation's population and economic growth created a different society where the tenets of deliberative democracy function at a different level of decision making? Has the dramatic expansion of governmental regulation through the increasingly large agency structure reached appoint where no small group of 535 legislators under any deliberative democracy circumstances can succeed at creating successful policies?

This research's analysis and conclusions tie back directly back to the Founder's recognition that there is a fundamental legislative construct and behavior which requires a wise and thoughtful design to best achieve nationally beneficial policy outcomes. Federalist 10 was not written in a vacuum. It was written in a time and 
place where it was recognized that absent a well-designed legislative construct, the future of the American Republic would be in jeopardy. To compose Federalist 10 Madison realized the deficiency of the then current paradigm and the Constitution under consideration proposed a solution. Bessette insightfully builds upon Federalist 10 by presenting political perspectives (figure 5) as possible explanations of deliberative democracy outcomes. An inescapable conclusion is that Madison knew that absent such a legislative construct as being proposed, political attributes of deliberation would trump all others. Madison and the Founders clearly understood seminal political behavior and strove to create a structure which would direct positive conduct, beneficial outcomes and minimize narrow sectarian interests. Given this astute deliberative constitutional construct having been in place for over two hundred years, a question arises in this research: How and/or why could a series of laws be enacted over time that have been so detrimental to the Nation? Was ethanol, as an energy policy, a failure of the system so thoughtfully constructed given the Founders acknowledged wisdom - or are individual policy developments an adequate measure for assessing the outcomes of the current system?

The above enumerated conclusions, when aggregated, suggest an additional explanation for the failure of ethanol energy policy at virtually all inflection points. There appears to be an unusual and unique political history to the evolution of all the ethanol policy bills and laws examined in this work. In the normal deliberative process with its attendant attributes as presented in figure 5, there should be visible ongoing give and take in the consideration of beneficial 
national policies. It may be that deliberation occurred at a different, less visible, level of analysis than in this study and that provisions were across multiple policies rather than between provisions of a single policy in any given legislation. It would be expected that there would be strenuous debate and disagreement amongst legislators regarding the value, efficacy or wisdom of proposed legislative provisions. The deliberative model suggests that there would be changes in positions and that legislators could be prevailed upon to change their minds when presented with persuasive data and information. It is expected that given the partisan nature of the legislative process there would be strong disagreement regarding legislation based on simple political differences. This may have occurred at a level not visible in this analysis. If it were the political perspectives shown in figure 5 that informed the formation of ethanol policy, it would have required a significant difference of opinion about the proposed policy. Such differences would then have been logrolled or negotiated in order to reach a consensus or agreement. Such debate would have required give and take on the aspects of ethanol policy. Such a political deliberation could easily result in the documented failures of ethanol energy policy; however, the narrow sectional success of ethanol agricultural policy shows some negotiating success by legislators of farm states. The examination herein showed a very different process suggesting a possible explanation for the painful failure of the long term policy enactments.

It appears that for the framework of deliberative democracy to satisfactorily result in nationally beneficial outcomes (at least in so far as ethanol policies are 
concerned) there is a necessity for there to be different, varied and even contentious perspectives across political boundaries on the proposed policies so that real and deliberative legislative debate occurs. Therefore:

- It appears that the absence of any fundamental disagreement between political parties over time regarding ethanol policy, and with there being no substantive differences over such time during ethanol debate regardless of political control of either the Congress or Executive branch, the process lead to very detrimental ethanol policy outcomes. A lack of disagreement resulted in there being a myopic, self-reinforcing political behavior limiting real differences of opinion. Intelligent and realistic alternatives to proposed ethanol policies were not heard or seriously considered by ether party or the Executive branch anywhere along the several decade long policy timeline.

- In the Constitutional construct designed by the Founders it appears clear that they recognized a need for opposing positions, robust debate and substantive debate over proposed bills in order to reach intelligently considered policy conclusions.

- The unique course of ethanol policy formation over several decades makes it virtually impossible to calibrate the degree to which political perspectives presented in figure 5 factored into legislation enacted, although it appears inescapable that such factors were present to a significant degree. 
This work, while concluding that at every phase of ethanol policy there were active attributes of deliberative democracy present, also begs the question: would outcomes plausibly be any worse in the absence of deliberative democracy processes? In as much as ethanol policies have been shown to be significantly detrimental to the national benefit, it is difficult to imagine how the outcomes could have been worse. Assessing such a possibility would be worthy of further study.

It would certainly appear that there is a profound deliberative democracy dilemma that has faced corn state legislators for many years. It is clear that they (from both parties) truly believe in the value and importance of ethanol for the strategic security of the nation, yet over time it has become increasingly clear that the policy has been terribly flawed from the very beginning. So then, what does the true believing corn state legislator do? If they support and vote for ethanol subsidies they are assured of voter support in their states regardless of party as ethanol certainly trumps party amongst farmers and ethanol producers. Those legislators clearly are working to bring the greatest possible benefit to their constituencies. Yet at the same time they are more clearly not bringing a benefit to the nation. The even more difficult question then is how does the corn state legislator (or any other supporting ethanol policy) rationally reconcile in his or her mind the overwhelming evidence presented in Washington that the policy is not in the national interest? And of even more personal consequence to any such legislator is the realization that should they do what is best for the national benefit, they will certainly not be reelected no matter what party they represent 
nor how substantial their campaign funds. Andreas' recollections shed a different light on the origins of ethanol production and use which enriches understanding of national ethanol policy.

Possibly the best summation of the change over time outcomes of deliberative democracy behavior in energy policy is found in the comments of Ken Glozer reminiscing about his many years of observing the legislative process in action. It appears to him that over the past 30 plus years of national energy policy challenges there has been a transition from 'deliberative' legislation to 'special interest' law making. It is difficult to argue with his conclusion. 


\section{Appendix I}

\section{1 actions proposed in 1979 related to Gasohol or Alcohol Fuel}

H.R.1006: Gasohol Motor Fuel Act of 1979

Sponsor: Rep Edwards, Don [CA-10] (introduced 1/18/1979)

Cosponsors (50)

Committees: House Interstate and Foreign Commerce

Latest Major Action: 1/18/1979 Referred to House committee. Status: Referred to House Committee on Interstate and Foreign Commerce.

H.R.1467: Alcohol Fuel Encouragement Act of 1979

Sponsor: Rep Young, C.W. Bill [FL-6] (introduced 1/24/1979)

Cosponsors (None)

Committees: House Interstate and Foreign Commerce; House Ways and Means

Latest Major Action: 1/24/1979 Referred to House committee. Status: Referred to House Committee on Ways and Means.

H.R.1980: Grain Products Utilization Act of 1979

Sponsor: Rep Hagedorn, Thomas M. [MN-2] (introduced 2/8/1979)

Cosponsors (42)

Committees: House Agriculture; House Interstate and Foreign Commerce; House Science and Technology; House Ways and Means

Latest Major Action: 2/8/1979 Referred to House committee. Status: Referred to House Committee on Ways and Means.

H.R.2153: National Fuel Alcohol and Farm Commodity Production Act of 1979 Sponsor: Rep Bedell, Berkley W. [IA-6] (introduced 2/15/1979) Cosponsors (30)

Committees: House Agriculture

Latest Major Action: 2/15/1979 Referred to House committee. Status: Referred to House Committee on Agriculture.

H.R.2647: A bill to amend the Clean Air Act to promote the use of alcohol as a motor vehicle fuel and as an additive to motor vehicle fuels, and for other purposes.

Sponsor: Rep Glickman, Dan [KS-4] (introduced 3/6/1979) Cosponsors (106)

Committees: House Interstate and Foreign Commerce 
Latest Major Action: 3/6/1979 Referred to House committee. Status: Referred to House Committee on Interstate and Foreign Commerce.

H.R.3018: Alcohol Fuel Additive Act of 1979

Sponsor: Rep Miller, Clarence E. [OH-10] (introduced 3/15/1979)

Cosponsors (18)

Committees: House Agriculture; House Science and Technology

Latest Major Action: 3/15/1979 Referred to House committee. Status: Referred to House Committee on Science and Technology.

H.R.3029: A bill to amend the Federal Property and Administrative Services Act of 1949 to require the General Services Administration to provide for fueling not less than 10 percent of Federal non-military vehicles with gasohol fuels, and for other purposes.

Sponsor: Rep Smith, Virginia [NE-3] (introduced 3/15/1979)

Cosponsors (None)

Committees: House Government Operations

Latest Major Action: 3/15/1979 Referred to House committee. Status: Referred to House Committee on Government Operations.

H.R.3030: A bill to extend for an additional 5 years the provisions of the Energy Tax Act of 1978 which exempt certain alcohol fuels from Federal motor fuels excise taxes.

Sponsor: Rep Smith, Virginia [NE-3] (introduced 3/15/1979)

Cosponsors (None)

Committees: House Ways and Means

Latest Major Action: 3/15/1979 Referred to House committee. Status: Referred to House Committee on Ways and Means.

H.R.3905: National Alcohols and Alcohol Fuel and Farm Commodity Production Act of 1979

Sponsor: Rep Bedell, Berkley W. [IA-6] (introduced 5/3/1979) Cosponsors (52)

Committees: House Agriculture; House Banking, Finance, and Urban Affairs House Reports: 096-515 Part 1

Latest Major Action: 10/26/1979 Committee on Banking, Finance and Urban Affairs discharged in House. 
H.R.3958: Gasohol Marketing Freedom Act of 1979

Sponsor: Rep Daschle, Thomas A. [SD-1] (introduced 5/7/1979) Cosponsors (67)

Committees: House Interstate and Foreign Commerce

Latest Major Action: 5/7/1979 Referred to House committee. Status: Referred to House Committee on Interstate and Foreign Commerce.

H.R.4056: Federal Gasohol Purchase Act

Sponsor: Rep Hughes, William J. [NJ-2] (introduced 5/10/1979) Cosponsors (24)

Committees: House Government Operations

Latest Major Action: 5/10/1979 Referred to House committee. Status: Referred to House Committee on Government Operations.

H.R.4215: A bill to amend the Internal Revenue Code of 1954 to facilitate the production of alcohol fuels.

Sponsor: Rep Ullman, Al [OR-2] (introduced 5/23/1979) Cosponsors

(7)

Committees: House Ways and Means

Latest Major Action: 5/23/1979 Referred to House committee. Status: Referred to House Committee on Ways and Means.

H.R.4245: National Alcohol Fuel and Farm Commodity Production Act of 1979 Sponsor: Rep Corman, James C. [CA-21] (introduced 5/30/1979) Cosponsors (None)

Committees: House Agriculture

Latest Major Action: 5/30/1979 Referred to House committee. Status: Referred to House Committee on Agriculture.

H.R.4368: A bill to amend the Internal Revenue Code of 1954 to make certain technical corrections with respect to the treatment of gasoline mixed with alcohol.

Sponsor: Rep Bedell, Berkley W. [IA-6] (introduced 6/7/1979) Cosponsors (None)

Committees: House Ways and Means

Latest Major Action: 6/7/1979 Referred to House committee. Status: Referred to House Committee on Ways and Means. 
H.R.4558: National Alcohol Fuel and Farm Commodity Production Act of 1979 Sponsor: Rep Bedell, Berkley W. [IA-6] (introduced 6/21/1979) Cosponsors (None)

Committees: House Agriculture; House Banking, Finance, and Urban Affairs;

House Interstate and Foreign Commerce

Latest Major Action: 6/21/1979 Referred to House committee. Status: Referred to House Committee on Interstate and Foreign Commerce.

H.R.4722: A bill to make permanent the exemption of gasohol from the Federal motor fuel excise taxes, and for other purposes.

Sponsor: Rep Peyser, Peter A. [NY-23] (introduced 7/10/1979)

Cosponsors (None)

Committees: House Ways and Means

Latest Major Action: 7/10/1979 Referred to House committee. Status: Referred to House Committee on Ways and Means.

H.R.4815: A bill to amend the Internal Revenue Code of 1954 to facilitate the production of alcohol fuels.

Sponsor: Rep Abdnor, James [SD-2] (introduced 7/17/1979)

Cosponsors (None)

Committees: House Ways and Means

Latest Major Action: 7/17/1979 Referred to House committee. Status: Referred to House Committee on Ways and Means.

H.R.4819: Gasohol Motor Fuel Act of 1979

Sponsor: Rep Gaydos, Joseph M. [PA-20] (introduced 7/17/1979) Cosponsors (None)

Committees: House Interstate and Foreign Commerce

Latest Major Action: 7/17/1979 Referred to House committee. Status: Referred to House Committee on Interstate and Foreign Commerce.

H.R.5044: A bill to amend the Internal Revenue Code of 1954 to provide for the credit or refund of the tax on any gasoline which is used in the production of certain alcohol fuels.

Sponsor: Rep Bedell, Berkley W. [IA-6] (introduced 8/1/1979)

Cosponsors (None)

Committees: House Ways and Means

Latest Major Action: 8/1/1979 Referred to House committee. Status: Referred to House Committee on Ways and Means. 
H.R.5296: A bill to make permanent the exemption of gasohol from the Federal motor fuels excise taxes, and for other purposes.

Sponsor: Rep Smith, Virginia [NE-3] (introduced 9/14/1979)

Cosponsors (30)

Committees: House Ways and Means

Latest Major Action: 9/14/1979 Referred to House committee. Status: Referred to House Committee on Ways and Means.

H.R.6161: National Alcohols and Alcohol Fuel and Farm Commodity Production Act of 1979

Sponsor: Rep Bowen, David R. [MS-2] (introduced 12/18/1979) Cosponsors (None)

Committees: House Agriculture; House Banking, Finance, and Urban Affairs; House Interstate and Foreign Commerce

Latest Major Action: 12/18/1979 Referred to House committee. Status: Referred to House Committee on Interstate and Foreign Commerce.

H.R.6248: Gasohol Marketing Practices Act of 1980

Sponsor: Rep Gore, Albert, Jr. [TN-4] (introduced 1/22/1980)

Cosponsors (None)

Committees: House Interstate and Foreign Commerce

Latest Major Action: 1/22/1980 Referred to House committee. Status: Referred to House Committee on Interstate and Foreign Commerce.

H.R.6691: A bill to amend the Clayton Act to prohibit restrictions on the use of credit instruments in the purchase of gasohol.

Sponsor: Rep Hughes, William J. [NJ-2] (introduced 3/4/1980)

Cosponsors (38)

Committees: House Judiciary

Latest Major Action: 3/4/1980 Referred to House committee. Status: Referred to House Committee on the Judiciary.

H.R.7656: Ethanol Production Incentive Act of 1980

Sponsor: Rep Findley, Paul [IL-20] (introduced 6/25/1980)

Cosponsors (None)

Committees: House Agriculture; House Banking, Finance, and Urban Affairs

Latest Major Action: 6/25/1980 Referred to House committee. Status: Referred to House Committee on Banking, Finance and Urban Affairs. 
H.R.7873: Gasohol Competition Act of 1980

Sponsor: Rep Hughes, William J. [NJ-2] (introduced 7/30/1980) Cosponsors (40)

Committees: House Judiciary

House Reports: 096-1464

Latest Major Action: 11/17/1980 Passed/agreed to in House. Status: Measure passed House, amended.

Latest Action: 11/17/1980 Measure laid on table in House, S. 2251 passed in lieu.

H.CON.RES.278: A concurrent resolution expressing the sense of the Congress that the President and the Congress should establish programs and enact legislation that will assure that not later that January 1, 1990, the total quantity of gasoline sold in commerce in the United States by any refiner for use as motor fuel shall contain, on the average, not less than ten percent alcohol fuel by volume.

Sponsor: Rep Skelton, Ike [MO-4] (introduced 2/12/1980) (None)

Committees: House Interstate and Foreign Commerce

Latest Major Action: 2/12/1980 Referred to House committee. Status: Referred to House Committee on Interstate and Foreign Commerce.

H.RES.617: A resolution to express the sense of the House regarding the immediate need for expedited federal action on programs to aid domestic alcohol fuels production.

Sponsor: Rep Roe, Robert A. [NJ-8] (introduced 3/20/1980)

Cosponsors (5)

Committees: House Agriculture; House Interstate and Foreign Commerce

Latest Major Action: 3/20/1980 Referred to House committee. Status: Referred to House Committee on Interstate and Foreign Commerce.

S.750: Gasohol Motor Fuel Act of 1979

Sponsor: Sen. Church, Frank [ID] (introduced 3/26/1979)

Cosponsors (None)

Committees: Senate Energy and Natural Resources

Latest Major Action: 3/26/1979 Referred to Senate committee. Status: Referred to Senate Committee on Energy and Natural Resources. 
S.819: Clean Air Act Amendments of 1979

Sponsor: Sen. Pressler, Larry [SD] (introduced 3/28/1979)

Cosponsors

(3)

Committees: Senate Energy and Natural Resources

Latest Major Action: 3/28/1979 Referred to Senate committee. Status: Referred to Senate Committee on Energy and Natural Resources.

S.850: National Fuel Alcohol and Farm Commodity Production Act of 1979

Sponsor: Sen. McGovern, George [SD] (introduced 4/2/1979)

Cosponsors (3)

Committees: Senate Agriculture, Nutrition, and Forestry

Latest Major Action: 4/2/1979 Referred to Senate committee. Status: Referred to Senate Committee on Agriculture, Nutrition and Forestry.

S.862: A bill to extend the exemption from federal excise tax on the use of gasohol and for other purposes.

Sponsor: Sen. Dole, Robert J. [KS] (introduced 4/2/1979) Cosponsors (None)

Committees: Senate Finance

Latest Major Action: 4/2/1979 Referred to Senate committee. Status: Referred to Senate Committee on Finance.

S.1042: Public Vehicle Gasohol Incentive Act of 1979

Sponsor: Sen. Durkin, John A. [NH] (introduced 4/30/1979)

Cosponsors (None)

Committees: Senate Finance

Latest Major Action: 4/30/1979 Referred to Senate committee. Status: Referred to Senate Committee on Finance.

S.1200: A bill entitled the "Alcohol Fuels Regulatory Simplification Act of 1979".

Sponsor: Sen. Bayh, Birch [IN] (introduced 5/22/1979)

Cosponsors (24)

Committees: Senate Finance

Latest Major Action: 5/22/1979 Referred to Senate committee. Status: Referred to Senate Committee on Finance.

S1208: Public Vehicle Gasohol Incentive Act of 1979

Sponsor: Sen. Durkin, John A. [NH] (introduced 5/22/1979)

Cosponsors (None)

Committees: Senate Energy and Natural Resources 
Latest Major Action: 5/22/1979 Referred to Senate committee. Status: Referred to Senate Committee on Energy and Natural Resources.

S.1268: Gasohol Marketing Freedom Act of 1979

Sponsor: Sen. Bayh, Birch [IN] (introduced 6/4/1979)

Cosponsors (12)

Committees: Senate Energy and Natural Resources

Latest Major Action: 6/4/1979 Referred to Senate committee. Status: Referred to Senate Committee on Energy and Natural Resources.

S.1520: A bill to amend the Internal Revenue Code of 1954 to make certain technical corrections with respect to the treatment of gasoline mixed with alcohol.

Sponsor: Sen. Bayh, Birch [IN] (introduced 7/16/1979)

Cosponsors (None)

Committees: Senate Finance

Latest Major Action: 7/16/1979 Referred to Senate committee. Status: Referred to Senate Committee on Finance.

S.1587: United States Motor Fuel Independence Act of 1979

Sponsor: Sen. McClure, James A. [ID] (introduced 7/26/1979)

Cosponsors (3)

Committees: Senate Finance

Latest Major Action: 7/26/1979 Referred to Senate committee. Status: Referred to Senate Committee on Finance.

S.1746: A bill to amend the Internal Revenue Code of 1954 to provide for the credit or refund of the tax on any gasoline which is used in the production of certain alcohol fuels.

Sponsor: Sen. Bayh, Birch [IN] (introduced 9/13/1979)

Cosponsors (None)

Committees: Senate Finance

Latest Major Action: 9/13/1979 Referred to Senate committee. Status: Referred to Senate Committee on Finance.

S.2251: Gasohol Competition Act of 1980

Sponsor: Sen. Metzenbaum, Howard M. [OH] (introduced 2/4/1980)

Cosponsors (28) 
Committees: Senate Finance; Senate Judiciary; House Judiciary

Senate Reports: 096-868

Latest Major Action: 12/2/1980 Public Law 96-493.

S. RES.2354: Energy Independence Grain Reserve Act

Sponsor: Sen. Bayh, Birch [IN] (introduced 2/27/1980)

Cosponsors (2)

Committees: Senate Agriculture, Nutrition, and Forestry

Latest Major Action: 2/27/1980 Referred to Senate committee. Status: Referred to Senate Committee on Agriculture, Nutrition and Forestry.

S.RES.387: A resolution to express the sense of the Senate regarding the immediate need for expedited federal action on programs to aid domestic fuels production.

Sponsor: Sen. Bayh, Birch [IN] (introduced 3/20/1980)

Cosponsors (4)

Committees: Senate Agriculture, Nutrition, and Forestry

Latest Major Action: 3/20/1980 Referred to Senate committee. Status: Referred to Senate Committee on Agriculture, Nutrition and Forestry. 


\section{Appendix II}

\section{FOOD, CONSERVATION, AND ENERGY ACT OF 2008--VETO MESSAGE FROM THE PRESIDENT OF THE UNITED STATES (H. DOC. NO. 110-125) -- (House of Representatives - June 18, 2008) \\ [Page: H5535]}

The SPEAKER pro tempore laid before the House the following veto message from the President of the United States:

\section{To the House of Representatives:}

I am returning herewith without my approval H.R. 6124, the "Food, Conservation, and Energy Act of 2008."

The bill that I vetoed on May 21, 2008, H.R. 2419, which became Public Law 110-234, did not include the title III provisions that are in this bill. In passing H.R. 6124, the Congress had an opportunity to improve on H.R. 2419 by modifying certain objectionable, onerous, and fiscally imprudent provisions. Unfortunately, the Congress chose to send me the same unacceptable farm bill provisions in H.R. 6124, merely adding title III. I am returning this bill for the same reasons as stated in my veto message of May 21, 2008, on H.R. 2419.

For a year and a half, I have consistently asked that the Congress pass a good farm bill that I can sign. Regrettably, the Congress has failed to do so. At a time of high food prices and record farm income, this bill lacks program reform and fiscal discipline. It continues subsidies for the wealthy and increases farm bill spending by more than $\$ 20$ billion, while using budget gimmicks to hide much of the increase. It is inconsistent with our objectives in international trade negotiations, which include securing greater market access for American farmers and ranchers. It would needlessly expand the size and scope of government. Americans sent us to Washington to achieve results and be good stewards of their hard-earned taxpayer dollars. This bill violates that fundamental commitment.

In January 2007, my Administration put forward a fiscally responsible farm bill proposal that would improve the safety net for farmers and move current programs toward more market-oriented policies. The bill before me today fails to achieve these important goals.

At a time when net farm income is projected to increase by more than $\$ 28$ billion in 1 year, the American taxpayer should not be forced to subsidize that group of farmers who have adjusted gross incomes of up to $\$ 1.5$ million. When commodity prices are at record highs, it is irresponsible to increase government subsidy rates for 15 crops, subsidize additional crops, and provide payments that 
further distort markets. Instead of better targeting farm programs, this bill eliminates the existing payment limit on marketing loan subsidies.

Now is also not the time to create a new uncapped revenue guarantee that could cost billions of dollars more than advertised. This is on top of a farm bill that is anticipated to cost more than $\$ 600$ billion over 10 years. In addition, this bill would force many businesses to prepay their taxes in order to finance the additional spending.

This legislation is also filled with earmarks and other ill-considered provisions. Most notably, H.R. 6124 provides: $\$ 175$ million to address water issues for desert lakes; \$250 million for a 400,000-acre land purchase from a private owner; funding and authority for the noncompetitive sale of National Forest land to a ski resort; and \$382 million earmarked for a specific watershed. These earmarks, and the expansion of Davis-Bacon Act prevailing wage requirements, have no place in the farm bill. Rural and urban Americans alike are frustrated with excessive government spending and the funneling of taxpayer funds for pet projects. This bill will only add to that frustration.

The bill also contains a wide range of other objectionable provisions, including one that restricts our ability to redirect food aid dollars for emergency use at a time of great need globally. The bill does not include the requested authority to buy food in the developing world to save lives. Additionally, provisions in the bill raise serious constitutional concerns. For all the reasons outlined above, I must veto H.R. 6124.

I veto this bill fully aware that it is rare for a stand-alone farm bill not to receive the President's signature, but my action today is not without precedent. In 1956, President Eisenhower stood firmly on principle, citing high crop subsidies and too much government control of farm programs among the reasons for his veto. President Eisenhower wrote in his veto message, "Bad as some provisions of this bill are, I would have signed it if in total it could be interpreted as sound and good for farmers and the nation." For similar reasons, I am vetoing the bill before me today.

George W. Bush.

The White House, June 18, 2008. ${ }^{278}$

${ }^{278}$ (Library of Congress, 2008) 


\section{Appendix III}

\section{Legislative Histories}

\section{Energy Tax Act}

Sponsor by Rostenkowski (D-IL)
Public Law 95-618

Cosponsors: 0

Introduced: 3/21/77

Official Title as introduced: A bill to suspend until the close of June 30, 1979, the duty on certain bicycle parts

Official Title as enacted: An Act to provide tax incentives for the production and conservation of energy, and for other purposes

Committees: House Ways and Means Committee

\section{Senate Committee on Finance}

House Science and Technology

Senate Energy and Natural Resources.

House Energy

House Interstate and Foreign Commerce

House Committee on Banking, Finance, and Urban Affairs

Signed into law: 11/9/78 by Jimmy Carter

Senate: $61 \mathrm{D} ; 38 \mathrm{R} ; 1 \mathrm{I}$

House: 292 D; 143 R

1980 Crude Oil Windfall Profit Tax Act

Sponsored by Cotter (R-CT)

\section{Public Law 96-223}

Cosponsors: 22

Introduced: 4/4/79

Official Title as introduced: A bill to impose a windfall profits tax on domestic crude oil

Official Title as enacted: Crude Oil Windfall Profit Act

Committees: House Ways and Means Committee 
Signed into law: 4/2/80 by Jimmy Carter

Senate: 58 D; 41 R; 1 I

House: $227 \mathrm{D} ; 158 \mathrm{R}$

1980 Energy Security Act

Public Law 96-294

Sponsored by: Proxmire (D-WI)

Cosponsors: 0

Introduced: 4/9/79

Official Title as introduced: A bill to extend the Defense Protection Act of 1950, as amended

Committees: Senate Banking, House and Urban Affairs

Senate Energy and Natural Resources

Signed into law: 6/30/80 by Jimmy Carter

Senate: 58 D; $41 \mathrm{R} ; 1$ I

House: $227 \mathrm{D} ; 158 \mathrm{R}$

1980 Gasohol Competition Act

Public Law 96-493

Sponsored by: Metzenbaum (D-OH)

Cosponsors: 28

Introduced: $2 / 4 / 80$

Official Title as introduced: A bill to amend the Clayton Act to prohibit restrictions on the use of credit instruments in the purchase of gasohol

Committees: Senate Finance

Senate Judiciary

House Judiciary

Signed into law: 12/2/80 by Jimmy Carter

Senate: 58 D; 41 R; 1 I

House: 227 D; 158 R

1980 Omnibus Budget Reconciliation Act

Public Law 96-499

Sponsored by: Giaimo (D-CT)

Cosponsors: 0 
Introduced: $7 / 21 / 80$

Official Title as introduced: A bill to provide for reconciliation pursuant to section 3 of the First Concurrent Resolution on the Budget for the fiscal year 1981.

Committees: House Budget

Senate Budget

Signed into law: 12/5/80 by Jimmy Carter

Senate: 58 D; 41 R; 1 I

House: $227 \mathrm{D} ; 158 \mathrm{R}$

1982 Surface Transportation Assistance Act

Sponsored by: Anderson (D-CA)
Public Law 97-424

Cosponsors: 3

Introduced: $4 / 29 / 82$

Official Title as introduced: A bill to authorize appropriations for construction of certain highways in accordance with title 23, United States Code, for highway safety, for mass transportation in urban and rural areas, and for other purposes.

Committees: House Public Works and Transportation

$$
\text { Senate Finance }
$$

Signed into law: 1/6/83 by Ronald Reagan

Senate: $46 \mathrm{D} ; 54 \mathrm{R}$

House: $269 \mathrm{D} ; 166 \mathrm{R}$

1984 Tax Reform Act

Public Law 98-369

Sponsored by: Rostenkowski (D-IL)

Cosponsors: 23

Introduced: $10 / 20 / 83$

Official Title as introduced: A bill for tax reform, and other purposes

Committees: House Ways and Means

Signed into law: 7/18/84 by Ronald Reagan 
Introduced: $7 / 21 / 87$

Official Title as introduced: A bill to amend the Motor Vehicle Information and Cost Savings Act to provide treatment of methanol and ethanol, and for other purposes.

Committees: Senate Commerce, Science and Transportation

Signed into law: 10/14/88 by Ronald Reagan

Senate: 55 D; 45 R

House: 258D; $177 \mathrm{R}$

1990 Customs and Trade Act

Public Law 101-382

Sponsored by: Gibbons (D-FL)

Cosponsors: 2

Introduced: $3 / 23 / 89$

Official Title as introduced: To extend nondiscriminatory treatment of the products of the Peoples' Republic of Hungary for 5 years.

Committees: House Ways and Means

Senate Finance

Signed into law: 8/20/90 by George H. W. Bush

Senate: 55 D; 45 R

House: $258 \mathrm{D} ; 177 \mathrm{R}$

1990 Omnibus Budget Reconciliation Act

Public Law 101-508

Sponsored by: Panetta (D-CA)

Cosponsors: 0

Introduced: $10 / 15 / 90$

Official Title as introduced: An Act to provide for reconciliation of section 4 of the concurrent resolution on the budget for fiscal year 1991. 
Committees: House Budget

Signed into law: 1/4/91 by George H. W. Bush

Senate: $55 \mathrm{D} ; 45 \mathrm{R}$

House: $260 \mathrm{D} ; 175 \mathrm{R}$

1990 Clean Air Act Amendments

Sponsored by: Baucus (D-MT)
Public Law 101-549

Cosponsors: 22

Introduced: 9/14/89

Official Title as introduced: To amend the Clean Air Act to provide for attainment and maintenance of health protective national ambient air quality standards, and for other purposes.

Committees: Senate Environment and Public Works

Signed into law: 11/15/90 by George H. W. Bush

Senate: $55 \mathrm{D} ; 45 \mathrm{R}$

House: 260 D; $175 \mathrm{R}$

1992 Energy Policy Tax Act

Public Law 102-486

Sponsored by: Sharp (D-IN)

Cosponsors: 54

Introduced: 2/4/91

Official Title as introduced: To provide for improved energy efficiency

Committees: House Energy and Commerce

House Government Operations

House Judiciary

House Interior and Insular Affairs

House Merchant Marine and Fisheries

House Public Works and Transportation

House Science, Space and Technology 
House Ways and Means

House Agriculture

Senate Finance

Signed into law: 10/24/92 by George H. W. Bush

Senate: $55 \mathrm{D} ; 45 \mathrm{R}$

House: 260 D; $175 \mathrm{R}$

1993 Omnibus Budget Reconciliation Act

Sponsored by: Sabo (D-MN)
Public Law 103-66

Cosponsors: 0

Introduced: $2 / 25 / 93$

Official Title as introduced: To provide for reconciliation pursuant to section 7 of the concurrent resolution on the budget for fiscal year 1994.

Committees: House Budget

House Judiciary

Signed into law: 8/10/93 by George H. W. Bush

Senate: $55 \mathrm{D} ; 45 \mathrm{R}$

House: $258 \mathrm{D} ; 177 \mathrm{R}$

1997 Taxpayer Relief Act

Public Law 105-34

Sponsored by: Kasich (R-OH)

Cosponsors: 0

Introduced: 6/24/97

Official Title as introduced: A bill to provide for reconciliation pursuant to subsections (b) (2) and (d) of section 105 of the concurrent resolution on the budget for fiscal year 1998.

Committees: House Budget

Signed into law: 8/5/97 by Bill Clinton

Senate: 45 D; 55 R

House: 207 D; 226 R; 21 
Introduced: 9/4/97

Official Title as introduced: A bill to authorize funds for Federal-aid highways, highway safety programs, and transit programs, and for other purposes.

Committees: House Transportation and Infrastructure

House Budget

House Ways and Means

Signed into law: 6/9/98 by Bill Clinton

Senate: 45 D; 55 R

House: 207 D; 226 R; 2

1998 Agricultural Research, Extension and Education Reform Act

Sponsored by: Lugar (R-IN)
Public Law 105-185

Cosponsors: 0

Introduced: $9 / 5 / 97$

Official Title as introduced: An original bill to ensure that federally funded agricultural research, extension, and education address high-priority concerns with national or multistate significance, to reform, extend, and eliminate certain agricultural research programs, and for other purposes.

Committees: Senate Agriculture, Nutrition and Forestry Signed into law: 6/23/98 by Bill Clinton

Senate: 45 D; 55 R

House: 207 D; 226 R; 2 I

2000 Agriculture Risk Protection Act

Sponsored by: Combest (R-TX)

Introduced: $7 / 20 / 99$
Public Law 106-224

Cosponsors: 12 
Official Title as introduced: To amend the Federal Crop Insurance Act to strengthen the safety net for agricultural producers by providing greater access to more affordable risk management tools and improved protection from production and income loss, to improve the efficiency and integrity of the Federal crop insurance program, and for other purposes.

Committees: House Agriculture

Senate Agriculture, Nutrition and Forestry

Signed into law: 6/20/00 by Bill Clinton

Senate: $45 \mathrm{D} ; 55 \mathrm{R}$

House: 207 D; 226 R; 2 I

\section{Agriculture, Rural Development, Food \& Drug Public Law 107-76 Administration \& Related Agencies Appropriations Act}

Sponsored by: Bonilla (R-TX)

Cosponsors: 0

Introduced: 6/27/01

Official Title as introduced: Making appropriations for Agriculture, Rural Development, Food and Drug Administration, and Related Agencies programs for the fiscal year ending September 30, 2002, and for other purposes.

Committees: House Appropriations

Senate Appropriations

Signed into law: 11/28/01by George W. Bush

Senate: $50 \mathrm{D} ; 50 \mathrm{R}$

House: 212 D; $221 \mathrm{R} ; 2$ I

2004 American Jobs Creation Act

Public Law 108-357

Sponsored by: Thomas (R-CA)

Cosponsors: 40

Introduced: 6/4/04

Official Title as introduced: A bill to amend the Internal Revenue Code of 1986 to remove impediments in such Code and make our manufacturing, service, and high-technology businesses and workers more competitive and productive both at home and abroad.

Committees: House Ways and Means 
House Agriculture

Signed into law: 10/22/04 by George W. Bush

Senate: 48 D; 51 R; 1 I

House: 205 D; 229 R; 1 I

2005 Energy Policy Act

Public Law 109-58

Sponsored by: Barton (R-TX)

Cosponsors: 2

Introduced:

Official Title as introduced: To ensure jobs for our future with secure, affordable, and reliable energy.

Committees: House Energy and Commerce

House Education and the Workforce

House Financial Services

House Agriculture; House Resources

House Science

House Ways and Means

House Transportation and Infrastructure

Signed into law: 8/8/05 by George W. Bush

Senate: 48 D; 51 R; 1 I

House: 205 D; 229 R; 1 I

2005 Safe, Accountable, Flexible, Efficient Transportation Equity Act

Public Law 109-59

Sponsored by: Young (R-AK)

Cosponsors: 79

Introduced: $2 / 9 / 05$

Official Title as introduced: A bill to authorize funds for Federal-aid highways, highway safety programs, and transit programs, and for other purposes. 
Committees: House Transportation and Infrastructure

Signed into law: 8/10/05 by George W. Bush

Senate: 48 D; 51 R; 1 I

House: 205 D; 229 R; 1 I

2006 National Defense Authorization Act

Sponsored by: Hunter (R-CA)
Public Law 109-163

Cosponsors: 1

Introduced: 4/26/05

Official Title as introduced: To authorize appropriations for fiscal year 2006 for military activities of the Department of Defense, to prescribe military personnel strengths for fiscal year 2006, and for other purposes.

Official Title as amended by the House: To authorize appropriations for fiscal year 2006 for military activities of the Department of Defense, for military construction, and for defense activities of the Department of Energy, to prescribe military personnel strengths for such fiscal year.

Committees: House Armed Services

Senate Armed Services

Signed into law: 6/1/06 by George W. Bush

Senate: 44 D; 55 R; 1 I

2006 Tax Relief and Heath Care Act

Sponsored by: Taucher (D-CA)
House: 202 D; 23 R; 1 I

Public Law 109-432

Cosponsors: 0

Introduced: 9/19/06

Official Title as introduced: To amend the Internal Revenue Code of 1986 to provide that the Tax Court may review claims for equitable innocent spouse relief and to suspend the running on the period of limitations while such claims are pending.

Official Title as amended by Senate: An act to amend the Internal Revenue Code of 1986 to extend expiring provisions, and for other purposes.

Committees: House Ways and Means 
Signed into law: 12/20/06 by George W. Bush

Senate: 49 D; 49 R; 2 I

House: 205 D; 229 R; 1 I

2007 Energy Independence and Security Act

Public Law 110-140

Sponsored by: Rahall (D-WV)

Cosponsors: 198

Introduced: $1 / 12 / 07$

Official Title as introduced: To reduce our Nation's dependency on foreign oil by investing in clean, renewable, and alternative energy resources, promoting new emerging energy technologies, developing greater efficiency, and creating a Strategic Energy Efficiency and Renewables Reserve to invest in alternative energy, and for other purposes.

Official Title as amended by Senate: An Act to move the United States toward greater energy independence and security, to increase the production of clean renewable fuels, to protect consumers, to increase the efficiency of products, buildings, and vehicles, to promote research on and deploy greenhouse gas capture and storage options, and to improve the energy performance of the Federal Government, and for other purposes.

Committees: House Ways and Means

House Natural Resources

House Budget; House Rules

House Transportation and Infrastructure

Signed into law: 12/19/07 by George W. Bush

Senate: 49 D; 49 R; 2 I

House: D 233; R 198

2007 Paul Wellstone Mental Health and Addiction Equity Act

Public Law 110-343

Sponsored by: Kennedy (D-RI)

Cosponsors: 274

Introduced: 3/9/07 
Official Title as introduced: To amend section 712 of the Employee Retirement Income Security Act of 1974, section 2705 of the Public Health Service Act, and section 9812 of the Internal Revenue Code of 1986 to require equity in the provision of mental health and substance-related disorder benefits under group health plans.

Official Title as amended by Senate: A bill to provide authority for the Federal Government to purchase and insure certain types of troubled assets for the purposes of providing stability to and preventing disruption in the economy and financial system and protecting taxpayers, to amend the Internal Revenue Code of 1986 to provide incentives for energy production and conservation, to extend certain expiring provisions, to provide individual income tax relief, and for other purposes.

Committees: House Energy and Commerce

House Education and Labor

House Ways and Means

Signed into law: 10/3/08 by George W. Bush

Senate: 49 D; 49 R; 2 I

House: 223 D; 198 R

2008 Food, Conservation and Energy Act

Public Law 110-234

Sponsored by: Peterson (D-MN)

Cosponsors: 0

Introduced: 5/22/07

Official Title as introduced: To provide for the continuation of agricultural programs through fiscal year 2012, and for other purposes.

Committees: House Agriculture

House Foreign Affairs

Passed into law by Senate: 5/22/08

Senate: 49 D; 49 R; 2 I

House: 233 D; $198 \mathrm{R}$

2008 Food, Conservation and Energy Act

Sponsored by: Peterson (D-MN)
Public Law 110-246

Cosponsors: 0 
Introduced: $5 / 22 / 08$

Official Title as introduced: To provide for the continuation of agricultural and other programs of the Department of Agriculture through fiscal year 2012, and for other purposes.

Committees: House Agriculture

House Foreign Affairs

Passed by Senate action: 6/18/08 by George W. Bush

Senate: 49 D; 49 R; 2 I

House: 233 D; $198 \mathrm{R}$

\section{Tax Relief, Unemployment Insurance Reauthorization and Job Creation Act}

Public Law 111-312

Sponsored by: Oberstar (D-MN)

Cosponsors: 5

Introduced: $3 / 16 / 10$

Official Title as introduced: To amend the Internal Revenue Code of 1986 to extend the funding and expenditure authority of the Airport and Airway Trust Fund, to amend title 49, United States Code, to extend authorizations for the airport improvement program, and for other purposes.

Committees: House Transportation and Infrastructure

$$
\text { House Ways and Means }
$$

Signed into law: 12/17/10by Barack Obama

Senate: 57 D; 41 R; 2 other

House $256 \mathrm{D} ; 178 \mathrm{R}$ 


\begin{tabular}{|l|c|c|c|c|}
\hline \multicolumn{1}{|c|}{ President } & $\begin{array}{c}\text { Number of } \\
\text { laws }\end{array}$ & $\begin{array}{c}\text { Energy } \\
\text { Laws }\end{array}$ & $\begin{array}{c}\text { Democrat } \\
\text { introduced }\end{array}$ & $\begin{array}{c}\text { Republican } \\
\text { introduced }\end{array}$ \\
\hline Carter & 5 & 3 & 4 & 1 \\
\hline Reagan & 3 & 1 & 3 & \\
\hline Bush I & 5 & 1 & 5 & \\
\hline Clinton & 4 & 1 & 4 & \\
\hline Bush II & 9 & 3 & 6 & 3 \\
\hline
\end{tabular}




\section{Appendix IV}

\section{Public Law 95-618 - Energy Tax Act - H. R. 5263 Timeline}

An Act to provide tax incentives for the production and conservation of energy, and for other purposes.

Introduced by: Dan Rostenkowski (D-IL)

Cosponsors: none

Committees:

House Subcommittee on Advanced Energy Technologies and Energy Conservation Research, Development, and Demonstration, Committee on Science and Technology.

Senate Committee on Energy and Natural Resources. Senate.

House Committee on Energy

Joint Subcommittee on Energy, Committee on Economic

House Committee on Ways and Means

House Committee on Interstate and Foreign Commerce

House Committee on Banking, Finance, and Urban Affairs

Senate Committee on Energy and Natural Resources

Senate Subcommittee on Administration of the Internal Revenue Code, Committee on Finance.

House Committee on Budget.

Senate Subcommittee on Energy and Foundations, Committee on Finance

Senate Subcommittee on Antitrust and Monopoly, Committee on Judiciary

Senate Subcommittee on Science, Technology, and Space, Committee on Commerce, Science, and Transportation

Senate Subcommittee on Energy Conservation and Regulation, Committee on Energy and Natural Resources

Senate Committee on Finance

Senate Committee on Energy and Natural Resources

Senate Subcommittee on Agricultural Research and General Legislation, Committee on Agriculture, Nutrition, and Forestry

Joint Committee on Economic.

Timeline of Congressional Actions:

\section{3/21/1977:}

Referred to House Committee on Ways and Means.

6/16/1977:

Reported to House from the Committee on Ways and Means with amendment, $\mathrm{H}$. Rept. 95-435.

7/18/1977: 
Measure called up under motion to suspend rules and pass in House.

Measure considered in House. Measure passed House, amended.

7/20/1977:

Referred to Senate Committee on Finance.

10/21/1977:

Reported to Senate from the Committee on Finance with amendment, S. Rept. 95529.

10/25/1977:

Measure called up by unanimous consent in Senate.

Measure considered in Senate.

10/26/1977:

Measure considered in Senate.

10/27/1977:

Measure considered in Senate.

10/28/1977:

Measure considered in Senate.

Motion to recommit to the Committee on Appropriations with instructions passed Senate.

10/29/1977:

Measure considered in Senate.

10/31/1977:

Measure considered in Senate.

Measure passed Senate, amended (52-35).

11/3/1977:

Conference scheduled in House.

11/4/1977:

Conference scheduled in Senate.

10/11/1978:

Conference report filed in Senate, S. Rept. 95-1324.

10/12/1978:

Conference report filed in House, H. Rept. 95-1773.

Motion to proceed to consider Conference report passed Senate, roll call \#482 (77-8).

Cloture Motion filed in Senate on Conference report.

10/14/1978:

House agreed to conference report (231-168).

Cloture Motion on Conference Report passed Senate (71-13).

Motion to table Conference Report rejected in Senate (22-56).

Motion to recommit Conference Report to the Committee of Conference with instructions tabled in Senate.

Motion to recommit Conference Report to the Committee of Conference tabled in Senate (67-11).

Senate agreed to conference report (60-17).

Cleared for White House

Measure enrolled in House.

Measure enrolled in Senate.

10/31/1978: 
Measure presented to President.

11/9/1978:

Signed by President.

Public Law 95-618. 


\section{Appendix V}

\section{Public Law 100-494 - Alternative Motor Fuels Act of 1988 - S 1518 Timeline}

A bill to amend the Motor Vehicle Information and Cost Savings Act to provide for the appropriate treatment of methanol and ethanol, and for other purposes.

Short Title: Alternative Motor Fuels Act of 1988

Introduced by: Rockefeller (D-WV) July 21, 1987

64 Cosponsors

Committees:

Senate Commerce, Science and Transportation

Timeline of Congressional Actions: ${ }^{279}$

\section{7/21/1987:}

Read twice and referred to the Committee on Commerce.

\section{1/12/1987:}

Subcommittee on Consumer. Hearings held.

\section{1/19/1987:}

Committee on Commerce. Ordered to be reported with an amendment in the nature of a substitute favorably.

\section{2/21/1987:}

Committee on Commerce. Reported to Senate by Senator Hollings with an amendment in the nature of a substitute.

\section{2/21/1987:}

Placed on Senate Legislative Calendar under General Orders.

\section{4/15/1988:}

Debates in Senate

Amendment proposed by Senator Rockefeller.

To strike section 8 .

Amendment proposed by Senator Danforth for Senator Chafee.

To recognize the need for the development of technologies to control increased carbon dioxide emissions that result with methanol from a coalto-methanol industry to avoid aggravation of the greenhouse effect and global climate change.

Amendment proposed by Senator Stafford.

To prevent increases in carbon dioxide and other air pollutants from the production and burning of methanol made from coal.

Rockefeller amendment agreed to in Senate by Voice Vote.

Danforth amendment agreed to in Senate by Voice Vote.

Stafford amendment SP 1952 not agreed to in Senate by Voice Vote.

${ }^{279}$ Modified from http://thomas.loc.gov/cgi-bin/bdquery/z?d106:HR02559:@@@S 
Measure laid before Senate by unanimous consent.

Passed Senate with amendments by Voice Vote.

4/18/1988:

Message on Senate action sent to the House.

6/28/1988:

Debates in Congress

Amendment Offered by Representative Bruce.

The Bruce amendment in the nature of a substitute consists of the

text as passed by the House.

Amendment Offered by Representative Bruce.

An amendment in the nature of a substitute.

Bruce Amendment II passed House.

Bruce Amendment I passed in Committee of the Whole by Voice Vote.

Called up by House by Unanimous Consent.

Passed House (Amended) by Voice Vote.

House Struck all After the Enacting Clause and Substituted the Language of the amended bill

House Insisted on its Amendments by Voice Vote.

House Requested a Conference and Speaker Appointed Conferees: Dingell,

Sharp, Bruce, Lent, Moorhead.

6/29/1988:

Message on House action received in Senate and held at desk: House amendment to Senate bill and House requests a conference.

7/6/1988:

Senate disagreed to the House amendment by Voice Vote.

7/6/1988:

Senate agreed to request for conference. Appointed conferees. Hollings; Gore;

Rockefeller; Danforth; McCain. From the committee on Commerce, Science, and Transportation.

7/6/1988:

Senate appointed conferees Glenn; Levin; Roth from the committee on

Governmental Affairs.

7/7/1988:

Message on Senate action sent to the House.

9/15/1988:

Conferees agreed to file conference report.

9/16/1988:

Conference Report 100-929 Filed in House.

9/20/1988:

Conference papers: official papers held at the desk in Senate.

Conference report considered in Senate. By Unanimous Consent.

Senate agreed to conference report by Voice Vote.

9/22/1988:

Message on Senate action sent to the House.

9/23/1988:

House Agreed to Conference Report by Voice Vote.

9/23/1988: 
Cleared for White House.

10/3/1988:

Measure Signed in Senate.

10/3/1988:

Presented to President.

Signed by President.

10/14/1988:

Became Public Law No: 100-494. 


\section{Appendix VI}

\section{Public Law 102-486 - Energy Policy Act of 1992 Timeline}

Introduced by: Sharp (D-IN) February 4, 1991

Cosponsors

Official Title as introduced: A bill to provide improved energy efficiency

Committees:

House Energy and Commerce

Subcommittee on Energy and Power

House Foreign Affairs

House Government Operations

Subcommittee on Environment, Energy and Natural Resources

Subcommittee on Government, Information, Justice and

Agriculture

Subcommittee on Government Activities and Transportation

Subcommittee on Legislation and National Security

House Judiciary

House Interior and Insular Affairs

House Merchant Marine and Fisheries

House Public Works and Transportation

Subcommittee on Public Buildings and Grounds

Subcommittee on Water and Resources

Subcommittee on Surface Transportation

House Ways and Means

House Agriculture

Subcommittee on Family Farms and Energy

Senate Finance

Timeline of Congressional Actions: ${ }^{280}$

\section{2/4/1991:}

Referred to the House Committee on Energy and Commerce.

2/25/1991:

Referred to the Subcommittee on Energy and Power.

5/29/1991:

Subcommittee Hearings Held.

7/17/1991:

Subcommittee Consideration and Mark-up Session Held.

7/18/1991:

${ }^{280}$ Modified from http://thomas.loc.gov/cgi-bin/bdquery/z?d102:HR00776:@@@ 
Subcommittee Consideration and Mark-up Session Held.

7/23/1991:

Subcommittee Consideration and Mark-up Session Held.

7/31/1991:

Subcommittee Consideration and Mark-up Session Held.

9/11/1991:

Subcommittee Consideration and Mark-up Session Held.

10/9/1991:

Subcommittee Consideration and Mark-up Session Held.

10/10/1991:

Subcommittee Consideration and Mark-up Session Held.

10/17/1991:

Subcommittee Consideration and Mark-up Session Held.

10/31/1991:

Subcommittee Consideration and Mark-up Session Held.

10/31/1991:

Forwarded by Subcommittee to Full Committee (Amended).

3/10/1992:

Committee Consideration and Mark-up Session Held.

3/11/1992:

Committee Consideration and Mark-up Session Held.

3/11/1992:

Ordered to be Reported (Amended).

3/30/1992 6:38pm:

Reported (Amended) by the Committee on Energy and Commerce. H. Rept. 102474, Part I.

3/30/1992:

Referred jointly and sequentially to the House Committee on Foreign Affairs for a period ending not later than May 1, 1992 for consideration of those provisions of titles XII and XIII contained in the amendment recommended by the Committee on Energy and Commerce that fall within the jurisdiction of the committee pursuant to rule $\mathrm{X}$.

4/29/1992:

Committee Consideration and Mark-up Session Held.

4/29/1992:

Ordered to be Reported (Amended) by Voice Vote.

3/30/1992:

Referred jointly and sequentially to the House Committee on Government Operations for a period ending not later than May 1, 1992 for consideration of those provisions of title III contained in the amendment recommended by the Committee on Energy and Commerce that fall within the jurisdiction of the committee pursuant to clause $\mathrm{X}$.

4/16/1992:

Referred to the Subcommittee on Environment, Energy, and Natural Resources.

4/28/1992:

Subcommittee Hearings Held.

4/30/1992: 
Subcommittee Consideration and Mark-up Session Held.

4/30/1992:

Forwarded by Subcommittee to Full Committee (Amended).

4/16/1992:

Referred to the Subcommittee on Government Information, Justice and

Agriculture.

4/28/1992:

Subcommittee Hearings Held.

4/30/1992:

Subcommittee Consideration and Mark-up Session Held.

4/30/1992:

Forwarded by Subcommittee to Full Committee (Amended).

4/16/1992:

Referred to the Subcommittee on Government Activities and Transportation.

4/28/1992:

Subcommittee Hearings Held.

4/16/1992:

Referred to the Subcommittee on Legislation and National Security.

4/30/1992:

Committee Consideration and Mark-up Session Held.

4/30/1992:

Ordered to be Reported (Amended).

3/30/1992:

Referred jointly and sequentially to the House Committee on Judiciary for a period ending not later than May 1, 1992 for consideration of those provisions of titles VI and VII contained in the amendment recommended by the Committee on Energy and Commerce that fall within the jurisdiction of the committee pursuant to rule $\mathrm{X}$.

4/30/1992:

Committee Consideration and Mark-up Session Held.

4/30/1992:

Ordered to be Reported (Amended).

3/30/1992:

Referred jointly and sequentially to the House Committee on Interior and Insular Affairs for a period ending not later than May 1, 1992 for consideration of those provisions of titles VIII, IX, X, XI and XIX contained in the amendment recommended by the Committee on Energy and Commerce that fall within the jurisdiction of the committee pursuant to rule $\mathrm{X}$.

4/8/1992:

Committee Consideration and Mark-up Session Held.

4/9/1992:

Ordered to be Reported (Amended) by the Yeas and Nays: 28 - 15.

4/9/1992:

Committee Consideration and Mark-up Session Held.

8/18/1992:

Executive Comment Received from NRC.

3/30/1992: 
Referred jointly and sequentially to the House Committee on Merchant Marine and Fisheries for a period ending not later than May 1, 1992 for consideration of those provisions of titles II, XVI and XVII contained in the amendment recommended by the Committee on Energy and Commerce that fall within the jurisdiction of the committee pursuant to rule $\mathrm{X}$.

4/30/1992:

Committee Consideration and Mark-up Session Held.

4/30/1992:

Ordered to be Reported (Amended).

3/30/1992:

Referred jointly and sequentially to the House Committee on Public Works + Transportation for a period ending not later than May 1, 1992 for consideration of those provisions of titles I, IV, and XVIII contained in the amendment recommended by the Committee on Energy and Commerce that fall within the jurisdiction of the committee pursuant to rule $\mathrm{X}$.

4/6/1992:

Referred to the Subcommittee on Public Buildings and Grounds.

4/8/1992:

Subcommittee Hearings Held.

4/28/1992:

Subcommittee Consideration and Mark-up Session Held.

4/28/1992:

Forwarded by Subcommittee to Full Committee (Amended).

4/6/1992:

Referred to the Subcommittee on Water Resources.

4/9/1992:

Subcommittee Hearings Held.

4/29/1992:

Subcommittee Consideration and Mark-up Session Held.

4/29/1992:

Forwarded by Subcommittee to Full Committee (Amended).

4/6/1992:

Referred to the Subcommittee on Surface Transportation.

4/9/1992:

Subcommittee Hearings Held.

4/29/1992:

Subcommittee Consideration and Mark-up Session Held.

4/29/1992:

Forwarded by Subcommittee to Full Committee (Amended).

4/30/1992:

Committee Consideration and Mark-up Session Held.

4/30/1992:

Ordered to be Reported (Amended).

3/30/1992:

Referred jointly and sequentially to the House Committee on Science, Space and Technology for a period ending not later than May 1, 1992 for consideration of those provisions of titles VI, IX, XII and XIII contained in the amendment 
recommended by the Committee on Energy and Commerce that fall within the jurisdiction of the committee pursuant to rule $\mathrm{X}$.

\section{4/2/1992:}

Committee Consideration and Mark-up Session Held.

\section{4/2/1992:}

Ordered to be Reported.

\section{3/30/1992:}

Referred jointly and sequentially to the House Committee on Ways and Means for a period ending not later than May 1, 1992 for consideration of those provisions of titles X, XI and XIV contained in the amendment recommended by the Committee on Energy and Commerce that fall within the jurisdiction of the committee pursuant to clause $\mathrm{X}$.

4/28/1992:

Committee Hearings Held.

4/29/1992:

Committee Consideration and Mark-up Session Held.

4/30/1992:

Committee Consideration and Mark-up Session Held.

4/30/1992:

Ordered to be Reported (Amended) by Voice Vote.

4/28/1992:

Referred jointly and sequentially to the House Committee on Agriculture for a period ending not later than May 1, 1992 for consideration of those provisions within titles XII, XVI and XIX contained in the amendment recommended by the Committee on Energy and Commerce that fall within the jurisdiction of the committee pursuant to clause $1(\mathrm{a})$, rule $\mathrm{X}$.

4/29/1992:

Referred to the Subcommittee on Forests, Family Farms, and Energy.

4/29/1992:

Subcommittee Hearings Held.

\section{$5 / 1 / 1992$}

House Committee on Foreign Affairs Granted an extension for further consideration ending not later than May 5, 1992.

House Committee on Government Operations Granted an extension for further consideration ending not later than May 5, 1992.

House Committee on Judiciary Granted an extension for further consideration ending not later than May 5, 1992.

House Committee on Interior and Insular Affairs Granted an extension for further consideration ending not later than May 5, 1992.

House Committee on Merchant Marine and Fisheries Granted an extension for further consideration ending not later than May 5, 1992.

House Committee on Agriculture Granted an extension for further consideration ending not later than May 5, 1992.

House Committee on Ways and Means Granted an extension for further consideration ending not later than May 5, 1992.

House Committee on Science, Space and Technology Granted an extension for further consideration ending not later than May 5, 1992. 
House Committee on Public Works + Transportation Granted an extension for further consideration ending not later than May 5, 1992.

Reported (Amended) by the Committee on Science, Space and Technology. H. Rept. 102-474, Part II.

Reported (Amended) by the Committee on Public Works + Transportation. H. Rept. 102-474, Part III.

\section{5/4/1992}

Reported (Amended) by the Committee on Foreign Affairs. H. Rept. 102-474, Part IV.

\section{$\mathbf{5 / 5 / 1 9 9 2}$}

Reported (Amended) by the Committee on Government Operations. H. Rept. 102474, Part V.

Reported (Amended) by the Committee on Ways and Means. H. Rept. 102-474, Part VI.

Reported (Amended) by the Committee on Judiciary. H. Rept. 102-474, Part VII. Reported (Amended) by the Committee on Interior and Insular Affairs. H. Rept. 102-474, Part VIII.

Reported (Amended) by the Committee on Merchant Marine and Fisheries. H. Rept. 102-474, Part IX.

Committee on Agriculture discharged.

Placed on the Union Calendar, Calendar No. 302.

$5 / 19 / 1992$

Rules Committee Resolution H. Res. 459 Reported to House. Rule provides for consideration of H.R. 776 with 5 hours of general debate. Measure will be read by section. Specified amendments are in order.

\section{$\mathbf{5 / 2 0 / 1 9 9 2}$}

Rule H. Res. 459 passed House.

Rule provides for consideration of H.R. 776 with 5 hours of general debate.

Measure will be read by section. Specified amendments are in order. It shall be in order to consider an amendment in the

House resolved itself into the Committee of the Whole House on the state of the Union pursuant to H. Res. 459 and Rule XXIII.

The Speaker designated the Honorable David E. Skaggs to act as Chairman of the Committee.

GENERAL DEBATE - Pursuant to the provisions of H. Res. 459, the Committee of the Whole proceeded with five hours of general debate.

Committee of the Whole House on the state of the Union rises leaving H.R.

776 as unfinished business.

Considered as unfinished business.

The House resolved into Committee of the Whole House on the state of the Union for further consideration.

H.AMDT.551 Amendment (A001) offered by Mr. Hoagland.

Amendment expands the definition of state regulatory agencies which are eligible to receive new energy efficiency grants to include a state energy office in cases where no single statewide ratemaking authority exists.

DEBATE - Pursuant to the provisions of H. Res. 459, the Committee of the Whole proceeded with ten minutes of debate on the Hoagland amendment. 
On agreeing to the Hoagland amendment (A001) Agreed to by voice vote. H.AMDT.552 Amendment (A002) offered by Mr. Kasich.

Amendment adds "performance based budgeting" language and requires the Department of Energy to include in its report to Congress on energy conservation grants made to federal agencies the extent to which those agencies have reached their stated goals and plans for conserving energy and water.

DEBATE - Pursuant to the provisions of H. Res. 459, the Committee of the Whole proceeded with 20 minutes of debate on the Kasich amendment. On agreeing to the Kasich amendment (A002) Agreed to by voice vote. H.AMDT.553 Amendment (A003) offered by Mr. Atkins.

Amendment establishes uniform national energy and water consumption standards for water-using plumbing products.

Atkins amendment (A003) modified by unanimous consent.

DEBATE - Pursuant to the provisions of H. Res. 459, the Committee of the

Whole proceeded with 20 minutes of debate on the Atkins amendment, as modified.

On agreeing to the Atkins amendment (A003) as modified Agreed to by recorded vote: 328 - 79

ORDER OF PROCEDURE - Mr. Sharp asked unanimous consent that amendment \#4 printed in House Report 102-528 may be offered (in a modified form) at any time during consideration of the bill in the Committee of the Whole today. Agreed to without objection.

Considered as unfinished business.

The House resolved into Committee of the Whole House on the state of the Union for further consideration.

H.AMDT.554 Amendment (A004) offered by Mr. Jontz.

Amendment sought to establish an octane replacement program and require an increasing number of octane points of fuel sold in the U.S. to be derived from domestically produced, renewable, non-petroleum sources such as ethanol; and would have required oil companies to phase in such a program over 14 years. DEBATE - Pursuant to the provisions of H. Res. 459, the Committee of the Whole proceeded with 20 minutes of debate on the Jontz amendment.

On agreeing to the Jontz amendment (A004) Failed by recorded vote: 198 - 211 H.AMDT.555 Amendment (A005) offered by Mr. Hall (TX).

Amendment sought to exempt Texas from the authority of the Federal Energy Regulatory Commission to order utilities to transmit electrical energy on behalf of others.

DEBATE - Pursuant to the provisions of H. Res. 459, the Committee of the Whole proceeded with ten minutes of debate on the Hall (TX) amendment. By unanimous consent, the Hall (TX) amendment was withdrawn. H.AMDT.556 Amendment (A006) offered by Mr. Clement.

Amendment replaces the nuclear power plant licensing provisions in the bill with language that authorizes the Nuclear Regulatory Commission (NRC) to issue a combined construction and operating license for new nuclear power plants. Under the amendment reactor manufacturers will be able to apply for pre-approval certification of standardized reactor designs. The combined license would outline 
required inspections and tests. Once a plant is completed, the NRC is required to find that all license requirements have been met.

DEBATE - Pursuant to the provisions of H. Res. 459, the Committee of the Whole proceeded with forty minutes of debate on the Clement amendment.

The House resolved into Committee of the Whole House on the state of the Union for further consideration.

DEBATE - The Committee of the Whole continued debate on the Clement amendment.

On agreeing to the Clement amendment (A006) Agreed to by recorded vote: 254 160

H.AMDT.557 Amendment (A007) offered by Mr. Markey.

Amendment establishes a federal standard for allowable state regulation of natural gas production. It prohibits States from implementing regulations that have the substantial purpose or effect of restricting natural gas production and raising the price of natural gas.

DEBATE - Pursuant to the provisions of H. Res. 459, the Committee of the Whole proceeded with twenty minutes of debate on the Markey amendment. On agreeing to the Markey amendment (A007) Agreed to by recorded vote: $238-169$

Committee of the Whole House on the state of the Union rises leaving H.R. 776 as unfinished business.

\section{$\mathbf{5 / 2 1 / 1 9 9 2}$}

Rule H. Res. 464 passed House.

Considered as unfinished business.

House resolved itself into the Committee of the Whole House on the state of the Union pursuant to H. Res. 459 and Rule XXIII.

H.AMDT.558 Amendments (A008) offered by Mr. Dingell.

Amendments expedite the permit process relating to site characterization activities of the Department of Energy at Yucca Mountain in Nevada in order to determine its suitability for the disposal of high-level radioactive waste and spent nuclear fuel.

On agreeing to the Dingell amendments (A008) Agreed to by voice vote. H.AMDT.559 Amendments (A009) offered by Mr. Dingell.

Amendments en bloc: (1) add energy saving performance contract provisions to federal agency efficiency programs; (2) establish a revolving fund within the Treasury Department to finance federal agency energy efficiency programs; (3) clarify that the renewable energy initiative for the Western Area Power Administration is intended as a demonstration of renewable technologies and clarifies that the Secretary of Energy, if necessary, shall make all decisions relating to local requirements; (4) extend the Office of Nuclear Waste Negotiator for 3 years; and (5) add site selection criteria for the atomic vapor laser isotope separation uranium enrichment technology (ALVIS) facility.

DEBATE - Pursuant to the provisions of H. Res. 464, the Committee of the Whole proceeded with 20 minutes of debate on the Dingell amendment. On agreeing to the Dingell amendments (A009) Agreed to by voice vote. ORDER OF PROCEDURE - Mr. Brown of California asked unanimous consent that it may be in order for the Committee of the Whole to consider amendments 
numbered 5 and 6 as contained in House Report 102-533 as the first order of business when the Committee resumes its sitting on H.R. 776 in order for the Committee to consider titles XX, XXII, and XXIII. Agreed to without objection. H.AMDT.560 Amendments (A010) offered by Mr. Walker.

Amendments reduce the authorization for research and development within the Department of Energy by $\$ 2$ billion over 5 years, and provide a total spending level for 1993 at the 1992 level.

H.AMDT.560 Walker amendment (A010) modified by unanimous consent. The modification provides certain conforming adjustments for authorization levels and sources.

On agreeing to the Walker amendments (A010) as modified Agreed to by voice vote.

H.AMDT.561 Amendment (A011) offered by Mr. Brown.

Amendment sought to specify that 10 to 15 percent of the Department of Energy's funds for environmental restoration and waste management shall be used for research and development.

H.AMDT.561 By unanimous consent, the Brown amendment was withdrawn.

$5 / 27 / 1992$

The House resolved into Committee of the Whole House on the state of the Union for further consideration.

H.AMDT.562 Amendment (A012) offered by Mr. Rostenkowski.

Amendment deletes language which requires oil companies to contribute a certain percentage of their oil to the strategic petroleum reserve, sufficient to achieve a fill rate of 150,000 barrels a day.

DEBATE - Pursuant to the provisions of H. Res. 464, the Committee of the Whole proceeded with one hour of debate on the Rostenkowski amendment.

On agreeing to the Rostenkowski amendment (A012) Agreed to by recorded vote: 263 - 135

H.AMDT.563 Amendment (A013) offered by Mr. Rahall.

Amendment, as amended, sought to modify provisions relating to coal, oil and gas development. It would have: (1) provided incentives for the remining of coal from abandoned mines and refuse piles; (2) required mining companies to provide compensation for damage caused by mine cave-ins or ground sinking, and replace contaminated local water supplies; (3) permitted the use of Abandoned Mine Reclamation Fund monies to suppress underground coal fires; (4) required the Department of the Interior to consider market demand, as well as competition in the coal industry, prior to issuing federal coal leases; (5) established dispute resolution procedures for certain oil shale claims; and (6) required the Bureau of Mines to develop a health, safety and mining technology research program. DEBATE - Pursuant to the provisions of H. Res. 464, the Committee of the Whole proceeded with forty minutes of debate on the Rahall amendment. H.AMDT.564 Amendment (A014) offered by Mr. Mavroules to the Rahall amendment (A013).

Amendment deletes the provisions in the Rahall amendment (A013) permitting oil and gas leasing on the naval oil shale reserve in Colorado.

DEBATE - The Committee of the Whole proceeded with ten minutes of debate on the Mavroules amendment to the Rahall amendment. 
On agreeing to the Mavroules amendment (A014) Agreed to by voice vote. DEBATE - The Committee of the Whole resumed debate on the Rahall amendment, as amended.

H.AMDT.563 By unanimous consent, the Rahall amendment was withdrawn. H.AMDT.565 Amendments (A015) offered by Mr. Dingell.

Amendments en bloc consist of the text of the Rahall amendment (A013), as amended by the Mavroules amendment (A014), and modified by deleting the following provisions originally contained therein: (1) the requirement for replacement of contaminated or reduced local water supplies; (2) consideration by the Interior Department of market demand as a factor in issuing coal leases; and (3) the incorporation into law of the terms and conditions of the settlement agreement in the civil action between Save Our Cumberland Mountains Inc. vs. Lujan.

Dingell amendment (A015) modified by unanimous consent.

DEBATE - Pursuant to the provisions of H. Res. 464, the Committee of the Whole proceeded with forty minutes of debate on the Dingell amendments. On agreeing to the Dingell amendments (A015) as modified Agreed to by voice vote.

H.AMDT.566 Amendment (A016) offered by Mr. Thomas (WY).

Amendment sought to delete language which extends the abandoned mine land tax for an additional 15 years to the year 2010 .

DEBATE - Pursuant to the provisions of H. Res. 464, the Committee of the Whole proceeded with 10 minutes of debate on the Thomas (WY) amendment. On agreeing to the Thomas (WY) amendment (A016) Failed by voice vote. H.AMDT.567 Amendments (A017) offered by Mr. Dingell.

Amendments en bloc: (1) eliminate the provisions of the bill which grant States authority to regulate disposal of low-level radioactive waste deregulated by the Nuclear Regulatory Commission; (2) require the EPA to establish decontamination standards for certain contaminated sites; and (3) restrict the disposal of certain radioactive material at uranium mill tailing sites.

Dingell amendment (A017) modified by unanimous consent.

DEBATE - Pursuant to the provisions of H. Res. 464, the Committee of the Whole proceeded with twenty minutes of debate on the Dingell amendments. On agreeing to the Dingell amendments (A017) as modified Agreed to by voice vote.

H.AMDT.568 Amendment (A018) offered by Mr. Gejdenson.

Amendment sought to establish new requirements governing the disposal of lowlevel radioactive waste. It would have: (1) removed class $\mathrm{C}$ and above radioactive wastes from State responsibility under the low-level waste disposal program; and (2) provided that low-level waste disposal facilities be located in areas of low population density which have limited potential for future population growth, and which are at least 5 kilometers away from urban residential property limits and from schools and other facilities which serve children.

DEBATE - Pursuant to the provisions of H. Res. 464, the Committee of the Whole proceeded with forty minutes of debate on the Gejdenson amendment. On agreeing to the Gejdenson amendment (A018) Failed by recorded vote: 117 293 
H.AMDT.569 Amendment (A019) offered by Mr. Miller (CA).

Amendment prohibits the Federal Energy Regulatory Commission from licensing hydroelectric projects on rivers that are protected by State law; prohibits the construction of new dams in national parks; and clarifies the authority of the Bureau of Land Management and the Forest Service regarding issuance of rightsof-way or special use permits associated with hydroelectric projects.

DEBATE - Pursuant to the provisions of H. Res. 464, the Committee of the Whole proceeded with forty minutes of debate on the Miller of California amendment.

H.AMDT.570 Amendment (A020) offered by Mr. Owens (UT) to the Miller (CA) amendment (A019).

Amendment to the Miller (CA) amendment (A019) sought to require that before a pipeline right-of-way through public lands is granted, the Secretary of the Interior must determine that the use of the pipeline will not conflict with the purposes for which the lands are managed or result in substantial degradation of natural resources, scenic, or recreational values.

DEBATE - Pursuant to the provisions of H. Res. 464, the Committee of the Whole proceeded with ten minutes of debate on the Owens of (UT) amendment. On agreeing to the Owens (UT) amendment (A020) Failed by voice vote. H.AMDT.571 Amendment (A021) offered by Mr. Owens (UT) to the Miller (CA) amendment (A019).

Amendment to the Miller (CA) amendment (A019) sought to: (1) give States the authority to prohibit the use of Federal public lands within a State for the disposal of radioactive or hazardous waste; and (2) impose certain conditions on the use of these lands for electric energy purposes.

DEBATE - Pursuant to the provisions of $\mathrm{H}$. Res. 464, the Committee of the Whole proceeded with ten minutes of debate on the Owens of Utah amendment. On agreeing to the Owens (UT) amendment (A021) Failed by voice vote. H.AMDT.572 Amendment (A022) offered by Mr. Dingell to the Miller (CA) amendment (A019).

Amendment to the Miller (CA) amendment (A019) sought to amend the Federal Power Act (FPA) by: (1) preventing hydroelectric power licensees from condemning State and local park, recreation, and wildlife refuge areas to build new dams; (2) requiring the Federal Energy Regulatory Commission (FERC) to give weight to State legislative actions in licensing decisions; (3) reversing a court decision which required new hydro projects to receive certain permits; and (4) authorizing FERC to assess and collect civil penalties for violations of the FPA and relevant regulations.

DEBATE - Pursuant to the provisions of H. Res. 464, the Committee of the Whole proceeded with twenty minutes of debate on the Dingell amendment. On agreeing to the Dingell amendment (A022) Failed by recorded vote: 195 - 221 On agreeing to the Miller (CA) amendment (A019) Agreed to by recorded vote: $318-98$

The previous question was ordered pursuant to the rule.

The House adopted the amendment in the nature of a substitute as agreed to by the Committee of the Whole House on the state of the Union. Mr. Fields moved to recommit to Energy and Commerce. 
The previous question on the motion to recommit was ordered without objection. On motion to recommit Failed by voice vote.

On passage Passed by recorded vote: 381 - 37

6/2/1992:

Received in the Senate.

6/4/1992:

Read twice and referred to the Committee on Finance.

6/16/1992:

Committee on Finance. Ordered to be reported with amendments favorably.

6/18/1992:

Committee on Finance. Reported to Senate by Senator Bentsen with amendments. Without written report.

6/18/1992:

Placed on Senate Legislative Calendar under General Orders. Calendar No. 493.

7/20/1992:

Motion to proceed to consideration of measure made in Senate.

7/20/1992:

Cloture motion on the motion to proceed presented in Senate.

7/20/1992:

Motion to proceed to consideration of measure withdrawn in Senate.

7/23/1992:

Cloture on the motion to proceed not invoked in Senate by Yea-Nay Vote. 58-33

7/27/1992:

Motion to proceed to consideration of measure made in Senate.

Cloture motion on the motion to proceed presented in Senate.

Motion to proceed to consideration of measure withdrawn in Senate.

7/28/1992:

Cloture on the motion to proceed invoked in Senate by Yea-Nay Vote. 93-3.

7/29/1992:

Measure laid before Senate by unanimous consent.

The Committee amendments were modified to provide for an amendment in the nature of a substitute by unanimous consent.

Amendment SP 2782 proposed by Senator Bradley.

S.AMDT.2782 Proposed by Senator Bradley.

Striking repeal of minimum tax preferences for depletion and intangible drilling costs.

Motion to table SP 2782 agreed to in Senate by Yea-Nay Vote. 63-32

Amendment SP 2783 proposed by Senator Specter.

To provide increased access to and affordability of health care.

Point of order raised in Senate with respect to SP 2783.

Motion to waive the Budget Act with respect to SP 2783 rejected in Senate by

Yea-Nay Vote. 35-60.

SP 2783 ruled out of order by the chair.

Amendment SP 2784 proposed by Senator Symms.

To amend the Internal Revenue Code of 1986 to remove certain high-speed intercity rail facility bonds from the State volume cap for tax-exempt bond financing. 
Motion to table SP 2784 rejected in Senate by Yea-Nay Vote. 40-55. Amendment SP 2785 proposed by Senator Pressler.

To amend the Hazardous Liquid Pipeline Safety Act of 1979.

Amendment SP 2785 agreed to in Senate by Voice Vote.

Amendment SP 2784 agreed to in Senate by Voice Vote.

Amendment SP 2786 proposed by Senator Johnston for Senator Brown.

To extend the authorization of the Uranium Mill Tailings Radiation Control Act of 1978.

Amendment SP 2786 agreed to in Senate by Voice Vote. Amendment SP 2787 proposed by Senator Rockefeller.

A substitute for the coal health provisions.

Amendment SP 2787 agreed to in Senate by Voice Vote.

Amendment SP 2788 proposed by Senator Johnston for Senator Simpson.

To provide for a survey of practices and policies under which electric

cooperatives prepare least-cost plans in rates charged to customers.

Amendment SP 2788 agreed to in Senate by Voice Vote.

Amendment SP 2789 proposed by Senator Wellstone.

To amend the Securities Exchange Act of 1934 with respect to limited partnership rollups.

Amendment SP 2790 proposed by Senator Dodd to Amendment SP 2789.

To establish the "Limited Partnership Rollup Reform Act of 1992".

Amendment SP 2791 proposed by Senator Murkowski.

To require the Council on Economic Advisors to complete and submit a jobs survey report on significant public and/or private sector construction, developmental or manufacturing projects scheduled or to be proposed.

Amendment SP 2791 agreed to in Senate by Voice Vote.

Amendment SP 2792 proposed by Senator Wallop for Senator Murkowski.

To require the Secretary of Energy to conduct a study of the status and future of the domestic oil and gas industry and the potential impacts of development of the coastal plain of the Arctic National Wildlife Refuge on the oil and gas industry, the economy, and national security.

Amendment SP 2792 as modified agreed to in Senate by Voice Vote.

S.AMDT.2789 Considered by Senate.

S.AMDT.2790 Considered by Senate.

Amendment SP 2793 proposed by Senator Wallop for Senator Stevens.

To provide for equitable treatment of taxpayers entitled to credits on account of payments into the Trans-Alaska Pipeline Liability Fund.

Amendment SP 2793 agreed to in Senate by Voice Vote.

Amendment SP 2794 proposed by Senator D'Amato.

To amend the Tariff Act of 1930 to prevent circumvention of antidumping and countervailing duty orders.

Amendment SP 2794 agreed to in Senate by Voice Vote.

Proposed amendment SP 2790 withdrawn in Senate.

Proposed amendment SP 2789 withdrawn in Senate.

The committee substitute as amended agreed to by Voice.

Passed Senate with an amendment by Yea-Nay Vote. 93-3. 
Senate insists on its amendment, asks for a conference, appoints conferees Johnston; Bumpers; Ford; Bingaman; Wirth; Conrad; Shelby; Wallop; Hatfield; Domenici; Murkowski; Nickles; Burns for all titles except Title XIX of the House bill and Title XX of the Senate amendment.

Senate appointed conferees. Glenn; Stevens from the Committee on Governmental Affairs for Subtitle B of Title VI of the Senate amendment. Senate appointed conferees. Hollings; Danforth from the Committee on Science, Commerce and Transportation for Subtitles A, B and C of Title XII of the Senate amendment.

Senate appointed conferees. Riegle; Garn from the Committee on Banking, Housing and Urban Affairs for Title XV of the Senate amendment.

Senate appointed conferees. Burdick; Chafee from the Committee on

Environment and Public Works for the following provisions of H.R.776:

Sec.2481, Title XXVIII, Subtitle A of the Title XXIX, Section 3009.

Senate appointed conferees. Cranston; Specter from the Committee on Veterans Affairs for Sections 6101 and 6102 of Title VI of the Senate amendment.

Senate appointed conferees. Bentsen; Moynihan; Baucus; Boren; Daschle; Breaux; Packwood; Dole; Roth; Danforth; Chafee from the Committee on Finance for Title XIX of H.R.776and Title XX of the Senate amendment.

\section{8/4/1992:}

Message on Senate action sent to the House.

\section{8/12/1992}

Mr. Sharp asked unanimous consent that the House disagree to the Senate amendment, and agree to a conference.

On motion that the House disagree to the Senate amendment, and agree to a conference Agreed to without objection.

Mr. Lent moved that the House instruct conferees.

DEBATE - The House proceeded with one hour of debate on the motion to instruct conferees on the part of the House to balance, within the scope of the conference, both energy conservation and energy efficiency with energy supply, and to achieve this goal in a manner which is consistent with environmental protection, using market mechanisms and incentives rather than command-andcontrol regulations and government subsidies.

The previous question was ordered without objection.

On motion that the House instruct conferees Agreed to by voice vote.

Motion to reconsider laid on the table Agreed to without objection.

The Speaker appointed conferees - from the Committee on Energy and Commerce for consideration of the House bill (except title XIX), and the Senate amendment (except title XX), and modifications committed to conference: Dingell, Sharp, Markey, Tauzin, Towns, Swift, Synar, Lent, Moorhead, and Dannemeyer.

The Speaker appointed conferees Provided, that Mr. Bliley is appointed only for consideration of titles I, VII, XII, XVII, and XXXI of the House bill, and titles V, VI and XV of the Senate amendment.

The Speaker appointed conferees - provided, that Mr. Bliley appointed only for consideration of titles I, VII, XII, XVII, and XXXI of the House bill, and titles V, $\mathrm{VI}$ and $\mathrm{XV}$ of the Senate amendment. 
The Speaker appointed conferees - Mr. Fields is appointed on for consideration of titles III, IV, V, XIV, XVIII, and XX of the House bill, and titles IV and XVI of the Senate amendment.

The Speaker appointed conferees Mr. Fields is appointed only for consideration of titles III, IV, V, XIV, XVIII, and XX of the House bill, and titles IV and XVI of the Senate amendment.

The Speaker appointed conferees Mr. Oxley is appointed only for consideration of titles II, VI, VIII, IX, X, XI, XIII, XV, XVI, XXI, XXII, XXIII, XXIV, XXV, XXVI, XXVII, XXVIII, XXIX, and XXX of the House bill, and titles I, II, VIII, IX, X, XI, XII, XIII, XIV, XVII, XVIII, XIX, XXI of the Senate amendment; and in lieu of Mr. Lent for title VII of the House bill and title XV of the Senate amendment.

Mr. Oxley is appointed only for consideration of titles II, VI, VIII, IX, X, XI, XIII, XV, XVI, XXI, XXII, XXIII, XIV, XXV, XXVI, XXVII, XXVIII, XXIX, and XXX of the House bill, and titles I, II, VIII, IX, X, XI, XII, XIII, XIV, XVII, XVIII, XIX, XXI of the Senate amendment; and in lieu of Mr. Lent for title VII of the House bill and title XV of the Senate amendment.

The Speaker appointed conferees - from the Committee on Ways and Means for consideration of title XIX of the House bill, and sec. 19108 and title XX of the Senate amendment, and modifications committed to conference: Rostenkowski, Gibbons, Pickle, Rangel, Stark, Archer, Vander Jagt, and Crane.

The Speaker appointed additional conferees - from the Committee on Ways and Means for that portion of sec. 1101 of the House bill which adds new secs. 1701 and 1702 to the Atomic Energy Act of 1974, and that portion of sec. 10103 of the Senate amendment which adds new secs. 1701 and 1702 to the Atomic Energy Act of 1954, and modifications committed to conference: Rostenkowski, Gibbons, Pickle, Rangel, Stark, Jacobs, Ford (TN), Archer, Vander Jagt, Crane, and Schulze.

The Speaker appointed additional conferees - from the Committee on Education and Labor for consideration of secs. 20141, 20142, and 20143 (except those portions which add new secs. 9702(a)(4), 9704, 9705(a)(4), 9706, 9712(d)(5) to the Internal Revenue Code of 1986) of the Senate amendment, and modifications committed to conference: Ford (MI), Clay, Miller (CA), Kildee, Williams, Roukema, Fawell, and Ballenger.

The Speaker appointed additional conferees - from the Committee on Education and Labor for consideration of those portions of sec. 901 which add new secs. 1305 and 1312 to the Atomic Energy Act of 1954, that portion of sec. 1101 which adds a new sec. 1704 to the Atomic Energy Act of 1954, and sec. 3004 of the House bill and secs. 4402, 6601-04, 10104, 13119, and 19113 of the Senate amendment, and modifications committed to conference: Ford (MI), Williams, and Goodling.

The Speaker appointed additional conferees - from the Committee on Foreign Affairs for consideration of secs. 1205, 1208, 1213-14, 1302-05, 1606, and 903 of the House bill, and secs. 5101-04, that portion of sec. 5201 which adds a new sec. 6 to the Renewable Energy and Energy Efficiency Technology Competitiveness Act of 1989, 14108-09, and 14301-02, of the Senate amendment, and 
modifications committed to conference: Fascell, Gejdenson, Wolpe, Levine (CA), Feighan, Johnston, Engel, Broomfield, Roth, Miller (WA), and Houghton. The Speaker appointed additional conferees - from the Committee on Foreign Affairs for consideration of secs. 1211, 1607, 2481, and 2704 of the House bill, and secs. 1201, 6701-02, 10223(b), 13102, 17101-02, 19101, and 19109 of the Senate amendment, and modifications committed to conference: Fascell, Gejdenson, and Broomfield.

The Speaker appointed additional conferees - from the Committee on Government Operations for consideration of secs. 121(e) and (f), 122, 127, and 128 of the House bill, and secs. 6207, 6216, 6218, and 6220-21 of the Senate amendment, and modifications committed to conference: Conyers, Bustamante, and Clinger. The Speaker appointed additional conferees - from the Committee on Government Operations for consideration of secs. 302 and 304-06 of the House bill, and secs. 4102, 4105-06, 4112-13, 4116, and 4119 of the Senate amendment, and modifications committed to conference: Conyers, Wise, and McCandless. The Speaker appointed additional conferees - from the Committee on Interior and Insular Affairs for consideration of secs. 133, 1314, 1607, 3002, 3004, 3009, 3101, 3102, and 3104 and titles VIII-XI and XXIV-XXIX of the House bill, and secs. 5302-04, 5308, 6303, 6501, 6506, 13115, 13118, 13120-21, 14114, 19110, 19112 and titles IX, X, XII, XVIII of the Senate amendment, and modifications committed to conference: Miller (CA), Rahall, Vento, Kostmayer, de Lugo, Gejdenson, DeFazio, Young (AK), Marlenee, Vucanovich, and Rhodes. Provided, Mr. Murphy is appointed in lieu of Mr. DeFazio for consideration of title XXV of the House bill and sec. 14114 of the Senate amendment only and Mr. Abercrombie is appointed in lieu of Mr. DeFazio for consideration of sec. 2481 of the House bill only.

Provided, Mr. Murphy is appointed in lieu of Mr. DeFazio for consideration of title XXV of the House bill and sec. 14114 of the Senate amendment only and Mr. Abercrombie is appointed in lieu of Mr. DeFazio for consideration of sec. 2481 of the House bill only.

The Speaker appointed additional conferees - from the Committee on Interior and Insular Affairs for consideration of that portion of sec. 723(h) which adds a new sec. 212(h) to the Federal Power Act, 1312-13, 1403, 2012, 2113 (g), 2307, and 3008 of the House bill, and secs. 19104, and 20143(b) and titles VIII and XXI of the Senate amendment, and modifications committed to conference: Miller (CA), Rahall, and Young (AK).

The Speaker appointed additional conferees - from the Committee on the Judiciary for consideration of sec. 3010 of the House bill, and sec. 19102 of the Senate amendment, and modifications committed to conference: Brooks, Edwards (CA), Glickman, Feighan, Staggers, Berman, Washington, Fish, Hyde, Campbell (CA), and Smith (TX).

The Speaker appointed additional conferees - from the Committee on the Judiciary for consideration of secs. 11107 of the Senate amendment, and modifications committed to conference: Brooks, Edwards (CA), and Fish. The Speaker appointed additional conferees - from the Committee on the Judiciary for consideration of sec. 19106 of the Senate amendment, and modifications committed to conference: Brooks, Frank (MA), and Gekas. 
The Speaker appointed additional conferees - from the Committee on Merchant Marine and Fisheries for consideration of sec. 1607, and title XXIV of the House bill, and title XII of the Senate amendment, and modifications committed to conference: Studds, Hughes, Hutto, Hertel, Tallon, Lancaster, Carper, Davis, Fields, Bateman, and Inhofe.

The Speaker appointed additional conferees - from the Committee on Merchant Marine and Fisheries for consideration of secs. 205, 1602, and 1701(b) of the House bill, and secs. 5204, 5302, 5304, and 11103 and title XXI of the Senate amendment, and modifications committed to conference: Studds, Hughes, and Davis.

The Speaker appointed additional conferees - from the Committee on Public Works and Transportation for consideration of secs. 121-28, 132, 411, 2453, 2461-64, 2705, 3102, and 3104 and title XVIII of the House bill, and secs. 4120, 4401, 5303, 5308, 6101, 6201-24, 6304, and 10224 of the Senate amendment, and modifications committed to conference: Roe, Mineta, Nowak, Applegate, de Lugo, Savage, Borski, Hammerschmidt, Shuster, Petri, and Inhofe.

The Speaker appointed additional conferees - from the Committee on Public Works and Transportation for consideration of sec. 164(h), that portion of sec. 723(h) which adds a new sec. 212(i) to the Federal Power Act, secs. 410, and 1316 of the House bill, and secs. 12103, 12204, and 14113 of the Senate amendment, and modifications committed to conference: Roe, Mineta, and Hammerschmidt.

The Speaker appointed additional conferees - from the Committee on Science, Space, and Technology for consideration of secs. 901-02, 1203, 1207, 1301, 1306-09, 1315, 1318-19, 2471, 2502-03, 2513, 3005, 3007, 3009 and titles VI and XX-XXIII of the House bill, and secs. 4201-18, 4305, 4401, 5201-02, 5204-06, 6104, 6501, 6506, 19103 and titles II, VIII, subtitle A of title X, except those portions adding new sections 1511, 1601, 1606, 1607, 1701-1703 to the Atomic Energy Act of 1954, XIII and XIV of the Senate amendment, and modifications committed to conference: Brown, Lloyd, Scheuer, Wolpe, Stallings, Roemer, Swett, Walker, Ritter, Morrison, and Fawell.

By unanimous consent, the Speaker reserved the authority to make additional appointments and to make changes in the appointment of conferees.

9/9/1992

MODIFICATIONS IN APPOINTMENT OF CONFEREES - The Speaker announced sundry modifications in the appointment of conferees.

The Speaker appointed additional conferees - from the Committee on Banking, Finance and Urban Affairs for consideration of secs. 5207, 6101-6103 of the Senate amendment, modifications committed to conference: Gonzalez, Oakar, and Roukema.

The Speaker appointed additional conferees - from the Committee on Veterans' Affairs for consideration of sec. 1934 of the House bill, and modification committed to conference: Montgomery, Edwards (CA), Applegate, Staggers, Stump, and Hammerschmidt.

The Speaker appointed additional conferees - from the Committee on Veterans' Affairs for consideration of secs. 6101 and 6102 of the Senate amendment, and modifications committed to conference: Montgomery, Staggers, and Stump. 
9/10/1992:

Message on House action received in Senate.

Conference held.

9/16/1992:

Conference held.

9/23/1992:

Conference held.

9/24/1992:

Conference held.

9/25/1992:

Conference held.

Senate appointed conferee Moynihan in lieu of Burdick, of ND, 3.

9/28/1992:

Message on Senate action sent to the House.

9/29/1992:

MODIFICATIONS TO APPOINTMENT OF CONFEREES - Pursuant to clause 6(f) of rule X, the Speaker made the following appointments from the Committee on Merchant Marine and Fisheries to fill vacancies occasioned by the death of Representative Jones (NC): Mr. Carper, for consideration of title XXIV and sec. 1607 of the House bill, and title XII of the Senate amendment; Mr. Hughes, for consideration of secs. 205, 1602, and 1701(b) of the House bill, and title XXI and secs. 5204, 5302, 5304, and 11103 of the Senate amendment.

9/30/1992:

Conference held.

Message on House action received in Senate.

10/5/1992

Rules Committee Resolution H. Res. 601 Reported to House. Rule provides for consideration of the conference report to H.R. 776. Upon the adoption of this resolution it shall be in order to consider the conference report to accompany H.R. 776. All points of order against the conference report and against its consideration are waived.

Conference report H. Rept. 102-1018 filed.

Rule H. Res. 601 passed House.

Mr. Sharp brought up conference report H. Rept. 102-1018 for consideration under the provisions of H. Res. 601.

DEBATE - Pursuant to the provisions of H. Res. 601, the House proceeded with two hours of debate on the conference report.

DEBATE - The House resumed debate on the conference report on H. R. 776.

The previous question was ordered without objection.

Mrs. Vucanovich moved to recommit with instructions to the conference committee.

RECOMMIT WITH INSTRUCTIONS - The instructions contained in the motion to recommit require the managers on the part of the House to disagree to section 801 (relating to EPA standards for nuclear waste disposal) in the conference substitute recommended by the committee of conference.

The previous question on the motion to recommit with instructions to conference committee was ordered without objection. 
On motion to recommit with instructions to conference committee Failed by the Yeas and Nays: $102-323$

On agreeing to the conference report Agreed to by the Yeas and Nays: 363 - 60

Motions to reconsider laid on the table Agreed to without objection.

Conference report considered in Senate.

Conference papers: Senate report and managers' statement and message on House action held at the desk in Senate.

Cloture motion on the conference report presented in Senate.

10/8/1992:

Cloture on the conference report invoked in Senate by Yea-Nay Vote. 84-8.

Conference report considered in Senate.

Senate agreed to conference report by Voice Vote.

Cleared for White House.

10/13/1992:

Message on Senate action sent to the House.

10/15/1992:

Presented to President.

10/24/1992:

Signed by President.

Became Public Law No: 102-486. 


\section{Appendix VII}

\section{Public Law 106-224}

\section{Agricultural Risk Protection Act of 2000 - HR 2559 Timeline}

To amend the Federal Crop Insurance Act to strengthen the safety net for agricultural producers by providing greater access to more affordable risk management tools and improved protection from production and income loss, to improve the efficiency and integrity of the Federal crop insurance program, and for other purposes.

Short Title: Agricultural Risk Protection Act 2000

Introduced by: Combest (R-TX) July 20, 1999

Cosponsors: Barrett (R-NE)

Bereuter (R-NE)

Blunt (R-MO)

Canady (R-FL)

Cooksey (R-LA)

Ewing (R-IL)

Gilman (R-NY)

Hayes (R-NC)

Hill (R-MT)

Sessions (R-TX)

Whitfield (R-KY)

Committees:

House Agriculture

Subcommittee on Risk Management, Research and Specialty Crops

Senate Agriculture, Nutrition and Forestry

Timeline of Congressional Actions: ${ }^{281}$

\section{7/20/1999:}

Referred to the House Committee on Agriculture.

7/21/1999:

Referred to the Subcommittee on Risk Management, Research and Specialty

Crops.

7/21/1999:

Subcommittee Consideration and Mark-up Session Held.

7/21/1999:

${ }^{281}$ Modified from http://thomas.loc.gov/cgi-bin/bdquery/z?d106:HR02559:@@@S 
Forwarded by Subcommittee to Full Committee (Amended) by Voice Vote.

7/30/1999:

Committee Consideration and Mark-up Session Held.

8/3/1999:

Committee Consideration and Mark-up Session Held.

8/3/1999:

Ordered to be Reported (Amended) by Voice Vote.

8/5/1999

Reported (Amended) by the Committee on Agriculture. H. Rept.106-300, Part I.

Placed on the Union Calendar, Calendar No. 179.

9/22/1999

Supplemental report filed by the Committee on Agriculture, H. Rpt 106-300, Part

II.

\section{9/28/1999}

Rules Committee Resolution H. Res. 308 Reported to House. Rule provides for consideration of H.R. 2559 with 1 hour of general debate. Previous question shall be considered as ordered without intervening motions except motion to recommit with or without instructions. Makes in order the Committee on Agriculture amendment in the nature of a substitute as an original bill for the purpose of amendment, modified by the amendments printed in H.Rpt 106-346. Measure will be read by title. Specified amendments are in order. Makes in order only those amendments preprinted in the Congressional Record.

Rule H. Res. 308 passed House.

\section{9/29/1999}

House resolved itself into the Committee of the Whole House on the state of the Union pursuant to H. Res. 308 and Rule XXIII.

The Speaker designated the Honorable Steven C. LaTourette to act as Chairman of the Committee.

GENERAL DEBATE - The Committee of the Whole proceeded with one hour of general debate on H.R. 2559.

Amendment (A001) offered by Mr. LaHood (R-IL).

Amendment provides for the creation of a pilot project to evaluate the effectiveness of risk management tools for livestock producers.

DEBATE - The Committee is debating the amendment offered by Mr. LaHood.

On agreeing to the LaHood amendment (A001) Agreed to by voice vote. Amendment (A002) offered by Mr. Upton (R-MI).

Amendment no. 4 printed in the Congressional Record to correct the erroneous crop insurance price paid to Michigan peach farmers by the Department of Agriculture.

By unanimous consent, the Upton amendment was withdrawn.

Amendment (A003) offered by Ms. Jackson-Lee (D-TX).

Amendment no. 2 printed in the Congressional Record to express the Sense of Congress that the Department of Agriculture should ensure the full participation of minority and limited-resource farmers and ranchers in crop insurance programs. 
DEBATE - The Committee is debating the amendment offered by Ms. JacksonLee of Texas.

On agreeing to the Jackson-Lee (D-TX) amendment (A003)

Agreed to by voice vote.

The previous question was ordered pursuant to the rule.

The House adopted the amendment in the nature of a substitute as agreed to by the Committee of the Whole House on the state of the Union.

On passage Passed by voice vote.

Motion to reconsider laid on the table Agreed to without objection. The Clerk was authorized to correct section numbers, punctuation, and cross references, and to make other necessary technical and conforming corrections in the engrossment of H.R. 2559

9/30/1999:

Received in the Senate and read twice and referred to the Committee on Agriculture.

3/23/2000:

Senate Committee on Agriculture, Nutrition, and Forestry discharged by Unanimous Consent.

Measure laid before Senate by unanimous consent.

(consideration: CR S1627-1642)

Senate struck all after the Enacting Clause and substituted the language of S. 2251 amended.

Passed Senate in lieu of S. 2251 with an amendment by Yea-Nay Vote. 95 - 5.

Senate insists on its amendment, asks for a conference, appoints conferees Lugar, Helms, Cochran, Coverdell, Roberts, Harkin, Leahy, Conrad and Kerrey.

3/27/2000:

Message on Senate action sent to the House.

3/30/2000

Mr. Combest asked unanimous consent that the House disagree to the Senate amendment, and agree to a conference.

On motion that the House disagree to the Senate amendment, and agree to a conference Agreed to without objection.

The Speaker appointed conferees: Combest(R-TX), Barrett (R-NE), Boehner (R-OH), Ewing (R-NE), Pombo (R-CA), Stenholm (D-TX), Condit (D-CA), Peterson (MN), and Dooley (D-CA).

Motion to reconsider laid on the table Agreed to without objection.

$5 / 24 / 2000$

Conference report filed.

Rules Committee Resolution H. Res. 512 Reported to House. Rule provides for consideration of the conference report to H.R. 2559. All points of order against the conference report and against its consideration are waived. The conference report shall be considered as read.

5/25/2000:

Conference papers: Senate report and manager's statement and message on House action held at the desk in Senate.

Rule H. Res. 512 passed House. 
Mr. Combest brought up conference report H. Rept. 106-639 for consideration under the provisions of H. Res. 512.

DEBATE - The House proceeded with one hour of debate on the conference report.

The previous question was ordered without objection.

On agreeing to the conference report Agreed to by voice vote.

Motions to reconsider laid on the table Agreed to without objection.

Conference report considered in Senate.

Senate agreed to conference report by Yea-Nay Vote. $91-4$.

Message on Senate action sent to the House.

Cleared for White House.

6/8/2000:

Presented to President.

6/20/2000:

Signed by President.

6/22/2000:

Became Public Law No: 106-224. 


\section{Appendix IX}

\section{Public Law Number 109-58 - Energy Policy Act - H.R. 6 Timeline}

An Act to ensure jobs for our future with secure, affordable and reliable energy.

Short Title: Energy Policy Act of 2005 (HR 6)

Introduced by: Joe Barton (R-TX), Chair of the House Committee on Energy and Commerce, 18 April 2005

Cosponsors: Richard Pombo (R-CA) and William Thomas (R-CA)

Committees:

House Energy and Commerce

Subcommittee on Energy and Air Quality

House Education and the Workforce

House Financial Services

House Agriculture

House Resources

House Science

House Ways and Means

House Transportation and Infrastructure

\section{4/18/2005:}

Referred to the Committee on Energy and Commerce, and in addition to the Committees on Education and the Workforce, Financial Services, Agriculture, Resources, Science, Ways and Means, and Transportation and Infrastructure, for a period to be subsequently determined by the Speaker, in each case for consideration of such provisions as fall within the jurisdiction of the committee concerned.

Referred to House Energy and Commerce

Referred to the Subcommittee on Energy and Air Quality.

Referred to House Education and the Workforce

Referred to House Financial Services

Referred to House Agriculture

Referred to House Resources

4/20/2005:

Committee Consideration and Mark-up Session Held by Committee on Resources

Prior to Introduction (April 13, 2005).

Referred to House Science

Referred to House Ways and Means

Referred to House Transportation and Infrastructure

4/19/2005

Rules Committee Resolution H. Res. 219 Reported to House. Rule provides for consideration of H.R. 6 with 1 hour and 30 minutes of general debate. Previous 
question shall be considered as ordered without intervening motions except motion to recommit with or without instructions. Measure will be considered read. Specified amendments are in order.

\section{4/20/2005}

Rule H. Res. 219 passed House.

Considered under the provisions of rule H. Res. 219. (consideration: CR H2192-

2366; text of measure as reported in House: CR H2210-2321)

Rule provides for consideration of H.R. 6 with 1 hour and 30 minutes of general debate. Previous question shall be considered as ordered without intervening motions except motion to recommit with or without instructions. Measure will be considered read. Specified amendments are in order.

House resolved itself into the Committee of the Whole House on the state of the Union pursuant to H. Res. 219 and Rule XVIII.

The Speaker designated the Honorable Shelley Moore Capito to act as Chairwoman of the Committee.

GENERAL DEBATE - The Committee of the Whole proceeded with one hour and thirty minutes of general debate on H.R. 6.

H.AMDT.70 Amendment (A001) offered by Mr. Hall

Amendment consists of the text of the amendment contained in House Report 109-49 and numbered 1 which is printed on pages $\mathrm{H} 2321-\mathrm{H} 2324$ in the Congressional Record for April 20, 2005.

DEBATE - Pursuant to the provisions of H. Res. 219, the Committee of the Whole proceeded with 10 minutes of debate on the Hall amendment.

On agreeing to the Hall amendment (A001) Agreed to by voice vote. H.AMDT.71 Amendment (A002) offered by Mr. Dingell.

of the bill.

Amendment sought to replace electricity provisions

DEBATE - Pursuant to the provisions of H. Res. 219, the Committee of the Whole proceeded with 20 minutes of debate on the Dingell amendment. POSTPONED PROCEEDINGS - At the conclusion of debate on the Dingell amendment the Chair put the question on adoption of the amendment and by voice vote, announced that the noes had prevailed. Mr. Dingell demanded a recorded vote and pursuant to the rule, the Chair postponed further proceedings on the question of adoption of the Dingell amendment until later in the legislative day. H.AMDT.72 Amendment (A003) offered by Mr. Markey

Amendment sought to strike provisions which allow oil and gas exploration in the Arctic National Wildlife Refuge. DEBATE - Pursuant to the provisions of H. Res. 219, the Committee of the Whole proceeded with 30 minutes of debate on the Markey amendment. POSTPONED PROCEEDINGS - At the conclusion of debate on the Markey amendment the Chair put the question on adoption of the amendment and by voice vote, announced that the noes had prevailed. Mr. Markey demanded a recorded vote and pursuant to the rule, the Chair postponed further proceedings on the question of adoption of the Markey amendment until later in the legislative day.

H.AMDT.73 Amendment (A004) offered by Mr. Boehlert 
Amendment sought to require the Department of Transportation to raise fuel economy standards for automobiles from today's average of 25 miles per gallon to 33 miles per gallon by 2015 .

DEBATE - Pursuant to the provisions of H. Res. 219, the Committee of the Whole proceeded with 20 minutes of debate on the Boehlert amendment. POSTPONED PROCEEDINGS - At the conclusion of debate on the Boehlert amendment the Chair put the question on adoption of the amendment and by voice vote, announced that the noes had prevailed. Mr. Boehlert demanded a recorded vote and pursuant to the rule, the Chair postponed further proceedings on the question of adoption of the Boehlert amendment until later in the legislative day.

H.AMDT.74 Amendment (A005) offered by Mrs. Johnson (CT)

Amendment originally sought to require the EPA to update the tests used in determining estimated fuel economy ratings for automobiles. As amended by the Rogers (MI) amendment (A006), the original language was revised to require the EPA to change the "adjustment factors" that the EPA currently uses to make fuel economy labels accurate.

DEBATE - Pursuant to the provisions of H. Res. 219, the Committee of the Whole proceeded with 10 minutes of debate on the Johnson (CT) amendment. H.AMDT.75 Amendment (A006) offered by Mr. Rogers (MI) to the Johnson (CT) amendment (A005).

DEBATE - Pursuant to the provisions of H. Res. 219, the Committee of the Whole proceeded with 10 minutes of debate on the Rogers (MI) amendment. POSTPONED PROCEEDINGS - At the conclusion of debate on the Rogers (MI) amendment the Chair put the question on adoption of the amendment and by voice vote, announced that the ayes had prevailed. Mr. Holt demanded a recorded vote and pursuant to the rule, the Chair postponed further proceedings on the question of adoption of the Rogers (MI) amendment until later in the legislative day. Disposition of the underlying Johnson (CT) amendment remains pending subject to the final action on the perfecting Rogers (MI) amendment. H.AMDT.76 Amendment (A007) offered by Mr. Bishop (NY)

Amendment consists of the text of the amendment contained in House Report 109-49 and numbered 7 which is printed on pages $\mathrm{H} 2347-\mathrm{H} 2360$ in the Congressional Record for April 20, 2005.

DEBATE - Pursuant to the provisions of H. Res. 219, the Committee of the Whole proceeded with 30 minutes of debate on the Bishop (NY) amendment. POSTPONED PROCEEDINGS - At the conclusion of debate on the Bishop (NY) amendment the Chair put the question on adoption of the amendment and by voice vote, announced that the noes had prevailed. Mr. Bishop demanded a recorded vote and pursuant to the rule, the Chair postponed further proceedings on the question of adoption of the Bishop amendment until later in the legislative day.

H.AMDT.77 Amendment (A008) offered by Ms. Slaughter

Amendment requires any new escalator being installed in Federal buildings to be an intermittent escalator.

DEBATE - Pursuant to the provisions of H. Res. 219, the Committee of the Whole proceeded with 10 minutes of debate on the Slaughter amendment. 
On agreeing to the Slaughter amendment (A008) Agreed to by voice vote. H.AMDT.78 Amendment (A009) offered by Mr. Dingell.

Amendment authorizes \$20 million for installation of a photovoltaic solar electric system at the headquarters of the Department of Energy.

On agreeing to the Dingell amendment (A009) Agreed to by voice vote.

ORDER OF PROCEDURE - Mr. Waxman asked unanimous consent that his amendment numbered 9 printed in House Report 109-49, be made in order during the consideration of H.R. 6 in the Committee of the Whole at any time. Agreed to without objection.

H.AMDT.79 Amendment (A010) offered by Mr. Waxman Amendment sought to require appropriate Federal departments and agencies, identified by the President, to propose voluntary, regulatory, and other actions sufficient to reduce demand for oil in the United States by at least 1.0 million barrels per day from the projected demand for oil in 2013.

DEBATE - Pursuant to the provisions of H. Res. 219, the Committee of the Whole proceeded with 10 minutes of debate on the Waxman amendment. POSTPONED PROCEEDINGS - At the conclusion of debate on the Waxman amendment the Chair put the question on adoption of the amendment and by voice vote, announced that the noes had prevailed. Mr. Waxman demanded a recorded vote and pursuant to the rule, the Chair postponed further proceedings on the question of adoption of the Waxman amendment until later in the legislative day.

H.AMDT.80 Amendment (A011) offered by Mr. Abercrombie

Amendment provides for the establishment in the Department of Energy of the Sugar Cane Ethanol Pilot Program.

DEBATE - Pursuant to the provisions of H. Res. 219, the Committee of the Whole proceeded with 10 minutes of debate on the Abercrombie amendment. On agreeing to the Abercrombie amendment (A011) Agreed to by voice vote. H.AMDT.81 Amendment (A012) offered by Ms. Kaptur.

Amendment sought to provide the Secretary of Energy the authority to include in the Strategic Fuels Reserve ethanol, biodiesel, and other alternative fuels.

DEBATE - Pursuant to the provisions of H. Res. 219, the Committee of the Whole proceeded with 10 minutes of debate on the Kaptur amendment. POSTPONED PROCEEDINGS - At the conclusion of debate on the Kaptur amendment the Chair put the question on adoption of the amendment and by voice vote, announced that the noes had prevailed. Ms. Kaptur demanded a recorded vote and pursuant to the rule, the Chair postponed further proceedings on the question of adoption of the Kaptur amendment until later in the legislative day. H.AMDT.82 Amendment (A013) offered by Mr. Conaway.

Amendment requires the Secretary of Energy, in consultation with the Secretary of Labor, to evaluate both the short term and longer term availability of skilled workers to meet the energy security requirements of the United States; and report to Congress recommendations as appropriate to meet the future labor requirements for the domestic extraction industries. 
DEBATE - Pursuant to the provisions of H. Res. 219, the Committee of the Whole proceeded with 10 minutes on the Conaway amendment.

On agreeing to the Conaway amendment (A013) Agreed to by voice vote. H.AMDT.83 Amendment (A014) offered by Ms. Solis

Amendment sought to delete refinery revitalization provisions in the bill. DEBATE - Pursuant to the provisions of H. Res. 219, the Committee of the Whole proceeded with 10 minutes of debate on the Solis amendment. POSTPONED PROCEEDINGS - At the conclusion of debate on the Solis amendment the Chair put the question on adoption of the amendment and by voice vote, announced that the noes had prevailed. Ms. Solis demanded a recorded vote and pursuant to the rule, the Chair postponed further proceedings on the question of adoption of the Solis amendment until later in the legislative day.

UNFINISHED BUSINESS - The Chair announced that the unfinished business was the question of adoption of specified amendments which were debated earlier in the legislative day and on which further proceedings had been postponed.

On agreeing to the Solis amendment (A014) Failed by recorded vote: 182 - 248

On agreeing to the Kaptur amendment (A012) Failed by recorded vote: 186 - 239

On agreeing to the Waxman amendment (A010) Failed by recorded vote: $166-262$

On agreeing to the Bishop (NY) amendment (A007) Failed by recorded vote: 170 $-259$

On agreeing to the Rogers (MI) amendment Agreed to by recorded vote: 259 172

On agreeing to the Johnson (CT) amendment (A005) as amended Agreed to by recorded vote: $346-85$

On agreeing to the Boehlert amendment (A004) Failed by recorded vote: 177 254 $200-231$

On agreeing to the Markey amendment (A003) Failed by recorded vote:

On agreeing to the Dingell amendment (A002) Failed by recorded vote: 188 - 243

Committee of the Whole House on the state of the Union rises leaving H.R. 6 as unfinished business.

4/21/2005 10:15am:

The House resolved into Committee of the Whole House on the state of the Union for further consideration.

H.AMDT.84 Amendment (A015) offered by Mr. Udall (NM).

Amendment sought to strike section 631 entitled "Cooperative Research

and Development and Special Demonstration Projects for the Uranium Mining Industry".

DEBATE - Pursuant to H. Res. 219, the Committee of the Whole proceeded with 10 minutes of debate on the Udall (NM) amendment.

POSTPONED PROCEEDINGS - At the conclusion of debate on the Udall (NM) amendment the Chair put the question on adoption of the amendment and by voice vote, announced that the noes had prevailed. Mr. Udall (NM) demanded a recorded vote and pursuant to the rule, the Chair postponed further 
proceedings on the question of

adoption of the Udall (NM) amendment

until later in the legislative day.

H.AMDT.85 Amendment (A016) offered by Mr. Ford.

Amendment requires the EPA to establish a program to encourage domestic production and sales of efficient hybrid and advanced diesel vehicles.

DEBATE - Pursuant to H. Res. 219, the Committee of the Whole proceeded with 10 minutes of debate on the Ford amendment.

On agreeing to the Ford amendment (A016) Agreed to by voice vote.

H.AMDT.86 Amendment (A017) offered by Mr. Kucinich

Amendment permits 30 communities to apply for grants to invest in alternative fuel vehicles under the Department of Energy Clean City program. Kucinich amendment (A017) modified by unanimous consent. Modification strikes the number "20" the first place it appears and replaces it with the number "30".

DEBATE - Pursuant to H. Res. 219, the Committee of the Whole proceeded with 10 minutes of debate on the Kucinich amendment, as modified.

On agreeing to the Kucinich amendment (A017) as modified Agreed to by voice vote.

H.AMDT.87 Amendment (A018) offered by Ms. Millender-McDonald.

Amendment requires the EPA to establish a program for awarding grants

on a competitive basis to public agencies and entities for fleet modernization programs including installation of retrofit technologies for diesel trucks.

DEBATE - Pursuant to H. Res. 219, the Committee of the Whole proceeded with 10 minutes of debate on the Millender-McDonald amendment.

On agreeing to the Millender-McDonald amendment (A018) Agreed to by voice vote.

H.AMDT.88 Amendment (A019) offered by Mr. Blumenauer

Amendment provides for the establishment in the Department of

Transportation of the "Conserve by Bicycle Program".

DEBATE - Pursuant to H. Res. 219, the Committee of the Whole proceeded with 10 minutes of debate on the Blumenauer amendment.

On agreeing to the Blumenauer amendment (A019) Agreed to by voice vote.

H.AMDT.89 Amendment (A020) offered by Ms. Jackson-Lee (TX)

Amendment authorizes $\$ 49$ million for integrated bioenergy

research and development programs, projects, and activities, for each of the

fiscal years 2005 through 2009; and provides that at least \$5 million for each

fiscal year shall be for training and education targeted to minority and social disadvantaged farmers and ranchers.

DEBATE - Pursuant to H. Res. 219, the Committee of the Whole proceeded with 10 minutes of debate on the Jackson-Lee amendment.

On agreeing to the Jackson-Lee (TX) amendment (A020) Agreed to by voice vote.

H.AMDT.90 Amendment (A021) offered by Mr. Davis, Tom.

Amendment strikes section 978 which expanded the number of Assistant Secretaries in the Department of Energy to eight.

DEBATE - Pursuant to H. Res. 219, the Committee of the Whole proceeded with 10 minutes of debate on the Tom Davis (VA) amendment. 
EXTENSION OF DEBATE - By unanimous consent, debate on the Tom Davis (VA) amendment was extended by 2 minutes to be equally divided and controlled.

On agreeing to the Davis, Tom amendment (A021) Agreed to by voice vote.

H.AMDT.91 Amendment (A022) offered by Mr. Walsh

Amendment provides for the establishment of the National Priority

Project designation, which shall be evidenced by a medal bearing the inscription "National Priority Project" which shall be presented to organizations to recognize advancement in the field of renewable energy technology.

DEBATE - Pursuant to H. Res. 219, the Committee of the Whole proceeded with 10 minutes of debate on the Walsh amendment.

On agreeing to the Walsh amendment (A022) Agreed to by voice vote.

H.AMDT.92 Amendment (A023) offered by Mr. Engel.

Amendment expands the types of renewable fuels eligible for a grant program in the bill.

DEBATE - Pursuant to H. Res. 219, the Committee of the Whole proceeded with 10 minutes of debate on the Engel amendment.

POSTPONED PROCEEDINGS - At the conclusion of debate on the Engel amendment the Chair put the question on adoption of the amendment and by voice vote, announced that the noes had prevailed. Mr. Engel demanded a recorded vote and pursuant to the rule, the Chair postponed further proceedings on the question of adoption of the Engel amendment until later in the legislative day. H.AMDT.93 Amendment (A024) offered by Mr. Israel.

Amendment requires the Comptroller General of the United States to conduct a study of the consolidation of the refiners, importers, producers, and wholesalers of gasoline with the sellers of such gasoline at retail.

DEBATE - Pursuant to H. Res. 219, the Committee of the Whole proceeded with 10 minutes of debate on the Israel amendment.

POSTPONED PROCEEDINGS - At the conclusion of debate on the Israel amendment the Chair put the question on adoption of the amendment and by voice vote, announced that the noes had prevailed. Mr. Israel demanded a recorded vote and pursuant to the rule, the Chair postponed further proceedings on the question of adoption of the Israel amendment until later in the legislative day.

UNFINISHED BUSINESS - The Chair announced that the unfinished business was the question of adoption of the amendments which had been debated earlier and on which further proceedings had been postponed.

H.AMDT.84 On agreeing to the Udall (NM) amendment (A015) Failed by recorded vote: 204 - 225

H.AMDT.92 On agreeing to the Engel amendment (A023) Agreed to by recorded vote: $239-190$

H.AMDT.93 On agreeing to the Israel amendment Agreed to by recorded vote: $302-128$ 
ORDER OF PROCEDURE - Mr. Hall of Texas asked unanimous consent that a motion to strike offered by Mrs. Capps be debatable for not to exceed 30 minutes, equally divided and controlled. Agreed to without objection.

H.AMDT.94 Amendment (A025) offered by Mr. Kucinich.

Amendment requires the Secretary of Energy to enter into an arrangement with the National Academy of Sciences for a study to determine the feasibility of using of mustard seed as a feedstock for biodiesel.

DEBATE - Pursuant to the provisions of H. Res. 219, the Committee of the Whole proceeded with 10 minutes of debate on the Kucinich amendment. POSTPONED PROCEEDINGS - At the conclusion of debate on the Kucinich amendment the Chair put the question on adoption of the amendment and by voice vote, announced that the ayes had prevailed. Mr. Hall demanded a recorded vote and pursuant to the rule, the Chair postponed further proceedings on the question of adoption of the Kucinich amendment until later in the legislative day. H.AMDT.95 Amendment (A026) offered by Mr. Holt.

Amendment requires the Secretary of Energy, in consultation with the Secretary of Transportation, to report to Congress on the potential fuel savings from information technology systems that help businesses and consumers to plan their travel and avoid delays.

DEBATE - Pursuant to the provisions of H. Res. 219, the Committee of the Whole proceeded with 10 minutes of debate on the Holt amendment.

On agreeing to the Holt amendment (A026) Agreed to by voice vote.

H.AMDT.96 Amendment (A027) offered by Mr. Grijalva

Amendment sought to strike section 2005 which provides for the suspension of the collection of royalty payments to the Treasury for offshore oil and gas production on the Outer Continental Shelf in the Gulf of Mexico. DEBATE - Pursuant to the provisions of H. Res. 219, the Committee of the Whole proceeded with 10 minutes of debate on the Grijalva amendment. POSTPONED PROCEEDINGS - At the conclusion of debate on the Grijalva amendment the Chair put the question on adoption of the amendment and by voice vote, announced that the noes had prevailed. Mr. Grijalva demanded a recorded vote and pursuant to the rule, the Chair postponed further proceedings on the question of adoption of the Grijalva amendment until later in the legislative day. H.AMDT.370 Amendment (A028) offered by Mrs. Capps.

Amendment sought to delete MTBE from section 1502 of the bill which provides MTBE with a "safe harbor" and provides product liability immunity to the producers of MTBE.

DEBATE - The Committee of the Whole proceeded with 30 minutes of debate on the Capps amendment.

POSTPONED PROCEEDINGS - At the conclusion of debate on the Capps amendment, the Chair put the question on adoption of the amendment and by voice vote, announced that the noes had prevailed. Mrs. Capps demanded a recorded vote and the Chair postponed further proceedings on the Capps amendment until later in the legislative day. 
H.AMDT.97 Amendment (A029) offered by Mr. Inslee

Amendment reduces by 50 percent royalty payments for wind energy generation on lands managed by the Bureau of Land Management.

DEBATE - Pursuant to the provisions of H. Res. 219, the Committee of the Whole proceeded with 10 minutes of debate on the Inslee amendment.

On agreeing to the Inslee amendment (A029) Agreed to by voice vote. H.AMDT.98 Amendment (A030) offered by Mr. Hastings (FL).

Amendment sought to codify Executive Order 12898 titled,

"Federal Actions to Address Environmental Justice in Minority Populations and Low Income Populations"; provide a definition of "environmental justice"; establish offices of environmental justice in appropriate agencies; and reestablish the Interagency Federal Working Group on Environmental Justice.

DEBATE - Pursuant to the provisions of H. Res. 219, the Committee of the Whole proceeded with 10 minutes of debate on the Hastings (FL) amendment.

POSTPONED PROCEEDINGS - At the conclusion of debate on the Hastings (FL) amendment the Chair put the question on adoption of the amendment and by voice vote, announced that the noes had prevailed. Mr. Hastings (FL) demanded a recorded vote and pursuant to the rule, the Chair postponed further proceedings on the question of adoption of the Hastings (FL) amendment until later in the legislative day.

H.AMDT.99 Amendment (A031) offered by Mr. Castle.

Amendment sought to strike section 320 concerning the siting of Liquefied Natural Gas Terminals.

DEBATE - Pursuant to the provisions of H. Res. 219, the Committee of the Whole proceeded with 10 minutes of debate on the Castle amendment. DEBATE EXTENSION - By unanimous consent, debate on the Castle amendment was extended by 4 minutes, equally divided and controlled. POSTPONED PROCEEDINGS - At the conclusion of debate on the Castle amendment the Chair put the question on adoption of the amendment and by voice vote, announced that the noes had prevailed. Mr. Castle demanded a recorded vote and pursuant to the rule, the Chair postponed further proceedings on the question of adoption of the Castle amendment until later in the legislative day. UNFINISHED BUSINESS - The Chair announced that the unfinished business was the question of adoption of amendments which had been debated earlier and on which further proceedings had been postponed.

H.AMDT.94 On agreeing to the Kucinich amendment (A025) Agreed to by recorded vote: 259 - 171

H.AMDT.96 On agreeing to the Grijalva amendment (A027) Failed by recorded vote: $203-227$

H.AMDT.370 On agreeing to the Capps amendment (A028) Failed by recorded vote: $\quad 213-219$

H.AMDT.98 On agreeing to the Hastings (FL) amendment (A030) Failed by recorded vote: 185 - 243

H.AMDT.99 On agreeing to the Castle amendment (A031) Failed by recorded vote: $194-237$ 
The House rose from the Committee of the Whole House on the state of the Union to report H.R. 6.

The previous question was ordered pursuant to the rule.

The House adopted the amendments en gross as agreed to by the Committee of the Whole House on the state of the Union.

On passage Passed by recorded vote: 249 - 183

Motion to reconsider laid on the table Agreed to without objection.

The Clerk was authorized to correct section numbers, punctuation, and cross references, and to make other necessary technical and conforming corrections in the engrossment of H.R. 6.

4/26/2005:

Received in the Senate.

6/9/2005:

Read twice. Placed on Senate Legislative Calendar under General Orders.

Calendar No. 124.

6/14/2005:

Measure laid before Senate by unanimous consent.

6/14/2005:

Amendment SA 775 proposed by Senator Domenici

To provide a complete substitute.

Amendment SA 775 agreed to in Senate by Unanimous Consent.

Amendment SA 779 proposed by Senator Domenici

To eliminate methyl tertiary butyl ether from the United States fuel

supply, to increase production and use of renewable fuel, and to increase the Nation's energy independence.

Amendment SA 781 proposed by Senator Boxer to Amendment SA 779

To ensure that ethanol is treated like all other motor vehicle fuels

and that taxpayers and local governments do not have to pay for environmental damage caused by ethanol.

Motion to table amendment SA 781 agreed to in Senate by Yea-Nay Vote. 59 38.

Amendment SA 782 proposed by Senator Schumer to Amendment SA 779.

To strike the reliable fuels subtitle of the amendment.

6/15/2005:

Considered by Senate.

SA779 Considered by Senate.

SA 782 Considered by Senate.

Motion to table amendment SA 782 agreed to in Senate by Yea-Nay Vote. $69-28$.

Amendment SA 779 as modified agreed to in Senate by Yea-Nay Vote. 70 - 26

Amendment SA 784 proposed by Senator Cantwell

To improve the energy security of the United States and reduce

United States dependence on foreign oil imports by 40 percent by 2025.

Amendment SA 791 proposed by Senator Bingaman

To establish a renewable portfolio standard.

Amendment SA 784 not agreed to in Senate by Yea-Nay Vote. 47 - 53

Amendment SA 791 agreed to in Senate by Yea-Nay Vote. 52 - 48 
Amendment SA 794 proposed by Senator Domenici

To make certain improvements to the bill relative to the institution of higher education, high performance building standards, and to provide for a study of overall employment in a hydrogen economy.

Amendment SA 794 agreed to in Senate by Unanimous Consent.

\section{6/20/2005:}

Considered by Senate.

Amendment SA 792 proposed by Senator Wyden.

To provide for the suspension of strategic petroleum reserve acquisitions. Amendment SA 799 proposed by Senator Voinovich.

To make grants and loans to States and other organizations to strengthen the economy, public health and environment of the United States by reducing emissions from diesel engines.

Amendment SA 800 proposed by Senator Domenici for Senator Grassley.

To amend the Internal Revenue Code of 1986 to provide energy policy tax incentives.

Amendment SA 800 agreed to in Senate by Unanimous Consent.

Amendment SA 783 proposed by Senator Martinez for Senator Nelson FL.

To strike the section providing for a comprehensive inventory of

Outer Continental Shelf oil and natural gas resources.

Amendment SA 805 proposed by Senator Schumer

To express the sense of the Senate regarding management of the Strategic

Petroleum Reserve to lower the burden of gasoline prices on the economy of the United States and circumvent the efforts of OPEC to reap windfall profits.

\section{6/21/2005:}

Considered by Senate.

SA 783 Considered by Senate.

SA 792 Considered by Senate

SA 799 Considered by Senate

SA 805 Considered by Senate

Amendment SA 783 not agreed to in Senate by Yea-Nay Vote. 44 - 52

Amendment SA 817 proposed by Senator Hagel.

To provide for the conduct of activities that promote the adoption of technologies that reduce greenhouse gas intensity in the United States and in developing countries and to provide credit-based financial assistance and investment protection for projects that employ advanced climate technologies or systems in the United States.

Amendment SA 790 proposed by Senator Dayton

To require that gasoline contain 10 percent ethanol by volume by 2015.

Proposed amendment SA 790 withdrawn in Senate.

Amendment SA 817 agreed to in Senate by Yea-Nay Vote. 66 - 29

Amendment SA 826 proposed by Senator McCain.

To provide for a program to accelerate the reduction of greenhouse gas emissions in the United States. 
Amendment SA 788 proposed by Senator DeWine.

To amend the Sherman Act to make oil-producing and exporting cartels illegal.

Amendment SA 788 agreed to in Senate by Voice Vote.

Amendment SA 799 agreed to in Senate by Yea-Nay Vote. 92 - 1.

Amendment SA 839 proposed by Senator Reid for Senator Lautenberg. To require any Federal agency that publishes a science-based climate change document that was significantly altered at White House request to make an unaltered final draft of the document publicly available for comparison.

Cloture motion on the bill presented in Senate.

6/22/2005:

Considered by Senate

SA 792 Considered by Senate

SA 805 Considered by Senate.

SA 826 Considered by Senate

SA 839 Considered by Senate.

Amendment SA 841 proposed by Senator Feinstein.

To prohibit the Commission from approving an application for the authorization of the siting, construction, expansion, or operation of facilities located onshore or in State waters for the import of natural gas from a foreign country or the export of natural gas to a foreign country without the approval of the Governor of the State in which the facility would be located.

Motion to table amendment SA 841 agreed to in Senate by Yea-Nay Vote. $52-45$.

Amendment SA 869 proposed by Senator Byrd.

To amend the Internal Revenue Code of 1986 to provide relief from high gas prices.

Amendment SA 869 agreed to in Senate by Voice Vote.

Amendment SA 811 proposed by Senator Schumer.

To provide for a national tire fuel efficiency program.

Motion to table amendment SA 805 agreed to in Senate by Yea-Nay Vote. 57 39

Amendment SA 826 not agreed to in Senate by Yea-Nay Vote. 38 - 60

Amendment SA 866 proposed by Senator Bingaman.

To express the sense of the Senate on climate change legislation.

Motion to table amendment SA 866 rejected in Senate by Yea-Nay Vote. 44 -

53.

Amendment SA 866 as modified agreed to in Senate by Voice Vote

6/22/2005:

Amendment SA 961 proposed by Senator Alexander

To provide for local control for the sitting of windmills. Amendment SA 844 proposed by Senator Kerry.

To express the sense of the Senate regarding the need for the United States to address global climate change through comprehensive and cost-effective national measures and through the negotiation of fair and binding international commitments under the United Nations Framework Convention on Climate Change. 
Amendment SA 961 not agreed to in Senate by Yea-Nay. 32 - 63.

Amendment SA 844 not agreed to in Senate by Yea-Nay Vote. 46 - 49.

Amendment SA 972 proposed by Senator Warner.

To provide for gas-only leases and State requests to examine energy areas on the outer Continental Shelf.

Proposed amendment SA 972 withdrawn in Senate.

Amendment SA 978 proposed by Senator Frist for Senator Conrad.

To clarify the definition of coal to liquid fuel technology.

Amendment SA 979 proposed by Senator Frist for Senator Hatch

To promote oil shale and tar sands development.

Amendment SA 818 proposed by Senator Frist for Senator Jeffords.

To commission a study for the roof of the Dirksen Senate Office Building in a manner that facilitates the incorporation of energy efficient technology and amends the Master Plan for the Capitol complex.

Amendment SA 980 proposed by Senator Frist for Senator Stabenow.

To require an investigation of gasoline prices.

Amendment SA 981 proposed by Senator Frist for Senator Kohl

To require the Secretary and the Administrator for Small Business to

coordinate assistance with the Secretary of Commerce for manufacturing related efforts.

Amendment SA 835 proposed by Senator Frist for Senator Clinton

To establish a National Priority Project Designation.

Amendment SA 787 proposed by Senator Frist for Senator Murkowski.

To make Alaska Native Corporations eligible for renewable energy

production incentives.

Amendment SA 822 proposed by Senator Frist for Senator Voinovich.

To promote fuel efficient engine technology for aircraft.

Amendment SA 982 proposed by Senator Frist for Senator Alexander.

To require the Secretary to conduct a study of best management practices for energy research and development programs.

Amendment SA 983 proposed by Senator Frist for Senator Jeffords.

To expand the types of qualified renewable energy facilities that are eligible for a renewable energy production incentive. Amendment SA 861 proposed by Senator Frist for Senator Dodd.

To require the Secretary to enter into a contract with the National

Academy of Sciences to determine the effect of electrical contaminants on the reliability of energy productions systems.

Amendment SA 850 proposed by Senator Frist for Senator Dorgan.

To modify the section relating to the establishment of a National Power

Plant Operations Technology and Education Center.

Amendment SA 984 proposed by Senator Frist for Senator Cornyn.

To require the Secretary to establish a program of research, development, demonstration, and commercial application to maximize the productive capacity of marginal wells and reservoirs. Amendment SA 864 proposed by Senator Frist for Senator Levin.

To ensure that cost-effective procedures are used to fill the Strategic Petroleum Reserve. 
Amendment SA 798 proposed by Senator Frist for Senator Pryor.

To require the submission of reports on the potential for biodiesel and hythane to be used as major, sustainable, alternative fuels.

Amendment SA 870 proposed by Senator Frist for Senator Boxer

To require the Federal Energy Regulatory Commission to complete its investigation and order refunds on the unjust and unreasonable rates charged to California during the 2000-2001 electricity crisis.

Amendment SA 927 proposed by Senator Frist for Senator Levin.

To provide a budget roadmap for the transition from petroleum to hydrogen in vehicles by 2020 .

Amendment SA 985 proposed by Senator Frist for Senator Hutchison.

To make petroleum coke gasification projects eligible for certain loan guarantees.

Amendment SA 786 proposed by Senator Frist for Senator Murkowski.

To make energy generated by oceans eligible for renewable energy

production incentives and to modify the definition of the term "renewable energy" to include energy generated by oceans for purposes of the Federal purchase requirement.

Amendment SA 986 proposed by Senator Frist for Senator Jeffords.

To authorize the Secretary of Energy to make grants to increase energy efficiency, promote siting or upgrading of transmission and distribution lines, and providing or modernizing electric facilities in rural areas.

Amendment SA 987 proposed by Senator Frist for Senator Alexander.

To require the Secretary to conduct a study on passive solar technologies.

Amendment SA 988 proposed by Senator Frist for Senator Harkin.

To require the Secretary to conduct a 3-year program of research, development, and demonstration on the use of ethanol and other low-cost transportable renewable feedstocks as intermediate fuels for the safe, energy efficient, and cost-effective transportation of hydrogen.

Amendment SA 989 proposed by Senator Frist for Senator Domenici.

To improve the bill.

Amendment SA 933 proposed by Senator Frist for Senator Grassley.

To provide a manager's amendment.

Amendment SA 978 agreed to in Senate by Unanimous Consent. Amendment SA 979 agreed to in Senate by Unanimous Consent. Amendment SA 818 agreed to in Senate by Unanimous Consent. Amendment SA 980 agreed to in Senate by Unanimous Consent. Amendment SA 981 agreed to in Senate by Unanimous Consent. Amendment SA 835 agreed to in Senate by Unanimous Consent. Amendment SA 787 agreed to in Senate by Unanimous Consent. Amendment SA 822 agreed to in Senate by Unanimous Consent. Amendment SA 982 agreed to in Senate by Unanimous Consent. Amendment SA 983 agreed to in Senate by Unanimous Consent. Amendment SA 861 agreed to in Senate by Unanimous Consent. Amendment SA 850 agreed to in Senate by Unanimous Consent. Amendment SA 984 agreed to in Senate by Unanimous Consent. Amendment SA 864 agreed to in Senate by Unanimous Consent. 
Amendment SA 798 agreed to in Senate by Unanimous Consent. Amendment SA 870 agreed to in Senate by Unanimous Consent. Amendment SA 927 agreed to in Senate by Unanimous Consent. Amendment SA 985 agreed to in Senate by Unanimous Consent. Amendment SA 786 agreed to in Senate by Unanimous Consent. Amendment SA 986 agreed to in Senate by Unanimous Consent. Amendment SA 987 agreed to in Senate by Unanimous Consent. Amendment SA 988 agreed to in Senate by Unanimous Consent. Amendment SA 989 agreed to in Senate by Unanimous Consent. Amendment SA 933 as modified agreed to in Senate by Unanimous Consent.

\section{6/23/2005:}

Considered by Senate.

Amendment SA 792Considered by Senate.

Amendment SA 811 Considered by Senate

Amendment SA 839 Considered by Senate

Cloture on the bill invoked in Senate by Yea-Nay Vote. 92 - 4

Point of order raised in Senate with respect to amendment SA 839.

Amendment SA 839 ruled non-germane by the chair.

Amendment SA 891 proposed by Senator Domenici

Point of order under the Budget Act raised in Senate with respect to amendment

SA 891.

Motion to waive the Budget Act with respect to amendment SA 891

agreed to in Senate by Yea-Nay Vote. $69-26$.

Amendment SA 891 agreed to in Senate by Voice Vote.

Amendment SA 810 proposed by Senator Schumer.

To strike a provision relating to medical isotope production.

Amendment SA 873 proposed by Senator Sununu.

To strike the title relating to incentives for innovative technologies.

Amendment SA 810 agreed to in Senate by Yea-Nay Vote. 52 - 46.

Amendment SA 873 not agreed to in Senate by Yea-Nay Vote. 21 - 76

Amendment SA 990 proposed by Senator Kyl.

To provide for a study relative to medical isotope production.

Amendment SA 990 as modified agreed to in Senate by Unanimous Consent Amendment SA 925 proposed by Senator Bond

To impose additional requirements for improving automobile fuel economy and reducing vehicle emissions.

Amendment SA 902 proposed by Senator Durbin.

To amend title 49, United States Code, to improve the system for enhancing automobile fuel efficiency, and for other purposes.

Amendment SA 819 proposed by Senator Talent

To increase the allowable credit for fuel use under the alternatively fueled

vehicle purchase requirement.

Amendment SA 819 agreed to in Senate by Voice Vote.

Amendment SA 925 agreed to in Senate by Yea-Nay Vote. 64 - 31.

Amendment SA 902 not agreed to in Senate by Yea-Nay Vote. 28 - 67.

Amendment SA 811 agreed to in Senate by Unanimous Consent. 
Amendment SA 832 proposed by Senator Craig for Senator Jeffords

To require the Secretary of the Interior to consult with the Administrator

of the Environmental Protection Agency in the conduct of a coal bed methane study.

Amendment SA 832 as modified agreed to in Senate by Unanimous Consent Amendment SA 871 proposed by Senator Craig for Senator Reid

To provide whistleblower protection for contract and agency employees at the Department of Energy.

Amendment SA 871 as modified agreed to in Senate by Unanimous Consent. Amendment SA 886 proposed by Senator Craig for Senator Cochran. To include waste-derived ethanol and biodiesel in a definition of biodiesel.

Amendment SA 886 as modified agreed to in Senate by Unanimous Consent Amendment SA 899 proposed by Senator Craig for Senator Enzi.

To establish procedures for the reinstatement of leases terminated due to unforeseeable circumstances.

Amendment SA 899 as modified agreed to in Senate by Unanimous Consent Amendment SA 808 proposed by Senator Craig for Senator Obama.

To establish a program to develop Fischer-Tropsch transportation fuels from Illinois basin coal.

Amendment SA 808 agreed to in Senate by Unanimous Consent.

Amendment SA 825 proposed by Senator Craig for Senator Kerry. To establish a 4-year pilot program to provide emergency relief to small business concerns affected by a significant increase in the price of heating oil, natural gas, propane, gasoline, or kerosene.

Amendment SA 825 agreed to in Senate by Unanimous Consent.

Amendment SA 940 proposed by Senator Craig for Senator Inhofe.

To provide for the control of hazardous air pollutants from motor vehicles and motor vehicle fuels.

Amendment SA 940 as modified agreed to in Senate by Unanimous Consent. Amendment SA 1005 proposed by Senator Craig for Senator Domenici

To make a technical correction.

Amendment SA 1005 agreed to in Senate by Unanimous Consent. Amendment SA 1006 proposed by Senator Craig for Senator Vitter

To require the Secretary to carry out a study and compile exhibiting science to determine the risks or benefits presented by cumulative impacts of multiple offshore liquefied natural gas facilities reasonably assumed to be constructed in an area of the Gulf of Mexico using the open-rack vaporization system.

Amendment SA 1006 agreed to in Senate by Unanimous Consent. Amendment SA 1007 proposed by Senator Craig for Senator Byrd

To improve the clean coal power initiative.

Amendment SA 1007 agreed to in Senate by Unanimous Consent. Amendment SA 1008 proposed by Senator Craig for Senator Cantwell.

To clarify provisions regarding relief for extraordinary violations. Amendment SA 1008 agreed to in Senate by Unanimous Consent. Amendment SA 1009 proposed by Senator Craig for Senator Grassley.

To provide a Manager's amendment. 
Amendment SA 1009 agreed to in Senate by Unanimous Consent. Amendment SA 851 proposed by Senator Craig for Senator Obama.

To require the Secretary to establish a Joint Flexible Fuel/Hybrid Vehicle Commercialization Initiative, and for other purposes.

Amendment SA 851 as modified agreed to in Senate by Unanimous Consent Amendment SA 892 proposed by Senator Craig for Senator Salazar.

To provide for the Western Integrated Coal Gasification Demonstration Project. Amendment SA 892 as modified agreed to in Senate by Unanimous Consent. Amendment SA 903 proposed by Senator Craig for Senator Durbin.

To provide that small businesses are eligible to participate in the Next Generation Lighting Initiative.

Amendment SA 903 as modified agreed to in Senate by Unanimous Consent. Amendment SA 919 proposed by Senator Craig for Senator Harkin

To enhance the national security of the United States by providing for the research, development, demonstration, administrative support, and market mechanisms for widespread deployment and commercialization of biobased fuels and biobased products.

Amendment SA 919 as modified agreed to in Senate by Unanimous Consent. Amendment SA 834 proposed by Senator Craig for Senator Snowe.

To provide for understanding of and access to procurement opportunities for small businesses with regard to Energy Star technologies and products, and for other purposes.

Amendment SA 834 agreed to in Senate by Unanimous Consent.

Proposed amendment SA 792 withdrawn in Senate.

The bill was read the third time by Unanimous Consent.

6/28/2005:

Passed Senate with an amendment by Yea-Nay Vote. 85 - 12

7/1/2005:

Senate insists on its amendment, asks for a conference, appoints conferees

Domenici; Craig; Thomas; Alexander; Murkowski; Burr; Bingaman; Akaka;

Dorgan; Wyden; Johnson from the Committee on Energy and Natural Resources. Senate appointed conferee(s) Grassley; Hatch; Baucus from the Committee on Finance.

Message on Senate action sent to the House.

7/13/2005

Mr. Barton (TX) asked unanimous consent that the House disagree to the Senate amendment, and agree to a conference.

On motion that the House disagree to the Senate amendment, and agree to a conference Agreed to without objection

Motion to reconsider laid on the table Agreed to without objection.

Mrs. Capps moved that the House instruct conferees

DEBATE - The House proceeded with one hour of debate on the Capps motion to instruct conferees. The instructions seek to direct the managers on the part of the House to not agree to the inclusion of any provisions in the conference report modifying the liability with respect to methyl tertiary butyl ether (MTBE). The previous question was ordered without objection. 
POSTPONED PROCEEDINGS - At the conclusion of debate on the Capps motion to instruct conferees, the Chair put the question on adoption of the motion and by voice vote, announced that the noes had prevailed. Mrs. Capps demanded the yeas and nays and the Chair postponed further proceedings on the question of adoption of the motion until July 14, 2005.

\section{7/14/2005}

Considered as unfinished business.

On motion that the House instruct conferees Failed by the Yeas and Nays: 201 217

Motion to reconsider laid on the table Agreed to without objection.

The Speaker appointed conferees - from the Committee on Energy and Commerce for consideration of the House bill and the Senate amendment, and modifications committed to conference: Barton (TX), Hall, Bilirakis, Upton, Stearns, Gillmor, Shimkus, Shadegg, Pickering, Blunt, Bass, Dingell, Waxman, Markey, Boucher, Stupak, Wynn, and Solis.

The Speaker appointed conferees Provided that Mrs. Capps is appointed in lieu of Mr. Wynn for consideration of secs. 1501-1506 of the House bill, and secs. 221 and 223-225 of the Senate amendment, and modifications committed to conference.

The Speaker appointed conferees - from the Committee on Agriculture for consideration of secs. 332, 344, 346, 1701, 1806, 2008, 2019, 2024, 2029, and 2030 of the House bill, and secs. 251-253, 264, 303, 319, 342, 343, 345, and 347 of the Senate amendment, and modifications committed to conference: Goodlatte, Lucas, and Peterson (MN).

The Speaker appointed conferees - from the Committee on Armed Services for consideration of secs. 104, 231, 601-607, 609-612, and 661 of the House bill, and secs. 104, 281, 601-607, 609, 610, 625, 741-743, 1005, and 1006 of the Senate amendment, and modifications committed to conference: Hunter, Weldon (PA), and Skelton.

The Speaker appointed conferees - from the Committee on Education and the Workforce for consideration of secs. 121, 632, 640, 2206, and 2209 of the House bill, and secs. 625, 1103, 1104, and 1106 of the Senate amendment, and modifications committed to conference: Norwood, Johnson, Sam, and Kind. The Speaker appointed conferees - from the Committee on Financial Services for consideration of secs. 141-149 of the House bill, and secs. 161-164 and 505 of the Senate amendment, and modifications committed to conference: Oxley, Ney, and Waters.

The Speaker appointed conferees - from the Committee on Government Reform for consideration of secs. 102, 104, 105, 203, 205, 502, 624, 632, 701, 704, 1002, 1227, and 2304 of the House bill, and secs. 102, 104, 105, 108, 203, 502, 625, 701-703, 723-725, 741-743, 939, and 1011 of the Senate amendment, and modifications committed to conference: Davis, Tom, Issa, and Watson. The Speaker appointed conferees - from the Committee on the Judiciary for consideration of secs. 320, 377, 612, 625, 632, 663, 665, 1221, 1265, 1270, 1283, 1442, 1502, and 2208 of the House bill, and secs. 137, 211, 328, 384, 389, 625, $1221,1264,1269,1270,1275,1280$, and 1402 of the Senate amendment, and modifications committed to conference: Sensenbrenner, Chabot, and Conyers. 
The Speaker appointed conferees - from the Committee on Resources for consideration of secs. 204, 231, 330, 344, 346, 355, 358, 377, 379, Title V, secs. 969-976, 1701, 1702, Title XVIII, secs. 1902, 2001-2019, 2022-2031, 2033, 2041, 2042, 2051-2055, Title XXI, Title XXII, and Title XXIV of the House bill, and secs. 241-245, 252, 253, 261-270, 281, 311-317, 319-323, 326, 327, 342-346, $348,371,387,391,411-414,416$, and 501-506 of the Senate amendment, and modifications committed to conference: Pombo, Cubin, and Rahall.

The Speaker appointed conferees - from the Committee on Rules for consideration of sec. 713 of the Senate amendment, and modifications committed to conference: Dreier, Diaz-Balart, L., and Slaughter.

The Speaker appointed conferees - from the Committee on Science for consideration of secs. 108, 126, 205, 209, 302, 401-404, 411, 416, 441, 601-607, 609-612, 631, 651, 652, 661, 711, 712, 721-724, 731, 741-744, 751, 754, 757, 759, 801-811, Title IX, secs. 1002, 1225-1227, 1451, 1452, 1701, 1820, and Title XXIV of the House bill, and secs. 125, 126, 142, 212, 230-232, 251-253, 302, $318,327,346,401-407,415,503,601-607,609,610,624,631-635,706,721$, 722, 725, 731, 734, 751, 752, 757, 801, Title IX, Title X, secs. 1102, 1103, 1105 , 1106, 1224, Title XIV, secs. 1601, 1602, and 1611 of the Senate amendment, and modifications committed to conference: Boehlert, Biggert, and Gordon.

Provided that Mr. Costello is appointed in lieu of Mr. Gordon for consideration of secs. 401-404, 411, 416, and 441 of the House bill, and secs. 401-407 and 415 of the Senate amendment, and modifications committed to conference The Speaker appointed conferees - from the Committee on Transportation and Infrastructure for consideration of secs. 101-103, 105, 108, 109, 137, 205, 208, 231, 241, 242, 320, 328-330, 377, 379, 721-724, 741-744, 751, 755, 756, 758, $811,1211,1221,1231,1234,1236,1241,1281-1283,1285,1295,1442,1446$, 2008, 2010, 2026, 2029, 2030, 2207, and 2210 of the House bill, and secs. $101-$ $103,105,107,108,281,325,344,345,383,731-733,752,1211,1221,1231$, $1233,1235,1261,1263,1266$, and 1291 of the Senate amendment, and modifications committed to conference: Young (AK), Petri, and Oberstar. The Speaker appointed conferees - from the Committee on Ways and Means for consideration of Title XIII of the House bill, and secs. 135, 405, Title XV, and sec. 1611 of the Senate amendment, and modifications committed to conference: Thomas, Camp, and Rangel.

Conference held.

Senate ordered measure printed as passed.

7/19/2005:

Conference held.

7/21/2005:

Conference held.

7/24/2005:

Conference held.

7/26/2005:

Conferees agreed to file conference report.

7/27/2005:

Conference report H. Rept. 109-190 filed. 
Rules Committee Resolution H. Res. 394 Reported to House. Rule provides for consideration of the conference report to H.R. 6. All points of order against the conference report and against its consideration are waived. The conference report is considered as read.

\section{7/28/2005:}

Rule H. Res. 394 passed House.

Mr. Barton (TX) brought up conference report H. Rept. 109-190 for consideration under the provisions of H. Res. 394.

DEBATE - The House proceeded with one hour of debate on the conference report to accompany H.R. 6.

Motions to reconsider laid on the table Agreed to without objection.

On agreeing to the conference report Agreed to by the Yeas and Nays: 275 - 156

Conference papers: message on House action held at the desk in Senate.

Conference report considered in Senate by Unanimous Consent.

7/29/2005:

Conference report considered in Senate by Unanimous Consent

Point of order that the Conference Report violates Section 302(f) of the

Congressional Budget Act against the measure raised in Senate.

Motion to waive the Budget Act with respect to the measure agreed to in Senate

by Yea-Nay Vote. 71 - 29

Point of order fell when the motion to waive the Budget Act was agreed to in

Senate.

Senate agreed to conference report by Yea-Nay Vote. 74 - 26.

Message on Senate action sent to the House.

Cleared for White House.

8/4/2005:

Presented to President.

8/8/2005:

Signed by President.

8/8/2005:

Became Public Law No: 109-58. 


\section{Appendix X}

\section{Public Law Number 110-140}

\section{Energy Independence and Security Act of 2007 - H.R. 6 Timeline}

Official Title: To move the United States toward greater energy independence and security, to increase the production of clean renewable fuels, to protect consumers, to increase the efficiency of products, buildings, and vehicles, to promote research on and deploy greenhouse gas capture and storage options, and to improve the energy performance of the Federal Government, and for other purposes.

Introduced by: Nick Rahall ${ }^{282}$ (D-WV), Chair of the House Committee on Natural Resources, with 198 cosponsors, January 12, 2007

Committees:

Senate Committee on Foreign Relations

Subcommittee on Energy and Environment of the House Committee on Science and Technology

House Committee on Ways and Means

House Committee on Small Business

Senate Committee on Energy and Natural Resources

Senate Committee on Energy and Natural Resources

Timeline of Congressional Actions:

\section{1/12/2007:}

Referred to the Committee on Ways and Means, and in addition to the Committees on Natural Resources, the Budget, and Rules, for a period to be subsequently determined by the Speaker, in each case for consideration of such provisions as fall within the jurisdiction of the committee concerned.

Referred to House Ways and Means

Referred to House Natural Resources

Referred to House Budget

1/16/2007

Referred to House Rules

Rules Committee: Motion proposed by Hastings (R-WA) to grant open rule defeated 4-8.

Rules Committee Resolution H. Res. 66 Reported to House. Rule provides for debate under closed rule with 3 hours of general debate: 60 minutes controlled by the Chairman and Ranking Member of the Committee on Ways and Means, 60 minutes by the Chairman and Ranking Member of the Committee

${ }^{282}$ Rahall was one of only four Democrats to oppose the final bill. Congressman King (DNY) changed his vote from yay to nay. 
on Natural Resources, 30 minutes controlled by the Chairman and Ranking Member of Committee on Agriculture and 30 minutes controlled by the Chairman and Ranking Member of the Committee on Science and Technology. Previous question shall be considered as ordered without intervening motions except motion to recommit with or without instructions. Measure will be considered read. Bill is closed to amendments.

\section{1/18/2007}

Rule H. Res. 66 passed House.

Rangel (D-NY) Chair of House Ways and Means called up H.R. 6and asked unanimous consent for its immediate consideration.

QUESTION OF CONSIDERATION -Price (R-GA) demanded that the question be put on consideration of the bill H.R. 6

Closed rule agreed to by recorded vote: 228 - 193 (roll number 37)

Rule provides for 3 hours of general debate (as above) Bill is closed to amendments. Mr. McCrery moved to recommit with instructions to Ways and Means, Natural Resources, The Budget, and Rules.

Floor Summary: Debate - The House proceeded with ten minutes of debate on the McCrery motion to recommit with instructions. The instructions contained in the motion seek to require the bill to be reported to the House after the Committee holds hearings on, and considers, the bill.

The previous question on the motion was ordered without objection.

On motion to recommit with instructions Failed by the Yeas and Nays: 194 - 232 (roll number 38)

Point of order raised by Mr. Blunt on the content of the measure. Point of order overruled by the Chair.

Mr. Blunt appealed the ruling of the chair. The question was then put on sustaining the ruling of the chair.

Mr. McDermott moved to table the appeal of the ruling of the chair.

On motion to table the appeal of the ruling of the chair Agreed to by the Yeas and Nays: 230 - 195 (roll number 39).

On passage Passed by the Yeas and Nays: 264 - 163 (roll number 40)

Motion to reconsider laid on the table Agreed to without objection. Received in the Senate. Read the first time. Placed on Senate Legislative Calendar under Read the First Time.

1/22/2007:

Read the second time. Placed on Senate Legislative Calendar under General Orders. Calendar No. 9.

6/6/2007:

Motion to proceed to consideration of measure made in Senate.

Cloture motion on the motion to proceed presented in Senate.

Motion to proceed to consideration of measure withdrawn in Senate.

6/7/2007:

Motion to proceed to measure considered in Senate.

6/11/2007:

Motion to proceed to measure considered in Senate.

Cloture on the motion to proceed invoked in Senate by Yea-Nay Vote. 91 
-0 (record number 208).

\section{6/12/2007:}

Motion to proceed to measure considered in Senate.

Motion to proceed to measure considered in Senate.

Motion to proceed to consideration of measure agreed to in Senate by Unanimous Consent.

Measure laid before Senate by unanimous consent.

Amendment SA 1502 proposed by Reid - in the nature of a substitute.

Amendment SA 1505 proposed by Inhofe to Amendment SA 1502 -- to

improve domestic fuels security.

Amendment SA 1508 proposed by Lieberman for Bayh to Amendment SA 1502 -- to provide for the publication and implementation of an action plan to reduce the quantity of oil used annually in the United States.

Amendment SA 1515 proposed by Sanders to Amendment SA 1502 -- to establish an energy efficiency and renewable energy worker training program. Amendment SA 1515 agreed to in Senate by Unanimous Consent. Amendment SA 1508 agreed to in Senate by Yea-Nay Vote. 63 -

6/13/2007:

30. (record number 209)

Considered by Senate.

Amendment SA 1502 Considered by Senate.

Amendment SA 1505 Considered by Senate.

Amendment SA 1505 not agreed to in Senate by Yea-Nay Vote. $43-52$ (record number 210).

Amendment SA 1537 proposed by Senator Reid for Senator Bingaman to Amendment SA 1502 -- to provide for a renewable portfolio standard.

Amendment SA 1538 proposed by Senator McConnell for Senator Domenici to Amendment SA 1537 -- to provide for the establishment of a Federal clean portfolio standard.

6/14/2007:

Considered by Senate.

SA 1502 considered by Senate.

SA 1537 considered by Senate.

SA 1538 considered by Senate.

Motion to table amendment SA 1538 agreed to in Senate by Yea-

Nay Vote. $\quad 56-39$ (record number 211).

Amendment SA 1573 proposed by Klobuchar for Bingaman to Amendment SA 1537 -- to provide for a renewable portfolio standard.

Amendment SA 1566 proposed by Warner to Amendment SA 1502 -- to authorize the State of Virginia to petition for authorization to conduct natural gas exploration and drilling activities in the coastal zone of the State.

Amendment SA 1557 proposed by Bingaman for Klobuchar to Amendment SA 1502 -- to establish a national greenhouse gas registry.

Amendment SA 1578 proposed by Menendez to Amendment SA 1566 -to authorize the State of Virginia to petition for authorization to conduct natural gas exploration and drilling activities in the coastal zone of the State.

Amendment SA 1519 proposed by Kohl to Amendment SA 1502 -- to 
amend the Sherman Act to make oil-producing and exporting cartels illegal.

Amendment SA 1546 proposed by Kohl for Senator DeMint to Amendment SA 1502 --

to provide that legislation that would increase the national average fuel prices for automobiles is subject to a point of order in the Senate.

Amendment SA 1578 was modified to be a 1st degree amendment by Unanimous Consent.

Amendment SA 1578 proposed by Menendez to Amendment SA 1502.

Amendment SA 1572 proposed by Salazar to Amendment SA 1502 -- to

reduce United States dependence on foreign oil by promoting the development of plug-in electric vehicles, deploying near-term programs to electrify the transportation sector, and including electric drive vehicles in the fleet purchasing programs.

Amendment SA 1566, having failed to achieve the 60 votes required for adoption, not agreed to in Senate by Yea-Nay Vote. 43 - 44 (record number 212).

Proposed amendment SA 1566, having failed to achieve the 60 votes required for adoption, withdrawn in Senate.

Proposed amendment SA 1578, amendment SA 1566 having failed to achieve the 60 votes required for adoption, withdrawn in Senate.

Amendment SA 1572 as modified agreed to in Senate by Voice Vote.

6/15/2007:

Considered by Senate.

Amendment SA 1502 Considered by Senate.

SA 1519 considered by Senate.

SA 1537considered by Senate.

SA 1546 considered by Senate.

SA 1557 considered by Senate.

SA 1573 considered by Senate.

Amendment SA 1608 proposed by Corker to Amendment SA 1502 -- to allow clean fuels to meet the renewable fuel standard.

Amendment SA 1520 proposed by Cardin to Amendment SA 1502 -- to promote the energy independence of the United States.

Amendment SA 1609 proposed by Domenici for Thune to Amendment SA 1502 -- to provide requirements for the designation of national interest electric transmission corridors.

Amendment SA 1610 proposed by Cardin to Amendment SA 1502 -- to provide for the siting, construction, expansion, and operation of liquefied natural gas terminals.

Amendment SA 1524 proposed by Salazar to Amendment SA 1502 -- to express the sense of Congress relating to the use of renewable resources to generate energy.

Amendment SA 1524 agreed to in Senate by Voice Vote.

Amendment SA 1615 proposed by Collins to Amendment SA 1502 -- to provide for the development and coordination of a comprehensive and integrated United States research program that assists the people of the 
United States and the world to understand, assess, and predict humaninduced and natural processes of abrupt climate change.

6/18/2007:

Considered by Senate.

SA 1502 considered by Senate.

SA 1519 considered by Senate.

SA 1520 considered by Senate.

SA 1537 considered by Senate.

SA 1546 considered by Senate.

SA 1557 considered by Senate.

SA 1573 considered by Senate.

SA 1608 considered by Senate.

SA 1609 considered by Senate.

SA 1610 considered by Senate.

SA 1615 Considered by Senate.

Amendment SA 1628 proposed by Domenici for Bunning to Amendment SA 1502 -- to provide standards for clean coal-derived fuels.

Amendment SA 1614 proposed by Bingaman for Tester to Amendment SA 1502 -- to establish a program to provide loans for projects to produce syngas from coal and other feedstocks while simultaneously reducing greenhouse gas emissions and reliance of the United States on petroleum and natural gas.

6/19/2007:

Considered by Senate.

SA 1502 considered by Senate.

SA 1519 considered by Senate.

SA 1520 considered by Senate.

SA 1537 considered by Senate.

SA 1546 considered by Senate.

SA 1557 considered by Senate.

SA 1573 considered by Senate.

SA 1608 considered by Senate.

SA 1609 considered by Senate.

SA 1610 considered by Senate.

SA 1614 considered by Senate.

SA 1615 considered by Senate.

SA 1628 considered by Senate.

Amendment SA 1628 not agreed to in Senate by Yea-Nay Vote. 39

- 55 (record number 213).

Amendment SA 1614 not agreed to in Senate by Yea-Nay Vote. 33

- 61 (record number 214).

Amendment SA 1609 agreed to in Senate by Voice Vote.

Amendment SA 1519 agreed to in Senate by Yea-Nay Vote. 70 -

23 (record number 215).

Amendment SA 1610 not agreed to in Senate by Yea-Nay Vote. 37

- 56 (record number 216).

Amendment SA 1704 proposed by Baucus to Amendment SA 1502 -- to

amend the Internal Revenue Code of 1986 to provide for energy advancement 
and investment, and for other purposes.

Cloture motion on amendment SA 1704 presented in Senate

Cloture motion on amendment SA 1502 presented in Senate.

Cloture motion on the bill presented in Senate.

6/20/2007:

Considered by Senate.

SA 1502 considered by Senate.

SA 1520 considered by Senate.

SA 1537 considered by Senate.

SA 1546 considered by Senate.

SA 1557 considered by Senate.

SA 1573 considered by Senate.

SA 1608 considered by Senate.

SA 1615 considered by Senate.

SA 1704 considered by Senate.

Point of order raised in Senate with respect to amendment SA 1546.

Motion to waive the Budget Act with respect to amendment SA

1546 rejected in Senate by Yea-Nay Vote. 37 - 55 (record number 217).

Amendment SA 1546 ruled out of order by the chair.

Amendment SA 1718 proposed by Gregg to Amendment SA 1704 -- to strike the provision extending the additional duty on ethanol and for other purposes.

Point of order raised in Senate with respect to amendment SA

1718.

Motion to waive the Budget Act with respect to amendment SA

1718 rejected in Senate by Yea-Nay Vote. 36 - 56 (record number 218)

Amendment SA 1718 ruled out of order by the chair.

Amendment SA 1528 proposed by Bingaman to Amendment SA 1502 -- to improve the section relating to energy storage competitiveness.

Amendment SA 1529 proposed by Bingaman to Amendment SA 1502 -- to require the Administrator of General Services to submit an annual report to the Energy Information Agency.

Amendment SA 1533 proposed by Bingaman for Menendez to Amendment SA 1502 -- to make the Commonwealth of Puerto Rico eligible for the Federal weatherization program.

Amendment SA 1551 proposed by Senator Bingaman for Senator Cantwell to Amendment SA 1502 -- to establish a standard for Federal agencies for the purchase of products that have standby power.

Amendment SA 1528 agreed to in Senate by Unanimous Consent.

Amendment SA 1529 agreed to in Senate by Unanimous Consent.

Amendment SA 1533 agreed to in Senate by Unanimous Consent.

Amendment SA 1551 as modified agreed to in Senate by Unanimous Consent.

Amendment SA 1800 proposed by Kyl to Amendment SA 1704 -- to disallow the credit for renewable diesel for fuel that is coprocessed with petroleum.

Amendment SA 1693 proposed by Bingaman to Amendment SA 1502 -- to 
ensure that the renewable fuel standard does not harm the environment. Amendment SA 1666 proposed by Inhofe to Amendment SA 1502 -- to ensure agricultural equity with respect to the renewable fuels standard.

Amendment SA 1693 agreed to in Senate by Yea-Nay Vote. 58 34 (record number).

Point of order raised in Senate with respect to amendment SA 1666.

Motion to waive the Budget Act with respect to amendment SA 1666 rejected in Senate by Yea-Nay Vote. $31-63$ (record number 220).

Amendment SA 1666 ruled out of order by the chair.

Amendment SA 1800 not agreed to in Senate by Yea-Nay Vote. 45 - 49 (record number 21). Amendment SA 1733 proposed by Kyl to Amendment SA 1502 -- to provide a condition precedent for the effective date of the revenue raisers.

Amendment SA 1733 was modified to be a second degree amendment to SA 1704 by Unanimous Consent. Amendment SA 1733 proposed by Kyl to Amendment SA 1704.

6/21/2007:

Considered by Senate.

SA 1502 considered by Senate.

SA 1520 considered by Senate.

SA 1537 considered by Senate.

SA 1557 considered by Senate.

SA 1573 considered by Senate.

SA 1608 considered by Senate.

SA 1615 considered by Senate.

SA 1704 considered by Senate.

SA 1733 considered by Senate.

Point of order raised in Senate with respect to amendment SA

1733.

Motion to waive the Budget Act with respect to amendment SA

1733 rejected in Senate by Yea-Nay Vote. 38 - 55 (record number 222).

Amendment SA 1733 ruled out of order by the chair.

Cloture an amendment SA 1704 not invoked in Senate by Yea-Nay Vote. 57 - 36 (record number 223).

Motion by Reid to reconsider the vote by which cloture was not invoked on SA 1704 (entered in Senate.

Cloture on amendment SA 1502 invoked in Senate by Yea-Nay Vote. 61 - 32 (record number 224).

Amendment SA 1537 ruled non-germane by the chair.

Amendment SA 1573 ruled non-germane by the chair.

Amendment SA 1557 ruled non-germane by the chair.

Amendment SA 1608 ruled out of order by the chair.

Amendment SA 1520 ruled non-germane by the chair.

Amendment SA 1615 ruled non-germane by the chair.

Motion by Reid to reconsider the vote by which cloture was not 
invoked on amendment SA 1704 withdrawn in Senate.

Amendment SA 1704 ruled non-germane by the chair.

Amendment SA 1792 proposed by Stevens to Amendment SA 1502 -- to

provide for corporate average fuel economy (CAFE) standards.

Amendment SA 1792 as modified agreed to in Senate by Voice

Vote.

Amendment SA 1639 proposed by Bingaman to Amendment SA 1502 -to make certain technical corrections to title III.

Amendment SA 1677 proposed by Bingaman to Amendment SA 1502 -to improve the bill.

Amendment SA 1798 proposed by Bingaman to Amendment SA 1502 -to make technical corrections.

Amendment SA 1698 proposed by Bingaman for Cantwell to Amendment SA 1502 -- to modify the definition of renewable biomass.

Amendment SA 1568 proposed by Bingaman to Amendment SA 1502 -to prevent supply disruptions from planned refinery outages.

Amendment SA 1569 proposed by Bingaman for Domenici to Amendment SA 1502 -- to provide an alternate sulfur dioxide removal measurement for certain coal gasification project goals.

Amendment SA 1597 proposed by Bingaman for Inouye to Amendment SA 1502 -- to propose a study of the adequacy of transportation of domesticallyproduced renewable fuel by railroads and other modes of transportation, and for other purposes.

Amendment SA 1624 proposed by Bingaman for Dole to Amendment SA 1502 -- to expand the scope of the applied research program on energy storage systems to include flow batteries.

Amendment SA 1764 proposed by Bingaman for Akaka to Amendment SA 1502 -- to promote the development and use of marine and hydrokinetic renewable energy technologies.

Amendment SA 1799 proposed by Bingaman for Boxer to Amendment SA 1502 -- to reduce emissions of carbon dioxide from the Capitol power plant.

Amendment SA 1602 proposed by Bingaman for Inhofe to Amendment SA 1502 -- to provide transitional assistance for farmers who plant dedicated energy crops for a local cellulosic refinery.

Amendment SA 1660 proposed by Bingaman for Inhofe to Amendment SA 1502 -- to modify sections to provide for the use of geothermal heat pumps.

Amendment SA 1513 proposed by Bingaman for Murkowski to Amendment SA 1502 -- $\quad$ to amend the Alaska Natural Gas Pipeline Act to allow the Federal Coordinator for Alaska Natural Gas Transportation Projects to hire employees more efficiently.

Amendment SA 1683 proposed by Bingaman for Voinovich to Amendment SA 1502 -- to implement the Convention on Supplementary Compensation for Nuclear Damage.

Amendment SA 1729 proposed by Senator Bingaman to Amendment SA 1502 -- to provide for the treatment of certain applications and requests.

Amendment SA 1675 proposed by Senator Bingaman for Senator Menendez to Amendment SA 1502 -- to provide for a study on the effect of laws 
limiting the siting of privately owned electric distribution wires on the development of combined heat and power facilities.

Amendment SA 1687 proposed by Bingaman for Burr to Amendment SA 1502 -- to express the sense of Congress that the Department of Energy should be the lead United States Government agency in charge of formulating and coordinating the national energy security policy of the United States.

Amendment SA 1688 proposed by Bingaman for Burr to Amendment SA 1502 -- to require the President to submit to Congress an annual national energy security strategy report.

Amendment SA 1689 proposed by Bingaman for S Burr to Amendment SA 1502 -- to amend the National Security Act of 1947 to add the Secretary of Energy to the National Security Council in recognition of the role energy and energy security issues play in the United States national security.

Amendment SA 1525 proposed by Bingaman for Sanders to Amendment SA 1502 --to require that not less than 30 percent of the hot water demand for certain new or substantially modified Federal buildings be met through the installation and use of solar hot water heaters.

Amendment SA 1567 proposed by Senator Bingaman to Amendment SA 1502 -- to require the Secretary of Energy to establish a program to evaluate the cost-effectiveness of installing advanced insulation into commercial refrigerated trailers, refrigerators, freezers, and refrigerator-freezers.

Amendment SA 1717 proposed by Bingaman for Carper to Amendment SA 1502 -- to require the Secretary of the Interior, acting through the Director of the Minerals Management Service, to conduct a study to assess each offshore wind resource located in the region of the eastern outer Continental Shelf.

Amendment SA 1710 proposed by Bingaman for Feingold to Amendment SA 1502 -- to clarify the purposes of the energy and environmental block grant program.

Amendment SA 1759 proposed by Bingaman for Wyden to Amendment SA 1502 -- to provide for a national assessment of carbon sequestration and methane and nitrous oxide emissions from terrestrial ecosystems.

Amendment SA 1797 proposed by Bingaman for Cantwell to Amendment SA 1502 -- to modernize the electricity grid of the United States by catalyzing the production, use, and integration of technologies capable of communicating and recording valuable information relating to conditions of supply, consumer loads, and system performance.

Amendment SA 1595 proposed by Bingaman for Kohl to Amendment SA 1502 -- to provide a set aside for small automobile manufacturers and component suppliers for awards under the advanced technology vehicles manufacturing incentive program.

Amendment SA 1676 proposed by Bingaman for Brown to Amendment SA 1502 - to establish a renewable energy innovation partnership program to support the development, demonstration, and deployment of systems and projects relating to renewable energy.

Amendment SA 1679 proposed by Bingaman for Hutchison to Amendment SA 1502 - to require the Secretary of Energy to enter into an arrangement with the National Academy of Sciences to assess the impact of the 
renewable fuel standard.

Amendment SA 1615 proposed by Bingaman for Collins to amendment SA 1502 by Unanimous Consent.

Amendment SA 1520 proposed to amendment SA 1502 by

Bingaman for Cardin by Unanimous Consent.

Amendment SA 1700 proposed by Bingaman for Collins to Amendment

SA 1502 -- to provide for research support to facilitate the development of sustainable markets and technologies to produce and use woody biomass and other low-carbon fuels.

Amendment SA 1724 proposed by Bingaman for Enzi to Amendment SA 1502 -- to modify the deadline by which the President is required to approve or disapprove a certain State petition.

Amendment SA 1702 proposed by Bingaman for Snowe to Amendment SA 1502 -- to authorize loans for renewable energy systems and energy efficiency projects under the Express Loan Program of the Small Business Administration.

Amendment SA 1706 proposed by Bingaman for Kerry to Amendment SA 1502 -- to establish a small business energy efficiency program, and for other purposes.

Amendment SA 1639 agreed to in Senate by Unanimous Consent. Amendment SA 1677 agreed to in Senate by Unanimous Consent. Amendment SA 1798 agreed to in Senate by Unanimous Consent. Amendment SA 1698 agreed to in Senate by Unanimous Consent. Amendment SA 1568 as modified agreed to in Senate by Unanimous Consent.

Amendment SA 1569 agreed to in Senate by Unanimous Consent. Amendment SA 1597 as modified agreed to in Senate by Unanimous Consent. Amendment SA 1624 agreed to in Senate by Unanimous Consent.

Amendment SA 1764 as modified agreed to in Senate by Unanimous Consent. Amendment SA 1799 agreed to in Senate by Unanimous Consent.

Amendment SA 1602 agreed to in Senate by Unanimous Consent. Amendment SA 1660 agreed to in Senate by Unanimous Consent. Amendment SA 1513 as modified agreed to in Senate by Unanimous Consent.

Amendment SA 1683 agreed to in Senate by Unanimous Consent. Amendment SA 1729 as modified agreed to in Senate by Unanimous Consent. Amendment SA 1675 agreed to in Senate by Unanimous Consent.

Amendment SA 1687 as modified agreed to in Senate by Unanimous Consent. Amendment SA 1688 agreed to in Senate by Unanimous Consent.

Amendment SA 1689 agreed to in Senate by Unanimous Consent. Amendment SA 1525 as modified agreed to in Senate by Unanimous Consent. Amendment SA 1567 as modified agreed to in Senate by Unanimous Consent. 
Amendment SA 1717 agreed to in Senate by Unanimous Consent. Amendment SA 1710 agreed to in Senate by Unanimous Consent. Amendment SA 1759 as modified agreed to in Senate by Unanimous Consent. Amendment SA 1797 as modified agreed to in Senate by Unanimous Consent. Amendment SA 1595 as modified agreed to in Senate by Unanimous Consent. Amendment SA 1676 as modified agreed to in Senate by Unanimous Consent. Amendment SA 1679 as modified agreed to in Senate by Unanimous Consent. Amendment SA 1615 as modified agreed to in Senate by Unanimous Consent. Amendment SA 1520 as modified agreed to in Senate by Unanimous Consent. Amendment SA 1700 as modified agreed to in Senate by Unanimous Consent. Amendment SA 1724 agreed to in Senate by Unanimous Consent. Amendment SA 1702 agreed to in Senate by Unanimous Consent. Amendment SA 1706 as modified agreed to in Senate by Unanimous Consent. Amendment SA 1502 agreed to in Senate by Unanimous Consent.

Cloture on the bill invoked in Senate by Yea-Nay Vote. 62 - 32 (record number 225).

Passed Senate with an amendment by Yea-Nay Vote. $65-27$ (record number 226).

\section{6/22/2007:}

Measure amended in Senate by unanimous consent after passage.

Title to H.R. 6 amended after passage.

Amendment SA 1867 proposed by Senator Reid for Senator Bingaman -to amend the title.

6/25/2007:

Amendment SA 1867 agreed to in Senate by Unanimous Consent.

Senate ordered measure printed as passed.

6/26/2007:

Message on Senate action sent to the House.

12/5/2007

Rules Committee Resolution H. Res. 846 reported to House -- rule provides for consideration of H.R. 6.

12/6/2007

Pursuant to the provisions of H. Res. 846 the House moved to agree with amendments to the Senate amendments

DEBATE - Pursuant to the provisions of H. Res. 846, the House proceeded with one hour of debate on the motion to agree to the Senate amendments with amendments.

The House resumed debate on the motion to agree to the Senate amendments to H.R. 6 with amendments.

The previous question was ordered pursuant to the rule.

On motion that the House agree with amendments to the Senate amendments Agreed to by the Yeas and Nays: 235 - 181 (roll number 1140).

Motion to reconsider laid on the table Agreed to without objection. 12/7/2007: 
Message on House action received in Senate and at desk: House amendments to Senate amendments.

Motion to agree to House amendments to Senate amendments made in Senate.

Cloture motion on the motion to agree to House amendments to Senate amendments presented in Senate.

Cloture on the motion to agree to the House amendments to the Senate amendments not invoked in Senate by Yea-Nay Vote. 53 - 42 (record number 416).

Motion to agree to House amendment to the Senate amendment to the text of H.R. 6 with an amendment (SA 3841) made in Senate.

Amendment SA 3841 proposed by Reid to the House amendment to the Senate amendment to the text -- in the nature of a substitute.

Amendment SA 3842 proposed by Reid to Amendment SA 3841 -- to change the enactment date.

Pursuant to the order of December 11, 2007, cloture motion on the motion to agree to the House amendment to the Senate amendment to the text of H.R. 6, with an amendment (SA 3841) presented in Senate.

\section{2/13/2007:}

Motion to agree to House amendment to the Senate amendment to the text of H.RT.6, with an amendment (SA 3841) considered in Senate.

SA 3841 Considered by Senate.

SA 3842 Considered by Senate.

Cloture on the motion to agree to the House amendment to the Senate amendment to the text of H.R.6, with an amendment (SA 3841) not invoked in Senate by Yea-Nay Vote 59 - 40 (record number 425).

Motion to agree to the House amendment to the Senate amendment to the text of H.R. 6 withdrawn in Senate.

SA 3841 fell when the motion to agree to House amendment to the Senate amendment to the text of H.R. 6 was withdrawn.

SA 3842 fell when SA 3841 fell.

Motion to concur in House amendment to the Senate amendment to the text of H.R. 6, with an amendment (SA 3850) made in Senate.

Amendment SA 3850 proposed by Senator Reid to the amendment of the House to the amendment of the Senate to the text of H.R. 6 -- in the nature of a substitute.

Cloture motion on the motion to agree to House amendments to Senate amendments withdrawn by unanimous consent in Senate.

Senate concurred in the House amendment to the Senate amendment to the text of H.R. 6 with an amendment (SA 3850) by Yea-Nay Vote. $86-8$ (record number 430)

Senate concurred in the House amendment SA 3850 to the Senate amendment to the title by Unanimous Consent.

\section{2/14/2007:}

Message on Senate action sent to the House.

12/17/2007

Rules Committee Resolution H.Res 877 reported to House. Upon adoption of the resolution, it shall be in order to take from the Speaker's table, H.R. 6, with the 
Senate amendment to the House amendment to the Senate amendment, and to agree with the Senate amendment.

\section{2/18/2007}

Pursuant to the provisions of H. Res 877, the House moved to agree to the Senate amendment to the House amendments to the Senate amendments.

DEBATE - The House proceeded with one hour of debate on the motion to agree to the Senate amendment to the House amendment to the Senate amendment to H.R. 6.

The previous question was ordered pursuant to the rule.

On motion that the House agree to the Senate amendment to the House

amendments to the Senate amendments Agreed to by the Yeas and Nays: $314-$ 100 (roll number 1177). Motion to reconsider laid on the table Agreed to without objection.

Cleared for White House.

Presented to President.

12/19/2007:

Signed by President.

Became Public Law No: 110-140. 


\section{Appendix XI}

\section{House Resolution 66 Floor Debate}

The use of the "closed rule" process in the House frequently leads to a very frustrated minority expressing their feelings during floor debate which is their first opportunity to vent their concerns. In as much as the closed rule is passed out of the Rules Committee by a majority vote and then the full House passes a resolution approving the closed rule, the minority feels it has had no opportunity for meaningful input, discussion or debate. The quotations below are from House floor debate on January $18^{\text {th }}, 2007$ regarding the introduction of House Resolution 66 which would bring to the floor H.R. 6, a bill to:

To reduce our Nation's dependency on foreign oil by investing in clean, renewable, and alternative energy resources, promoting new emerging energy technologies, developing greater efficiency, and creating a Strategic Energy Efficiency and Renewables Reserve to invest in alternative energy, and for other purposes ${ }^{283}$

While it can be argued that deliberative democracy was present institutionally in that the majority of the House by virtue of there having been debate and discussion amongst the majority at several different levels; the Committees on Natural Resources, the Budget, and Rules and then the full House, there can be no

escaping the conclusion that the floor debate the afternoon of January $18^{\text {th }}, 2007$

${ }^{283}$ (Library of Congress, 2007) 
was anything but "reasoning on the merits of public policy"284 and illuminated a complete lack of deliberative democracy in action.

Public Law 110-140 House debate Clean Energy Act of 2007 - House resolution 66 (H675) floor debate selected quotations from Thursday January $18^{\text {th }}, 2007$ during 3 hours of floor debate: ${ }^{285}$

The voters sent us a message in November. They called us to account for bill after bill of kickbacks to special interests like Big Oil. We were not sent here to allow huge corporations to reap the benefits of tax breaks while gouging their customers at the gas pump. McGovern (MA Dem) H676 - column 2

...fairness, openness, sunshine, transparency, bipartisanship, those are just some of the words that the new majority used to describe the way they were going to run the 110th Congress. But today we will begin debate on the sixth bill of the Democrats' '100 Hours for 6' or 100 hours' agenda; we have seen all too clearly, Mr. Speaker, the truth about those promises. They have been, at best, hollow promises. $\quad$ Diaz-Balart (FL - Rep) H677 - column 1

2 weeks ago we passed legislation to end the culture of corruption in Congress. Today we consider legislation to reverse some of the harmful consequences of that corruption. H.R. 6, the CLEAN Energy Act, will repeal $\$ 14$ billion in tax reduction subsidies and other outrageous benefits given to big oil companies. Many of these measures were included in legislation that was written in backroom and late-night meetings. With the passage of our ethics reform in this bill, we are fulfilling our responsibility to the American people to clean up Congress and reverse the past lapse that led us to where we are today. Sutton (OH - Dem) H677 - column 3

I understand the need for the majority party to want to make its move, to make its first impression; and I understand the first couple of bills had to come flying right to the floor. But we are short-circuiting democracy here, and I think my colleagues on both sides of the aisle understand that. Boehner (OH - Rep) H678 - column 2

...Chairman RAHALL, in his testimony before the Rules Committee 2 days ago, said that this was the first step, that there are a lot more issues that we need to address as a Congress to achieve our goal of energy independence, and we are going to do that. What we are doing today

\footnotetext{
284 (Bessette, 1994) pp. 46

285 (United States Congress, 2007) H676 - H696
} 
really is responding to the outcry of the American people who are outraged by the fact that in the midst of being gouged by Big Oil, the previous Congress decided to pass a bill to provide billions of dollars in subsidies and tax breaks to those very companies. McGovern (MADem) H680 - column 1

... I find it amusing to be lectured about energy independence and working hard to get things done from our colleagues on the other side who for the last 6 years could have solved the problems, but instead watched us sink further into dependence on foreign and polluting sources of energy. Hall (NY - Dem) H680 - column 1

I had to come down here and speak on this rule because I was in the Rules Committee the other night and I wasted my time, and everyone in that committee wasted their time because the Rules Committee chairwoman said, before we even met, that she was not going to accept any amendments or even a substitute. Nunes (CA - Rep) H682 - column 1

I appreciate the chairwoman's honesty earlier about the fact this was going to be a closed rule. We listened for 2 years about the whining on closed rules and the fact that it reflected a closed mind. So on our side, for the next 2 years, we will try to keep our whining to a minimum. Conway (TX - Rep) H683 - column 3

...the other side has now become so intoxicated with the power and authority that they have being in the majority, that they do not continue to misuse that power and authority and continue to ignore open debate and honest ideas and an exchange of honest ideas that the committee process typically allows and that brings better legislation to this floor and helps us address these things. Conway (TX - Rep) H684 - column 1

We cannot justifiably continue to allow big oil companies to reap astronomical financial benefits while the citizens of this country continue to struggle to pay their living expenses due to the outrageous cost of oil and gas. These high costs derive primarily from our overwhelming dependence on foreign oil. The Energy Information Administration estimates that the United States imports nearly 60 percent of the oil it consumes. Moreover, the world's greatest petroleum reserves reside in regions of high geopolitical risk, including 57 percent of which are in the Persian Gulf. Jackson-Lee (TX - Dem) H685 - column 1

H.R. 6 would also close gaping loopholes and end gigantic giveaways for Big Oil in the tax code and in the 2005 Energy bill. The bill would eliminate a loophole written into the international tax bill, H.R. 4520, which allowed oil companies to qualify for a tax provision intended to encourage domestic manufacturing. According to the New York Times, this loophole provided ConocoPhillips $\$ 106$ million in 2005, even though its profits totaled $\$ 13.5$ billion. The benefits which ConocoPhillips reaped 
from the tax loophole, represents just a snap-shot of the lopsided picture that overwhelmingly favors the financial well-being of big oil companies over average American families. Jackson-Lee (TX - Dem) H685 column 2

I understand the concerns expressed by my friends on the other side of the aisle. I served in the minority party during the last Congress, and I suspect my friends are worried that they will be treated as poorly and disrespectfully as we were. I was here when the Republican majority passed exactly one open rule on a non-appropriations bill. I was here when votes were held open for 3 hours to change people's votes. I was here when special interests provisions were tucked into conference reports after they were signed. This House is broken, Mr. Speaker, and the Democratic majority was elected to fix it, and that is what we are going to do. All I can tell my friends on the other side of the aisle is what I believe. I believe that every Member of this House deserves to be respected. I believe that one party does not hold a monopoly on good ideas; and I believe that openness should be the rule, and not the exception. And all I can offer my friends is my word that I will work as hard as I possibly can to make sure that this House runs in a more open, democratic fashion than was the norm over the past 12 years. McGovern (MA - Dem) H686 column 2

I was reminded once again of a recurring theme in this town from Republicans: have they ever met a special interest they didn't love. The struggles of Big Oil: profits last year of 117 percent. Remember as we heard these arguments just a couple of minutes ago from those champions of the average guy, as they would have you believe today, these are the people who in a craven moment in the closing days of the 109th Congress tied an increase in the minimum wage to repeal of the estate tax, conveniently forgetting about that individual who had to work one day a week at minimum wage just to fill their gasoline tanks.

This [H.R. 6] is good policy."Neal (MA - Dem) H691 - column 2

Mr. Speaker, today politics trumps policy. If regular order had been followed in this House, allowing this tax increase to go through the Ways and Means Committee, we would have a better understanding of the consequences of today's \$14 billion tax increase. You know, if the House of Representatives was subjected to the truth-in-labeling requirement, H.R. 6 would be called the Ship Jobs Overseas Act because it imposes a $\$ 14$ billion tax increase on investing in America. Weller (IL - Rep) Member of the Ways and Means Committee H691 - column 3

H.R. 6 will have profound and long-lasting harmful effects on our economy and our security. Overall, this bill takes our country in the opposite direction than the one in which we need to go. H.R. 6 is nothing more than a ploy by the Democratic Party to create political sound bites at the expense of sound energy policy" Cole (OK - Rep) H693 - column 1 
...the Congressional Research Service has reported that the net impact of the 2005 energy bill was to actually raise revenue from the domestic oil and gas industry by $\$ 300$ million. But let not the facts get in the way of good bumper sticker politics. Hulshof (PA - Rep) H693 - column 3

When we burn them, they are gone. The U.S. has only 2 percent of known oil reserves. We use 25 percent of the world's oil and import two-thirds of what we are using. We pump our reserves four times faster than the rest of the world. I just returned from a trip to China. China is preparing for a post-oil world. There are three reasons to pursue renewable alternatives to fossil fuels. One is climate change. A second reason is preparing for peak oil. A third reason is for national security risk of our dependence on foreign oil. Bartlett (MD - Rep) -- bill cosponsor H694 - column 1

...after 12 years of Republican misrule here in the House, it will take much more than 100 hours to undo the damage. Today is a first step toward energy independence. It is certainly not the conclusion of what will be a long process that will involve all Members of this House. We began this 100-hour legislative agenda with ethics laws to clean up this Congressand it sure needed cleaning up - and we conclude it today with this effort to clean up our environment and clean up our tax code. Although modest, the CLEAN bill is truly a breath of fresh air. Doggett (TX - Dem) H694 column 3

Why has this legislation not been an opportunity to discuss real solutions to our Nation's energy crisis? Why does this bill include no provisions to move our Nation away from oil use at all? Why, Mr. Speaker? Because the majority doesn't want a real solution. They only want to stand here today and play politics with our Nation's future. I truly wish this debate could have been about the virtues of developing alternative energies. Instead, this is a veiled tax hike to create what some may say is a slush fund for future use. This is unconscionable. Lewis (KY - Rep) H695 - column 1

Two weeks ago, we began the 100 hours by enacting the most comprehensive ethics reform since the Watergate era, and we end the culture of corruption where the special interests had a free rein in determining national policy. Nowhere was that corruption of the system more apparent than the handouts to the energy companies. Mr. Speaker, for the past 4 years, I have come to this podium and said that that gavel was supposed to open up the people's House, not the auction house. Today, I proudly can say that we have given the people a voice, stood up to the special interests, and fought for hardworking families. The score is tied, and we are just getting warmed up. Emanuel (IL - Dem) H695 column 2

... after 12 years of failure to deal meaningfully with a comprehensive energy policy Republicans instead, gave this Congress and the American 
public a legislative grab bag. Today, under Democratic leadership, we are starting in the right direction to give conservation and energy choice, which Americans understand will take more than 100 hours, given the schizophrenic approach to energy by this administration and the previous Republican Congress. Blumenauer (OR - Dem) H695 - column 3

I think we can appropriately dub this the Hold on to Your Wallet Congress. And today, the tax increase that is being passed is one that is being put on the energy that runs our cars and heats our homes; and tomorrow, who knows? But hold on to your wallet, America, because they are coming for it. Blackburn (TN-Rep) H696 - column 2

This plan will lead the Nation in a new direction on energy policy. The United States imports 65 percent of the oil we consume. We spend $\$ 800$ million every day on foreign oil-producing countries. This threatens our economic stability, our environmental security, and our national security. And today we say, enough. Today we roll back the Republican-led Congress's giveaways to the oil industry. We stop rewarding the oil companies with taxpayer dollars; and, instead, we start to turn our attention to energy independence in this country. Schwartz (PA - Dem) H696 - column 3

H.R.6 begins the process of weaning off of corporate welfare. This is the beginning of it, so you had better get used to it. I am very shocked to hear what the opponents are saying to this legislation... Why isn't this welfare looked at as our tax money that we provide for these corporations? They don't need it. You know it, and I know it. $\quad$ Pascrell (NJ-Dem) $H 696$ column 1

And lastly, one of the very few substantive statements of the day:

This bill today is a disappointment to those of us who care about the goal of energy independence. This legislation sabotages the incentives with American energy companies to expand their drilling operations and undermines the opportunities to take advantage of our Nation's untapped resources. American energy reserves are very real. The Bureau of Land Management recently estimated the United States territory contains over 2 trillion barrels of oil shale, 100 billion barrels of energy just alone on the North American slopes of Alaska, enough oil to trump Saudi oil by 10fold. And it is our U.S. policies that keep us from accessing the U.S. reserves. Fallin (OK - Rep) H695 - column 3 


\section{Appendix XII}

\section{The Closed Rule}

Professor Michael Doran, Professor of Law, Georgetown University Law Center,

in his article on the closed rule from 2010 presents a clear and informative explanation of what the closed rule is and how it functions: ${ }^{286}$

The closed rule constitutes a critical component of managerial power in the contemporary House of Representatives and an increasingly important element of the legislative process. Subject to approval by the full membership, the closed rule allows managers to block all amendments to a measure when bringing that measure to the floor. Despite objections from the minority, both Republicans and Democrats regularly use the closed rule when in the majority, and rank-and-file members ordinarily approve any closed rule put to a floor vote. Once rarely used, the closed rule has become managers' preferred instrument for controlling the House floor agenda.

When properly situated within its institutional and theoretical context, the closed rule stands out as a critical mechanism by which managers control the floor agenda in the House. The closed rule allows managers to determine which policy positions will be considered on the floor (spatial agenda control) and the time allocated to each measure brought up for debate and voting(temporal agenda control). Managers use this agenda control to move measures toward their preferred policy positions. Although both parties object to the closed rule when numbered as the minority, the record in the 109th and 110th Congresses shows that both parties now make the same use of the closed rule when numbered as the majority. Specifically, both parties use closed and effectively closed rules for half the controversial measures brought to the floor.

Understanding the closed rule is critical for assessing the legislative process. The closed rule reinforces the strong internal agency relationships that the rank and file use to organize the activities of the House. By conferring on managers broad discretionary control over the floor agenda, the closed rule strengthens both leadership and the committee chairs. The rank and file retain final authority to ratify or reject managers' decisions about when and how to use the closed rule, but outright rejection of a closed rule on the floor-such as the defeat of House Resolution 336 that angered President Reagan-is a rare event.

${ }^{286}$ (Doran, 2010, Volume 59, Issue 6) 
The closed rule thus bears directly and importantly on the internal structure of the House: it contributes significantly to the concentration of legislative power among a handful of members holding managerial positions and correspondingly weakens the institutional position of the rank and file. Although positive political theory locates the closed rule in specifically distributive, informational, and partisan theories of legislative organization, the closed rule is more accurately understood, by generalizing those accounts, as broadly managerial. The closed rule affects the substance of the House's legislative product and the relationship between House members and their constituents. The closed rule contributes to legislative fragmentation and redundancy, increases capture opportunities for interest groups and Executive Branch agents, and makes bipartisan cooperation and compromise more difficult. Additionally, the closed rule generally diminishes the ability of the rank and file to pursue constituent interests by preventing members from offering floor amendments that might move the policy content of measures closer to their constituents' policy preferences. But that is part of a considered, deliberate, and rational tradeoff: by allowing managers to restrict their amendment activity, the rank and file steer the floor safely away from the chaos that could result from a weaker managerial structure. The closed rule functions within a particular version of representative democracy - a version in which the rank and file delegate substantial discretionary control over the House floor agenda to make the House more orderly, predictable, and productive. Thus understood, the normative case against the closed rule remains doubtful. 


\section{Appendix XIII}

\section{Key Groups Supporting the 25x'25 concept}

\section{National Partners}

AGCO Corporation

Agenda 2020 Technology Alliance

Protection (PA)

AgExcellence

Agricultural Retailers Association

American Agriculture Movement, Inc.

American Agri-Women

Environmentally Responsible

American Biogas Alliance

American Biogas Council

American Coalition for Ethanol

Information

American Council on Renewable Energy

American Farm Bureau Federation

America

American Farmland Trust

American Loggers Council

American Renewable Energy Day

American Society of Agricultural and

Biological Engineers

Association

American Society of Agronomy

American Society of Farm Managers and

Rural Appraisers

American Solar Energy Society

(Vancouver, BC)

American Soybean Association

Study Institute

American Tree Farm System

American Wind Energy Association

Center

Americans for Energy Independence

Information Council

Apollo Alliance

Association of Consulting Foresters of
Ceres Inc.

Cheste Citizens for Climate

CHS

Citizens for Global Solutions

Climate Solutions

Coalition for

Economies (CERES)

CoBank

Conservation Technology

Center (CTIC)

Crop Science Society of

CropLife America

Curtis Instruments, Inc.

DaimlerChrysler

Deere \& Company

Distributed Wind Energy

Diversa Corporation

Dunlap and Company (TX)

$\mathrm{E}^{3}$ Biofuels

enerG Magazine,

Environmental and Energy

Environmental Defense

Environmental Law \& Policy

Ethanol Promotion and

(EPIC)

Farm Credit Council 
America

Association

Association of Equipment Manufacturers

Association of State Energy Research

and Technology Transfer Institutions

BBI International

Biofuels Journal (IL)

Association

Biomass Thermal Energy Council

Inc.

Biotechnology Industry Organization

Research

C2I, LLC (VA)

Case New Holland

Center for American Progress

Holistic Management International

Development

Independent Community Bankers of

America

Institute for Agriculture and Trade Policy

Intertribal Council on Utility Policy

Patrons of

Iogen Corporation

ITT Flygt Corporation

Federation

Izaak Walton League of America

Association, Inc.

Jeff Simmons - Team Ethanol Racing

Cooperative

LV Electronics (Belgium)

MacDon Industries Ltd

Association

Monsanto Company

Association

National Association of Conservation

LLC

Districts

National Association of Counties

National Association of Resource

Conservation and Development

Councils
Farm Equipment Manufacturers

Farmers Fuel

Farmers National Company

Farrell Growth Group

Ford Motor Company

Forest Landowners

Forest Resources Association

Foundation for Agronomic

General Motors

Governors Ethanol Coalition

Growth Energy

National Energy Education

Project

National Ethanol Vehicle Coalition

National Farmers Union

National Grange Order of

Husbandry

National Milk Producers

National Renderers

National Rural Electric

Association

National Sorghum Producers

National Woodland Owners

Natural Resource Solutions,

North American Equipment Dealers

Association

Novozymes Corporation

Packer Engineering, Inc

Pellet Fuels Institute 
National Association of State

Conservation

Conservation Agencies

Institute

National Association of State

Departments of Agriculture

National Association of State Energy

Officials

National Association of State Foresters

National Association of Wheat Growers

Foresters

National Barley Growers

America

National Biodiesel Board

Association

National Center for Appropriate

Technology

National Conference on Weights and

Measures

National Corn Growers Association

National Corn to Ethanol Research

Foundation

Center

National Council of Agricultural

Education

National Council of Farmer Cooperatives

National Defense Council Foundation

National Education Association

Producers Alliance

USAEnergyIndependence.com (IL)

USA Rice Federation

USPIRG - The National Association of State

Public Interest Research Groups

Economics

Vermeer Manufacturing
Pinchot Institute for

Potash and Phosphate

Primafuel, Inc.

Realtors Land Institute

Renewable Fuels Association

Sheet Metal Workers' International

Association

Society of American

Soil Science Society of

Solar Energy Industries

Solar Energy International

Sugar Processing Research Institute

Sunkist Growers

SynGest, Inc.

The Fertilizer Institute

The Samuel Roberts Noble

Theodore Roosevelt Conservation

Partnership

Tilth Foundation

United Biofuels Development

United Soybean Board

USA Biomass Power

Weyerhaeuser Company

Windustry

Winrock International

Women Involved in Farm

Worldwatch Institute 


\section{Regional Partners}

2425 Ventures, LLC (TX)

Energy (LA)

Abeo Renewable Energy (MS)

Energies

Access Creative (TX)

Ackdev Inc. $(\mathrm{OH})$

ACRES, LLC (MI)

(DC)

Active Energies (CO)

Knoxville, Inc.

ADAGE (MD)

Renewable

Adams County Farm Bureau (IL)

Adams County Soil \& Water Conservation

Corporation

District (IL)

Advanced Biofuels Coalition (VA)

of Upper

Aedifico, LLC (NC)

African Global Development Initiative (NY) (AR)

Ag Connect (WI)

Council (MN)

Ag Credit ACA $(\mathrm{OH})$

Ag Ventures Alliance (IA)

School (WI)

Agracel, Inc. (IL)

AgRefresh (VT)

(VT)

Agricultural Council of Arkansas

Conservation

Agricultural Watershed Institute (IL)

AHL-TECH, Inc. (OH)

Resource

Alabama Clean Fuels Coalition

Development

Alabama Department of Agriculture and Industries
Alliance for Affordable

Alternative Fuels Renewable

Council (PA)

American Bio-Fuels (AL)

American Biogas Council

American Classifieds of

American Cooperative

Energy Sources (MI)

American Homegrown Fuel

(FL)

American Lung Association

Midwest

American Spirit Enterprises

American Sustainable Energy

AMFC, Inc (NY)

Arbor Vitae-Woodruff

ArborGen (SC)

Archimedes Aerospace, LLC

Arkansas Association of

Districts

Arkansas Association of

Conservation and

Councils

Arkansas Climate Awareness Project 
Alabama Department of Economic and Federation

Community Affairs

(MD)

Alabama Farmers Federation

and Water

Alabama Forestry Commission

Alabama State Legislature

Alabama Solar Association

(CA)

Alpha Solar Etc. (AL)

(FL)

AlgaeFuel (CA)

Bandit Industries (MI)

Bank of Newman Grove (NE)

(IL)

Barnards Soil Service (IL)

Basin Electric Power Cooperative (ND)

(IL)

Bauer Power, Inc.

BEECS Lab, Florida International

(KY)

University

Berkshire-Pioneer Resource Conservation and Development Council (MA)

BEST Energies (WI)

Association $(\mathrm{OH})$

Biggers Process Group (GA)

Performance Outpost

Bingham Economic Development

Corporation (ID)

Inc (NC)

Biobasednews.com (TN)

(IL)

Biodiesel Logic, Inc (AL)

Commissioners and

BioEarth, Inc. (PA)

Bioeconomy Development Corporation (NY)

Winegrape

Bioenergy Engineering (TN)
Arkansas Farm Bureau

Association of Forest Industries

Association of Illinois Soil

Conservation Districts

Auburn University (AL)

Avatar Alternative Energy

Azure Realty Services, Inc.

Balcones Resources (AR)

Blue Green Energy, MI

Bond County Farm Bureau

Boomtown Institute (IL)

Boone County Farm Bureau

Boyd Livestock Services (ID)

Bright Developments Corp

Brown County Farm Bureau (IL)

B.S.E. Consultants, Inc. (FL)

Buckeye Ethanol (OH)

Buckeye Renewable Fuels

Building Energy \&

(WI)

Bull Mountain Enterprises,

Bureau County Farm Bureau

California Agriculture

Sealers Association

California Association of

Growers 
BioEnergy Products Discovery Group

Commerce

BioPower Distributed Generation (NV)

Federation

Bioenergy Systems, LLC (AR)

Food and

BioFlorida, Inc.

BioFuelBox (CA)

Biofuels America, Inc. (TN)

Biofuels Racing Alliance (GA)

(VA)

Biomass Connections, LLC (PA)

Biomass Energy Council (DC)

(IL)

Biomass Partners (AL)

(MT)

Biomass Rules, LLC (IL)

Cooperative (ND)

BioNebraska

Bureau (IL)

BioResource Management (FL)

Bioroot Energy (MT)

Bioenergy

BIOWA (IA)

University

Black Farmers and Agriculturalists

Association, California Chapter

Environmental

BlackBelt Cooperative (AL)

Madison

Blount County Soil Conservation District

(TN)

and

Blount International, Inc (OR)

Washington State

BlueFire Ethanol, Inc. (CA)

Coalition Compass Strategies (FL)

Ethanol

Comves Ltd. (Bulgaria)

Champaign County Farm Bureau (IL)
California Chamber of

California Farm Bureau

California State Board of

Agriculture

California State Grange

California State Legislature

Capitol Greenroofs, LLC

CarbonTech, LLC (AZ)

Carroll Country Farm Bureau

Cascade County Commission

Cass County Electric

Cass-Morgan County Farm

Cedars Capital, LLC (TX)

Center for Advanced

Research, College of ACES,

of Illinois

Center for Energy and

Sustainability, James

University (VA)

Center for Sustaining Agriculture

Natural Resources,

Central Alabama Clean Cities

Central Indiana

Consumers Energy (IA) 
Chenango County Farm Bureau (NY)

(IL)

Chickasaw-Shilo RC\&D (TN)

Chieftain Energy Corporation $(\mathrm{OH})$

Opportunity Community Biomass Technologies

Chippewa County Board of Commissioners

Foresters

$(\mathrm{MN})$

Chippewa Valley Ethanol Company (MN)

Christian County Farm Bureau (IL)

Citizens for Pennsylvania's Future

City of Aspen (CO)

(FL)

City of Barry (IL)

City of Griggsville (IL)

Bureau

City of Marion (IN)

City of Pittsfield (IL)

Smoothies (FL)

City of Portland (OR)

City of Salt Lake City (UT)

Management

City of Visalia (CA)

Association

CJ Enterprises (WI)

C-Jays Garden Creations (ID)

(IL)

Clark County Farm Bureau (IL)

Clay County Farm Bureau (IL)

(NE)

Clouston Energy Research, LLC (MI)

Company (FL)

Clean Biofuels Coalition of Mississippi

Council

Clean Cities of West Tennessee

Clean Fuel Technologies (FL)

Ltd (MS)

Cloud Country Farm Bureau (KS)

Science

Colorado Farm Bureau

Coles County Soil \& Water Conservation
Cook County Farm Bureau

Cool Planet (MN)

Corporation for Economic

(SC)

Council of Western State

(NV)

CP Holdings, LLC (MN)

Crain Consulting (MS)

Crestone Solar School (CO)

Crop Input Systems, Inc.

CTL Engineering (OH)

Cumberland County Farm

(IL)

Cuppy's Coffee and

Cygnet Biofuel, Inc. (CA)

Delaware Nutrient

Delta-Montrose Electric

(CO)

DeWitt County Farm Bureau

DFA, Inc. (GA)

Dinkel Implement Company

Dioko Environmental

Distillers Grains Technology

(KY)

Domes International India

Donald Danforth Plant

Center (MO)

Donnell Consulting $(\mathrm{OH})$ 
District (IL)

Collin College (TX)

Ethanol

Colorado Harvesting Energy Network

Colorado Renewable Energy Society

Colorado State Legislature

Colorado State University Cooperative

Management (KY)

Extension

Coalition

Community Bankers Association of Illinois

Eckman's Computer Services (PA)

(IL)

EcoAchievers, LLC (IL)

Development

Ecology Center of Ann Arbor (MI)

Ecovation (NY)

Edgar County Farm Bureau (IL)

Edwards County Farm Bureau (IL)

Effingham County Farm Bureau (IL)

(NJ)

ELF Inc. (FL)

Inc.

Empire State Forest Products Association

Agriculture

(NY)

Encompass Biotech LLC (SC)

Energize Now Initiative (MA)

Federation

Energy Alliance of Puerto Rico

Energy Heritage (AR)

Energy Strategy Group (MI)

EnergyWorks (MD)

Enerkem, Inc. (Canada)

Producers

Enerjyn (MN)

EnSave, Inc. (VT)

Entegrity Wind Systems (VT)

Enterprise Projects, Inc. (OK)

Entira (TN)

(AZ)
Douglas County Farm Bureau (IL)

Dupont Danisco Cellulosic

(IL)

Early Tractor Company (GA)

Earth Friendly Fuels (AZ)

Earthwell Energy

East Tennessee Clean Fuels

Fayette County Farm Bureau

Fay-Penn Economic

Council (VA)

Feedlot Biofuel, LLC (KS)

Fibrowatt, LLC (PA)

First Coast Biofuels (FL)

Fishcreek Asset Management

Florida Biofuels Association,

Florida Department of

and Consumer Services

Florida Earth Foundation

Florida Farm Bureau

Florida Forestry Association

Florida Fruit and Vegetable

Association

Florida Legislature

Florida Renewable Energy

Association

Florida Tropical Fuels, LLC

Flower Power USA of WA

Focus the Nation (OR)

Foresight Wind Energy, LLC 
Enviro Board Corporation (CA)

Environment Maine

(AL)

Environment Maryland

(AZ)

Environment Michigan

Inc.

Environment North Carolina

Environmental Power Corporation (NH)

Envy Solar (NV)

ePower Synergies, Inc. (IL)

EPRIDA Scientific Carbons (GA)

(TN)

Ernst Conservation Seeds (PA)

$(\mathrm{MN})$

Eufaula Pulpwood Company (AL)

Exergy Development Group, LLC (ID)

(IL)

Far West Agribusiness Association

(IL)

Faribault County (MN)

(FL)

Faribault County Board of

Commissioners (MN)

Energy,

Farmergy Inc. (MO)

of Agriculture

Georgia General Assembly

Gevo (CO)

Resource Consulting

Glacial Hills Resource Conservation and

Development Region, Inc (KS)

(IL)

Global Biomass Fuels, LLC (FL)

Global Emissions Exchange (NJ)

Institute

Glover Oil Company (FL)

Golden Grain Energy, LLC (IA)

Grand Targhee Resort (WY)

(MN)
Forest Concepts, LLC (WA)

Forest Energy Association

Forest Energy Corporation

Forest Resource Consultants,

(GA)

Forest2Market, Inc (NC)

Foster Brothers Farm (VT)

F.R. Hall (MD)

Frazier, Barnes \& Associates

Fredrikson \& Byron, P.A.

Full Belly Music (CO)

Fulton County Farm Bureau

Gallatin County Farm Bureau

Gamma Solar Corporation

Genera Energy LLC (TN)

Georgia's Center of Innovation,

Georgia Department

Heissenbuttel Natural

(VA)

Henry County Farm Bureau

High Noon Solar (CO)

Hocking College Energy

$(\mathrm{OH})$

Holy Cross Energy (CO)

Home Farm Technologies 
Grasslands Renewable Energy LLC (MT)

Development

Great River Economic Development

Foundation (IL)

Green Capital Network, LLC (CA)

Green Electricity Buying Cooperative (MT)

Green Energy Products (AR)

Inc

Greenline Industries (AR)

Green Montgomery (AL)

Interim

Green Renewable Energy LLC (PA)

Energy,

Green State Solutions (IA)

Technology Greene County Farm Bureau (IL)

Bureau

Greenfield Plantation, Inc. (MS)

Greenstock, LLC: California Biodiesel

Feedstock Development

Areas

Green Vector Energy Technologies, LLC

Regional

(FL)

Greenway Renewable Energy (AR)

Association

Greenwood Technologies (WA)

Vintners

Green Warders, Inc. (NJ)

GridPoint, Inc. (D.C.)

Affairs

Grundy County Farm Bureau (IL)

Cooperative

Gulf Coast Biofuels, LLC (LA)

Association

Gulf Coast Energy, Inc. (AL)

Association

Gulf States Paper Corporation (AL)

Hancock County Farm Bureau (IL)

Handcrafted Log (CO)

Colorado
Homeland Energy Resources

(NY)

Hopping Green \& Sams (FL)

Horan Bio Production (IA)

Hybrid Fuels Inc of MB

Hybrid Power Technologies,

(TX)

Idaho Legislative Council

Committee on

Environment and

Idaho Farm

Ikehorn Industries (WI)

Illinois Agri-Women

Illinois Association of RC\&D

Illinois Association of

Councils

Illinois Corn Growers

Illinois Grape Growers and

Association

Illinois Institute for Rural

Illinois Rural Electric

Illinois Soil Testing

Illinois Solar Energy

Illinois Soybean Association

Illinois State Grange

Independent Bankers of 
Harbec Plastics, Inc. (NY)

Energy,

Harvesting Clean Energy (WA)

Haywood Community College (NC)

and Water

Headland Industrial Development Board

(AL)

Indiana Corn Growers Association

Indiana Corn Marketing Council

Association

Indiana Farm Bureau

Agriculture

Indiana Soybean Board

Cooperative,

Indiana Soybean Growers Association

IndoDanish Wind Technologies (India)

Federation

Innovative Energy Technologies (AZ)

Producers

Institute for Ethics and Emerging

Technology (MN)

Institute of Forest Biotechnology (NC)

INTACT Community Development

Association

Corporation (NY)

Intelligent Transportation Systems (CO)

International Wood Fuels, LLC (CA)

Interstate Traveler Company (MI)

Interwest Energy Alliance (CO)

(IL)

Iowa Central Community College

Iowa Farm Bureau Federation

Iowa Institute for Cooperatives

Coalition

Iowa Renewable Fuels Association

Renewable

Iowa Soybean Association

Inc

IPower Energy Systems (IN)

Agriculture IQ Learning Systems, Inc (MO)

Farm Bureau
Indian Orchard Renewable

LLC (PA)

Indiana Association of Soil

Conservation Districts

Kansas Agri-Women

Kansas Corn Growers

Kansas Department of

Kansas Electric Power

Inc

Kansas Farm Bureau

Kansas Grain Sorghum

Association

Kansas Soybean Association

Kansas State Legislature

Kaskaskia Watershed

(IL)

K.C. Larson, Inc. (PA)

$\mathrm{K} \& \mathrm{C}$ Machining (IL)

KEMA Consulting

Kendall County Farm Bureau

KenGro Corporation (MS)

Kennedy and Coe, LLC (KS)

Kentucky Clean Fuels

Kentucky Coalition for

Energy Resources,

Kentucky Department of

Kentucky 
Irrigation Association (VA)

Representatives

Jackson County Farm Bureau (IL)

Consortium

Jackson County Board of

Commissioners (MN)

Jacksonville Regional Economic

Development Corporation (IL)

Jane Addams Resource Corporation (IL)

(PA)

Jasper County Farm Bureau (IL)

Conservation

Jefferson County (GA) Board of

Commissioners

Jerome County Fair (ID)

(MI)

Jetson Green (TX)

Jo Daviess County Farm Bureau (IL)

(IL)

John Wood Community College (IL)

Juhl Wind Inc. (MN)

Kadrmas Lee and Jackson (ND)

Kankakee County Farm Bureau (IL)

(IL)

Lebanon County Conservation District (PA)

Cooperatives

Lenawee County Board of Commissioners

(MI)

LightBeam Energy, Inc. (CA)

Research

Lincoln County Board of Commissioners

$(\mathrm{MN})$

Lincoln Land FS, Inc. (IL)

(NM)

Lipten Company (MI)

Retailers

LiveWell Alamosa (CO)

Livingston County Farm Bureau (IL)

Cooperative

Losonoco Inc. of (FL)

Company
Kentucky House of

Kentucky Rural Energy

(KREC)

Knobel Seeds (NE)

Konrad Advising (CO)

Krause Corporation (KS)

Lake Erie Biofuels, LLC

Lake Region Resource

(KS)

Lake Superior State University

Biology Department

LandPro, LLC (IL)

Langhauser Associates, Inc.

Lanworth Inc. (IL)

Larrabee Farms (CA)

La Rue Construction (CA)

LaSalle County Farm Bureau

Michigan Alliance of

Michigan Farm Bureau

Michigan House of Representatives

Michigan Public Interest

Group

Michigan Technological University

Microforestry Resource, Inc.

Mid-America Equipment

Association (IN, KY)

Mid-Ohio Energy

Mid-South Engineering 
Louisiana CleanTech Network

Louisiana Dept. of Agriculture and

Renewable

Forestry

Louisiana Farm Bureau Federation

Louisiana State Legislature

Loup Basin Resource Conservation and

LLC

Development Council (NE)

LPP Combustion, LLC (MD)

(MN) LS9, Inc. (CA)

Renewable Energy

M\&D Distributors (TX)

Macon County Farm Bureau (IL)

Association Macoupin County Farm Bureau (IL)

Enterprises Inc. (OH)

Maine Rural Partners

(TN)

Martin County (MN)

Company

Maryland Energy Administration

Maryland Forests Association

Mason County Farm Bureau (IL)

Association

Massac County Farm Bureau (IL)

McDonough County Farm Bureau (IL)

Cooperative, Inc. (ND)

McGuire Trading Company Inc. (WA)

Conservation

McHenry County Farm Bureau (IL)

McLean County Farm Bureau (IL)

McNairy County Tennessee

RC\&D

Menard County Farm Bureau (IL)

Mendel Biotechnology (CA)

Mercer County Farm Bureau (IL)

Agriculture

Merritt Oil (AL)

Federation

Metabolix (MA)
(AR)

Midwest Alliance for

Energy

Midwest Biofuels (IN)

Midwest Biogas, LLC (MN)

Midwest Ethanol Producers,

(NE)

Midwest Forage Association

Midwest

Association (WI)

Midwestern Governors

Mike Farm

Milagro Biofuels of Memphis

Millennium Capital Finance

(TX)

Minnesota Agri-Women

Minnesota Corn Growers

Minnesota Project

Minnkota Power

Mississippi Association of

Districts

Meadow Springs Farm $(\mathrm{OH})$

Mississippi Association of

Councils

Mississippi Biomass Council

Mississippi Department of

Mississippi Farm Bureau 
Mississippi Soil and Water Conservation

Board

Commission

Association

Mississippi State Legislature

Association

Missouri Farm Bureau

Association

Missouri Farmers Union

Misty Hills Farm (NY)

Molpus Timberlands Management (TX)

Association

Molpus Woodlands Group (TX)

Environmental (TX)

Montgomery County Farm Bureau (IL)

LLC (NH)

Montgomery Soil and Water Conservation

Cooperative

District $(\mathrm{OH})$

Association

Montana Department of Natural Resources

and Conservation

Montana Farmers Union

Montana Legislature

Institute

Montana State University

Montanans for a Healthy Climate

(NC)

Moonlighting Energy Solutions (NJ)

(ND)

MOU Citrus Partnership, LLC (CA)

Moultrie County Farm Bureau (IL)

Mount Wachusett Community College (MA)

Mountrail-Williams Electric Cooperative

Energy

(ND)

Myriant Technologies (MA)

$\&$ Barbecue

NandoGroup (DC)

National Algae Association Mid-South

Rural
Nebraska Grain Sorghum

Nebraska Renewable Energy

Nebraska Rural Electric

Nebraska Soybean

Nebraska State Legislature

Nebraska Wheat Board

Nebraska Wheat Growers

New Beginnings

New England Wood Pellet,

New Hampshire Electric

New Hampshire Wind Energy

New Uses Council (MD)

New World Wind Power LLC (MT)

New York Farm Bureau, Inc.

New York Farm Viability

New York State Grange

NewGen Technologies, Inc.

Nodak Electric Cooperative

Nebraska State Grange (WI)

North Carolina Farm Bureau

North Carolina Solar Center

North Carolina Sustainable

Association

North Central Hearth, Patio

Association (WI)

North Dakota Association of 
Chapter (KY)

National Energy Education Development

Agriculture

Project (VA)

NativeEnergy (VT)

Assembly

Nava Bio-Energy Ltd (VT)

Association

Nebraska Association of Resource Districts

Nebraska Cattlemen's Association

Resource Conservation

Nebraska Congressional Delegation

Nebraska Cooperative Association

Association of State

Nebraska Corn Board

Nebraska Ethanol Board

Association (OR/WA)

Nebraska Farm Bureau

Nebraska Grain and Feed Association

North American Industrial Hemp Council

Off Grid Solar (FL)

Ogle County Farm Bureau (IL)

Commerce (IL)

Ohio Corn Growers Association

Development

Ohio Environmental Council

Ohio Farm Bureau Federation

(IL)

Ohio Farmers Union

Ohio Federation of Soil and Water

Conservation Districts

Ohio League of Conservation Voters

Ohio-Michigan Equipment Dealers

Conservation (IL)

Association

Ohio Soybean Association

(AR)

Oklahoma Bioenergy Center

(UT)

Online Community News (PA)

Corporation (IA)
Electric Cooperatives

North Dakota Department of

North Dakota Farm Bureau

North Dakota Legislative

Northeast Renewable Energy

(NY)

Northeast Wyoming

and Development

Northeastern Area

Foresters (DC)

Northwest Biofuels

Northwind Resources (IL)

Northern Biodiesel, Inc (NY)

Nova Fuels (CA)

Pike County (IL)

Pike County Chamber of

Pike County Economic

Corporation (IL)

Pike County Farm Bureau

Pike County SWCD (IL)

Pine 2 Energy Coalition (GA)

POET, LLC (SD)

Pragmaxis, LLC (TX)

Prairie Hills Resource

Premier Alternative Energy (TX)

Price BIOstock Services

ProActive Energy Concepts

Pro-Vision Development 
Opaxis (NJ)

Oregon Department of Agriculture

Bureau of IL

Oregon Intelligent Ethanol Systems, LLC

(CO)

Osage Bio Energy (VA)

Outpost Solar, LLC (TN)

Ovio Energy Inc. (LA)

(LA)

OwnEnergy, Inc. (NY)

Colorado

OXBO International (NY)

Pacific Ethanol (OR)

Palisades Convention Management (NY)

Commissioners

Palmetto State Clean Fuels Coalition (SC)

Parts Express $(\mathrm{OH})$

Pellet Futures (VT)

Peloton Energy, LLC (CA)

(ID)

Pennsylvania Energy Resources Group

(AL)

Pennsylvania Forestry Association

Pennsylvania Farm Bureau

(ID)

Pennsylvania Farm Country Radio Network

Cooperative (AR)

Pennsylvania Farm News

LLC (FL)

Pennsylvania Rural Electric Association

Perry County Farm Bureau (IL)

Phase 3 Renewables $(\mathrm{OH})$

Commissioners

Phase Four Environmental Technologies (TN)

Piatt County Farm Bureau (IL)

Company, Inc (KS)

P.I.B. Inc. Wind Energy (MO)

(IL)

Rieke Office Interiors (IL)

Agriculture and Forestry
Public Policy Virginia

Pulaski-Alexander Farm

Pure Vision Technologies

Purgo-Terra Corp (SC)

PvH Communications (CO)

Raceland Raw Sugar Corp.

Ratepayers United of

Rebirth Capital (LA)

ReDriven Power Inc. (MA)

Redwood County Board of

(MN)

Regal Blue Eagle, LLC (CA)

Relevant Ideas, LLC (VA)

Reliant PM Services, LLC

REM Solar Technologies

Renew Missouri

Renewable Ag Energy Inc.

Renewable Energy

Renewable Energy Systems,

Renewable Energy Vermont

Renewafuel, LLC (MN)

Renville County Board of

(MN)

Resolute Marine Energy, Inc. (MA)

Resource Management

Richland Community College

SAFER (Southeast 
River Valley Sugarbeet Growers

Alliance)

Association (MN, ND, IL)

RJRdata, LLC (IA)

Alliance (GA)

Rock County Board of Commissioners

Manufacturers

(MN)

Rock Island County Farm Bureau (IL)

Energy

Rocket Industries, LLC (TX)

Utilization of

Rocky Mountain Farmers Union (CO)

Rocky Mountain Sustainable Enterprises

Association (GA)

(CO)

Association

Rocky Mountain Wood Company (MA)

RS Enterprises (WI)

Partnership (GA)

Runkel Consulting (CA)

Foresters

Rural Minnesota Energy Board

Regional Planning

Saline County Farm Bureau (IL)

Board (NY)

Salmon Valley Stewardship (ID)

Sangamon County Board Office (IL)

Sangamon County Farm Bureau (IL)

Save the Springs (CO)

Schuyler County Farm Bureau (IL)

(GA)

Scott County Board of Commissioners

Water

(IL)

Scott County Farm Bureau (IL)

Scott County SWCD (IL)

Seminole SWCD (FL)

Bureau (IL)

Shaw Company (MO)

Commissioners
Energy Resources

Southeast Carbon Management (FL)

Southeast Energy Efficiency

Southeastern Lumber

Association

Southern Alliance for Clean

Southern Alliance for the

Biomass Resources

Southern Crop Production

Southern Equipment Dealers

(GA)

Southern Forest Research

Southern Group of State

Southern Tier Central

and Development

Southwest Windpower (AZ)

Soy Energy, LLC (IA)

Spider Energies (MI)

Sriya Innovations (GA)

Sriya Green Energies, LLC

St. John Valley Soil and

Conservation District (ME)

StarOilco (OR)

Steel City Biofuels (PA)

Stephenson County Farm

Stevens County Board of 
Shield Ag Equipment of KS

Show Me Energy Cooperative (MO)

Simplicity Energy Farms, Inc. (CO)

Skyhorse Media Inc. (CA)

Farms (MO)

Smartgrowth Associates (CO)

Solar Signs Project, Inc. (FL)

SolarWrights, Inc. (RI)

South Carolina Biomass Council

South Carolina Dept. of Agriculture

South Carolina Farm Bureau Federation

Corporation (KS)

South Dakota State Legislature

South Dakota Veterans of Foreign Wars

South Dakota Wind Energy Association SUNRNR (VA)

(AL)

SunSouth (AL)

Sunvention USA, Inc. (IN)

Sustainable Fuels, LLC (LA)

Swatara Creek Watershed Association (PA)

(TN)

SynGest, Inc. (IA)

Tarm USA, Inc. (NH)

Taylor County Board of Commissioners (FL)

Summit (IL)

Tazewell County Farm Bureau (IL)

Techno-Square (Bangladesh)

Tele-Consultants, Inc. (VA)

Templin Forestry, Inc (LA)

of Public

Tennessee Farm Bureau Federation

Tennessee Legislature

Conservation (IL)

Terror-Free Oil Initiative (FL)

Tetra Tech EC (FL)

Texas Agri-Women

(FL)
$(\mathrm{MN})$

Stinger Ltd (KS)

Stinker Stores (ID)

Stone House Hermitage and

Strata-G (MS)

Stratex Energy (ME)

Sukup Manufacturing (IA)

Summers Consulting (CA)

Suncrest Group, LLC (CO)

Sunflower Electric Power

Sun Grant Initiative (DC)

SunBelt Biofuels LLC (GA)

Sunbow Farm (OR)

The Westervelt Company

Think Energy, Inc. (MD)

TimberCorp, Inc. (MS)

Town of Fowler (CO)

Tranquility International Inc.

Tree Doctors of Pennsylvania

Triangle Energy Group (MN)

Tri-State Development

Triple G Inc (CA)

TSS Consultants (CA)

Two Rivers FS, Inc (IL)

Two Rivers Regional Council

Officials (IL)

Two Rivers Resource

Unity Ethanol, LLC (IA)

United Bio Energy (KS)

United Energy Technology 
Texas CHP Initiative

LLC (GA)

Texas Farm Bureau

Texas Forestry Association

Texas Impact

County IFAS

Texas Office of Rural Community Affairs

of

Texas Renewable Energy Industries

Association

Central

Texas Rural Alliance for Renewable

Outreach Center

Energy

Rivers

Texas Solar Energy Society

The Alternative Energy Store (MI)

MD

The Center for Rural Development (KY)

Publications (IL)

The Energy Initiative, University of

Colorado - Boulder

The Facility Place (MA)

Corporation (CO)

The Fresh Idea Farm (WA)

Cooperative (ND)

The McFarren Group (PA)

The McGregor Company (WA)

Bureau (IL)

The Minnesota Project

Association

The Powell Group/Agrilectric Power (LA)

Federation

The Samuels Group, Inc (TX)

The Sign Center (FL)

LLC (FL)

The Traylor Group (AL)

Village of Hull (IL)

Development

Virent Energy Systems (WI)

Energy
United Renewable Energy,

University of Alabama

University of Florida, IFAS

University of Florida, Lee

University of Florida, Office

Sustainability

University of Minnesota - West

Research and

Upper Mississippi, Illinois, Missouri

Association (IL)

US Composting Council of

USA Energy Independence

VanCoe (IN)

Vayda Energy Associates (MD)

Verdant BioSciences

Verendrye Electric

Verenium Corporation (MA)

Vermilion County Farm

Vermont Bio Fuels

Vermont Farm Bureau

Vermont General Assembly

Veterans Energy Solutions,

VFA, Inc (MA)

Western Illinois Economic

Western Indiana Sustainable 
Virginia Clean Cities

Virginia Education Association

(CO)

Virginia Farm Bureau Federation

Virginia Forestry Association

(IL)

Virginia Forest Products Association

(IL)

Vision Press (PA)

Walker Enterprises (VA)

Walsh Timber Company (LA)

Warren County Board (IL)

Bureau (IL)

Warren-Henderson Farm Bureau (IL)

SustainAbility

Washington Grain Alliance

Research Group

Washington State Conservation

(MD)

Commission

Wayne County Farm Bureau (IL)

Inc. (VA)

West Arapahoe Conservation District (CO)

Westar Trade Resources (TX)

Board of

Westcrete Building Systems (TN)

Western Illinois Corridor Council (TN)

Partnership
Region (WISER)

Western Resource Advocates

White Construction, Inc (IN)

White County Farm Bureau

Will County Farm Bureau

Williams Farms LP $(\mathrm{OH})$

Wind for Illinois (IL)

WindRosePower, LLC (TX)

Winnebago County Farm

Wisconsin Partners for

Wisconsin Public Interest

Woodland Biofuels, Inc.

WPC, Inc (NC)

Xcelplus Global Holdings

Xethanol Corporation (NY)

Yellow Medicine County

Commissioners (MN)

Zandergreen Technologies

Zilkha Biomass Energy (TX)

\section{Supporting Organizations}

American Bankers Association 


\section{Appendix XIV}

\section{Congressional Endorsements for the 25x'25 Vision}

\section{Senate Members in the $110^{\text {th }}$ Congress}

Jeff Sessions (R-AL)

Ken Salazar (D-CO)

Wayne Allard (R-CO)

Joe Lieberman (D-CT)

Bill Nelson (D-FL)

Dick Durbin (R-IL)

Barack Obama (D-IL)

Dick Lugar (R-IN)

Chuck Grassley (R-IO)

Tom Harkin (D-IO)

Sam Brownback (R-KS)

John Kerry (D-MA)

Carl Levin (D-MI)

Norm Coleman (R-MN)

Thad Cochran (R-MS)

Max Baucus (D-MT)

Russ Feingold (D-WI)
Jon Tester (D-MT)

Chuck Hagel (R-NE)

Ben Nelson (D-NE)

Robert Menendez (D-NJ)

Hillary Clinton (D-NY)

Kent Conrad (D-ND)

Byron Dorgan (D-ND)

Sherrrod Brown (D-OH)

George Voinovich (R-OH)

Ron Wyden (D-OR)

Bob Casey (D-PA)

Tim Johnson (D-SD)

John Thune (R-SD)

Patrick Leahy (D-VT)

Bernie Sanders (I-VT)

Maria Cantwell (D-WA)

Herb Kohl (D-WI)

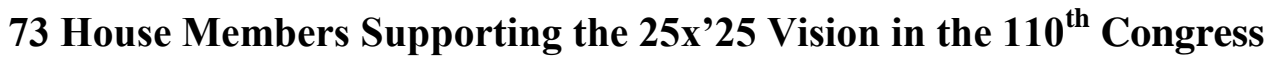

Jo Bonner (R-AL)

Raul Grijalva (D-AZ)

Rick Renzi (R-AZ)

Mike Ross (D-AR)

Joe Baca (D-CA)

Dorris Matsui (D-CA)

Lynn Woolsey (D-CA)

George Radanovich (R-CA)

Marilyn Musgrave (R-CO)

Mark Udall (D-CO)

John Salazar (D-CO)

Ed Perlmutter (D-CO)

Mario Diaz-Balart (R-FL)

Corrine Brown (D-FL)

Bill Young (R-FL)
Dennis Moore (D-KS)

Jerry Moran (R-KS)

Ben Chandler (D-KY)

William Jefferson (D-LA)

Wayne Gilchrest (R-MD)

Betty McCollum (D-MN)

Collin Peterson (D-MN)

Bennie Thompson (D-MS)

Sam Graves (R-MO)

Thaddeus McCotter (R-MI)

John Conyers (D-MI)

Fred Upton (R-MI)

Denny Rehberg (R-MT)

Jeff Fortenberry (R-NE)

Adrian Smith (R-NE) 
John Barrow (D-GA)

Jim Marshall (D-GA)

David Scott (D-GA)

Mike Simpson (R-ID)

Dennis Hastert (R-IL)

Tim Johnson (R-IL)

Mark Kirk (R-IL)

Ray LaHood (R-IL)

Dan Lipinski (D-IL)

Jan Schakowsky (D-IL)

Jerry Weller (R-IL)

Phil Hare (D-IL)

John Shimkus (R-IL)

Mark Souder (R-IN)

Pete Visclosky (D-IN)

Joe Donnelly (D-IN)

Mike Pence (R-IN)

Leonard Boswell (D-IA)

Bruce Braley (D-IA)

Tom Latham (R-IA)

Dave Loebsack (D-IA)
Lee Terry (R-NE)

Frank Pallone (D-NJ)

Randy Kuhl (R-NY)

Mike McIntyre (D-NC)

Earl Pomeroy (D-ND)

Marcy Kaptur (D-OH)

Zack Space (D-OH)

Frank Lucas (R-OK)

Tim Holden (D-PA)

Joe Pitts (R-PA)

Bill Shuster (R-PA)

Stephanie Herseth (D-SD)

Zach Wamp (R-TN)

Henry Cuellar (D-TX)

Sheila Jackson-Lee (D-TX)

Randy Neugebauer (R-TX)

Peter Welch (D-VT)

Bob Goodlatte (R-VA)

Jay Inslee (D-WA)

Cathy McMorris (R-WA)

Steve Kagen (D-WI)

Donna Christensen (D-Virgin Islands) 


\section{Appendix XV}

\section{Legislative Executive Dominance}

\begin{tabular}{|c|c|c|c|c|c|}
\hline Year & Law & Number & President & Senate & Congress \\
\hline 1978 & Energy Tax Act of 1978 & $95-618$ & Carter & $\begin{array}{l}61 \text { Dem - } 38 \\
\text { Rep - } 1 \text { other }\end{array}$ & $\begin{array}{l}292 \text { Dem - } 143 \\
\text { Rep }\end{array}$ \\
\hline 1980 & $\begin{array}{l}\text { Crude Oil Windfall Profit } \\
\text { Tax Act }\end{array}$ & $96-223$ & Carter & $\begin{array}{l}58 \text { Dem - } 41 \\
\text { Rep- } 1 \text { other }\end{array}$ & $\begin{array}{l}227 \text { Dem - } 158 \\
\text { Rep }\end{array}$ \\
\hline 1980 & Energy Security Act & $96-294$ & Carter & $\begin{array}{l}58 \text { Dem - } 41 \\
\text { Rep- } 1 \text { other }\end{array}$ & $\begin{array}{l}227 \text { Dem - } 158 \\
\text { Rep }\end{array}$ \\
\hline 1980 & Gasohol Competition Act & $96-493$ & Carter & $\begin{array}{l}58 \text { Dem }-41 \\
\text { Rep- } 1 \text { other }\end{array}$ & $\begin{array}{l}227 \text { Dem - } 158 \\
\text { Rep }\end{array}$ \\
\hline 1980 & $\begin{array}{l}\text { Omnibus Budget } \\
\text { Reconciliation Act }\end{array}$ & $96-499$ & Carter & $\begin{array}{l}58 \text { Dem - } 41 \\
\text { Rep- } 1 \text { other }\end{array}$ & $\begin{array}{l}227 \text { Dem - } 158 \\
\text { Rep }\end{array}$ \\
\hline 1982 & $\begin{array}{l}\text { Surface Transportation } \\
\text { Assistance Act }\end{array}$ & $97-424$ & Reagan & $\begin{array}{l}46 \text { Dem - } 53 \\
\text { Rep - } 1 \text { other }\end{array}$ & $\begin{array}{l}242 \text { Dem - } 192 \\
\text { Rep - } 1 \text { other }\end{array}$ \\
\hline 1984 & Tax Reform Act & $98-369$ & Reagan & $\begin{array}{l}\text { 46 Dem - } 54 \\
\text { Rep }\end{array}$ & $\begin{array}{l}269 \text { Dem - } 166 \\
\text { Rep }\end{array}$ \\
\hline 1988 & $\begin{array}{l}\text { Alternative Motor Fuels } \\
\text { Act }\end{array}$ & $100-494$ & Reagan & $\begin{array}{l}\text { 55 Dem - } 45 \\
\text { Rep }\end{array}$ & $\begin{array}{l}258 \text { Dem - } 177 \\
\text { Rep }\end{array}$ \\
\hline 1988 & Customs and Trade Act & 101-382 & GHW Bush & $\begin{array}{l}\text { 55 Dem - } 45 \\
\text { Rep }\end{array}$ & $\begin{array}{l}258 \text { Dem - } 177 \\
\text { Rep }\end{array}$ \\
\hline 1990 & $\begin{array}{l}\text { Omnibus Budget } \\
\text { Reconciliation Act }\end{array}$ & $101-508$ & GHW Bush & $\begin{array}{l}55 \text { Dem - } 45 \\
\text { Rep }\end{array}$ & $\begin{array}{l}260 \text { Dem - } 175 \\
\text { Rep }\end{array}$ \\
\hline 1990 & $\begin{array}{l}\text { Clean Air Act } \\
\text { Amendments }\end{array}$ & $101-549$ & GHW Bush & $\begin{array}{l}55 \text { Dem - } 45 \\
\text { Rep }\end{array}$ & $\begin{array}{l}260 \text { Dem - } 175 \\
\text { Rep }\end{array}$ \\
\hline 1990 & Energy Policy Tax Act & $102-486$ & GHW Bush & $\begin{array}{l}55 \text { Dem - } 45 \\
\text { Rep }\end{array}$ & $\begin{array}{l}260 \text { Dem - } 175 \\
\text { Rep }\end{array}$ \\
\hline 1993 & $\begin{array}{l}\text { Omnibus Budget } \\
\text { Reconciliation Act }\end{array}$ & $103-66$ & GHW Bush & $\begin{array}{l}\text { 57 Dem - } 43 \\
\text { Rep }\end{array}$ & $\begin{array}{l}258 \text { Dem - } 176 \\
\text { Rep }\end{array}$ \\
\hline 1997 & Taxpayer Relief Act & $105-34$ & Clinton & $\begin{array}{l}45 \text { Dem - } 55 \\
\text { Rep }\end{array}$ & $\begin{array}{l}207 \text { Dem - } 226 \\
\text { Rep - } 2 \text { other }\end{array}$ \\
\hline 1998 & $\begin{array}{l}\text { Transportation Equity Act } \\
21 \text { st Century }\end{array}$ & $105-178$ & Clinton & $\begin{array}{l}45 \text { Dem - } 55 \\
\text { Rep }\end{array}$ & $\begin{array}{l}207 \text { Dem - } 226 \\
\text { Rep - } 2 \text { other }\end{array}$ \\
\hline 1998 & $\begin{array}{l}\text { Agricultural Research, } \\
\text { Extension, and Education } \\
\text { Reform Act }\end{array}$ & $105-185$ & Clinton & $\begin{array}{l}45 \text { Dem - } 55 \\
\text { Rep }\end{array}$ & $\begin{array}{l}207 \text { Dem - } 226 \\
\text { Rep - } 2 \text { other }\end{array}$ \\
\hline 1998 & $\begin{array}{l}\text { Internal Revenue Service } \\
\text { Restructuring and Reform } \\
\text { Act }\end{array}$ & $105-206$ & Clinton & $\begin{array}{l}45 \text { Dem - } 55 \\
\text { Rep }\end{array}$ & $\begin{array}{l}207 \text { Dem - } 226 \\
\text { Rep - } 2 \text { other }\end{array}$ \\
\hline 2000 & $\begin{array}{l}\text { Agriculture Risk } \\
\text { Protection Act }\end{array}$ & $106-224$ & Clinton & $\begin{array}{l}45 \text { Dem - } 55 \\
\text { Rep }\end{array}$ & $\begin{array}{l}207 \text { Dem - } 226 \\
\text { Rep - } 2 \text { other }\end{array}$ \\
\hline
\end{tabular}




\begin{tabular}{|c|c|c|c|c|c|}
\hline 2002 & $\begin{array}{l}\text { Development, Food \& } \\
\text { Drug Administration, \& } \\
\text { Related Agencies } \\
\text { Appropriations Act }\end{array}$ & $107-76$ & GW Bush & $\begin{array}{l}50 \text { Dem - } 50 \\
\text { Rep }\end{array}$ & $\begin{array}{l}212 \text { Dem - } 221 \\
\text { Rep - } 2 \text { other }\end{array}$ \\
\hline 2004 & $\begin{array}{l}\text { American Jobs Creation } \\
\text { Act }\end{array}$ & $108-357$ & GW Bush & $\begin{array}{l}48 \text { Dem - } 51 \\
\text { Rep - } 1 \text { other }\end{array}$ & $\begin{array}{l}205 \text { Dem - } 229 \\
\text { Rep - } 1 \text { other }\end{array}$ \\
\hline 2005 & Energy Policy Act & $109-58$ & GW Bush & $\begin{array}{l}48 \text { Dem - } 51 \\
\text { Rep - } 1 \text { other }\end{array}$ & $\begin{array}{l}205 \text { Dem - } 229 \\
\text { Rep - } 1 \text { other }\end{array}$ \\
\hline 2005 & $\begin{array}{l}\text { Safe, Accountable, } \\
\text { Flexible, Efficient } \\
\text { Transportation Equity Act }\end{array}$ & $109-59$ & GW Bush & $\begin{array}{l}44 \text { Dem - } 55 \\
\text { Rep - } 1 \text { other }\end{array}$ & $\begin{array}{l}202 \text { Dem - } 231 \\
\text { Rep - } 1 \text { other }\end{array}$ \\
\hline 2006 & $\begin{array}{l}\text { National Defense } \\
\text { Authorization Act }\end{array}$ & $109-163$ & GW Bush & $\begin{array}{l}44 \text { Dem - } 55 \\
\text { Rep - } 1 \text { other }\end{array}$ & $\begin{array}{l}202 \text { Dem }-231 \\
\text { Rep - } 1 \text { other }\end{array}$ \\
\hline 2006 & $\begin{array}{l}\text { Tax Relief and Heath } \\
\text { Care Act }\end{array}$ & $109-432$ & GW Bush & $\begin{array}{l}49 \text { Dem - } 49 \\
\text { Rep - } 2 \text { other }\end{array}$ & $\begin{array}{l}233 \text { Dem - } 198 \\
\text { Rep }\end{array}$ \\
\hline 2007 & $\begin{array}{l}\text { Energy Independence and } \\
\text { Security Act }\end{array}$ & $110-140$ & GW Bush & $\begin{array}{l}49 \text { Dem - } 49 \\
\text { Rep - } 2 \text { other }\end{array}$ & $\begin{array}{l}233 \text { Dem - } 198 \\
\text { Rep }\end{array}$ \\
\hline 2008 & $\begin{array}{l}\text { Food, Conservation and } \\
\text { Energy Act }\end{array}$ & $110-234$ & GW Bush & $\begin{array}{l}49 \text { Dem - } 49 \\
\text { Rep - } 2 \text { other }\end{array}$ & $\begin{array}{l}233 \text { Dem - } 198 \\
\text { Rep }\end{array}$ \\
\hline 2008 & $\begin{array}{l}\text { Food, Conservation and } \\
\text { Energy Act }\end{array}$ & $110-246$ & GW Bush & $\begin{array}{l}49 \text { Dem - } 49 \\
\text { Rep - } 2 \text { other }\end{array}$ & $\begin{array}{l}233 \text { Dem - } 198 \\
\text { Rep }\end{array}$ \\
\hline 2008 & $\begin{array}{l}\text { Emergency Economic } \\
\text { Stabilization Act }\end{array}$ & $110-343$ & GW Bush & $\begin{array}{l}49 \text { Dem - } 49 \\
\text { Rep - } 2 \text { other }\end{array}$ & $\begin{array}{l}233 \text { Dem - } 198 \\
\text { Rep }\end{array}$ \\
\hline 2010 & $\begin{array}{l}\text { Tax Relief, } \\
\text { Unemployment Insurance } \\
\text { Reauthorization, and Job } \\
\text { Creation Act }\end{array}$ & $111-312$ & Obama & $\begin{array}{l}57 \text { Dem - } 41 \\
\text { Rep - } 2 \text { other }\end{array}$ & $\begin{array}{l}256 \text { Dem - } 178 \\
\text { Rep }\end{array}$ \\
\hline
\end{tabular}




\section{Appendix XVI}

\section{Summary of deliberative democracy attributes}

\begin{tabular}{|c|c|c|c|c|c|c|}
\hline & $95-618$ & $100-494$ & $102-486$ & $106-224$ & $109-58$ & $110-140$ \\
\hline Sponsored by & $\begin{array}{l}\text { Rostenkowski } \\
\text { (D-IL) }\end{array}$ & $\begin{array}{l}\text { Rockefeller } \\
(\mathrm{D}-\mathrm{WV})\end{array}$ & $\begin{array}{l}\text { Sharp } \\
(\mathrm{D}-\mathrm{IN})\end{array}$ & $\begin{array}{l}\text { Combest } \\
\text { (R-TX) }\end{array}$ & $\begin{array}{l}\text { Barton } \\
\text { (R-TX) }\end{array}$ & $\begin{array}{l}\text { Rahall } \\
\text { (D-WV) }\end{array}$ \\
\hline Cosponsors & 0 & 64 & 54 & 12 & 2 & 198 \\
\hline - ratio D:R & N/A & $44: 20$ & $49: 5$ & $0: 12$ & $0: 2$ & $195: 3$ \\
\hline Introduced in & House & Senate & House & House & House & House \\
\hline $\begin{array}{l}\text { Committees } \\
\text { referred to }\end{array}$ & 19 & 1 & 20 & 3 & 9 & 12 \\
\hline $\begin{array}{l}\text { Hearings } \\
\text { conducted }\end{array}$ & 0 & 8 & 105 & 14 & 90 & 72 \\
\hline $\begin{array}{l}\text { House } \\
\text { amendments } \\
\text { proposed }\end{array}$ & 0 & 3 & 22 & 3 & 34 & 0 \\
\hline $\begin{array}{l}\text { amendments } \\
\text { passed }\end{array}$ & 0 & 3 & 13 & 2 & 19 & 0 \\
\hline $\begin{array}{l}\text { Senate } \\
\text { amendments } \\
\text { proposed }\end{array}$ & 9 & 3 & 13 & 0 & 119 & 331 \\
\hline $\begin{array}{l}\text { amendments } \\
\text { passed }\end{array}$ & 8 & 2 & 10 & 0 & 34 & 45 \\
\hline $\begin{array}{l}\text { House debate } \\
\text { duration }\end{array}$ & & & 8 hours & 3 hours & 11 hours & 5 hours \\
\hline $\begin{array}{l}\text { Senate debate } \\
\text { duration }\end{array}$ & 6 days & 1 day & 3 days & 3 days & 5 days & 10 days \\
\hline $\begin{array}{l}\text { Conference } \\
\text { duration }\end{array}$ & 1 day & 3 days & 3 weeks & & 5 days & \\
\hline $\begin{array}{l}\text { House vote } \\
\text { - yay (D: R: } \\
\text { I) }\end{array}$ & 231 & voice vote & $\begin{array}{r}363 \\
(239: 123: 1) \\
\end{array}$ & $\begin{array}{c}\text { voice } \\
\text { vote }\end{array}$ & $\begin{array}{r}275 \\
(75: 200) \\
\end{array}$ & $\begin{array}{r}314 \\
(219: 95) \\
\end{array}$ \\
\hline - nay (D:R: I) & 168 & & $60(20: 40)$ & & $\begin{array}{r}156 \\
(124: 31: 1) \\
\end{array}$ & $\begin{array}{r}100 \\
(4: 96) \\
\end{array}$ \\
\hline $\begin{array}{l}\text { Senate vote } \\
\text { - yay (D:R:I) }\end{array}$ & 60 & voice vote & voice vote & $\begin{array}{r}91 \\
(43: 48) \\
\end{array}$ & $\begin{array}{r}74 \\
(25: 49)\end{array}$ & $\begin{array}{r}86 \\
(47: 38: 1) \\
\end{array}$ \\
\hline - nay (D:R) & 17 & & & $\begin{array}{r}4 \\
(0: 4) \\
\end{array}$ & $\begin{array}{r}26 \\
(20: 6) \\
\end{array}$ & $\begin{array}{r}8 \\
(1: 7) \\
\end{array}$ \\
\hline
\end{tabular}




\section{Appendix XVII}

\section{Public Law 100-494}

\section{Alternative Motor Fuels Act of 1988}

\section{Hearings Summary}

$\begin{array}{lll}\text { Title: } & \text { Rollback of CAFE Standards and Methanol Vehicle Incentives Act of } \\ \text { 1985 } & & \\ \text { Committee: } & \text { Senate Committee on Commerce, Science and Transportation } \\ \text { CIS number: } & \text { 86-S261-6 } & \\ \text { Date: } & \text { June 20 and July 17, 1985 } & \\ \text { Location: } & \text { Russell Senate Building } & \\ \text { Chair: } & \text { John Danforth (MO) } & \text { Ernest Hollings (SC) } \\ \text { Committee } & \text { Members: } & \text { Bob Packwood (OR) } \\ & \text { Barry Goldwater (AZ) } & \text { Russell Long (LA) } \\ & \text { Nancy Landon Kassenbaum (SD) } & \text { Daniel Inouye (HI) } \\ & \text { Larry Pressler (SD) } & \text { Wendell Ford (KY) } \\ & \text { Slade Gorton (WA) } & \text { Donald Riegle (MI) } \\ & \text { Ted Stevens (R-AK) } & \text { James Exon (NE) } \\ & \text { Bob Kasten (WI) } & \text { Albert Gore (TN) } \\ & \text { Paul Trible (VA) } & \text { John Rockefeller (WV) }\end{array}$

Pages: $\quad 191$ pages

Summary: Hearings to consider the following bills regarding fuel economy

standards:

S. 1097 (text, p. 3-5), the Methanol Vehicle Incentives Act of 1985, to amend the Motor Vehicle Information and Cost Savings Act to establish special fuel economy standards for methanol-powered automobiles for use in determining automobile manufacturer compliance with DOT Corporate Average Fuel Economy (CAFE) regulations administered by the National Highway Traffic Safety Administration (NHTSA).

S. Res. 178 (text, p. 6-7), to express the sense of the Senate that NHTSA should reject petitions of certain auto manufacturers requesting a rollback in scheduled model year 1986 automobile fleet CAFE standards.

WITNESS PANEL \#1 - STATEMENTS AND DISCUSSION:

Differing views on S. Res. 178.

Thomas F. Eagleton (Sen., D-MO)

Daniel J. Evans (Sen., R-WA)

Howard M. Metzenbaum (Sen., D-OH)

Don Nickles (Sen., R-OK)

\section{WITNESS PANEL \#2 - STATEMENTS AND DISCUSSION:}


Perspectives on NHTSA rulemaking procedures and activities regarding CAFE standards, including requested rollback of model year 1986 standards.

STEED, Diane K., Administrator, NHTSA.

\section{WITNESS PANEL \#3 - STATEMENTS AND DISCUSSION:}

Differing views on merits of requested rollback of 1986 CAFE standards; reasons for Ford Motor Co. and GM petitions for standards rollback; competitive issues involved in proposed rollback; perspectives on use of methanol as an alternative automobile fuel.

MILLER, Robert S., Jr., Executive Vice President, Finance and Administration, Chrysler Corp.

PETRAUSKAS, Helen O., Vice President, Environmental and Safety

Engineering Staff, Ford Motor Co.

WHITMAN, Marina Vice President, Public Affairs Group, General Motors Corp (GM).

MILLET, Ralph T., Chairman, Automobile Importers of America (AIA).

LEONE, Robert A., Public Policy Professor, Harvard University - representing AIA.

\section{WITNESS PANEL \#4 - STATEMENTS AND DISCUSSION:}

Achievements of represented company methanol-powered vehicle development programs; support for incentives for methanol fuel development and use, with views on S. 1097.

PETRAUSKAS, Helen O., Vice President, Environmental and Safety

Engineering, Ford Motor Co.

KLIMISCH, Richard L., Executive Director, Environmental Activities Staff, General Motors Corp.

\section{WITNESS PANEL \#5 - STATEMENTS AND DISCUSSION:}

Experience of Bank of America with use of methanol as a motor fuel; importance of incentives for development and use of methanol motor fuel.

FISHER, Merle R., Vice President, Corporate Services Div, Bank of America BUCHANAN, Harry W., Vice President, Celanese Corp.

\section{WITNESS PANEL \#6 - STATEMENTS AND DISCUSSION:}

Issues involved in S. 1097.

WISE, Robert E., Jr. (Rep, D-WV)

GRAY, Charles L., Jr., Director, Emission Control Technology Division, Office of Mobile Sources, EPA

DITLOW, Clarence M., III, Director, Center for Auto Safety

MULLAN, Joseph W., Senior Vice President, Environmental Affairs, National

Coal Association

Title: $\quad$ Methanol Fuel and the Future

Committee: Subcommittee on Fossil, Synthetic Fuels, House Committee on Energy and Commerce

CIS number: 86-H361-61

Date: $\quad$ November 20, 1985 


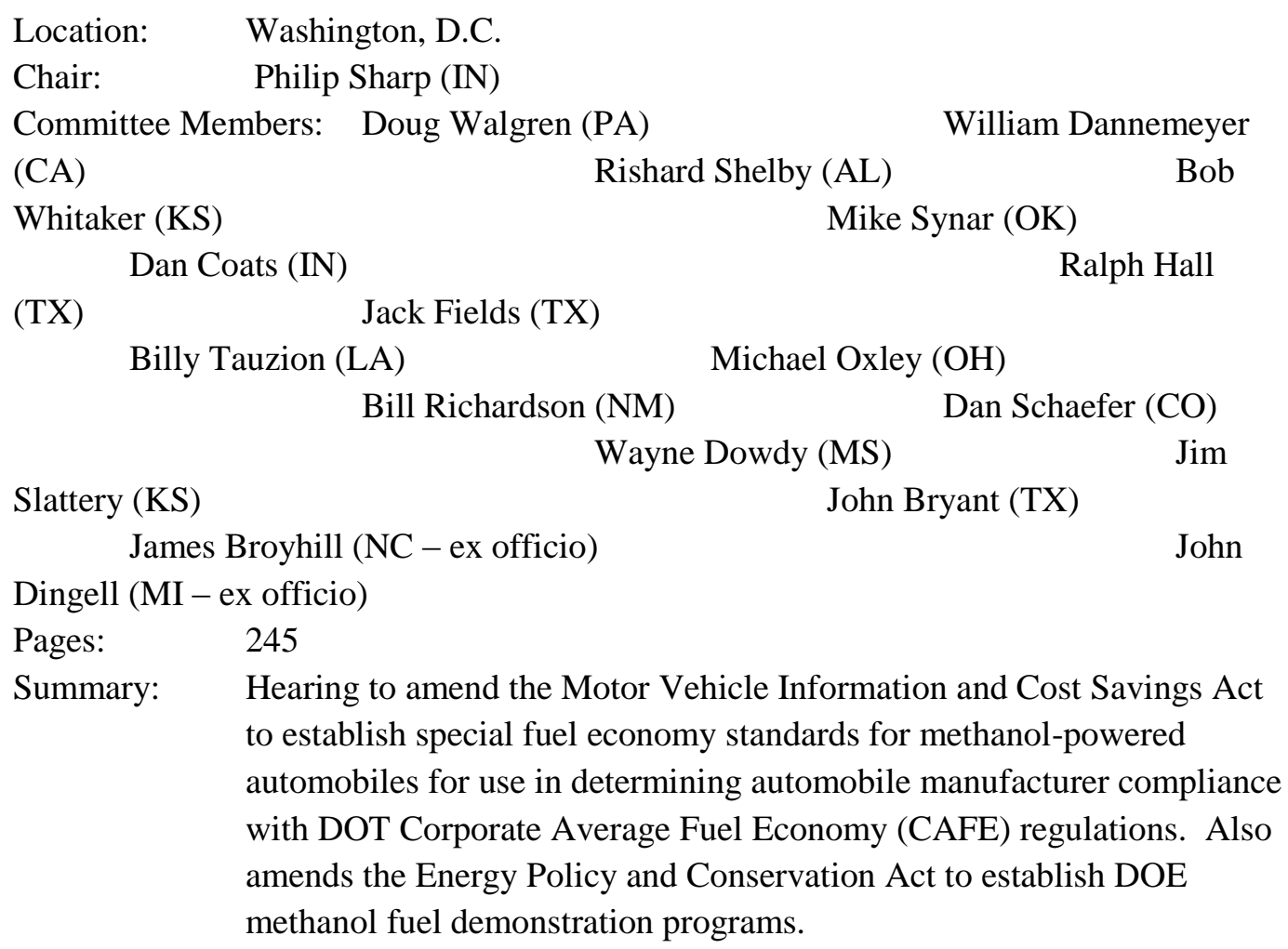

\section{WITNESS PANEL \#1 - STATEMENTS AND DISCUSSION:}

Merits of methanol use in motor vehicles

Robert E. Wise, Jr. (Rep, D-WV)

Jerry Lewis (Rep, R-CA)

\section{WITNESS PANEL \#2 - STATEMENTS AND DISCUSSION:}

Review of methanol motor fuel R\&D and demonstration programs; advantages of methanol use, including fuel efficiency and environmental benefits; merits of H.R. 3355, with recommendations; support for and viability of methanol use as an alternative to gasoline, citing air quality improvement.

WILSON, Richard D., Director, Office of Mobile Sources, EPA.

DITLOW, Clarence M., III, Director, Center for Auto Safety.

BERG, Larry L., Board Member, South Coast Air Quality Management District. ARCHER, John, Managing Director, Government Affairs, American Automobile Assn.

\section{WITNESS PANEL \#3 - STATEMENTS AND DISCUSSION:}

Support for H.R. 3355; status of Ford and General Motors methanol vehicle development programs; importance of industry incentives for methanol fuel development and use, with views on proposed CAFE standards.

ROBERTSON, Bernard I., Director, Power Train Engineering, Chrysler Corp. BUIST, Donald R., Director, Automotive Emissions and Fuel Economy Office, Ford Motor Co.

KLIMISCH, Richard L., Executive Director, Environmental Activities Staff, Gen Motors Corp. 
Title: $\quad$ Alternative Automotive Fuel Hearings

Committee: Subcommittee on Energy and Power, House Committee on Energy and

Commerce

CIS number: $\quad 88-\mathrm{H} 261-47$

Date: June 17, 24, July 9, 1987

Location: Washington, D.C.

Chair: $\quad$ Philip Sharp (IN)

Subcommittee Members: $\quad$ Mike Synar (OK)

Tom Corcoran (IL)

Billy Tauzin (LA)

William Dannemeyer

(CA)

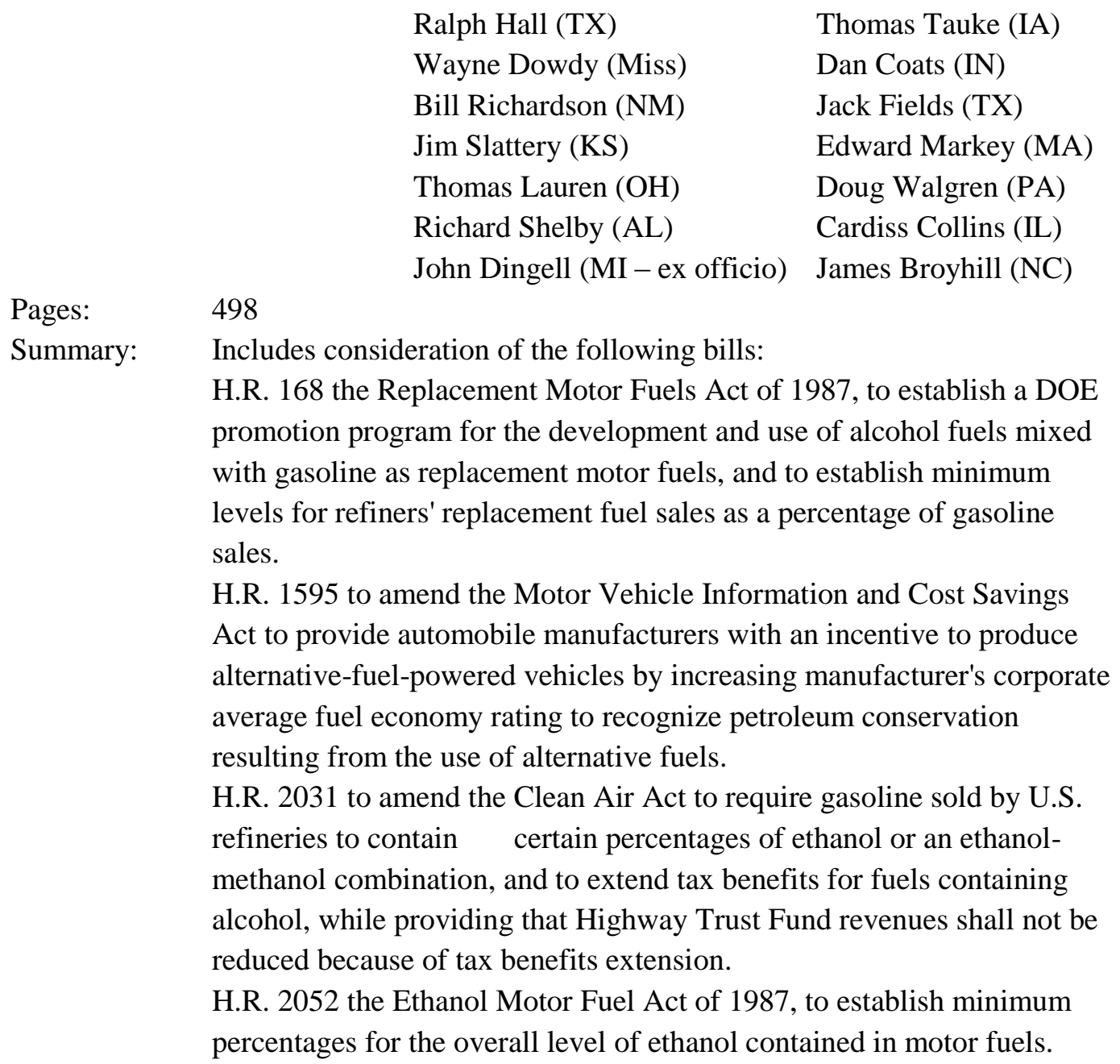

PANEL \#1 - STATEMENTS AND DISCUSSION:

Support for promotion of alternative transportation fuels, with concerns about aspects of alternative fuel proposals related to DOE responsibilities; objections to alternative fuel bills.

Analysis of the emissions reduction potential of various alternative fuels, including gasoline replacements and gasoline mixed with low levels of additives; description of DOE study to determine the value of alternative fuels for U.S. energy security. 
HASELTINE, Philip W., Deputy Asst. Sec, Policy and International Affairs, DOT.

WILSON, Richard D., Director, Office of Mobile Sources, Office of Air and Radiation, EPA.

CAMPBELL, Scott L., Director, Policy, Planning and Analysis, DOE.

\section{PANEL \#2 - STATEMENTS AND DISCUSSION:}

Assessment of alternatives to petroleum-based motor fuels; support for continued development of long-range transportation fuel alternatives; recommendations regarding proposed bills.

PADGHAM, Howard B., Chief Engineer, Powertrain Engineering Programs, Chrysler Motors.

GUSTAFSON, Paula A., Director, Product Environmental Management, Cummins Engine Co.

BUIST, Donald R., Director, Automotive Emissions and Fuel Economy Office, Ford Motor Co.

KLIMISCH, Richard L., Executive Director, Environmental Activities staff, Gen Motors Corp.

\section{PANEL \#3 - STATEMENTS AND DISCUSSION:}

Anticipated economic and environmental benefits of H.R. 2031 and H.R. 2052; support for a national policy to encourage use of alternative fuels; benefits of ethanol as an alternative fuel; desirability of reducing U.S. dependence on foreign imports through promotion of domestic alternative fuels.
ALEXANDER, Bill (Rep, D-AR)
MADIGAN, Edward R. (Rep, R-IL)
DURBIN, Richard J. (Rep, D-IL)
STALLINGS, Richard H. (Rep, D-ID)
GLICKMAN, Dan (Rep, D-KS)

\section{PANEL \#4 - STATEMENTS AND DISCUSSION:}

Overview of ethanol benefits and industry status; analysis of economic feasibility of alcohol fuels development; anticipated impact on the agricultural sector of increased alcohol fuels production as specified in H.R. 2052 and H.R. 2031.

VAUGHN, Eric, pres. and chief exec officer, Renewable Fuels Assn.

POTTER, Frederick L., President, Info Resources, Inc.

CARR, A. Barry, Agri Policy Specialist, Environment and Natural Resources Policy Div, CRS.

\section{PANEL \#5 - STATEMENTS AND DISCUSSION:}

Enumeration of economic, environmental, and public safety advantages of natural gas as a petroleum replacement; support for increased promotion and use of propane as a motor fuel; description of various alternative fuel R\&D programs; recommendations for appropriate national policy concerning alternative transportation fuels.

PARKER, Wallace P., Manager, Marketing and Advertising, Brooklyn Union Gas Co.; also representing New York Gas Group, American Gas Association, 
and International Association of Natural Gas Vehicles.

MYERS, Daniel N., Vice President, Government Relations; General Counsel, National LP-Gas Association.

MYERS, Robert E., Vice President, Marketing, Petrolane Gas Service.

KOLEDA, Michael S., President, Council on Alternate Fuels.

WEBB, David O., Senior Vice President, Policy and Regulatory Affairs, Gas

Research Inst.

SMITH, Dixon B., General Manager, Operations and Business Planning,

Chevron USA; representing American Petroleum Inst.

STERNFELS, Urvan R., President, National Petroleum Refiners Assn.

\section{PANEL \#6 - STATEMENT AND DISCUSSION:}

Benefits of alcohol fuels.

\section{DORGAN, Byron L. (Rep, D-ND)}

\section{PANEL \#7 - STATEMENTS AND DISCUSSION:}

Merits of methanol as a transportation fuel; assessment of policies to encourage use of methanol and other alternative fuels; superiority of methanol over other replacement fuels; need for strong fuel economy standards to create incentives for automobile manufacturers to develop and promote use of alternative-fuel-powered vehicles.

IMBRECHT, Charles R., Chairman, California Energy Commission.

RASHEED, Victor, Executive Director, Service Station Dealers of America.

DITLOW, Clarence M., III, Director, Center for Auto Safety.

\section{PANEL \#8 - STATEMENTS AND DISCUSSION:}

Opposition to Federal intervention in transportation fuel market; perspectives on use of ethanol and methanol as replacement motor fuels; support for increased use of alcohol fuels; need for additional research regarding the potential benefits and impacts of alcohol fuels; enumeration of concerns about alcohol fuels.

Experiences with marketing and use of gasohol; opposition to legislation favoring development of one specific alternative fuel.

FRANK, J. Louis, President, Marathon Petroleum Co.

MCDONALD, S. L., Vice President, Marketing Distribution, ARCO Petroleum Products Co.

SCOTT, Carleton B., Director, Environmental Sciences, Union Oil Co. of

California.

MCHENRY, Keith W., Jr., Vice President, Research and Development, Amoco Corp.
Title:
Solar Power
Committee:
Subcommittee on Energy and Power, House Committee on Energy and
Commerce
CIS number: $\quad 89-\mathrm{H} 361-2$
Date: $\quad$ October 7, 1987
Location: Washington, D.C. 
Chair: $\quad$ Philip Sharp (IN)

$\begin{array}{llc}\text { Committee Members: } & \text { Doug Warren (PA) } & \text { Carlos Moorhead (CA) } \\ & \text { Al Swift (WA) } & \text { William Dennemeyer (CA) } \\ & \text { Mike Synar (OK) } & \text { Jack Fields (TX) } \\ & \text { Billy Tauzin (LA) } & \text { Michael Oxley (OH) } \\ & \text { Bill Richardson (NM) } & \text { Michael Bilikaris (FL) } \\ & \text { John Bryant (TX) } & \text { Dan Schaefer (CO) } \\ & \text { Terry Bruce (IL) } & \text { Joe Barton (TX) } \\ & \text { Edward Markey (MA) } & \text { Sonny Callahan (AL) } \\ & \text { Michael Leland (TX) } & \text { Ron Wyden (OR) } \\ & \text { Ralph Hall (TX) } & \text { Wayne Dowdy (MS) } \\ & \text { John Dingell (MI - ex officio) } & \text { Norman Lent (NY - ex }\end{array}$

officio)

Pages: $\quad 125$

Summary: Varying views on H.R. 2858; explanation of disparity between FERC treatment of wholesale rate increase and decrease requests; arguments against H.R. 2858, focusing on utility financial risks; importance of bill TESTIMONY to protect wholesale customers from excessive power costs.

SCULLY, MAURICE R., (Executive Director, Connecticut Municipal Electric Energy Cooperative; representing American Public Power Association) PLUMB, DAVID, General Manager, Pasadena, Calif., Department of Water and Power

MUNDY, RODNEY O., Attorney, representing Edison Electric Institute) OLDAK, MICHAEL D., Regulatory Counsel, National Rural Electric Cooperative Association MOORE, STEPHEN J., Director, Illinois Office of Public Counsel; also representing National Association of State Utility Consumer Advocates

Title: $\quad$ Methanol and Alternative Fuels Promotion Act of 1987

Committee: Subcommittee on Consumer Affairs, Senate Committee on Commerce, Science and Transportation

CIS number: $\quad 88-S 261-24$

Date: November 12, 1987

Location: Dirksen Senate Office Building

Chair: $\quad$ Ernest Hollings (SC)

Committee Members: Daniel Inouye (HI) John Danforth (MO)

Wendell Ford (KY) Bob Packwood (OR)

Kassebaum (KS)

Donald Riegle (MI) Nancy Landon

James Exon (NE) Larry Pressler (SD)

Al Gore (TN) Ted Stevens (AK) 


$\begin{array}{ll}\text { John Rockefeller (WV) } & \text { Robert Kasten (WI) } \\ \text { Lloyd Bentsen (TX) } & \text { Paul Tribble (VA) } \\ \text { John Kerry (MA) } & \text { Pete Wilson (CA) } \\ \text { John Breaux (LA) } & \text { John McCain (AZ) } \\ \text { Brock Adams (WA) } & \end{array}$

Pages: $\quad 101$

Summary: Hearing before the Subcommittee on the Consumer to consider S. 1518, the Methanol and Alternative Fuels Promotion Act of 1987, to amend the Motor Vehicle Information and Cost Savings Act to provide incentives for manufacture of automobiles powered by methanol, ethanol, or natural gas, and for dual-fuel automobiles, by increasing the DOT-set corporate average fuel economy (CAFE) rating of manufacturers of automobiles powered by alternative fuels.

Full Committee Member John D. Rockefeller IV (D-WV) chairs the hearing. Full Committee Member Pete Wilson (R-CA) presents a statement. Full Committee Member Larry Pressler (R-SD) participates in questioning witnesses.

\section{Testimony 1 -- STATEMENT AND DISCUSSION:}

Potential of motor vehicles using alternative fuels to reduce air pollution in urban areas.

WILSON, RICHARD D., (Dir., Office of Mobile Sources, EPA)

\section{TESTIMONY 2 -STATEMENTS \& DISCUSSION:}

General support for S. 1518; desirability of expanding proposed Federal CAFE incentives to promote manufacture of motor vehicles powered by alternative fuels, including methanol- and dual-fuel automobiles.

BUIST, DONALD R., (dir., automotive emissions and fuel economy office, Ford Motor Co)

LEONARD, SAMUEL A., (dir., automotive emission control dept., environmental activities staff, Gen Motors Corp)

PADGHAM, HOWARD B., (Chief Engineer, Power Train Engineering

Programs, Chrysler Motors)

\section{TESTIMONY 3 - STATEMENTS \& DISCUSSION:}

Support for S. 1815; positive implications of CEC research on methanol-powered motor vehicle technology; outlook for development of ethanol- and natural gas-powered automobiles; need to expand Government incentives for manufacture of alternative fuel vehicles.

NOTEWARE, WARREN D., Commissioner, California Energy Commission (CEC))

BALY, MICHAEL, III, (Vice President, Government Relations, Amer Gas Assn (AGA); also on behalf of:; also on behalf of: )

THOMASON, LEO B. II, (vp, marketing and conservation, Southwest Gas Corp; both representing, AGA)

VAUGHN, ERIC, (pres and chief exec officer, Renewable Fuels Assn)

DITLOW, CLARENCE M., III, (Director, Center for Auto Safety) 
Title: $\quad$ Review of the Role of Ethanol in the 1990s

Committee: Subcommittee on Forests, Family Farms and Energy and Subcommittee on Wheat, Soybeans and Feed Grains, House Committee on Energy and Commerce

CIS number: $\quad 89-\mathrm{H} 161-2$

Date: $\quad$ May 11, 1988

Location: Washington, D.C.

Chair: $\quad$ Dan Glickman (KS)

Subcommittee Members: Tim Johnson (SD) Ron Marlenee (MO)

Glenn English (OK) Arlan Stageland (MN)

Jerry Huckaby (LA) Pat Roberts (KS)

Lane Evans (IL) Bill Emerson (MS)

Timothy Penny (MN) Bob Smith (OR)

David Nagle (IA) Bill Schuette (MI)

Harold Volkmer (MO) Fred Grady (IA)

Mike Espy (MS) Walter Jones (CA)

Pages: $\quad 156$

Summary: Committee Serial No. 100-80. Joint hearing before the Subcommittee on Forests, Family Farms, and Energy, the Subcommittee on Wheat, Soybeans, and Feed Grains, and the House Energy and Commerce Committee Subcommittee on Energy and Power to examine issues involved in continued development and use of blended ethanolgasoline as an alternative motor fuel.

\section{Testimony I - STATEMENTS \& DISCUSSION:}

Status of ethanol industry; views on role of ethanol in Federal agricultural, energy, and environmental policies; effect of ethanol development and use on grain and fuel prices; extent of governmental research for alternative fuel development.

MYERS, PETER C., Deputy Secretary, USDA

FITZPATRICK, DONNA R., Assistant Secretary, Conservation and Renewable Energy, DOE WILSON, RICHARD D., Director, Office of Mobile Sources, EPA

\section{TESTIMONY 2 -STATEMENTS \& DISCUSSION:}

Benefits of ethanol production to producers and consumers; availability of corn and other grains for conversion to fuel; review of studies on ethanol cost-effectiveness and environmental effects; impact of tax incentives on ethanol development and use.

SWANK, C. WILLIAM (Executive Vice President and Chief Executive Officer, Ohio Farm Bureau Federation)

SMEDLEY, HAROLD (Executive Director, Colorado Corn Administrative Committee; also representing National Corn Growers Association)

CARR, A. BARRY (Senior Fellow, National Center for Food and Agricultural Policy, Resources for the Future)

\section{TESTIMONY 3 - STATEMENTS \& DISCUSSION:}

Varying views on desirability of present use of gasoline-ethanol blended fuel; review of studies on ethanol environmental impact; importance of Federal subsidy to ethanol blenders to permit competition with other marketed fuels. 
VAUGHN, ERIC (President and Chief Executive Officer, Renewable Fuels Association)

WHITTEN, GARY Z. (Manager, Environmental Sciences, Systems

Applications, Inc.; representing Renewable Fuels Foundation)

SMITH, DIXON B. (General Manager, Operations and Business Planning, Chevron, USA; representing American Petroleum Institute and National Petroleum Refiners Association)

Title: $\quad$ Methanol as an Alternative Transportation Fuel

Committee: Subcommittee on Fossil and Synthetic Fuels, House Committee on

Energy and Commerce

CIS number: $85-\mathrm{H} 3261-19$

Date: $\quad$ August 13, September 24, 1982

Location: $\quad$ House Annex, Washington, D.C.

Chair: $\quad$ Philip Sharp (IN)

Subcommittee Members: $\quad$ Mike Synar (OK) Tom Corcoran (IL)

Billy Tauzin (LA) William Dannemeyer

(CA)

$\begin{array}{ll}\text { Ralph Hall (TX) } & \text { Thomas Tauke (IA) } \\ \text { Wayne Dowdy (MS) } & \text { Dan Coats (IN) } \\ \text { Bill Richardson (NM) } & \text { Jack Fields (TX) } \\ \text { Jim Slattery (KS) } & \text { Edward Markey (MA) } \\ \text { Thomas Lauren (OH) } & \text { Doug Walgren (PA) } \\ \text { Richard Shelby (AL) } & \text { Cardiss Collins (IL) } \\ \text { John Dingell (MI - ex officio) } & \text { James Broyhill (NC) }\end{array}$

Summary: Hearings to examine the status of and outlook for development of methyl alcohol (methanol) as an alternative fuel for automobiles and other motor vehicles.

\section{TESTIMONY 1 -- STATEMENTS AND DISCUSSION:}

Overview of Bank of America fleet experience with methanol-fueled automobiles; description of California alcohol fuels development programs; examination of and outlook for methanol use as an alternative transportation fuel, with policy recommendations.

FISHER, MERLE R., (vp, admin services, Bank of Amer)

SMITH, KENNETH D., (mgr., synthetic fuels office, California Energy

Resources Conservation and Dev. Commission)

WILSON, RICHARD D., (Dir., Office of Mobile Sources, EPA)

FRI, ROBERT W., (pres, Energy Transition Corp)

MCCORMICK, JOHN L., (representing Environmental Policy Center)

\section{TESTIMONY 2 -- STATEMENTS AND DISCUSSION:}

Differing appraisals of methanol-gasoline blends use as a motor fuel; recommendations for Federal role in methanol motor fuels development, including suggested environmental regulatory revisions; technical aspects of methanol blends use as alternative motor fuels; conditions affecting development and mass marketing of methanol fuels. 
GUETENS, EDWARD G., JR., (business mgr., oxygenated fuels, Atlantic Richfield Co)

COLUCCI, JOSEPH M., (head, fuels and lubricants dept., Gen Motors Research Labs)

MARONI, JACQUES R., (Director, Environmental research and energy planning, Ford Motor Co)

\section{TESTIMONY 3 -- STATEMENTS AND DISCUSSION:}

Issues involved in development of methanol motor fuels; merits and potential of methanol as an alternative to petroleum fuels.

BOLAND, F. KEVIN, (Acting Departmental Director, Energy and Minerals Div, GAO)

HUNT, PETER S., (Energy Consultant, Peter Hunt Associates)

Title: $\quad$ Methanol as Transportation Fuel

Committee: Subcommittee on Fossil and Synthetic Fuels, House Committee on

Energy and Commerce

CIS number: $\quad 48-\mathrm{H} 361-15$

Date: $\quad$ April 4, 25, 1984

Location: Rayburn House Office Building

Chair: $\quad$ Philip Sharp (IN)

Committee Members: Doug Walgren (PA)

Rishard Shelby (AL)

William Dannemeyer (CA)

Mike Synar (OK)

Bob Whitaker (KS)

Ralph Hall (TX)

Dan Coats (IN)

Billy Tauzion (LA)

Jack Fields (TX)

Bill Richardson (NM)

Michael Oxley $(\mathrm{OH})$

Wayne Dowdy (MS)

Dan Schaefer (CO)

John Bryant (TX)

Jim Slattery (KS)

John Dingell (MI - ex officio)

Pages: $\quad 372$

Summary: Committee on Energy and Commerce Serial No. 98-145. Hearings

before the Subcommittee on Fossil and Synthetic Fuels and the Subcommittee on Energy Conservation and Power to consider H.R. 4855, the Methanol Energy Policy Act of 1984, to amend the Urban Mass Transportation Act, and similar H.R. 5075, the Methanol Policy Act of 1984, to amend the Energy Policy and Conservation Act and the Motor Vehicle Information and Cost Savings Act, both to authorize DOE research and demonstration projects involving methanol-powered vehicles.

\section{TESTIMONY 1 - STATEMENTS \& DISCUSSION:}

Overview of DOE methanol fuel R\&D programs; views on H.R. 4855 and H.R. 5075; findings of EPA research programs on air quality aspects and environmental benefits of methanol use as a substitute for petroleum fuel products; review of EPA proposed 
regulation concerning methanol use

COLLINS, PAT, (Under Sec, DOE)

HASELTINE, PHILIP W., (Dep Asst Sec, Policy and Intl Aff, DOT)

CANNON, JOSEPH A., (Asst Administrator, Air and Radiation, EPA)

\section{TESTIMONY 2 - STATEMENTS \& DISCUSSION:}

Perspectives on environmental effects of conversion to methanol fuel; general support for H.R. 4855 and H.R. 5075.

BERG, LARRY L., (bd member, South Coast Air Quality Mgmt Dist, Calif)

BOLAND, F. KEVIN, (Sr Assoc Dir., Resources, Community, and Economic

Dev Div, GAO)

ARCHER, JOHN, (managing dir., govt aff, Amer Automobile Assn)

MEADE, GLADYS, (environmental health dir., Amer Lung Assn of Calif)

TESTIMONY 3 - STATEMENTS \& DISCUSSION:

Findings and implications of methanol-powered vehicles testing and use; views on H.R. 4855 and H.R. 5075; issues involved in producing methanol-fueled vehicles.

PETRAUSKAS, HELEN O., (vp, Ford Motor Co)

FROSCH, ROBERT A., (vp, research labs, Gen Motors Corp)

RUSSELL, J. KIRK, (dir., ops, Championship Auto Racing Teams, Inc)

ALEXANDER, R. JACK, (pres, Alexander-Seewald Co; representing

Automotive Warehouse Distributors Assn (AWDA))

TESTIMONY 4 - STATEMENTS \& DISCUSSION:

Limited prospects for public utility conversion to methanol fuel; recommendations for methanol conversion policy; differing views on methanol cost.

MCCARTHY, CHARLES B., JR., (vp, Southern Calif Edison Co)

SIMMONS, STANLEY H., (technology dev mgr., FDOT)

HUNT, PETER S., (consultant, Peter S Hunt Assocs)

\section{TESTIMONY 5 - STATEMENTS \& DISCUSSION:}

Outline of Tennessee Eastman Co. production of methanol and other chemicals from synthetic coal gas.

LONG, ROBERT L., (dir., strategic planning, Eastman chemical div, Eastman

Kodak Co)

ANDERSEN, GALEN E., (pres, Nokota Co)

BUCHANAN, HARRY W., (VP, Celanese Corp; representing Oxygenated Fuels Assn) 


\title{
Appendix XVIII
}

\author{
Public Law 102-486 \\ Energy Policy Act of 1992
}

\section{Hearings Summary}

$\begin{array}{ll}\text { Title: } & \text { Nuclear Licensing and Regulatory Reform } \\ \text { Committee: } & \text { Senate Subcommittee on Nuclear Regulation, Committee on } \\ & \text { Environment and Public Works } \\ \text { CIS number: } & 84-\mathrm{S} 321-1 \\ \text { Date: } & \text { May 25, 26, June 14, 16, July 14, } 1983 \\ \text { Pages: } & 671 \\ \text { Summary: } & \text { Hearings to consider NRC-proposed S. 893, the Nuclear Power Plant } \\ & \text { Licensing Reform Act of 1983, and DOE-proposed S. 894, the Nuclear } \\ & \text { Licensing and Regulatory Reform Act of 1983, both to amend the } \\ & \text { Atomic Energy Act of 1954 to revise the NRC nuclear power plant } \\ & \text { licensing and regulatory process. Bills include provisions to revise the } \\ & \text { nuclear power plant license application hearing process; establish a one- } \\ & \text { step procedure for issuance of a combined construction permit/operating } \\ & \text { license (CP/OL); and facilitate site selection and construction through } \\ & \text { use of standardized power plant designs. } \\ & \text { S. } 894 \text { also provides for NRC revision of requirements relating to design } \\ & \text { modifications in existing plants (backfitting) to improve plant safety. }\end{array}$

TESTIMONY \#1 - STATEMENTS AND DISCUSSION:

Basis for S. 893; critical examination of nuclear power plant licensing process, with differing recommendations for reform; comparison of bills, focusing on S. 894 backfitting requirements; issues involved in proposed $\mathrm{CP} / \mathrm{OL}$ procedures.

PALLADINO, NUNZIO J., Chairman, NRC

GILINSKY, VICTOR., Commissioner, NCR

AHEARNE, JOHN F., Commissioner, NCR

ASSELSTINE, JAMES K., Commissioner, NCR

\section{TESTIMONY \#2 - STATEMENTS AND DISCUSSION:}

Explanation of S. 894, with comparison to S. 893; importance of S. 894 backfitting requirements to ensure plant safety and public health protection; examination of proposed revisions in licensing hearing process, including implications for $\mathrm{CP} / \mathrm{OL}$ procedures and public participation.

HODEL, DONALD P., (Sec, DOE;); accompanied by GREENLEIGH, Stephen, Dep Gen Counsel for Programs.

\section{TESTIMONY \#3 - STATEMENTS AND DISCUSSION:}

Overview of electric utility nuclear power programs; criticism of current NRC power plant licensing and regulatory process, focusing on delays and cost factors; support for S. 
894 provisions regarding backfitting requirements and combined CP/OL licensing procedures; comparative analysis of S. 893 and S. 894, focusing on power plant licensing hearing reforms; summary of public opinion survey findings on nuclear power plant licensing.

LEE, WILLIAM S., (chm and chief exec officer, Duke Power Co; representing Edison Electric Inst and three additional electric power groups)

POKORNY, EUGENE, (pres, Cambridge Rpts, Inc)

COWAN, BARTON Z., (chm, lawyers' committee, Atomic Industrial Forum)

\section{TESTIMONY \#4 - STATEMENTS AND DISCUSSION:}

Benefits of nuclear power plant design standardization, including increased operating safety, reduced construction costs, and regulatory efficiency; need for NRC power plant backfitting requirements reform; comparison of U.S. and foreign nuclear power plant regulatory programs; sectional analysis of bills, with support for S. 894.

BRAY, A. PHILIP, (vp and gen mgr., nuclear power systems div, Gen Electric Co)

MOORE, JAMES S., (vp and gen mgr., water reactor divs, Westinghouse Electric Corp)

\section{TESTIMONY \#5 - STATEMENTS AND DISCUSSION:}

Inconsistencies in NRC nuclear power plant regulation and decisionmaking process; recommendations to improve power plant licensing procedures and regulatory programs, citing merits of proposed plant design standardization and combined CP/OL; advantages of and support for nuclear power plant single-stage licensing process.

LEVENSON, MILTON, (exec engr, Bechtel Power Corp)

KENNEDY, WILLIAM J., (sr vp, Stone and Webster Engineering Corp)

\section{TESTIMONY \#6 - STATEMENTS AND DISCUSSION:}

Timeliness of nuclear power plant regulatory reform proposals; arguments for NRC authority to certify regional electric power needs if a proposed power plant will serve more than one State; economic impact of NRC regulations on electric utilities. WITNESSES:

HOBART, LAWRENCE S., (dep exec dir., Amer Public Power Assn)

\section{TESTIMONY \#7 - STATEMENTS AND DISCUSSION:}

Criticism of bills, citing inadequacy of public participation provisions; feared impact of S. 894 backfitting requirements on nuclear power plant safety; accounts of interventor participation in NRC licensing proceedings for specific power plants..

WEISS, ELLYN R., (gen counsel, Union of Concerned Scientists)

RILEY, JESSE L., (representing Carolina Environmental Study Group)

BACKUS, ROBERT A., (representing Seacoast Antipollution League)

BUCKHORN, PEGGY, (exec dir., Citizens for Equitable Utilities)

DEVINE, THOMAS M., (legal dir., Govt Accountability Project (GAP))

BERNABEI, LYNNE, (gen counsel, GAP)

\section{TESTIMONY \#8 - STATEMENTS AND DISCUSSION:}

Perspectives on nuclear power plant licensing and safety issues, including backfitting requirements; benefits of proposals to standardize power plant designs and expedite site selection. 
BRADFORD, PETER A., (chm, Maine Public Utilities Commission; also representing Natl Assn of Regulatory Utility Commrs)

\section{TESTIMONY \#9 - STATEMENTS AND DISCUSSION:}

Additional testimony -- views on nuclear power plant regulatory and licensing issues.

CHARNOFF, GERALD, (Chm, Ad Hoc Committee for Review of Nuclear

Reactor Licensing Reform Proposals;); accompanied by ROISMAN, Anthony Z., exec dir., Trial Lawyers for Public Justice

REDMOND, ROBERT F., (assoc dean, Coll of Engineering, Ohio State Univ,)

LONG, STEPHEN, (dir., powerplant siting program, Md Dept of Resources; all

Members, Ad Hoc Committee for Review of Nuclear Reactor Licensing

Proposals, p. 436-449, 495-523)

RAY, DIXY L., vice chm, committee on regulatory assessment, Scientists and Engrs for Secure Energy;; accompanied by ROWDEN, MARCUS A., chm, committee on regulatory assessment

DEVLIN, J. HUGH, managing dir., Morgan Stanley International

MEYER, EUGENE W., bd member, Kidder, Peabody and Co.

BABBITT, BRUCE, Gov, Ariz

LEWIS, NICHOLAS D., chm, Wash State Energy Facility Site Evaluation

Council

MUNDY, DANIEL J., legis dir., bldg and construction trades dept., AFL-CIO

ERB, ROBERT E., JR., staff engr, Va Power and Electric Co

Title: $\quad$ Nuclear Licensing and Regulatory Reform

Committee: House Subcommittee on Energy and the Environment, Committee on Interior and Insular Affairs

CIS number: $\quad 84-\mathrm{H} 441-17$

Date: $\quad$ July 16,1985

Pages: $\quad 365$

Summary: Hearings before the Subcom on Energy and the Environment to consider DOE-proposed H.R. 2511 (text, p. 3-32), the Nuclear Licensing and Regulatory Reform Act of 1983, and NRC-proposed H.R. 2512 (text, p. 33-57), the Nuclear Power Plant Licensing Reform Act of 1983, both to amend the Atomic Energy Act of 1954 to revise the NRC nuclear power plant licensing and regulatory process.

Bills include provisions to revise the nuclear power plant license application hearing process; establish a one-step procedure for issuance of a combined construction permit/operating license (CP/OL); and facilitate site selection and construction through use of standardized power plant designs.

H.R. 2511 also provides for NRC revision of requirements relating to design modifications in existing plants (backfitting) to improve plant safety.

\section{TESTIMONY \#1 - STATEMENTS AND DISCUSSION:}


Basis for and description of H.R. 2512; review of H.R. 2511 provisions and objectives, including improved power plant safety and public participation in hearing process.

PALLADINO, NUNZIO J., (Chm, NRC)

HODEL, DONALD P., (Sec, DOE)

GILINSKY, VICTOR.()

ASSELSTINE, JAMES K., (both Commrs, NRC)

\section{TESTIMONY \#2 - STATEMENTS AND DISCUSSION:}

Adverse impact of current NRC power plant licensing procedures on electric utilities nuclear power programs; timeliness of nuclear power plant regulatory reform proposals.

LEE, WILLIAM S., (chm and chief exec officer, Duke Power Co; representing

Edison Electric Inst, Atomic Industrial Forum, and Amer Nuclear Energy

Council)

MOORE, JAMES S., (vp and gen mgr., water reactor divs, Westinghouse

Electric Corp)

BRAY, A. PHILIP, (vp and gen mgr., nuclear power systems div, Gen Electric

Co)

RAMEY, JAMES T., (vp, Stone and Webster Engineering Corp)

LEVENSON, MILTON, (exec engr, Bechtel Power Corp)

WEISS, ELLYN R., (gen counsel, Union of Concerned Scientists; also representing 6 other environmental organizations)

FADEN, MICHAEL E., (legis counsel, Union of Concerned Scientists)

ROISMAN, ANTHONY Z., (exec dir., Trial Lawyers for Public Justice)

DOROSHOW, JOANNE, (intervenor, Three Mile Island restart proceedings;

representing Three Mile Island Alert, Inc)

Title: $\quad$ Nuclear Licensing and Regulatory Reform

Committee: House Subcommittee on Energy Conservation and Power, Committee on Energy and Commerce.

CIS number: $\quad 84-\mathrm{H} 361-29$

Date: $\quad$ May 25, 26, June 14, 16, July 14, 1983

Pages: $\quad 522$

Summary: Committee on Energy and Commerce Serial No. 98-83. Hearing before the Subcom on Energy Conservation and Power to consider DOEproposed H.R. 2511 (text, p. 3-32), the Nuclear Licensing and Regulatory Reform Act of 1983, and NRC-proposed H.R. 2512 (text, p. 33-57), the Nuclear Power Plant Licensing Reform Act of 1983, both to amend the Atomic Energy Act of 1954 to revise the NRC nuclear power plant licensing and regulatory process.

Bills include provisions to revise the nuclear power plant license application hearing process; establish a one-step procedure for issuance of a combined construction permit/operating license (CP/OL); and facilitate site selection and construction through use of standardized power plant designs. 
H.R. 2511 also provides for NRC revision of requirements relating to design modifications in existing plants (backfitting) to improve plant safety.

\section{WITNESS PANEL \#1 - STATEMENTS AND DISCUSSION:}

Basis for H.R. 2512, with comparison to H.R. 2511; critical examination of nuclear power plant licensing process, with differing recommendations for reform; benefits of standardized power plant designs, including implications for CP/OL process.

PALLADINO, NUNZIO J., (Chm, NRC)

GILINSKY, VICTOR. (Commissioners, NRC)

ASSELSTINE, JAMES K., (Commissioners, NRC)

\section{WITNESS PANEL \#2 - STATEMENTS AND DISCUSSION:}

Overview of H.R. 2511 objectives, including improved power plant safety and public participation in hearing process; importance of H.R. 2511 backfitting requirements to ensure plant safety; examination of power plant licensing hearing process, citing merits of proposed one-step licensing procedure and standardized plant designs.

BREWER, SHELBY T., (Asst Sec, Nuclear Energy, DOE;); accompanied by DILLON, Thomas A., Principal Dep Asst Sec, Nuclear Energy.

\section{WITNESS PANEL \#3 - STATEMENTS AND DISCUSSION:}

Perspectives on nuclear power plant licensing and safety issues; doubted relationship of NRC licensing process to power plant construction delays.

BRADFORD, PETER A., (chm, Maine Public Utilities Commission; representing Natl Assn of Regulatory Utility Commrs)

\section{WITNESS PANEL \#4 - STATEMENTS AND DISCUSSION:}

Description of NRC nuclear power plant licensing hearing process, including statutory requirements and Atomic Safety and Licensing Board role; timeliness of nuclear power plant regulatory reform proposals; merits of H.R. 2511 backfitting requirements; comparison of H.R. 2511 and H.R. 2512 CP/OL licensing provisions, with preference for H.R. 2511.

Support for standardizing power plant designs and expediting site selection; critical examination of power plant licensing process; shortcomings of proposed legislation, including lack of public participation and power plant safety concerns; issues involved in power plant backfitting requirements, including cost-benefit considerations.

COTTER, B. PAUL, JR., (Chief Administrative Judge, Atomic Safety and Licensing Bd, NRC;); accompanied by PURPLE, Robert A., Dep Dir., Div of Licensing.

CUNNINGHAM, GUY H., III, (Exec Legal Dir., NRC)

COWAN, BARTON Z., (chm, lawyers committee, Atomic Industrial Forum (AIF); also representing Edison Electric Inst and Amer Nuclear Energy Council) WEISS, ELLYN R., (gen counsel, Union of Concerned Scientists; also representing six other environmental organizations)

Title: $\quad$ Nuclear Regulatory Reform 
Committee: Senate Subcommittee on Nuclear Regulation, Committee on Environment and Public Works

CIS number: $\quad 86-S 321-1$

Date: July 16, 1985

Pages: $\quad 513$

Summary: $\quad$ S. 16, the National Nuclear Powerplant Personnel Training Act of 1985, to establish an NRC National Academy for Nuclear Power Safety to provide training programs for civilian nuclear power plant personnel; to require academy training for personnel employed at NRC-licensed commercial nuclear power plants; and to establish an Academic Advisory Board to make recommendations regarding academy curricula and admission standards.

S. 836, the Nuclear Powerplant Licensing and Standardization Act of 1985, to amend the Atomic Energy Act of 1954 to revise NRC regulatory process for nuclear power plant licensing and siting. Includes provisions to modify procedures for public participation in power plant license applications; establish a one-step procedure for issuance of a combined construction permit/operating license (CP/OL); and facilitate site selection and construction through use of standardized power plant designs.

\section{WITNESS PANEL \#1 - STATEMENTS AND DISCUSSION:}

Recommendations to upgrade selection and training of nuclear reactor operators, citing value of a college engineering degree; agreement with S. 16 objectives, with preference for continuation of INPO industry-sponsored training programs and NRC enforcement of INPO program standards; views on nuclear power plant management and technical personnel requirements.

AHEARNE, JOHN F., (vp, Resources for the Future; former Commr, NRC) ROGOVIN, MITCHELL, (atty; former head, NRC's Special Inquiry Group on Three Mile Island (TMI))

PIGFORD, THOMAS H., (nuclear engineering prof, Univ of Calif at Berkeley; chm, advisory council, Inst of Nuclear Power Ops (INPO); former member, Pres' Commission on the Accident at TMI)

\section{WITNESS PANEL \#2 - STATEMENTS AND DISCUSSION:}

Overview of improved utility training programs for power plant personnel; detailed description of Carolina Power and Light Co. reactor operator and technical staff training, including use of computerized power plant simulators; merits of INPO training program policies and standards.

SMITH, SHERWOOD H., JR., (pres and chm, Carolina Power and Light Co.; also representing Edison Electric Inst and Amer Nuclear Energy Council)

\section{WITNESS PANEL \#3 - STATEMENTS AND DISCUSSION:}

Explanation of INPO training standards and qualification guidelines for utility nuclear power plant personnel; importance of independent National Nuclear Accrediting Board to ensure utility compliance with INPO training standards. 
Elaboration on nuclear industry plant safety and personnel training improvements in response to 1979 TMI nuclear accident; components of comprehensive power plant training programs.

PATE, ZACK T., (pres and chief exec officer, INPO)

REMICK, FORREST J., (assoc vp, research, Pa State Univ; member, Natl

Nuclear Accrediting Bd)

CARROLL, JOHN E., (former vp, training, United Airlines; member, Natl

Nuclear Accrediting Bd)

\section{WITNESS PANEL \#4 - STATEMENTS AND DISCUSSION:}

Support for combined CP/OL power plant licensing process, with differing views on $\mathrm{S}$. 836 requirements; perspectives on power plant licensing and regulatory reform issues.

PALLADINO, NUNZIO J., (Chm, NRC)

ASSELSTINE, JAMES K. (Commissioner, NRC)

BERNTHAL, FREDERICK M. (Commissioner, NRC)

ZECH, LANDO W., JR., (Commissioner, NRC)

\section{WITNESS PANEL \#5 - STATEMENTS AND DISCUSSION:}

Benefits of nuclear power plant design standardization, including early construction site selection; advantages of and support for combined CP/OL licensing procedures;

timeliness of nuclear power plant regulatory reform proposals, with analysis of S. 836.

WOLFE, BERTRAM, (vp and gen mgr., nuclear technologies and fuel div, Gen Electric Co)

MOORE, JAMES S., (vp and gen mgr., water reactor divs, Westinghouse

Electric Corp)

BREWER, SHELBY T., (sr vp, Combustion Engineering, Inc)

RAMEY, JAMES T., (vp, Stone and Webster Engineering Corp)

DAVIS, W. KENNETH, (consultant, Bechtel Power Corp)

\section{WITNESS PANEL \#6 - STATEMENTS AND DISCUSSION:}

Presentation of Administration bill to revise NRC power plant regulatory and licensing process.

VAUGHAN, JAMES W., JR., (Act Asst Sec, Nuclear Energy, DOE)

WITNESS PANEL \#7 - STATEMENTS AND DISCUSSION:

Criticism of current NRC power plant licensing and regulatory process; support for and benefits of proposals to standardize power plant designs and expedite site selection; comparative analysis of S. 836 and Administration bill, with preference for Administration proposal.

BEHNKE, WALLACE B., JR., (vp, Commonwealth Edison Co; representing Edison Electric Inst, Atomic Industrial Forum, and Amer Nuclear Energy Council)

COWAN, BARTON Z., (chm, lawyers committee, Atomic Industrial Forum)

FADEN, MICHAEL E., (legis counsel, Union of Concerned Scientists; also representing six other environmental organizations)

WITNESS PANEL \#8 - STATEMENTS AND DISCUSSION:

Views on bills 
KANTER, MANUEL A., (head, nuclear power training program, div of educ programs, Argonne Natl Lab)

WEAVER, LYNN E., (dean, Coll of Engineering, Auburn Univ, p. 39-46)

JONES, GRANT, (State sen, Tex; representing Southwest Regional Energy

Council, p. 268-272)

Title: $\quad$ Uranium Mill Tailings Reclamation Act of 1985

Committee: House Subcommittee on Energy and the Environment, Committee on Interior and Insular Affairs

CIS number: $\quad 86-\mathrm{H} 441-23$

Date: July 16,1985

Pages: $\quad 671$

Title: $\quad$ Nuclear Powerplant Design Standardization

Committee: House Subcommittee on Energy Conservation and Power, Committee on Energy and Commerce

CIS number: $\quad 86-\mathrm{H} 361-26$

Date: July 25, December 10, 1985

Pages: $\quad 785$

Title: Uranium Revitalization, Tailings Reclamation, and Uranium Enrichment

Programs

Committee: Senate Subcommittee on Energy Research and Development, Committee on Energy and Natural Resources

CIS number: $\quad 86-S 311-47$

Date: $\quad$ April 10, 1986

Pages: $\quad 451$

Title: $\quad$ Nuclear Facility Standardization Act of 1986

Committee: Senate Committee on Energy and Natural Resources

CIS number: $\quad 86-S 311-43$

Date: $\quad$ April 22, 1986

Pages: $\quad 483$

Title: Public Participation in Nuclear Licensing

Committee: House Subcom on Energy Conservation and Power, Committee on Energy and Commerce

CIS number: $\quad$ 87-H361-28

Date: $\quad$ April 30, 1986

Pages: $\quad 201$

Title: $\quad$ Nuclear Licensing and Regulatory Reform Legislation 
Committee: House Subcommittee on Energy and the Environment, Committee on Interior and Insular Affairs

CIS number: $\quad 88-\mathrm{H} 441-18$

Date: $\quad$ June 26, July 22, 1986

Pages: $\quad 402$

Title: $\quad$ Restructuring the Department of Energy's Uranium Enrichment Program

Committee: Senate Subcommittee on Energy Research and Development, Committee on Energy and Natural Resources

CIS number: $\quad 88-S 311-27$

Date: $\quad$ May 4, 8, 1987

Pages: $\quad 504$

Title: $\quad$ Reducing Energy Expenditures in Federal Facilities

Committee: HouseSubcommittee on Energy and Power, Committee on Energy and

Commerce

CIS number: $\quad 89-\mathrm{H} 361-54$

Date: $\quad$ Mar. 8,1988

Pages: $\quad 92$

Title: $\quad$ Uranium Revitalization, Tailings Reclamation, and Enrichment

Legislation

Committee: House Subcommittee on Energy and the Environment, Committee on Interior and Insular Affairs

CIS number: $\quad 89-\mathrm{H} 441-22$

Date: $\quad$ June 28, 1988

Pages: $\quad 466$

Title: Domestic Uranium Industry and Enrichment Program"

Committee: House on Energy and Power, Committee on Energy and Commerce

CIS number: $\quad 89-\mathrm{H} 361-118$

Date: July 28, Aug. 10, 1988

Pages: $\quad 425$

Title: $\quad$ Uranium Enrichment and Mill Tailings Reclamation Legislation

Committee: House Committee on Ways and Means

CIS number: $\quad 89-\mathrm{H} 781-32$

Date: $\quad$ Aug. 10, 1988

Pages: $\quad 120$

Title: $\quad$ National Energy Policy Act of 1988 and Global Warming

Committee: Senate Committee on Energy and Natural Resources

CIS number: $\quad 89-S 311-26$

Date: $\quad$ Aug. 11, Sept. 19, 20, 1988 
Pages: $\quad 543$

Title: Uranium Enrichment

Committee: House Subcommittee on Energy Research and Development, Committee on Science, Space, and Technology

CIS number: $\quad$ 89-H701-36

Date: $\quad$ Oct. 6, 1988

Pages: $\quad 132$

Title: National Energy Policy Act of 1989. (Energy Efficiency and Renewable Energy), Part 1"

Committee: Senate Committee on Energy and Natural Resources

CIS number: $\quad$ 89-S311-39

Date: $\quad$ Mar. 14, 1989

Pages: $\quad 582$

Title: $\quad$ Need for Uranium Enrichment Enterprise Restructuring and Uranium Mining Revitalization

Committee: Senate Subcommittee on Energy Research and Development, Committee on Energy and Natural Resources

CIS number: $\quad 89-\mathrm{S} 311-50$

Date: $\quad$ Apr. 19, 20, May 11, 1989

Pages: $\quad 563$

Title: $\quad$ DOE's National Energy Plan and Global Warming

Committee: Senate Committee on Energy and Natural Resources

CIS number: $\quad 89-S 311-69$

Date: $\quad$ July 26, 1989

Pages: $\quad 155$

Title: $\quad$ H.R. 2480: The Uranium Enrichment Reorganization Act

Committee: House the Subcommittee on Energy Research and Development, Committee on Science, Space, and Technology

CIS number: $\quad$ 90-H701-39

Date: $\quad$ July 26, 1989

Pages: $\quad 422$

Title: $\quad$ National Plumbing Products Efficiency Act of 1989

Committee: Senate Subcommittee on the Consumer, Committee on Commerce, Science, and Transportation

CIS number: $\quad$ 90-S261-28

Date: $\quad$ Oct. 4,1989

Pages: $\quad 219$

Title: $\quad$ National Energy Policy Act of 1989 (PURPA), Part 2 
Committee: Senate Committee on Energy and Natural Resources

CIS number: $\quad$ 90-S311-12

Date: $\quad$ Oct. 26, Nov. 7, 1989.

Pages: $\quad 501$

Title: $\quad$ Competitive Wholesale Electric Generation Act of 1989

Committee: Senate on Energy and Natural Resources

CIS number: $\quad$ 90-S311-19

Date: $\quad$ Nov. $9,16,1989$.

Pages: $\quad 802$

Title: $\quad$ Electric Powerlines: Health and Public Policy Implications

Committee: House Subcommittee on General Oversight and Investigations, Committee on Interior and Insular Affairs

CIS number: $\quad$ 90-H441-32

Date: $\quad$ Mar. 8, 1990

Pages: $\quad 382$

Title: $\quad$ S. 633, Renewable Energy/Fuel Cell Systems Integration Act of 1989

Committee: House Subcommittee on Energy Research and Development, Committee on Science, Space, and Technology

CIS number: $\quad$ 90-H701-75

Date: $\quad$ Mar. 21, 1990

Pages: $\quad 74$

Title: $\quad$ Residential Energy Efficiency Ratings Act

Committee: Senate Subcommittee on Energy Regulation and Conservation, Committee on Energy and Natural Resources

CIS number: $\quad$ 90-S311-38

Date: $\quad$ Mar. 27, 1990

Pages: $\quad 223$

Title: $\quad$ National Energy Policy Act of 1989 and Federal Energy Management Amendments of 1990

Committee: Senate Committee on Energy and Natural Resources

CIS number: $\quad$ 90-S311-36

Date: $\quad$ Apr. 5, 1990

Pages: $\quad 172$

Title: Octane Mislabeling

Committee: House Subcommittee on Energy and Power, Committee on Energy and

Commerce

CIS number: $\quad$ 91-H361-30

Date: June 20, 1990 
Pages: $\quad 134$

Title: Department of Energy's Uranium Enrichment Enterprise

Committee: Senate Subcommittee on Energy Research and Development, Committee on Energy and Natural Resources

CIS number: $\quad$ 91-S311-12

Date: June 28, 1990

Pages: $\quad 64$

Title: $\quad$ Smith Barney Uranium Enrichment Report

Committee: House Subcommittee on Energy Research and Development, Committee on Science, Space, and Technology

CIS number: $\quad$ 91-H701-21

Date: July 11, 1990

Pages: $\quad 130$

Title: $\quad$ Federal Research on Electromagnetic Radiation

Committee: House Subcommittee on Natural Resources, Agriculture Research, and Environment, Committee on Science, Space, and Technology

CIS number: $\quad$ 90-H701-79

Date: July 25, 1990

Pages: $\quad 1941$

Title: $\quad$ Uranium Enrichment Program

Committee: House Subcommittee on Energy and Power, Committee on Energy and Commerce

CIS number: 91-H361-33

Date: July 31,1990

Pages: $\quad 246$

Title: $\quad$ Global Environment: A National Energy Strategy

Committee: House Subcommittee on Energy and Power, Committee on Energy and

Commerce

CIS number: $\quad$ 91-H361-62

Date: $\quad$ Sept. 13, 1990

Pages: $\quad 257$

Title: $\quad$ Licensing and Standardization for Nuclear Powerplants

Committee: Senate Subcommittee on Nuclear Regulation, Committee on Environment and Public Works

CIS number: $\quad$ 91-S321-6

Date: $\quad$ Sept. 18,1990 
Pages: $\quad 103$

Title: $\quad$ Electric Vehicle Technology and Commercialization

Committee: House Subcommittee on Transportation, Aviation, and Materials, Committee on Science, Space, and Technology

CIS number: $\quad$ 91-H701-22

Date: $\quad$ Sept. 25, 1990

Pages: $\quad 142$

Title: $\quad$ Vehicular Natural Gas Jurisdiction Act of 1990

Committee: Senate Subcommittee on Energy Regulation and Conservation, Committee on Energy and Natural Resources

CIS number: 91-S311-20

Date: $\quad$ Sept. 25, 1990

Pages: $\quad 24$

Title: $\quad$ H.R. 2480: The Uranium Enrichment Reorganization Act

Committee: House Committee on Science, Space, and Technology

CIS number: 91-H701-28

Date: $\quad$ Oct. 11, 1990

Pages: $\quad 221$

Title: $\quad$ Energy Impact of the Persian Gulf Crisis

Committee: House Committee on Energy and Commerce

CIS number: $\quad 91-\mathrm{H} 361-87$

Date: Jan. 9, 1991

Pages: $\quad 189$

Title: $\quad$ National Energy Strategy. (Part 1)

Committee: House Subcommittee on Energy and Power, Committee on Energy and

Commerce

CIS number: $92-\mathrm{H} 361-5$

Date: $\quad$ Feb. 20, 27, 28, Mar. 7, 13, 20, 1991

Pages: $\quad 841$

Title: $\quad$ National Energy Security Act of 1991, Part 1

Committee: Senate Committee on Energy and Natural Resources

CIS number: 91-S311-32

Date: $\quad$ Feb. 21, 1991

Pages: $\quad 573$

Title: $\quad$ National Energy Security Act of 1991. Part 14

Committee: Senate Committee on Energy and Natural Resources 
CIS number: $\quad$ 91-S311-51

Date: $\quad$ 21, 26, 28, Mar. 20, 1991

Pages: $\quad 887$

Title: $\quad$ National Energy Security Act of 1991. Part 2

Committee: Senate Committee on Energy and Natural Resources

CIS number: 91-S311-33

Date: $\quad$ Feb. 26, 1991

Pages: $\quad 183$

Title: $\quad$ National Energy Security Act of 1991. Part 3

Committee: Senate Committee on Energy and Natural Resources

CIS number: $\quad$ 91-S311-34

Date: $\quad$ Feb. 26, 1991

Pages: $\quad 140$

Title: $\quad$ National Energy Strategy. (Part I \& II)

Committee: House Committee on Science, Space, and Technology

CIS number: $\quad$ 91-H701-36

Date: $\quad$ Feb. 26, 28, 1991

Pages: $\quad 340$

Title: $\quad$ National Energy Security Act of 1991. Part 4

Committee: Senate Committee on Energy and Natural Resources

CIS number: $91-S 311-35$

Date: $\quad$ Feb. 28, Mar. 20, 1991

Pages: $\quad 374$

Title: National Energy Security Act of 1991. Part 5

Committee: Senate Committee on Energy and Natural Resources

CIS number: 91-S311-36

Date: $\quad$ Mar. 5, 1991

Pages: $\quad 138$

Title: National Energy Security Act of 1991. Part 15

Committee: Senate Committee on Energy and Natural Resources

CIS number: 91-S311-55

Date: $\quad$ Mar. 5, 7, 11, 1991

Pages: $\quad 814$

Title: $\quad$ National Energy Security Act of 1991. Part 6

Committee: Senate Committee on Energy and Natural Resources

CIS number: $91-S 311-37$

Date: $\quad$ Mar. 7, 1991 
Pages: $\quad 266$

Title: $\quad$ Comprehensive Uranium Act of 1991

Committee: Senate Subcommittee on Energy Research and Development, Committee on Energy and Natural Resources

CIS number: $\quad$ 91-S311-46

Date: $\quad$ Mar. 7, 1991

Pages: $\quad 135$

Title: $\quad$ National Energy Security Act of 1991. Part 7

Committee: Senate Committee on Energy and Natural Resources

CIS number: $\quad$ 91-S311-38

Date: $\quad$ Mar. 11, 1991

Pages: $\quad 215$

Title: $\quad$ National Energy Security Act of 1991. Part 8 (Title IX)

Committee: Senate Committee on Energy and Natural Resources

CIS number: 91-S311-39

Date: $\quad$ Mar. 12, 1991

Pages: $\quad 445$

Title: $\quad$ National Energy Security Act of 1991. Part

Committee: Senate Committee on Energy and Natural Resources

CIS number: $\quad$ 91-S311-59

Date: $\quad$ Mar. 12, 14, 18, 19, 21, 1991

Pages: $\quad 665$

Title: Global Warming and Other Environmental Consequences of Energy

Strategies"

Committee: Senate Subcommittee on Environmental Protection, Committee on Environment and Public Works

CIS number: $\quad$ 91-S321-25

Date: $\quad$ Mar. 13, 20, Apr. 26, 1991

Pages: $\quad 332$

Title: $\quad$ National Energy Security Act of 1991. Part 9 (Title XV)

Committee: Senate Committee on Energy and Natural Resources

CIS number: 91-S311-40

Date: $\quad$ Mar. 14, 1991

Pages: $\quad 560$

Title: $\quad$ National Energy Security Act of 1991. Part 10

Committee: Senate Committee on Energy and Natural Resources 


\begin{tabular}{|c|c|}
\hline CIS number: & 91-S311-41 \\
\hline Date: & Mar. 18, 1991 \\
\hline Pages: & 65 \\
\hline Title: & National Energy Security Act of 1991. Part 11 (Subtitle A of Title V \\
\hline Committee: & $\begin{array}{l}\text { Senate Subcommittee on Energy Research and Development, Committee } \\
\text { on Energy and Natural Resources }\end{array}$ \\
\hline CIS number: & $91-S 311-42$ \\
\hline Date: & Mar. 19, 1991 \\
\hline Pages: & 203 \\
\hline Title: & National Energy Security Act of 1991. Part 12 (Subtitle A of Title III) \\
\hline Committee: & $\begin{array}{l}\text { Senate Subcommittee on Energy Regulation and Conservation, } \\
\text { Committee on Energy and Natural Resources }\end{array}$ \\
\hline CIS number: & $91-S 311-43$ \\
\hline Date: & Mar. 19, 1991 \\
\hline Pages: & 116 \\
\hline Title: & Alternative Fuel Fleets. (Title VII of S. 570)" \\
\hline Committee: & Senate Committee on Energy and Natural Resources \\
\hline CIS number: & $91-\mathrm{S} 311-47$ \\
\hline Date: & Mar. 20, 1991 \\
\hline Pages: & 123 \\
\hline Title: & National Energy Security Act of 1991. Part 13 (Subtitle A of Title IV)" \\
\hline Committee: & $\begin{array}{l}\text { Senate Subcommittee on Energy Regulation and Conservation, } \\
\text { Committee on Energy and Natural Resources }\end{array}$ \\
\hline CIS number: & $91-\mathrm{S} 311-44$ \\
\hline Date: & Mar. 21, 1991 \\
\hline Pages: & 81 \\
\hline $\begin{array}{l}\text { Title: } \\
\text { Gas" }\end{array}$ & Implications of Proposed National Energy Policy Legislation for Natural \\
\hline Committee: & $\begin{array}{l}\text { Senate Subcommittee on Energy Regulation and Conservation, } \\
\text { Committee on Energy and Natural Resources }\end{array}$ \\
\hline CIS number: & $91-S 311-52$ \\
\hline Date: & Apr. 3, 1991 \\
\hline Pages: & 270 \\
\hline Title: & National Energy Strategy. (Part 2) \\
\hline $\begin{array}{l}\text { Committee: } \\
\text { Commerce }\end{array}$ & House Subcommittee on Energy and Power, Committee on Energy and \\
\hline CIS number: & 92-H361-6 \\
\hline Date: & Apr. 10, May 8, 1991 \\
\hline
\end{tabular}


Pages: $\quad 872$

Title: $\quad$ National Energy Strategy. (Part 3)

Committee: House Subcommittee on Energy and Power, Committee on Energy and Commerce

CIS number: $\quad 92-\mathrm{H} 361-24$

Date: $\quad$ Apr. 16, 17, 25, 1991

Pages: $\quad 1007$

Title: $\quad$ National Energy Strategy. Part I: Energy Facility Siting

Committee: House the Subcommittee on Energy and the Environment, Committee on Interior and Insular Affairs

CIS number: $92-\mathrm{H} 441-60$

Date: $\quad$ Apr. 30, 1991

Pages: $\quad 456$

Title: $\quad$ National Energy Strategy. (Part 4)

Committee: House Subcommittee on Energy and Power, Committee on Energy and

Commerce

CIS number: $\quad$ 92-H361-25

Date: $\quad$ May 1, 2, June 26, 1991

Pages: $\quad 887$

Title: $\quad$ Nuclear Waste Management Provisions of the National Energy Strategy

Act

Committee: Senate Committee on Energy and Natural Resources. Senate

CIS number: 91-S311-65

Date: $\quad$ May 13, 1991

Pages: $\quad 82$

Title: $\quad$ Energy Efficiency in the U.S. Government

Committee: Senate Committee on Governmental Affairs

CIS number: $\quad$ 93-S401-24

Date: $\quad$ May 14, 1991

Pages: $\quad 431$

Title: $\quad$ H.R. 1538: National Electric Vehicle Act of 1991

Committee: House Subcommittee on Environment, Committee on Science, Space, and Technology

CIS number: $\quad$ 91-H701-76

Date: $\quad$ May 16, 1991

Pages: $\quad 211$

Title: $\quad$ National Energy Strategy. (Part 5)" 
Committee: House Subcommittee on Energy and Power, Committee on Energy and Commerce

CIS number: $\quad$ 92-H361-44

Date: $\quad$ May 16, 29, 1991

Pages: $\quad 523$

Title: $\quad$ National Energy Strategy. Part II: Enhanced Oil Recovery

Committee: House Subcommittee on Energy and the Environment, Committee on Interior and Insular Affairs

CIS number: $\quad$ 92-H441-61

Date: $\quad$ May 21, 1991

Pages: $\quad 173$

Title: $\quad$ Review of DOT Role in National Energy Strategy

Committee: House Subcommittee on Government Activities and Transportation, Committee on Government Operations

CIS number: $\quad 92-\mathrm{H} 401-10$

Date: $\quad$ May 29, 1991

Pages: $\quad 314$

Title: $\quad$ National Energy Strategy. (Part 6)

Committee: House Subcommittee on Energy and Power, Committee on Energy and Commerce

CIS number: $\quad$ 92-H361-45

Date: $\quad$ June 5, 12, 13, 1991

Pages: $\quad 772$

Title: $\quad$ Electric and Hybrid Vehicle Technologies Committee: Senate Subcommittee on Toxic Substances, Environmental Oversight, Research and Development, Committee on Environment and Public Works

CIS number: 91-S321-36

Date: June 11, 1991

Pages: $\quad 56$

Title: $\quad$ Energy Tax Incentives

Committee: Senate Subcommittee on Energy and Agricultural Taxation, Committee on Finance

CIS number: $\quad$ 92-S361-7

Date: June 13, 14, 1991

Pages: $\quad 256$

Title: $\quad$ National Energy Strategy. (Part 7)" 
Committee: House Subcommittee on Energy and Power, Committee on Energy and Commerce

CIS number: $\quad$ 92-H361-67

Date: $\quad$ June 19, 25, Sept. 10, 0, 1991

Pages: $\quad 800$

Title: $\quad$ Renewable Hydrogen Energy Research and Development Act of 1991

Committee: Senate Subcommittee on Energy Research and Development, Committee on Energy and Natural Resources

CIS number: $\quad$ 91-S311-63

Date: June 25, 1991

Pages: $\quad 81$

Title: Has the National Energy Strategy Been Short-Circuited?

Committee: House Subcommittee on Regulation, Business Opportunities, and Energy, Committee on Small Business

CIS number: $\quad$ 92-H721-18

Date: July 8, 1991

Pages: $\quad 167$

Title: $\quad$ U.S. Energy Research and Development Policy: Parts I-IV

Committee: House Subcommittee on Energy, Committee on Science, Space, and

Technology

CIS number: $\quad$ 92-H701-17

Date: $\quad$ July 11, 16, 25, Aug. 1, 1991.

Pages: $\quad 580$

Title: $\quad$ Energy Goals Act of 1991

Committee: Senate Committee on Energy and Natural Resources

CIS number: 91-S311-67

Date: $\quad$ July 18, 1991.

Pages: $\quad 98$

Title: $\quad$ Ensuring an Effective Alternative Fuels Program

Committee: House Subcommittee on Environment, Energy, and Natural Resources, Committee on Government Operations

CIS number: $\quad$ 92-H401-64

Date: July 29, 1991

Pages: $\quad 168$

Title: Legislation to Amend the Public Utility Holding Company Act of 1935 Committee: Senate Subcommittee on Securities, Committee on Banking, Housing, and Urban Affairs

CIS number: $\quad$ 92-S241-14 
Date: $\quad$ Sept. 17,1991

Pages: $\quad 632$

Title: Coal Commission Report on Health Benefits of Retired Coal Miners

Committee: Senate Subcommittee on Medicare and Long-Term Care, Committee on

Finance

CIS number: $\quad$ 92-S361-34

Date: $\quad$ Sept. 25, 1991

Pages: $\quad 326$

Title: $\quad$ Automotive Technologies for Fuel Economy

Committee: House Subcommittee on Environment, Committee on Science, Space, and Technology

CIS number: $\quad 92-\mathrm{H} 701-40$

Date: $\quad$ Oct. 2,1991

Pages: $\quad 122$

Title: $\quad$ National Energy Strategy

Committee: House Subcommittee on Investigations and Oversight, Committee on Science, Space, and Technology

CIS number: $\quad$ 92-H701-37

Date: $\quad$ Oct. 16, 1991

Pages: $\quad 261$

Title: $\quad$ National Energy Policy: Implications for Economic Growth

Committee: House Subcommittee on Economic Stabilization, Committee on Banking, Finance, and Urban Affairs

CIS number: $\quad$ 92-H241-38

Date: $\quad$ Oct. 17, Nov. 6, 1991.

Pages: $\quad 262$

Title: High-Level Radioactive Waste Legislation

Committee: House Subcommittee on Energy and the Environment, Committee on Interior and Insular Affairs

CIS number: $\quad 92-\mathrm{H} 441-77$

Date: $\quad$ Jan. 10,1992

Pages: $\quad 233$

Title: $\quad$ National Energy Strategy: Hot Dry Rock Geothermal Energy

Committee: House Subcommittee on Energy and the Environment, Committee on Interior and Insular Affairs

CIS number: $\quad 92-\mathrm{H} 441-79$

Date: Jan. 23, 1992

Pages: $\quad 125$ 
Title: $\quad$ Renewable Energy Technologies

Committee: House Subcommittee on Energy and Power, Committee on Energy and

Commerce

CIS number: $\quad$ 92-H361-84

Date: Jan. 29, 1992

Pages: $\quad 109$

Title: $\quad$ Energy Conservation Development: The Federal Government's Role

Committee: Senate Committee on Governmental Affairs

CIS number: $\quad 92-S 401-42$

Date: $\quad$ Feb. 18, 1992

Pages: $\quad 193$

Title: National Electromagnetic Fields Research and Public Information

Dissemination Act

Committee: House Subcommittee on Environment, Committee on Science, Space, and Technology

CIS number: $\quad$ 92-H701-62

Date: $\quad$ Mar. 10, 1992

Pages: $\quad 382$

Title: $\quad$ Strategies for Control of Greenhouse Emissions

Committee: House Subcommittee on Health and the Environment, Committee on Energy and Commerce

CIS number: $\quad$ 92-H361-86

Date: $\quad$ Mar. 19, 1992

Pages: $\quad 194$

Title: $\quad$ H.R. 4559: National Energy, Environment, and Competitiveness

Research Act of 1992

Committee: House Committee on Science, Space, and Technology

CIS number: 92-H701-97

Date: $\quad$ Apr. 1, 2, 1992

Pages: $\quad 1047$

Title: $\quad$ Department of Energy's Civilian Nuclear Waste Program

Committee: Senate Committee on Energy and Natural Resources

CIS number: $\quad$ 92-S311-37

Date: $\quad$ Mar. 31, 1992

Pages: $\quad 144$

Title: $\quad$ Oil and Gas Farmout Agreements in Bankruptcy

Committee: House Subcommittee on Economic and Commercial Law, Committee on Judiciary. House 
CIS number: $\quad$ 93-H521-22

Date: Apr. 1, 1992

Pages: $\quad 34$

Title: Comprehensive National Energy Policy Act

Committee: House Subcommittee on Public Buildings and Grounds, Committee on Public Works and Transportation.

CIS number: $\quad$ 92-H641-53

Date: $\quad$ Apr. 8, 1992

Pages: $\quad 123$

Title: $\quad$ Comprehensive National Energy Policy Act of 1992. (Surface

Transportation Issues)

Committee: House Subcommittee on Surface Transportation, Committee on Public Works and Transportation

CIS number: $\quad$ 92-H641-40

Date: $\quad$ Apr. 9, 1992

Pages: $\quad 22$

Title: $\quad$ H.R. 776, the Comprehensive National Energy Policy Act, Title I, Subtitle B, and Title III

Committee: House Subcommittee on Environment, Energy, and Natural Resources, Committee on Government Operations

CIS number: $\quad 93-\mathrm{H} 401-54$

Date: Apr. 28, 1992

Pages: $\quad 261$

Title: Comprehensive National Energy Policy Act

Committee: House Committee on Ways and Means

CIS number: 92-H781-67

Date: $\quad$ Apr. 28, 1992

Pages: $\quad 303$

Title: $\quad$ Renewable Energy and the National Energy Strategy

Committee: House Subcommittee on Investigations and Oversight, Committee on Science, Space, and Technology

CIS number: CIS NO: 92-H701-58

Date: $\quad$ Apr. 30, 1992

Pages: $\quad 150$

Title: Global Climate Change

Committee: Senate Committee on Energy and Natural Resources

CIS number: CIS NO: 92-S311-55

Date: $\quad$ May 6, 12, 1992. 
Pages: $\quad 427$

Title: $\quad$ State Regulation of Natural Gas Production

Committee: Senate Committee on Energy and Natural Resources.,.

CIS number: CIS NO: 92-S311-59

Date: June 18, 1992

Pages: $\quad 219$ 


\title{
Appendix XVIX
}

\section{Public Law 106-224}

\section{Agricultural Risk Protection Act of $\mathbf{2 0 0 0}$}

\section{Hearings Summary}

\author{
Title: $\quad$ Plant Protection Act \\ Committee: House Subcommittee on Department Operations, Nutrition, and Foreign \\ Agriculture, Committee on Agriculture \\ CIS number: $\quad 98-\mathrm{H} 161-24$ \\ Date: $\quad$ May 20, 1998 \\ Location: Washington, D.C. \\ Pages: $\quad 52$ \\ Summary: Hearing before the Subcommittee on Department Operations, Nutrition, \\ and Foreign Agriculture to consider H.R. 3766, the Plant Protection Act, \\ to consolidate and revise various laws to strengthen USDA authorities to \\ prevent the introduction and spread of non-indigenous invasive plants \\ and plant pests harmful to agricultural production. \\ Includes provisions to: \\ a. Increase civil penalties for smuggling prohibited items into the U.S. \\ b. Expand Animal and Plant Health Inspection Service (APHIS) \\ investigatory and enforcement authorities.
}

\section{TESTIMONY \#1 - STATEMENTS AND DISCUSSION:}

Support for H.R. 3766, with recommended amendment. REED, CRAIG A., (Acting Administrator, APHIS)

\section{TESTIMONY \#2 - STATEMENTS AND DISCUSSION:}

Merits of H.R. 3766, with importance to agricultural producers.

STUART, MICHAEL J., (President, Florida Fruit and Vegetable Association)

REGELBRUGGE, CRAIG J., (Director, Regulatory Affairs and Grower

Services, American Nursery and Landscape Association)

CROSS, GENE B., (Member, Federal Noxious and Invasive Weeds Committee, Weed Science Society)

JOHNSON, STEPHEN, (President, National Plant Board)

URMSTON, DEAN, (Executive Vice President, American Seed Trade

Association)

Title: $\quad$ Review of the Federal Crop Insurance Program

Committee: House Subcommittee on Risk Management and Specialty Crops, Committee on Agriculture. 
CIS number: $99-\mathrm{H} 161-9$

Date: $\quad$ November 12, 1998

Location: $\quad$ Sioux Falls, S.D.

Pages: $\quad 113$

Summary: $\quad$ Hearing to review the Federal crop insurance program administered by USDA Risk Management Agency (RMA). Includes audience participation.

\section{TESTIMONY \#1 - STATEMENTS AND DISCUSSION:}

Experiences with crop insurance program in South Dakota, with recommendations for improvements.

OLSEN, TOM, (Vice President, South Dakota Farm Bureau)

CYRE, PHIL, (Vice President, South Dakota Farmers Union)

TSCHAKERT, DELBERT, (Treasurer, South Dakota Soybean Association)

EDINGER, CHET, (President, South Dakota Wheat, Inc)

KOESTER, WALLY, (President, South Dakota Corn Growers Association)

\section{TESTIMONY \#2 - STATEMENTS AND DISCUSSION:}

Importance of crop insurance program, with recommendations for improvements.

KAUER, TOM, (Vice President, Spreckels Insurance; also representing

Independent Insurance Agents of America and Independent Insurance Agents of South Dakota)

MILLER, MICHAEL A., (President, Blakely Crop Hail, Inc.; also representing

American Association of Crop Insurers)

WHITE, JAMES L., (President, Norwest Bank, Aberdeen, SD)

CHRISTOFFERSON, DENNIS, (President, AGForce Insurance Services;

representing Crop Insurance Research Bureau)

GERDES, RUTH, (crop insurance agent)

LARSON, DENNIS K., (Owner, L\&S Agency; also representing Crop Insurance Agents of America)

ZIRSCHKY, JOHN, (Associate Administrator, RMA)

Title: $\quad$ Review of the Federal Crop Insurance Program

Committee: House Subcommittee on Risk Management, Research, and Specialty

Crops, Committee on Agriculture

CIS number: $\quad$ 99-H161-14

Date: $\quad$ February 16, 18, 1999

Location: Washington, D.C.

Committee Members:

Pages: $\quad 103$

Summary: Hearings before the Subcommittee on Risk Management, Research, and Specialty Crops to review the Federal crop insurance program administered by USDA Risk Management Agency (RMA).

Hearings on Feb. 16 were held in Perry, Ga. and in Douglas, Ga., and on Feb. 18 in Laurinburg, N.C. 
Includes audience participation.

Kenneth D. Ackerman, RMA Administrator, responds to questions from audience members in first two hearings.

Title: $\quad$ Review of the Federal Crop Insurance Program, Part II

Committee: House Subcommittee on Risk Management, Research, and Specialty Crops, Committee on Agriculture

CIS number: 99-H161-15

Date: $\quad$ March 10, 1999

Location: Washington, D.C.

Pages: $\quad 123$

Summary: Continuation of hearings before the Subcommittee on Risk Management, Research, and Specialty Crops to review the Federal crop insurance program administered by USDA Risk Management Agency (RMA).

\section{TESTIMONY \#1 - STATEMENTS AND DISCUSSION:}

Concerns regarding crop insurance program, with recommendations for program reform; need for partnership between USDA and industry to create new livestock income risk management tool

MCCLURE, TERRY, (Board Member, Ohio Farm Bureau; representing

American Farm Bureau Federation)

JONES, FRANK B., JR., (Board Advisor, National Cotton Council)

BODDIFORD, JOE, (Chairman, Subcommittee on Crop Insurance Reform, National Peanut Growers Group)

CROMLEY, LEE, (farmer)

BOSSMAN, DAVID A., (President, American Feed Industry Association)

\section{TESTIMONY \#2 - STATEMENTS AND DISCUSSION:}

Views on and recommendations regarding crop insurance program reform.

BRICHLER, RONALD L., (Senior Vice President, Great American Insurance

Co.; representing National Crop Insurance Services)

MILLER, MICHAEL A., (President, Blakely Crop Hail, Inc.; representing American Association of Crop Insurers)

BILL, RICHARD, (Actuary, Country Mutual Insurance Co.; representing Crop Insurance Research Bureau)

EVERSON, DENNIS, (Senior Vice President, First Dakota National Bank; representing American Bankers Association)

CASPARY, JAMES, (President and CEO, First National Bank of Clifton; representing Independent Bankers Association)

WISE, WILLIAM H., JR., (Executive Vice President and Chief Operating

Officer, Pee Dee Farm Credit; representing Farm Credit System)

Title: $\quad$ Crop Insurance 
Committee: Senate Committee on Agriculture, Nutrition, and Forestry

CIS number: $\quad$ 2000-S161-9

Date: $\quad$ March 17, 1999

Location: Washington, D.C.

Pages: $\quad 147$

Summary: Hearing to examine proposals to revise the Federal crop insurance program administered by USDA Risk Management Agency, in light of concerns that risk management tools available to farmers and ranchers are insufficient.

TESTIMONY \#1 - STATEMENTS AND DISCUSSION:

Review of Federal crop insurance program operations and revision proposals. ACKERMAN, KENNETH D., (Administrator, Risk Management Agency)

\section{TESTIMONY \#2 - STATEMENTS AND DISCUSSION:}

Perspectives of farmers on risk management and crop insurance reform proposals.

RULON, KEN, (Partner, Rulon Enterprises)

CYRE, PHILLIP, (Vice President, South Dakota Farmers Union; representing National Farmers Union)

KLECKNER, DEAN R., (President, American Farm Bureau Federation)

PHILLIPS, KYLE, (President, Iowa Corn Growers Association; representing

National Corn Growers Association)

HELMS, ALLEN, (Chairman, American Cotton Producers; also representing

National Cotton Council)

CURTIS, MARC, (First Vice President, American Soybean Association)

\section{TESTIMONY \#3 - STATEMENTS AND DISCUSSION:}

Perspectives of insurance industry on crop insurance reform.

MILLER, MIKE, (President, Blakely Crop Hail, Inc.; representing American Association of Crop Insurers)

SWARTZ, ROGER, (Vice President and General Manager, American Farm

Bureau Insurance Services; representing Crop Insurance Research Bureau)

Title: $\quad$ Crop Insurance

Committee: Senate Committee on Agriculture, Nutrition, and Forestry

CIS number: 2000-S161-19

Date: $\quad$ March 10, 1999

Location: Washington, D.C.

Pages: $\quad 201$

Summary: Hearing to examine proposals to revise the Federal crop insurance program administered by USDA Risk Management Agency, in light of concerns that risk management tools available to farmers and ranchers are insufficient.

\section{TESTIMONY \#1 - STATEMENTS AND DISCUSSION:}

Negative assessment of Federal crop insurance program effectiveness; reluctance of insurance companies to cover agricultural producers, citing risks associated with farming; 
strategies to manage agricultural risks, including Federal crop insurance program; elaboration on Federal crop insurance program reform issues.

SKEES, JERRY R., (Professor, Policy and Risk, Department of Agricultural

Economics, University of Kentucky)

COBLE, KEITH H., (Assistant Professor, Department of Agricultural

Economics, Mississippi State University)

GLAUBER, JOSEPH W., (Deputy Chief Economist, USDA)

BIEDERMANN, WILLIAM W., (Vice President, Co-Owner, and Director,

Research, Allendale, Inc)

\section{TESTIMONY \#2 - STATEMENTS AND DISCUSSION:}

Need to reform Federal crop insurance program.

GRAMS, ROD, (Sen., R-MN)

\section{TESTIMONY \#3 - STATEMENTS AND DISCUSSION:}

Overview of AFIA proposal to authorize USDA to partner with insurance companies to provide cattle and hog insurance (related tables, p. 187-198 passim); recommendations to reform Federal crop insurance program; need to expand risk management tools available to farmers and ranchers.

BOSSMAN, DAVID A., (President and Treasurer, American Feed Industry

Association (AFIA))

DOUD, GREGG, (Vice President, Market Intelligence Services Division, World Perspectives, Inc. (WPI))

COYLE, TOM, (Vice President, Origination, Continental Grain)

Title: $\quad$ Crop Insurance

Committee: Senate Committee on Agriculture, Nutrition, and Forestry

CIS number: 2000-S161-6

Date: $\quad$ April 21, 1999

Location: Washington D.C.

Pages: $\quad 97$

Summary: Hearing to review findings of a USDA Office of the Inspector General

(OIG) report assessing USDA Risk Management Agency-administered crop insurance program.

\section{TESTIMONY - STATEMENTS AND DISCUSSION:}

Overview of OIG report on Federal crop insurance reform; objections to certain OIG report findings regarding crop insurance program; findings of GAO reports assessing crop insurance program operations; differing views on OIG crop insurance program report findings

VIADERO, ROGER C., (Inspector General, USDA;); accompanied by EBBITT, James R., Assistant Inspector General, Audit.

ACKERMAN, KENNETH D., (Administrator, Risk Management Agency) BRICHLER, RON, (Board Chairman, National Crop Insurance Services; also representing American Association of Crop Insurers) 
DYCKMAN, LAWRENCE J., (Director, Food and Agriculture Issues, Resources, Community, and Economic Development Division, GAO)

Title: $\quad$ Review of the Federal Crop Insurance Program, Part III

Committee: House Subcommittee on Risk Management, Research, and Specialty Crops, Committee on Agriculture

CIS number: 99-H161-30

Date: $\quad$ May 3, 1999

Location: Russell Senate Building

Pages: $\quad 41$

Summary: Committee on Agriculture Serial No. 106-3. Continuation of hearings before the Subcom on Risk Management, Research, and Specialty Crops, in this volume held in Lexington, Ky., to review the Federal crop insurance program administered by USDA Risk Management Agency. Also examines status of Federal tobacco price support program.

TESTIMONY - STATEMENTS AND DISCUSSION:

Concerns of Kentucky farmers regarding crop insurance program, with recommendations for program reform; need to maintain Federal tobacco price support program.

COYLE, MARSHALL, (First Vice President, Kentucky Farm Bureau

Federation)

SNELL, WILLIAM M., (Associate Extension Professor, Agricultural

Economics, University of Kentucky)

BULLOCK, JOHN, (President, Burley Farmers' Advisory Council)

HORNBACK, PAUL, (President, Council for Burley Tobacco)

WEST, HENRY, (Vice President, Burley Tobacco Growers Cooperative)

Title: $\quad$ S. 910: The Noxious Weed Coordination and Plant Protection Act

Committee: Senate Subcommittee on Forestry, Conservation, and Rural

Revitalization, Committee on Agriculture, Nutrition, and Forestry

CIS number: 2000-S161-5

Date: $\quad$ May 18, 1999

Location: Washington, D.C.

Pages: $\quad 79$

Summary: Hearing to consider S. 910, the Noxious Weed Coordination and Plant Protection Act, to consolidate and revise various laws to strengthen USDA authorities to prevent the introduction and spread of nonindigenous invasive plants and plant pests harmful to agricultural production.

Includes provisions to:

a. Increase civil penalties for smuggling prohibited items into the U.S.

b. Expand Animal and Plant Health Inspection Service (APHIS) investigatory and enforcement authorities. 


\section{TESTIMONY \#1 - STATEMENTS AND DISCUSSION:}

Overall support for S. 910; recommendations to include provision to coordinate authority of various Federal agencies which respond to invasive species introduction.

REED, CRAIG A., (Administrator, APHIS, USDA)

LEWIS, ROBERT, JR., (Deputy Chief, R\&D, Forest Service)

BROWN, WILLIAM Y., (Science Advisor to the Secretary, Department of Interior)

TESTIMONY \#2 - STATEMENTS AND DISCUSSION:

Support for S. 910, with recommendations; impact of invasive weeds on agricultural producers.

WATKINS, JOHN, (President, Watkins Nurseries; representing American Nursery and Landscape Association)

PRIESTLEY, FRANK, (President, Idaho Farm Bureau Federation; representing American Farm Bureau Federation)

CHORNESKY, ELIZABETH A., (Director, Stewardship, Nature Conservancy)

CROSS, GENE B., (Plant Pest Administrator, North Carolina Department of

Agriculture and Consumer Services; representing Weed Science Society and National Plant Board)

TESTIMONY \#3 - STATEMENTS AND DISCUSSION:

Issues related to plant protection.

AKAKA, DANIEL K., (Sen., D-HI)

Title: $\quad$ New Petroleum: S. 935, the National Sustainable Fuels and Chemicals

Act of 1999

Committee: Senate Committee on Agriculture, Nutrition, and Forestry

CIS number: $\quad 99-S 161-13$

Date: $\quad$ May 27, 1999

Location: Washington, D.C.

Pages: $\quad 78$

Summary: Hearing to consider S. 935, the National Sustainable Fuels and Chemicals Act of 1999, to authorize research to promote the conversion of biomass into biobased industrial products, including fuels and commodity chemicals.

Support for S. 935, with recommendations; benefits of biomass energy production and use.

TESTIMONY \#1 - STATEMENTS AND DISCUSSION:

Support for S. 935, with recommendations; benefits of biomass energy production and use.

GLICKMAN, DANIEL R., (Secretary, USDA)

REICHER, DAN W., (Assistant Secretary, Energy Efficiency and Renewable Energy, DOE)

TESTIMONY \#2 - STATEMENTS AND DISCUSSION: 
Support for S. 935, with recommendations; anticipated positive effect of biomass R\&D in reducing the cost of biomass conversion.

KLECKNER, DEAN R., (President, American Farm Bureau Federation)

DALE, BRUCE E., (Chair, Department of Chemical Engineering, Michigan

State University)

SHUTER, MIKE, (Chairman, Indiana Corn Growers Association; representing

National Corn Growers Association and American Soybean Association)

SELLERS, JOHN, (President, Prairie Lands Bio-products)

LYND, LEE R.()

WYMAN, CHARLES E., (both Professors, Engineering, Thayer School of

Engineering, Dartmouth College)

\section{TESTIMONY \#3 - STATEMENTS AND DISCUSSION:}

Support for S. 935, with recommendations; advantages of enhanced biomass R\&D programs.

FIEDLER, JEFFREY B., (Climate Policy Specialist, Natural Resources Defense Council)

CLEMMER, STEVEN, (Energy Analyst, Union of Concerned Scientists)

SANFORD, KARL J., (Vice President, Technology Development, Genencor International)

DORSCH, ROBERT R., (Director, Biotechnology Development, DuPont Co)

Title: $\quad$ Risk Management/Crop Insurance Legislation

Committee: Senate Committee on Agriculture, Nutrition, and Forestry

CIS number: 2000-S161-14

Date: $\quad$ October 14, 1999

Location: Washington, D.C.

Pages: $\quad 78$

Summary: Hearing to review proposals to reform the Federal crop insurance program administered by USDA Risk Management Agency.

TESTIMONY \#1 - STATEMENTS AND DISCUSSION:

Merits of sponsored proposal for crop insurance program reform.

GRAHAM, BOB, (D-FL)

TESTIMONY \#2 - STATEMENTS AND DISCUSSION:

Views on crop insurance program reform

GARDNER, BRUCE L., (Department of Agricultural and Resource Economics, University of Maryland, College Park)

TESTIMONY \#3 - STATEMENTS AND DISCUSSION:

Recommendations regarding crop insurance program reform.

HILL, CRAIG, (Board Member, Iowa Farm Bureau Federation; representing American Farm Bureau Federation)

Title: $\quad$ National Sustainable Fuels and Chemicals Act of 1999 and Biomass

Research 
Committee: House Subcommittee on Risk Management, Research, and Specialty Crops, Committee on Agriculture

CIS number: 99-H161-49

Date: $\quad$ October 19, 1999

Location: Washington, D.C.

Pages: $\quad 68$

Summary: Hearing to consider H.R. 2827, the National Sustainable Fuels and Chemicals Act of 1999, and H.R. 2819, the Biomass Research and Development Act of 1999, both to authorize research to promote the conversion of biomass into biobased industrial products, including fuels and commodity chemicals.

TESTIMONY \#1 - STATEMENTS AND DISCUSSION:

Merits of H.R. 2819

UDALL, MARK, (Rep, D-CO)

TESTIMONY \#2 - STATEMENTS AND DISCUSSION:

Support for H.R. 2827 goals, with recommendations; issues related to biomass energy production and use.

GONZALEZ, I. MILEY, (Under Secretary, Research, Education, and

Economics, USDA)

REICHER, DAN W., (Assistant Secretary, Energy Efficiency and Renewable

Energy, DOE)

\section{TESTIMONY \#3 - STATEMENTS AND DISCUSSION:}

Support for H.R. 2827, with recommendations; benefits of biomass energy production and use.

HOLT, DONALD A., (Senior Associate Dean, College of Agricultural, Consumer, and Environmental Sciences, University of Illinois)

JONES, RICHARD L., (Chair, Experiment Station Committee on Organization and Policy, National Association of State Universities and Land-Grant Colleges)

WILSON, DOUGLAS A., (President, Illinois Corn Growers Association; representing National Corn Growers Association)

YOST, MICHAEL W., (Chairman, American Soybean Association)

DESROCHERS, PAUL E., (Director, Biomass Fuel Procurement, Thermo Ecotek)

Title: $\quad$ H.R. 2819, Biomass Research and Development Act of 1999 and H.R. 2827, National Sustainable Fuels and Chemicals Act of 1999

Committee: House Subcommittee on Energy and Environment, Committee on

Science

CIS number: 2000-H701-44

Date: $\quad$ October 285, 1999

Location: Washington, D.C.

Pages: $\quad 954$

Summary: Hearing to consider H.R. 2819, the Biomass Research and Development Act of 1999, and H.R. 2827, the National Sustainable Fuels and 
Chemicals Act of 1999, to amend the National Agricultural Research, Extension, and Teaching Policy Act of 1977, both to authorize research to promote the conversion of biomass into biobased industrial products, including fuels and commodity chemicals.

Bills include provisions to:

a. Require DOE and USDA to coordinate bioenergy R\&D in Federal departments and agencies.

b. Establish bioenergy research initiatives to award competitive grants, contracts, and other financial assistance to biomass research entities.

H.R. 2827 also authorizes USDA to construct a pilot plant for cornbased ethanol research to determine benefits of ethanol to the Federal reformulated gasoline program.

\section{TESTIMONY - STATEMENTS AND DISCUSSION:}

Importance of establishing legislation to promote bioenergy industry integration;perspectives on H.R. 2819 and H.R. 2827, with recommendations; efforts of USDA to promote biobased product $R \& D$; benefits of increased biomass $R \& D$ and bioenergy industry integration (related materials, p. 606-635).

Differing views on H.R. 2827 provision to establish a corn-based ethanol research pilot program; analysis of costs associated with H.R. 2819 and H.R. 2827 implementation; differences between H.R. 2819 and H.R. 2827; issues related to H.R. 2819 and H.R. 2827 impact on the bioenergy industry.

REICHER, DAN W., (Assistant Secretary, Energy Efficiency and Renewable Energy, DOE)

GONZALEZ, I. MILEY, (Under Secretary, Research, Education, and Economics, USDA)

DALE, BRUCE E., (Chairman, Department of Chemical Engineering, Michigan State University; representing National Research Council)

CLEMMER, STEVE, (Senior Energy Analyst, Union of Concerned Scientists)

Title: $\quad$ Invasive Species

Committee: House Subcommittee on Livestock and Horticulture, Committee on

Agriculture

CIS number: 2000-H161-3

Date: January 31, 2000

Location: $\quad$ Lake Alfred, FL

Pages: $\quad 76$

Summary: Hearing to examine the threat to agricultural production by nonindigenous invasive plants and plant pests, and to review Federal and State response measures.

Briefly considers H.R. 1504, the Plant Protection Act, to strengthen USDA authorities to prevent the introduction and spread of nonindigenous invasive plants and plant pests harmful to agricultural production.

TESTIMONY \#1 - STATEMENTS AND DISCUSSION: 
Perspectives on invasive species threat to agriculture and Federal and State prevention measures, including prevention efforts in Florida.

SCHWALBE, CHARLES P., (Associate Deputy Administrator, Plant Protection and Quarantine, Animal and Plant Health Inspection Service, USDA)

PUTNAM, ADAM, (State Representative, Florida)

ROBERTS, MARTHA R., (Deputy Commissioner, Food Safety, Florida

Department of Agriculture and Consumer Services)

\section{TESTIMONY \#2 - STATEMENTS AND DISCUSSION:}

Support for H.R. 1504; concerns of citrus and other agricultural producers regarding invasive species problem, with recommendations; overview of invasive plant, insect, and disease pest problem in U.S., including Florida.

LOOP, CARL B., JR., (President, Florida Farm Bureau)

LAVIGNE, ANDREW W., (Executive Vice President and CEO, Florida Citrus Mutual)

BOLUSKY, BEN, (Executive Vice President, Florida Nurserymen and Growers Association; also representing American Nursery and Landscape Association) STUART, MICHAEL J., (President, Florida Fruit and Vegetable Association) TAYLOR, R. JAY, (President, Florida Tomato Exchange) WHEELING, CRAIG, (CEO, Brooks Tropicals) BROWNING, HAROLD W., (Director, Citrus Research and Education Center, Institute of Food and Agricultural Sciences, College of Veterinary Medicine, University of Florida)

RALEY, LINDSAY, (Vice President, Operations, Thelma C. Raley, Inc.; also representing Polk County, Fla., Farm Bureau)

Title: Carbon Cycle Research and Agriculture's Role in Reducing Climate Change

Committee: Senate Subcommittee on Research, Nutrition, and General Legislation, Committee on Agriculture, Nutrition, and Forestry

CIS number: 2000-S161-11

Date: $\quad$ May 4, 2000

Location: Washington, D.C.

Pages: $\quad 116$

Summary: Hearing to examine the status of carbon cycle research and the role of agriculture in mitigating human-produced greenhouse gas effects associated with global climate change.

\section{TESTIMONY \#1 - STATEMENTS AND DISCUSSION:}

Perspectives on atmospheric carbon dioxide research, including role of plants and soil in the absorption of human-produced carbon dioxide; review of USDA research on the carbon cycle and implications of human-produced greenhouse gas emissions for agricultural production.

HOFMANN, DAVID J., (Director, Climate Monitoring and Diagnostic Laboratory, NOAA)

COLLINS, KEITH J., (Chief Economist, USDA) 
STUCKEY, RICHARD E., (Executive Vice President, Council for Agricultural

Science and Technology (CAST))

\section{TESTIMONY \#2 - STATEMENTS AND DISCUSSION:}

Role of agriculture soils in carbon cycling and the mitigation of greenhouse gases (related bibl, p. 82); status of research on agriculture role in the sequestration of carbon in the soil; perspectives on soil conservation issues.

RICE, CHARLES W., (Professor, Soil Microbiology, Department of Agronomy, Kansas State University)

KIMBLE, JOHN M., (Research Soil Scientist, Natural Resources Conservation Service)

RICHARDS, WILLIAM J., (former Chief, Soil Conservation Service)

HAAS, JOHN C., (farmer) 


\title{
Appendix XX
}

\section{Public Law 109-58}

\section{Energy Policy Act of 2005}

\section{Hearings Summary}

\author{
Title: $\quad$ Energy Tax Issues \\ Committee: Senate Subcommittee on Taxation and IRS Oversight, Committee on \\ Finance \\ CIS number: 2001-S361-9 \\ Date: $\quad$ July 18,2000 \\ Location: Washington, D.C. \\ Pages: $\quad 109$ \\ Summary: Hearing to review proposals to provide tax incentives to encourage the \\ development and use of alternative fuel vehicles and increase production \\ of domestic oil and gas to reduce reliance on foreign oil.
}

\section{WITNESS PANEL \#1 - STATEMENTS AND DISCUSSION:}

Support for tax incentives to increase the use of non-petroleum alternative motor fuels; importance of alternative motor fuels and advanced vehicle technologies in reducing U.S. dependence on foreign oil; perspectives on natural gas vehicles.

KOLODZIEJ, Richard R., President, Natural Gas Vehicle Coalition.

GROSCOST, Jeff, Speaker of the House, Arizona House of Representatives. GRAMS, Rod (Sen., R-MN)

BALL, William L., Director, Strategic Planning, Advanced Technology

Vehicles, General Motors Corp.; representing Electric Vehicle Association of the Americas.

ROBINSON, Michelle, Senior Transportation Advocate, Union of Concerned Scientists.

MILLER, Beverly, Director, Salt Lake Clean Cities Coalition.

\section{WITNESS PANEL \#2 - STATEMENTS AND DISCUSSION:}

Differing views on tax incentives to encourage domestic oil and gas production; anticipated benefits of tax incentives to encourage domestic gas and oil production; need for tax incentives to encourage the use of renewable energies and alternative fuels rather than oil and gas.

NOONAN, A. Shawn, General Tax Council, Vastar Resources; representing Domestic Petroleum Council.

SHULTZ, Alexandra, Staff Attorney, U.S. Public Interest Research Group. CAVANEY, Red, President and CEO, American Petroleum Institute. HOERNER, J. Andrew, Director, Research, Center for a Sustainable Economy. 
SWORDS, John, Partner-Independents, PricewaterhouseCoopers LLP;

representing Independent Petroleum Association and 34 other organizations.

Title: $\quad$ National Energy Policy

Committee: House Subcommittee on Energy and Air Quality, Committee on Energy and Commerce

CIS number: 2001-H361-11

Date: $\quad$ February 28, 2001

Location: Washington, D.C.

Pages: $\quad 132$

Summary: Hearing to examine energy policy issues related to natural gas market conditions and recent increases in natural gas prices.

\section{TESTIMONY \#1 - STATEMENTS AND DISCUSSION:}

Role of natural gas in meeting domestic energy demand; perspectives on natural gas supply, price, and regulatory issues.

HEBERT, CURTIS L., JR., (Chairman, FERC)

\section{TESTIMONY \#2 - STATEMENTS AND DISCUSSION:}

Review of natural gas price and supply trends and outlook; recommendations for national energy policies to improve domestic gas supply and increase use; importance of natural gas as a component of the national energy strategy.

CAMPBELL, ELIZABETH, (Director, Natural Gas Division, Energy

Information Administration)

WADLINGTON, CUBA, JR., (President and CEO, Williams Gas Pipeline;

representing Interstate Natural Gas Association)

JORDAN, JERRY, (President, Jordan Energy, Inc.; representing Independent

Petroleum Association, National Stripper Well Association, and numerous State and regional oil and gas associations)

REITEN, RICHARD G., (President and CEO, NW Natural; representing

American Gas Association)

LITTLEFAIR, ANDREW J., (President, Pickens Fuel Corp.; also representing Natural Gas Vehicle Coalition)

LUXBACHER, ROBERTA A., (Vice President-Americas, ExxonMobil Gas

Marketing Co.; representing Natural Gas Supply Association)

HENDRIX, WALKER, (Consumer Counsel, Kansas Citizens' Utility Ratepayer Board)

HILLIARD, JACK, (General Manager, Florence, Ala., Utilities; representing American Public Gas Association)

GILL, JAS, (Vice President, Manufacturing, CYTEC Industries; representing Louisiana Chemical Association)

SILVA, PATRICIO, (Project Attorney and Midwest Activities Coordinator, Natural Resources Defense Council) 
Title: $\quad$ Nation's Energy Future: Role of Renewable Energy and Energy

Efficiency

Committee: Committee on Science

CIS number: 2002-H701-4

Date: $\quad$ February 28, 2001

Location: Washington, D.C.

Pages: $\quad 147$

Summary: Hearing to examine role of renewable energy resources and energy efficiency in U.S. energy policy

\section{TESTIMONY - STATEMENTS AND DISCUSSION:}

Outlook for energy supply, consumption, and prices (related graphs, p. 17-23, 30-40); results of Pacific Northwest National Laboratory energy modeling efforts, citing energy efficiency and renewable energy role; views on role of renewable energy resources and energy efficiency in future energy policy.

HUTZLER, MARY J., (Director, Office of Integrated Analysis and Forecasting, Energy Information Administration)

HUMPHREYS, KENNETH K., (Senior Staff Engineer, Energy, Science, and Technology Division, Pacific Northwest National Laboratory)

HOLDREN, JOHN P., (former Chair, President's Committee of Advisors on Science and Technology)

DARMSTADTER, JOEL, (Senior Fellow, Energy and Natural Resources Division, Resources for the Future)

Title: $\quad$ Energy Supply and Prices

Committee: House Subcommittee on Oversight, Committee on Ways and Means

CIS number: 2001-H781-79

Date: $\quad$ March 5, 2001

Location: $\quad$ Mayville, NY

Pages: $\quad 104$

Summary: Hearing in Mayville, N.Y., before the Subcommittee on Oversight to examine issues related to U.S. energy market conditions, including recent increases in energy prices

TESTIMONY \#1 - STATEMENTS AND DISCUSSION:

Overview of energy-related tax incentives, including tax incentives for domestic oil and gas production.

MIKRUT, JOSEPH M., (Tax Legislative Counsel, Department of Treasury) TESTIMONY \#2 - STATEMENTS AND DISCUSSION:

Review of U.S. energy markets short-term outlook

COOK, JOHN S., (Director, Petroleum Division, Office of Oil and Gas, Energy Information Administration)

TESTIMONY \#3 - STATEMENTS AND DISCUSSION:

Perspectives on high energy costs in New York State and elsewhere, with details on consumer concerns; issues related to energy supply and prices. 
LINDSLEY, MOIRA L., (energy consumer)

SOSINSKI, CAROLINE, (energy consumer)

AIKEN, JEFF, (Council Representative, Western New York Regional Council of Carpenters)

HOLBROOK, DENNIS, (Board Member, Independent Oil and Gas Association of New York)

HEINE, BRUCE D., (Assistant Vice President, National Fuel Gas Distribution Corp)

NALBONE, JOHN J., JR., (President, Universal Resources Holdings)

Title: $\quad$ H.R. 723: Civil Penalties for Nuclear Safety Violations by Non-Profit Department of Energy Contractors Under the Atomic Energy Act of 1954

Committee: House Subcommittee on Energy, Committee on Science

CIS number: 2002-H701-23

Date: $\quad$ March 22, 2001

Location: Washington, D.C.

Pages: $\quad 136$

Summary: $\quad$ Hearing before the Subcommittee on Energy to consider H.R. 723, to amend the Atomic Energy Act of 1954 to repeal the nuclear safety violation civil penalty exemption for nonprofit DOE contractors established under the Price-Anderson Amendment Act of 1988. The Price-Anderson Act established a financial liability and indemnification system for compensation of claims resulting from nuclear accidents.

TESTIMONY - STATEMENTS AND DISCUSSION:

Qualified support for H.R. 723, with recommendations; elaboration on nuclear safety regulation and civil penalty exemptions for nonprofit DOE contractors.

FYGI, ERIC J., (Acting General Counsel, DOE)

JONES, GARY L., (Director, Natural Resources and Environment, GAO) CUNNINGHAM, GUY H., (Associate General Counsel, Battelle Memorial Institute)

VAN NESS, ROBERT L., (Assistant Vice President, Laboratory Administration Office, University California)

Title: $\quad$ National Energy Policy: Nuclear Energy

Committee: House Subcommittee on Energy and Air Quality, Committee on Energy and Commerce

CIS number: 2001-H361-10

Date: $\quad$ March 27, 2001

Location: Washington, D.C.

Pages: $\quad 141$ 
Summary: Hearing before the Subcommittee on Energy and Air Quality to examine energy policy issues related to nuclear power.

\section{WITNESS PANEL \#1 - STATEMENTS AND DISCUSSION:}

Role of nuclear power in national energy policy; perspectives on nuclear reactor safety and regulation; status of DOE efforts to support nuclear power technology development; overview of current and future prospects for nuclear power use.

TRAVERS, WILLIAM D., (Executive Director, Operations, NRC)

MAGWOOD, WILLIAM D., IV, (Director, Office of Nuclear Energy, Science, and Technology, DOE)

HUTZLER, MARY J., (Director, Office of Integrated Analysis and Forecasting, Energy Information Administration)

\section{WITNESS PANEL \#2 - STATEMENTS AND DISCUSSION:}

Importance of nuclear power.

DOMENICI, PETE V., (Sen., R-NM)

\section{WITNESS PANEL \#3 - STATEMENTS AND DISCUSSION:}

Significance of nuclear power in meeting current and future domestic energy needs; progress of nuclear utility industry in improving safety and performance of nuclear power plant operations; recommendations for national energy policies to ensure a reliable supply of nuclear fuel, with status of uranium enrichment industry; arguments against nuclear power.

HUTCHINSON, C. RANDY, (Senior Vice President, Nuclear Business

Development, Entergy Nuclear, Inc.; also representing Nuclear Energy Institute)

TOLLISON, ALFRED C., JR., (Executive Vice President, Institute of Nuclear

Power Operations)

SPROAT, EDWARD F., III, (Vice President, International Projects, Exelon

Generation Co)

LONGENECKER, JOHN R., (representing Management Consultants, Longenecker and Associates Inc)

AURILIO, ANNA, (Legislative Director, U.S. Public Interest Research Group)

Title: Department of Energy FY2002 Budget Request

Committee: House Subcommittee on Energy, Committee on Science

CIS number: 2002-H701-16

Date: $\quad$ April 26, 2001

Location: Washington, D.C.

Pages: $\quad 329$

Summary: Hearing before the Subcommittee on Energy to review DOE FY2002

budget proposal for programs under Committee jurisdiction, including Office of Science; environment, safety, and health; environmental management; energy efficiency and renewable energy; fossil energy; and nuclear energy, science, and technology programs TESTIMONY \#1 - STATEMENTS AND DISCUSSION: 
Explanation of Office of Science FY2002 budget request for energy research programs, including basic energy sciences, biological and environmental research, and high energy physics research; review of Office of Science research status and priorities.

DECKER, JAMES F., (Acting Director, Office of Science, DOE)

SULLIVAN, JOHN R., (Acting Deputy Assistant Secretary, Office of Planning, Budget, and Management, Office of Energy Efficiency and Renewable Energy (EERE)

HASPEL, ABRAHAM E., (Acting Director, EERE)

KRIPOWICZ, ROBERT S., (Acting Assistant Secretary, Office of Fossil Energy)

MARCUS, GAIL H., (Principal Deputy Director, Office of Nuclear Energy, Science and Technology

MAGWOOD, WILLIAM D., IV, (Director)

CARY, STEVEN V., (Acting Assistant Secretary, Office of Environment, Safety, and Health)

OWENDOFF, JAMES M., (Deputy Assistant Secretary, Office of Environmental Management)

\section{TESTIMONY \#2 - STATEMENTS AND DISCUSSION:}

Perspectives on DOE FY2002 budget request; importance of energy research programs; recommendations for FY2002 funding for various DOE programs, including nuclear energy research and energy efficiency programs; elaboration on DOE FY2002 budget request and related issues

TRILLING, GEORGE H., (President, American Physical Society)

TINKER, SCOTT W., (Director, Texas Bureau of Economic Geology)

LAKE, JAMES A., (President, American Nuclear Society)

MARVIN, MICHAEL L., (President, Business Council for Sustainable Energy)

Title: $\quad$ Geothermal Resources on Public Lands

Committee: House Subcommittee on Energy and Mineral Resources, Committee on Resources

CIS number: 2002-H651-28

Date: $\quad$ May 3, 2001

Location: Washington, D.C.

Pages: $\quad 71$

Summary: Hearing before the Subcommittee on Energy and Mineral Resources to examine issues involved in development of geothermal resources on public lands.

\section{TESTIMONY \#1 - STATEMENTS AND DISCUSSION:}

Status of and outlook for geothermal resource development on public lands; role of DOE and BLM in geothermal energy systems development.

WILLIAMS, COLIN F., (Supervisory Geophysicist, Geological Survey)

DIXON, ROBERT K., (Deputy Assistant Secretary, Office of Power

Technologies, DOE) 
ANDERSON, BOB, (Deputy Assistant Director, Minerals, Realty, and Resource Protection, BLM)

\section{TESTIMONY \#2 - STATEMENTS AND DISCUSSION:}

Support for geothermal energy development, citing need to increase use of renewable energy sources; challenges faced in harnessing geothermal energy on public lands.

GAWELL, KARL, (Executive Director, Geothermal Energy Association)

PIGOTT, JACK, (Electric Regulatory Director, Calpine Corp)

AIN, ROSS D., (Senior Vice President, Caithness Energy, LLC)

Title: $\quad$ Energy Realities: Rates of Consumption, Energy Reserves, and Future

Options

Committee: House Subcommittee on Energy, Committee on Science

CIS number: 2002-H701-21

Date: $\quad$ May 3, 2001

Location: Washington, D.C.

Pages: $\quad 359$

Summary: Hearing before the Subcommittee on Energy to examine issues related to national energy policy, including measures to promote energy efficiency and renewable resources in energy policy

\section{WITNESS PANEL \#1 - STATEMENTS AND DISCUSSION:}

Perspectives on national energy situation and adequacy of energy resources; views on current national energy policies; importance of energy efficiency promotion as a component of energy policy; strategies to strengthen national electricity infrastructure; role of renewable energy resources in national energy policy, with specifics on solar and wind power.

BARTLETT, ALBERT A., (Professor Emeritus, Physics, University of Colorado at Boulder)

WEEDMAN, SUZANNE D., (Program Coordinator, Energy Resources Program, Geologic Division, Geological Survey)

MONTGOMERY, W. DAVID, (Vice President, Charles River Associates)

GELLER, HOWARD S., (former Executive Director, American Council for an

Energy-Efficient Economy (ACEEE); representing ACEEE)

COURTRIGHT, HENRY A., (Vice President, Power Generation and Distributed Resources, Electric Power Research Institute)

VONMEIER, ALEXANDRA, (Director, Environmental Technology Center, Sonoma State University)

Title: First in Series on Effect of Federal Tax Laws on the Production, Supply, and Conservation of Energy

Committee: House Subcommittee on Select Revenue Measures, Committee on Ways and Means

CIS number: $\quad$ 2001-H781-87 
Date: $\quad$ May 3, 2001

Location: Washington, D.C.

Pages: $\quad 111$

Summary: Hearing before the Subcommittee on Select Revenue Measures to review Federal income tax laws impacting energy conservation, energy supply, and oil and gas production

\section{TESTIMONY \#1 - STATEMENTS AND DISCUSSION:}

Overview of Federal tax rules impacting energy production, supply, and conservation, with specifics on incentives to increase oil and gas production

MIKRUT, JOSEPH M., (Tax Legislative Counsel, Department of Treasury)

\section{TESTIMONY \#2 - STATEMENTS AND DISCUSSION:}

Long-term outlook for U.S. energy consumption, supply, and efficiency

HUTZLER, MARY J., (Director, Office of Integrated Analysis and Forecasting, Energy Information Administration)

\section{TESTIMONY \#3 - STATEMENTS AND DISCUSSION:}

Importance of tax credits to encourage energy production from non-conventional and renewable resources; perspectives on non-conventional and renewable energy resources, including wind power.

WILLIAMS, STEVEN R., (President, Petroleum Development Corp)

MORRISON, ROBERT, (Vice President, Business Development, FPL Energy)

CARLSON, WILLIAM H., (Vice President, Wheelabrator Environmental

Systems; representing USA Biomass Power Producers Alliance)

WALLACE, DAN, (Owner, Columbus Oil Co)

Title: Department of Energy Office of Science: Issues and Opportunities

Committee: House Subcommittee on Energy, Committee on Science

CIS number: 2002-H701-19

Date: $\quad$ May 17, 2001

Location: Washington, D.C.

Pages: $\quad 238$

Summary: Hearing before the Subcommittee on Energy to examine status of DOE Office of Science research programs

TESTIMONY \#1 - STATEMENTS AND DISCUSSION:

Assessment of DOE Office of Science programs and activities; role of Office of Science in supporting scientific R\&D; issues related to Office of Science operations and research programs.

HODGSON, KEITH O., (Director, Stanford Synchotron Radiation Laboratory, Department of Chemistry, Stanford University; representing Biological and Environmental Research Advisory Committee)

WRIGHT, MARGARET H., (Professor, Computer Science and Mathematics, New York University; representing Advanced Scientific Computing Advisory Committee)

RICHMOND, GERALDINE L., (Department of Chemistry, University of 
Oregon; representing Basic Energy Sciences Advisory Committee)

HAZELTINE, RICHARD D., (Director, Institute for Fusion Studies, University of Texas at Austin; representing Fusion Energy Sciences Advisory Committee)

GILMAN, FREDERICK J., (Professor, Department of Physics, Carnegie Mellon University; representing High Energy Physics Advisory Panel)

SYMONS, T. JAMES, (Nuclear Sciences Division, Lawrence Berkeley National Laboratory; representing DOE/NSF Nuclear Science Advisory Committee)

\section{TESTIMONY \#2 - STATEMENTS AND DISCUSSION:}

Findings and recommendations on DOE science programs of an independent report stemming from discussions of the Physics Policy Committee of the American Physical Society; importance of DOE Office of Science programs, including fusion energy sciences program; elaboration on issues related to Office of Science research programs.

RICHARDSON, ROBERT C., (Vice Provost, Research, Cornell University) SHANK, CHARLES V., (Director, Lawrence Berkeley National Laboratory) DRAKE, JAMES F., JR., (Professor, Institute for Plasma Research, University of Maryland)

Title: $\quad$ National Energy Policy: Report of the National Energy Policy

Development Group

Committee: House Committee on Science

CIS number: 2002-H701-26

Date: $\quad$ May 23, 2001

Location: Washington, D.C.

Pages: $\quad 354$

Summary: Hearing to examine Administration national energy plan and policy priorities. Reviews final report of the National Energy Policy Development (NEPD) Group, and assesses implications of proposed plan for energy conservation and research, and alternative/renewable energy technologies.

\section{TESTIMONY - STATEMENTS AND DISCUSSION:}

Perspectives on NEPD Group report; critique of Administration energy policy proposals, with support for alternative/renewable energy technologies and research (related docs, $\mathrm{p}$. 48-51); elaboration on energy policy issues, including energy resource development and conservation.

MARTIN, WILLIAM F., (Chairman, Washington Policy and Analysis, Inc.; representing Alliance for Energy and Economic Growth)

HAMILTON, KATHERINE H., (Co-Director, American Bioenergy Association; representing Sustainable Energy Coalition)

HAWKINS, DAVID G., (Director, Climate Center, Natural Resources Defense Council (NRDC)) 
Title: $\quad$ Energy Conservation Potential of Extended and Double Daylight Saving

Time

Committee: House Subcommittee on Energy, Committee on Science

CIS number: 2002-H701-9

Date: $\quad$ May 24, 2001

Location: Washington, D.C.

Pages: $\quad 140$

Summary: Hearing to examine proposals to extend or double daylight saving time to conserve energy, including H.R. 704, the Energy Time Adjustment Authorization Act, to allow States in the Pacific time zone consisting of California, Nevada, Oregon, and Washington State to temporarily adjust standard time in response to the energy crisis

\section{TESTIMONY \#1 - STATEMENTS AND DISCUSSION:}

Overview of H.R. 704.

SHERMAN, BRAD, (Rep, D-CA)

\section{TESTIMONY \#2 - STATEMENTS AND DISCUSSION:}

Potential of extended daylight saving time for energy conservation; viewed societal effects of extending daylight saving time.

LAWSON, LINDA L., (Acting Deputy Assistant Secretary, Policy, DOT)

BENFIELD, JAMES C., (Founder, Daylight Saving Time Coalition)

Title: $\quad$ National Energy Issues, Part 1

Committee: Senate Committee on Energy and Natural Resources

CIS number: 2001-S311-60

Date: $\quad$ May 24, June 26, July 12, 2001

Location: Washington, D.C.

Pages: $\quad 196$

Summary: Hearings to examine various energy policy issues, including

Administration national energy policy and proposals to revise DOE programs to ensure energy supply and security.

Considers various bills and proposals to encourage development of domestic oil and gas resources and to enhance utilization of nuclear power.

Also considers various bills and proposals to extend and revise financial liability and indemnification system established under the Price-

Anderson Act of 1957 for compensation of claims resulting from nuclear accidents.

\section{TESTIMONY \#1 - STATEMENTS AND DISCUSSION:}

Overview of Administration national energy policy.

ABRAHAM, SPENCER, (Secretary, DOE)

TESTIMONY \#2 - STATEMENTS AND DISCUSSION:

Support for extension of Price-Anderson Act of 1957 financial liability and indemnification system without substantial changes; background on Price-Anderson Act 
liability and indemnification system.

Objections to extension of Price-Anderson Act system, in light of viewed dangers of nuclear power and inability of the Price-Anderson system to provide the public with adequate protection.

FYGI, ERIC J., (Deputy General Counsel, DOE)

GRAY, JOSEPH R., (Associate General Counsel, Licensing and Regulation, NRC)

BRADBURNE, JOHN, (President and CEO, Fluor Fernald, Inc.; representing

Energy Contractors' Price-Anderson Group)

FERTEL, MARVIN S., (Senior Vice President, Business Operations, Nuclear

Energy Institute)

QUATTROCCHI, JOHN L., (Senior Vice President, Underwriting, American

Nuclear Insurers)

PICA, ERICH, (Economic Policy Analyst, Friends of the Earth)

\section{TESTIMONY \#3 - STATEMENTS AND DISCUSSION:}

Merits of Administration national energy policy, with specifics on provisions impacting Department of Interior programs; opinions on various energy policy proposals and issues, including Alaska oil and gas initiatives.

NORTON, GALE A., (Secretary, Department of Interior)

BLAKE, FRANCIS S., (Deputy Secretary, DOE)

\section{TESTIMONY \#4 - STATEMENTS AND DISCUSSION:}

Views on various energy policy issues and proposals; opinions on oil and gas

development, including Alaska initiatives; review of environmental concerns associated with development of oil and gas resources; recommendations to increase ability of petroleum and gas producers to access undeveloped resources.

JOHNSTON, J. BENNETT, (Chairman, Johnston and Associates, LLC)

BURTON, BILL, (attorney)

CLUSEN, CHARLES M., (Senior Policy Analyst, Natural Resources Defense Council)

HOOD, JERRY, (Special Assistant to the General President for Energy, International Brotherhood of Teamsters)

YOUNG, TOM, (Vice President, Business Development, Mariner Energy, Inc.; representing Independent Petroleum Association)

TESTIMONY \#5 - STATEMENTS AND DISCUSSION:

Differing views on nuclear power policy issues and proposals.

FERTEL, MARVIN S., (Senior Vice President, Business Operations, Nuclear

Energy Institute)

THADANI, ASHOK C., (Director, Office of Nuclear Regulatory Research, $\mathrm{NRC)}$

AURILIO, ANNA, (Legislative Director, U.S. Public Interest Research Group)

Title: Second in Series on Effect of Federal Tax Laws on the Production, Supply, and Conservation of Energy 
Committee: House Subcommittee on Select Revenue Measures, Committee on Ways and Means

CIS number: $\quad$ 2001-H871-88

Date: June 12, 2001

Location: Washington, D.C.

Pages: $\quad 126$

Summary: Hearing before the Subcommittee on Select Revenue Measures to consider proposals to extend or establish Federal income tax incentives to encourage energy conservation and increase energy supplies, including provisions to provide incentives for oil and gas production

TESTIMONY - STATEMENTS AND DISCUSSION:

Recommendations regarding energy tax incentives.

JOHNSON, NANCY L., (Rep, R-CT)

CAMP, DAVE, (Rep, R-MI)

NUSSLE, JIM, (Rep, R-IO)

CUNNINGHAM, RANDY, (Rep, R-CA)

MARKEY, EDWARD J., (Rep, D-MA)

DUNN, JENNIFER, (Rep, R-WA)

COLLINS, MICHAEL A., (Rep, R-GA)

WELLER, JERRY, (Rep, R-IL)

LEWIS, RON, (Rep, R-KY)

GEPHARDT, RICHARD A., (Rep, D-MO)

STENHOLM, CHARLES W., (Rep, D-TX)

FILNER, BOB, (Rep, D-CA)

SANDLIN, MAX, (Rep, D-TX)

INSLEE, JAY, (Rep, D-WA)

MOORE, DENNIS, (Rep, D-KS)

ENGEL, ELIOT L., (Rep, D-NY)

TERRY, LEE, (Rep, R-NE)

CAPITO, SHELLEY MOORE, (Rep, R-WV)

ISSA, DARRELL E., (Rep, R-CA)

MCDERMOTT, JIM, (Rep, D-WA)

Title: $\quad$ President's National Energy Policy, Parts 1 \& 2

Committee: House Subcommittee on Energy, Committee on Science

CIS number: 2002-H701-28

Date: June 12, 14, 2001

Location: Washington, D.C.

Chair:

Pages: $\quad 580$

Summary: Hearings to review Administration national energy plan and policy

priorities. Examines proposals to revise DOE energy R\&D 
programs/investments, and assesses the relative merits of developing and deploying various advanced energy resource technologies

\section{TESTIMONY \#1 - STATEMENTS AND DISCUSSION:}

Perspectives on coal and DOE clean coal technology program; role of coal in meeting national energy needs, with support for continued/expanded clean coal R\&D; critique of DOE clean coal technology program management: elaboration on clean coal technology issues.

KRIPOWICZ, ROBERT S., (Acting Assistant Secretary, Fossil Energy, DOE) YAMAGATA, BEN, (Executive Director, Coal Utilization Research Council)

WELLS, JAMES E., JR., (Director, Natural Resources and Environment, GAO) ABEND, KATHERINE, (Global Warming Associate, U.S. Public Interest Research Group)

MEAD, JOHN S., (Director, Coal Extraction and Utilization Research Center, Southern Illinois University)

\section{TESTIMONY \#2 - STATEMENTS AND DISCUSSION:}

Perspectives on petroleum and natural gas $R \& D$, with review of related technological developments; need and support for expanded oil and gas R\&D

KRIPOWICZ, ROBERT S., (Acting Assistant Secretary, Fossil Energy, DOE) LAZENBY, VIRGINIA B., (Chairman and CEO, Bretagne, G.P.; representing Independent Petroleum Association, National Stripper Well Association, and numerous other oil and gas associations)

CUNEO, PAUL L., (Vice President and Chief Information Officer, Equiva Services, LLC; representing American Petroleum Institute)

VANKIRK, CRAIG W., (Professor, Petroleum Engineering, Colorado School of Mines)

HUFFMAN, ALAN R., (Manager, Seismic Imaging Technology Center, Conoco, Inc)

\section{TESTIMONY \#3 - STATEMENTS AND DISCUSSION:}

Perspectives on hydrogen fuel and hydrogen R\&D; support for upcoming reauthorization of the Hydrogen Future Act, which authorizes the DOE R\&D and demonstration program on the storage, transportation, and use of hydrogen as a fuel; elaboration on hydrogen technology issues, developments, and challenges.

GARMAN, DAVID K., (Assistant Secretary, Energy Efficiency and Renewable Energy, DOE)

HUBBARD, H. M., (Chair, Committee on Programmatic Review of DOE Office of Power Technologies, National Research Council)

KATSAROS, ARTHUR T., (Group Vice President, Engineered Services and Development, Air Products and Chemicals, Inc.; also representing National Hydrogen Association)

HABERMAN, DAVID P., (Chairman, DCH Technology, Inc)

LEHMAN, PETER, (Director, Schatz Energy Research Center, Humboldt State University)

TESTIMONY \#4 - STATEMENTS AND DISCUSSION:

Views on H.R. 1679 and H.R. 2126. 
GRAHAM, LINDSEY O., (Rep, R-SC)

BIGGERT, JUDY, (Rep, R-IL)

\section{TESTIMONY \#5 - STATEMENTS AND DISCUSSION:}

Differing perspectives on nuclear power and nuclear technologies R\&D; rationale for expanded nuclear infrastructure investment, with overview of and support for H.R. 1679 and H.R. 2126; conflicting views on viability of nuclear power and nuclear technologies; elaboration on related issues and policy considerations.

COLVIN, JOE F., (President and CEO, Nuclear Energy Institute)

MAGWOOD, WILLIAM D., IV, (Director, Office of Nuclear Energy, Science

and Technology, DOE)

KOTEK, JOHN F., (Manager, Special Projects Section, Argonne National

Laboratory-West, DOE; representing American Nuclear Society)

AURILIO, ANNA, (Legislative Director, U.S. Public Interest Research Group)

Title:

Third in Series on Effect of Federal Tax Laws on the Production, Supply, and Conservation of Energy

Committee: House Subcommittee on Select Revenue Measures, Committee on Ways and Means

CIS number: 2001-H781-105

Date: June 13, 2001

Location: Washington, D.C.

Pages: $\quad 125$

Summary: Hearing before the Subcommittee on Select Revenue Measures to consider proposals to extend or establish Federal income tax incentives to encourage energy conservation and increase energy supplies, including provisions to provide incentives for oil and gas production

\section{TESTIMONY \#1 - STATEMENTS AND DISCUSSION:}

Support for various proposals to establish tax credits to encourage energy efficiency and the development of energy efficient technologies.

COOPER, JOSEPHINE S., (President and CEO, Alliance of Automobile

Manufacturers)

ROBINSON, DAN, (President and CEO, Placid Refining Co)

SAILLANT, ROGER, (President and CEO, Plug Power, Inc.; representing Fuel Cell Advocates)

MURRAY, ROBERT E., (President and CEO, Murray Energy Corp.; representing National Mining Association)

GELLER, HOWARD, (former Executive Director, American Council for an Energy-Efficient Economy; representing Sustainable Energy Coalition)

\section{TESTIMONY \#2 - STATEMENTS AND DISCUSSION:}

Perspectives on energy-related tax policies; support for H.R. 1986, to clarify the tax treatment of tax-exempt bonds used to fund long-term prepaid contracts for natural gas; recommendations for tax law changes to encourage development of domestic petroleum and natural gas resources 
MCHUGH, TOM E., (Executive Director, Louisiana Municipal Association; representing American Public Gas Association)

MACFARLANE, CHARLES N., (Assistant General Tax Counsel, Chevron Corp.; representing American Petroleum Institute, Domestic Petroleum Council, and U.S. Oil and Gas Association)

VAN SON, VINCE T., (Manager, Business Development, Energy Division, Alcoa, Inc)

HALL, DAVID S., (Manager, Taxation, Berry Petroleum Co.; representing Independent Petroleum Association, National Stripper Well Association, and numerous State and regional oil and gas associations)

\section{TESTIMONY \#3 - STATEMENTS AND DISCUSSION:}

Opinions on tax policy impacting electric utilities; support for H.R. 1459, the Electric Power Industry Tax Modernization Act, to revise tax policies impacting electric power generation and transmission capabilities.

WILLIAMS, JERRY D., (General Manager and CEO, Claiborne Electric Co-Op; representing National Rural Electric Cooperative Association)

TIENCKEN, JOHN H., (President and CEO, South Carolina Public Service Authority; representing American Public Power Association and Large Public Power Council)

NELSON, GREGORY, (Vice President and Tax Counsel, Ameren Corp.; representing Edison Electric Institute)

Title: $\quad$ Restructuring of Energy Industries

Committee: Senate Committee on Governmental Affairs

CIS number: 2002-S401-43

Date: June 13, 20, 28, 2001

Location: Washington, D.C.

Pages: $\quad 830$

Summary: Hearings to examine factors contributing to and adverse effects of recent increases in California electricity prices, and to review features of California electric utility restructuring and Federal energy policies, including concerns about FERC response to energy crisis.

TESTIMONY \#1 - STATEMENTS AND DISCUSSION:

Views on energy crisis in California.

BOXER, BARBARA, (Sen., D-CA)

CRAIG, LARRY E., (Sen., R-ID)

FEINSTEIN, DIANNE, (Sen., D-CA)

\section{TESTIMONY \#2 - STATEMENTS AND DISCUSSION:}

Factors contributing to energy crisis in California, with policy recommendations;

concerns about electric utilities deregulation in California, with details on FERC role;

overview of electricity market restructuring initiatives; problems with California electric utilities pricing structure. 
KAHN, ALFRED E., (Professor Emeritus, Political Economy, Cornell

University)

BORENSTEIN, SEVERIN, (Director, University of California Energy Institute)

HOGAN, WILliAM W., (Professor, Public Policy and Administration, School

of Government, Harvard University)

JOSKOW, PAUL L., (Director, Center for Energy and Environmental Policy

Research, MIT)

MAKOVICH, LAWRENCE J., (Senior Director and Co-Head, North American

Energy Group, Cambridge Energy Research Associates)

WOLAK, FRANK A., (Professor, Economics, Stanford University)

TESTIMONY \#3 - STATEMENTS AND DISCUSSION:

Views on California energy crisis.

MURKOWSKI, FRANK H., (Sen., R-AK)

MURRAY, PATTY, (Sen., D-WA)

CANTWELL, MARIA, (Sen., D-WA)

\section{TESTIMONY \#4 - STATEMENTS AND DISCUSSION:}

Steps taken to resolve energy crisis in California and stabilize energy prices; role of FERC in California energy crisis, with recommendations.

DAVIS, GRAY, (Governor, CA)

TESTIMONY \#5 - STATEMENTS AND DISCUSSION:

Views on California energy crisis and possible solutions.

MARTZ, JUDY, (Governor, MT)

HOEVEN, JOHN, (Governor, ND)

TESTIMONY \#6 - STATEMENTS AND DISCUSSION:

Effects of California energy crisis on other western States.

GREGOIRE, CHRISTINE O., (Attorney General, Washington)

HEMMINGWAY, ROY, (Chairman, Oregon Public Utility Commission)

\section{TESTIMONY \#7 - STATEMENTS AND DISCUSSION:}

Review of FERC efforts to resolve California energy crisis; description of events that led to California energy crisis and price spikes; need for energy conservation measures and new generation opportunities to prevent future energy crises; effects of supply and demand problems on California energy markets and consumers.

HEBERT, CURTIS L., JR., (Chairman, FERC)

BREATHITT, LINDA K., (Commissioner, FERC)

BROWNELL, NORA M., (Commissioner, FERC)

MASSEY, WILLIAM L., (Commissioner, FERC)

WOOD, PATRICK H., III, (Commissioner, FERC)

TESTIMONY \#8 - STATEMENTS AND DISCUSSION:

Explanation of electricity generation and transmission systems; views on FERC oversight of energy industry deregulation; concerns about deregulation effects on electricity reliability for consumers.

COOK, DAVID N., (General Counsel, North American Electric Reliability

Council)

HARRIS, PHILLIP G., (President and CEO, PJM Interconnection, L.L.C) 
KELLY, KEVIN A., (Director, Division of Policy Innovation and Communication, Office of Markets, Tariffs, and Rates, FERC) POPOWSKY, IRWIN A., (Pennsylvania Consumer Advocate; representing National Association of State Utility Consumer Advocates)

Title: National Energy Policy: Report of the National Energy Policy Development Group, Administration Review

Committee: House Committee on Science

CIS number: 2002-H701-27

Date: June 21, 2001

Location: Washington, D.C.

Pages: $\quad 151$

Summary: Hearing to examine Administration national energy plan and policy priorities, based on recommendations of the National Energy Policy Development Group. Assesses implications of proposed plan for energy conservation and research, and alternative/renewable energy technologies.

\section{TESTIMONY \#1 - STATEMENTS AND DISCUSSION:}

Overview and defense of Administration national energy plan and policy priorities; views on energy R\&D and conservation, with support for energy resource diversification and development; elaboration on energy policy issues and challenges.

ABRAHAM, SPENCER, (Secretary, DOE)

Title: $\quad$ National Energy Policy: Conservation and Energy Efficiency

Committee: House Subcommittee on Energy and Air Quality, Committee on Energy and Commerce

CIS number: 2001-H361-50

Date: June 22, 2001

Location: Washington, D.C.

Pages: $\quad 137$

Summary: Hearing before the Subcommittee on Energy and Air Quality to examine recommendations for measures to promote energy efficiency in U.S. energy policy.

TESTIMONY \#1 - STATEMENTS AND DISCUSSION:

Importance of energy efficiency promotion as a component of energy policy; specifics on various State energy efficiency programs; issues related to energy efficiency.

GARMAN, DAVID K., (Assistant Secretary, Energy Efficiency and Renewable Energy, DOE)

HOOVER, FREDERICK H., JR., (Director, Maryland Energy Administration; representing National Association of State Energy Officials)

TESTIMONY \#2 - STATEMENTS AND DISCUSSION: 
Importance of energy policies to promote energy efficiency; recommendations for energy efficiency policies; description of private sector efforts to promote energy efficiency; role of Federal government in promoting energy efficiency.

NADEL, STEVEN, (Executive Director, American Council for an EnergyEfficient Economy)

WAGNER, MARK F., (Director, Federal Government Relations, Johnson

Controls, Inc)

O'HAGAN, MALCOLM,(President, National Electrical Manufacturers

Association)

COOPER, JOSEPHINE S., (President and CEO, Alliance of Automobile

Manufacturers)

NEMTZOW, DAVID M., (President, Alliance To Save Energy)

SWOFFORD, GARY B., (Vice President and Chief Operating Officer, Delivery

Business Unit, Puget Sound Energy)

RODGERS, MARK E., (President and CEO, SmartSynch, Inc)

PETERSON, DEAN E., (Director, Superconductivity Technology Center, Los

Alamos National Laboratory)

SILVA, PATRICIO, (Midwest Coordinator, Air and Energy Programs, Natural

Resources Defense Council)

CLARK, JORDAN, (President, United Homeowners Association)

Title: $\quad$ Renewable Fuels for Energy Security

Committee: Senate Committee on Energy and Natural Resources

CIS number: 2002-S311-5

Date: $\quad$ July 6, 2001

Location: Washington D.C.

Pages: $\quad 47$

Summary: Hearing in Sioux Falls, S.Dak., to consider S. 1006, the Renewable Fuels and Energy Security Act of 2001, to require motor fuel produced and used in the U.S. to contain a certain quantity of ethanol, biodiesel, or other bio-based renewable fuels.

Purpose of bill is to reduce national dependence on foreign oil, while creating a long-term, sustainable demand for bio-based fuels.

\section{TESTIMONY \#1 - STATEMENTS AND DISCUSSION:}

Support for S. 1006, in light of anticipated impact on corn and soybean producers of increased demand for ethanol and biodiesel.

IHNEN, DARIN, (Vice President, South Dakota Corn Growers Association)

METZ, ROBERT, (representing South Dakota Soybean Association)

SCHAUNAMAN, KIRK, (Member, South Dakota Farmers Union; representing

National Farmers Union)

SHUBECK, PAUL, (Director, Clay County Farm Bureau; representing South

Dakota Farm Bureau)

TESTIMONY \#2 - STATEMENTS AND DISCUSSION: 
Merits of S. 1006 and other proposals to increase the production and use of ethanol and biodiesel.

GUTHMILLER, TREVOR T., (Executive Director, American Coalition for Ethanol)

CHRISTIANSON, RODNEY, (CEO, South Dakota Soybean Processors; also representing Minnesota Soybean Processors)

ALVERSON, RON, (Chairman, Lake Area Corn Processors)

TESTIMONY \#3 - STATEMENTS AND DISCUSSION:

Support for proposals to increase use of renewable transportation fuels.

TWISS, JOHN, (Supervisor, Black Hills National Forest, Forest Service)

CAMPBELL, JOHN B., (Vice President, Ag Processing Inc)

Title: $\quad$ Climate Change Technology and Policy Options

Committee: Senate Committee on Commerce, Science, and Transportation

CIS number: 2004-S261-83

Date: $\quad$ July 10, 2001

Location: Washington, D.C.

Pages: $\quad 199$

Summary: Hearing to review Federal policy options to address global climate change, and to examine R\&D of technologies to reduce emission of carbon dioxide and other greenhouse gases.

TESTIMONY \#1 - STATEMENTS AND DISCUSSION:

Overview of NOAA research on global climate change and greenhouse gas impact; need for additional research and initiatives to mitigate climate change.

EVANS, DAVID L., (Assistant Administrator, Oceanic and Atmospheric

Research, NOAA)

\section{TESTIMONY \#2 - STATEMENTS AND DISCUSSION:}

Benefits of renewable and clean energy technologies, including fuel cells, nuclear and wind power, and hybrid gas-electric automobiles; need to increase Federal funding for clean energy $R \& D$, with recommendations.

MILLER, WILLIAM T., (President, International Fuel Cells)

KOETZ, MAUREEN, (Director, Environmental Policy and Programs, Nuclear

Energy Institute)

DUFFY, DENNIS J., (Vice President, Regulatory Affairs, Energy Management, Inc)

KAMMEN, DANIEL M., (Professor, Energy and Society, Energy and Resources Group, University of California, Berkeley)

GERMAN, JOHN, (Manager, Environment and Energy Analyses, Product Regulatory Office, American Honda Motor Co)

\section{TESTIMONY \#3 - STATEMENTS AND DISCUSSION:}

Perceived benefits of emissions trading whereby companies that reduce emissions in excess of required levels would earn credits that could be sold to other emissions producers; need to reduce emissions levels to prevent global warming, with 
recommendations (related materials, p. 111-126); summary of energy industry proposal to reduce power plant emissions.

SANDOR, RICHARD L., (Chairman and CEO, Environmental Financial

Products LLC)

CLAUSSEN, EILEEN, (President, Pew Center on Global Climate Change)

HAWKINS, DAVID G., (Director, Climate Center, Natural Resources Defense

Council)

CASSIDY, FRANK, (President and Chief Operating Officer, Public Service

Enterprise Group; also representing Clean Energy Group)

Title: $\quad$ Role of Tax Incentives in Energy Policy

Committee: Senate Committee on Finance

CIS number: 2002-S361-13

Date: $\quad$ July 1, 11, 2001

Location: Washington, D.C.

Pages: $\quad 226$

Summary: Hearings to examine proposals to revise Federal tax incentives to encourage energy conservation and increase energy supply, focusing on incentives for alternative energy technologies and renewable fuels.

\section{TESTIMONY \#1 - STATEMENTS AND DISCUSSION:}

Perspectives on Federal policies regarding alternative fuels and energy efficient technologies; rationale for expansion of Federal alternative fuel and technology tax incentives; potential impact of energy tax revisions on highway funding; support for tax incentives to increase the economic viability of hybrid vehicles and non-petroleum fuels, including ethanol.

WELLS, JAMES E., JR., (Director, Natural Resources and Environment, GAO) CANNON, JAMES S., (President, Energy Futures, Inc.; representing INFORM, Inc)

RUANE, T. PETER, (President and CEO, American Road and Transportation

Builders Association)

COOPER, JOSEPHINE S., (President and CEO, Alliance of Automobile

Manufacturers)

LASHOF, DANIEL A., (Science Director, Climate Center, Natural Resources

Defense Council)

DINNEEN, ROBERT, (Vice President, Renewable Fuels Association)

HASSETT, KEVIN A., (Resident Scholar, American Enterprise Institute for Public Policy Research)

\section{TESTIMONY \#2 - STATEMENTS AND DISCUSSION:}

Views on tax incentives for alternative fuels.

DAYTON, MARK, (Sen., D-MN)

\section{TESTIMONY \#3 - STATEMENTS AND DISCUSSION:}

Review of energy tax policy issues and potential shortcomings of targeted energy tax incentives; impact of Federal tax policies on domestic oil and natural gas production; 
arguments for tax incentives to encourage the use and development of renewable energies and alternative fuels

HAKES, JAY E., (former Administrator, Energy Information Administration, DOE)

HALL, DAVID S., (Manager, Taxation, Berry Petroleum Co.; representing Independent Petroleum Association, National Stripper Well Association and numerous other oil and gas organizations)

WILLIAMS, RONALD W., (President, Gary-Williams Energy Corp.; representing ad hoc coalition of small refiners)

KAMMEN, DANIEL M., (Director, Renewable and Appropriate Energy Laboratory, University of California, Berkeley)

SINGH, VIRINDER, (Research Director, Renewable Energy Policy Project)

Title: $\quad$ H.R. 2436, the Energy Security Act

Committee: House Committee on Resources

CIS number: 2002-H651-36

Date: $\quad$ July 11, 2001

Location: Washington, D.C.

Pages: $\quad 112$

Summary: Hearing to consider H.R. 2436, the Energy Security Act, to protect U.S. energy security, including provision to establish an oil and gas exploration, development, and production leasing program in the Arctic National Wildlife Refuge (ANWR) coastal plain area in Alaska.

\section{TESTIMONY \#1 - STATEMENTS AND DISCUSSION:}

Overall support for H.R. 2436, with recommendations; review of Administration energy policy.

NORTON, GALE A., (Secretary, Department of Interior)

\section{TESTIMONY \#2 - STATEMENTS AND DISCUSSION:}

Support for H.R. 2436.

JOHNSTON, J. BENNETT, (former Senator, LA)

\section{TESTIMONY \#3 - STATEMENTS AND DISCUSSION:}

Opposing views on H.R. 2436 provision to establish oil and gas exploration, development, and production leasing program in ANWR coastal plain; viewed adverse environmental impact of H.R. 2436.

HERRERA, ROGER C., (representing Arctic Power)

GLENN, RICHARD, (Vice President, Lands, Arctic Slope Regional Corp)

HOOD, JERRY, (Special Assistant to General President, Energy, International

Brotherhood of Teamsters)

KOLTON, ADAM M., (Arctic Campaign Director, Alaska Wilderness League)

LANCE, LINDA, (Vice President, Public Policy, Wilderness Society)

Title: $\quad$ National Energy Issues, Part 2 
Committee: Senate Committee on Energy and Natural Resources

CIS number: 2001-S311-61

Date: $\quad$ July $13,17,18,2001$

Location: Washington, D.C.

Pages: $\quad 256$

Summary: Hearings to consider legislative proposals to extend and revise various

DOE and other Federal agency energy security and conservation

programs and policies.

Briefly considers S. 352, the Energy Emergency Response Act of 2001,

to extend and revise the State Energy Program providing grants to States

for emergency energy programs and energy conservation initiatives, and to extend and revise low-income weatherization grant programs.

\section{TESTIMONY \#1 - STATEMENTS AND DISCUSSION:}

Concerns regarding S. 352 and other legislative proposals to revise Federal energy policies and programs.

GARMAN, DAVID K., (Assistant Secretary, Energy Efficiency and Renewable Energy, DOE)

\section{TESTIMONY \#2 - STATEMENTS AND DISCUSSION:}

Support for S. 352, citing benefits for State energy programs; need to improve regulations regarding energy efficiency in buildings, with views on bills under consideration.

MANOOGIAN, MARY A., (Director, Office of Energy and Community

Services, New Hampshire Governor's Office; representing National Association of State Energy Officials)

CHOATE, JO-ANN L., (Manager, Low Income Home Energy Assistance Program, Energy and Housing Services, Maine Housing Authority; representing National Energy Assistance Directors Association)

EMBLEM, ERIK S., (Executive Director and Administrator, National Energy Management Institute)

WAGNER, MARK F., (Director, Federal Government Relations, Johnson Controls, Inc.; also representing Federal Performance Contracting Coalition)

\section{TESTIMONY \#3 - STATEMENTS AND DISCUSSION:}

Views on energy proposals impacting use of petroleum products in light duty vehicles.

MCNUTT, BARRY D., (Senior Policy Analyst, Office of Domestic Policy and International Affairs, DOE)

SHELTON, L. ROBERT, (Executive Director, NHTSA)

\section{TESTIMONY \#4-STATEMENTS AND DISCUSSION:}

Review of alternative fuel vehicle (AFV) use and development; need for Federal policies to encourage AFV use; analysis of natural gas vehicle market issues; examination of electric vehicle and other alternative vehicle development; recommendations for Federal policies to reduce difficulties in AFV production.

GIBBENS, CHARLES, (Automotive Fleet Manager, Henrico County, Va.; representing National Association of Fleet Administrators)

MCCORMICK, J. BYRON, (Director, Global Alternative Propulsion Center, General Motors Corp) 
DANA, GREGORY, (Vice President, Environmental Affairs, Alliance of Automobile Manufacturers)

KOLODZIEJ, RICHARD R., (President, Natural Gas Vehicle Coalition)

MARSHALL, GARY, (Vice Chairman, National Ethanol Vehicle Coalition)

ZELTMANN, EUGENE, (President and Chief Operating Officer, New York

State Power Authority; representing Electric Vehicle Association of the

Americas)

\section{TESTIMONY \#5 - STATEMENTS AND DISCUSSION:}

Assessment of recent Federal energy R\&D programs and findings; need for funding to continue and improve various Federal energy R\&D programs and priorities; findings of studies to assess efficacy of DOE and other Federal energy R\&D programs in improving energy policies and programs.

Recommendations to improve energy sciences education and training to ensure qualified energy sector workforce; opinions on proposals to revise energy R\&D programs, focusing on nuclear energy R\&D proposals; review of nuclear waste management considerations and policy recommendations.

HOLDREN, JOHN P., (Director, Program on Science, Technology, and Public

Policy, Kennedy School, Harvard University)

RICHARDSON, ROBERT C., (Professor, Physics, Cornell University)

MONIZ, ERNEST J., (Professor, Physics, MIT)

FRI, ROBERT W., (former Chairman, Committee on Benefits of DOE R\&D on Energy Efficiency and Fossil Energy, National Academy of Sciences)

HUBBARD, H. M., (former Chair, Study Committee for the Programmatic

Review of the Office of Power Technologies, NRC)

CORRADINI, MICHAEL L., (Chairman, Engineering Physics Department, University of Wisconsin, Madison)

COCHRAN, THOMAS B., (Director, Nuclear Program, Natural Resources

Defense Council)

BOUCHARD, JACQUES, (Director, Nuclear Energy Division, French Atomic

Energy Commission)

CHOPPIN, GREGORY R., (Professor, Department of Chemistry, Florida State University)

Title:

S. 1008--The Climate Change Strategy and Technology Innovation Act

of 2001

Committee: Senate Committee on Governmental Affairs

CIS number: 2002-S311-1

Date: July 18, 2001

Location: Washington, D.C.

Pages: $\quad 206$

Summary: Hearing to consider S. 1008 (text, p. 144-206), the Climate

Change Strategy and Technology Innovation Act of 2001, to amend the Energy

Policy Act of 1992 to authorize FY2002-FY2011 appropriations for R\&D and other activities related to global climate change. 
Includes provisions to:

a. Establish the National Office of Climate Change Response within the Executive Office of the President to coordinate Federal climate change initiatives and develop a national climate change response strategy to include greenhouse gas emissions mitigation measures, technology innovation programs, and climate adaptation research.

b. Establish the Center for Strategic Climate Change Response and the Office of Carbon Management within DOE to conduct climate technology R\&D, including the development of greenhouse gas emission reduction, capture, and sequestration technology.

c. Establish an independent U.S. Climate Change Response Strategy Review Board comprised of scientific and technical experts to review the work of the National Office of Climate Change Response and Federal agencies in meeting commitments under the national climate change response strategy.

\section{TESTIMONY \#1 - STATEMENTS AND DISCUSSION:}

Need for sponsored S. 1008

BYRD, ROBERT C. (D-WV)

\section{TESTIMONY \#2 - STATEMENTS AND DISCUSSION:}

Strategies to address global climate change problem, including reduction of carbon dioxide emissions; status of scientific knowledge regarding global climate change

HANSEN, JAMES E., (Head, Goddard Institute for Space Studies, NASA)

KARL, THOMAS R., (Director, National Climatic Data Center, National

Environmental Satellite Data and Information Services, NOAA)

\section{TESTIMONY \#3 - STATEMENTS AND DISCUSSION:}

Views on S. 1008; aspects of global climate change; recommendations to address global climate change problem; review of economic issues related to proposals to reduce carbon dioxide emissions

CLAUSSEN, EILEEN, (President, Pew Center on Global Climate Change) EDMONDS, JAMES A., (Senior Staff Scientist, Pacific Northwest National Laboratory)

HEYDLAUFF, DALE E., (Senior Vice President, Environmental Affairs, American Electric Power Co)

LASH, JONATHAN, (President, World Resources Institute)

THORNING, MARGO, (Senior Vice President and Chief Economist, American Council for Capital Formation)

Title: $\quad$ National Energy Issues

Committee: Senate Committee on Energy and Natural Resources

CIS number: 2002-S311-1

Date: July 19, 24-26, 2001

Location: Washington, D.C.

Pages: $\quad 344$ 
Summary: Hearings to consider legislative proposals to extend and revise various

DOE and other Federal agency energy programs and policies, including proposals to restructure the electric power industry.

Also reviews the need to develop a comprehensive national energy policy.

TESTIMONY \#1 - STATEMENTS AND DISCUSSION:

Opinions on various energy-related legislative proposals; need for energy policies to support use of renewable energy sources; elaboration on energy proposals and renewable energy issues.

BOYD, ROBERT T., (Vice President, Enron Wind Corp)

DEMETER, CHRISTIAN P., (CEO, Antares Group)

HALL, MARK, (Vice President, External Affairs, Trigen Energy Corp)

STARRS, THOMAS J., (Senior Partner, Kelso Starrs and Associates, LLC)

TESTIMONY \#2 - STATEMENTS AND DISCUSSION:

Opinions on various energy-related legislative proposals; need for energy policies to support use of renewable energy sources; elaboration on energy proposals and renewable energy issues.

BOYD, ROBERT T., (Vice President, Enron Wind Corp)

DEMETER, CHRISTIAN P., (CEO, Antares Group)

HALL, MARK, (Vice President, External Affairs, Trigen Energy Corp)

STARRS, THOMAS J., (Senior Partner, Kelso Starrs and Associates, LLC)

\section{TESTIMONY \#3 - STATEMENTS AND DISCUSSION:}

Need to revise FERC hydropower licensing process; deficiencies in existing hydropower licensing procedures; overview of environmental and other benefits of hydropower use; views on various proposals to improve FERC hydropower licensing.

BETTENBERG, WILLIAM, (Deputy Director, Office of Policy Analysis, Department of Interior)

ROBINSON, J. MARK, (Director, Office of Energy Projects, FERC)

BIRNBAUM, S. ELIZABETH, (Director, Government Affairs, American

Rivers)

GRAY, GERALD J., (Vice President, Policy, American Forests)

KEIL, JULIE, (Director, Hydro-Licensing and Water Rights, Portland General Electric Co)

\section{TESTIMONY \#4 - STATEMENTS AND DISCUSSION:}

Aspects of Administration energy efficiency R\&D programs; views on various energy proposals under consideration, including proposals to encourage carbon dioxide sequestration and reduce greenhouse gas emissions.

BLAKE, FRANCIS S., (Deputy Secretary, DOE)

RISBRUDT, CHRISTOPHER, (Acting Associate Deputy Chief, Programs and Legislation, Forest Service, USDA)

\section{TESTIMONY \#5 - STATEMENTS AND DISCUSSION:}

Recommendations for carbon dioxide sequestration and greenhouse gas emissions reduction measures, in light of concerns about possible negative effects on energy 
industries and other industries; need for improved emissions reduction measures, with views on related legislative proposals.

CAMPBELL, JOHN B., (Vice President, Ag Processing Inc.; also representing

Ag Environmental Products LLC)

CASSIDY, FRANK, (President and Chief Operating Officer, PSEG Power LLC;

also representing Clean Energy Group)

HILL, GARDINER, (Director, CO2, BP)

GEBOLYS, GENE J., (President, World Energy Alternatives LLC)

LYONS, JAMES R., (Professor, Resource Management, Yale School of Forestry and Environmental Studies)

\section{TESTIMONY \#6 - STATEMENTS AND DISCUSSION:}

Need to revise current Federal electricity regulations to reflect changes in electricity markets.

BLAKE, FRANCIS S., (Deputy Secretary, DOE)

\section{TESTIMONY \#7 - STATEMENTS AND DISCUSSION:}

Importance of establishing a national comprehensive energy policy for the electric utilities industry, with recommendations; concerns regarding electric power policies that preclude effective energy supply reliability and efficiency; issues related to electric utilities industry and related Federal energy proposals.

AYERS, JEFFREY D., (Senior Vice President and General Counsel, Aquila, Inc.; also representing Electric Power Supply Association)

ROWE, JOHN W., (President and Co-CEO, Exelon Corp.; representing Edison Electric Institute)

THILLY, ROY, (CEO, Wisconsin Public Power; representing American Public Power Association)

ENGLISH, GLENN, (CEO, National Rural Electric Cooperative Association)

\section{TESTIMONY \#8 - STATEMENTS AND DISCUSSION:}

Views on various energy-related legislative proposals; support for creation of a public benefits fund to impose charges for use of transmission grids to distribute to State and tribal governments for energy resources conservation and development; views on electric power market competition; importance of implementing standards for electric power reliability, with recommendations.

NUGENT, WILLIAM M., (Commissioner, Maine Public Utilities Commission; representing National Association of Regulatory Utility Commissioners) DUSHAW, JAMES L., (Director, Utility Department, International Brotherhood of Electrical Workers)

HAMILTON, DAVID, (Policy Director, Alliance To Save Energy)

ROUSE, JAMES B., (Associate Director, Energy Policy, Praxair, Inc.;

representing Electricity Consumers Resource Council)

WARD, STEPHEN, (President, National Association of State Utility Consumer

Advocates)

COOK, DAVID N., (General Counsel, North American Electric Reliability

Council)

TESTIMONY \#9 - STATEMENTS AND DISCUSSION: 
Recommendations for legislation to restructure the electric power industry.

SALISBURY, JENNIFER, (Secretary, Minerals and Natural Resources, New

Mexico Department of Energy; representing Western Governors' Association)

\section{TESTIMONY \#10 - STATEMENTS AND DISCUSSION:}

Review of issues to consider in development of electric power industry restructuring legislation; views on electric power legislation and national energy policy proposals.

HEBERT, CURTIS L., JR., (Chairman, FERC)

BREATHITT, LINDA K. (Commissioners)

MASSEY, WILLIAM L. (Commissioners)

WOOD, PATRICK H., III. (Commissioners)

BROWNELL, NORA M., (Commissioners)

Title: $\quad$ Renewable Fuels

Committee: House Subcommittee on Rural Enterprises, Agriculture, and Technology, Committee on Small Business

CIS number: 2001-H721-43

Date: $\quad$ July 24, 2001

Location: Washington, D.C.

Pages: $\quad 65$

Summary: Hearing before the Subcommittee on Rural Enterprises, Agriculture, and Technology to assess the importance of renewable fuels and alternative energy development technologies in U.S. energy policy.

Also briefly considers H.R. 2423, the Renewable Fuels for Energy

Security Act of 2001, to establish a national standard and related programs to phase-in replacement of a certain percentage of the petroleum-based content of highway transportation fuels with renewable fuels, including ethanol and biodiesel.

\section{TESTIMONY - STATEMENTS AND DISCUSSION:}

Importance of including ethanol and other renewable fuels in national energy policy; support for H.R. 2423; benefits of geothermal heat pump energy development technology; role of biomass resources in meeting U.S. energy needs, with related energy policy recommendations.

DINNEEN, ROBERT, (Vice President, Renewable Fuels Association)

DONALDSON, GUY F., (President, Pennsylvania Farm Bureau; also representing American Farm Bureau Federation)

HECK, RONALD R., (farmer; representing American Soybean Association) ABNEE, CONN, (Executive Director, Geothermal Heat Pump Consortium)

SMITH, MEGAN, (Co-Director, American Bioenergy Association)

Title: H.R. 2407, the Federal Photovoltaic Utilization Act 
Committee: House Subcommittee on Economic Development, Public Buildings and Emergency Management, Committee on Transportation and Infrastructure

CIS number: 2002-H751-32

Date: $\quad$ August 1, 2001

Location: Washington, D.C.

Pages: $\quad 85$

Summary: Hearing to consider H.R. 2407, the Federal Photovoltaic Utilization Act, to amend the Public Buildings Act of 1959 to authorize GSA to establish a solar photovoltaic (PV) energy systems procurement and installation program for new and existing Federal buildings.

Bill is intended to enhance PV industry viability, reduce Federal fossil fuel consumption, and promote public/private energy conservation and efficiency.

\section{TESTIMONY \#1 - STATEMENTS AND DISCUSSION:}

Perspectives on renewable energy and solar PV; reservations about PV cost effectiveness and H.R. 2407.

MORAVEC, F. JOSEPH, (Commissioner, Public Building Service, GSA)

EWING, MARK, (Director, Energy Center of Expertise, GSA)

GARMAN, DAVID K., (Assistant Secretary, Energy Efficiency and Renewable Energy, DOE)

\section{TESTIMONY \#2 - STATEMENTS AND DISCUSSION:}

Perspectives on solar PV, with support for H.R. 2407.

HAMER, GLENN, (Executive Director, Solar Energy Industries Association)

LEYDEN, THOMAS, (Vice President, PowerLight Corp.; also representing New Jersey Solar Energy Industries Association)

EMBLEM, ERIK, (Executive Director, National Energy Management Institute)

Title: $\quad$ Role of Tax Incentives in Addressing Rural Energy Needs and

Conservation

Committee: Senate Committee on Finance

CIS number: 2002-S361-3

Date: $\quad$ August 24, 2001

Location: Billings, MT

Pages: $\quad 203$

Summary: Hearing to examine the role of tax incentives in addressing energy infrastructure and production requirements in Montana and other rural western States, and to review tax issues impacting energy development on tribal lands.

\section{TESTIMONY \#1 - STATEMENTS AND DISCUSSION:}

Perspectives on tax issues impacting electric power and other energy infrastructure in western rural States; role of energy efficiency strategies and enhanced use of renewable energy resources in easing infrastructure needs in northwestern States. 
ANDERSON, BOB, (Member, Montana Public Service Commission)

PASCOE, WILlIAM A., (Vice President, Energy Supply, Montana Power Co)

HOLZER, TERRY, (General Manager, Yellowstone Valley Electric Co-op)

SUBART, DARWIN L., (Executive Vice President and General Manager, WBI

Southern, Inc.; representing MDU Resources Group)

HIRSH, NANCY, (Policy Director, NW Energy Coalition)

\section{TESTIMONY \#2 - STATEMENTS AND DISCUSSION:}

Perspectives on tax incentives impacting energy production and the use of renewable energy resources in rural western States; specifics on energy tax incentive needs in Montana.

HARPER, RONALD, (CEO, Basin Electric Power Cooperative)

HORTON, DALE, (Sustainable Energy Program Manager, National Center for Appropriate Technology)

SEWELL, GINA E., (Tax Manager, Devon Energy Corp.; representing Domestic Petroleum Council)

\section{TESTIMONY \#3 - STATEMENTS AND DISCUSSION:}

Views on tax incentives impacting energy development on tribal lands.

EDER, RAY K., (Vice Chairman, Fort Peck Tribal Executive Board)

MARTEL, WESLEY, (Member, Eastern Shoshone Tribe of the Wind River

Reservation Business Council)

KENNERLY, LEO, III, (Member, Blackfeet Tribal Business Council)

Title: $\quad$ Potential Alternative Energy Sources Available on National Public Lands

Committee: House Committee on Resources

CIS number: 2002-H651-43

Date: $\quad$ October 3, 2001

Location: $\quad$ Longworth Office Building, Washington, D.C.

Pages: $\quad 70$

Summary: Hearing to assess the potential of alternative energy development on public lands to increase domestic energy supply.

TESTIMONY \#1 - STATEMENTS AND DISCUSSION:

Potential of renewable energy sources to supply anticipated energy consumption increase; accomplishments of and potential for alternative energy technology development; support for land use policy changes to promote alternative energy production.

HUTZLER, Mary J., Acting Administrator, Energy Information Administration.

GARMAN, David K., Assistant Secretary, Energy Efficiency and Renewable

Energy, DOE.

GRILES, J. Steven, Deputy Secretary, Department of Interior.

\section{TESTIMONY \#2 - STATEMENTS AND DISCUSSION:}

Overview of wind, geothermal, and solar energy production potential on public lands; issues affecting alternative energy production on Federal lands; support for streamlined access approval for public land use to increase economic viability of alternative energy production. 
HULEN, Jeffrey B., Senior Geologist, Energy and Geoscience Institute, University of Utah.

WEISGALL, Jonathan M., Vice President, Legislative and Regulatory Affairs, Mid-American Energy Holdings Co.; representing Geothermal Energy Association.

STEVE, Jaime C., Legislative Director, American Wind Energy Association. BUTLER, Barry L., Vice President and Manager, Energy Productions Division, Science Applications International Corp.; representing Solar Energy Industries Association.

Title: U.S. Energy Security: Options to Decrease Petroleum Use in the Transportation Sector

Committee: House Subcommittee on Energy, Committee on Science

CIS number: 2002-H701-32

Date: $\quad$ November 1, 2001

Location: Washington, D.C.

Pages: $\quad 127$

Summary: Hearing to examine effects of U.S. dependence on imported oil on national security and to assess transportation industry efforts to develop alternative fuels to decrease U.S. oil consumption

\section{TESTIMONY - STATEMENTS AND DISCUSSION:}

Overview of U.S. oil production and consumption trends; implications for national security of U.S. dependence on imported oil; status of R\&D on alternative fuel and enhanced fuel efficiency projects; overview of potential options to reduce U.S. petroleum consumption, including electric and hybrid vehicles.

WOOLSEY, R. JAMES, (former Director, CIA)

GARMAN, DAVID K., (Assistant Secretary, Energy Efficiency and Renewable Energy, DOE)

DANA, GREGORY J., (Vice President, Environmental Affairs, Alliance of Automobile Manufacturers)

BURNETTE, ROBERT H., (Project Manager, Bulk Power, Dominion Virginia

Power; representing Electric Vehicles Association of the Americas)

DONIGER, DAVID D., (Policy Director, Climate Center, Natural Resources Defense Council)

MACKENZIE, JAMES J., (Senior Associate, Climate, Energy, and Pollution Program, World Resources Institute)

Title: $\quad$ Electric Supply and Transmission Act of 2001

Committee: House Subcommittee on Energy and Air Quality, Committee on Energy and Commerce

CIS number: 2002-H361-26

Date: $\quad$ December 12, 13, 2001 
Location: Washington, D.C.

Pages: $\quad 217$

Summary: Hearings to consider H.R. 3406, the Electric Supply and Transmission

Act of 2001, to amend the Federal Power Act, the Public Utility Holding Company Act (PUHCA) of 1935, and the Public Utility Regulatory

Policies Act of 1978 to restructure the electric power industry to promote effective wholesale competition, including provision to repeal PUHCA and replace its restrictions on certain activities of multistate electric and natural gas holding companies with increased access by FERC and State regulators to certain books and records.

\section{TESTIMONY \#1 - STATEMENTS AND DISCUSSION:}

Review of FERC actions to ensure transition to competitive wholesale electricity market, citing support for H.R. 3406; views on various H.R. 3406 provisions; summary of TVA efforts to promote competitive and restructured electricity marketplace; perspectives on electricity market competition and restructuring issues and H.R. 3406.

BLAKE, FRANCIS S., (Deputy Secretary, DOE)

WOOD, PATRICK H., III, (Chairman, FERC)

BREATHITT, LINDA K., (Commissioner, FERC)

BROWNELL, NORA M., (Commissioner, FERC)

MASSEY, WILLIAM L., (Commissioner, FERC)

MCCULLOUGH, GLENN L., JR., (Chairman, TVA)

\section{TESTIMONY \#2 - STATEMENTS AND DISCUSSION:}

Support for PUHCA repeal; concerns regarding specific H.R. 3406 provisions, with recommendations

HUNT, ISAAC C., JR., (Commissioner, SEC)

HOCHSTETTER, SANDRA L., (Chairman, Arkansas Public Service

Commission; representing National Association of Regulatory Utility

Commissioners)

\section{TESTIMONY \#3 - STATEMENTS AND DISCUSSION:}

Differing views on H.R. 3406; concerns of rural electric cooperatives regarding specific H.R. 3406 provisions; viewed failure of H.R. 3406 to protect consumers, with recommendations; importance of energy efficiency and demand response as vital components of electricity policy, with suggestions for revisions to H.R. 3406.

SOKOL, DAVID L., (Chairman and CEO, MidAmerican Energy Holdings Co)

RICHARDSON, ALAN H., (President and CEO, American Public Power

Association)

ENGLISH, GLENN, (CEO, National Rural Electric Cooperative Association)

GENT, MICHEHL R., (President and CEO, North American Electric Reliability

Council)

CHURCH, LYNNE H., (President, Electric Power Supply Association)

ROUSE, JAMES B., (Director, Energy Policy, Praxair, Inc.; representing

Electricity Consumers Resource Council)

ACQUARD, CHARLES A., (Executive Director, National Association of State

Utility Consumer Advocates; representing Consumers for Fair Competition) 
PRINDLE, WILLIAM R., (Director, Buildings and Utilities Programs, Alliance To Save Energy)

HYMAN, LEONARD S., (Senior Industry Advisor, Salomon Smith Barney)

JOHNSTON, ROBERT, (President and CEO, MEAG Power; representing Large Public Power Council)

Title: $\quad$ Price-Anderson Act Reauthorization

Committee: Senate Subcommittee on Transportation, Infrastructure, and Nuclear Safety, Committee on Environment and Public Works

CIS number: 2003-S321-21

Date: January 23, 2002

Location: Washington, D.C.

Pages: $\quad 188$

Summary: Hearing to examine proposed reauthorization of financial liability and indemnification systems established under the Price-Anderson Act for compensation of claims resulting from nuclear accidents.

TESTIMONY \#1 - STATEMENTS AND DISCUSSION:

Support for and issues relating to Price-Anderson Act reauthorization.

KANE, WILLIAM F., (Deputy Executive Director, Reactor Programs, NRC)

TESTIMONY \#2 - STATEMENTS AND DISCUSSION:

Differing views on continuation of current financial liability and indemnification systems established under Price-Anderson Act for the nuclear power industry; issues relating to Price-Anderson Act reauthorization; examination of insurance-related matters involved in Price-Anderson Act; elaboration of views on the Price-Anderson Act and related issues.

BRINKLEY, CHRISTIE, (Board Member, STAR Foundation)

BRADFORD, PETER A., (Visiting Lecturer, Energy Policy and Environmental Protection, Yale University)

GUTTMAN, DAN, (Fellow, Center for Study of American Government, Johns Hopkins University)

QUATTROCCHI, JOHN L., (Senior Vice President, Underwriting, American

Nuclear Insurers; also representing National Association of Independent Insurers and Alliance of American Insurers)

FERTEL, MARVIN S., (Senior Vice President, Business Operations, Nuclear Energy Institute)

Title: $\quad$ Effects of Subtitle B of S. 1766 to the Public Utility Holding Company

Act

Committee: Senate Committee on Energy and Natural Resources

CIS number: 2002-S311-32

Date: $\quad$ February 6, 2002

Location: Washington, D.C. 
Pages: $\quad 94$

Summary: Hearing to examine the pros and cons of proposals to repeal the Public

Utility Holding Company Act of 1935 (PUHCA) and to revise regulation of multistate electric and natural gas holding companies, in light of potential adverse impacts on energy utility competition and energy consumer protection.

\section{TESTIMONY - STATEMENTS AND DISCUSSION:}

Arguments for repeal of PUHCA; rationale for utility regulation modernization, with support for expansion of FERC and State jurisdiction/authority; reservations about PUHCA repeal impact on energy competition and consumers; issues related to PUHCA repeal and enforcement.

HUNT, ISAAC C., JR., (Commissioner, SEC)

HEMMINGWAY, ROY, (Chairman, Oregon Public Utility Commission; representing National Association of Regulatory Utility Commissioners)

MARLETTE, CYNTHIA A., (General Counsel, FERC)

SOKOL, DAVID L., (Chairman and CEO, MidAmerican Energy Holdings Co) HEMPLING, SCOTT, (attorney)

Title: Department of Energy's FreedomCAR: Hurdles, Benchmarks for Progress, and Role in Energy Policy

Committee: House Subcommittee on Oversight and Investigations, Committee on Energy and Commerce

CIS number: 2002-H361-56

Date: June 6, 2002

Location: Washington, D.C.

Pages: $\quad 110$

Summary: Hearing before the Subcommittee on Oversight and Investigations to examine DOE FreedomCAR program, a public-private research and development partnership to develop hydrogen fuel cell technologies for use in transportation.

\section{TESTIMONY \#1 - STATEMENTS AND DISCUSSION:}

Views on FreedomCAR initiative; issues related to commercial feasibility of fuel cell technologies; technical explanation of DOE strategy for development of fuel cell vehicles; overview of DOE goals and time tables for fuel cell technology development; rationale for DOE investment in fuel cell technology research.

WELLS, JAMES E., JR., (Director, Natural Resources and Environment, GAO) GARMAN, DAVID K., (Assistant Secretary, Energy Efficiency and Renewable Energy, DOE)

CULVER, ROBERT N., (Executive Director, U.S. Council for Automotive Research)

\section{TESTIMONY \#2 - STATEMENTS AND DISCUSSION:}

Views on fuel cell technology and FreedomCAR program; merits of hydrogen fuel cell powered vehicles, including fuel efficiency and low emissions; challenges to commercial 
viability of fuel cell technology, citing expense of production; support for DOE investment in fuel cell technology research; importance of cooperative Federal-industry efforts in fuel cell development.

ROAN, VERNON P., (Professor, Mechanical Engineering, University of Florida; representing PNGV Peer Review Committee, National Research Council) MILLER, WILLIAM T., (President, UTC Fuel Cells, United Technologies Corp) PAUL, DONALD L., (Vice President and Chief Technology Officer, ChevronTexaco Corp)

Title: $\quad$ Energy: Maximizing Resources, Meeting Needs and Retaining Jobs

Committee: House Subcommittee on Energy Policy, Natural Resources, and Regulatory Affairs, Committee on Government Reform

CIS number: 2003-H401-136

Date: $\quad$ June 17, 2001

Location: Peabody, MA

Pages: $\quad 196$

Summary: Hearing to examine issues related to national energy policy, including measures to promote energy efficiency and renewable resources

TESTIMONY - STATEMENTS AND DISCUSSION:

Perspectives on national energy policy issues; assessment of national energy situation, including adequacy of energy resources and environmental issues; recommendations for national energy policies to reduce U.S. energy consumption and greenhouse gas emissions; importance of energy efficiency promotion as a component of energy policy. Need to remove regulatory barriers to renewable energy technology development, including solar energy; recommendations for Federal energy research priorities. BERNOW, STEPHEN, (Director, Energy Group, Tellus Institute) SWIFT, BYRON, (Director, Energy and Innovation Center, Environmental Law Institute)

FAIRMAN, DAVID, (Vice President, International Dispute Resolution, Consensus Building Institute; representing National Energy Policy Initiative Expert Group) STERZINGER, GEORGE, (Executive Director, Renewable Energy Policy Project)

LITTLE, ROGER G., (CEO, Spire Corp)

Title: $\quad$ Fuel Cells: The Key to Energy Independence?

Committee: House Subcommittee on Energy, Committee on Science

CIS number: 2003-H701-14

Date: June 24, 2002

Location: Napperville, IL

Pages: $\quad 66$ 
Summary: Hearing to review the status of fuel cell technology development and to examine potential applications of fuel cell technology in electric power generation and transportation

\section{TESTIMONY - STATEMENTS AND DISCUSSION:}

Overview of fuel technology development status and possible applications; challenges to implementation of fuel cell technologies, including establishment of hydrogen production and distribution systems; review and status of represented companies programs to develop fuel cells for use in electric power plants and transportation.

Support for Federal role in promoting fuel cell development, citing need to focus and coordinate fuel cell R\&D; elaboration on benefits and potential applications of hydrogen energy systems.

GRUNDER, HERMANN A., (Director, Argonne National Laboratory)

UIHLEIN, JAMES P., (Manager, Fuels Project, BP p.l.c)

CULVER, ROBERT N., (Executive Director, U.S. Council for Automotive Research)

BORYS, STANLEY, (Executive Vice President and Chief Operating Officer, Gas Technology Institute)

SERFASS, JEFFREY A., (President, National Hydrogen Association)

CAMARA, ELIAS H., (Vice President, H2Fuel, LLC)

Title: $\quad$ FreedomCAR: Getting New Technology into the Marketplace

Committee: House Subcommittee on Energy, Committee on Science

CIS number: 2003-H701-18

Date: June 26, 2002

Location: Washington, D.C.

Pages: $\quad 135$

Summary: Hearing before the Subcommittee on Energy to examine DOE

FreedomCAR program, a public-private R\&D partnership to develop

hydrogen fuel cell technologies for use in transportation. Focuses on

FreedomCAR program R\&D priorities, and issues related to commercialization of fuel cell technologies

\section{TESTIMONY - STATEMENTS AND DISCUSSION:}

Views on FreedomCAR initiative, focusing on strategies to promote fuel cell commercialization; recommendations for fuel cell R\&D priorities and transportation infrastructure modifications to accommodate hydrogen powered vehicles.

Explanation of private sector innovations in automotive technologies that increase vehicle efficiency and reduce emissions; issues related to development of infrastructure to generate and deliver hydrogen fuel; perspectives on Federal role in development and commercialization of fuel cell technology.

LOVINS, AMORY B., (CEO, Rocky Mountain Institute)

MCCORMICK, J. BYRON, (Executive Director, Fuel Cell Activities, General

Motors Corp)

ROTHWELL, DOUG, (President and CEO, Michigan Economic Development 
Corp. (MEDC))

SAILLANT, ROGER, (President and CEO, Plug Power, Inc)

TEMPLIN, ROBERT J., (Board Member, Paice Corp)

Title: $\quad$ Electricity Infrastructure

Committee: Senate Committee on Energy and Natural Resources

CIS number: 2003-S311-5

Date: July 24, 2002

Location: Dirksen Senate Office Building, Washington, D.C.

Pages: $\quad 63$

Summary: Hearing to examine adequacy of U.S. electric transmission infrastructure and to assess electricity infrastructure investment needs.

TESTIMONY \#1 - STATEMENTS AND DISCUSSION:

Views on adequacy of U.S. energy infrastructure; review of FERC electricity

infrastructure improvement efforts, including R\&D initiatives; examination of barriers to electricity infrastructure development, with recommendations for Federal policies to promote electricity infrastructure expansion.

WOOD, PATRICK H., III, (Chairman, FERC)

NEVIUS, DAVID R., (Vice President, North American Electric Reliability Council)

TESTIMONY \#2 - STATEMENTS AND DISCUSSION:

Views on U.S. electricity infrastructure status and adequacy; need for electricity delivery infrastructure additions; recommendations for policies to remove barriers to energy infrastructure investment.

COALE, M. CAROL, (Senior Vice President, Prudential Financial, Inc)

MAKOVICH, LAWRENCE J., (Senior Director, North American Energy Group, Cambridge Energy Research Associates)

LANDRIEU, PETE, (Vice President, Electric Transmission, Public Service Electric and Gas Co)

WARD, STEPHEN, (Public Advocate, Maine; representing National Association of State Utility Consumer Advocates)

Title: $\quad$ Overview of the Federal R\&D Budget for FY2004

Committee: House Committee on Science

CIS number: 2003-H701-23

Date: $\quad$ February 13, 2003

Location: Washington, D.C.

Pages: $\quad 121$

Summary: Hearing to review Administration FY2004 budget request for science and technology R\&D programs

TESTIMONY - STATEMENTS AND DISCUSSION: 
Review of Administration FY2004 R\&D budget; summary of Department of Commerce FY2004 budget request for NOAA, Technology Administration, and National Institute of Standards and Technology science and technology programs; overview of NSF FY2004 budget request; description of DOE FY2004 budget request for energy and science programs.

Elaboration on issues related to represented agencies FY2004 budget requests for science and technology R\&D.

MARBURGER, JOHN H., III, (Director, Office of Science and Technology Policy)

BODMAN, SAMUEL W., (Deputy Secretary, Department of Commerce) COLWELL, RITA R., (Director, NSF)

CARD, ROBERT G., (Under Secretary, Energy, Science, and Environment, DOE)

Title: $\quad$ Oil Supply and Prices

Committee: Senate Committee on Energy and Natural Resources

CIS number: 2003-S311-25

Date: $\quad$ February 13, 2003

Location: Washington, D.C.

Pages: $\quad 67$

Summary: Status of and outlook for natural gas supply and prices; factors

responsible for recent increase in natural gas prices, with

recommendations; elaboration on natural gas market conditions and price trends, focusing on possible effects of increased domestic production; need to expand natural gas domestic production.

\section{TESTIMONY - STATEMENTS AND DISCUSSION:}

Examination of problems in U.S. oil supply system, focusing on consequences of dependence on foreign oil supplies; background on and explanation of factors affecting oil prices and supply trends; recommendations for policies to address rising oil prices and U.S. energy supply needs, including need to increase development of domestic oil resources.

Views on economic consequences of oil price volatility.

SIMMONS, MATTHEW R., (Chairman and CEO, Simmons \& Co. International)

EBEL, ROBERT E., (Director, Energy Program, Center for Strategic and International Studies)

CAVANEY, RED, (President and CEO, American Petroleum Institute)

MAY, JAMES C., (President and CEO, Air Transport Association)

Title: $\quad$ Natural Gas Supply and Prices

Committee: Senate Committee on Energy and Natural Resources

CIS number: 2003-S311-29 
Date: $\quad$ February 25, 2003

Location: Washington, D.C.

Pages: $\quad 84$

Summary: Hearing to examine natural gas market conditions, in light of recent increases in natural gas prices.

\section{TESTIMONY \#1 - STATEMENTS AND DISCUSSION:}

Status of and outlook for natural gas supply and prices; factors responsible for recent increase in natural gas prices, with recommendations; elaboration on natural gas market conditions and price trends, focusing on possible effects of increased domestic production; need to expand natural gas domestic production.

CARUSO, GUY F., (Administrator, Energy Information Administration)

WELCH, DAVID, (President, Alaska-Canada Gas Pipelines, BP p.l.c)

RATTIE, KEITH, (President and CEO, Questar Corp)

BEST, ROBERT W., (Chairman, Atmos Energy Corp.; representing American Gas Association)

Title: $\quad$ Energy Production on Federal Lands

Committee: Senate Committee on Energy and Natural Resources

CIS number: 2003-S311-32

Date: $\quad$ February 27, 2003

Location: Washington, D.C.

Pages: $\quad 87$

Summary: Hearing to examine management and utilization of energy resources located on public lands, including oil and natural gas.

\section{TESTIMONY \#1 - STATEMENTS AND DISCUSSION:}

Examination of BLM management of energy resources on public lands; review of BLM actions to increase energy production on public lands; issues related to oil and natural gas production on public lands.

GRILES, J. STEVEN, (Deputy Secretary, Department of Interior)

\section{TESTIMONY \#2 - STATEMENTS AND DISCUSSION:}

Issues related to energy production on public lands; criticisms of regulatory treatment of public lands energy production; importance of public lands energy resources to U.S.

energy independence from foreign oil and natural gas imports; environmental concerns related to energy production on public lands.

BAYLESS, ROBERT L., JR., (President, Independent Petroleum Association of Mountain States)

LEER, STEVEN F., (President and CEO, Arch Coal, Inc.; also representing National Mining Association)

ALBERSWERTH, DAVID, (Director, Bureau of Land Management Program, Wilderness Society)

Title: $\quad$ Financial Condition of the Electricity Market 
Committee: Senate Committee on Energy and Natural Resources

CIS number: 2003-S311-31

Date: $\quad$ March 4, 2003

Location: Washington, D.C.

Pages: $\quad 68$

Summary: Hearing to examine status of and recommendations to improve U.S. electricity market financial conditions, including strategies to reduce Federal regulation of the electricity market.

\section{TESTIMONY \#1 - STATEMENTS AND DISCUSSION:}

Overview of electric market financial conditions; factors affecting electric industry stability, including financial challenges; analysis of electricity markets financial decline; need to remove regulatory impediments to capital investment in energy markets; recommendations for Federal regulatory policies to promote electricity market stability. SVANDA, DAVID A., (Commissioner, Michigan Public Service Commission; representing National Association of Regulatory Utility Commissioners) SILVERSTEIN, EVAN J., (General Partner, SILCAP LLC) CASSIDY, FRANK, (President and Chief Operating Officer, PSEG Power LLC; also representing Electric Power Supply Association) SMITH, SUZANNE G., (Director, Corporate and Government Ratings, Standard \& Poor's)

SOKOL, DAVID L., (Chairman and CEO, MidAmerican Energy Holdings Co)

Title: $\quad$ Path to a Hydrogen Economy

Committee: House Committee on Science

CIS number: 2004-H701-7

Date: $\quad$ March 5, 2003

Location: Washington, D.C.

Pages: $\quad 483$

Summary: Hearing to review the status of hydrogen fuel cell technology development, and to examine issues related to fuel cell R\&D priorities and applications, including automotive applications

\section{TESTIMONY - STATEMENTS AND DISCUSSION:}

Overview of Administration hydrogen energy technology R\&D initiatives; outlook for commercial application of fuel cell technologies; examination of technological challenges for application of fuel cell technologies, including development of hydrogen fuel production and delivery infrastructure; examination of various fuel cell R\&D ventures. GARMAN, DAVID K., (Assistant Secretary, Energy Efficiency and Renewable Energy, DOE)

LLOYD, ALAN C., (Chairman, California Air Resources Board; also representing California Fuel Cell Partnership)

OGDEN, JOAN M., (Research Scientist, Princeton Environmental Institute, Princeton University)

BURNS, LAWRENCE D., (Vice President, Research and Development and 
Planning, General Motors Corp)

HUBERTS, DONALD P., (CEO, Shell Hydrogen)

Title: $\quad$ Comprehensive National Energy Policy

Committee: House Subcommittee on Energy and Air Quality, Committee on Energy and Commerce

CIS number: 2003-H361-20

Date: $\quad$ Mar. 5, 12, 13, 2003

Location: Washington, D.C.

Pages: $\quad 498$

Summary: Hearings before the Subcommittee on Energy and Air Quality to consider legislative proposals to revise and extend various DOE and other Federal agency energy programs and policies, including proposals to restructure the electric power industry.

Also reviews the need to develop a comprehensive national energy policy

\section{TESTIMONY \#1 - STATEMENTS AND DISCUSSION:}

Review of Administration national energy policy; background on and status of energy markets under FERC jurisdiction, including electricity and natural gas; examination of FERC proposed rulemaking policies for various energy markets; elaboration on issues affecting energy markets.

MCSLARROW, KYLE E., (Deputy Secretary, DOE)

MESERVE, RICHARD A., (Chairman, NRC)

WOOD, PATRICK H., III, (Chairman, FERC)

MASSEY, WILLIAM L., (Commissioner, FERC)

BROWNELL, NORA M., (Commissioner, FERC)

\section{TESTIMONY \#2 - STATEMENTS AND DISCUSSION:}

Review of U.S. nuclear energy operations; perspectives on nuclear plant safety and security issues, in light of recent terrorist attacks against the U.S.; support to reauthorize nuclear plant security programs and increase funding; overview of proposed energy conservation and efficiency programs; need for energy policies to support renewable energy sources.

FERTEL, MARVIN S., (Senior Vice President, Nuclear Energy Institute) AURILIO, ANNA, (Legislative Director, U.S. Public Interest Research Group) BENJAMIN, JEFFREY A., (Vice President, Licensing and Regulatory Affairs, Exelon Nuclear)

LYMAN, EDWIN S., (President, Nuclear Control Institute)

NADEL, STEVEN, (Executive Director, American Council for an Energy-

Efficient Economy)

O'HAGAN, MALCOLM,(President, National Electrical Manufacturers

Association)

MEYER, ALDEN, (Director, Government Relations, Union of Concerned

Scientists) 


\section{TESTIMONY \#3 - STATEMENTS AND DISCUSSION:}

Overview of FERC hydroelectric licensing and regulation process; support to reform hydroelectric licensing process, citing inefficiencies; opposition to energy-related legislative proposals relating to hydroelectric licensing reform, citing environmental concerns.

ROBINSON, J. MARK, (Director, Office of Energy Products, FERC)

KEIL, JULIE, (Director, Hydro Licensing and Water Rights, Portland General Electric Co)

MASONIS, ROB, (Director, Northwest Regional Office, American Rivers; also representing Hydropower Reform Coalition)

SZEPTYCKI, LEON, (Director, Eastern Conservation and General Counsel, Trout Unlimited)

\section{TESTIMONY \#4 - STATEMENTS AND DISCUSSION:}

Examination of electricity transmission infrastructure; impact of proposed energy reforms on electricity markets; recommended changes to proposed energy legislation, citing need to remove barriers to wholesale competition and investment in electricity markets; support to delay enactment of any legislation affecting electricity industry. Overview of legislative proposals relating to electricity; recommended energy policy changes on electricity; opposition to FERC proposed implementation of standard market design for electricity industry.

OWENS, DAVID K., (Executive Vice President, Business Operations Group, Edison Electric Institute)

SCHORI, JAN, (General Manager, Sacramento, Calif., Municipal Power District; representing Large Public Power Council)

TWITTY, JOHN, (General Manager, City Utilities, Springfield, Mo.; representing American Public Power Association)

ENGLISH, GLENN, (CEO, National Rural Electric Cooperative Association)

WALTER, RON, (Executive Vice President, Calpine Corp.; also representing Electric Power Supply Association)

MOORE, W. HENSON, (President and CEO, American Forest \& Paper Association; also representing Electricity Consumers Resource Council and American Chemistry Council)

ERVIN, SAM J., IV, (Commissioner, North Carolina Utilities Commission)

\section{TESTIMONY \#5 - STATEMENTS AND DISCUSSION:}

Need to improve reliability of electric systems and reduce power outages; overview of energy-related legislative proposals relating to electricity industry; views on various electricity proposals under consideration; recommended initiatives to protect consumers from electric company abuses

GENT, MICHEHL R., (President and CEO, North American Electric Reliability Council)

NORLANDER, GERALD A., (Executive Director, Public Utility Law Project of New York; representing National Association of State Utility Consumer Advocates)

TEZAK, CHRISTINE L., (Electricity Analyst, Washington Research Group, 
Schwab Capital Markets)

KANNER, MARTY, (Coordinator, Consumers for Fair Competition)

BUCCINO, SHARON, (Senior Attorney, Natural Resources Defense Council) TESTIMONY \#6 - STATEMENTS AND DISCUSSION:

Review of Federal oxygen content requirement for reformulated gasoline; overview of U.S. oil supply problem; examination of challenges facing oil refiners, with recommendations; need to eliminate methyl tertiary-butyl ether (MTBE) additives in gasoline.

MURPHY, EDWARD, (General Manager, Downstream, American Petroleum Institute)

SLAUGHTER, BOB, (President, National Petrochemical and Refiners

Association)

DOUGLASS, BILL, (CEO, Douglass Distributing Co.; representing National

Association of Convenience Stores and Society of Independent Gasoline Marketers)

EARLY, A. BLAKEMAN, (Environmental Consultant, American Lung Association; also representing Northeast States for Coordinated Air Use Management)

OLSON, ERIK D., (Senior Attorney, Natural Resources Defense Council; also representing Environmental Working Group)

SEGAL, SCOTT H., (attorney, representing Oxygenated Fuels Association)

Title: $\quad$ H.R. 793 and H.R. 794

Committee: House Subcommittee on Energy and Mineral Resources, Committee on

Resources

CIS number: 2003-H651-69

Date: $\quad$ March 6, 2003

Location: Washington, D.C.

Pages: $\quad 65$

Summary: Hearing before the Subcommittee on Energy and Mineral Resources to consider the following bills:

H.R. 793, to amend the Outer Continental Shelf Lands Act to authorize the Department of Interior to grant easements and rights-of-way for energy-related uses on the outer continental shelf, including oil and natural gas development.

H.R. 794, the Coal Leasing Amendments Act, to amend the Mineral Leasing Act to streamline coal leasing on Federal lands.

TESTIMONY \#1 - STATEMENTS AND DISCUSSION:

Explanation of H.R. 793 and H.R. 794 provisions, with support for both bills.

BURTON, R. M., (Director, Minerals Management Service, Department of Interior)

TESTIMONY \#2 - STATEMENTS AND DISCUSSION: 
Differing views on H.R. 793; issues related to energy resources development on outer continental shelf.

REILLY, TOM, (Attorney General, Massachusetts)

SMITH, ERIC, (Vice President, Strategic Planning, Global Industries, Ltd.; also representing six other organizations)

BAILEY, BRUCE H., (President, AWS Scientific Inc.; also representing American Wind Energy Association)

SHELLEY, PETER, (Vice President, Conservation Law Foundation; also representing Union of Concerned Scientists, Natural Resources Defense Council, and Environmental Defense)

TESTIMONY \#3 - STATEMENTS AND DISCUSSION:

Differing views on H.R. 794.

QUINN, HAROLD P., JR., (Senior Vice President, Legal and Regulatory

Affairs, National Mining Association)

KENDALL, SARA, (Director, D.C. Office, Western Organization of Resource Councils)

Title: $\quad$ Energy Use in the Transportation Sector

Committee: Senate Committee on Energy and Natural Resources

CIS number: 2003-S311-35

Date: $\quad$ March 6, 2003

Location: Washington, D.C.

Pages: $\quad 99$

Summary: Hearing to examine options to decrease U.S. oil consumption, focusing on potential for development of alternative fuel and engine technologies to reduce energy use in the transportation sector.

\section{TESTIMONY - STATEMENTS AND DISCUSSION:}

Options to reduce transportation sector oil consumption; review of Federal programs to develop hydrogen fuel technologies; status of R\&D on alternative fuel and enhanced fuel efficiency projects; overview of U.S. oil production and consumption trends; options to reduce U.S. petroleum consumption, including electric and hybrid vehicles.

GARMAN, DAVID K., (Assistant Secretary, Energy Efficiency and Renewable Energy, DOE)

FRANKEL, EMIL H., (Assistant Secretary, Transportation Policy, DOT)

GREG, DANA, (Vice President, Environmental Affairs, Alliance of Automobile Manufacturers)

FRIEDMAN, DAVID, (Senior Analyst, Clean Vehicles Program, Union of Concerned Scientists)

CROMWELL, RICHARD, III, (General Manager and CEO, SunLine Transit Agency)

Title: $\quad$ Energy Efficiency and Conservation 
Committee: Senate Committee on Energy and Natural Resources

CIS number: 2003-S311-39

Date: $\quad$ March 11, 2003

Location: Washington, D.C.

Pages: $\quad 57$

Summary: Hearing to examine role of energy conservation and efficiency in U.S. energy policy.

TESTIMONY - STATEMENTS AND DISCUSSION:

Overview of DOE energy conservation and efficiency programs; views on role of energy efficiency in Federal energy policy, with recommendations; evaluation of specific Federal energy conservation and efficiency policies and programs; details on energy efficiency programs for Federal facilities.

GARMAN, DAVID K., (Assistant Secretary, Office of Energy Efficiency and Renewable Energy, DOE)

LYNCH, PAUL, (Assistant Commissioner, Business Operations, Public Buildings Service, GSA) NEMTZOW, DAVID M., (President, Alliance To Save Energy) MCGUIRE, JOSEPH M., (President, Association of Home Appliance Manufacturers; also representing High Tech Energy Working Group) KEITH, ERBIN B., (Senior Vice President, Operations and Commercial Pricing, Sempra Energy Solutions; representing Federal Performance Contracting Coalition)

Title: $\quad$ Energy Efficiency Improvements in Federal Buildings and Vehicles

Committee: House Committee on Government Reform

CIS number: 2003-H401-72

Date: $\quad$ March 12, 2003

Location: Washington, D.C.

Pages: $\quad 61$

Summary: Hearing to examine efforts to reduce Federal energy consumption, including implementation of energy conservation standards in Federal facilities and Federal departments and agencies use of alternative fuel vehicles.

\section{TESTIMONY - STATEMENTS AND DISCUSSION:}

Overview of Federal energy management policies for buildings and vehicles; examination of efforts to incorporate energy efficiency features into Federal buildings design; review of GSA actions to increase Federal energy efficiency; details on progress in Federal energy usage reduction efforts.

GARMAN, DAVID K., (Assistant Secretary, Energy Efficiency and Renewable Energy, DOE)

LYNCH, PAUL, (Assistant Commissioner, Business Operations, Public Buildings Service, GSA) 
RIVERS, WILLIAM, (Director, Federal Vehicle Policy Division, Office of Government-Wide Policy, GSA)

$\begin{array}{ll}\text { Title: } & \text { Enhancing America's Energy Security } \\ \text { Committee: } & \text { House Committee on Resources } \\ \text { CIS number: } & \text { 2003-H651-83 } \\ \text { Date: } & \text { March 19, 2003 } \\ \text { Location: } & \text { Washington, D.C. } \\ \text { Pages: } & 153 \\ \text { Summary: } & \text { Hearing to examine the need and security rationale for increased } \\ & \text { development of energy resources on public lands. }\end{array}$

\section{TESTIMONY \#1 - STATEMENTS AND DISCUSSION:}

Factors affecting U.S. energy security, citing imbalance between domestic energy production and consumption; explanation of Administration strategy to promote energy security; issues related to development of energy resources on Federal lands.

WATSON, REBECCA W., (Assistant Secretary, Land and Minerals

Management, Department of Interior)

SMITH, CARL M., (Assistant Secretary, Fossil Energy, DOE)

\section{TESTIMONY \#2 - STATEMENTS AND DISCUSSION:}

Overview of trends in and issues affecting natural gas consumption and production; negative impact of high natural gas prices on chemical industry; rationale for increased energy resource development on public lands, with recommendations to encourage development of domestic natural gas; issues related to development of energy resources on tribal lands.

DOWNER, HUNT, (State Representative, Louisiana)

GUPTA, RAJ, (Chairman and CEO, Rohm and Haas Co.; also representing American Chemistry Council)

PARKER, DAVID N., (President and CEO, American Gas Association)

NOVAK, MARY H., (Managing Director, Energy Services, Global Insight, Inc)

SANTISTEVAN, ROBERT, (Executive Director, Southern Ute Indian Tribe Growth Fund)

\section{TESTIMONY \#3 - STATEMENTS AND DISCUSSION:}

Perspectives on energy supply and demand situation, with specifics on natural gas; need to expand access to energy resources on Federal lands; concerns about energy development impact on natural resources and surface property rights; issues related to geothermal energy development, including obstacles to development on public lands, with recommendations.

TRUE, DIEMER, (Chairman, Independent Petroleum Association; also representing numerous other oil and gas associations)

WOOD, WAYNE, (President, Michigan Farm Bureau; representing American Farm Bureau Federation)

SWEENEY, PATRICK, (Executive Director, Western Organization of Resource Councils (WORC); on behalf of:) 
BARLOW, ERIC, (rancher; representing WORC and Powder River Basin

Resource Council)

GAWELL, KARL, (Executive Director, Geothermal Energy Association)

\section{TESTIMONY \#4 - STATEMENTS AND DISCUSSION:}

Issues affecting alternative energy production on Federal lands; concerns about energy development on public lands negative impact on wildlife and natural resources.

STEVE, JAIME, (Legislative Director, American Wind Energy Association)

SPARROWE, ROLLIN D., (President, Wildlife Management Institute)

ALBERSWERTH, DAVID, (Director, BLM Program, Wilderness Society)

CARLSON, WILLIAM H., (Vice President, Business Development, Wheelabrator Technologies; representing USA Biomass Power Producers Alliance)

Title: $\quad$ Tribal Energy Self-Sufficiency Act and the Native American Energy Development and Self-Determination Act

Committee: Senate Committee on Indian Affairs

CIS number: 2003-S411-25

Date: $\quad$ March 19, 2003

Location: Washington, D.C.

Pages: $\quad 172$

Summary: Hearing to consider the following bills:

S. 424, the Tribal Energy Self-Sufficiency Act, to amend the Energy Policy Act of 1992, the Department of Energy Organization Act, and the Rural Electrification Act of 1936 to establish, reauthorize, and improve tribal energy programs.

S. 522, the Native American Energy Development and Self-

Determination Act of 2003, to amend the Energy Policy Act of 1992 and the Native American Housing and Self-Determination Act of 1996 to assist Indian tribes in developing energy resources.

\section{TESTIMONY \#1 - STATEMENTS AND DISCUSSION:}

Views on S. 424 and S. 522.

ROSIER, THERESA, (Counselor to the Assistant Secretary, Indian Affairs, Department of Interior)

BAILEY, VICKY A., (Assistant Secretary, Policy and International Affairs, DOE)

\section{TESTIMONY \#2 - STATEMENTS AND DISCUSSION:}

Concerns about specific provisions of S. 424 and S. 522, with recommendations.

TRUJILLO, ARVIN, (Executive Director, Division of Natural Resources, Navajo Nation)

HILL, VERNON, (Chairman, Eastern Shoshone Business Council of the Wind

River Indian Reservation)

MAYNES, FRANK E., (Tribal Attorney, Southern Ute Indian Tribe)

\section{TESTIMONY \#3 - STATEMENTS AND DISCUSSION:}


Overall support for S. 424 and S. 522, with recommendations; overview of available energy resources on Indian reservations; perspectives on S. 424 and S. 522.

LESTER, A. DAVID, (Executive Director, Council of Energy Resource Tribes (CERT))

ROUBIDOUX, VICTOR, (Tribal Treasurer, Iowa Tribe of Oklahoma; also representing CERT)

GOUGH, ROBERT P., (Secretary, Intertribal Council on Utility Policy; also representing Rosebud Sioux Tribe Utility Commission)

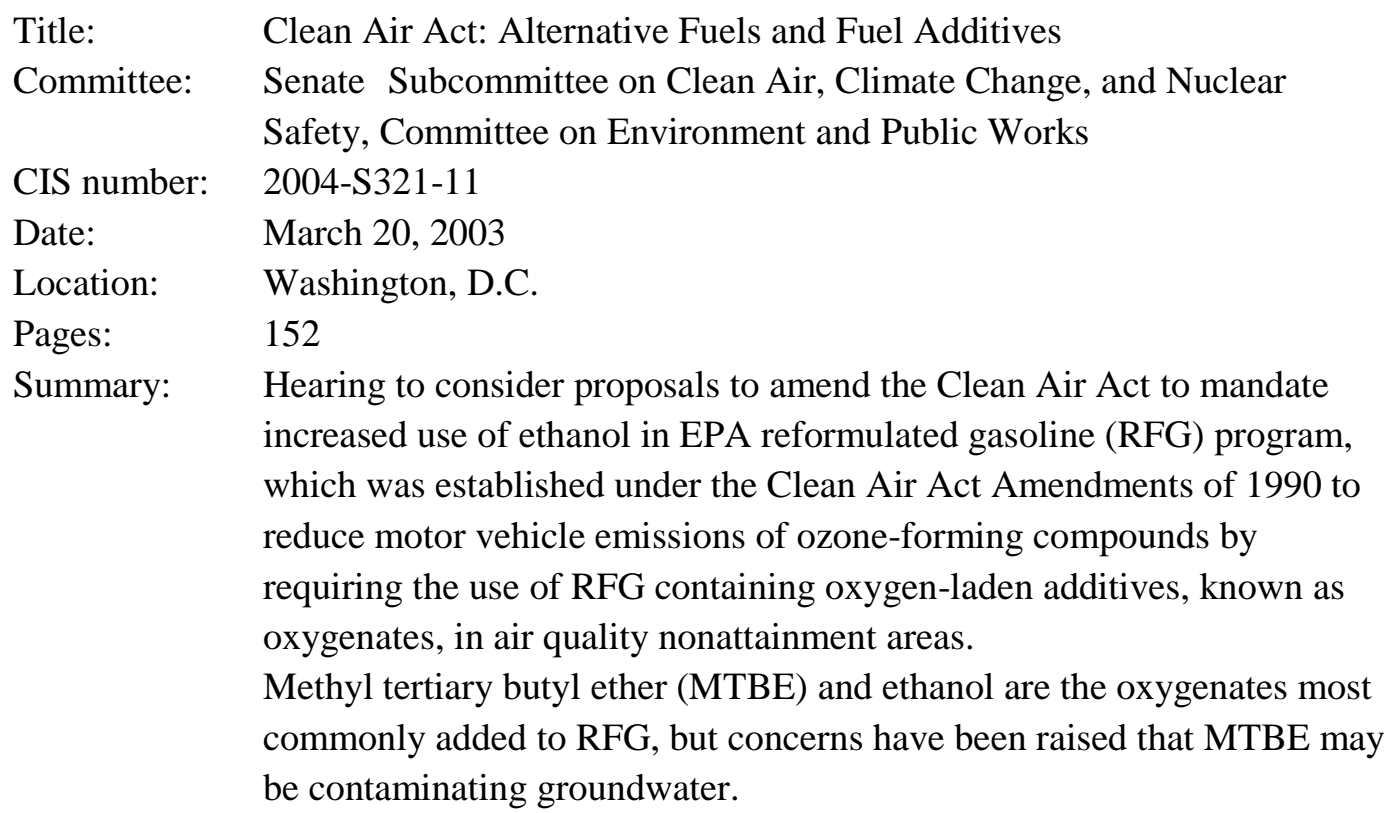

TESTIMONY \#1 - STATEMENTS AND DISCUSSION:

Views on proposals to mandate increased use of ethanol in RFG program; benefits of increased ethanol use in RFG.

HOLMSTEAD, JEFFREY R., (Assistant Administrator, Office of Air and Radiation, EPA)

GARMAN, DAVID K., (Assistant Secretary, Energy Efficiency and Renewable Energy, DOE)

\section{TESTIMONY \#2 - STATEMENTS AND DISCUSSION:}

Support for proposals to expand ethanol use in RFG; views on RFG program potential to address U.S. fuel supply problems; review of problems associated with MTBE use in RFG; recommendations to promote increase in U.S. domestic oil refining capacity. Differing assessments of health risks associated with MTBE; recommendations to address MTBE groundwater contamination: background on extent of MTBE contamination.

YODER, FRED, (President, National Corn Growers Association)

MURPHY, EDWARD, (Downstream General Manager, American Petroleum Institute)

SLAUGHTER, ROBERT, (President, National Petrochemical and Refiners 
Association)

SEGAL, SCOTT H., (attorney; representing Oxygenated Fuels Association)

WAGMAN, RICHARD E., (First Vice Chairman, American Road and

Transportation Builders Association)

EARLY, A. BLAKEMAN, (Consultant, American Lung Association)

GRANGER, PAUL J., (Superintendent, Plainview Water District, Nassau

County, NY)

PERKINS, CRAIG, (Director, Environment and Public Works Management, Santa Monica, CA)

Title: $\quad$ Electricity Proposals and Electric Transmission and Reliability

Enhancement Act of 2003

Committee: Senate Committee on Energy and Natural Resources

CIS number: 2003-S311-41

Date: $\quad$ March 27, 2003

Location: Washington, D.C.

Pages: $\quad 240$

Summary: Hearing to consider legislative proposals to restructure the electric power industry, including S. 475, the Electric Transmission and Reliability Enhancement Act of 2003, to improve electric transmission system operations and enhance electric grid reliability.

TESTIMONY \#1 - STATEMENTS AND DISCUSSION:

Viewed success of wholesale electricity markets in Mid-Atlantic region, with perspectives on electricity proposals; differing views on proposed electricity restructuring legislation.

GLAZER, CRAIG S., (Vice President, Government Policy, PJM Interconnection, LLC; on behalf of HARRIS, Phillip G., President and CEO)

PARA, P. G., (Director, Legislative Affairs, Jacksonville, Fla., Electric

Authority; representing nine member companies of SeTrans RTO)

TORGERSON, JAMES P., (President and CEO, Midwest Independent Transmission System Operator)

\section{TESTIMONY \#2 - STATEMENTS AND DISCUSSION:}

Views on and priorities concerning electricity legislation; perspectives of electric cooperatives on various provisions contained in electricity proposals; opposition of electric utilities to efforts to include electricity title in energy bill, with views on electricity industry regulatory issues.

Perspectives of large public power systems on electricity proposals; overall support for proposed electricity legislation, with recommendations.

FRANKLIN, H. ALLEN, (Chairman, President, and CEO, Southern Co.; representing Edison Electric Institute)

ENGLISH, GLENN, (CEO, National Rural Electric Cooperative Association) RICHARDSON, ALAN H., (President and CEO, American Public Power Association) 
TOLLEFSON, PHIL, (CEO, Colorado Springs, Colo., Utilities; representing Large Public Power Council)

MOLER, ELIZABETH A., (Executive Vice President, Government and Environmental Affairs and Public Policy, Exelon Corp.; representing Electric Power Supply Association)

\section{TESTIMONY \#3 - STATEMENTS AND DISCUSSION:}

Overall support for FERC-related provisions of electricity legislative proposals, with recommendations; elaboration on electricity legislation and energy market regulation.

WOOD, PATRICK H., III, (Chairman, FERC)

MASSEY, WILLIAM L.(Commissioner, FERC)

BROWNELL, NORA M., (Commissioner, FERC)

Title: $\quad$ Future of the Hydrogen Fuel Cell

Committee: Senate Subcommittee on Science, Technology, and Space, Committee on Commerce, Science, and Transportation

CIS number: 2005-S261-44

Date: $\quad$ May 7, 2003

Location: Washington, D.C.

Pages: $\quad 62$

Summary: Hearing to examine issues and initiatives related to hydrogen fuel cell technology development, focusing on automotive applications.

TESTIMONY \#1 - STATEMENTS AND DISCUSSION:

Overview of and issues involved in Administration hydrogen-related initiatives, including technological challenges.

MARBURGER, JOHN H., III, (Director, Office of Science and Technology

Policy)

GARMAN, DAVID K., (Assistant Secretary, Energy Efficiency and Renewable Energy, Department of Energy)

TESTIMONY \#2 - STATEMENTS AND DISCUSSION:

Need for strategy to eliminate U.S. transportation sector dependence on petroleum, with recommendations; perspectives on hydrogen fuel cell technology and related development efforts of represented companies; elaboration on hydrogen fuel cell technology issues.

FRIEDMAN, DAVID J., (Senior Engineer, Clean Vehicles Program, Union of Concerned Scientists)

MCCORMICK, J. BYRON, (Executive Director, Global Fuel Cell Activities, General Motors Corp)

PRELI, FRANCIS R., JR., (Vice President, Engineering, UTC Fuel Cells)

Title: Hydrogen Energy Economy

Committee: House Subcommittee on Energy and Air Quality, Committee on Energy and Commerce

CIS number: 2003-H361-34 
Date: $\quad$ May 20, 2003

Location: Washington, D.C.

Pages: $\quad 94$

Summary: Hearing to review the status of hydrogen fuel cell technology

development, and to examine issues related to fuel cell $R \& D$ priorities and applications, including automotive applications.

TESTIMONY \#1 - STATEMENTS AND DISCUSSION:

Overview of Administration hydrogen energy technology R\&D initiatives; outlook for commercial application of fuel cell technologies; examination of technological challenges for application of fuel cell technologies, including development of hydrogen fuel production and delivery infrastructure.

GARMAN, DAVID K., (Assistant Secretary, Energy Efficiency and Renewable Energy, DOE)

\section{TESTIMONY \#2 - STATEMENTS AND DISCUSSION:}

Examination of various fuel cell R\&D ventures; perspectives on technological and commercialization challenges for fuel cell technology development; details on fuel cell $R \& D$ progress and accomplishments; views on fuel cell $R \& D$ priorities, focusing on fuel cell research directed toward automotive applications.

MCCORMICK, J. BYRON, (Executive Director, Global Fuel Cell Activities, General Motors Corp)

RIPS, CATHERINE, (Director, Hydrogen Programs, SunLine Transit Agency)

PRELI, FRANCIS R., JR., (Vice President, Engineering, UTC Fuel Cells, United Technologies Corp)

VESEY, GREGORY M., (President, Technology Ventures, ChevronTexaco Corp)

SAMUELSEN, SCOTT, (Director, National Fuel Cell Research Center, University of California, Irvine)

SCHWANK, JOHANNES, (Professor, Chemical Engineering, University of Michigan)

Title: $\quad$ Future of University Nuclear Science and Engineering Programs

Committee: House Subcommittee on Energy, Committee on Science

CIS number: 2004-H701-8

Date: June 10, 2003

Location: Washington, D.C.

Summary: Hearing before the Subcommittee on Energy to examine the status of and outlook for nuclear science and engineering programs at U.S. colleges and universities, and to review DOE support for university-based nuclear science and engineering programs

\section{TESTIMONY-STATEMENTS AND DISCUSSION:}

Overview of DOE role in supporting nuclear science and engineering programs; concerns about ability of university nuclear science and engineering programs to meet future nuclear industry workforce needs; need for Federal support of university nuclear 
science and engineering programs.

Overview of nuclear production and employment trends and outlook; recommendations to improve nuclear engineering education programs.

MARCUS, GAIL H., (Principal Deputy Director, Office of Nuclear Energy, Science and Technology, DOE)

KAMMEN, DANIEL M., (Professor, Energy and Resources Group, Goldman School of Public Policy, University of California at Berkeley)

HOWARD, ANGELINA S., (Executive Vice President, Policy, Planning, and External Affairs, Nuclear Energy Institute)

STUBBINS, JAMES F., (Head, Nuclear, Plasma, and Radiological Engineering Department, University of Illinois at Urbana-Champaign; representing Nuclear Engineering Department Heads Organization)

SLAUGHTER, DAVID M., (Chair, Nuclear Engineering Program, University of Utah)

Title: $\quad$ Competition for Department of Energy Laboratory Contracts: What Is the Impact on Science?

Committee: House Subcommittee on Energy, Committee on Science

CIS number: 2004-H701-6

Date: July 10, 2003

Location: Washington, D.C.

Pages: $\quad 69$

Summary: Hearing before the Subcommittee on Energy to examine the impact of DOE policy of competitive laboratory management contracting on the science conducted at DOE research laboratories

\section{TESTIMONY - STATEMENTS AND DISCUSSION:}

Views on DOE use of competition in laboratory management contract awarding process; rationale for DOE initiative to compete laboratory management contracts; benefits and disadvantages for scientific research of competitive DOE laboratory management contracts; recommendations for laboratory management contracting policies to best facilitate scientific research.

NAZZARO, ROBIN M., (Director, Natural Resources and Environment, GAO) CARD, ROBERT G., (Under Secretary, Energy, Science and Environment, DOE)

FLEURY, PAUL A., (former Vice President, Research and Exploratory Technology, Sandia National Laboratories)

MCTAGUE, JOHN P., (former Chairman, National Synchrotron Light Source, Brookhaven National Laboratory)

Title: $\quad$ H.R. 2772, 'The John Rishel Geothermal Steam Act Amendments of 2003. 
Committee: House Subcommittee on Energy and Mineral Resources, Committee on

Resources

CIS number: 2003-H651-122

Date: July 22, 2003

Location: Washington, D.C.

Pages: $\quad 39$

Summary: Hearing to consider H.R. 2772, the John Rishel Geothermal Steam Act Amendments of 2003, to amend the Geothermal Steam Act of 1970 to promote development of geothermal resources on public lands, and to revise geothermal resource leasing and permitting procedures.

Includes provisions to:

a. Direct the Department of Interior to conduct a review of moratoria and withdrawals from geothermal leasing on public lands.

b. Direct Geological Survey to conduct a national geothermal resource assessment.

c. Direct the Department of Interior to process pending geothermal development lease applications within one year of enactment.

\section{TESTIMONY \#1 - STATEMENTS AND DISCUSSION:}

Review of BLM efforts to enhance geothermal production on Federal lands.

MORRISON, PATRICIA E., (Principal Deputy Assistant Secretary, Land and

Minerals Management, Department of Interior)

\section{TESTIMONY \#2 - STATEMENTS AND DISCUSSION:}

Support for H.R. 2772, citing need to promote development of geothermal resources; issues related to geothermal energy development.

GAWELL, KARL, (Executive Director, Geothermal Energy Association)

WITCHER, JAMES C., (Project Manager, Southwest Technology Development

Institute, New Mexico State University)

CONNELLY, JEANNE, (Vice President, Federal Relations, Calpine Corp)

Title: $\quad$ Rural Economy, Renewable Energy, and the Role of Our Cooperatives

Committee: Senate Committee on Finance

CIS number: 2004-S361-25

Date: $\quad$ August 26, 2003

Location: Dallas Center, Iowa

Pages: $\quad 65$

Summary: Hearing to examine strategies to assist agricultural producers in developing producer-owned, value-added marketing cooperatives, including tax incentives for rural cooperatives involved in renewable energy production.

\section{TESTIMONY \#1 - STATEMENTS AND DISCUSSION:}

Review of programs to assist agricultural value-added cooperatives, with recommendations.

DORR, THOMAS C., (Under Secretary, Rural Development, USDA) 


\section{TESTIMONY \#2 - STATEMENTS AND DISCUSSION:}

Importance of agricultural value-added product and service development; views on various proposals and strategies to assist agricultural producers in developing valueadded cooperatives; benefits of tax credits for renewable energy cooperatives; elaboration on tax issues facing renewable energy cooperatives.

GEU, THOMAS E., (Professor, Law, University of South Dakota; representing

National Conference of Commissioners on Uniform State Laws)

GOODALE, REGINALD V., (Director, Regulatory Affairs, Iowa Association of Electric Cooperatives)

CAMPBELL, JOHN B., (Vice President, Government Relations and Industrial Products, Ag Processing Inc)

BLAISDELL, JOHN, (Director, Tax, CHS, Inc)

DINNEEN, ROBERT, (President, Renewable Fuels Association)

Title: $\quad$ Blackout 2003: How Did It Happen and Why?

Committee: House Committee on Energy and Commerce

CIS number: 2004-H361-14

Date: $\quad$ September 3, 4, 2003

Location: Washington, D.C.

Pages: $\quad 389$

Summary: Hearings to review factors contributing to and the series of events leading up to the electrical blackout in the Midwest and Northeast on Aug. 14, 2003, and to examine policy options for preventing similar incidents in the future.

\section{TESTIMONY \#1 - STATEMENTS AND DISCUSSION:}

Review of factors and events contributing to Aug. 2003 blackout; status of DOE efforts to investigate causes of blackout; issues related to efforts to collect and review data relevant to blackout; implications of Aug. 2003 blackout for energy regulation policies. ABRAHAM, SPENCER, (Secretary, DOE)

\section{TESTIMONY \#2 - STATEMENTS AND DISCUSSION:}

Overview of Aug. 2003 blackout impact in represented States; factors and events contributing to Aug. 2003 blackout; concerns for vulnerabilities of U.S. energy infrastructure; recommendations for reform initiatives to prevent future blackouts; views on Federal reliability standards for electricity transmission.

TAFT, BOB, (Governor, OH)

GRANHOLM, JENNIFER M., (Governor, MI)

KILPATRICK, KWAME M., (Mayor Detroit, MI)

\section{TESTIMONY \#3 - STATEMENTS AND DISCUSSION:}

Overview of FERC efforts to identify and address causes of Aug. 2003 blackout; background on electricity transmission system and related Federal regulatory powers; need to address weaknesses in electricity transmission system and regulation; examination of factors and events contributing to Aug. 2003 blackout; details on sequence of events preceding Aug. 2003 blackout. 
WOOD, PATRICK H., III, (Chairman, FERC)

SCHRIBER, ALAN R., (Chairman, Ohio Public Utilities Commission; also

representing Ohio Power Siting Board)

LARK, J. PETER, (Chairman, Michigan Public Service Commission)

FLYNN, WILLIAM M., (Chairman, New York State Public Service

Commission)

GENT, MICHEHL R., (President and CEO, North American Electric Reliability

Council)

ELDRIDGE, BRANT H., (Executive Manager, East Central Area Reliability

Council)

DURKIN, CHARLES J., JR., (Chairman, Northeast Power Coordinating

Council)

\section{TESTIMONY \#4 - STATEMENTS AND DISCUSSION:}

Perspectives of electric utility industry representatives on causes and implications of Aug. 2003 blackout; views on and recommendations regarding Aug. 2003 blackout investigation process; details on Aug. 2003 electricity transmission system conditions, with analysis of blackout causes; background on and issues related to electricity transmission system functionality.

Recommendations to prevent blackout recurrences; views on implications of Aug. 2003 blackout for Federal energy policy, with suggestions to enhance reliability of electricity transmission; assessment of protective systems performance during Aug. 2003 blackout.

BURG, H. PETER, (Chairman and CEO, FirstEnergy Corp)

MCGRATH, EUGENE R., (CEO, Consolidated Edison, Inc)

WINSER, NICHOLAS P., (Group Director, Transmission, National Grid

Transco, plc; representing National Grid USA)

KESSEL, RICHARD, (Chairman and CEO, Long Island Power Authority)

DRAPER, E. LINN, JR., (Chairman, President, and CEO, American Electric

Power)

WELCH, JOSEPH L., (President and CEO, International Transmission Co)

MOLER, ELIZABETH A., (Executive Vice President, Government and

Environmental Affairs, and Public Policy, Exelon Corp)

\section{TESTIMONY \#5 - STATEMENTS AND DISCUSSION:}

Views of represented independent system operators on causes and impact of Aug. 2003 blackout; briefing on Aug. 2003 electricity restoration operations; analysis of sequence of events leading up to Aug. 2003 blackout; assessment of electricity transmission system protective mechanisms performance during Aug. 2003 blackout, citing minimal damage to power plants and transmission lines.

MUSELER, WILLIAM J., (President and CEO, New York Independent System Operator)

TORGERSON, JAMES P., (President and CEO, Midwest Independent

Transmission System Operator, Inc)

GOULDING, DAVID, (President and CEO, Independent Market Operator of Ontario)

VANWELIE, GORDON, (President and CEO, Independent System Operator 
New England Inc)

HARRIS, PHILLIP G., (President and CEO, PJM Interconnection, LLC) TESTIMONY \#6 - STATEMENTS AND DISCUSSION:

Perspectives on causes of Aug. 2003 blackout; overview of electric transmission industry efforts to prevent and minimize blackouts; recommendations to improve reliability of U.S. electric transmission system; views on energy policy implications of Aug. 2003 blackouts.

MAKOVICH, LAWRENCE J., (Senior Director, Americas Gas and Power Research, Cambridge Energy Research Associates)

FLEISHMAN, STEVEN I., (First Vice President, Merrill Lynch \& Co) POPOWSKY, SONNY, (Consumer Advocate, Pennsylvania Office of Consumer Advocate)

GLAUTHIER, THEODORE J., (President and CEO, Electricity Innovation Institute)

OWENS, DAVID K., (Executive Vice President, Edison Electric Institute)

Title: Keeping the Lights On: The Federal Role in Managing the Nation's

Electricity

Committee: Senate Subcommittee on Oversight of Government Management, the Federal Workforce, and D.C., Committee on Governmental Affairs

CIS number: 2004-S401-21

Date: $\quad$ Sept. 10, Nov. 20, 2003.

Location: Washington, D.C.

Pages: $\quad 487$

Summary: Hearings to review factors contributing to and the series of events leading up to the electrical blackout in the Midwest and Northeast on Aug. 14, 2003, and to examine policy options to prevent future blackouts.

\section{TESTIMONY \#1 - STATEMENTS AND DISCUSSION:}

Review of factors and events contributing to Aug. 2003 blackout; status of DOE efforts to investigate causes of blackout; issues related to efforts to collect and review data relevant to blackout; implications of Aug. 2003 blackout for energy regulation policies; views on Federal role in regulating electricity generation and transmission.

MCSLARROW, KYLE E., (Deputy Secretary, DOE)

WOOD, PATRICK H., III, (Chairman, FERC)

\section{TESTIMONY \#2 - STATEMENTS AND DISCUSSION:}

Views of represented organizations on causes and impact of Aug. 2003 blackout; factors and events contributing to Aug. 2003 blackout; views on Federal role and response to 2003 blackout; concerns about U.S. energy infrastructure vulnerability, with recommendations; need for Federal investment in electricity transmission infrastructure development.

Assessment of FERC efforts to identify and address causes of Aug. 2003 blackout; status 
of electricity transmission system in various U.S. regions; recommendations to prevent blackouts, focusing on need to improve reliability standards.

SCHRIBER, ALAN R., (Chairman, Public Utilities Commission of Ohio)

GLAZER, CRAIG A., (Vice President, Government Policy, PJM

Interconnection, LLC)

TORGERSON, JAMES P., (President and CEO, Midwest Independent

Transmission System Operator, Inc)

MUSELER, WILLIAM J., (President and CEO, New York Independent System Operator)

KERR, JAMES Y., II, (President, North Carolina Utilities Commission)

COOPER, MARK N., (Director, Research, Consumer Federation; also

representing Consumers Union)

\section{TESTIMONY \#3 - STATEMENTS AND DISCUSSION:}

Perspectives on causes of Aug. 2003 blackout; views on regulatory reforms needed to minimize impact of and prevent blackouts; elaboration on factors contributing to Aug. 2003 blackout; perspectives on energy policy implications of Aug. 2003 blackouts.

WOOD, PATRICK H., III, (Chairman, FERC)

GLOTFELTY, JAMES W., (Director, Office of Electric Transmission and Distribution, DOE)

GENT, MICHEHL R., (President and CEO, North America Electric Reliability Council)

Title: Keeping the Lights On: Removing Barriers to Technology to Prevent

Blackouts

Committee: House Subcommittee on Energy, Committee on Science

CIS number: 2004-H701-11

Date: $\quad$ September 25, 2003

Location: Washington, D.C.

Pages: $\quad 184$

Summary: Hearing to examine economic, regulatory, and technical barriers to improve the reliability of U.S. electricity transmission system, in light of the electrical blackouts in the Midwest and Northeast in Aug. 2003

\section{TESTIMONY - STATEMENTS AND DISCUSSION:}

Overview of infrastructure problems with electricity transmission system; need to modernize electricity transmission system, citing economic costs and security risks associated with blackouts; views on barriers inhibiting electricity transmission system modernization efforts.

Perspectives on electricity transmission system weaknesses exposed by Aug. 2003 blackouts; need to reform Federal reliability standards for electricity transmission.

GLOTFELTY, JAMES W., (Director, Office of Electric Transmission and Distribution, DOE)

GLAUTHIER, THEODORE J., (President and CEO, Electricity Innovation Institute) 
SMITH, VERNON L., (Professor, George Mason University)

CASTEN, THOMAS R., (Chairman and CEO, Private Power, LLC)

Title: What Are the Administration Priorities for Climate Change Technology?

Committee: House Subcommittee on Energy, Committee on Science

CIS number: 2004-H701-15

Date: $\quad$ November 6, 2003

Location: Washington, D.C.

Pages: $\quad 66$

Summary: Hearing to examine Administration climate change R\&D programs, focusing on research priorities for the interagency Climate Change Technology Program (CCTP)

TESTIMIONY - STATEMENTS AND DISCUSSION:

Overview of CCTP climate change technology R\&D activities and priorities; review of technical issues and challenges associated with carbon sequestration technology development; merits of a balanced climate change technology R\&D strategy, with support for energy conservation initiatives; elaboration on related issues and policy considerations.

CONOVER, DAVID W., (Director, CCTP)

RUDINS, GEORGE, (Deputy Assistant Secretary, Coal and Power Systems, DOE)

BENSON, SALLY M., (Deputy Director, Operations, Lawrence Berkeley

National Laboratory)

BROWN, MARILYN A., (Director, Energy Efficiency and Renewable Energy

Program, Oak Ridge National Laboratory)

Title: $\quad$ Review of Non-Oil and Gas Research Activities in the HoustonGalveston-Gulf Coast Area

Committee: House Subcommittee on Energy, Committee on Science

CIS number: 2004-H701-16

Date: December 4, 2003

Location: Houston, TX

Pages: $\quad 142$

Summary: Hearing to examine energy conservation and alternative fuels production research activities in the Houston-Galveston-Gulf Coast area of Texas

Former Texas Governor Mark White presents opening remarks

TESTIMONY - STATEMENTS AND DISCUSSION:

Overview of alternative energy research activities in the Houston-Galveston-Gulf Coast area of Texas; challenges and priorities for alternative energy and energy conservation research and technologies development.

Examples of and need for alternative energy sources to address future oil and gas resource exhaustion and environmental degradation associated with fossil fuel 
combustion; explanation of represented alternative energy research projects, including projects to develop coal gasification technology.

MITCHELL, TODD, (President, Houston Advanced Research Center)

SMALLEY, RICHARD E., (Director, Carbon Nanotechnology Laboratory, Rice University)

HOLTZAPPLE, MARK, (Professor, Department of Chemical Engineering, Texas A\&M University) HENNEKES, ROBERT, (Vice President, Technology Marketing, Shell Global Solutions)

CHANG-DIAZ, FRANKLIN R., (Director, Advanced Space Propulsion Laboratory, Johnson Space Center, NASA)

Title: $\quad$ Overview of the Federal R\&D Budget for FY2005

Committee: House Committee on Science

CIS number: 2004-H701-28

Date: $\quad$ February 11, 2004

Location: Washington, D.C.

Pages: $\quad 197$

Summary: Hearing to review Administration FY2005 budget request for science and technology R\&D programs

\section{TESTIMONY - STATEMENTS AND DISCUSSION:}

Review of Administration FY2005 R\&D budget; overview of NSF FY2005 budget request; description of DHS FY2005 budget request for science and technology programs, including homeland security and counterterrorism programs (related doc, $\mathrm{p}$. 67-75); summary of Department of Commerce FY2005 budget request.

Examination of DOE FY2005 budget request for energy and science programs; elaboration on issues related to represented agencies FY2005 budget requests for science and technology R\&D.

MARBURGER, JOHN H., III, (Director, Office of Science and Technology

Policy)

COLWELL, RITA R., (Director, NSF)

MCQUEARY, CHARLES E., (Under Secretary, Science and Technology, DHS)

BOND, PHILLIP J., (Under Secretary, Technology, Department of Commerce)

ORBACH, RAYMOND L., (Director, Office of Science, DOE)

Title: $\quad$ Reviewing the Hydrogen Fuel and FreedomCAR Initiatives

Committee: House Committee on Science

CIS number: 2005-H701-15

Date: $\quad$ March 3, 2004

Location: Washington, D.C.

Pages: $\quad 171$ 
Summary: $\quad$ Hearing to examine findings of National Academy of Sciences Feb. 2004 report and American Physical Society Mar. 2004 report on status of DOE hydrogen fuel cell technology development initiatives and the FreedomCAR program, which is a public-private R\&D partnership to develop fuel cell technologies for use in transportation

\section{TESTIMONY - STATEMENTS AND DISCUSSION:}

Findings of NAS and APS reports on DOE hydrogen fuel cell technology development, with recommendations; overview of DOE hydrogen energy technology R\&D initiatives; elaboration on issues relating to DOE fuel cell initiatives and FreedomCAR program.

GARMAN, DAVID K., (Assistant Secretary, Energy Efficiency and Renewable Energy, Department of Energy)

RAMAGE, MICHAEL P., (Chair, Committee on Alternatives and Strategies for Future Hydrogen Production and Use, National Research Council, National Academy of Sciences) EISENBERGER, PETER, (Chair, Panel on Public Affairs, Energy Subcommittee, American Physical Society)

Title: $\quad$ Renewable Energy and the Rural Economy

Committee: House Subcommittee on Department Operations, Oversight, Nutrition, and Forestry, Committee on Agriculture

CIS number: 2004-HJ161-10

Date: $\quad$ March 15, 2004

Location: $\quad$ Rochester, MN

Pages: $\quad 57$

Summary: Hearing to examine development of renewable energy resources and technologies to improve U.S. energy efficiency and energy security, including potential renewable energy applications in rural areas.

TESTIMONY \#1 - STATEMENTS AND DISCUSSION:

Overview of renewable energy development programs in Minnesota.

PAWLENTY, TIM, (Governor, MN)

TESTIMONY \#2 - STATEMENTS AND DISCUSSION:

Overview of USDA and DOE renewable energy research programs.

MOSELEY, JAMES R., (Deputy Secretary, USDA)

GARMAN, DAVID K., (Assistant Secretary, Energy Efficiency and Renewable Energy, DOE)

\section{TESTIMONY \#3 - STATEMENTS AND DISCUSSION:}

Background on renewable energy R\&D programs; views on potential renewable energy applications in rural areas and economic impact on agriculture sector; recommendations for Federal energy policy to promote renewable energy development.

TRULY, RICHARD H., (Director, National Renewable Energy Laboratory)

OBERMOLLER, RON, (President, Minnesota Corn Growers Association)

JACOBSEN, RON, (President, Minnesota Soybean Growers Association)

HAUBENSCHILD, DENNIS, (President, Haubenschild Farm) 
Title: $\quad$ Priorities in the Department of Energy Budget for FY2005

Committee: House Subcommittee on Energy, Committee on Science

CIS number: 2005-H701-4

Date: $\quad$ March 24, 2004

Location: Washington, D.C.

Pages: $\quad 113$

Summary: Hearing to review DOE FY2005 budget proposal for programs under

Committee jurisdiction, including Office of Science; energy efficiency and renewable energy; fossil energy; nuclear energy, science, and technology; and electric transmission and distribution programs

\section{TESTIMONY - STATEMENTS AND DISCUSSION:}

Review of Office of Science FY2005 budget request for energy research programs, with description of program priorities; summary of EERE FY2005 budget request for energy efficiency and renewable energy technology programs; overview of Office of Fossil Energy FY2005 budget request for fossil energy programs.

Description of Office of Nuclear Energy, Science and Technology FY2005 budget request for nuclear energy R\&D programs; outline of Office of Electric Transmission and Distribution FY2005 budget request for electric transmission and distribution programs; issues related to FY2005 budget requests for various DOE programs.

DECKER, JAMES F., (Principal Deputy Director, Office of Science, Department of Energy)

GARMAN, DAVID K., (Assistant Secretary, Energy Efficiency and Renewable Energy (EERE), Department of Energy)

MADDOX, MARK R., (Acting Assistant Secretary, Fossil Energy, Department of Energy)

MAGWOOD, WILLIAM D., IV, (Director, Office of Nuclear Energy, Science and Technology, Department of Energy)

GLOTFELTY, JAMES W., (Director, Office of Electric Transmission and Distribution, Department of Energy)

Title: $\quad$ Electricity Generation

Committee: Senate Committee on Energy and Natural Resources

CIS number: 2004-S311-31

Date: $\quad$ April 27, 2004

Location: Washington, D.C.

Pages: $\quad 52$

Summary: Hearing to examine importance of and options for energy technologies development to meet future electricity generation needs.

TESTIMONY - STATEMENTS AND DISCUSSION: 
Application of energy technologies use in electricity generation, including nuclear power and renewable energy technologies; support for energy technologies development, with recommendations; examination of clean coal development technologies.

SMALLEY, RICHARD E., (Director, Carbon Nanotechnology Laboratory, Rice University)

MONIZ, ERNEST J., (Professor, Physics, MIT)

GARMAN, DAVID K., (Assistant Secretary, Energy Efficiency and Renewable Energy, DOE)

BURKE, FRANK P., (Vice President, Research and Development, CONSOL Energy; also representing National Mining Association)

Title: $\quad$ Impact of Federal Energy Efficiency and Renewable Energy R\&D

Programs

Committee: House Subcommittee on Energy, Committee on Science

CIS number: 2005-H701-3

Date: $\quad$ May 19, 2004

Location: Washington, D.C.

Pages: $\quad 102$

Summary: Hearing to examine role of renewable energy resources and energy

efficiency technologies in meeting future national energy needs, and to review State and private sector programs to promote energy efficiency and renewable energy resources use

\section{TESTIMONY - STATEMENTS AND DISCUSSION:}

Review of current energy situation, with views on role of energy efficiency and renewable energy in meeting future national energy needs; perspectives on home building strategies that incorporate energy efficiency and renewable energy technologies, including solar power.

Overview of opportunities for energy efficiency in building sector, citing benefits of increased national investments in and policies focused on building energy efficiency; experiences of DuPont Co. with energy efficiency measures and renewable energy use. Review of State energy efficiency and renewable energy technology initiatives in New York State and Connecticut; issues related to energy efficiency and renewable energy technologies development and use.

NADEL, STEVEN M., (Executive Director, American Council for an EnergyEfficient Economy)

KONOVE, PAUL, (President, Carolina Country Builders of Chatham County Inc.; also representing Sustainable Buildings Industry Council)

LOFTNESS, VIVIAN E., (Head, School of Architecture, Carnegie Mellon University)

CARBERRY, JOHN B., (Director, Environmental Technologies, Central

Research \& Development, du Pont de Nemours, E. I., and Co)

SMITH, PETER R., (President, New York State Energy Research and 
Development Authority)

SOSLAND, DANIEL L., (Executive Director, Environment Northeast)

Title: Oversight of the Nuclear Regulatory Commission

Committee: Senate Subcommittee on Clean Air, Climate Change, and Nuclear

Safety, Committee on Environment and Public Works

CIS number: 2006-S321-6

Date: $\quad$ May 20, 20041

Location: Washington, D.C.

Pages: $\quad 342$

Summary: Hearing to review NRC safety and regulatory programs.

TESTIMONY \#1 - STATEMENTS AND DISCUSSION:

Overview of NRC nuclear regulatory and safety programs; perspectives on problem with reactor vessel degradation at the Davis-Besse nuclear power plant in Ohio, with description of NRC response; elaboration on various nuclear facilities safety and security issues.

DIAZ, NILS J., (Chairman, Nuclear Regulatory Commission)

MERRIFIELD, JEFFREY S., (Commissioner, Nuclear Regulatory Commission)

MCGAFFIGAN, EDWARD, JR., (Commissioner, Nuclear Regulatory

Commission)

\section{TESTIMONY \#2 - STATEMENTS AND DISCUSSION:}

Importance of nuclear energy role in supplying U.S. energy needs; perspectives on NRC nuclear power industry and facilities oversight; concerns about nuclear energy safety issues, including NRC nuclear safety and regulatory program reform needs; overview of industry related safety issues.

FERTEL, MARVIN S., (Senior Vice President and Chief Nuclear Officer,

Nuclear Generation, Nuclear Energy Institute)

LOCHBAUM, DAVID, (Nuclear Safety Engineer, Union of Concerned

Scientists)

KRAY, MARILYN, (Vice President, Project Development, Exelon Nuclear; also representing NuStart Energy Development, LLC)

JONES, BARCLAY G., (Professor, Nuclear, Plasma, and Radiological

Engineering Department, University of Illinois, Urbana-Champaign)

Title: $\quad$ Nuclear R\&D and the Idaho National Laboratory

Committee: House Subcommittee on Energy, Committee on Science

CIS number: 2005-H701-6

Date: June 24, 2004

Location: Washington, D.C.

Pages: $\quad 68$

Summary: Hearing to examine DOE plan to establish the Idaho National Laboratory (INL) as the lead Federal laboratory for nuclear energy R\&D 


\section{TESTIMONY - STATEMENTS AND DISCUSSION:}

Overview of and support for DOE plan to establish INL, with recommendations; views on prospects for nuclear power and nuclear research; elaboration on INL establishment plans and issues affecting nuclear R\&D.

MAGWOOD, WILLIAM D., IV, (Director, Office of Nuclear Energy, Science and Technology, Department of Energy)

WALTAR, ALAN E., (Director, Nuclear Energy, Pacific Northwest National Laboratory)

LONG, ROBERT L., (Chair, Infrastructure Task Force, Nuclear Energy

Research Advisory Committee)

KLEIN, ANDREW C., (Chair, Subcommittee on Nuclear Laboratory

Requirements, Nuclear Energy Research Advisory Committee)

Title: $\quad$ Nuclear Power

Committee: Senate Committee on Energy and Natural Resources

CIS number: 2004-S311-43

Date: July 13, 2004

Location: Washington, D.C.

Pages: $\quad 44$

Summary: $\quad$ Hearing to examine role of nuclear power in Administration national energy policy, and to review status of and future prospects for nuclear power.

\section{TESTIMONY - STATEMENTS AND DISCUSSION:}

Role of nuclear power in Administration national energy policy; perspectives on issues affecting construction of new nuclear power plants; elaboration on future prospects for nuclear power.

MCSLARROW, KYLE E., (Deputy Secretary, DOE)

Title: $\quad$ Natural Gas Symposium

Committee: Senate

CIS number: 2005-S311-17

Date: January 24, 2005

Location: Washington, D.C.

Pages: $\quad 95$

Summary: Hearing to examine issues relating to natural gas production and market conditions, in light of recent increases in natural gas prices.

Hearing was conducted as a symposium with panels of participants.

\section{TESTIMONY \#1 - STATEMENTS AND DISCUSSION:}

Perspectives on natural gas supply and demand issue; need to expand natural gas domestic production and develop new sites for drilling.

DOWNES, LARRY, (Chairman, Natural Gas Council; also representing American Gas Association) 
KUUSKRAA, VELLO, (President, Advanced Resources International)

BARLOW, ERIC, (Western Organization of Resource Councils)

THERIOT, NOLTY, (Director, Congressional Affairs, National Ocean Industries Association)

KALISCH, BERT, (President and CEO, American Public Gas Association)

GALLAGHER, BOB, (President, New Mexico Oil and Gas Association)

MYERS, MARK D., (Director, Division of Oil and Gas, Alaska Department of

Natural Resources)

HOUSEKNECHT, DAVE, (Research Geologist, Geological Survey)

CRUICKSHANK, WALTER, (Deputy Director, Minerals Management Service)

LONNIE, THOMAS P., (Assistant Director, Minerals Reality and Resource

Protection, Bureau of Land Management)

\section{TESTIMONY \#2 - STATEMENTS AND DISCUSSION:}

Benefits of and issues relating to use of liquefied natural gas.

SHARPLES, RICHARD J., (Executive Director, Center for Liquid Natural Gas)

STUNTZ, LINDA, (Member, National Commission on Energy Policy)

SYPOLT, GARY, (President, Dominion Transmission)

GERARD, STACEY L., (Associate Administrator, Pipeline Safety, Department of Transportation)

SHOWALTER, MARILYN, (President, National Association of Regulatory Utility Commissioners)

ROBINSON, J. MARK, (Director, Office of Energy Projects, Federal Energy

Regulatory Commission)

SCOTT, DAVID L. (CAPT.), (Chief, Office of Operating and Environmental

Standards, Coast Guard)

\section{TESTIMONY \#3 - STATEMENTS AND DISCUSSION:}

Perspectives on natural gas transport, distribution, and storage infrastructure.

ANGELLE, SCOTT A., (Secretary, Louisiana Department of Natural Resources) HANSEN, CHRISTINE, (Executive Director, Interstate Oil and Gas Compact Commission)

COOPER, MARK N., (Director, Research, Consumer Federation)

GERARD, STACEY L., (Associate Administrator, Pipeline Safety, Department of Transportation)

RATTIE, KEITH, (Chairman, CEO, and President, Questar Corp.; representing Interstate Natural Gas Association)

ROBINSON, J. MARK, (Director, Office of Energy Projects, Federal Energy

Regulatory Commission)

DAVIES, PHILIP, (Vice President and General Counsel, EnCana Gas Storage, Inc.; also representing Pine Prairie Energy and eCORP, LLC)

CRUICKSHANK, WALTER, (Deputy Director, Minerals Management Service)

\section{TESTIMONY \#4 - STATEMENTS AND DISCUSSION:}

Perspectives on environmental issues relating to petroleum and natural gas production. GRUMET, JASON, (Executive Director, National Commission on Energy Policy) 
ALBERSWERTH, DAVID, (Program Director, Wilderness Society)

WHITSITT, WILLIAM, (President, Domestic Petroleum Council)

LONNIE, THOMAS P., (Assistant Director, Minerals Reality and Resource

Protection, Bureau of Land Management)

TESTIMONY \#5 - STATEMENTS AND DISCUSSION:

Support for energy policy focusing on energy efficiency and diversification.

SHOWALTER, MARILYN, (President, National Association of Regulatory

Utility Commissioners)

NADEL, STEVEN M., (Executive Director, American Council for an Energy-

Efficient Economy)

COOPER, ROGER, (Executive Vice President, American Gas Association)

CONNELLY, JEANNE, (Vice President, Federal Relations, Calpine Corp)

KANE, JOHN E., (Senior Vice President, Governmental Affairs, Nuclear Energy Institute)

VAN ALDERWERELT, PETER, (Senior Vice President, PPM Energy)

ROSENBERG, WILLIAM, (Senior Fellow, School of Government, Harvard

University)

YAMAGATA, BEN, (Executive Director, Coal Utilization Research Council)

TESTIMONY \#6 - STATEMENTS AND DISCUSSION:

Issues relating to natural gas prices and inventory data estimation.

ANDERSON, BOB, (Executive Director, Committee of Chief Risk Officers)

BARNETT, KEITH, (Vice President, Fundamental Analysis for American

Electric Power)

CHAPMAN, GARY, (Senior Commercial Manager, Dow Chemical Co.;

representing Consumers Alliance for Affordable Natural Gas)

HARVEY, STEVE, (Deputy Director, Market Oversight and Assessment,

Federal Energy Regulatory Commission)

LEVIN, ROBERT, (Senior Vice President, New York Mercantile Exchange)

CAMPBELL, ELIZABETH, (Director, Natural Gas Division, Energy

Information Administration)

HANSEN, CHRISTINE, (Executive Director, Interstate Oil and Gas Compact

Commission)

HORVATH, SKIP, (President and CEO, Natural Gas Supply Association; also representing other organizations)

SHILTS, RICHARD A., (Director, Division of Market Oversight, Commodity Futures Trading Commission)

Title: Department of Energy's FY2006 Budget Proposal and the Energy Policy Act of 2005: Ensuring Jobs for Our Future with Secure and Reliable Energy

Committee: House

CIS number: 2005-H361-23

Date: $\quad$ February 9, 2005 
Location: Washington, D.C.

Pages: $\quad 85$

Summary: Hearing to review FY2006 budget request for DOE programs.

TESTIMONY - STATEMENTS AND DISCUSSION:

Overview of DOE FY2006 budget request and program priorities; views on various DOE programs.

BODMAN, SAMUEL W., (Secretary, Department of Energy)

Title: Improving the Nation's Energy Security: Can Cars and Trucks Be Made More Fuel Efficient?

Committee: House Committee on Science

CIS number: 2005-H701-26

Date: $\quad$ February 9, 20052

Location: Washington D.C.

Pages: $\quad 140$

Summary: Committee on Science Serial No. 109-3. Hearing to review status of fuel efficiency technology development, and to examine proposals to increase fuel efficiency standards under the corporate average fuel economy (CAFE) program, which requires automobiles and light trucks to meet specified fuel economy standards for each model year

\section{TESTIMONY - STATEMENTS AND DISCUSSION:}

Need to improve fuel economy in cars and light trucks, with recommendations; review of National Research Council 2001 report findings on implementation of CAFE program; overview of technologies to improve fuel economy in cars and light trucks; perspectives on policy options to encourage use of automobile fuel efficiency technologies; views on impact of CAFE program for increasing vehicle fuel efficiency.

REILLY, WILLIAM K., (former Co-Chairman, National Commission on Energy Policy)

PORTNEY, PAUL R., (President, Resources for the Future; representing

National Research Council)

DULEEP, K. G., (Managing Director, Transportation, Energy and Environmental Analysis, Inc)

STANTON, MICHAEL J., (Vice President, Government Affairs, Alliance of Automobile Manufacturers)

GREENE, DAVID L., (Corporate Research Fellow, National Transportation Research Center, Oak Ridge National Laboratory)

Title: $\quad$ Energy Policy Act of 2005

Committee: House Subcommittee on Energy and Air Quality, Committee on Energy and Commerce

CIS number: 2005-H361-26 
Date: $\quad$ February 10, 16, 2005

Location: Washington D.C.

Pages: $\quad 601$

Summary: Committee on Energy and Commerce Serial No. 109-1. Hearings before the Subcom on Energy and Air Quality to consider provisions of the conference report on 108th Congress H.R. 6, and a similar draft bill, the Energy Policy Act of 2005, both to revise energy policies and programs to promote increased energy conservation and increase the availability and security of energy supplies.

\section{WITNESS PANEL \#1 - STATEMENTS AND DISCUSSION:}

Overview of Administration priorities for energy legislation, with views on various provisions of the conference report on H.R. 6 and related energy policy issues.

GARMAN, DAVID K., (Assistant Secretary, Energy Efficiency and Renewable Energy, Department of Energy)

MARLETTE, CYNTHIA A., (General Counsel, Federal Energy Regulatory

Commission)

REYES, LUIS A., (Executive Director, Operations, Nuclear Regulatory

Commission)

\section{WITNESS PANEL \#2 - STATEMENTS AND DISCUSSION:}

Briefing on long-term outlook for U.S. and international energy markets (related graphs, p. 79-100); views on the conference report on H.R. 6 and related energy policy issues

CARUSO, GUY F., (Administrator, Energy Information Administration)

MURKOWSKI, FRANK H., (Governor, Alaska; representing National

Governors Association)

SHOWALTER, MARILYN, (President, National Association of Regulatory

Utility Commissioners)

CARRILLO, VICTOR, (Chairman, Texas Railroad Commission; also representing Interstate Oil and Gas Compact Commission)

\section{WITNESS PANEL \#3 - STATEMENTS AND DISCUSSION:}

Support for the conference report on H.R. 6, in light of electric power industry interests; examination of various aspects of H.R. 6, focusing on electricity-related provisions; views on and recommendations regarding promotion of U.S. energy efficiency; perspectives on energy policy issues.

KUHN, THOMAS R., (President, Edison Electric Institute)

CHURCH, LYNNE H., (President, Electric Power Supply Association)

RICHARDSON, ALAN H., (President and CEO, American Public Power

Association)

HANSEN, ED, (General Manager, Snohomish, Wash., Public Utility District;

also representing Large Public Power Council)

ENGLISH, GLENN, (CEO, National Rural Electric Cooperative Association)

CALLAHAN, KATERI, (President, Alliance To Save Energy)

COOPER, MARK N., (Director, Research, Consumer Federation; also

representing Consumers Union) 
NADEL, STEVEN M., (Executive Director, American Council for an EnergyEfficient Economy)

\section{WITNESS PANEL \#4 - STATEMENTS AND DISCUSSION:}

Differing views on merits of the conference report on H.R. 6; issues related to the use of methyl tertiary butyl ether, a fuel additive found to contaminate water sources; views on promoting petroleum and natural gas production and related matters.

CAVANEY, RED, (President, American Petroleum Institute)

DINNEEN, BOB, (President and CEO, Renewable Fuels Association)

SLAUGHTER, ROBERT, (President, National Petrochemical \& Refiners

Association)

OLSON, ERIK D., (Senior Attorney, Natural Resources Defense Council)

FULLER, LEE, (Vice President, Government Relations, Independent Petroleum Association; also representing other organizations)

DOWNES, LAURENCE M., (Chairman and CEO, New Jersey Resources; also representing American Gas Association)

NORLANDER, GERALD A., (Executive Director, Public Utility Law Project of New York, Inc.; also representing National Association of State Utility

Consumer Advocates)

HAMILTON, DAVID, (Director, Global Warming and Energy Programs, Sierra Club)

SANTA, DONALD F., JR., (President, Interstate Natural Gas Association)

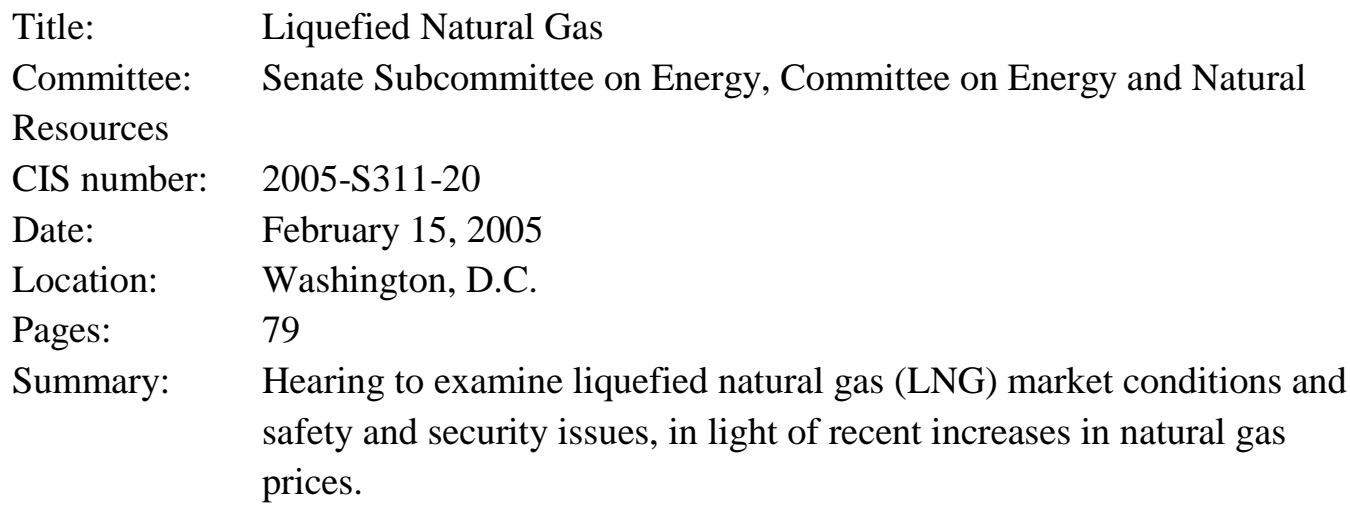

TESTIMONY \#1 - STATEMENTS AND DISCUSSION:

Perspectives on FERC role in LNG projects approval process; review of LNG market conditions and safety issues; elaboration on LNG safety and security concerns.

CICILLINE, DAVID N., (Mayor, Providence, R.I)

PEEVEY, MICHAEL R., (President, California Public Utilities Commission)

GILES, THOMAS E., (Executive Vice President and CEO, Sound Energy

Solutions)

GRANT, RICHARD L., (President and CEO, Tractabel LNG North America

LLC; also representing Distrigas of Massachusetts LLC)

ROBINSON, J. MARK, (Director, Office of Energy Products, Federal Energy

Regulatory Commission) 


\section{TESTIMONY \#2 - STATEMENTS AND DISCUSSION:}

Review of LNG vessels and facilities safety and security issues; elaboration on LNG industry safety and security, with recommendations.

SCOTT, DAVID L. (CAPT.), (Chief, Office of Operating and Environmental Standards, Coast Guard)

KRAMER, WILLIAM, JR., (Deputy Director, New Jersey Division of Fire Safety; representing National Association of State Fire Marshals) HIGHTOWER, MIKE, (Member, Technical Staff, Sandia National Laboratories) ROBINSON, J. MARK, (Director, Office of Energy Products, Federal Energy Regulatory Commission)

Title: $\quad$ Overview of the Federal R\&D Budget for FY2006

Committee: House Committee on Science

CIS number: 2005-H701-22

Date: $\quad$ February 16, 2005

Location: Washington D.C.

Pages: $\quad 190$

Summary: Committee on Science Serial No. 109-4. Hearing to review

Administration FY2006 budget request for science and technology R\&D programs

\section{TESTIMONY - STATEMENTS AND DISCUSSION:}

Review of Administration FY2006 R\&D budget; examination of DOE FY2006 budget request for energy and science programs; overview of NSF FY2006 budget request for technology and education; summary of Department of Commerce FY2006 budget request for technology programs; details of DHS FY2006 budget request for science and technology programs, including homeland security and counterterrorism programs

MARBURGER, JOHN H., III, (Director, Office of Science and Technology Policy)

BODMAN, SAMUEL W., (Secretary, Department of Energy)

BEMENT, ARDEN L., JR., (Director, National Science Foundation)

KASSINGER, THEODORE W., (Deputy Secretary, Department of Commerce)

MCQUEARY, CHARLES E., (Under Secretary, Science and Technology

Directorate, Department of Homeland Security)

Title: $\quad$ Power Generation Resource Incentives and Diversity

Committee: Senate Committee on Energy and Natural Resources

CIS number: 2005-S311-26

Date: $\quad$ March 8, 2005

Location: Washington, D.C.

Pages: $\quad 110$

Summary: Hearing to examine proposals to establish a federally-mandated national renewable energy portfolio standard (RPS) that would require retail 
suppliers to obtain up to 10 percent of electricity from renewable resources, such as wind, solar, geothermal, and traditional renewables.

Also reviews State RPS programs.

\section{TESTIMONY \#1 - STATEMENTS AND DISCUSSION:}

Opposition to national RPS program, citing merits of State RPS programs; views on and recommendations regarding Federal electricity generation diversity program; findings of study examining relationship between natural gas prices and investments in renewable generation and energy efficiency; viewed central role of States in efforts to encourage diverse supply of power generation and develop clean power resources, with suggestions. Support for Pennsylvania State government decision to establish RPS program, citing overall support for Federal RPS; perspectives on power generation resources diversification efforts, including Federal RPS proposals and State RPS programs.

GARMAN, DAVID K., (Assistant Secretary, Energy Efficiency and Renewable Energy, Department of Energy)

BRUNETTI, WAYNE, (Chairman and CEO, Xcel Energy, Inc)

WISER, RYAN, (Scientist, Lawrence Berkeley National Laboratory)

MORGAN, RICHARD E., (Commissioner, D.C. Public Service Commission; representing National Association of Regulatory Utility Commissioners)

POPOWSKY, SONNY, (Consumer Advocate, Pennsylvania Office of Consumer Advocate)

\section{TESTIMONY \#2 - STATEMENTS AND DISCUSSION:}

Opposing views on national RPS proposals; refutation of criticisms of proposed national RPS, citing benefits of renewable energy; arguments against proposals to mandate Federal RPS for electricity generators; perspectives on national RPS proposals and related issues.

FURMAN, DONALD N., (Senior Vice President, Regulation and External Affairs, PacifiCorp) BOWERS, KERRY W., (Technology Manager, Southern Co) NOGEE, ALAN, (Director, Clean Energy Program, Union of Concerned Scientists)

O'SHAUGHNESSY, BRIAN,(President and CEO, Revere Copper Products; representing National Association of Manufacturers)

Title: $\quad$ Energy Demand in the 21st Century: Are Congress and the Executive Branch Meeting the Challenge?

Committee: House Subcommittee on Energy and Resources, Committee on Government Reform

CIS number: 2005-H401-97

Date: $\quad$ March 16, 2005

Location: Washington D.C.

Pages: $\quad 116$

Summary: Committee on Government Reform Serial No. 109-12. Hearing before the Subcom on Energy and Resources to examine energy market 
conditions and outlook, and to review effectiveness of U.S. energy policy to meet growing demand for energy resources, in light of increase in petroleum and natural gas prices.

\section{TESTIMONY - STATEMENTS AND DISCUSSION:}

Review of challenges facing U.S. to meet demand for energy resources, including oil and natural gas; examination of U.S. production and consumption issues for various energy resources; overview of U.S. energy market conditions and outlook; perspectives on petroleum natural gas pricing and price volatility issues; suggestions for national energy policy to meet energy demand; need to reduce U.S. dependence on foreign oil and energy imports, with recommendations.

WELLS, JIM, (Director, Natural Resources and Environment, Government Accountability Office) CARUSO, GUY F., (Administrator, Energy Information Administration) PORTNEY, PAUL R., (President, Resources for the Future)

Title: $\quad$ America's Energy Needs as Our National Security Policy

Committee: House Subcommittee on Energy and Resources, Committee on Government Reform

CIS number: 2005-H401-90

Date: $\quad$ April 6, 2005

Location: Washington, D.C.

Pages: $\quad 96$

Summary: Hearing to examine U.S. energy policy and security issues.

\section{TESTIMONY - STATEMENTS AND DISCUSSION:}

Review of Administration national energy policy; benefits to U.S. energy security of increased use of advanced technology vehicles and clean diesel fuels; need to decrease U.S. dependence on imported oil; examination of factors affecting U.S. energy supply and security, with recommendations for U.S. energy policy.

SELL, JEFFREY C., (Deputy Secretary, Department of Energy)

WOOLSEY, R. JAMES, (Member, National Commission on Energy Policy) HORMATS, ROBERT D., (Vice Chairman, Goldman Sachs (International)) EBEL, ROBERT E., (Chairman, Energy Program, Center for Strategic and International Studies)

Title: Oil Resource Development

Committee: Senate Committee on Energy and Natural Resources

CIS number: 2005-S311-30

Date: $\quad$ April 12, 2005

Location: Washington, D.C.

Pages: $\quad 77$

Summary: Hearing to examine technical and policy issues and recommendations related to possible development of oil shale deposits in Colorado, Utah, 
and Wyoming as an alternative energy source, in light of concerns about U.S. dependence on oil imports.

Oil shale is petroleum extracted from fine-grained sedimentary rock rich in bituminous material through the chemical process of pyrolysis, or "steam cracking."

\section{TESTIMONY \#1 - STATEMENTS AND DISCUSSION:}

Support for oil shale development in represented States.

HATCH, ORRIN G., (Sen., R-Utah)

ALLARD, WAYNE, (Sen., R-Colo)

\section{TESTIMONY \#2 - STATEMENTS AND DISCUSSION:}

Issues and challenges related to development of oil shale as an energy source.

MADDOX, MARK R., (Principal Deputy Assistant Secretary, Office of Fossil

Energy, Department of Energy)

BARNA, THEODORE K., (Assistant Deputy Under Secretary, Advanced

Systems and Concepts, Department of Defense)

LONNIE, THOMAS P., (Assistant Director, Minerals, Realty and Resource

Protection, Bureau of Land Management)

\section{TESTIMONY \#3 - STATEMENTS AND DISCUSSION:}

Perspectives on past, current and future oil shale R\&D efforts, with related policy recommendations.

MUT, STEPHEN, (CEO, Unconventional Resources, Shell Exploration and

Production Co)

GEORGE, RUSSELL, (Executive Director, Colorado Department of Natural

Resources)

EVANS, JIM, (Executive Director, Associated Governments of Northwest

Colorado)

SMITH, STEVE, (Assistant Regional Director, Four Corners States Office, Wilderness Society)

Title: $\quad$ Offshore Hydrocarbon Production

Committee: Senate Committee on Energy and Natural Resources

CIS number: 2005-S311-37

Date: $\quad$ April 19, 2005

Location: Washington, D.C.

Pages: $\quad 91$

Summary: Hearing to examine status of and issues relating to oil and natural gas exploration and production on the outer continental shelf (OCS).

TESTIMONY \#1 - STATEMENTS AND DISCUSSION:

Findings and recommendations of Commission on Ocean Policy final report regarding national ocean policy, including OCS energy management; role of Federal OCS lands in U.S. energy production; review of Minerals Management Service activities relating to OCS mineral resources leasing and development; issues related to ocean policy and OCS energy production. 
WATKINS, JAMES D. (ADM., RET.), (Chairman, Commission on Ocean

Policy)

BURTON, R. M., (Director, Minerals Management Service)

THRESHER, ROBERT W., (Director, National Wind Technology Center,

National Renewable Energy Laboratory)

\section{TESTIMONY \#2 - STATEMENTS AND DISCUSSION:}

Opposition to proposed lifting of moratorium on oil and gas drilling in certain OCS

coastal areas; need for Federal sharing of OCS revenue with coastal energy-producing

States, citing Louisiana major role in U.S. oil and gas production.

BOGER, DEBBIE, (Deputy Legislative Director, Sierra Club)

ANGELLE, SCOTT A., (Secretary, Louisiana Department of Natural Resources)

WAGNER, FRANK W., (State Senator, Virginia)

DAVIDSON, CHARLES, (Chairman, President, and CEO, Noble Energy;

representing Domestic Petroleum Council and Independent Petroleum

Association)

Title: $\quad$ Nuclear Power 2010 Program

Committee: Senate Committee on Energy and Natural Resources

CIS number: 2005-S311-40

Date: $\quad$ April 26, 2005

Location: Washington, D.C.

Pages: $\quad 47$

Summary: Hearing to examine DOE nuclear power 2010 program, a public-private cost-sharing arrangement to address the technical, regulatory, and institutional challenges to new nuclear power plant construction.

\section{TESTIMONY \#1 - STATEMENTS AND DISCUSSION:}

Overview of DOE nuclear power 2010 program; review of NRC actions regarding licensing and regulation of new nuclear power plants.

SELL, CLAY, (Deputy Secretary, Department of Energy)

DIAZ, NILS J., (Chairman, Nuclear Regulatory Commission)

\section{TESTIMONY \#2 - STATEMENTS AND DISCUSSION:}

Overall support for nuclear power 2010 program, citing need for additional public-private investment initiatives in nuclear power.

WALLACE, MICHAEL J., (Executive Vice President, Constellation Energy

Group)

Title: $\quad$ Priorities in the Department of Energy Budget for FY2006

Committee: House Subcommittee on Energy, Committee on Science

CIS number: 2005-H401-105

Date: $\quad$ April 27, 2005

Location: Washington D.C.

Pages: $\quad 112$ 
Summary: Hearing to review DOE FY2006 budget proposal for programs under Committee jurisdiction, including Office of Science; energy efficiency and renewable energy; fossil energy; nuclear energy, science, and technology; and electricity delivery and energy reliability programs

\section{TESTIMONY - STATEMENTS AND DISCUSSION:}

Review of Office of Science FY2006 budget request for energy research programs, with description of program priorities; summary of Office Energy Efficiency and Renewable Energy FY2006 budget request for energy efficiency and renewable energy technology programs; overview of Office of Fossil Energy FY2006 budget request for fossil energy programs.

Description of Office of Nuclear Energy, Science and Technology FY2006 budget request for nuclear energy R\&D programs; outline of Office of Electricity Delivery and Energy Reliability FY2006 budget request for electricity system modernization programs; issues related to FY2006 budget requests for various DOE programs.

ORBACH, RAYMOND L., (Director, Office of Science, Department of Energy) FAULKNER, DOUGLAS L., (Principal Deputy Assistant Secretary, Office of Energy Efficiency and Renewable Energy, Department of Energy)

MADDOX, MARK R., (Principal Deputy Assistant Secretary, Office of Fossil Energy, Department of Energy)

JOHNSON, ROBERT S., (Deputy Director, Technology, Office of Nuclear Energy, Science and Technology, Department of Energy)

KOLEVAR, KEVIN M., (Director, Office of Electricity Delivery and Energy Reliability, Department of Energy)

Title: $\quad$ Role of Nuclear Power Generation in a Comprehensive National Energy

Policy

Committee: House Subcommittee on Energy and Resources, Committee on

Government Reform

CIS number: 2005-H401-105

Date: $\quad$ April 28, 2005

Location: Washington D.C.

Pages: $\quad 126$

Summary: Hearing to examine role of nuclear power in a comprehensive national energy policy and future prospects for nuclear power.

TESTIMONY - STATEMENTS AND DISCUSSION:

Examination of economic considerations and other issues involved in construction of new nuclear power plants; merits of nuclear energy, focusing on environmental benefits; elaboration on technological and policy issues related to nuclear power and other energy sources.

JONES, DONALD W., (Vice President, RCF Economic and Financial Consulting)

FERTEL, MARVIN S., (Senior Vice President and Chief Nuclear Officer, Nuclear Energy Institute)

MOORE, PATRICK, (Chair and Chief Scientist, Greenspirit Strategies Ltd) 
Title: Oversight on the Nuclear Regulatory Commission

Committee: Senate Subcommittee on Clean Air, Climate Change, and Nuclear Safety, Committee on Environment and Public Works

CIS number: 2007-S321-10

Date: $\quad$ May 26, 2005

Location: Washington, D.C.

Pages: $\quad 603$

Summary: Hearing to review NRC safety and regulatory programs.

\section{TESTIMONY \#1 - STATEMENTS AND DISCUSSION:}

Overview of NRC nuclear regulatory and safety programs, including reactor licensing and materials security; description of NRC responses to GAO and other findings and recommendations regarding various nuclear facility safety and security issues; views on NRC staffing and budget issues; elaboration on various nuclear facilities safety and security and NRC operational issues.

DIAZ, NILS J., (Chairman, Nuclear Regulatory Commission); accompanied by McGAFFIGAN, Edward, Jr., Commissioner, Nuclear Regulatory Commission.

\section{TESTIMONY \#2 - STATEMENTS AND DISCUSSION:}

Need for and criticism of NRC efforts to improve regulatory and oversight functions, including review of various GAO report findings; nuclear power industry views on and experiences with nuclear power plant construction and licensing, including related Federal nuclear regulatory process; concerns about and recommendations regarding nuclear power plant and materials safety and security, including nuclear power plant vulnerability to terrorist attack.

WELLS, JIM, (Director, Natural Resources and the Environment, Government Accountability Office)

KRAY, MARILYN C., (President, NuStart Energy Development, LLC)

LYMAN, EDWIN S., (Senior Staff Scientist, Global Security Program, Union of Concerned Scientists)

Title: $\quad$ S. 1265, the Diesel Emissions Reduction Act of 2005

Committee: Senate Subcommittee on Clean Air, Climate Change, and Nuclear Safety, Committee on Environment and Public Work

CIS number: 2007-S321-14

Date: July 123, 2005

Location: Washington, D.C.

Pages: $\quad 112$

Summary: Hearing to consider S. 1265, the Diesel Emissions Reduction Act of 2005, to establish voluntary national and State-level grant and loan programs for diesel engine emission reduction projects, programs, and technologies, including provision to authorize FY2007-FY2011 
appropriations for EPA programs to support grants and loans to States and other organizations working to reduce emissions from diesel engines.

\section{TESTIMONY \#1 - STATEMENTS AND DISCUSSION:}

Overview of EPA efforts to reduce diesel emissions, with concerns about funding levels contained in S. 1265.

NASTRI, WAYNE, (Administrator, Region IX, Environmental Protection

Agency)

\section{TESTIMONY \#2 - STATEMENTS AND DISCUSSION:}

Merits of S. 1265 to aid in State implementation of diesel emissions reduction programs.

KELIHER, MARGARET, (Judge, Dallas County, Tex)

KONCELIK, JOSEPH P., (Director,)

\section{TESTIMONY \#3 - STATEMENTS AND DISCUSSION:}

Support for S. 1265; overview of diesel emissions reduction technology developments and initiatives; elaboration on merits of S. 1265.

CROSS, MICHAEL, (Vice President, Cummins, Inc.; also representing

Fleetguard Emissions Solutions)

SCHNEIDER, CONRAD G., (Advocacy Director, Clean Air Task Force)

REGAN, TIMOTHY J., (President, Emissions Control Technology Association)

NEMSER, STUART, (Founder and CEO, Compact Membrane Systems)

Title: $\quad$ Fueling the Future: On the Road to the Hydrogen Economy

Committee: House Subcom on Energy, Committee on Science

CIS number: 2006-H161-12

Date: July 20, 2005

Location: Washington D.C.

Pages: $\quad 366$

Summary: Hearing to examine status of DOE hydrogen fuel cell technology development initiatives including the FreedomCAR program, which is a public-private R\&D partnership to develop fuel cell technologies for use in transportation (Subcom witness list and hearing charter, p. 2-7).

TESTIMONY - STATEMENTS AND DISCUSSION:

Overview and status of DOE hydrogen energy technology R\&D initiatives; views on transition to a hydrogen economy, citing need for increased research and innovation; perspectives on DaimlerChrysler efforts and research and policy issues related to development of hydrogen technology; elaboration on issues and challenges relating to emergence of a hydrogen economy.

FAULKNER, DOUGLAS L., (Acting Assistant Secretary, Energy Efficiency and Renewable Energy, Department of Energy)

BODDE, DAVID L., (Director, Innovation and Public Policy, International

Center for Automotive Research, Clemson University)

CHERNOBY, MARK, (Vice President, Advanced Vehicle Engineering,

DaimlerChrysler Corp)

CRABTREE, GEORGE W., (Director, Materials Science Division, Argonne 
National Laboratory)

HEYWOOD, JOHN B., (Director, Sloan Automotive Laboratory, Massachusetts Institute of Technology)

Title: $\quad$ Agriculture's Role in a Renewable Fuels Standard

Committee: House Committee on Agriculture

CIS number: 2005-H161-12

Date: July 21, 2005

Location: Washington D.C.

Pages: $\quad 137$

Summary: Committee on Agriculture Serial No. 109-12. Hearing to examine agriculture role in a renewable fuels standard, and impact on agricultural sector of the development of renewable energy resources and technologies to improve U.S. energy efficiency and energy security. Also briefly considers H.R. 3081, the Renewable Fuels Act of 2005, to direct the EPA to establish a program to require motor vehicle fuel to contain a certain amount of ethanol or other renewable fuel.

\section{TESTIMONY \#1 - STATEMENTS AND DISCUSSION:}

Overview of ethanol and renewable fuel development programs in Minnesota; views on potential renewable energy applications and economic impact on agriculture sector.

PAWLENTY, TIM, (Governor, MN)

COLLINS, KEITH J., (Chief Economist, Department of Agriculture)

\section{TESTIMONY \#2 - STATEMENTS AND DISCUSSION:}

Support for H.R. 3081; overview of economic and environmental benefits of biodiesel and ethanol; views on potential renewable energy applications and economic impact on agriculture sector.

FREDERICKSON, DAVE, (President, National Farmers Union)

CORZINE, LEON, (President, National Corn Growers Association)

FAULKNER, DOUGLAS, (Owner, Virginia Biodiesel Refinery)

MASON, JAMES L., (General Manager, Virginia Poultry Growers Cooperative)

PERINE, LORI A., (Executive Director, Agenda 2020 Technology Alliance, American Forest \& Paper Association) 


\section{Appendix XXI}

\section{Public Law 110-140}

\section{Energy and Security Act of 2007}

\section{Hearings Summary}

Title: $\quad$ Policy Options for Iraq

Committee: Senate Committee on Foreign Relations

CIS number: 2006-S381-17

Date: July 18-20, 2005

Location: Washington, D.C.

Pages: $\quad 199$

Summary: Hearings to examine U.S. policy toward Iraq, including efforts to improve security and promote political and economic development in Iraq.

\section{TESTIMONY \#1 - STATEMENTS AND DISCUSSION:}

Critique of U.S. counterinsurgency strategy in Iraq, with recommendations; views on and recommendations regarding U.S. security and other policies in Iraq; elaboration on issues related to U.S. Iraq policies.

POLLACK, KENNETH M., (Senior Fellow and Director, Research, Saban

Center for Middle East Policy, Brookings Institution)

MCCAFFREY, BARRY R., (President, BR McCaffrey Associates, LLC)

CORDESMAN, ANTHONY H., (Fellow, Strategy, Center for Strategic and International Studies)

\section{TESTIMONY \#2 - STATEMENTS AND DISCUSSION:}

Views on and recommendations regarding coalition efforts to advance Iraqi political development; perspectives on U.S. policy toward Iraqi constitutional committee, with suggestions; issues relating to Iraq political developments and U.S. policy.

MARR, PHEBE, (Senior Fellow, U.S. Institute of Peace)

VAN REST, JUDY, (Executive Vice President, International Republican Institute)

FELDMAN, NOAH, (Professor, Law, New York University)

\section{TESTIMONY \#3 - STATEMENTS AND DISCUSSION:}

Perspectives on and recommendations regarding coalition economic development and reconstruction assistance efforts in Iraq; outline of strategy for Iraq reconstruction;

elaboration on coalition economic development and reconstruction assistance measures in Iraq and related issues.

CRANE, KEITH, (Senior Economist, RAND Corp)

BARTON, FREDERICK D., (Senior Advisor, International Security Program, Center for Strategic and International Studies) 
Title: $\quad$ Energy Trends in China and India: Implications for the U.S.

Committee: Senate Committee on Foreign Relations

CIS number: 2006-S381-20

Date: July 26, 2005

Location: Washington, D.C.

Pages: $\quad 57$

Summary: Hearing to examine energy market trends and related foreign and domestic energy policies in China and India, in light of increased consumption and demand for energy resources in the two countries.

Also reviews U.S. policy implications of Chinese and Indian efforts to acquire energy resources.

\section{TESTIMONY \#1 - STATEMENTS AND DISCUSSION:}

Overview of current and projected energy consumption trends in China and India; role of China and India in global energy markets, with review of U.S. energy policy response.

WAYNE, E. ANTHONY, (Assistant Secretary, Economic and Business Affairs, Department of State)

GARMAN, DAVID K., (Under Secretary, Science and Environment, Department of Energy)

\section{TESTIMONY \#2 - STATEMENTS AND DISCUSSION:}

Review of China and India energy security concerns, citing implications for Asia and U.S.; impact of China energy resources diversification efforts on Chinese foreign policy, with views on consequences and opportunities for U.S.; summary of geopolitical issues related to Indian efforts to acquire energy resources, including impact on U.S.-India relations.

HERBERG, MIKKAL E., (Director, Globalization and Asian Energy Security

Program, National Bureau of Asian Research)

SCHRIVER, RANDALL G., (Partner, Armitage International)

GANGULY, SUMIT, (Professor, Political Science, and Director, India Studies Program, Indiana University)

Title: Winning Teams and Innovative Technologies from the 2005 Solar

Decathlon

Committee: House Subcommittee on Energy, Committee on Science

CIS number: 2006-H701-10

Date: $\quad$ November 2, 2005

Location: Washington, D.C.

Pages: $\quad 104$

Summary: Hearing to examine highlights from the 2005 Solar Decathlon, a DOEsponsored competition for university students to design and build 
energy-efficient solar-powered houses, and to examine research and policy implications of the contest for solar power

\section{TESTIMONY - STATEMENTS AND DISCUSSION:}

Perspectives on the 2005 Solar Decathlon and selected house designs from the contest; views on the development of solar energy technology and related issues.

MOORER, RICHARD F., (Deputy Assistant Secretary, Technology

Development, Office of Energy Efficiency and Renewable Energy, Department of Energy)

SCHUBERT, ROBERT P., (Team Faculty Coordinator, College of Architecture and Urban Studies, Virginia Polytechnic Institute and State University)

LYNG, JEFFREY R., (Team Project Manager, Civil, Environmental, and

Architectural Engineering, University of Colorado)

KNOWLES, JONATHAN R., (Team Faculty Advisor, Department of

Architecture, Rhode Island School of Design)

SCHIEREN, DAVID G., (Energy Team Leader, Energy Management, New York Institute of Technology; also representing Merchant Marine Academy)

Title: $\quad$ High Costs of Crude: The New Currency of Foreign Policy

Committee: Senate Committee on Foreign Relations

CIS number: 2006-S381-23

Date: $\quad$ November 16, 2005

Location: Washington, D.C.

Pages: $\quad 39$

Summary: Hearing to examine the effects of U.S. foreign oil dependence on the economy and national security, in light of high oil prices and foreign policy in the Middle East.

\section{TESTIMONY \#1 - STATEMENTS AND DISCUSSION:}

Perspectives on U.S. reliance on foreign oil for energy, focusing on economic, political, and security implications; concerns regarding future oil supplies in light of current prices, resources, and political climate in the Middle East; recommendations for policies to reduce dependence on imported oil, including development of alternative transportation fuels.

SCHLESINGER, JAMES R., (Senior Advisor, Lehman Brothers Holdings)

WOOLSEY, R. JAMES, (Vice President, Booz Allen Hamilton, Inc)

Title: $\quad$ Hidden Cost of Oil

Committee: Senate Committee on Foreign Relations

CIS number: 2007-S381-16

Date: $\quad$ March 30, 2006

Location: Washington, D.C.

Pages: $\quad 53$

Summary: Hearing to examine economic impact and other costs associated with U.S. oil consumption and dependence on foreign oil. 


\section{TESTIMONY - STATEMENTS AND DISCUSSION:}

Concerns about economic impact of U.S. oil consumption and dependence on foreign oil, with recommendations; adverse economic effects of potential future oil supply disruptions; support for oil prices to reflect long-term environmental impact of oil consumption, with policy suggestions.

COPULOS, MILTON R., (President, National Defense Council Foundation) HUNTINGTON, HILLARD, (Executive Director, Energy Modeling Forum, Stanford University)

YOHE, GARY W., (Professor, Economics, Wesleyan University)

Hearings on U.S.-India atomic energy cooperation legislative proposal before the Committee on Foreign Relations. Senate, Apr. 5, 2006 (No information available.)

Title: Implementation of the Provisions of the Energy Policy Act of 2005

Committee: Senate Committee on Energy and Natural Resources

CIS number: 2006-S5311-44

Date: $\quad$ April 24, May 1, 8, 2006

Location: Washington, D.C.

Pages: $\quad 190$

Summary: Hearings to examine implementation of Energy Policy Act of 2005 (EPAct) provisions relating to coal gasification and coal-to-liquid (CTL) technology development and hydroelectric facilities licensing.

\section{TESTIMONY \#1 - STATEMENTS AND DISCUSSION:}

Background on and status of CTL R\&D.

MILLER, CLARENCE L., (Director, Office of Sequestration, Hydrogen, and

Clean Coal Fuels, Office of Fossil Energy, Department of Energy)

\section{TESTIMONY \#2 - STATEMENTS AND DISCUSSION:}

Recommendations for development of CTL industry in U.S.; views on possible adverse environmental impact of large-scale CTL program, with suggestions; benefits of CTL technology development and use; elaboration on issues related to coal liquefaction R\&D.

GEERTSEMA, ARIE, (Director, Center for Applied Energy Research, University of Kentucky)

HAWKINS, DAVID G., (Director, Climate Center, Natural Resources Defense Council)

RAMSBOTTOM, D. HUNT, (President and CEO, Rentech, Inc)

ROBERTS, JAMES F., (President and CEO, Foundation Coal Corp.; representing National Mining Association)

\section{TESTIMONY \#3 - STATEMENTS AND DISCUSSION:}

Benefits of gasification-based power systems; review of Federal loan guarantee program and other incentives for development of gasification-based power systems

GARMAN, DAVID K., (Under Secretary, Department of Energy)

TESTIMONY \#4 - STATEMENTS AND DISCUSSION: 
Concerns about implementation of EPAct provisions related to tax credits and Federal loan guarantees for industrial gasification projects; review of coal gasification systems developed by represented companies to produce fuel from coal, citing benefits of coal gasification technologies; potential benefits to coal gasification industry of EPAct provisions implementation; perspectives on possible adverse environmental impact of coal gasification technology.

FERGUSON, BRIAN, (Chairman and CEO, Eastman Chemical Co)

BRUCE, WILLIAM F., (President, BRI Energy, LLC)

DOUGLAS, WILLIAM C., (Senior Vice President, Business Development, Econo-Power International Corp)

BOYCOTT, WILLIAM A., (General Manager, Kenai Nitrogen Operations, Agrium U.S., Inc)

HERZOG, ANTONIA, (Staff Scientist and Climate Advocate, Climate Center, Natural Resources Defense Council)

\section{TESTIMONY \#5 - STATEMENTS AND DISCUSSION:}

Review of FERC implementation of and EPAct provisions related to hydropower licensing program; perspectives on Federal agencies implementation of EPAct hydropower provisions, with recommendations; viewed problems with hydropower licensing provisions of EPAct.

ROBINSON, J. MARK, (Director, Office of Energy Projects, Federal Energy

Regulatory Commission)

FINFER, LAWRENCE, (Acting Director, Office of Policy Analysis, Department of Interior)

ADAMSON, DAN, (Vice Chair, Legislative Affairs Committee, National Hydropower Association; also representing other organizations)

FAHLUND, ANDREW, (Vice President, Conservation, American Rivers; also representing Hydropower Reform Coalition)

Hearings on strategic and nonproliferation implications of U.S.-India atomic energy cooperation before the Committee on Foreign Relations. Senate, Apr. 26, 2006 (No information available.)

Title: $\quad$ H.R. 5143, the H-Prize Act of 2006

Committee: House Committee on Science

CIS number: 2007-H701-10

Date: $\quad$ April 27, 2006

Location: Washington, D.C.

Pages: $\quad 84$

Summary: Hearing to consider H.R. 5143, the H-Prize Act of 2006, to direct DOE to establish monetary prizes to advance $\mathrm{R} \& \mathrm{D}$, demonstration, and commercial application of hydrogen energy technologies, including prizes for advancements in hydrogen production, storage, and 
distribution technologies and for prototypes of hydrogen-powered vehicles or hydrogen-based products

\section{TESTIMONY - STATEMENTS AND DISCUSSION:}

Overview of and support for H.R.5143, with recommendations; perspectives on hydrogen energy technology R\&D issues; need for monetary prizes to increase development of hydrogen energy technologies.

DIAMANDIS, PETER H., (Founder, Chairman, and CEO, X PRIZE Foundation) BODDE, DAVID L., (Director, Innovation and Public Policy, International Center for Automotive Research, Clemson University)

GREENE, DAVID L., (Corporate Fellow, Oak Ridge National Laboratory) BAXLEY, PHILLIP, (President, Shell Hydrogen LLC)

Title: $\quad$ Examining Pool Safety Issues

Committee: Senate Subcommittee on Consumer Affairs, Product Safety, and Insurance, Committee on Commerce, Science, and Transportation

CIS number: 2006-S261-92

Date: $\quad$ May 3, 2006

Location: Washington, D.C.

Pages: $\quad 60$

Summary: Hearing before the Subcom on Consumer Affairs, Product Safety, and Insurance to examine proposals to improve safety of swimming pools and spas to reduce incidence of child accidental drownings.

Also briefly considers the Pool and Spa Safety Act, to direct the CPSC to administer a grant program to encourage States to enact comprehensive swimming pool and spa safety laws and educate the public about pool and spa safety.

TESTIMONY \#1 - STATEMENTS AND DISCUSSION:

Overview of swimming pool and spa safety issues and hazard mitigation efforts.

ELDER, JACQUELINE, (Assistant Executive Director, Hazard Identification and Reduction, Consumer Product Safety Commission)

\section{TESTIMONY \#2 - STATEMENTS AND DISCUSSION:}

Personal experiences with death of a child due to entrapment and drowning in a spa; summary of pool and spa safety standard proposals; examination of pool and spa safety issues, citing support for the Pool and Spa Safety Act

BAKER, NANCY, (mother of spa drowning victim)

LAVEN, MARK, (President and CEO, Latham International; representing Association of Pool \& Spa Professionals)

KORN, ALAN, (General Counsel and Director, Public Policy, Safe Kids Worldwide)

Title: Implementation of the Provisions of the Energy Policy Act of 2005

Committee: Senate Committee on Energy and Natural Resources

CIS number: 2006-S311-48 
Date: $\quad$ May 15, 22, June 12, 19, 2006

Location: Washington, D.C.

Pages: $\quad 213$

Summary: Hearings to review implementation of Energy Policy Act of 2005 (EPAct) provisions relating to electricity reliability, construction of new nuclear power plants, and the next generation nuclear plant and renewable fuel standard initiatives.

\section{TESTIMONY \#1 - STATEMENTS AND DISCUSSION:}

Review of FERC efforts to implement electricity reliability provisions of EPAct; perspectives on EPAct reliability standards and related issues.

MOOT, JOHN S., (General Counsel, Federal Energy Regulatory Commission)

SERGEL, RICK, (CEO, North American Electric Reliability Council)

\section{TESTIMONY \#2 - STATEMENTS AND DISCUSSION:}

Views on EPAct electricity reliability provisions implementation issues, including provisions establishing an electric reliability organization (ERO) and North American Electric Reliability Council application to be the ERO; need for reliable electricity transmission.

OWENS, DAVID K., (Executive Vice President, Business Operations, Edison Electric Institute)

MOSHER, ALLEN, (Director, Policy Analysis, American Public Power Association)

EASLEY, MICHAEL E., (CEO, Powder River Energy Corp.; also representing Wyoming Infrastructure Authority and National Rural Electric Cooperative Association)

ANDERSON, JOHN A., (President and CEO, Electricity Consumers Resource Council)

HARPER, TRUDY A., (President, Tenaska Power Services Co.; representing Electric Power Supply Association)

\section{TESTIMONY \#3 - STATEMENTS AND DISCUSSION:}

Overview of DOE progress in implementing EPAct provisions encouraging new nuclear power plant construction; details regarding NRC regulation of new nuclear reactors

SPURGEON, DENNIS R., (Assistant Secretary, Nuclear Energy, Department of Energy)

DIAZ, NILS J., (Chairman, Nuclear Regulatory Commission)

ASSELSTINE, JAMES K., (Managing Director, Lehman Brothers, Inc)

\section{TESTIMONY \#4 - STATEMENTS AND DISCUSSION:}

Overview of DOE progress in implementation of EPAct provisions pertaining to the next generation nuclear plant initiative for the R\&D and operation of Generation IV advanced nuclear reactors.

SPURGEON, DENNIS R., (Assistant Secretary, Nuclear Energy, Department of Energy)

CHAPIN, DOUGLAS M., (Principal Officer, MPR Associates; representing Nuclear Energy Research Advisory Committee)

\section{TESTIMONY \#5 - STATEMENTS AND DISCUSSION:}


Views of nuclear industry sector on next generation nuclear plant design and development; importance to U.S. economy and energy policy of next generation plant hydrogen and fuel cell technologies.

CHRISTOPHER, THOMAS A., (CEO, AREVA, Inc)

MATZIE, REGIS A., (Senior Vice President and Chief Technology Officer, Westinghouse Electric Co)

KEUTER, DAN R., (Vice President, Nuclear Business Development, Entergy

Nuclear)

BURNS, LAWRENCE D., (Vice President, R\&D and Strategic Planning,

General Motors Corp)

SERFASS, JEFFREY, (President, National Hydrogen Association)

\section{TESTIMONY \#6 - STATEMENTS AND DISCUSSION:}

Status of EPA implementation of renewable fuel standards provisions of EPAct.

WEHRUM, WILLIAM L., (Acting Assistant Administrator, Office of Air and

Radiation, Environmental Protection Agency)

\section{TESTIMONY \#7 - STATEMENTS AND DISCUSSION:}

Advantages of ethanol and other biofuels in meeting future U.S. energy needs; aspects of additional research, technological advancements, and financing needed to realize biofuels potential; views on EPAct renewable fuel standard implementation

PACHECO, MICHAEL A., (Director, National Bioenergy Center, National

Renewable Energy Laboratory)

STANDLEE, CHRIS, (Executive Vice President and General Counsel, Abengoa

Bioenergy Corp.; also representing Renewable Fuels Association)

JOBE, JOE, (CEO, National Biodiesel Board)

CAREY, CHARLES P., (Chairman, Chicago Board of Trade)

MORE, DANIEL, (Managing Director and Head, Renewable Energy Effort within Investment Banking, Morgan Stanley)

Title: $\quad$ Energy Security and Oil Dependence

Committee: Senate Committee on Foreign Relations

CIS number: 2007-S381-15

Date: $\quad$ May 16, 2006

Location: Washington, D.C.

Pages: $\quad 61$

Summary: Hearing to examine strategies to reduce U.S. dependence on foreign oil, focusing on Federal policy options to expedite transition to alternative, sustainable energy sources including ethanol and biofuels, in light of concerns about energy security.

\section{TESTIMONY - STATEMENTS AND DISCUSSION:}

Benefits of and recommended strategies to facilitate transition to ethanol and biofuel use; need for Federal support to alternative energy infrastructure development and to improve fuel economy of vehicles; elaboration on potential policy measures to reduce oil dependence and promote alternative energy supplies (related table, graphs, p. 31-34); 
issues related to reducing domestic oil dependence, including economic and environmental impacts.

KHOSLA, VINOD, (Partner, Khosla Ventures)

GRUMET, JASON S., (Executive Director, National Commission on Energy Policy)

Title: Iran's Political/Nuclear Ambitions and U.S. Policy Options

Committee: Senate Committee on Foreign Relations

CIS number: 2007-S381-5

Date: $\quad$ March 17, 18, 2006

Location: Washington, D.C.

Pages: $\quad 130$

Summary: Hearings to review status of Iranian nuclear program and related U.S. policy issues.

TESTIMONY \#1 - STATEMENTS AND DISCUSSION:

Overview and assessment of Iranian nuclear program R\&D efforts; outlook on Iran ability to produce highly enriched uranium and nuclear weapons; elaboration on Iran nuclear program developments, with U.S. policy recommendations.

EINHORN, ROBERT J., (Senior Advisor, Center for Strategic and International Studies)

ALBRIGHT, DAVID, (President and Founder, Institute for Science and International Security)

\section{TESTIMONY \#2 - STATEMENTS AND DISCUSSION:}

Review of Iran nuclear program status and political and economic developments; analysis of U.S. policy options to deter Iranian Government efforts to develop nuclear weapons; perspectives on Iran nuclear program development and related U.S. policy.

POLLACK, KENNETH M., (Director, Research, Saban Center for Middle East

Policy, Brookings Institution)

SADJADPOUR, KARIM, (Iran Analyst, International Crisis Group)

CLAWSON, PATRICK L., (Deputy Director, Research, Washington Institute for Near East Policy)

KEMP, GEOFFREY, (Director, Regional Strategic Programs, Nixon Center)

\section{TESTIMONY \#3 - STATEMENTS AND DISCUSSION:}

Assessment of U.S.-Iranian relations in context of Iranian nuclear program development, with policy recommendations; views on threat of Iran nuclear program development; elaboration on U.S. policy options related to Iran nuclear program.

WISNER, FRANK G., (Vice Chairman, External Affairs, American International Group)

NASR, VALI R., (Professor, National Security Affairs, Naval Postgraduate

School)

NANAY, JULIA, (Senior Director, PFC Energy)

PHILLIPS, JAMES A., (Research Fellow, Middle Eastern Affairs, Center for

Foreign Policy Studies, Heritage Foundation) 
Title: $\quad$ Oil Dependence and Economic Risk

Committee: Senate Committee on Foreign Relations

CIS number: 2007-S381-34

Date: June 7, 2006

Location: Washington, D.C.

Pages: $\quad 48$

Summary: Hearing to review global oil production and supply situation, and to examine implications of U.S. foreign oil dependence on U.S. economy and oil and as prices.

\section{TESTIMONY - STATEMENTS AND DISCUSSION:}

Overview of global oil production and supply situation; impact of U.S. foreign oil dependence on U.S. economy and oil and gas prices; review of U.S. policy considerations to reduce U.S. dependence on foreign energy; perspectives on use of alternative fuels, including ethanol-based fuels; elaboration on economic impact of U.S. foreign oil dependence.

GREENSPAN, ALAN C., (President, Greenspan Associates LLC)

Title: $\quad$ Energy Security in Latin America

Committee: Senate Committee on Foreign Relations

CIS number: 2006-S381-13

Date: June 22, 2006

Location: Washington, D.C.

Pages: $\quad 221$

Summary: Hearing to examine energy security situation in Latin America, and to examine importance of Latin America to U.S. energy security. Also briefly considers S. 2435, the Energy Diplomacy and Security Act of 2006, to express the sense of Congress that the U.S. should increase cooperation and form partnerships with foreign governments on energy issues, including provision to establish a regional-based Hemisphere Energy Cooperation Forum to promote energy relations with Western Hemisphere countries.

\section{TESTIMONY \#1 - STATEMENTS AND DISCUSSION:}

Merits of S. 2435.

CRAIG, LARRY E., (Sen., R-ID)

SALAZAR, KEN, (Sen., D-CO)

\section{TESTIMONY \#2 - STATEMENTS AND DISCUSSION:}

Overview of energy production and related issues in Latin American countries; perspectives on Latin America energy production challenges and opportunities; examination of issues affecting energy production in Latin America, with U.S. foreign policy implications.

CAVALLO, DOMINGO, (former Minister, Economy, Argentina)

GIUSTI, LUIS E., (Senior Advisor, Center for Strategic and International Studies)

PEREIRA DE CARVALHO, EDUARDO, (President, Brazilian Association of 
Sugar Cane and Ethanol Producers)

GOLDWYN, DAVID L., (President, Goldwyn International Strategies, LLC)

Title: Implementation of the Provisions of the Energy Policy Act of 2005

Committee: Senate Committee on Energy and Natural Resources

CIS number: 2006-S311-52

Date: June 27 and July 11, 17, 2006

Location: Washington, D.C.

Pages: $\quad 221$

Summary: Hearings to review implementation of Energy Policy Act (EPAct) provisions relating to oil and natural gas resources production and geothermal and other renewable energy resources development on Federal lands, and to examine status of hydrogen and fuel cell R\&D

\section{TESTIMONY \#1 - STATEMENTS AND DISCUSSION:}

Overview of BLM and Fish and Wildlife Service efforts to improve oil and gas permitting process; assessment of progress in oil and natural gas production enhancement implementation, focusing on production on public lands in Wyoming and other western States; elaboration on issues related to oil and natural gas development on public lands.

CLARKE, KATHLEEN, (Director, Bureau of Land Management)

HALL, H. DALE, (Director, Fish and Wildlife Service)

FLANDERKA, MARY, (State Planning Coordinator, Wyoming Governor's

Office)

ZAVADIL, DUANE, (Vice President, Government and Regulatory Affairs, Bill

Barnett Corp.; representing Independent Petroleum Association of Mountain

States)

EPPINK, JEFFREY, (Senior Vice President, Advanced Resources International)

REED, TOM, (Wyoming Field Organizer, Trout Unlimited)

\section{TESTIMONY \#2 - STATEMENTS AND DISCUSSION:}

Overview of Department of Interior and Forest Service efforts to facilitate development of renewable and alternative energy resources on public lands; summary of GAO recent report findings regarding extent of and potential for geothermal development on Federal lands and challenges to develop geothermal resources.

SCARLETT, P. LYNN, (Deputy Secretary, Department of Interior)

COLLINS, SALLY, (Associate Chief, Forest Service)

WELLS, JIM, (Director, Natural Resources and Environment, Government

Accountability Office)

\section{TESTIMONY \#3 - STATEMENTS AND DISCUSSION:}

Importance of renewable energy resources development and use; perspectives on geothermal and other renewable energy development issues affecting western States; views on and recommendations regarding Federal role in assessment and promotion of renewable energy development and production; aspects of renewable energy research and technology development.

SNYDER, WALTER S., (Director, Intermountain West Geothermal Consortium) THOMSEN, PAUL A., (Public Policy Administrator, ORMAT Technologies; 
also representing Geothermal Energy Association)

TAYLOR, CHRIS, (Director, Development, Horizon Wind Energy; also representing American Wind Energy Association)

LIDEN, ROBERT B., (Executive Vice President and General Manager, Stirling Energy Systems; also representing Solar Energy Industries Association)

KARL, BERNIE, (Proprietor, Chena Hot Springs Resort)

WHITE, V. JOHN, (Executive Director, Center for Energy Efficiency and

Renewable Technologies)

\section{TESTIMONY \#4 - STATEMENTS AND DISCUSSION:}

Description of Administration efforts to promote hydrogen and fuel cell technology development.

GARMAN, DAVID K., (Under Secretary, Department of Energy)

\section{TESTIMONY \#5 - STATEMENTS AND DISCUSSION:}

Overview of represented organizations hydrogen and fuel cell technology R\&D activities, focusing on automotive applications; need for development of hydrogen technologies in automotive industry, with recommendations; issues involved in and requirements for achieving hydrogen and fuel cell potential, with views on Federal role under EPAct.

MCCORMICK, J. BYRON, (Executive Director, Fuel Cell Activities, General

Motors Corp)

LEULIETTE, TIMOTHY D., (Chairman, President, and CEO, Metaldyne Corp)

PAUL, DONALD L., (Vice President and Chief Technology Officer, Chevron Corp)

BALCOM, JAMES D., (President and CEO, PolyFuel, Inc)

Title: $\quad$ Russia: Back to the Future

Committee: Senate Committee on Foreign Relations

CIS number: 2007-S381-7

Date: June 29, 2006

Location: Washington, D.C.

Pages: $\quad 45$

Summary: Hearing to examine recent Russian political and economic developments under the leadership of President Vladimir V. Putin, and to review issues involved in U.S.-Russia relations.

TESTIMONY \#1 - STATEMENTS AND DISCUSSION:

Perspectives on economic, political, and social situation in Russia; views on Russian domestic and foreign policies and U.S.-Russia relations; examination of Russian energy policy and resources, with recommendations for U.S. policy.

SESTANOVICH, STEPHEN, (Senior Fellow, Russian and Eurasian Studies, Council on Foreign Relations)

TRENIN, DMITRI, (Deputy Director, Carnegie Endowment for International Peace)

JAFFE, AMY M., (Fellow, Energy Studies, Rice University) 
Title: $\quad$ Multilateral Development Banks: Development Effectiveness of Infrastructure Projects

Committee: Senate Committee on Foreign Relations

CIS number: 2007-S381-29

Date: July 12, 2006

Location: Washington, D.C.

Pages: $\quad 94$

Summary: Continuation of hearings to examine the problem of corruption associated with lending by the World Bank Group and other multilateral development banks (MDBs) to developing countries for projects to alleviate poverty and promote economic growth and to institute structural reforms, focusing on Inter-American Development Bank (IADB) lending to Peru for the Camisea natural gas pipeline project and World Bank Group lending to Chad and Cameroon for the Chad-Cameroon oil pipeline.

\section{TESTIMONY \#1 - STATEMENTS AND DISCUSSION:}

Review of U.S. policy towards and corruption issues related to MDB lending to developing countries to finance large-scale infrastructure projects.

LOWERY, CLAY, (Assistant Secretary, International Affairs, Department of Treasury)

\section{TESTIMONY \#2 - STATEMENTS AND DISCUSSION:}

Background on and evaluation of Camisea pipeline project, including IADB funding issues; differing views on benefits of Camisea pipeline for Peru; concerns about corruption issues related to World Bank Group financing for Chad-Cameroon pipeline project, citing negative impact in Chad and Cameroon; analysis of MDB financing of and perspectives on large-scale infrastructure projects in developing countries, with recommendations.

QUIJANDRIA, JAIME, (former Minister, Peru Ministry of Energy and Mines) HERRERA DESCALZI, CARLOS, (former Minister, Peru Ministry of Energy and Mines)

HORTA, KORINNA, (Senior Economist, Environmental Defense; representing Chadian Association for the Promotion and Defense of Human Rights and Center for Environment and Development in Cameroon) BAPNA, MANISH, (Executive Director, Bank Information Center; also representing Environmental Defense and International Rivers Network)

Title: $\quad$ H.R. 547, the Advanced Fuels Infrastructure Research and Development

Act

Committee: House Subcommittee on Energy and Environment, Committee on Science and Technology

CIS number: 2007-H701-26

Date: January 30, 2007

Location: Washington, D.C.

Pages: $\quad 71$ 
Summary: Hearing to consider H.R. 547 (text, p. 48-52), the Advanced Fuels Infrastructure Research and Development Act, to direct DOE, in consultation with the National Institute of Standards and Technology, to undertake $\mathrm{R} \& \mathrm{D}$ and demonstration programs involving additives to improve biofuel and ultra low sulfur diesel (ULSD) fuel compatibility with existing petroleum-based motor fuel storage and delivery infrastructure, and to develop portable, low-cost, and accurate methods and technologies for testing sulfur content of diesel fuels

\section{TESTIMONY - STATEMENTS AND DISCUSSION:}

Benefits of alternative and ULSD fuels; support for H.R. 547, citing need to improve biofuel compatibility with petroleum-based fuel storage and delivery infrastructure; perspectives on H.R. 547, with recommendations for EPA implementation; status of and challenges facing ethanol industry.

EICHBERGER, JOHN, (Vice President, Government Relations, National Association of Convenience Stores)

KASSEL, RICHARD, (Senior Attorney and Director, Clean Fuels and Vehicles Project, Natural Resources Defense Council)

DINNEEN, ROBERT, (President and CEO, Renewable Fuels Association)

Title: $\quad$ Transportation Sector Fuel Efficiency

Committee: Senate Committee on Energy and Natural Resources

CIS number: 2007-S311-12

Date: January 30, 2007

Location: Washington, D.C.

Pages: $\quad 76$

Summary: Hearing to examine transportation sector efforts to develop and utilize fuel-saving technologies and vehicles, including electric and hybrid vehicle technologies, and to review Federal policy options to encourage development and use of fuel-saving technologies.

\section{TESTIMONY - STATEMENTS AND DISCUSSION:}

Overview of transportation industry efforts to develop fuel-saving technologies and vehicles, including electrical and hybrid vehicle technologies; status of battery technology R\&D for automobiles; need for and elaboration on Federal policies to encourage use of fuel-saving technologies, with recommendations; analysis of vehicle manufacturer efforts to increase vehicle fuel efficiency.

LOWERY, ELIZABETH, (Vice President, Environment and Energy, General Motors Corp)

GERMAN, JOHN, (Manager, Environmental and Energy Analysis, Product Regulator Office, American Honda Motor Co.; representing Honda Motor Co) ANDERMAN, MENAHEM, (President, Advanced Automotive Batteries) LOGUE, WILLIAM J., (Executive Vice President, FedEx Express) MCMANUS, WALTER, (Director, Automotive Analysis Division, Transportation Research Institute, University of Michigan) 
GREENE, DAVID L., (Corporate Fellow, Engineering Science and Technology Division, Oak Ridge National Laboratory)

Title: $\quad$ Accelerated Biofuels Diversity

Committee: Senate Committee on Energy and Natural Resources

CIS number: 2007-S311-21

Date: $\quad$ February 12, 2007

Location: Washington, D.C.

Pages: $\quad 66$

Summary: Hearing to examine benefits of and policy issues related to biofuels use and research for transportation sector, in light of increasing U.S.

dependence on foreign oil and need to diversify transportation energy resources.

\section{TESTIMONY \#1 - STATEMENTS AND DISCUSSION:}

Review of energy and biofuels issues; recommendations for biofuel and energy policies, citing merits of initiatives from represented organizations.

DETCHON, REID, (Executive Director, Energy Future Coalition)

CONOVER, DAVID, (Counsel; representing National Commission on Energy

Policy)

DINNEEN, ROBERT, (President and CEO, Renewable Fuels Association)

WALD, CHARLES F. (GEN., RET.), (former Deputy Commander, U.S.

European Command; representing Energy Security Leadership Council)

PERSHING, JONATHAN, (Director, World Resources Institute)

\section{TESTIMONY \#2 - STATEMENTS AND DISCUSSION:}

Perspectives on current and potential future use of biofuels for transportation sector, including ethanol production.

MITCHELL, LARRY, (CEO, American Corn Growers Association)

TERRY, DAVID, (Project Coordinator, Governors' Ethanol Coalition)

FRALEY, ROBERT, (Executive Vice President and Chief Technology Officer,

Monsanto Co)

MCCAULEY, KEN, (President, National Corn Growers Association)

BOSTWICK, TOBY, (President, New Mexico Sorghum Producers)

WHITTINGTON, CHARLES, (President, Grammer Industries; representing

American Trucking Associations)

\section{TESTIMONY \#3 - STATEMENTS AND DISCUSSION:}

Examination of represented organizations efforts to develop, produce, and market biofuels technologies.

STANDLEE, CHRIS, (Executive Vice President, Abengoa Bioenergy Corp)

MELO, JOHN, (Chief Executive, Amyris Biotechnologies)

PIERCE, JOHN, (Vice President, Research and Development, du Pont de

Nemours, E. I., and Co)

PASSMORE, JEFF, (Executive Vice President, Iogen Corp)

HUSHKA, NILES, (CEO, KLJ Solutions Co) 
PERINE, LORI, (Executive Director, Agenda 2020 Technology Alliance;

representing American Forest \& Paper Association)

\section{TESTIMONY \#4-STATEMENTS AND DISCUSSION:}

Review of represented organizations efforts to promote ethanol and other biofuels use and availability to consumers; issues related to biofuels production and a national infrastructure to support biofuels use.

BURKE, EDMUND, (Board Chairman, Dennis K. Burke, Inc.; representing Coalition of E85 Retailers)

BURK, LOU, (Manager, Alternative Energy and Programs Group, ConocoPhillips Co)

BROWN, ROBERT D., (Director, Vehicle Environmental Engineering, Ford Motor Co)

PLAZA, JOHN, (President, Imperium Renewables, Inc)

MEARS, MICHAEL N., (Vice President, Transportation, Magellan Midstream Partners, L.P)

DREVNA, CHARLES T., (Executive Vice President, National Petrochemical and Refiners Association)

\section{TESTIMONY \#5 - STATEMENTS AND DISCUSSION:}

Importance of U.S. energy security and biofuels diversification for transportation sector.

PAUL, DON, (Vice President and Chief Technology Officer, Chevron Corp)

FOLTZ, TOMMY, (Vice President, Public Affairs, Earth Biofuels, Inc)

FITCH, GEORGE, (Mayor, Warrenton, Va)

RIGAS, NICHOLAS, (Director, South Carolina Institute for Energy Studies, Clemson University)

LEHMAN, JONATHON, (VeraSun Energy Corp)

TESTIMONY \#6 - STATEMENTS AND DISCUSSION:

Analysis of represented organizations R\&D activities for transportation biofuels.

TAYLOR, STEVEN, (Chair, Biosystems Engineering Department, Auburn University)

PRATHER, KRISTALA, (Assistant Professor, Chemical Engineering, Laboratory for Energy and Environment, Massachusetts Institute of Technology) ARVIZO, DAN, (Director, National Renewable Energy Laboratory)

DAVIS, MICHAEL, (Pacific Northwest Laboratory)

MICHALSKE, TERRY, (Sandia National Laboratories)

Title: $\quad$ Energy Efficiency of Buildings

Committee: Senate Subcommittee on Energy, Committee on Energy and Natural

Resources

CIS number: 2007-S311-25

Date: $\quad$ February 12, 2007

Location: Washington, D.C.

Pages: $\quad 66$

Summary: Hearing to examine energy efficiency of residential and other buildings TESTIMONY - STATEMENTS AND DISCUSSION: 
Review of State energy efficiency policies and efforts; perspectives on building energy efficiency issues; examination of energy usage demonstration projects in Alaska, with recommendations to improve energy efficiency in homes and buildings throughout the U.S.; assessment of policies and programs to improve energy efficiency of buildings by encouraging electric utility energy-efficient programs.

CHRISTIANSON, KIM, (Manager, Office of Renewable Energy and Energy Efficiency, North Dakota Department of Commerce; also representing National Association of State Energy Officials)

STEWART, R. K., (President, American Institute of Architects)

ZIMMERMAN, CHARLES R., (Vice President, Prototype and New Format Development, Wal-Mart Stores)

HEBERT, JACK, (President and CEO, Cold Climate Housing Research Center; also representing National Association of Home Builders)

ROGERS, JAMES E., (Chairman, CEO, and President, Duke Energy Corp.; also representing Edison Electric Institute)

CALLAHAN, KATERI, (President, Alliance To Save Energy)

Title: $\quad$ Evolving West

Committee: House Committee on Natural Resources

CIS number: 2007-H581-5

Date: $\quad$ February 28, 2007

Location: Washington, D.C.

Pages: $\quad 86$

Summary: Hearing to examine economic development and natural resources

conservation issues in the western U.S., including issues relating to Federal land management policies, energy resources development, and forest management.

TESTIMONY \#1 - STATEMENTS AND DISCUSSION:

Viewed adverse impact of Federal, State, and local regulatory land policies on economic development in the western U.S.

WALDEN, GREG, (Rep, R-OR)

REHBERG, DENNIS R., (Rep, R-MT)

NUNES, DEVIN, (Rep, R-CA)

HERGER, WALLY, (Rep, R-CA)

\section{TESTIMONY \#2 - STATEMENTS AND DISCUSSION:}

Description of Montana State government initiatives to promote economic and energy resources development; perspectives on economic growth and development in Montana and other western States, with related policy recommendations; elaboration on environmental and energy policy issues impacting Montana, including coal resources development.

SCHWEITZER, BRIAN, (Governor, MT)

WILLIAMS, PAT, (former Representative, MT)

TESTIMONY \#3 - STATEMENTS AND DISCUSSION: 
Overview of land and natural resources management issues impacting represented tribal governments in western States; perspectives on economic changes in the western U.S.; summary of issues and challenges impacting lumber industry, with suggestions.

MARSHALL, CLIFFORD L., (Chairman, Hoopa Valley Tribe, California) BOX, MATTHEW, (Vice Chairman, Southern Ute Indian Tribe of the Southern Ute Reservation, Colorado)

PROPST, LUTHER, (Executive Director, Sonoran Institute)

VAAGEN, RUSSELL C., (Vice President, Vaagen Brothers Lumber; also representing Northeast Washington Forest Coalition)

LEE, ROBERT G., (Professor, Sociology of Natural Resources, University of Washington)

Title: Review of the Administration's Energy Proposals for the Transportation Sector

Committee: House Subcommittee on Energy and Air Quality, Committee on Energy and Commerce

CIS number: 2007-H361-31

Date: $\quad$ February 282007

Location: Washington, D.C.

Pages: $\quad 55$

Summary: Hearing to examine Administration transportation sector energy proposals, including initiatives for alternative fuel technologies, energy security, and corporate advantage fuel economy (CAFE) standards for passenger cars.

TESTIMONY - STATEMENTS AND DISCUSSION:

Overview of Administration transportation sector energy proposals; examination of CAFE standards for passenger cars; review of Administration proposals to enhance energy security and alternative fuel development.

NASON, NICOLE R., (Administrator, National Highway Traffic Safety

Administration)

LAZEAR, EDWARD P., (Chairman, Council of Economic Advisers)

Hearings on corporate average fuel economy before the Committee on Commerce, Science, and Transportation. Senate, Mar. 6, 2007 (No information available.)

Title: $\quad$ Advanced Energy Technologies

Committee: Senate Committee on Energy and Natural Resources

CIS number: 2007-S311-31

Date: $\quad$ March 7, 2007

Location: Washington, D.C.

Pages: $\quad 68$ 
Summary: Hearing to examine Federal policies and market issues related to the development of and investments in advanced energy technologies, in light of increasing U.S. dependence of foreign oil.

\section{TESTIMONY - STATEMENTS AND DISCUSSION:}

Perspectives on Federal policy measures to enhance private sector investment in energy efficiency and clean energy technologies, with recommendations; review of efforts to accelerate and challenges facing deployment of advanced energy technologies; examination of issues related to existing Federal policies and programs in driving new technologies; review of investment trends in renewable energy markets.

REICHER, DAN W., (Director, Climate Change and Energy Initiatives, Google, Inc)

MUSK, ELON, (Chairman, Tesla Motors, Inc)

PETERS, JEROME P., JR., (Senior Vice President, TD Banknorth, N.A)

DENNISTON, JOHN, (Partner, Kleiner Perkins Caufield \& Byers)

LIEBREICH, MICHAEL, (CEO and Founder, New Energy Finance, Ltd)

Title: Climate Change and Energy Security: Perspectives from the Automobile Industry

Committee: House Subcommittee on Energy and Air Quality, Committee on Energy and Commerce

CIS number: 2009-H361-1

Date: $\quad$ March 14, 2007

Location: Washington, D.C.

Pages: $\quad 144$

Summary: Hearing to examine automobile industry efforts to develop fuel-saving technologies and vehicles, and to review Federal policy options to encourage fuel-saving technologies development and use, in light of concerns about energy security and global climate change.

\section{TESTIMONY - STATEMENTS AND DISCUSSION:}

Views on current and proposed Federal policies to promote higher fuel economy standards and reduce greenhouse gas emissions, with recommendations; overview of represented automobile manufacturers efforts to improve automobile fuel efficiency and develop alternative fuel technologies; perspectives on corporate average fuel economy program requirements and impact on petroleum consumption, with policy suggestions; merits of hybrid vehicle technology and alternative automotive fuel R\&D to improve motor vehicle fuel efficiency; issues related to Federal fuel economy standards. GETTELFINGER, RON, (President, International Union, United Automobile Workers) WAGONER, G. RICHARD, JR., (Chairman and CEO, General Motors Corp) PRESS, JIM, (President and Chief Operating Officer, Toyota Motor North America, Inc) MULALLY, ALLAN R., (President and CEO, Ford Motor Co) LASORDA, THOMAS W., (CEO and President, Chrysler Group, DaimlerChrysler AG) 
Title: $\quad$ Toward a Clean Energy Future: Energy Policy and Climate Change on

Public Lands

Committee: House Subcommittee on Energy and Mineral Resources, Committee on Natural Resources

CIS number: 2007-H581-13

Date: $\quad$ March 20, 2007

Location: Washington, D.C.

Pages: $\quad 82$

Summary: Hearing to examine impact on Federal lands and resources of global climate change.

TESTIMONY \#1 - STATEMENTS AND DISCUSSION:

Review of Geological Survey role in global climate change research and efforts to determine climate change impact; examination of climate change effect on public lands and resources.

MYERS, MARK D., (Director, Geological Survey)

TESTIMONY \#2 - STATEMENTS AND DISCUSSION:

Review of global climate change impact on public lands and renewable energy resources, including in Alaska; differing views on need for additional Federal regulations to reduce energy emissions; examination of global climate change impact on forests; adverse impact on wildlife of global warming and U.S. energy policies, with recommendations. WILLIAMS, DEBORAH, (President, Alaska Conservation Solutions; representing Alaska Conservation Alliance)

MURRAY, ROBERT E., (Chairman, President, and CEO, Murray Energy Corp) WESTERLING, ANTHONY, (Assistant Professor, Environmental Engineering, University of California, Merced)

SCHENDLER, AUDEN, (Executive Director, Community and Environmental Responsibility, Aspen Skiing Co)

MATSON, NOAH, (Director, Federal Lands Program, Defenders of Wildlife)

BALL, TIMOTHY F., (Chair, Natural Resources Stewardship Project)

Title: $\quad$ Energy Innovation

Committee: Senate Subcommittee on Science, Technology, and Innovation, Committee on Commerce, Science, and Transportation

CIS number: 2009-S261-8

Date: $\quad$ March 20, 2007

Location: Washington, D.C.

Pages: $\quad 70$

Summary: Hearing to examine energy efficiency technologies development to meet increased energy demands

TESTIMONY - STATEMENTS AND DISCUSSION:

Need for acceleration of energy efficiency technologies, with recommendations; assessment of how renewable sources can meet U.S. energy needs; examination of coalbased power generation technology and sequestration of carbon dioxide emissions; elaboration on energy efficiency technologies 
PRINDLE, WILLIAM, (Acting Executive Director, American Council for an EnergyEfficient Economy)

PRELI, FRANCIS R., JR., (Vice President, Engineering, UTC Power)

ECKHART, MICHAEL T., (President, American Council On Renewable Energy)

SRIDHAR, K. R., (Principal Co-Founder and CEO, Bloom Energy)

KATZER, JAMES R., (Visiting Scholar, Laboratory for Energy and the Environment, MIT)

Hearings on the conflict between hunting and fishing and energy development on Federal lands before the Committee on Natural Resources. House, Mar. 27, 2007 (No information available.)

Title: $\quad$ Royalties at Risk

Committee: House Committee on Natural Resources

CIS number: 2007-H581-9

Date: $\quad$ March 28, 2007

Location: Washington, D.C.

Pages: $\quad 96$

Summary: Hearing to examine Minerals Management Service management of oil and natural gas royalty-in-kind (RIK) program, which allows Minerals Management Service to accept as royalties a portion of natural gas and oil produced on Federal leases instead of a cash payment.

\section{TESTIMONY \#1 - STATEMENTS AND DISCUSSION:}

Review of Minerals Management Service program management of oil and natural gas royalties and RIK program; examination of Department of Interior role in management of mineral lease revenues.

GAFFIGAN, MARK E., (Acting Director, Natural Resources and Environment, Government Accountability Office)

ALLRED, C. STEPHEN, (Assistant Secretary, Department of Interior)

TESTIMONY \#2 - STATEMENTS AND DISCUSSION:

Concerns about MMS management of RIK program; criticisms of MMS oil and natural gas royalties policies, citing unfair advantages to energy companies and adverse impact on Indian tribes; perspectives on MMS RIK program management problems, with recommendations.

MAXWELL, BOBBY L., (former Auditor, Minerals Management Service)

GAMBRELL, KEVIN L., (former Director, Federal Indian Minerals Office, Minerals Management Service; representing Indian Land Working Group)

ALEXANDER, RYAN, (President, Taxpayers for Common Sense)

TESTIMONY \#3 - STATEMENTS AND DISCUSSION:

Issues related to MMS royalties tracking system and royalties paid to Indian tribes; perspectives on applicability to Federal employees of False Claims Act, which allows individuals who file claims of fraudulent activity by companies against the Government to receive a percentage of any civil judgment. 
ROLLER, DENNIS, (Audit Manager, Royalty Audit Section, North Dakota Auditor's Office)

LESTER, A. DAVID, (Executive Director, Council of Energy Resource Tribes)

GEESEY, MICHAEL, (Director, Wyoming Department of Audit)

BUCY, PAMELA, (Professor, Law, University of Alabama School of Law)

Title: Reducing Government Building Operational Costs Through Innovation and Efficiency: Legislative Solutions

Committee: Senate Committee on Environment and Public Works

CIS number: 2011-S321-4

Date: $\quad$ March 28, 2007

Location: Washington, D.C.

Pages: $\quad 56$

Summary: Hearing to examine Federal Government efforts to improve energy

efficiency and reduce energy costs.

TESTIMONY \#1 - STATEMENTS AND DISCUSSION:

Review of GSA efforts to reduce Federal building operational costs through energy efficiency and innovation.

WINSTEAD, DAVID L., (Commissioner, Public Buildings Service; also representing GSA)

TESTIMONY \#2 - STATEMENTS AND DISCUSSION:

Perspectives on energy use in Federal buildings through innovative technologies and practices, with recommendations.

CALLAHAN, KATERI, (President, Alliance To Save Energy)

TOWNSHEND, MELANIE, (Project Executive, Gilbane Building Co.; representing

Associated General Contractors)

Title: Ocean Policy Priorities in the U.S.; and H.R. 21, Oceans Conservation, Education, and National Strategy for the 21st Century Act

Committee: House Subcommittee on Fisheries, Wildlife, and Oceans, Committee on Natural Resources

CIS number: 2007-H581-6

Date: $\quad$ March 29 and April 26, 2007

Location: Washington, D.C.

Pages: $\quad 159$

Summary: Hearings before the Subcommittee on Fisheries, Wildlife, and Oceans to review Federal ocean and coastal policy priorities, in light of national ocean policy recommendations made by the Joint Ocean Commission Initiative.

TESTIMONY \#1 - STATEMENTS AND DISCUSSION:

Overview of Joint Ocean Commission Initiative policy recommendations to coordinate and improve Federal ocean and coastal policies; review of accomplishments in NOAA Ocean Action Plan implementation; elaboration on Federal ocean and coastal policy issues. 
WATKINS, JAMES D. (ADM., RET.), (Co-Chair, Joint Ocean Commission Initiative)

PANETTA, LEON E., (Co-Chair, Joint Ocean Commission Initiative)

GLACKIN, MARY M., (Assistant Administrator, Program Planning and Integration, NOAA)

TESTIMONY \#2 - STATEMENTS AND DISCUSSION:

Merits of sponsored H.R. 21.

FARR, SAM, (Rep, D-CA)

ALLEN, THOMAS H., (Rep, D-ME)

TESTIMONY \#3 - STATEMENTS AND DISCUSSION:

Opposition to H.R. 21, citing provisions conflicting with current Administration policies; overall merits of H.R. 21, with recommendations; elaboration on issues related to ocean policy and H.R. 21.

DUNNIGAN, JOHN H., (Assistant Administrator, Ocean Services and Coastal Zone

Management, NOAA)

LEYDEN, KATHLEEN, (Director, Coastal Program, Maine Planning Office;

representing Coastal States Organization)

\section{TESTIMONY \#4 - STATEMENTS AND DISCUSSION:}

Overall merits of H.R. 21, with recommendations; outline of H.R. 21 provisions;

concerns regarding H.R. 21 impact on fisheries management, with suggestions.

GRADER, WILLIAM F., JR., (Executive Director, Pacific Coast Federation of

Fishermen's Associations)

CHASIS, SARAH, (Senior Attorney and Director, Ocean Initiative, Natural Resources

Defense Council)

ROSENBERG, ANDREW A., (Professor, Natural Resources, Institute for the Study of Earth, Oceans and Space, University of New Hampshire)

BENTON, DAVID, (Executive Director, Marine Conservation Alliance)

Title: $\quad$ Biofuels for Energy Security and Transportation Act of 2007

Committee: Senate Committee on Energy and Natural Resources

CIS number: 2007-S311-38

Date: $\quad$ April 12, 2007

Location: Washington, D.C.

Committee Members:

Pages: $\quad 75$

Summary: Hearing to consider S. 987, the Biofuels for Energy Security and

Transportation Act of 2007, to enhance energy security by promoting biofuel

development and use.

Includes provisions to:

a. Require the President to promulgate regulations to ensure that renewable fuels are

consumed for motor vehicles, home heating oil, and boiler fuels in increasing amounts by 2022.

b. Direct DOE to establish geographically-dispersed renewable fuel corridors through competitive grants.

c. Direct DOE to contract with the National Academy of Sciences to study status of 
technologies related to production of biofuels.

TESTIMONY \#1 - STATEMENTS AND DISCUSSION:

Merits of S. 987; perspectives on Federal energy policies, including DOE biofuel programs.

KARSNER, ALEXANDER A., (Assistant Secretary, Office of Energy Efficiency and Renewable Energy, Department of Energy)

\section{TESTIMONY \#2 - STATEMENTS AND DISCUSSION:}

Pros and cons of S. 987, with recommendations; views on feasibility of proposed ethanol production levels contained in S. 987.

DINNEEN, ROBERT, (President and CEO, Renewable Fuels Association)

LASHOF, DANIEL A., (Science Director, Climate Center, Natural Resources Defense Council)

CAVANEY, RED, (President and CEO, American Petroleum Institute)

FOODY, BRIAN, (President and CEO, Iogen Corp)

Title: $\quad$ National Carbon Dioxide Storage Capacity Assessment Act of 2007, and Department of Energy Carbon Capture and Storage Research, Development, and Demonstration Act of 2007

Committee: Senate Committee on Energy and Natural Resources

CIS number: 2007-S311-39

Date: $\quad$ April 16, 2007

Location: Washington, D.C.

Pages: $\quad 77$

Summary: Hearing to consider the following bills:

S. 731, the National Carbon Dioxide Storage Capacity Assessment Act of 2007, to require the Department of Interior to develop a methodology for conducting a national assessment of geological storage capacity for carbon dioxide.

S. 962, the Department of Energy Carbon Capture and Storage Research, Development, and Demonstration Act of 2007, to amend the Energy Policy Act of 2005 to revise and extend DOE carbon capture and storage R\&D program.

TESTIMONY \#1 - STATEMENTS AND DISCUSSION:

Overall support for S. 731 and S. 962, with recommendations

MYERS, MARK D., (Director, Geological Survey, Department of Interior)

SHOPE, THOMAS D., (Acting Assistant Secretary, Office of Fossil Energy, Department of Energy)

TESTIMONY \#2 - STATEMENTS AND DISCUSSION:

Need for capture of carbon dioxide, citing overall support for S. 731 and S. 962; views on liability issues standing as an impediment to commercial deployment of carbon capture and storage technology in U.S.

GUTHRIE, GEORGE, (Program Director, Fossil Energy and Environment Programs, Los Alamos National Laboratory)

HAWKINS, DAVID G., (Director, Climate Center, Natural Resources Defense Council) CODDINGTON, KIPP, (attorney) 
Title: Implementation of Title III, Oil and Gas Provisions of the Energy Policy

Act of 2005

Committee: House Subcommittee on Energy and Mineral Resources, Committee on Natural Resources

CIS number: 2007-H581-12

Date: $\quad$ April 17, 2007

Location: Washington, D.C.

Pages: $\quad 81$

Summary: Hearing to review implementation of Energy Policy Act (EPAct) of 2005 Title III provisions relating to oil and natural gas resources production and development on Federal lands, and to examine policy issues related to oil shale resources development.

TESTIMONY \#1 - STATEMENTS AND DISCUSSION:

Overview of and perspectives on BLM implementation of EPAct Title III provisions; viewed adverse ecological effects of EPAct Title III provisions, citing negative impact on public lands of increase in oil and natural gas development

HASPEL, ABRAHAM E., (Assistant Deputy Secretary, Department of Interior)

MORGAN, ANN J., (former Colorado Director, Bureau of Land Management;

representing Wilderness Society)

TESTIMONY \#2 - STATEMENTS AND DISCUSSION:

Perspectives on oil shale resources development; problems with EPAct provisions for and BLM management of commercial oil shale development leases, with recommendations; opposition to EPAct Title III provisions, citing environmental concerns.

BRAMBLE, CURTIS S., (Majority Leader, Utah Senate; representing American

Legislative Exchange Council)

BARTIS, JAMES T., (Senior Policy Researcher, RAND Corp)

KELLEY, KATHLEEN S., (former State Representative, Colorado)

SIMPSON, OSCAR, (Chair, Conservation Policy, New Mexico Wildlife Federation; representing National Wildlife Federation)

CICIO, PAUL N., (President, Industrial Energy Consumers of America)

Title: Wildlife and Oceans in a Changing Climate

Committee: House Subcommittee on Fisheries, Wildlife, and Oceans, Committee on Natural Resources

CIS number: 2007-S311-39

Date: $\quad$ April 17, 2007

Location: Washington, D.C.

Pages: $\quad 176$

Summary: Hearing to examine status of scientific knowledge regarding impact of global climate change on wildlife and oceans, and to review Federal policy options to address global climate change

WITNESS PANEL \#1 - STATEMENTS AND DISCUSSION:

Review of scientific research on global climate change impact on plant and wildlife species; specifics on global climate change impact on ice forms and marine animals in Alaska; perspectives on U.S. policy related to global climate change mitigation and 
resources management, with recommendations; elaboration on global climate change issues; perspectives on global climate change research, including Intergovernmental Panel on Climate Change.

MCKIBBEN, WILLIAM, (author; organizer, Stepitup07.org)

LAWLER, JOSHUA J., (Assistant Professor, College of Forest Resources, University of Washington)

ROOT, TERRY L., (Senior Fellow, University Faculty, Stanford University)

MEDINA, MONICA, (Acting Director, International Fund for Animal Welfare)

HANEY, J. CHRISTOPHER, (Chief Scientist, Defenders of Wildlife)

\section{WITNESS PANEL \#2 - STATEMENTS AND DISCUSSION:}

Review of scientific research related to climate change impact on coral reefs and related marine ecosystems (related bibl, p. 86-87, 123-124); explanation of global climate change impact on oceans and ocean acidity (related bibl, p. 95-96); perspectives on relationship between global warming and changes to marine and coastal conditions and ecosystems; summary of Intergovernmental Panel on Climate Change findings on climate change impact on marine ecosystems

EAKIN, C. MARK, (Coordinator, Coral Reef Watch, National Environmental Satellite, Data, and Information Service, National Oceanic and Atmospheric Administration) CALDEIRA, KENNETH, (Department of Global Ecology, Carnegie Institution of Washington)

KLEYPAS, JOAN A., (Scientist, Institute for the Study of Society and Environment, National Center for Atmospheric Research)

SHARP, GARY D., (Scientific Director, Center for Climate/Ocean Resources Study) EVERETT, JOHN T., (Member, Intergovernmental Panel on Climate Change)

Title: $\quad$ Alternative Transportation Fuels: An Overview

Committee: House Subcommittee on Energy and Air Quality, Committee on Energy and Commerce

CIS number: 2009-H361-7

Date: $\quad$ April 18, 2007

Location: Washington, D.C.

Pages: $\quad 124$

Summary: Hearing to examine status of alternative transportation fuel technologies $R \& D$, in light of concerns about energy security.

WITNESS PANEL \#1 - STATEMENTS AND DISCUSSION:

Perspectives on need to improve U.S. energy independence through greater use of domestic coal to produce clean transportation fuels; examination of gasification-based projects to utilize coal resources and other carbon-based fuels, with views on Government incentives to assist new technology deployment; review of Government and industry efforts to promote cellulosic ethanol use.

WARD, JOHN N., (Vice President, Marketing and Government Affairs, Headwaters, Inc)

MALEY, DONALD W., JR., (Vice President, Leucadia National Corp)

FOODY, BRIAN, (President and CEO, Iogen Corp) 
HUGHES, SCOTT, (Director, Governmental Affairs, National Biodiesel Board) LAMPERT, PHILLIP J., (Executive Director, National Ethanol Vehicle Coalition) FARRELL, ALEXANDER E., (Assistant Professor, Energy and Resources Group and Director, Transportation Sustainability Research Center, University of California, Berkeley)

Title: Renewable Energy Opportunities and Issues on Federal Lands: Review of Title II, Subtitle B, Geothermal Energy of EPACT; and Other Renewable Programs and Proposals for Public Resources

Committee: House Subcommittee on Energy and Mineral Resources, Committee on Natural Resource

CIS number: 2007-H581-20

Date: $\quad$ April 19, 2007

Location: Washington, D.C.

Pages: $\quad 97$

Summary: Hearing to examine the potential of renewable energy resources development on public lands, and to review implementation of Energy Policy Act of 2005 (EPAct) renewable energy resources development provisions.

\section{TESTIMONY \#1 - STATEMENTS AND DISCUSSION:}

Overview of BLM efforts to facilitate development of renewable energy resources on public lands and progress in implementing EPAct requirements; endorsement of expanded geothermal energy R\&D, citing MIT study findings (related bibl, p. 19); elaboration on importance of geothermal energy resources development and use and related issues.

HUGHES, JIM, (Acting Director, Bureau of Land Management) TESTER, JEFFERSON, (Professor, Chemical Engineering and Chair, Climate Change Panel, Massachusetts Institute of Technology)

KUNZ, DANIEL, (President and CEO, U.S. Geothermal, Inc)

THOMSEN, PAUL A., (Public Policy Administrator, ORMAT Technologies, Inc)

\section{TESTIMONY \#2 - STATEMENTS AND DISCUSSION:}

Status of wind energy industry, with views on potential development of wind-generated electricity using public lands; viewed benefits of wind energy resources development on tribal lands; merits of solar energy resources development on public lands, with policy recommendations; elaboration on issues related to renewable energy development on public lands

SWISHER, RANDALL, (Executive Director, American Wind Energy Association)

GOUGH, ROBERT, (Secretary, Intertribal Council on Utility Policy)

JUNGWIRTH, LYNN, (Executive Director, Watershed Research and Training Center) BAR-LEV, JOSHUA, (Vice President, Regulatory Affairs, BrightSource Energy, Inc.; also representing Solar Energy Industries Association)

LUTGEN, WILL, JR., (Executive Director, Northwest Public Power Association)

Title: $\quad$ Energy Efficiency Promotion Act of 2007 
Committee: Senate Committee on Energy and Natural Resources

CIS number: 2007-S311-40

Date: $\quad$ April 23, 2007

Location: Washington, D.C.

Pages: $\quad 98$

Summary: Hearing to consider S. 1115, the Energy Efficiency Promotion Act of 2007 , to promote energy efficiency measures, focusing on provisions to authorize DOE to set regional energy efficiency standards and establish certain limits on Federal preemption of State energy efficiency standards, and to authorize DOE to provide block grants to States and local governments to implement energy efficiency programs.

\section{WITNESS PANEL \#1 - STATEMENTS AND DISCUSSION:}

Merits of S. 1115, with perspectives on various provisions; overview of DOE energy efficiency promotion efforts.

MIZROCH, JOHN, (Principal Deputy Assistant Secretary, Office of Energy Efficiency and Renewable Energy, Department of Energy)

\section{WITNESS PANEL \#2 - STATEMENTS AND DISCUSSION:}

Support for S. 1115 provision to provide block grants to implement energy efficiency programs; conflicting views on S. 1115 provisions relating to energy efficiency standards, including concerns about Federally-mandated regional standards and increased State preemption of Federal standards; diverse views on various S. 1115 provisions, with recommendations; elaboration on energy efficiency standards, including economic issues. CHAVEZ, MARTIN J., (Mayor, Albuquerque, N.Mex.; representing U.S. Conference of Mayors)

KERR, JAMES Y., II, (Commissioner, North Carolina Public Utilities Commission; representing National Association of Regulatory Utility Commissioners) COLLIER, ALICIA, (Director, Global Energy Policy, National Energy Solutions, Honeywell International; representing Federal Performance Contracting Coalition) SCHJERVEN, ROBERT E., (CEO Emeritus, Lennox International, Inc.; representing Gas Appliance Manufacturers Association)

PRINDLE, WILLIAM, (Acting Executive Director, American Council for an EnergyEfficient Economy) PITSOR, KYLE, (Vice President, Government Relations, National Electrical Manufacturers Association)

Title: Implementation of EPAct 2005 Loan Guarantee Programs by the Department of Energy

Committee: House Subcommittee on Energy and Air Quality, Committee on Energy and Commerce

CIS number: 2009-H361-8

Date: $\quad$ April 24, 2007

Location: Washington, D.C.

Pages: $\quad 88$ 
Summary: Hearing to review DOE implementation of Energy Policy Act (EPAct) of 2005 provisions relating to loan guarantee programs for projects that promote increased energy efficiency and conservation.

WITNESS PANEL \#1 - STATEMENTS AND DISCUSSION:

Status of DOE implementation of EPAct loan guarantee programs.

SPURGEON, DENNIS R., (Acting Under Secretary, Nuclear Energy, DOE)

WITNESS PANEL \#2 - STATEMENTS AND DISCUSSION:

Analysis of DOE implementation of EPAct loan guarantee programs; views on challenges facing loan guarantee programs for renewable energy projects; merits of EPAct loan guarantee programs for nuclear development projects.

COSGROVE, JAMES C., (Acting Director, Natural Resources and Environment, GAO)

JORGENSEN, JULIE, (Co-President and CEO, Excelsior Energy)

DEVOS, DENNY, (Director, Corporate Finance, POET)

CRANE, CHRISTOPHER, (President and Chief Nuclear Officer, Exelon Generation)

Title: $\quad$ Renewable Energy Opportunities and Issues on the Outer Continental

Shelf

Committee: House Subcommittee on Fisheries, Wildlife, and Oceans, Committee on

Natural Resources

CIS number: 2009-H581-18

Date: $\quad$ April 24, 2007

Location: Washington, D.C.

Pages: $\quad 107$

Summary: Hearing to examine Federal and private sector efforts to develop

alternative energy resources and technologies on the outer continental shelf (OCS).

TESTIMONY \#1 - STATEMENTS AND DISCUSSION:

Review of Department of Interior and Minerals Management Service efforts to establish a program, as authorized by Section 388 of the Energy Policy Act of 2005, to regulate and administer OCS alternative energy projects; overview of FERC ocean-based hydropower licensing and regulatory activities; perspectives on Federal-State and Federal interagency cooperation on OCS alternative energy projects; elaboration on OCS alternative energy project issues.

OLSEN, MICHAEL D., (Deputy Assistant Secretary, Land and Minerals Management, Department of Interior)

MILES, ANN F., (Director, Division of Hydropower Licensing, Office of Energy Projects, Federal Energy Regulatory Commission)

KEENEY, TIMOTHY R., (Deputy Assistant Secretary, Oceans and Atmosphere, National Oceanic and Atmospheric Administration)

DIERS, TED, (Program Manager, New Hampshire Coastal Program, New Hampshire Department of Environmental Services; representing Coastal States Organization)

TESTIMONY \#2 - STATEMENTS AND DISCUSSION:

Potential benefits of and perspectives on marine alternative energy projects; overview of wave energy projects and related technologies; recommendations for energy policies to encourage OCS alternative energy project development, including tax and other financial 
incentives; suggestions to improve regulatory structures for OCS alternative energy projects; elaboration on OCS alternative energy development.

O'NEILL, SEAN,(President, Ocean Renewable Energy Coalition)

BAK, JASON, (CEO, Finavera Renewables)

GRADER, WILLIAM F., JR., (Executive Director, Pacific Coast Federation of

Fishermen's Associations)

RADER, DOUGLAS N., (Principal Scientist, Oceans and Estuaries, Environmental

Defense)

HAGERMAN, GEORGE M., JR., (Senior Research Associate, Virginia Tech Advanced

Research Institute)

HOAGLAND, PORTER, (Research Specialist, Marine Policy Center, Woods Hole

Oceanographic Institution)

Title: $\quad$ Land-Use Issues Associated with Onshore Oil and Gas Leasing and

Development

Committee: House Subcommittee on National Parks, Forests, and Public Lands, Committee on Natural Resources

CIS number: 2007-H581-22

Date: $\quad$ April 26, 2007

Location: Washington, D.C.

Pages: $\quad 124$

Summary: Hearing to examine issues relating to oil and natural gas resources production and development on Federal lands, including effects on the environment and on other public lands uses.

\section{TESTIMONY \#1 - STATEMENTS AND DISCUSSION:}

Role of Forest Service in oil and natural gas leasing and development on national forest system lands; outline of BLM management of public lands, focusing on oil and natural gas leases and development

FERGUSON, TONY L., (Director, Minerals and Geology Management, National Forest System, Forest Service)

BISSON, HENRI, (Deputy Director, Operations, Bureau of Land Management) TESTIMONY \#2 - STATEMENTS AND DISCUSSION:

Concerns about Energy Policy Act of 2005 provisions authorizing oil and natural gas development on public lands without perceived adequate analysis and State agency involvement, citing need to ensure compatibility of energy development on public lands with fish and wildlife conservation; need to develop intertribal cultural consultation teams to inform Indian tribes about energy development decisions that impact sacred sites on public lands; experiences of Ute Tribe in Utah with energy resources development on reservation lands.

EMMERICH, JOHN, (Deputy Director, Wyoming Department of Game and Fish; representing Western Governors' Association and Association of Fish and Wildlife Agencies)

JAMES, JEWELL, (Policy Analyst, Lummi Tribe of the Lummi Reservation, Washington) 
JURRIUS, JOHN P., (Financial Advisor, Ute Indian Tribe of the Uintah and Ouray Reservation, Utah)

\section{TESTIMONY \#3 - STATEMENTS AND DISCUSSION:}

Concerns about impact on recreation users of Forest Service and BLM issuance of oil and natural gas leases on public lands; importance of oil and natural gas leasing on public lands, citing need to maintain balance between oil and natural gas exploration and development and environmental protection; perspectives on problems regarding natural gas development on public lands.

ADAMI, STEVEN M., (rancher; representing Powder River Basin Resource Council) KORENBLAT, ASHLEY, (President, Western Spirit Cycling)

MOSELEY, CLAIRE M., (Executive Director, Public Lands Advocacy)

MUGGLI, ROGER, (Manager, Tongue and Yellowstone River Irrigation Distict, Mont.; also representing Muggli Brothers, Inc. and Northern Plains Resource Council) UTESCH, PEGGY, (landowner; representing Western Organization of Resource Councils and Western Colorado Congress)

Title: $\quad$ Future of Fossil Fuels: Geological and Terrestrial Sequestration of Carbon Dioxide

Committee: House Subcommittee on Energy and Mineral Resources, Committee on Natural Resources

CIS number: 2007-H581-23

Date: $\quad$ May 1, 2007

Location: Washington, D.C.

Pages: $\quad 88$

Summary: Hearing to examine methods and technological potential of geological and terrestrial carbon sequestration to help reduce greenhouse gas emissions and curb global climate change.

\section{TESTIMONY \#1 - STATEMENTS AND DISCUSSION:}

Role of terrestrial sequestration and geologic capture and storage of carbon dioxide in efforts to reduce atmospheric carbon; outline of DOE efforts to develop carbon sequestration technologies to mitigate climate change; elaboration on geological and terrestrial sequestration of carbon dioxide and related issues.

LEAHY, P. PATRICK, (Associate Director, Geology, Geological Survey)

BAUER, CARL O., (Executive Director, National Energy Technology Laboratory, Department of Energy)

\section{TESTIMONY \#2 - STATEMENTS AND DISCUSSION:}

Overview of EnCana Corp. Weyburn carbon dioxide storage project in Saskatchewan, Canada, to reduce greenhouse gas emissions and reduce the impact of global climate change; findings and recommendations of MIT study on future of coal, focusing on role of carbon capture and sequestration in reducing carbon dioxide emissions; views on use and reuse of industrial and power plant carbon dioxide emissions for increasing domestic oil recovery; role of forests in carbon sequestration FAIRBURN, JUDY, (Vice President, Downstream Operations, EnCana Corp) HERZOG, HOWARD, (Principal Research Engineer, Laboratory for Energy and the 
Environment, Massachusetts Institute of Technology)

KUUSKRAA, VELLO A., (President, Advanced Resources International)

SCHLESINGER, WILLIAM H., (Dean, Nicholas School of the Environment and Earth

Sciences, Duke University)

KELLY, GEORGE W., (Treasurer, National Mitigation Banking Association)

GOERGEN, MICHAEL, (Executive Vice President and CEO, Society of American

Foresters)

Title: $\quad$ Gone with the Wind: Impacts of Wind Turbines on Birds and Bats

Committee: House Subcommittee on Fisheries, Wildlife, and Oceans, Committee on Natural Resources

CIS number: 2007-H581-21

Date: $\quad$ May 1, 2007

Location: Washington, D.C.

Pages: $\quad 86$

Summary: Hearing before to examine adverse effects on birds, bats, and other wildlife of wind turbine power-generating facilities, and to examine proposals to mitigate wind turbines adverse impact on wildlife.

TESTIMONY \#1 - STATEMENTS AND DISCUSSION:

Concerns about adverse impact of wind turbines on West Virginia wildlife.

MOLLOHAN, ALAN B., (Rep, D-WV)

TESTIMONY \#2 - STATEMENTS AND DISCUSSION:

Review of Fish and Wildlife service efforts to minimize wind turbines adverse impact on wildlife; concerns about injury and mortality to bats and birds caused by wind turbines, with recommendations (related bibl, p. 32-33); views on effect of wind turbine energy projects on birds; examination of legal and regulatory issues applicable to wind turbines impact on wildlife; pros and cons of wind turbines to environment, with support to address wind turbines adverse impact on wildlife.

HALL, H. DALE, (Director, Fish and Wildlife Service)

ARNETT, EDWARD B., (Program Coordinator, Bats and Wind Energy Cooperative;

also representing Bat Conservation International)

FRY, DONALD M., (Director, Pesticides and Birds Program, American Bird

Conservancy)

GLITZENSTEIN, ERIC R., (attorney)

DAULTON, MICHAEL, (Director, Conservation Policy, National Audubon Society)

Title: Achieving--At Long Last--Appliance Efficiency Standards

Committee: House Subcommittee on Energy and Air Quality, Committee on Energy

and Commerce

CIS number: 2009-H361-9

Date: $\quad$ May 1, 2007

Location: Washington, D.C.

Pages: $\quad 253$ 
Summary: Hearing before to examine DOE administration of energy conservation standards for household appliances under the Energy Policy and Conservation Act of 1975.

\section{TETIMONY - STATEMENTS AND DISCUSSION:}

Overview of DOE appliance standards and energy conservation programs; need for statutory reform and new DOE standards on energy efficiency (related slides, tables, graphs, p. 33-41); significance of national energy efficiency standards; arguments against proposals to develop regional energy efficiency standards; merits of Federal appliance energy standards program; description of Consumer Electronics Association efforts to inform consumers about appliance energy use and conservation; views on DOE appliance standards rulemaking process, with recommendations; importance of appliance efficiency standards for low-income consumers

KARSNER, ALEXANDER A., (Assistant Secretary, Energy Efficiency and Renewable Energy, DOE)

ROSENFELD, ARTHUR H., (Commissioner, California Energy Commission)

GADDIS, EVAN R., (President and CEO, National Electrical Manufacturers

Association)

MYERS, C. DAVID, (Vice President, Building Efficiency, Johnson Controls, Inc.; representing Air-Conditioning and Refrigeration Institute and Gas Appliance Manufacturers Association)

MCGUIRE, JOSEPH M., (President, Association of Home Appliance Manufacturers) JOHNSON, DOUGLAS K., (Senior Director, Technology Policy and International Affairs, Consumer Electronics Association) DELASKI, ANDREW, (Executive Director, Appliance Standards Awareness Project) HARAK, CHARLES, (Senior Attorney, Energy Project, National Consumer Law Center)

Hearings on corporate average fuel economy before the Committee on Commerce, Science, and Transportation. Senate, May 3, 2007 (No information available.)

Title: Energy Security and Oil Dependence -- Recommendations on Policies and Funding To Reduce U.S. Oil Dependence, Special Hearing

Committee: Senate Subcommittee on Energy and Water Development Appropriations, Committee on Appropriations

CIS number: 2008-S181-6

Date: $\quad$ May 8, 2007

Location: Washington, D.C.

Pages: $\quad 50$

Summary: Hearing to examine proposals to reduce U.S. dependence on foreign oil and promote U.S. energy security.

Also considers S. 875, the Security and Fuel Efficiency Energy Act of 2007, also known as the SAFE Energy Act of 2007, to revise energy policies and programs to promote increased energy efficiency and conservation, including provisions to increase corporate average fuel economy standards for passenger automobiles. 


\section{TESTIMONY - STATEMENTS AND DISCUSSION:}

Views on major provisions of S. 875, with outline of policies implemented by DOE to reduce U.S. oil dependence; recommendations for measures to reduce U.S. dependence on foreign sources of oil; analysis of economic effects of energy policy options proposed by the Energy Security Leadership Council; elaboration on policies to reduce U.S.

foreign oil dependence and related issues.

KARSNER, ALEXANDER A., (Assistant Secretary, Energy Efficiency and Renewable Energy, Department of Energy)

BURTON, R. M., (Director, Minerals Management Service)

SMITH, FREDERICK W., (Chairman, President, and CEO, FedEx Corp.; representing Energy Security Leadership Council)

JOHNSON, GREGORY G. (ADM., RET.), (former Commander, U.S. Naval Forces, Europe) WESCOTT, ROBERT F., (President, Keybridge Research LLC)

Title: Alternative Fuels: Current Status, Proposals for New Standards, and Related Infrastructure Issues

Committee: House Subcommittee on Energy and Air Quality, Committee on Energy and Commerce

CIS number: 2009-H361-13

Date: $\quad$ May 8, 2007

Location: Washington, D.C.

Pages: $\quad 195$

Summary: Hearing to examine Federal efforts and proposal to promote use of renewable and alternative fuels to improve energy security and environmental protection, and to review proposals to revise renewable fuel standard (RFS) established under the Energy Policy Act of 2005 and to increase renewable fuels use.

\section{TESTIMONY \#1 - STATEMENTS AND DISCUSSION:}

Review of Administration alternative fuel standard proposal to promote use of renewable and alternative fuels; overview of DOE programs to accelerate development and deployment of renewable and alternative fuels to reduce gasoline consumption and U.S. dependence on oil; elaboration on Administration renewable and alternative fuels development and use promotion efforts and proposal.

MEYERS, ROBERT J., (Associate Assistant Administrator, Office of Air and Radiation, EPA)

KARSNER, ALEXANDER A., (Assistant Secretary, Energy Efficiency and Renewable Energy, DOE)

\section{TESTIMONY \#2 - STATEMENTS AND DISCUSSION:}

Concerns about economic and consumer consequences of Federal alternative and renewable fuels mandates, with recommendations; views on proposals to expand RFS and renewable fuels use, with suggestions; impact on gasoline supply of alternative fuels and proposals for new alternative fuel standards, with recommendations; perspectives on RFS implementation and principles to guide increased biofuels use; viewed positive effects of RFS in promoting increased ethanol use, with suggestions. 
LOWERY, ELIZABETH A., (Vice President, Environment, Energy, and Safety Policy, General Motors Corp)

MITCHELL, WARREN I., (Board Chairman, Clean Energy Fuels Corp)

REID, PAUL D., (CEO, Reid Group; representing Society of Independent Gasoline

Marketers and National Association of Convenience Stores)

GRECO, ROBERT, (Group Director, Downstream and Industry Operations, American

Petroleum Institute)

DREVNA, CHARLES T., (Executive Vice President, National Petrochemical and

Refiners Association)

LASHOF, DANIEL A., (Science Director, Climate Center, Natural Resources Defense

Council)

DINNEEN, ROBERT, (President and CEO, Renewable Fuels Association)

Title: $\quad$ Administration Proposals on Climate Change and Energy Independence

Committee: House Committee on Transportation and Infrastructure

CIS number: 2008-H751-38

Date: $\quad$ May 11, 16, 2007

Location: Washington, D.C.

Pages: $\quad 531$

Summary: Hearings to examine potential impacts of global climate change, and to review Federal, State, and private sector efforts to promote energy efficiency and reduce greenhouse gas emissions in relation to surface transportation, Federal buildings,

aviation, and water resources

TESTIMONY \#1 - STATEMENTS AND DISCUSSION:

Overview of Administration climate change strategy, focusing on DOT congestion initiative; outline of EPA initiatives to address energy security and challenges posed by climate change; summary of Army Corps of Engineers efforts to address global climate change; description of GSA energy conservation initiatives; elaboration on represented agencies energy conservation initiatives and related issues

PETERS, MARY E., (Secretary, DOT)

JOHNSON, STEPHEN L., (Administrator, EPA)

WOODLEY, JOHN P., JR., (Assistant Secretary, Civil Works, Department of Army)

DOAN, LURITA A., (Administrator, GSA)

TESTIMONY \#2 - STATEMENTS AND DISCUSSION:

Outline of House of Representatives green the capital initiative to reduce environmental impacts associated with operation of House building complex in D.C.; description of AOC initiatives to conserve energy across U.S. Capitol complex.

BEARD, DANIEL P., (Chief Administrative Officer, House of Representatives)

AYERS, STEPHEN T., (Acting Architect of the Capitol, Office of the Architect of the Capitol (AOC))

FITZGERALD, STEVE, (Chief Engineer, Harris County, Tex., Flood Control District; representing National Association of Flood and Stormwater Management Agencies) GALLOWAY, GERALD E., (President, American Water Resources Association) RICHTER, BRIAN, (Director, Global Freshwater Initiative, Nature Conservancy) 
BRANDT, ALF W., (Principal Consultant, Committee on Water, Parks and Wildlife, California State Assembly)

STROUT, LINDA, (Deputy CEO, Port of Seattle; representing American Association of Port Authorities)

\section{TESTIMONY \#3 - STATEMENTS AND DISCUSSION:}

Views on climate change as potential design factor for stormwater and flood protection systems, with recommendations; review of water resource challenges facing U.S. and other countries, including impacts of climate change; perspectives on and recommendations regarding measures to address climate change ecosystem impacts, including streamflow alteration and flooding; overview of California water system, with outline of State government efforts to prepare for climate change effects on State water system; outline of seaport agencies efforts to reduce diesel engine emissions in commercial ports.

LASH, JONATHAN, (President, World Resources Institute)

MILLAR, WILLIAM W., (President, American Public Transportation Association)

HAMBERGER, EDWARD R., (President and CEO, Association of American Railroads)

CLARKE, ANDY D., (Executive Director, League of American Bicyclists)

HALL, EDWARD J., (General Manager, Engine Engineering, GE Transportation)

RADER, THOMAS G., (President, Colorado Railcar Manufacturing, LLC)

COHEN, GREGORY M., (President and CEO, American Highway Users Alliance)

\section{TESTIMONY \#4 - STATEMENTS AND DISCUSSION:}

Need to reduce energy use in buildings, citing importance of establishing new energy consumption standards for Federal buildings; benefits of energy efficiency, citing importance of accelerated investments in energy efficiency infrastructure; importance of improving energy efficiency and reducing energy waste within Federal Government in fixed facilities and mobile operations, with recommendations; role of solar technologies in reducing energy use in Federal buildings, with suggestions; elaboration on energy efficiency measures in buildings, including Federal buildings.

STEWART, R. K., (President, American Institute of Architects)

PRINDLE, WILLIAM, (Acting Executive Director, American Council for an Energy-

Efficient Economy)

HARRIS, JEFFREY, (Vice President, Programs, Alliance To Save Energy)

O'BRIEN, CHRISTOPHER,(Vice President, Strategy and Government Relations, Solar Energy Solutions Group, Sharp Electronics Corp.; representing Solar Energy Industries Association)

\section{TESTIMONY \#5 - STATEMENTS AND DISCUSSION:}

Overview of commercial airlines achievements in improving fuel efficiency and reducing carbon emissions, with recommendations; outline of greenhouse gas emission reduction strategies used by airports; description of United Technologies Corp. efforts to develop advanced energy efficient technologies for aviation and other uses; assessment of various alternative fuel options for aviation.

MAY, JAMES C., (President and CEO, Air Transport Association)

PRINCIPATO, GREGORY, (President, Airports Council International-North America)

MCQUADE, J. MICHAEL, (Senior Vice President, Science and Technology, United 
Technologies Corp)

ALTMAN, RICHARD L., (Executive Director, Commercial Aviation Alternative Fuels Initiative)

\section{TESTIMONY \#6 - STATEMENTS AND DISCUSSION:}

Views on climate change as potential design factor for stormwater and flood protection systems, with recommendations; review of water resource challenges facing U.S. and other countries, including impacts of climate change; perspectives on and recommendations regarding measures to address climate change ecosystem impacts, including streamflow alteration and flooding; overview of California water system, with outline of State government efforts to prepare for climate change effects on State water system; outline of seaport agencies efforts to reduce diesel engine emissions in commercial ports.

FITZGERALD, STEVE, (Chief Engineer, Harris County, Tex., Flood Control District; representing National Association of Flood and Stormwater Management Agencies) GALLOWAY, GERALD E., (President, American Water Resources Association) RICHTER, BRIAN, (Director, Global Freshwater Initiative, Nature Conservancy) BRANDT, ALF W., (Principal Consultant, Committee on Water, Parks and Wildlife, California State Assembly)

STROUT, LINDA, (Deputy CEO, Port of Seattle; representing American Association of Port Authorities)

Title: $\quad$ Protecting Our Children: Current Issues in Children's Product Safety Committee: House Subcommittee on Commerce, Trade, and Consumer Protection, Committee on Energy and Commerce

CIS number: 2009-H361-21

Date: $\quad$ May 15, 2007

Location: Washington, D.C.

Pages: $\quad 242$

Summary: Hearing to examine CPSC consumer product safety regulatory and reform activities in light of child death and injury due to product malfunctions, and to review proposals to improve child product safety.

Also briefly considers H.R. 1721, the Pool and Spa Safety Act, to direct the CPSC to administer a grant program to encourage States to enact comprehensive swimming pool and spa safety laws and educate the public about pool and spa safety.

TESTIMONY \#1 - STATEMENTS AND DISCUSSION:

Review of CPSC activities, citing accomplishments in efforts to increase child product safety; examination of CPSC prevention and response measures regarding potentially unsafe toys.

NORD, NANCY A., (Acting Chairman, CPSC)

\section{TESTIMONY \#2 - STATEMENTS AND DISCUSSION:}

Merits of proposals to establish safety regulations to help prevent accidental child injury and death; support for H.R. 1721; need to increase CPSC budget and resources and to expand CPSC authority to implement product safety standards. 
KORN, ALAN, (Director, Public Policy and General Counsel, Safe Kids Worldwide) WEINTRAUB, RACHEL, (Director, Product Safety and Senior Counsel, Consumer

Federation)

LOCKER, FREDERICK B., (General Counsel, Toy Industry Association)

FELCHER, E. MARLA, (Adjunct Lecturer, Public Policy, Kennedy School of

Government, Harvard University)

THOMAS, JAMES A., (President, ASTM International)

COWLES, NANCY, (Executive Director, Kids in Danger)

Title: Prospects for Advanced Coal Technologies: Efficient Energy Production, Carbon Capture and Sequestration

Committee: House Subcommittee on Energy and Environment, Committee on

Science and Technology

CIS number: 2008-H701-22

Date: $\quad$ May 15, 2007

Location: Washington, D.C.

Pages: $\quad 93$

Summary: Hearing to examine development of clean coal-based generation of energy, focusing on development of carbon capture and sequestration (CCS) technologies to address global climate change concerns associated with coal use in energy generation TESTIMONY - STATEMENTS AND DISCUSSION:

Overview of DOE clean coal technologies and CCS programs; views on and suggestions regarding development of CCS technologies to reduce greenhouse gas emissions from coal-based power systems in electricity generation; elaboration on benefits of clean coal and CCS technologies for domestic energy resources development BAUER, CARL O., (Director, National Energy Technology Laboratory, DOE)

FINLEY, ROBERT J., (Director, Energy and Earth Resources Center, Illinois Geological Survey)

RENCHECK, MICHAEL W., (Senior Vice President, Engineering Projects and Field Services, American Electric Power Co)

DALTON, STUART M., (Director, Generation, Electric Power Research Institute)

HILL, GARDINER, (Director, CCS Technology, BP p.l.c)

Hearings on green building before the Committee on Environment and Public Works. Senate, May 15, 2007 (No information available.)

Title: $\quad$ H.R. 2635, the Carbon-Neutral Government Act of 2007

Committee: House Subcommittee on Government Management, Organization, and Procurement, Committee on Oversight and Government Reform

CIS number: 2008-H601-24

Date: $\quad$ May 17, 2007

Location: Washington, D.C. 
Pages: $\quad 104$

Summary: Hearing before the Subcom on Government Management, Organization, and Procurement to consider H.R. 2635 (text, p. 4-39), the Carbon-Neutral Government Act of 2007, to amend the Energy Policy Act of 1992, the Energy Conservation and Production Act, and the National Energy Conservation Policy Act to promote Federal Government energy efficiency and require Federal agencies to achieve zero net greenhouse gas emissions by 2050.

\section{TESTIMONY - STATEMENTS AND DISCUSSION:}

Importance of greenhouse gas emissions reduction to reduce global climate change; benefits of energy efficiency in Federal facilities, with support for H.R. 2635; merits of H.R. 2635, with recommendations for Federal building energy efficiency standards; perspectives on energy conservation efforts in the Federal Government.

FIGDOR, EMILY, (Director, Federal Global Warming Program, U.S. Public Interest

Research Group)

HARRIS, JEFFREY, (Vice President, Programs, Alliance To Save Energy)

PURNELL, MARSHALL E., (President-Elect, American Institute of Architects)

Title: Developing Untapped Potential: Geothermal and Ocean Power

Technologies

Committee: House Subcommittee on Energy and Environment, Committee on

Science and Technology

CIS number: 2008-H701-11

Date: $\quad$ May 17, 2007

Location: Washington, D.C.

Pages: $\quad 126$

Summary: Hearing to consider the following bills:

H.R. 2304, the Advanced Geothermal Energy Research and Development Act of 2007, to direct DOE to support R\&D, demonstration, and commercial application programs for advanced technologies to locate and characterize geothermal resources and produce geothermal energy.

H.R. 2313, the Marine Renewable Energy Research and Development Act of 2007, to direct DOE to support R\&D, demonstration, and commercial application programs for marine renewable energy technologies, including tidal flow and ocean thermal energy conversion technologies.

\section{TESTIMONY - STATEMENTS AND DISCUSSION:}

Support for H.R. 2304 and H.R. 2313; merits of H.R. 2304 for U.S. geothermal resource development; overview and status of ocean power R\&D and technological innovations; need for assessments regarding energy technologies environmental impact.

TESTER, JEFFERSON, (Professor, Chemical Engineering, MIT)

THOMSEN, PAUL A., (Public Policy Manager, ORMAT Technologies, Inc.; also representing Geothermal Energy Association)

VON JOUANNE, ANNETTE, (Professor, Power Electronics and Energy Systems, Oregon State University) 
O'NEILL, SEAN,(President, Ocean Renewable Energy Coalition)

GREENE, NATHANAEL, (Senior Policy Analyst, Natural Resources Defense Council)

Title: $\quad$ Current Energy Legislation

Committee: Senate Subcommittee on Energy, Committee on Energy and Natural

Resources

CIS number: 2007-S311-45

Date: $\quad$ May 22, 2007

Location: Washington, D.C.

Pages: $\quad 19$

Summary: Hearing to consider the following bills:

S. 645, to amend the Energy Policy Act of 2005 to provide an alternate sulfur dioxide removal measurement for coal gasification projects that must meet certain emissions standards to be eligible to receive Federal funding under the clean coal power initiative for development of coal-based gasification technologies.

S. 1089, to authorize the Office of the Federal Coordinator for Alaska Natural Gas Transportation Projects to hire and terminate personnel as appropriate.

H.R. 85, to amend the Energy Policy Act of 2005 to direct DOE to establish a network of advanced energy technology transfer centers to encourage demonstration and commercial application of advanced energy methods and technologies.

S. 838, to establish a DOE program to provide grants for joint ventures between

nonfederal U.S. and Israeli entities to research, develop, and commercialize alternative and renewable energy sources.

S. 1203, to increase the number of Assistant Secretaries serving in DOE from seven to eight, and to express the sense of Congress that missions of DOE related to electricity delivery and reliability should be at the Assistant Secretary level.

H.R. 1126, to amend the Steel and Aluminum Energy Conservation and Technology Competitiveness Act of 1988 to extend and revise DOE R\&D programs to enhance the energy efficiency of processes that create steel and aluminum to reduce greenhouse gas emissions believed to contribute to global climate change.

TESTIMONY - STATEMENTS AND DISCUSSION:

Review of various bills under consideration.

PEARCE, DRUE, (Federal Coordinator, Office of the Federal Coordinator for Alaska

Natural Gas Transportation Projects)

HILL, DAVID R., (General Counsel, DOE)

Hearings on the Energy Policy Reform and Revitalization Act of 2007 before the Committee on Natural Resources. House, May 23, 2007 (No information available.)

Title: Discussion Drafts Concerning Energy Efficiency, Smart Electricity Grid, Energy Policy Act of 2005 Title XVII Loan Guarantees, and Standby Loans for Coal-to-Liquids Projects 
Committee: House Committee on Energy and Commerce

CIS number: 2009-H361-23

Date: $\quad$ May 24, 2007

Location: Washington, D.C.

Pages: $\quad 119$

Summary: Hearing before the Subcom on Energy and Air Quality to consider draft bill, to establish and implement various measures to promote renewable energy sources use and energy efficiency.

Includes provisions to:

a. Implement energy efficiency regulations, including new appliance standards, lighting efficiency improvements, and green building provisions.

b. Promote development of a smart electricity grid allowing consumers to shift power generation to off-peak hours.

c. Promote alternative energy R\&D by amending the Energy Policy Act of 2005 to address lack of DOE loan guarantees to the alternative energy industry.

d. Implement a Federal price guarantee for six coal-to-liquids (CTL) technology facilities.

\section{TESTIMONY \#1 - STATEMENTS AND DISCUSSION:}

Views on draft bill provisions, with recommendations to improve proposed energy regulations; overall merits of draft bill energy efficiency provisions, with suggestions; merits of smart electric grid systems, with views on and recommendations regarding smart grid provisions in draft bill; elaboration on draft bill provisions and related issues. RODGERS, DAVID E., (Deputy Assistant Secretary, Energy Efficiency, DOE) CALLAHAN, KATERI, (President, Alliance To Save Energy) BIRNBAUM, JAY, (Senior Vice President and General Counsel, CURRENT Group, LLC)

\section{TESTIMONY \#1 - STATEMENTS AND DISCUSSION:}

Mixed views regarding draft bill provisions; assessment of risks associated with CTL technology projects, with recommendations regarding Federal financial incentives to assist new technology deployment; support for draft bill energy efficiency and smart grid provisions, with opposition to draft bill provisions to promote CTL technologies.

FREDRIKSEN, KATHARINE A., (Principal Deputy Assistant Secretary, Policy and International Affairs, DOE)

MALEY, DONALD W., JR., (Vice President, Leucadia National Corp)

LASHOF, DANIEL A., (Science Director, Climate Center, National Resources Defense Council)

Title: Legislative Hearing on Discussion Draft Concerning Alternative Fuels, Infrastructure, and Vehicles

Committee: House Subcommittee on Energy and Air Quality, Committee on Energy and Commerce

CIS number: 2007-S311-39

Date: June 7, 2007

Location: Washington, D.C. 
Pages: $\quad 261$

Summary: Hearing before the Subcommittee on Energy and Air Quality to consider draft bill, to amend the Clean Air Act to establish additional Federal regulations and programs to reduce air pollution and greenhouse gas emissions from motor vehicles and to expand use of renewable and alternative motor vehicle fuels.

\section{TESTIMONY \#1 - STATEMENTS AND DISCUSSION:}

Review of ethanol industry status and future; analysis of alternative fuel program proposals contained in draft bill, with recommendations; differing views on draft bill, citing concerns about perceived bill failure to effectively limit fuel emissions; perspectives on draft bill possible impact on automobile industry. DINNEEN, ROBERT, (President and CEO, Renewable Fuels Association) DREVNA, CHARLES T., (Executive Vice President, National Petrochemical and Refiners Association) LAMPERT, PHILLIP J., (Executive Director, National Ethanol Vehicle Coalition) HUBBARD, SONJA, (CEO, E-Z Mart Stores; representing National Association of Convenience Stores and Society of Independent Gasoline Marketers) DECICCO, JOHN, (Senior Automotive Fellow, Environmental Defense) REUTHER, ALAN, (Legislative Director, United Automobile Workers) MCCURDY, DAVE, (President and CEO, Alliance of Automobile Manufacturers) TESTIMONY \#2 - STATEMENTS AND DISCUSSION:

Summary of DOE and EPA views on draft bill; perspectives on draft bill relating to President Bush May 2007 Executive order to reduce gasoline consumption and greenhouse gas emissions KARSNER, ALEXANDER A., (Assistant Secretary, Energy Efficiency and Renewable Energy, DOE) MEYERS, ROBERT J., (Acting Assistant Administrator, Office of Air and Radiation, EPA)

Title: $\quad$ Alternate Energy-Related Uses on the Outer Continental Shelf

Committee: Senate Committee on Energy and Natural Resources

CIS number: 2007-S311-49

Date: $\quad$ June 7, 2007

Location: Washington, D.C.

Pages: $\quad 60$

Summary: Hearing to examine Federal and State efforts to develop alternative energy resources and technologies on the outer continental shelf (OCS).

TESTIMONY \#1 - STATEMENTS AND DISCUSSION:

Review of Department of Interior and Minerals Management Service efforts to establish a program, as authorized by Section 388 of the Energy Policy Act of 2005, to regulate and administer OCS alternative energy projects; overview of FERC ocean-based hydropower licensing and regulatory activities; rationale for increased State authority over offshore alternative energy project development and regulation; elaboration on related issues, including MMS and FERC OCS jurisdictional conflicts. 
ALLRED, C. STEPHEN, (Assistant Secretary, Land and Minerals Management, Department of Interior; representing Minerals Management Service)

ROBINSON, J. MARK, (Director, Office of Energy Projects, Federal Energy Regulatory

Commission)

GRAINEY, MICHAEL W., (Director)

\section{TESTIMONY \#2 - STATEMENTS AND DISCUSSION:}

Negative impact of Federal jurisdictional conflicts and regulatory delays on private sector efforts to deploy offshore and OCS alternative energy projects

BAK, JASON, (CEO, Finavera Renewables, Inc)

STEVE, JAIME, (Legislative Director, American Wind Energy Association)

Title: Path Toward the Broader Use of Biofuels: Enhancing the Federal Commitment to Research and Development to Meet the Growing Need

Committee: House Subcommittee on Energy and Environment, Committee on

Science and Technology

CIS number: 2008-H701-24

Date: June 14, 2007

Location: Washington, D.C.

Pages: $\quad 92$

Summary: Hearing to examine energy industry efforts to develop biofuels technologies, in light of increasing U.S. dependence on foreign oil

TESTIMONY - STATEMENTS AND DISCUSSION:

Examination of represented organizations efforts to develop, produce, and market biofuels technologies; review of biomass resources, including ethanol industry; recommendations for biofuel and energy policies (related slides, graphs, p. 30-38 passim); support for Biofuels Research and Development Enhancement Act draft bill; analysis of R\&D priorities related to environmental impact of biofuel expansion; elaboration on biofuel technology R\&D activities.

FOUST, THOMAS D., (Biomass Technology Manager, National Renewable Energy Laboratory)

BERGER, JOHN, (President and CEO, Standard Renewable Energy; also representing BioSelect Fuels)

DINNEEN, ROBERT, (President and CEO, Renewable Fuels Association)

MCADAMS, MICHAEL J., (Executive Director, Government Affairs Group, Hart Downstream Energy Services; Advanced Biofuels Coalition)

WASKOW, DAVID, (International Program Director, Friends of the Earth)

Title: Research, Education and Training Programs to Facilitate Adoption of Solar Energy Technologies

Committee: House Subcommittee on Energy and Environment, Committee on

Science and Technology

CIS number: 2008-H701-6

Date: June 19, 2007 
Location: Washington, D.C.

Pages: $\quad 115$

Summary: Hearing to consider draft bill, the Solar Energy Research and

Advancement Act of 2007, to extend and revise DOE solar energy R\&D and commercial application of solar energy technologies programs

\section{TESTIMONY - STATEMENTS AND DISCUSSION:}

Overview of importance and availability of solar energy technology; support for draft bill, with views on benefits of solar energy R\&D reform and improved workforce training programs (related photos, p. 33-40); analysis of draft legislation, with recommendations; challenges to implementing solar energy technology.

HAYDEN, HERBERT T., (Coordinator, Solar Technology, Arizona Public Service Co) RESCH, RHONE, (President, Solar Energy Industries Association)

WEISSMAN, JANE M., (Executive Director, Interstate Renewable Energy Council; also representing North American Board of Certified Energy Practitioners)

SARUBBI, JOSEPH T., (Chair, Building Systems Technology Department, Hudson Valley Community College)

ARVIZU, DANIEL E., (Director, National Renewable Energy Laboratory)

Hearings on energy efficiency technologies before the Subcommittee on Science, Technology, and Innovation, Committee on Commerce, Science, and Transportation. Senate, June 21, 2007 (No available.)

Title: $\quad$ Renewable Fuels Infrastructure

Committee: Senate Subcommittee on Energy, Committee on Energy and Natural

Resources

CIS number: 2007-S311-57

Date: July 31, 2007

Location: Washington, D.C.

Pages: $\quad 82$

Summary: Hearing before the Subcommittee on Energy to examine use of alternative renewable energy resources within the transportation sector.

\section{TESTIMONY - STATEMENTS AND DISCUSSION:}

Review of successful renewable fuel production in Minnesota, focusing on implications for Federal energy policy KLOBUCHAR, AMY, (Sen., D-MN)

Title: $\quad$ Energy Efficiency Lighting

Committee: Senate Committee on Energy and Natural Resources

CIS number: 2008-S311-7

Date: $\quad$ September 12, 2007

Location: Washington, D.C.

Pages: $\quad 71$ 
Summary: Hearing to consider S. 2017, the Energy Efficient Lighting for a Brighter Tomorrow Act, to amend the Energy Policy and Conservation Act to provide for national energy efficiency standards for general service incandescent lamps.

TESTIMONY \#1 - STATEMENTS AND DISCUSSION:

Support for and merits of sponsored S. 2017.

HARMAN, JANE, (Rep, D-CA)

UPTON, FREDERICK S., (Rep, R-MI)

\section{TESTIMONY \#2 - STATEMENTS AND DISCUSSION:}

Overview of DOE initiatives to improve energy efficient lighting technologies; qualified support for S. 2017, with policy recommendations.

KARSNER, ALEXANDER A., (Assistant Secretary, Energy Efficiency and Renewable Energy, DOE)

\section{TESTIMONY \#3 - STATEMENTS AND DISCUSSION:}

Review of international status of policy efforts to phase-out inefficient incandescent lighting and potential energy savings of energy efficient lighting, with recommendations; support for S. 2017 to improve national energy efficiency standards; merits of S. 2017 to improve efficiency of lighting, with policy recommendations

WAIDE, PAUL, (Senior Policy Analyst, Energy Efficiency and Environment Division, International Energy Agency)

PITSOR, KYLE, (Vice President, Government Relations, National Electrical Manufacturers Association)

NADEL, STEVEN, (Executive Director, American Council for an Energy-Efficient Economy)

Title: $\quad$ Renewable Electricity Standards: Lighting the Way

Committee: House Committee on Energy Independence and Global Warming

CIS number: 2011-H961-10

Date: $\quad$ September 20, 2007

Location: Washington, D.C.

Pages: $\quad 115$

Summary: Hearing to examine State efforts to promote energy production from renewable electricity resources, and to review impact of proposal to establish a national renewable electricity standard (RES) to require electric utilities to obtain a certain percentage of electricity from renewable resources to mitigate global climate change.

TESTIMONY \#1 - STATEMENTS AND DISCUSSION:

Review of Colorado efforts to promote electric utilities use of renewable electricity resources.

RITTER, BILL, JR., (Governor, CO)

\section{TESTIMONY \#2 - STATEMENTS AND DISCUSSION:}

Views on renewable energy industry and benefits of a national RES; positive impact of State RES on wind energy industry in Texas; perspectives on renewable resources use and effects of proposed national RES on electric utilities; viewed importance and positive impact of renewable energy 
FLOYD, NANCY, (Founder and Managing Director, Nth Power LLC; also representing Environmental Entrepreneurs and American Council On Renewable Energy)

SLOAN, MIKE, (Managing Consultant, Wind Coalition)

HOBSON, CHRIS M., (Senior Vice President, Research and Environmental Affairs, Southern Co)

REEDY, BOB, (Director, Solar Energy Division, Florida Solar Energy Center)

FOSTER, DAVID, (Executive Director, Blue Green Alliance)

Title: $\quad$ Revisiting the Industrial Technologies Program (ITP): Achieving Industrial Efficiency

Committee: House Subcommittee on Energy and Environment, Committee on

Science and Technology

CIS number: 2008-H701-23

Date: $\quad$ September 25, 2007

Location: Washington, D.C.

Pages: $\quad 50$

Summary: Hearing to examine DOE industrial technologies program (ITP), which seeks to improve the energy intensity of U.S. industry through coordinated R\&D and dissemination of innovative energy efficiency technologies and practices

\section{TESTIMONY - STATEMENTS AND DISCUSSION:}

Perspectives on DOE ITP regulations, with policy recommendations to improve program to increase manufacturing industry energy efficiency; views on and suggestions regarding ITP program; merits of university-based industrial assessment centers sponsored by ITP program.

MOORE, FREDERICK L., (Global Director, Manufacturing and Technology, Dow Chemical Co.; also representing National Association of Manufacturers)

CICIO, PAUL N., (President, Industrial Energy Consumers of America)

KAVANAGH, LAWRENCE W., (Vice President, Manufacturing and Technology, American Iron and Steel Institute; representing Alliance for Materials Manufacturing Excellence)

VERDICT, MALCOLM E., (Associate Director, Energy Systems Laboratory, Texas Engineering Experiment Station)

Title: Geothermal Energy Initiative

Committee: Senate Committee on Energy and Natural Resources

CIS number: 2008-S311-8

Date: $\quad$ September 26, 2007

Location: Washington, D.C.

Pages: $\quad 117$

Summary: Hearing to consider S. 1543, the National Geothermal Initiative Act of 2007, to amend the Energy Policy Act of 2005 to establish a national goal to produce twenty percent of electrical energy production from geothermal resources by 2030, and to direct DOE and Department of Interior to establish research, development, and 
demonstration programs in support of the national goal.

Also briefly examines enhanced geothermal systems (EGS) technologies, to produce electricity from geothermal resources that lack sufficient water or permeability for conventional geothermal resource production methods.

\section{TESTIMONY \#1 - STATEMENTS AND DISCUSSION:}

Benefits of and perspectives on geothermal energy resource production, with background on Iceland industry development; suggestions and viewed potential for development of U.S. geothermal energy production, with views on U.S.-Iceland cooperation; elaboration on geothermal energy resource production technologies and international geothermal energy industry issues.

GRIMSSON, OLAFUR RAGNAR, (President of Iceland)

\section{TESTIMONY \#2 - STATEMENTS AND DISCUSSION:}

Concerns about S. 1543, citing feasibility of achieving provision goals within mandated timeframes; review of DOE and Geological Survey geothermal energy resource R\&D programs; perspectives on geothermal energy resource development potential KARSNER, ALEXANDER A., (Assistant Secretary, Energy Efficiency and Renewable Energy, DOE) MYERS, MARK D., (Director, Geological Survey, Department of Interior) TESTIMONY \#3 - STATEMENTS AND DISCUSSION:

Viewed potential for development of geothermal resources, focusing on EGS technologies; support for and perspectives on S. 1543; benefits of Federal funding for geothermal resource development programs.

PETTY, SUSAN, (President, AltaRock Energy, Inc)

SHEVENELL, LISA, (Director, Great Basin Center for Geothermal Energy, University of Nevada, Reno)

WUNSCH, DAVID R., (Geologist and Director, New Hampshire Geological Survey; representing Association of American State Geologists)

WILLIAMSON, KENNETH H., (geothermal consultant)

Title: Energy Storage Technologies: State of Development for Stationary and Vehicular Applications

Committee: House Subcommittee on Energy and Environment, Committee on Science and Technology

CIS number: 2008-H701-34

Date: $\quad$ October 3, 2007

Location: Washington, D.C.

Pages: $\quad 88$

Summary: Hearing to examine energy storage R\&D programs for stationary and vehicular technologies

TESTIMONY \#1 - STATEMENTS AND DISCUSSION:

Review of DOE stationary and vehicular energy storage technologies R\&D programs; views on value of deploying energy storage in U.S. electrical grid; significance of deploying energy storage for improvement in security and performance of U.S. electricity infrastructure. 
HOFFMAN, PATRICIA A., (Deputy Director, Research and Development, Office of Electricity Delivery and Energy Reliability, DOE)

ROBERTS, BRADFORD P., (Board Chairman, Electricity Storage Association)

DICKERMAN, LARRY, (Director, Distribution Engineering Services, American

Electric Power)

KEY, THOMAS S., (Technical Leader, Renewable and Hydropower Generation, Electric Power Research Institute)

\section{TESTIMONY \#2 - STATEMENTS AND DISCUSSION:}

Perspectives on efforts to promote advanced battery technologies for energy storage; review of alternative energy resources $R \& D$ for automobiles; outline of challenges facing hybrid vehicles production and electric vehicle industry development, with policy recommendations.

ZIEGLER, LYNDA L., (Senior Vice President, Customer Service, Southern California Edison)

GRAY, DENISE, (Director, Hybrid Energy Storage Systems, General Motors Corp) WRIGHT, MARY ANN, (Vice President and General Manager, Hybrid Battery Systems, Johnson Controls, Inc)

Title: $\quad$ Full Committee Hearing on Small Business Energy Priorities

Committee: House Committee on Small Business

CIS number: 2008-H721-45

Date: $\quad$ October 17, 2007

Location: Washington, D.C.

Pages: $\quad 69$

Summary: Hearing to examine economic impact of rising energy costs and energy resources availability on small businesses.

Also considers H.R. 3221, the New Direction for Energy Independence, National Security, and Consumer Protection Act, to revise energy tax incentives to promote renewable energy and energy conservation.

TESTIMONY - STATEMENTS AND DISCUSSION:

Concerns about H.R. 3221 impact on residential construction; support for H.R. 3221, including provisions to promote energy conservation and efficiency; criticism of H.R. 3221, citing burdens on oil and natural gas energy resources development THOMPSON, FRANK, (Owner, Sweetwater Builders; representing National Association of Home Builders)

CROPP, MITCHELL, (President, Cropp-Metcalfe Air Conditiong-Heating-Security; representing Air Conditioning Contractors of America and Plumbing-Heating-Cooling Contractors Association)

RODRIGUEZ, MIGUEL A., (Principal, Rodriguez Architects, Inc.; representing American Institute of Architects)

FULLER, LEE, (Vice President, Government Relations, Independent Petroleum Association) 


\section{Appendix XXII}

\section{Bill cosponsors}

Public Law 95-618 - Energy Tax Act - H. R. 5263

Sponsored by Rostenkowski (D-IL)

No cosponsors

Public Law 100-494 - Alternative Motor Fuels Act of 1988 - S 1518

Sponsored by: Rockefeller (D-WV)

64 cosponsors (20:44 Republicans: Democrats)

John Danforth [R-MO] - 7/21/1987

Pete Wilson [R-CA] - 7/21/1987

Timothy Wirth [D-CO] - 7/21/1987

Alan Cranston [D-CA] - 7/21/1987

Robert Byrd [D-WV] - 7/21/1987

Bennett Johnston [D-LA] - 7/21/1987

Tom Daschle [D-SD] - 7/21/1987

Robert Kasten [D-WI] - 7/21/1987

Richard Lugar [R-IN] - 7/21/1987

John McCain [D-AZ] - 7/21/1987

Jeff Bingaman [D-NM] - 7/21/1987

James Exon [D-NE] - 7/21/1987

Alan Dixon [D-IL] - 7/21/1987

Patrick Moynihan [D-NY] - 7/21/1987

Donald Riegle [D-MI] - 8/6/1987

Dale Bumpers [D-AR] - 8/6/1987

Kent Conrad [D-ND] - 8/6/1987

Lloyd Bentsen [D-TX] - 8/6/1987

Paul Tribble [R-VA] - 9/25/1987

Joe Biden [D-DE] - 9/25/1987

Tom Harkin [D-IA] - 9/25/1987

Larry Pressler [R-SD] - 10/28/1987

Bob Packwood [R-OR] - 10/28/1987

Ted Stevens [R-AK] - 11/18/1987

Ernest Hollings [D-SC] - 11/19/1987

Daniel Inouye [D-HI] - 11/19/1987

Al Gore [D-TN] - 11/19/1987

Brock Adams [D-WA] - 11/19/1987

John Breaux [D-LA] - 11/19/1987

Nancy Kassebaum [R-KS] - 11/19/1987

Wendell Ford [D-KY] - 11/19/1987

John Kerry [D-MA] - 11/19/1987

Bob Graham [D-FL] - 11/19/1987

David Pryor [D-AR] - 11/19/1987 
John Melcher [D-MT] - 11/19/1987

John Heinz [R-PA] - 11/19/1987

Howell Heflin [D-AL] - 11/19/1987

Richard Shelby [D-AL] - 11/19/1987

John Warner [R-VA] - 11/19/1987

Paul Simon [D-IL] - 11/19/1987

Jim Sasser [D-TN] - 11/19/1987

Spark Matsunaga [D-HI] - 11/19/1987

Claiborne Pell [D-RI] - 11/19/1987

Alfonse D'Amato [R-NY] - 11/19/1987

Harry Reid [D-NV] - 11/19/1987

Max Baucus [D-MT] - 11/19/1987

Terry Sanford [D-NC] - 11/19/1987

Chuck Grassley [R-IA] - 11/19/1987

Quentin Burdick [D-ND] - 11/19/1987

Dennis DeConcini [D-AZ] - 11/19/1987

William Roth [R-DE] - 11/19/1987

Wyche Fowler [D-GA] - 11/19/1987

William Armstrong [R-CO] - 11/19/1987

Arlen Specter [R-PA] - 11/19/1987

Dan Quayle [D-IN] - 11/19/1987

Mitch McConnell [R-KY] - 11/19/1987

Alan Simpson [R-WY] - 11/20/1987

Carl Levin [D-MI] - 11/20/1987

Thad Cochran [R-MS] - 11/20/1987

David Boren [D-OK] - 11/20/1987

John Glen [D-OH] - 12/18/1987

John Stennis [D-MS] - 12/18/1987

Daniel Evans [R-WA] - 3/21/1988

James McClure [R-ID] - 4/13/1988

Public Law 102-486 - Energy Policy Act of 1992

Sponsored by: Sharp (D-IN)

54 cosponsors $\quad$ (5:49 Republicans: Democrats)

John Dingell [D-MI-16] - 2/4/1991

Edward Markey [D-MA-7] - 2/4/1991

Al Swift [D-WA-2] - 2/4/1991

Jim Slattery [D-KS-2] - 2/4/1991

Edolphus Towns [D-NY-11] - 2/4/1991

Charles Wilson [D-TX-2] - 3/20/1991

John LaFalce [D-NY-32] - 3/20/1991

Marcy Kaptur [D-OH-9] - 3/20/1991

Christopher Shays [R-CT-4] - 3/20/1991

Donald Pease [D-OH-13] - 3/20/1991

Sam Gejdenson [D-CT-2] - 3/20/1991

Eliot Engel [D-NY-19] - 3/20/1991 
Doug Barnard [D-GA-10] - 3/20/1991

Bart Gordon [D-TN-6] - 3/20/1991

Jolene Unsoeld [D-WA-3] - 3/20/1991

Peter DeFazio [D-OR-4] - 3/20/1991

James Scheuer [D-NY-8] - 3/20/1991

Martin Frost [D-TX-24] - 3/20/1991

Lee Hamilton [D-IN-9] - 3/20/1991

Stephen Neal [D-NC-5] - 3/20/1991

Jill Long [D-IN-4] - 3/20/1991

Nita Lowey [D-NY-20] - 3/20/1991

Ted Weiss [D-NY-17] - 3/20/1991

Charles Schumer [D-NY-10] - 3/20/1991

Frank Horton [R-NY-29] - 4/15/1991

Michael McNulty [D-NY-23] - 4/15/1991

William Ford [D-MI-15] - 4/15/1991

Jose Serrano [D-NY-18] - 4/15/1991

Jim Jontz [D-IN-5] - 4/15/1991

George Hochbrueckner [D-NY-1] - 4/15/1991

Vic Fazio [D-CA-4] - 4/15/1991

Floyd Flake [D-NY-6] - 4/22/1991

Gerald Kleczka [D-WI-4] - 4/22/1991

Louise Slaughter [D-NY-30] - 4/24/1991

Gerry Sikorski [D-MN-6] - 4/24/1991

Henry Nowak [D-NY-33] - 4/24/1991

Gerry Studds [D-MA-10] - 4/29/1991

William Hughes [D-NJ-2] - 5/8/1991

David Skaggs [D-CO-2] - 5/8/1991

Sidney Yates [D-IL-9] - 5/8/1991

Ronald Machtley [R-RI-1] - 5/8/1991

Terry Bruce [D-IL-19] - 5/14/1991

Ben Jones [D-GA-4] - 5/14/1991

Jack Reed [D-RI-2] - 6/18/1991

Robert Wise [D-WV-3] - 6/24/1991

Dick Swett [D-NH-2] - 7/9/1991

Richard Neal [D-MA-2] - 7/25/1991

John Olver [D-MA-1] - 7/31/1991

Eni Faleomavaega [D-AS] - 9/11/1991

Barbara Boxer [D-CA-6] - 9/19/1991

Ben Blaz [R-GU] - 2/11/1992

Bill Alexander [D-AR-1] - 3/24/1992

Thomas Caper [D-DE-98] - 4/1/1992

Jim Ramstad [R-MN-3] - 5/5/1992 
Public Law 106-224 Agricultural Risk Protection Act of 2000 HR 2559

Sponsored by: Combest (R-TX)

12 cosponsors (all Republicans)

Thomas Ewing [R-IL-15] - 7/20/1999

Bill Barrett [R-NE-3] - 7/20/1999

Roy Blunt [R-MO-7] - 7/20/1999

Charles Canady [R-FL-12] - 7/20/1999

Ed Whitfield [R-KY-1] - 7/20/1999

Doug Bereuter [R-NE-1] - 7/20/1999

Pete Sessions [R-TX-5] - 7/20/1999

Robin Hayes [R-NC-8] - 7/20/1999

Rick Hills [R-MT] - 8/3/1999

Benjamin Gilman [R-NY-20] - 8/3/1999

Nick Smith [R-MI-7] - 8/3/1999

John Cooksey [R- LA-5] - 8/3/1999

Public Law Number 109-58 - Energy Policy Act - H.R. 6 Sponsored by: Barton (R-TX)

2 cosponsors

Richard Pombo [R-CA-11] - 4/18/2005

William Thomas [R-CA-22] - 4/18/2005

Public Law Number 110-140

Energy Independence and Security Act of 2007 - H.R. 6 Sponsored by: Rahall (D-WV)

198 cosponsors $\quad$ (3:195 Republicans: Democrats)

Charles Rangel [D-NY-15] - 1/12/2007

Jerry McNerney [D-CA-11] - 1/12/2007

Roscoe Bartlett [R-MD-6] - 1/12/2007

Wayne Gilchrest [R-MD-1] - 1/12/2007

Pete Stark [D-CA-13] - 1/12/2007

Sander Levin [D-MI-12] - 1/12/2007

Jim McDermott [D-WA-7] - 1/12/2007

John Lewis [D-GA-5] - 1/12/2007

Richard Neal [D-MA-2] - 1/12/2007

Michael McNulty [D-NY-21] - 1/12/2007

John Tanner [D-TN-8] - 1/12/2007(withdrawn - 1/16/2007)

Xavier Becerra [D-CA-31] - 1/12/2007

Lloyd Doggett [D-TX-25] - 1/12/2007

Earl Pomeroy [D-ND] - 1/12/2007

Stephanie Jones [D-OH-11] - 1/12/2007

Mike Thompson [D-CA-1] - 1/12/2007

John Larson [D-CT-1] - 1/12/2007 
Rahm Emanuel [D-IL-5] - 1/12/2007

Earl Blumenauer [D-OR-3] - 1/12/2007

Ron Kind [D-WI-3] - 1/12/2007

Bill Pascrell [D-NJ-8] - 1/12/2007

Shelley Berkley [D-NV-1] - 1/12/2007

Joseph Crowley [D-NY-7] - 1/12/2007

Chris Van Hollen [D-MD-8] - 1/12/2007

Kendrick Meek [D-FL-17] - 1/12/2007

Allyson Schwartz [D-PA-13] - 1/12/2007

Artur Davis [D-AL-7] - 1/12/2007

Gary Ackerman [D-NY-5] - 1/12/2007

Thomas Allen [D-ME-1] - 1/12/2007

Jason Altmire [D-PA-4] - 1/12/2007

Robert Andrews [D-NJ-1] - 1/12/2007

Michael Arcuri [D-NY-24] - 1/12/2007

Joe Baca [D-CA-43] - 1/12/2007

Brian Baird [D-WA-3] - 1/12/2007

Tammy Baldwin [D-WI-2] - 1/12/2007

Howard Berman [D-CA-28] - 1/12/2007

Marion Berry [D-AR-1] - 1/12/2007

Timothy Bishop [D-NY-1] - 1/12/2007

Sanford Bishop [D-GA-2] - 1/12/2007

Madeleine Bordallo [D-GU] - 1/12/2007

Leonard Boswell [D-IA-3] - 1/12/2007

Rick Boucher [D-VA-9] - 1/12/2007

Robert Brady [D-PA-1] - 1/12/2007

Bruce Braley [D-IA-1] - 1/12/2007

G.K. Butterfield [D-NC-1] - 1/12/2007

Lois Capps [D-CA-23] - 1/12/2007

Michael Capuano [D-MA-8] - 1/12/2007

Dennis Cardoza [D-CA-18] - 1/12/2007

Ross Carnahan [D-MO-3] - 1/12/2007

Christopher Carney [D-PA-10] - 1/12/2007

Julia Carson [D-IN-7] - 1/12/2007

Kathy Castor [D-FL-11] - 1/12/2007

Ben Chandler [D-KY-6] - 1/12/2007

Donna Christensen [D-VI] - 1/12/2007

Yvette Clarke [D-NY-11] - 1/12/2007

Lacy Clay [D-MO-1] - 1/12/2007

Emanuel Cleaver [D-MO-5] - 1/12/2007

James Clyburn [D-SC-6] - 1/12/2007

Steve Cohen [D-TN-9] - 1/12/2007

John Conyers [D-MI-14] - 1/12/2007

Jim Cooper [D-TN-5] - 1/12/2007

Joe Courtney [D-CT-2] - 1/12/2007

Elijah Cummings [D-MD-7] - 1/12/2007

Danny Davis [D-IL-7] - 1/12/2007 
Lincoln Davis [D-TN-4] - 1/12/2007

Peter DeFazio [D-OR-4] - 1/12/2007

Diana DeGette [D-CO-1] - 1/12/2007

William Delahunt [D-MA-10] - 1/12/2007

Rosa DeLauro [D-CT-3] - 1/12/2007

Norman Dicks [D-WA-6] - 1/12/2007

John Dingell [D-MI-15] - 1/12/2007

Michael Doyle [D-PA-14] - 1/12/2007

Keith Ellison [D-MN-5] - 1/12/2007

Brad Ellsworth [D-IN-8] - 1/12/2007

Anna Eshoo [D-CA-14] - 1/12/2007

Bob Etheridge [D-NC-2] - 1/12/2007

Eni Faleomavaega [D-AS] - 1/12/2007

Sam Farr [D-CA-17] - 1/12/2007

Chaka Fattah [D-PA-2] - 1/12/2007

Bob Filner [D-CA-51] - 1/12/2007

Barney Frank [D-MA-4] - 1/12/2007

Gabrielle Giffords [D-AZ-8] - 1/12/2007

Kristen Gillibrand [D-NY-20] - 1/12/2007

Charles Gonzalez [D-TX-20] - 1/12/2007(withdrawn - 1/16/2007)

Bart Gordon [D-TN-6] - 1/12/2007

Raul Grijalva [D-AZ-7] - 1/12/2007

Luis Guitierrez [D-IL-4] - 1/12/2007

Phil Hare [D-IL-17] - 1/12/2007

Jane Harman [D-CA-36] - 1/12/2007

Alcee Hastings [D-FL-23] - 1/12/2007

Stephanie Herseth [D-SD] - 1/12/2007

Brian Higgins [D-NY-27] - 1/12/2007

Baron Hill [D-IN-9] - 1/12/2007

Maurice Hinchey [D-NY-22] - 1/12/2007

Mazie Hirono [D-HI-2] - 1/12/2007

Paul Hodes [D-NH-2] - 1/12/2007

Tim Holden [D-PA-17] - 1/12/2007

Rush Holt [D-NJ-12] - 1/12/2007

Michael Honda [D-CA-15] - 1/12/2007

Darlene Hooley [D-OR-5] - 1/12/2007

Steny Hoyer [D-MD-5] - 1/12/2007

Jay Inslee [D-WA-1] - 1/12/2007

Steve Israel [D-NY-2] - 1/12/2007

Jesse Jackson, Jr. [D-IL-2] - 1/12/2007

Sheila Jackson-Lee [D-TX-18] - 1/12/2007

Hank Johnson [D-GA-4] - 1/12/2007

Steve Kagen [D-WI-8] - 1/12/2007

Marcy Kaptur [D-OH-9] - 1/12/2007

Patrick Kennedy [D-RI-1] - 1/12/2007

Dale Kildee [D-MI-5] - 1/12/2007

Carolyn Kilpatrick [D-MI-13] - 1/12/2007 
Ron Klein [D-FL-22] - 1/12/2007

Dennis Kucinich [D-OH-10] - 1/12/2007

James Langevin [D-RI-2] - 1/12/2007

Tom Lantos [D-CA-12] - 1/12/2007

Rick Larsen [D-WA-2] - 1/12/2007

Barbara Lee [D-CA-9] - 1/12/2007

David Loebsack [D-IA-2] - 1/12/2007

Zoe Lofgren [D-CA-16] - 1/12/2007

Nita Lowey [D-NY-18] - 1/12/2007

Stephen Lynch [D-MA-9] - 1/12/2007

Tim Mahoney [D-FL-16] - 1/12/2007

Carolyn Maloney [D-NY-14] - 1/12/2007

Edward Markey [D-MA-7] - 1/12/2007

Doris Matsui [D-CA-5] - 1/12/2007

Carolyn McCarthy [D-NY-4] - 1/12/2007

Betty McCollum [D-MN-4] - 1/12/2007

James McGovern [D-MA-3] - 1/12/2007

Mike McIntyre [D-NC-7] - 1/12/2007

Martin Meehan [D-MA-5] - 1/12/2007

Michael Michaud [D-ME-2] - 1/12/2007

Juanita Millender-McDonald [D-CA-37] - 1/12/2007

George Miller [D-CA-7] - 1/12/2007

Harry Mitchell [D-AZ-5] - 1/12/2007

Dennis Moore [D-KS-3] - 1/12/2007

James Moran [D-VA-8] - 1/12/2007

Christopher Murphy [D-CT-5] - 1/12/2007

Patrick Murphy [D-PA-8] - 1/12/2007

Jerrold Nadler [D-NY-8] - 1/12/2007

Grace Napolitano [D-CA-38] - 1/12/2007

Eleanor Norton [D-DC] - 1/12/2007

James Oberstar [D-MN-8] - 1/12/2007

David Obey [D-WI-7] - 1/12/2007

John Olver [D-MA-1] - 1/12/2007

Frank Pallone [D-NJ-6] - 1/12/2007

Ed Pastor [D-AZ-4] - 1/12/2007

Donald Payne [D-NJ-10] - 1/12/2007

Ed Perlmutter [D-CO-7] - 1/12/2007

Collin Peterson [D-MN-7] - 1/12/2007

David Price [D-NC-4] - 1/12/2007

Silvestre Reyes [D-TX-16] - 1/12/2007

Ciro Rodriguez [D-TX-23] - 1/12/2007

Mike Ross [D-AR-4] - 1/12/2007

Steven Rothman [D-NJ-9] - 1/12/2007

Lucille Roybal-Allard [D-CA-34] - 1/12/2007

Dutch Ruppersberger [D-MD-2] - 1/12/2007

Bobby Rush [D-IL-1] - 1/12/2007

Tim Ryan [D-OH-17] - 1/12/2007 
Linda Sanchez [D-CA-39] - 1/12/2007

John Sarbanes [D-MD-3] - 1/12/2007

Janice Schakowsky [D-IL-9] - 1/12/2007

Adam Schiff [D-CA-29] - 1/12/2007

David Scott [D-GA-13] - 1/12/2007

Bobby Scott [D-VA-3] - 1/12/2007

Jose Serrano [D-NY-16] - 1/12/2007

Joe Sestak [D-PA-7] - 1/12/2007

Carol Shea-Porter [D-NH-1] - 1/12/2007

Brad Sherman [D-CA-27] - 1/12/2007

Albio Sires [D-NJ-13] - 1/12/2007

Ike Skelton [D-MO-4] - 1/12/2007

Louise Slaughter [D-NY-28] - 1/12/2007

Adam Smith [D-WA-9] - 1/12/2007

Hilda Solis [D-CA-32] - 1/12/2007

Zachary Space [D-OH-18] - 1/12/2007

John Spratt [D-SC-5] - 1/12/2007

Bart Stupak [D-MI-1] - 1/12/2007

Betty Sutton [D-OH-13] - 1/12/2007

Ellen Tauscher [D-CA-10] - 1/12/2007

Bennie Thompson [D-MS-2] - 1/12/2007

John Tierney [D-MA-6] - 1/12/2007

Mark Udall [D-CO-2] - 1/12/2007

Tom Udall [D-NM-3] - 1/12/2007

Nydia Valezquez [D-NY-12] - 1/12/2007

Timothy Walz [D-MN-1] - 1/12/2007

Debbie Wasserman Schultz [D-FL-20] - 1/12/2007

Maxine Waters [D-CA-35] - 1/12/2007

Diane Watson [D-CA-33] - 1/12/2007

Henry Waxman [D-CA-30] - 1/12/2007

Anthony Weiner [D-NY-9] - 1/12/2007

Peter Welch [D-VT] - 1/12/2007

Robert Wexler [D-FL-19] - 1/12/2007

Charles Wilson [D-OH-6] - 1/12/2007

Lynn Woolsey [D-CA-6] - 1/12/2007

David Wu [D-OR-1] - 1/12/2007

Albert Wynn [D-MD-4] - 1/12/2007

John Yarmuth [D-KY-3] - 1/12/2007

Eliot Engel [D-NY-17] - 1/17/2007

Daniel Lipinski [D-IL-3] - 1/17/2007

Susan Davis [D-CA-53] - 1/17/2007

Christopher Shays [R-CT-4] - 1/17/2007 


\section{Appendix XXIII}

\section{Public Law 95-618 Hearing Excerpts}

Lobbying, both pro and con, by interested parties was evident in many of these hearings. The "Economic Feasibility of Gasohol" hearing record conducted on December 12th, 1977 before the Senate Committee on Agriculture, Nutrition and Forestry contains several illuminative statements: Witness: HENDERSON, Robert, exec director, Indianapolis, Ind., Center for Advanced Research. Summary: Witness thanks subcommittee for bringing the hearing to Indiana. He states that using today's techniques for farm production and grain fermentation, the utilization of ethanol in gasohol will not have the effect of reducing oil imports, and might possibly increase oil imports., Witness: MILLER, Dwight L., Assistant Director, North Regional Research Center, Agricultural Research Service, USDA. Summary: Witness testifies that it is economics that prevents alcohol (ethanol) from being used as fuel. One bushel of grains can produce 2.5 gallons of alcohol. A $10 \%$ blend in the 110 billion gallons of gasoline per year (in the U.S.) means 11 billion gallons of ethanol which means 4.4 billion bushels of grain needed, which would have a major impact on U.S. agriculture. Witness states that there are no large-volume factories, and even if there were they would have to be producing non-stop (even in grain-shortage periods) in order to keep costs down. Furthermore, more energy is required to produce the ethanol than the energy that would be released by the ethanol produced. Witness: KOHLS, Richard L., Dean, School of Agriculture, Purdue University. Summary: The witness states that a subsidy of alcohol to the tune of $\$ 0.60$ per gallon (for a total of $\$ 6.5$ billion is necessary to make gasohol competitive with gasoline (these are 1977 dollars). The second problem is that for a mix of $10 \%$ alcohol to $90 \%$ gasoline, we would need 4.3 billion bushels of grain; to put it in perspective, the total U.S. production in 1976 was 6.4 billion bushels (only 500 million bushels in surplus). This would result in less than $10 \%$ reduced imports of oil. A negative side effect would be the reduction of U.S. exports of petroleum byproducts. The witness summarizes the view of researchers at Purdue: The proposal to move from gasoline to gasohol is over simplistic. Although it is desirable from a policy standpoint, food supplies and international trade would be greatly affected by it. Encouraging more alcohol production from grain sources would increase the market for corn and decrease the use of petroleum in making alcohol. The Purdue process to make alcohol from cellulose has great potential but it is still in its initial stages of development. Witness: ORR, Robert D., Lt Governor, Indiana. Summary: The witness testifies to Indiana efforts in the matter. Indiana legislature created a research fund (paid for by the farmers) and a Research Council to 
provide policy guidance. Two research studies have been done. The first shows that gasohol as a mixture of gasoline and grain alcohol is functionally feasible, but not economically feasible. The second research project was the blueprint of a plant that would produce ethanol from grain, but the economics of it have resulted in little investment and no functioning plant as to date. The witness commends the loan guarantees (for building ethanol plants) provided in the new farm bill. He advocates for geographical proximity for pilot plants and research facilities. The witness advocates for a subsidy, and claims that this is his understanding on how Brazil does it (he visited Brazil). Witness: FRENCH, Philip F., assistant executive vice-president Indiana Farm Bureau Co-operative Association, Indianapolis. Summary: Witness started by stating that the current economics of natural resources (read oil) only takes into account the price of discovering them and developing them, it does not take into account the millions of years that it took in creating them; that is take into account the fact that natural resources are dwindling. He suggests the need for commitment to technology similar to the space program in the 1960s. He proposes three avenues: Remove price controls and environmental restraints on developing existing natural resources. Establish a massive research program for alternative sources, including alcohol from grain. Aggressively pursue opportunities for export of U.S. grains and soybean crops. Witness says that an excess profit tax mechanism on the oil industry would be needed. He thinks that is what Brazil is doing. Witness: CRAY, Cloud L., Jr., President, Midwest Solvents Co. Summary: This witness conducted a gasohol seminar in September of that year in Brazil. His business has been producing grain ethanol for 35 years (these are beverage alcohol plants). The witness testifies that his plants were making the least expensive alcohol during WWII, at $\$ 0.63$ per gallon when average price was $\$ 0.96$ per gallon. He bought a plant that used to make gasohol (10\%) with cheap corn (1935-1937 when grain was in excess) and cheap natural gas, and that plant still went bankrupt. Basically the witness says that gasohol does not make sense to power automobiles. The witness further states that for one of his plants alone a subsidy of $\$ 18$ million a year (which is two thirds what the plant initially cost) would be required to make ethanol competitive. He resents government subsidies, and says that plants will be built by entrepreneurs (without subsidies) for ethanol to be used in industrial processes (where it makes sense economically) and not for gasohol. The witness summarizes his position by saying that gasoline cost $\$ 0.32$ a gallon while ethanol cost is $\$ 0.98$ per gallon, and any increase in cost of gasoline will be matched by an increase in cost of ethanol. The spread is too big. It's like a dog chasing its tail. Finally a gallon of ethanol has less energy to give than a gallon of gasoline. 


\section{Bibliography}

States that have enacted legislation to ban MTBE. (2007, August). Retrieved March 20th, 2011, from EPA's Office of Transportation and Air Quality (OTAQ): http://www.epa.gov/mtbe/contacts.htm

Abraham, S. (2010). Lights Out ! St. Martin's Press: New York.

Adelman, M. A. (Winter, 1972-1973). Is the Oil Shortage Real? Oil Companies As OPEC Tax-Collectors. Foreign Policy, Number 9, 69-107.

Adkins, J. E. (April 1973). The Oil Crisis: This Time the Wolf Is Here. Foreign Affairs, 51, No. 3, 462-490.

Alboudwarej, H. F., \& Taylor, J. (2006, Summer). Oilfield Review. Retrieved October 31, 2010, from Schlumberger:

http://www.slb.com/ /media/Files/resources/oilfield_review/ors06/sum06/heavy_ oil.ashx

Amadeo, K. (2010, Spring). The U.S. Trade Deficit. Retrieved October 31st, 2010, from About. Com:

http://useconomy.about.com/od/tradepolicy/p/Trade_Deficit.htm

Babcock, B. A. (2010). Costs and Benefits to Taxpayers, Consumers, and Producers from U.S. Ethanol Policies. Ames, Iowa: Center for Agricultural and Rural Development, Iowa State University.

Babcock, B. A., \& Barr, K. a. (2010). Costs and Benefits to Taxpayers, Consumers and Producers from U.S. Ethanol Policies. Ames, Iowa: Center for Agricultural and Rural Development, Iowa State University.

Bacevich, A. (2010, April 1st). The Carter Doctrine at 30. World Affairs, 1-3 http://www.worldaffairsjournal.org/new/blogs/bacevich/The_Carter_Doctrine_at_ 30.

Bahgat, G. (2006, February 27th). U.S. Oil Outlook. Middle East Energy Survey, pp. VOL. XLIX, No. 9.

Bahgat, G. (Winter 2003). Oil and Militant Islam: Strains on U. S. - Saudi Relations. World Affairs, pp. 115-122. 
Bellows, A. (2007, December 8th). The Ethyl-Poisoned Earth. Retrieved March 19th, 2011, from DamnInteresting.com: http://www.damninteresting.com/theethyl-poisoned-earth

Bessette, J. M. (1980). Deliberative Democracy: The Majority Principle in Republican Government. In R. A. Goldwin, How Democratic is the Constitution? (pp. 102- ). Washington, D.C.: American Enterprise Institute for Public Policy Research.

Bessette, J. M. (1994). The Mild Voice of Reason. Chicago: University of Chicago Press.

Bovard, J. (1995, September 26th). Cato Policy Analysis number 241. Retrieved March 15th, 2011, from Cato Institute: http://www.cato.org/pubs/pas/pa-241.html

Bryce, R. (2010). Despite Billions in Subsidies, Corn Ethanol Has Not Cut U.S. Oil Imports. New York: Manhattan Institute.

Bullock, D. S. (2007). Ethanol Policy and Ethanol Politics. Urbana-Champaign: University of Illinois.

Columbia Communities. (2010). Environmental Uses of the Land: Bonneville Dam. Center For Columbia River History, http://www.ccrh.org/comm/camas/bonnev.htm.

Commons, J. R. (1950). The Economics of Collective Action. New York, New York: Macmillan.

Congress, U. S. (1966, June 8th). Subcommittee on Air and Water Pollution Hearing, Senator Edmund Muskie Chairman. Retrieved March 19th, 2011, from LexisNexis Congressional Research - Congressional Record: http://web.lexisnexis.com.ezproxy.libraries.claremont.edu/congcomp/document?_m=a078d50cda 49554e872fc3e27adabb72\&_docnum=11\&wchp=dGLbVtbzSkSA\&_md5=d9c909f5206683327d5023f241c938cc

Congressional Quarterly, I. (1988). 100th Congress Second Session. Congressional Almanac, 175.

Congressional Quarterly, Inc. (1987). 100th Congress First Session. Congressional Almanac, 325-326.

Congressional Quarterly, Inc. (2007). 110th Congress First Session 2007. Congressional Almanac, 10-3. 
Congressional Research Service. (1992, January - December). CIS/Annual 1992. Legislative History of U.S. Public Laws, pp. 348-416.

Cox, C. a. (2010, June). Driving Under the Influence - Corn Ethanol and Energy Security. Retrieved April 23rd, 2011, from Environmental Working Group: www.ewg.org/files/EWG-corn-ethanol-energy-security.pdf

Creagh, J. (1998, August 27th). Ethanol vs. MTBE Presentation Outline. Retrieved March 20th, 2011, from Joint Advisory Committee for the Improvement of Air Quality: http://www.jac-ccc.org/minutes/jac-0898/JACETOH-0898.pdf

Dammer, A. R. (2006). National Strategic Unconventional Resource Model. Washington, D.C.: Office of Naval Petroleum and Oil Shale Reserves, U.S. Department of Energy.

Department of the Treasury. (2010, October 18th). Major Foreign Holders Of Treasury Securities. Retrieved November 1st, 2010, from United States Treasury: http://www.ustreas.gov/tic/mfh.txt

Doran, M. (2010, Volume 59, Issue 6). The Closed Rule. Emory Law Journal, $1364-1451$.

Duffield, J. A. (2006, First Quarter). Evolution of Renewable Energy Policy. Choices, pp. 9-14.

Duncan, R. C. (Winter 2005-2006). The Olduvai Theory. The Social Contract Press, 1-12.

Dyni, J. R. (2006, June). Geology and Resources of Some World Oil-Shale Deposits. Retrieved October 30th, 2010, from Geology.com: http://pubs.usgs.gov/sir/2005/5294/pdf/sir5294_508.pdf

Elass, J., \& Jaffe, A. M. (2010, September). Energy Forum. Retrieved October 30th, 2010, from Baker Institute at Rice University: http://bakerinstitute.org/

Energy Information Administration. (2005). Renewable Fuels Legislation Impact Analysis July 2005. Washington D.C.: United States Department of Energy Energy Information Administration.

Environmental Defense Fund. (2006, October 30th). Clean Air Act Timeline. Retrieved March 20th, 2011, from Environmental Defense Fund: http://www.edf.org/documents/2695_cleanairact.htm 
Fershee, J. P. (2009). "Atomic Power, Fossil Fuels, and the Environment: Lessons Learned and The Lasting Impact of the Kennedy Energy Policies". Selected Works of Joshua P. Fershee, University of North Dakota, http://works.bepress.com/joshua_fershee/1/.

Fishkin, J. S. (1995). The Voice of the People. New Haven, CT: Yale University Press.

Fishkin, J. S. (2003). Debating Deliberative Democracy. Malden, MA: Blackwell Publishing.

Fletcher, S. R. (2006, June 23rd). Congressional Research Service Environmental Protection Issues in the 109th Congress RL33481. Retrieved November 10th, 2011, from National Council for Science and the Environment (NCSE): http://www.cnie.org/NLE/CRSreports/06Nov/RL33481.pdf

Fooks, G. (2003). Auditors and the Permissive Society: Market Failure, Globalisation and Financial Regulation in the US. Risk Management, Vol. 5, No. 2, 17-26.

Fri, R. W. (Summer 2003). U.S. Oil Dependence Remains a Problem. Issues in Science and Technology, pp. 53-54.

Gerholdt, R. (2010, June 18th). Energy Independence Is Nation's Most Elusive Technological Goal. Retrieved September 25th, 2011, from Climate Action: http://blog.usclimatenetwork.org/administration/energy-independence-is-nationsmost-elusive-technological-goal/

Glozer, K. G. (2011). Corn Ethanol Who - Pays? Who Benefits? Stanford, California: Hoover Institution Press.

Glozer, K. G. (2011, August 24). Retired Associate Deputy Director, White House Office of Management and Budget. (M. C. Johnson, Interviewer)

Goldwin, R. A. (1980). How Democratic Is the Constitution? Lanham, MD: American Enterprise Institute.

Gray, C. B., Podesta, J. D., \& Wirth, T. E. (July-August 2003). The Future of Energy Policy. Foreign Affairs, pp. 133-134.

Gutman, A. a. (2004). Why Deliberative Democracy? Princeton, New Jersey: Princeton University Press. 
Hakes, J. E. (1998, September 3rd). 25th Anniversary of the Arab Oil Embargo. Retrieved October 30th, 2010, from The Energy Information Administration: http://www.eia.doe.gov/emeu/25opec/anniversary.html

Hewlett, R. G., \& Holl, J. M. (1989). Atoms for Peace and War, 1953-1961: Eisenhower and the Atomic Energy Commission. Berkeley and Los Angeles: University of California Press.

Hirsh, R. F. (2002, September). Energy Crises of the 1970's. Retrieved July 7, 2010, from Powering The Past: A Look Back:

http://americanhistory.si.edu/powering/backpast.htm

Hubbert, M. K. (1956, March 7th). The Coming Global Oil Crisis. Retrieved November 2nd, 2010, from Marion King Hubbert:

http://www.hubbertpeak.com/hubbert/

Huber, P. W., \& Mills, M. P. (2005). The Bottomless Well: The Virtue of Waste, and Why We Will Never Run Out of Energy. New York: Basic Books.

Inflation Data. (2008, July 16th). Inflation Adjusted Corn Prices 1973 - 2008.

Retrieved November 12th, 2011, from Inflation Data:

http://inflationdata.com/inflation/inflation_articles/Corn_Inflation.asp

Issawi, C. (1973, Dec). Oil and Middle East Politics. Proceedings of the Academy of Political Science, 31(2), 111-122.

Jackson, P. J. (2006, April 4th). The Federal Excise Tax on Gasoline and the Highway Trust Fund: A Short History RL30304. Retrieved March 15th, 2011, from Congressional Research Service "The Library of Congress" CRS Web: http://www.cnie.org/nle/crsreports/06may/r130304.pdf

Keeney, D. (2008, December 29th). Ethanol USA. Environmental Science and Technology, pp. 8-11.

Kuhn, T. S. (1962). The Structure of Scientific Revolutions. Chicago: University of Chicago.

Lockwood, D. E., \& Siehl, G. (2004, October 18th). Military Base Closures: A Historical Review from 1988 to 1995. Retrieved November 13th, 2010, from CRS Report for Congress: http://www.fas.org/sgp/crs/natsec/97-305.pdf

Maass, A. (1983). Congress and the Common Good. New York: Basic Books.

MacDonald, T. (2004). Ethanol Fuel Incentives Applied in the U.S. Sacramento: California Energy Commission. 
McCarthy, J. E. (2005, May 9th). Clean Air Act: A Summary of the Act and Its Major Requirements RL30853. Retrieved March 15th, 2011, from Congressional Research Service "The Library of Congress" CRS Web.

McClay, W. M. (2010, Fall). The Moral Equivalent of War? Retrieved October 30th, 2010, from National Affairs:

http://www.nationalaffairs.com/publications/detail/the-moral-equivalent-of-war

Mead, W. J. (Vol. 197, No. 4301 (Jul. 22, 1977)). An Economic Appraisal of President Carter's Energy Program. American Association for the Advancement of Science, pp. 340-345.

Mills, M. P. (2009, April 7th). The Efficacy Of Presidential Energy Policy. Retrieved October 30th, 2010, from Forbes.com:

http://www.forbes.com/2009/04/07/roosevelt-reagan-bush-clayton-christensenenergy-policy_print.html

Minerals Management Service, U.S. Department of the Interior. (2006, February). Outer Continental Shelf Oil \& Gas Assessment 2006. Retrieved October 31st, 2010, from Bureau of Ocean Energy Management, Regulation and Enforcement: http://www.boemre.gov/revaldiv/PDFs/2006NationalAssessmentBrochure.pdf

MLR Solutions - Fuel Testers. (2009, March). Ethanol History Timeline. Retrieved April 15th, 2011, from Ethanol Fuel History: www.fueltesters.com/ethanol_fuel_history.html

MTBE and Ethanol. (n.d.). Retrieved March 20th, 2011, from State Energy Conservation Office: http://www.seco.cpa.state.tx.us/re_ethanol_mtbe.htm

Mucciaroni, G. \&. (2006). Deliberative Choices. Chicago, Il: The University of Chicago Press.

National Institutes of Health. (1988, November 4th). Ethanol - Compound Summary. Retrieved April 22, 2011, from National Center for Biotechnology Information: www.ncbi.nlm.nih.goc

National Resources Defense Council. (2005). Safe, Strong and Secure: Reducing America's Oil Dependence. Retrieved October 31st, 2010, from Natural Resources Defense Council: http://www.nrdc.org/air/transportation/aoilpolicy2.asp

Oilism. (2007, December 15th). OILISM Crude Oil Prices, History \& Analysis. Retrieved October 31st, 2010, from Oilism.com: http://www.oilism.com/oil/2007/12/15/crude-oil-price-history-1950-2008/ 
Olson, M. (1965). The Logic of Collective Action. Cambridge, Massachusetts: Harvard University Press.

Olson, M. (1982). The Rise and Decline of Nations. New Haven: Yale University Press.

Patterson, C. (1965). Contaminated and Natural Lead Environments of Man. Archives of Environmental Health, 344-360.

Perry, M. J. (2010, April 28th). Foreign Oil Dependency by U.S. President. Retrieved October 31st, 2010, from CARPE DIEM:

http://mjperry.blogspot.com/2010/04/foreign-oil-dependency-by-uspresident.html

Pimentel, D. (2003, January 17th). Ethanol Fuels: Energy Balance, Economics, Retrieved October 15th, 2011, from Natural Resources Research, Vol. 12, No. 2, June 2003 : http://www.college.wustl.edu/ anthro/articles/pimentel-ethanol.pdf

Pimentel, D., \& Patzek, T. W. (2005, March). Ethanol Production Using Corn, Switchgrass and Wood; Biodiesel Using Soybean and Sunflower. Natural Resources Research, pp. 65-76.

PricewaterhouseCoopers. (2009). The Economic Impacts of the Oil and Natural Gas Industry On the US Economy. National Economics and Statistics (For American Petroleum Institute), 1-85.

Proxmire, S. W. (1974, August 5th). LexisNexis Congressional - Congressional Publications. Retrieved March 19th, 2011, from Congressional Record - Senate: http://web.lexis-nexis.com.ezproxy.libraries.claremont.edu/congcomp/

Rapier, R. (2010, January 25th). Prices of Various Energy Sources. Retrieved November 3rd, 2010, from Scitizen: http://scitizen.com/future-energies/prices-ofvarious-energy-sources_a-14-3353.html

Renewable Fuels Association. (2011, January). Statistics - Historic U.S. fuel Ethanol Production. Retrieved October 10th, 2011, from Renewable Fuels Association: http://www.ethanolrfa.org/pages/statistics

Sanders, M. A. (2011). Legislative History Report and Analysis Public Law 95618. woodland, California: Legislative Intent Service.

Sanders, M. A. (2011). Legislative History Report and Analysis Public Law 98369. Woodland, California: Legislative Intent Service. 
Schnepf, R. a. (2010, October 14). Renewable Fuel Standards (RFS) - Overview and Issues. Retrieved April 20, 2011, from National Law Center - Congressional Research Service: www.nationallaw center.org/assets/crs/R40155.pdf

Schroedel, J. R. (1994). Congress, The President and Policymaking - A Historical Analysis. Armonk, New York: M.E. Sharpe.

Shapouri, H., \& Duffield, J. A. (2002, July). The Energy Balance of Corn Ethanol: An Update - Agricultural Economic Report No. 814. Retrieved March 28th, 2011, from U.S. Department of Agriculture, Office of the Chief Economist: http://ageconsearch.umn.edu/bitstream/34075/1/ae020814.pdf

Squillace, P. J. (1995). South Dakota Water Science Center. Retrieved March 20th, 2011, from USGS Publications Warehouse:

http://sd.water.usgs.gov/nawqa/pubs/abstracts/squillace/dap.cvp.occ.mtbe.gw.ur.a g.areas.html

Stubbs, M. (2011, March 18th). Renewable Energy Programs in the 2008 Farm Bill RL34130. Retrieved August 15th, 2010, from Congressional Research Service "The Library of Congress" CRS Web: http://nepinstitute.org/get/CRS_Reports/CRS_Energy/Renewable_Fuels/Renewab le_Energy_Programs_in_the_08_Farm_Bill_Mar_2011.pdf

Sweeney, J. L. (2002). The California Electricity Crisis. Stanford, California: Hoover Institution Press.

Tao, L., \& Aden, A. (2009, March 9th). The Economics of Current and Future Biofuels. In Vitro Cellular \& Developmental Biology - Plant, pp. 199-217.

The National Security Council. (1950, April 14th). A Report to the National Security Council - NSC 68. Retrieved November 16th, 2010, from Harry S. Truman Library and Museum: http://www.trumanlibrary.org/

The Theodore Roosevelt Association. (2010). The Theodore Roosevelt Association, http://www.theodoreroosevelt.org/index.htm.

Toman, M. A. (2002, Spring, Vol. 20, No. 2). International Oil Security: Problems and Policies. Brookings Review, pp. pp. 20-23.

Tugwell, F. (1988). The Energy Crisis and the American Political Economy. Stanford, California: Stanford University Press.

Tyner, W. E. (2007, January). U.S. Ethanol Policy - Possibilities for the Future. Retrieved March 15th, 2011, from Purdue Extension: http://www.ces.purdue.edu/bioenergy 
U.S Energy Information Administration. (August 19th, 2010). United States

Energy History. Washington D.C. http://www.eia.doe.gov/aer/eh/eh.html: U.S. Department of Energy, Report No. DOE/EIA-0384(2009).

U.S. Energy Information Administration. (2008, January 15). American Jobs Creation Act of 2004 Legislation and Regulations AEO2005. Retrieved November 10th, 2011, from Independent Statistics and Analysis: http://www.eia.gov/oiaf/aeo/otheranalysis/aeo_2005analysispapers/ajca.html U.S. Energy Information Administration. (2008, October 29th). Independent Statistics and Analysis. Retrieved October 31st, 2010, from This Week In Petroleum: http://www.eia.doe.gov/oog/info/twip/twiparch/081029/twipprint.html

U.S. Energy Information Administration. (2008, July 30th). Independent Statistics and Analysis. Retrieved October 31st, 2010, from Energy Perspectives: http://perotcharts.com/2008/07/us-primary-energy-consumption-by-source-andsector-2007/

U.S. Energy Information Administration. (2009, July). Independent Statistics and Analysis. Retrieved October 30th, 2010, from Country Analysis Briefs-Canada: http://www.eia.doe.gov/cabs/Canada/Background.html

U.S. Energy Information Administration. (August 19th, 2010). United States Energy History. Washington D.C. http://www.eia.doe.gov/aer/eh/eh.html: U.S. Department of Energy, Report No. DOE/EIA-0384(2009).

U.S. Government Printing Office. (2007, January 3rd). US Code Main Page; SECTION 2687, TITLE 10. Retrieved November 13th, 2010, from GPO Access: http://frwebgate.access.gpo.gov/cgi-bin/multidb.cgi

United States Congress. (2006, January 6th). The National Defense Authorization Act of 2006, Public Law 109-163. Retrieved August 20th, 2010, from United States Department of Defense: http://www.dod.gov/dodgc/olc/docs/PL109163.pdf

United States Congress. (2008, October 3rd). Emergency Economic Stabilization Act of 2008 Congressional Research Service Summary. Retrieved August 15th, 2011, from GovTrack.us: http://www.govtrack.us/Congress/bill.xpd?tab=summary\&bill=h110-1424

United States Department of Agriculture. (1998, June 23rd). Public Law 105-185 page 28. Retrieved March 15th, 2011, from National Institute of Food and Agriculture: http://www.csrees.usda.gov/about/offices/legis/pdfs/areera98.pdf 
United States Department of Energy. (2006, April). U.S. Shale Oil Economics. Retrieved October 30th, 2010, from Department of Energy:

fossil.energy.gov/.../Oil_Shale_Economics_Fact_Sheet1.pdf

United States Department of Energy. (n.d.). U.S. Shale Oil Economics. Retrieved October 30th, 2010, from Department of Energy:

fossil.energy.gov/.../Oil_Shale_Economics_Fact_Sheet1.pdf

United States Government Printing Office. (2000, June 20th). Federal Digital System - Public Law 106 - 224 page 73. Retrieved March 17th, 2011, from United States Government Printing Office.

Whitney, G., Behrens, C. E., \& Glover, C. (2009 (October 29th)). U.S. Fossil Fuel Resources: Terminology, Reporting and Summary. Washington, D.C.:

Congressional Research Service.

Woolley, J. a. (2000, June 20th). President Clinton Statement on Signing the Agricultural Risk Protection Act of 2000. Retrieved August 16th, 2011, from The American Presidency Project:

http://www.presidency.ucsb.edu/ws/index.php?pid=58665\&st=\&st1=\#axzz1dSSv $6 \mathrm{C} 6 \mathrm{Z}$

World Energy Council. (2007). Geothermal - Electricity Generation - Chart. Survey of Energy Resources 2007, p. http://www.worldenergy.org/documents/fig_geo_11_6.gif.

WTR Economics. (2003, February 3rd). The Coming Energy Crisis. Retrieved October 8th, 2011, from Energy Economics Newsletter:

http://www.wtrg.com/EnergyCrisis/index.html

Yacobucci, B. D. (2006, July 25th). Biofuels Incentives: A Summary of Federal Programs RL33572. Retrieved March 15th, 2011, from Congressional Research Service "The Library of Congress" CRS Web: http://lugar.senate.gov/energy/links/pdf/Biofuels_Incentives.pdf

Yacobucci, B. D. (2006, March 3rd). Fuel Ethanol: Background and Public Policy Issues RL33290. Retrieved March 15th, 2011, from Congressional Research Service "The Library of Congress" CRS Web: http://assets.opencrs.com/rpts/RL33290_20060303.pdf

Yacobucci, B. D. (2008, March 18th). Ethanol Imports and the Caribbean Basin Initiative RS21930. Retrieved March 15th, 2011, from Congressional Research Service "The Library of Congress" CRS Web: http://www.cnie.org/NLE/CRs/abstract.cfm?NLEid=177 
Yacobucci, B. D. (2008, April 24th). Fuel Ethanol - Background and Public Policy Issues RL33290. Retrieved March 23rd, 2011, from Congressional Research Service "The Library of Congress" CRS Web:

http://www.nationalaglawcenter.org/assets/crs/RL33290.pdf 